\begin{abstract}
UNIVERSIDADE DE SÃO PAULO
FACULDADE DE FILOSOFIA, LETRAS E CIÊNCIAS HUMANAS

DEPARTAMENTO DE LETRAS CLÁSSICAS E VERNÁCULAS

PROGRAMA DE PÓS-GRADUAÇÃO EM FILOLOGIA E LÍNGUA PORTUGUESA

YURI FABRI VENANCIO
\end{abstract}

Um estudo etimológico de internacionalismos: cognatos na língua portuguesa e norueguesa

São Paulo

2016 


\author{
UNIVERSIDADE DE SÃO PAULO \\ FACULDADE DE FILOSOFIA, LETRAS E CIÊNCIAS HUMANAS \\ DEPARTAMENTO DE LETRAS CLÁSSICAS E VERNÁCULAS \\ PROGRAMA DE PÓS-GRADUAÇÃO EM FILOLOGIA E LÍNGUA PORTUGUESA
}

\title{
Um estudo etimológico de internacionalismos: cognatos na língua portuguesa e norueguesa
}

\section{YURI FABRI VENANCIO}

Dissertação de Mestrado apresentada ao Programa de Pós-Graduação em Filologia e Língua Portuguesa da Faculdade de Filosofia, Letras e Ciências Humanas, da Universidade de São Paulo, como parte dos requisitos para obtenção do título de Mestre em Letras.

Orientador: Prof. Dr. Mário Eduardo Viaro

São Paulo

2016 
Aurorizo a reprochuçĩo e divulgaçio total ou parcial deste trabsitho, por qualquer meio cotvencional ou eletróaico, para fins de estido e pescuisa, desde que citada a fonte

Catalogaçầ m Pubìcação

Serviç de Biblioteca e Documentraço

Faculdade de Filosofia Letras e Cièncias Humanas da Universidade de Sšo Parulo

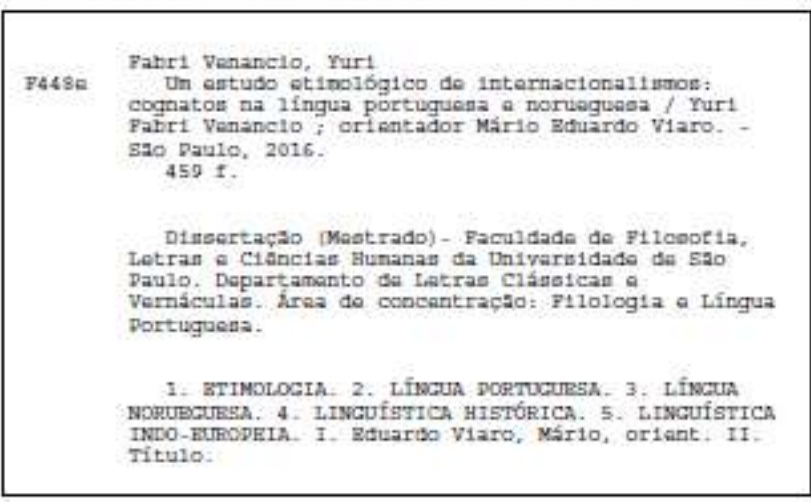


VENANCIO, Y. F. Um estudo etimológico de internacionalismos: cognatos na língua portuguesa e norueguesa. Dissertação apresentada à Faculdade de Filosofia, Letras e Ciências Humanas da Universidade de São Paulo para obtenção do título de Mestre em Letras.

Aprovado em:

\section{Banca Examinadora}

Prof. Dr. Instituição:

Julgamento: Assinatura:

Prof. Dr. Instituição:

Julgamento: Assinatura:

Prof. Dr. Instituição:

Julgamento: Assinatura: 


\section{Agradecimentos}

Agradeço ao professor e orientador Mário Eduardo Viaro pela assistência e incentivo ininterruptos nesta dissertação;

Aos colegas do NEHiLP, principalmente ao Prof. Dr. Aldo Bizzocchi, ao Prof. Dr. Bruno Maroneze, ao Prof. Dr. Daniel Kölligan, à Profa. Dra. Érica Santos Soares de Freitas, à Jasmim Sedie Drigo, ao Prof. Dr. José Marcos Mariani de Macedo, à

Dra. Nilsa Areán-Garcia, ao Prof. Dr. Paulo Chagas de Souza e ao Prof. Dr. Vanderlei Gianastacio;

Aos meus professores nas disciplinas de mestrado - Profa. Dra. Margarida Taddoni Petter, à Profa. Dra. Mária Clara Paixão de Souza, ao Prof. Dr. Thomas Daniel Fimbow e, novamente, aos Prof. Dr. Mário Eduardo Viaro, os conhecimentos transmitidos;

Ao Prof. Dr. Francis Henrik Aubert, os conhecimentos adquiridos em Tradução e Língua norueguesa;

À FFLCH-USP, o apoio institucional as oportunidades e facilidades concedidas durante o período da elaboração desta dissertação;

À CAPES, a concessão de bolsa de estudo;

À Biblioteca Nacional da Noruega, todos os livros disponíveis;

Ao meu amigo norueguês e linguista Bror-Magnus Sviland Strand, o apoio e companheirismo;

Aos meus amigos Bruno Cruz Marques, Eduardo Sadalla Bucci, Guilherme Stecher Pinto, João Henrique Simon de Medeiros, Ricardo Rossi, Sthefan Fugagnolli Pegorari e Wendel Mene Costa, o apoio e companheirismo;

Aos meus pais, Luís Antônio Venancio e Lilian Cristina Fabri Venâncio, por acreditarem e investirem em mim;

Ao meu irmão, Matheus Fabri Venancio; aos meus avós José Luís Fabri e Claudete Therezinha Marchi Fabri; Sétimo Venancio e Ana Fischer Blumer Venancio. À toda minha família;

A todos grandes autores que li em minha vida, os conhecimentos adquiridos. 
Certa palavra dorme na sombra de um livro raro. Como desencantá-la?

É a senha da vida a senha do mundo.

Vou procurá-la.

Vou procurá-la a vida inteira no mundo todo.

Se tarda o encontro, se não a encontro, não desanimo, procuro sempre.

Procuro sempre, e minha procura

ficará sendo minha palavra.

(A Palavra Mágica - Carlos Drummond de Andrade) 
Kvat er no ein Nation? Ordet kjem av Latinen og tyder eigenlega eit Føde (fødselskull), ei Att elder Slaegt, og dernoest ei Landscett (elder Tjod), eit stort Folkaslag av same Uppkoma og soleides nokorlunda med same Hug og Seder, med same Maal og same Minne. Naar no slikt eit Folkaslag kann bu $i$ eit Land fyre seg sjølv og skipa eit Rike, soleides som vaart Folk, so er det ein Landslyd. (Lyd er Familie.).

Ivar Aasen

(Minningar fraa Maalstriden - 1859) 


\section{Resumo}

Esta dissertação é principalmente um estudo de Etimologia; porém, tem um caráter interdisciplinar, pois nos valhamos de outros estudos linguísticos, como a Morfologia, Fonologia, Linguística Histórica, Semântica, assim como os Estudos de Tradução e de Filologia.

O objetivo desta dissertação é analisar a etimologia de alguns elementos lexicais terminados em -ção, que têm cognatas em -sjon no norueguês. Estes elementos são atribuídos aos chamados internacionalismos que, por sua vez, integram o conjunto de empréstimos na língua. Para analisar a etimologia de cada uma das palavras da amostragem, pesquisamos o terminus a quo de cada cognata, tanto do português quanto do norueguês, e também de outras línguas do ramo latino e germânico a fim de traçar o caminho percorrido pelo elemento lexical. Propusemos outros procedimentos para fortalecer a determinação do étimo destes elementos lexicais. A análise deste tipo de elemento lexical é um grande desafio, uma vez que suas cognatas têm grafia e pronúncia muito parecidas.

Também nos propusemos a comparar os resultados de nossa pesquisa etimológica com as informações contidas em outros dicionários: no Grande Dicionário Houaiss, para a língua portuguesa, no Bokmål Ordbok, no Nynorsk Ordbok (ambos da Universidade de Bergen), no Norsk Ordbok e no Riskmålsordbok, para a língua norueguesa.

Consultamos muitas obras online e corpora para a realização dessa pesquisa. O Google Books e a Biblioteca Nacional da Noruega (Nasjonalbibliothek) foram fundamentais para este fim.

PALAVRAS-CHAVE: Etimologia, Linguística Histórica, Língua norueguesa, Língua portuguesa, Morfologia Diacrônica 


\begin{abstract}
The present dissertation is mainly an etymological study. It has, however, an interdisciplinary character as it is part of other linguistics studies, such as Morphology, Phonology, Historical Linguistics, Semantics, as well as Translation Studies and Philology.

The aim of this work is to analyse the etymology of some lexical elements formed by the derivational suffix -ção in the Portuguese language with cognates formed by -sjon in the Norwegian language. These elements are assigned to the internationalisms which, in turn, are part of the set of loanwords in the language. With a view to analysing each of the collected lexical elements of the sampling, we searched for the terminus a quo of each cognate both in the Portuguese language and in the Norwegian language as well as in the other Romance and Germanic languages. From this collection, we succeeded in tracing the path each word took. Furthermore, we proposed other procedures to strengthen the establishment of the etymon of these lexical elements. Such an analysis is a big challenge, since the cognates are very alike both in the spelling and in the pronunciation.

We also aimed to compare the results of our research with the etymological information provided by the Dicionário Houaiss da Língua Portuguesa and by some Norwegian dictionaries, such as Bokmål Ordbok, Nynorsk Ordbok (both from the Bergen University), Norsk Ordbok and Riksmålsordbok.
\end{abstract}

We accessed many online works and corpora in order to carry out our research. The Google Books and the National Library of Norway (Nasjonalbibliothek) were fundamental for this end.

KEY WORDS: Etymology, Historical Linguistics, Norwegian language, Portuguese language, Diachronic Morphology 


\section{Lista de símbolos e abreviaturas}

\section{Símbolos:}

$\begin{array}{ll}x \rightarrow y \text { ou } y \leftarrow y & \text { o dado linguístico y é derivado morfológico de } x \\ x \Rightarrow y \text { ou } y \nLeftarrow y & \text { o dado linguístico y é afetado por analogia com } x \\ x \mapsto y \text { ou } y \bullet x & \text { o empréstimo } x \text { transforma-se em } y \\ x \equiv y & x \text { e y são homófonos } \\ x \cong y & x \text { é cognato de } y \\ x \approx y & x \text { é uma variante de y } \\ x \sim y & x \text { e y são flexões do mesmo paradigma } \\ x+y \rightarrow z & z \text { é uma composição de } x \text { e de y } \\ x>y \text { ou } y<x & x \text { é étimo/origem de y } \\ x>y \text { ou } y<<x & x \text { mudou semanticamente para y } \\ x \geq y \text { ou } y \leq x & \text { y é um decalque de } x\end{array}$

\section{Abreviação das línguas:}

AAA

AEE

AFranc.

AFris.

AHol.

AD

Ai.

ale.

AN

AS

ASue.

ATch.

av.

din.

EsC. antigo alto-alemão

antigo eslavônico-eclesiástico

Antigo frâncico

antigo frísio

antigo holandês

antigo dinamarquês

Antigo índico

alemão

antigo nórdico

antigo saxão

antigo sueco

Antigo tcheco

avéstico

dinamarquês

Escandinavo comum 
fr.

fr.ant.

Go.

germ.oest.

gr.

IA

ing.

isl.

lat.

LEsc

MBA

MHol.

nbok.

nyn.

PN

pt.

rún.

snscr.

sue.

francês

francês antigo

gótico

germânico do oeste

grego

inglês antigo

inglês

islandês

latim

línguas escandinavas

médio baixo-alemão

Médio holandês

norueguês bokmål

norueguês nynorsk

proto-nórdico

português

Rúnico

sânscrito

sueco

\section{Abreviação de algumas obras:}

CLG

Deli

DHW

LPR

$\mathrm{NbUiB}$

NyUiB

NTG

OADS

ODS

ROB
Curso de linguística geral

Dizionario Etimologico dela Lingua Italiana

Dicionário - das Herkunftswörterbuch

Le Petit Robert 2014

Dicionário - bokmål ordbok (Universidade de Bergen)

Dicionário - nynorsk ordbok (Universidade de Bergen)

Dicionário - norsk ordbok (riksmål/moderat bokmål) (GUTTU)

Dicionário - Ordbog til det ældre danske sprog

Dicionário - Ordbog over det danske sprog

Dicionário - riksmålsordbok 
SAO Dicionário - Svenska Akademiens Ordbog

TLF Dicionário - Trésor de la langue française

VHCPM Vocabulário histórico-chronológico do português medieval

WNT Dicionário - Woordenboek der Nederlandsche Taal 


\section{Sumário}

1 INTRODUÇÃO

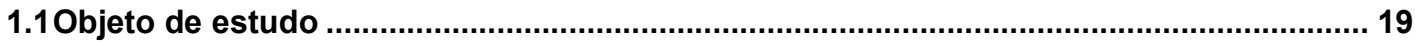

1.2A Etimologia, a origem das línguas e a Linguística Histórica na Escandinávia até o

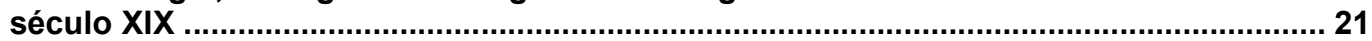

1.2.1 O pensamento linguístico tradicional até o século XVIII ..................................... 22

1.2.1.1 Os vernáculos como reflexões imperfeitas da lógica ......................................... 22

1.2.1.2 O vernáculo como continuação da língua do Éden e a Etimologia vista como semântica da explicação .................................................................................... 25

1.2.2 O pensamento comparativo na realização da Etimologia ..................................... 33

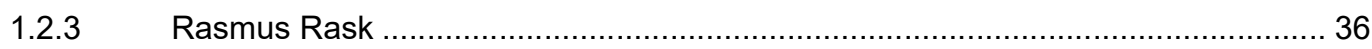

1.2.3.1 Algumas considerações sobre o capitulo Etimologia de Rasmus Rask (Om Etymologien overhovedet) ......................................................................... 36

1.2.3.2 Alguns exemplos dados por Rasmus Rask suas relações com a Linguística

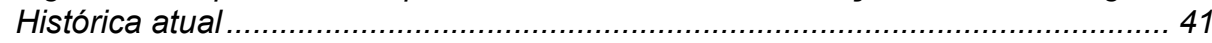

1.2.4 Outros nomes contemporâneos ou posteriores a Rasmus Rask........................... 49

1.3A Etimologia e os processos etimológicos na Noruega ..................................................... 51

1.40s dialetos e as duas formas oficiais de escrita do norueguês ........................................ 62

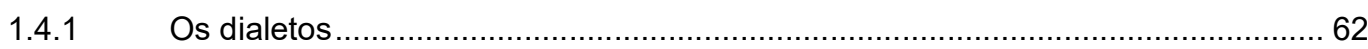

1.4.1.1 Introdução aos dialetos e às duas formas oficiais............................................ 62

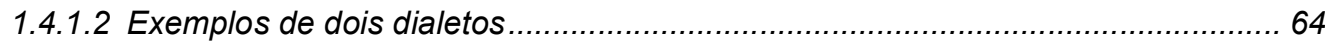

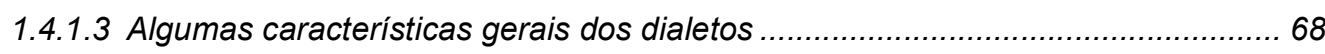

1.4.2 As línguas escritas oficiais: bokmål e nynorsk .................................................... 74

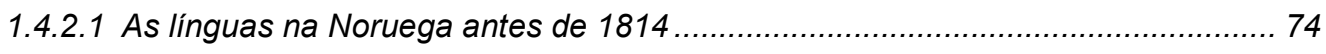

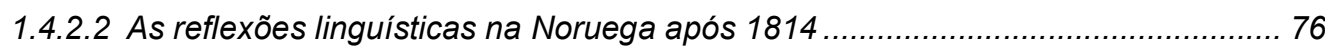

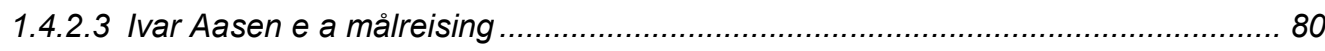

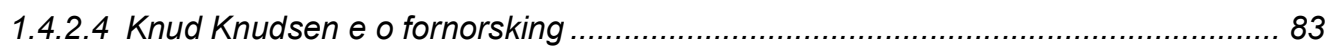

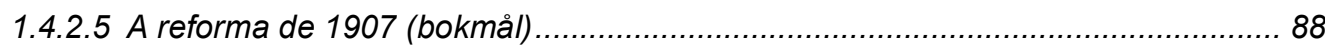

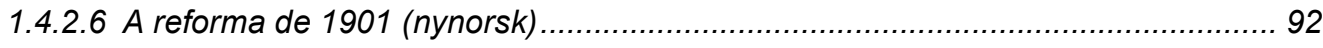

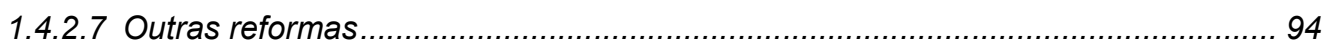

1.4.2.8 Quando se inicia o uso das duas formas escritas da língua norueguesa?............ 96

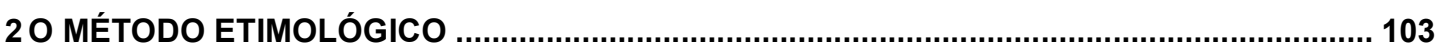

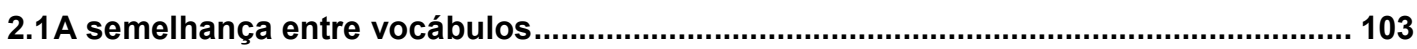

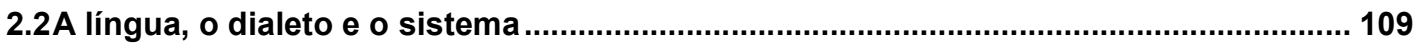

2.3As sincronias pretéritas das línguas portuguesa e norueguesa e as modificações

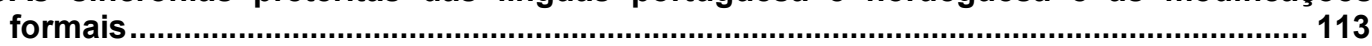

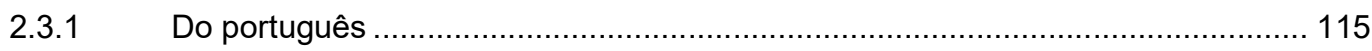

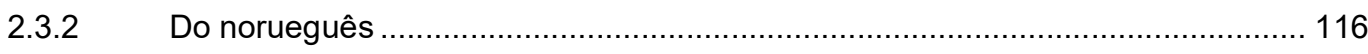

2.3.2.1 SN1 - O germânico do continuum Norte-Oeste.............................................. 120

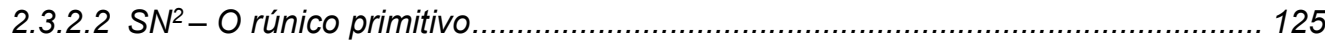


2.3.2.3 $S N^{3}-A$ Era das síncopes

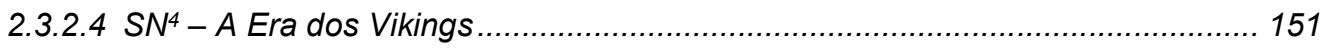

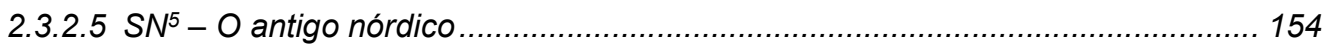

2.3.2.6 $S N^{6}-\mathrm{O}$ médio norueguês......................................................... 159

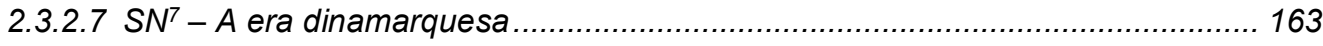

2.3.2.8 $S N^{8}-$ A era norueguesa .............................................................. 165

2.4Étimo (de herança, de língua anterior e de empréstimo), a origem e o terminus a quo168

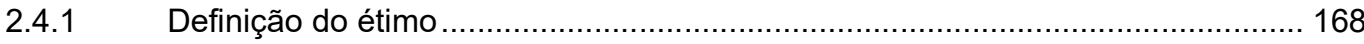

2.4.2 Étimo de empréstimo ou de decalque ...................................................... 176

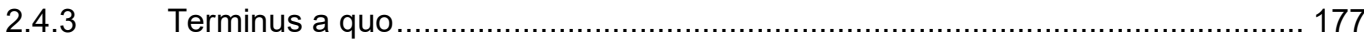

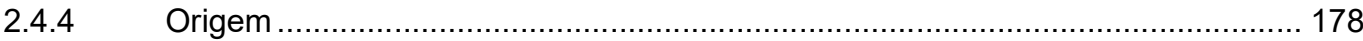

2.4.5 Um estudo de caso para apresentar o étimo e a origem em uma palavra

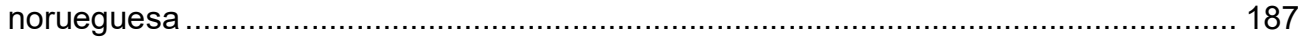

2.5A discussão etimológica: herança, empréstimo, decalque, derivação, entre outros ... 193

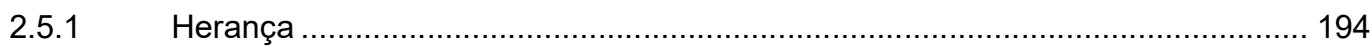

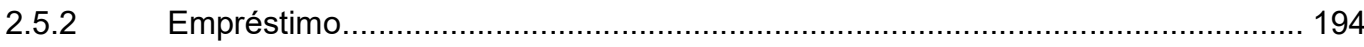

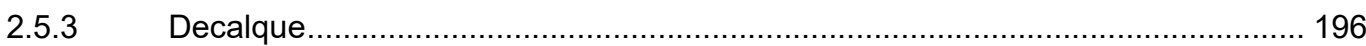

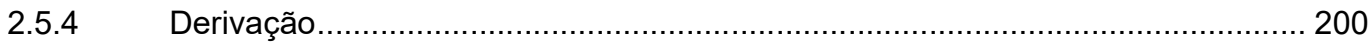

2.6Levantamento da amostragem para análise e o método de pesquisa ........................ 205

2.7Obras, dicionários e corpora utilizados................................................................... 206

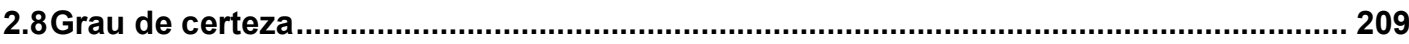

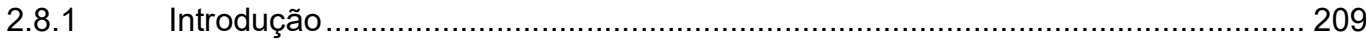

2.8.2 O terminus a quo e outros elementos que podem fortalecer/enfraquecer a determinação do étimo de empréstimo ou de decalque............................................ 212

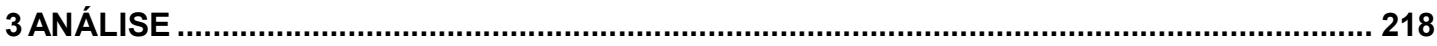

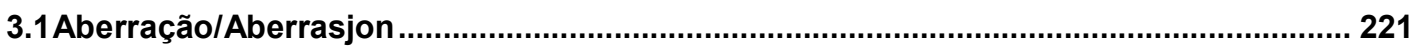

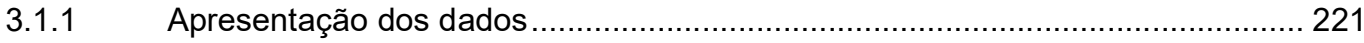

3.1.1.1 Mundo germânico ..................................................................... 221

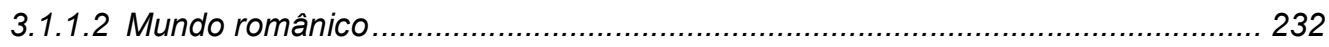

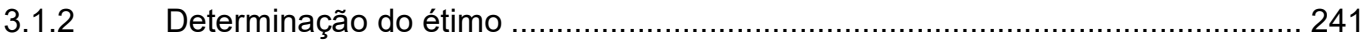

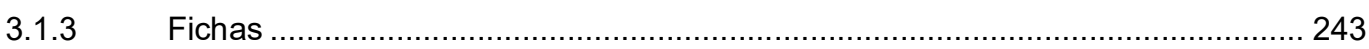

3.1.3.1 Para o português ....................................................................... 243

3.1.3.2 Para o norueguês .......................................................................... 245

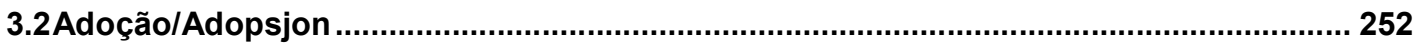

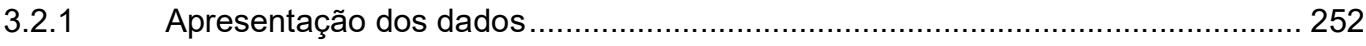

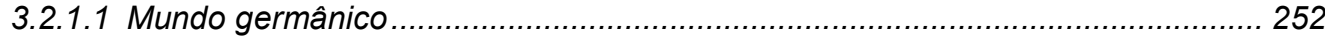

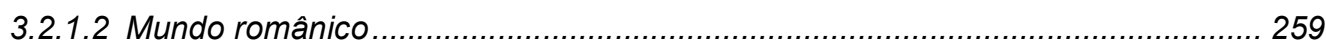

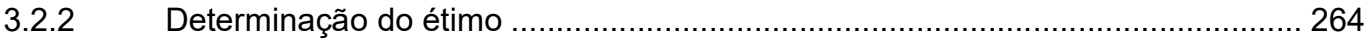

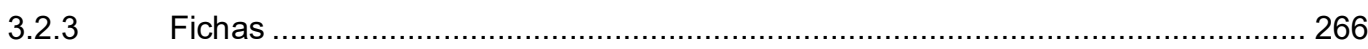

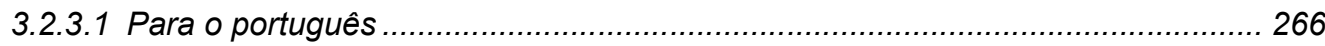




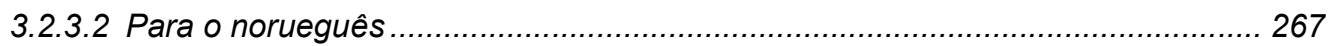

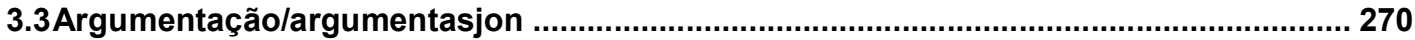

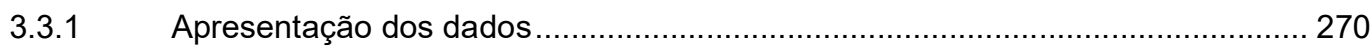

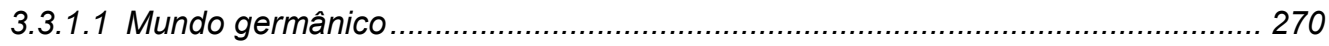

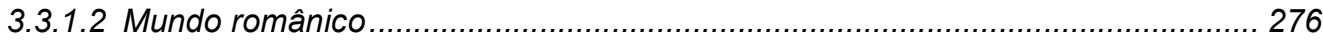

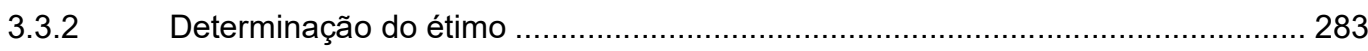

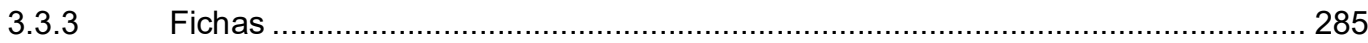

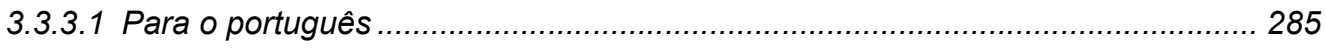

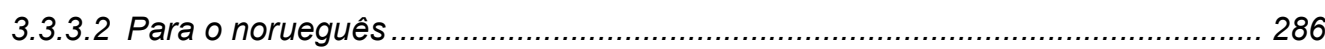

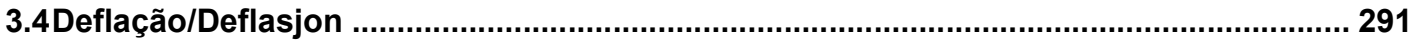

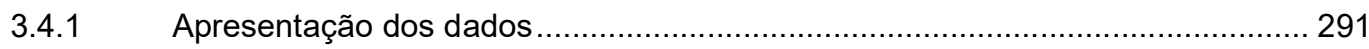

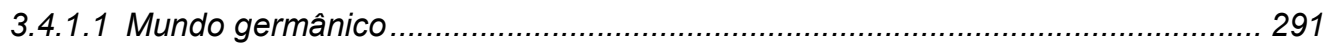

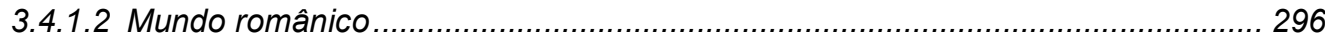

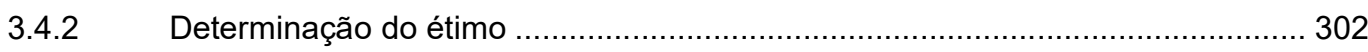

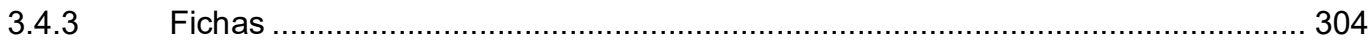

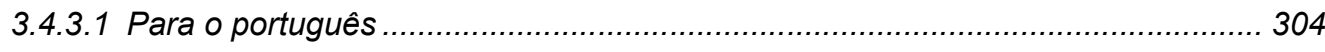

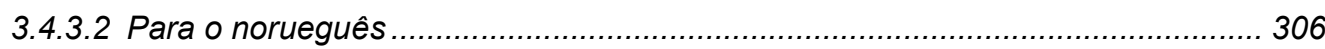

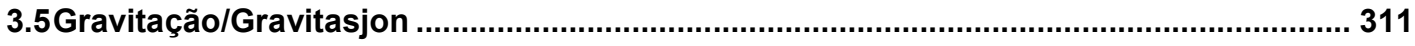

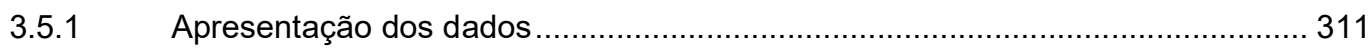

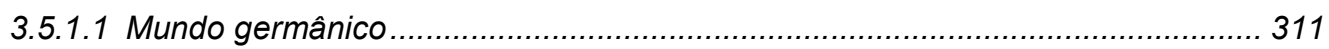

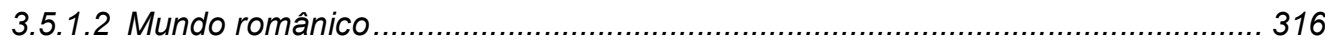

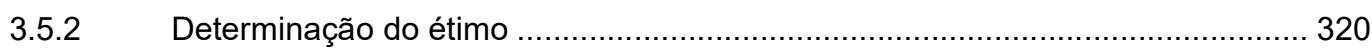

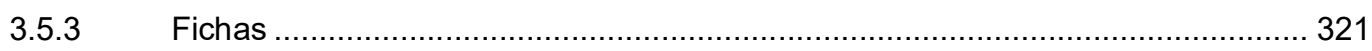

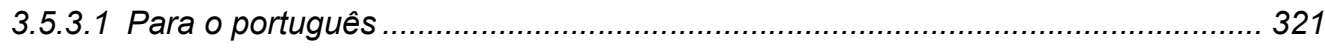

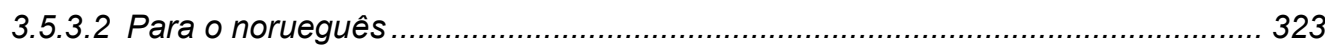

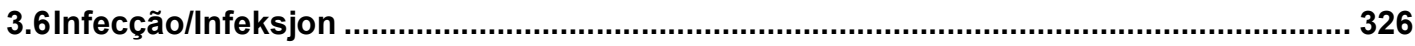

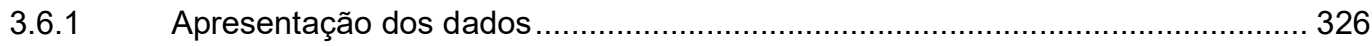

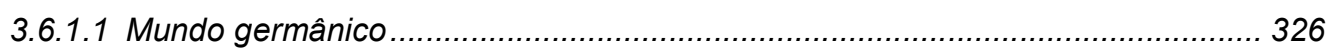

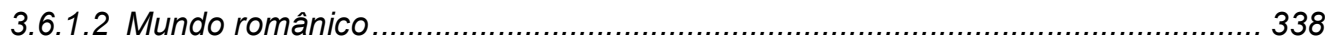

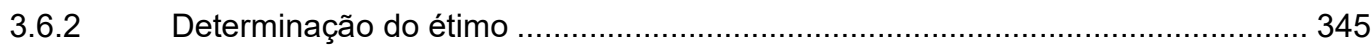

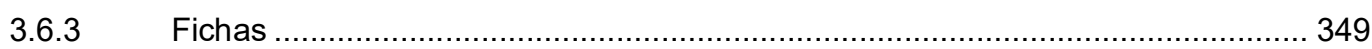

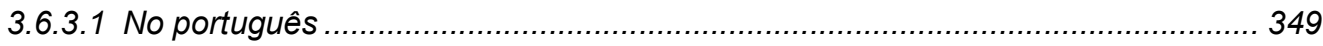

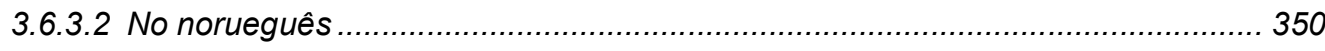

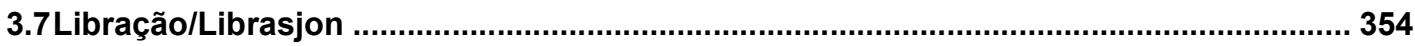

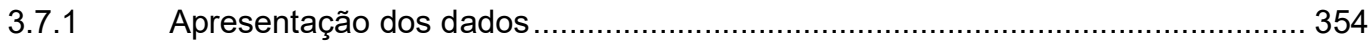

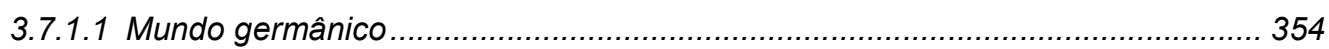

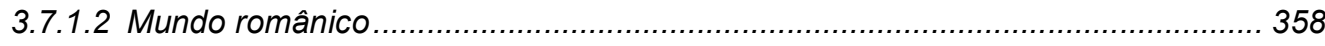

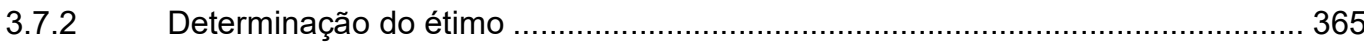

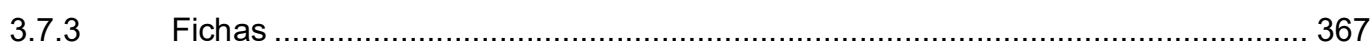




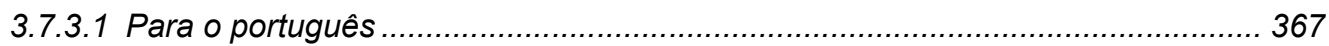

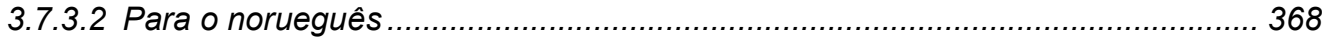

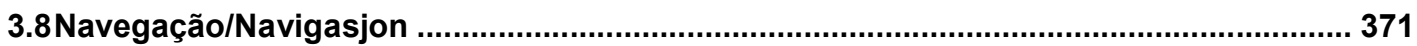

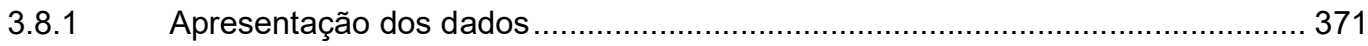

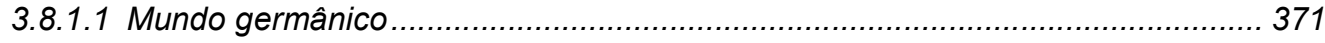

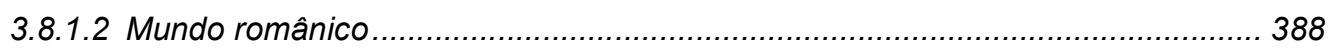

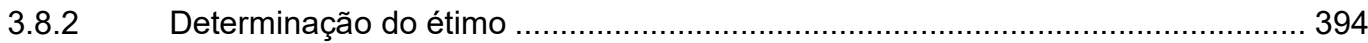

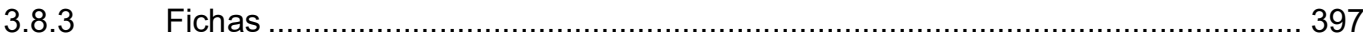

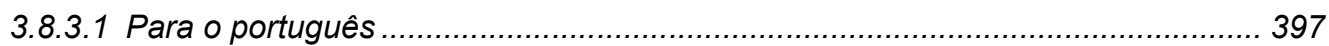

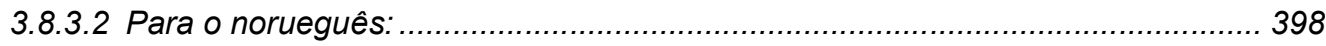

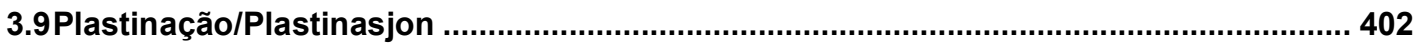

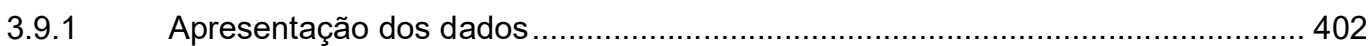

3.9.1.1 Mundo germânico ......................................................................... 402

3.9.1.2 Mundo românico.................................................................... 405

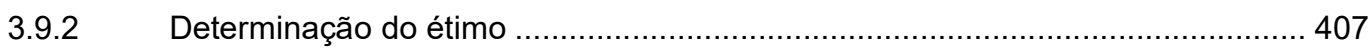

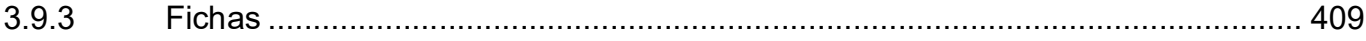

3.9.3.1 Para o português ...................................................................................... 409

3.9.3.2 Para o norueguês.................................................................................. 410

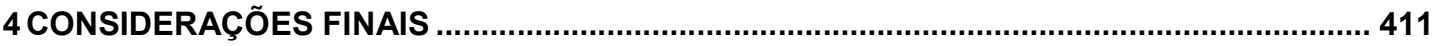

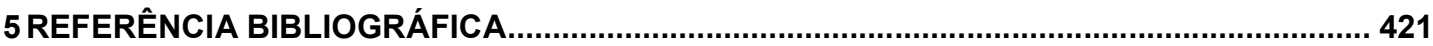




\section{Introdução}

Este trabalho é principalmente um estudo de Etimologia, embora nos valhamos também de outros estudos linguísticos, como a Morfologia, Fonologia, Linguística Histórica, Semântica, assim como os Estudos de Tradução e de Filologia.

No Brasil há inúmeras obras no mercado que se dizem etimológicas, principalmente aquelas que tratam da etimologia dos nomes próprios. Elas, entretanto, não seguem um método rigoroso de investigação, sendo apenas livros de diversão. A partir de muita imaginação, formam-se conclusões pouco fundamentadas (vide os inúmeros livros sobre nomes para bebês, por exemplo). Segundo Viaro (2011, p. 97-99), a pesquisa etimológica assemelha-se, quanto ao rigor, à uma edição crítica. Deve passar por inúmeras etapas rigorosas e, mesmo assim, suas conclusões são variadas e sujeitas à revisão, ou seja, não é possível apresentar os étimos como versões definitivas e com frequência pode haver várias hipóteses etimológicas. Com o surgimento de novos dados e argumentos igualmente bem fundamentados, cabe a outros confirmar ou rejeitar tais hipóteses. A explicação que remete a um determinado étimo pode sofrer modificações ao longo do tempo por meio de novas informações descobertas: um livro que é descoberto pode conter alguma atestação que mude completamente a história desse possível étimo. Portanto, a simples semelhança formal entre o étimo proposto e as palavras investigadas é insuficiente para tirarmos conclusões certeiras. No mercado norueguês há também muitas obras pouco fundamentadas com o único objetivo de entreter o leitor. Por conta disso, estudos científicos são necessários para a Etimologia.

O português e o norueguês foram as línguas escolhidas nessa dissertação porque são periféricas e, consequentemente, estão mais distantes dos centros difusores de cultura. Portanto, é possível que em tais línguas essas palavras internacionais não entrem diretamente a partir da língua difusora, mas por uma língua intermediária, o que será discutido na análise da dissertação. A escolha da língua norueguesa se deve ao fato de que os estudos etimológicos na Noruega não são adequadamente realizados e, também, por não haver dicionários etimológicos muito criteriosos. 
Apresentaremos inicialmente (subcapítulo 1.2) um estudo historiográfico sobre a Etimologia na Escandinávia até o século XIX, que teve como principalmente representante o dinamarquês Rasmus Rask. O subcapítulo seguinte (1.3.) retratará a maneira como a Etimologia é realizada na Noruega atualmente. Em vista disso, há comentários sobre a Etimologia de algumas palavras em dicionários atuais e, também, tentamos coletar métodos etimológicos e explicações sobre como a Etimologia é compreendida. Neste subcapítulo se encontra um dos motivos da inclusão da língua norueguesa nessa dissertação: as informações etimológicas nos dicionários noruegueses são errôneas, com base em nossos pressupostos. O subcapítulo 1.4. demonstrará as duas línguas germânicas oficiais e os dialetos do norueguês. Para tal, apresentamos as características dos dialetos e a formação dessas duas línguas oficiais, o bokmål e o nynorsk, que surgiram em um período em que o dinamarquês era a única língua oficial.

No capítulo 2, retrataremos inicialmente a semelhança entre vocábulos (subcapítulo 2.1), que nem sempre se deve a uma origem comum. No subcapítulo 2.2. definiremos a maneira como entendemos a língua, o dialeto e o sistema. As sincronias da língua estudada têm o testemunho de como ela funcionava em cada um dos períodos e, por conta disso, são indispensáveis; consequentemente, no subcapítulo 2.3. apresentaremos os processos e desenvolvimentos linguísticos que contribuíram tanto para a formação do português quanto para a formação do norueguês. $\mathrm{O}$ subcapítulo 2.4. tratará do étimo, da origem e do terminus a quo. A discussão etimológica, que envolve herança, empréstimo, decalque, derivação, etc. estarão apresentadas no subcapítulo 2.5. No subcapítulo 2.6. descreveremos como realizamos o método de pesquisa e no subcapítulo 2.7. apresentaremos as obras, dicionários e corpora utilizados. O subcapítulo final (2.8.) abordará os graus de certeza do étimo, que até o momento se relacionaram com os elementos lexicais herdados; em vista disso, no subcapítulo 2.8.2. apresentaremos de que maneira o terminus a quo e outros procedimentos podem fortalecer/enfraquecer a determinação do étimo de elementos lexicais emprestados.

No capítulo 3 se encontrará a análise dos nove elementos lexicais estudados nessa dissertação. As considerações finais estarão descritas no capítulo 4. 


\subsection{Objeto de estudo}

A presente dissertação tem como objetivo analisar a etimologia de alguns elementos lexicais terminados em -ção, que têm cognatas em -sjon no norueguês. Estes elementos são atribuídos aos chamados internacionalismos que, por sua vez, fazem parte das palavras emprestadas dentro de uma determinada língua. Nas análises aplicaremos alguns procedimentos que podem fortalecer ou enfraquecer a determinação do étimo de elementos lexicais desse tipo. Pesquisadores do NEHiLP ${ }^{1}$ criaram os graus de certeza para a avaliação da etimologia dos elementos lexicais herdados do português, os quais serão apresentados no capítulo 2.8 .

De acordo com Kocsány (2010), internacionalismos são importantes mediadores entre culturas e considerados como representantes de um globalismo positivo no nível das ciências e da moral (p. 72). Para Volmert (2003), o termo internacionalismo é discutível e aparece nos dicionários, de maneira muito ingênua, como uma "palavra que há em muitas línguas" e, por isso, segundo o autor, não pode ser considerado um conceito linguístico. Ele define o internacionalismo da seguinte maneira (p.24)

Internacionalismos são ocorrências linguísticas com formas iguais ou quase iguais que aparecem em várias línguas, em um determinado período, e têm um mesmo conteúdo; por conta disso, são entendidas sem a necessidade de uma tradução (p. 24 tradução nossa)

$\mathrm{O}$ autor afirma que elementos lexicais desse tipo podem surgir em vários setores lexicais, como por exemplos na área das novas tecnologias (computadores). Por fim, ele define mais precisamente o conceito internacionalismo da seguinte maneira:

É uma palavra que se difunde com o mesmo (ou similar) plano de expressão, com o mesmo (ou similar) significado em diferentes línguas e, na grande maioria dos casos, é compreendida

Núcleo de Apoio à Pesquisa em Etimologia e História da Língua Portuguesa, coordenado pelo Prof. Dr. Mário Eduardo Viaro. O núcleo tem como objetivo a criação de um novo dicionário etimológico da língua portuguesa. 
espontaneamente sem a necessidade de tradução (p. 25 tradução nossa)

Uma vez que os internacionalismos são muito parecidos nas diferentes línguas, eles desafiam a deliberação de uma etimologia apenas pela análise da forma do elemento lexical. A respeito do sufixo -ção do português, o elemento lexical surge via empréstimo por conta de tradução, que é a substituição do sufixo da língua-fonte (por exemplo, -tio do latim ou -tion do francês, etc.) para o herdado -ção, que existe em elementos lexicais como canção e lição. No norueguês, por outro lado, como ocorre no francês, o sufixo é importado na sua forma original latina, uma vez que não há elementos lexicais terminados em -tion. Além do mais, a reforma ortográfica do norueguês em 1917 transformou a grafia tion para -sjon, adaptação ortográfica que pretende assemelhar-se mais à pronúncia.

Tomemos, por exemplo, o elemento lexical deflação em algumas línguas latinas e germânicas:

\begin{tabular}{|l|l|l|l|}
\hline Língua & Forma & Pronúncia & Radical \\
\hline Espanhol & Deflación & [defla'Ejon] & Defl- \\
\hline Francês & Déflation & [defla'sjõ] & Défl- \\
\hline Italiano & Deflazione & [defla'tsjone] & Defl- \\
\hline Alemão & Deflação & [defla'sẽw] & Defl- \\
\hline Dinamarquês & Deflation & [defla'tsjo:n] & Defl- \\
\hline Holandês & Deflatio & [,defla']s:n] & Defl- \\
\hline Inglês & Deflation & [dr'fleIfən] & Defl- \\
\hline
\end{tabular}




\begin{tabular}{|l|l|l|l|}
\hline Norueguês & Deflasjon & [,defla'fu:n] & Defl- \\
\hline Sueco & Deflation & [,defla'fs:n] & Defl- \\
\hline
\end{tabular}

Vale considerar que não encontramos o verbete deflatio no latim.

Fica claro com base nesse exemplo que essas cognatas são muito parecidas na escrita (e também na pronúncia). Disso gera-se uma problematização e a seguinte pergunta: quais outros meios poderiam ser utilizados para definir o étimo de um internacionalismo quando a forma das cognatas nada indica? A similaridade entre as cognatas é devido à manutenção do radical, que muitas vezes é latino, ocorrendo apenas a adaptação do sufixo.

\subsection{A Etimologia, a origem das línguas e a Linguística Histórica na Escandinávia até o século XIX}

Uma vez que essa dissertação também trata da Etimologia e da Linguística Histórica da língua norueguesa, fez-se necessário realizar uma introdução sobre como esses estudos foram desenvolvidos e abordados por toda a Escandinávia até o século XIX.

Primeiramente é necessário ter em mente que o estudo da origem das línguas e de suas características foi um tema popular na Europa após a Renascença. Hovdhaugen et al. (2000) afirmam que tal tema foi primeiramente discutido como uma questão teológica: o hebraico era aceito como primeira língua a partir da qual todas as outras se desenvolveram. Tentativas foram realizadas para relacionar certas línguas europeias como holandês e sueco (ou estágios mais antigos das línguas germânicas) diretamente ao hebraico. Os autores também afirmam que o termo Etimologia tinha um significado diferente do atual, adquirido no século XIX, pois era entendido antes de 1800 como uma análise morfológica de uma palavra e/ou uma comparação entre uma palavra (ou seus morfemas) com outras palavras (e seus 
próprios morfemas) com o intuito de obter um melhor conhecimento e compreensão do significado da palavra em questão (p. 66)².

Segundo Rischel (2002a), o estudo da Linguística Histórica e da Etimologia na Escandinávia antes do século XVIII era puramente especulativo; contudo, num campo que hoje em dia poderíamos chamar de Linguística Aplicada, foram realizados bons trabalhos nesse período, como, por exemplo, o estudo da estrutura sonora da língua por motivação da Reforma com o intuito de adaptar novos hinos e estabelecer ortografias consistentes para, por exemplo, as edições bíblicas (p. 108). O autor também afirma que o pensamento linguístico tradicional até o século XVIII pode ser entendido como detentor de três perspectivas: o vernáculo como reflexões imperfeitas da lógica, o vernáculo como continuação da língua do Éden e a Etimologia vista como semântica de explicação (p. 108-109), que serão resumidos a seguir.

\subsubsection{O pensamento linguístico tradicional até o século XVIII}

\subsubsection{Os vernáculos como reflexões imperfeitas da lógica}

A respeito da primeira perspectiva, o método humanista e medieval para o estudo da língua era baseado na ideia clássica de que haveria uma língua ideal que estaria de acordo com a estrutura lógica do mundo e, por conta disso, as línguas, como as conhecemos, são reflexos mais ou menos perfeitos de uma língua lógica, ao passo que as línguas europeias vulgares são vistas como resultado de uma corrupção que vem ocorrendo desde a antiguidade. Assim, o grego e o latim eram mais relevantes para um método baseado na nessa lógica.

2 Com relação a essa afirmação, temos apenas que tomar cuidado de não cair no anacronismo uma vez que termos como morfema e seu significado ainda não existiam. 
Os representantes escandinavos da teoria linguística da Europa medieval, da escola modista (gramáticos especulativos), eram quatro eruditos dinamarqueses: Martinus de Dacia, Boetius de Dacia, Johannis de Dacia e Simonis de Dacia. Eles estiveram em atividade na França a partir da metade do século XIII. De acordo com Bursill-Hall (1975), eles construíram suas gramáticas na teoria do modus significandi "modo de significado, expressão semântica" e o trabalho deles inicia, de maneira muito sistemática, a filosofia da linguagem que filósofos acadêmicos estavam desenvolvendo; por isso, representa o apogeu da teoria gramatical medieval (p. 164).

Bursill-Hall (1975) também atesta que Boetius de Dacia era o mais antigo e mais importante teórico do grupo, pois realizou uma minuciosa investigação sobre a base epistemológica e teórica da gramática e, nesse sentido, pode ser considerado um prolegômeno para a gramática modista. Ele percebeu de maneira muito clara que o linguísta deve tratar das abstrações linguísticas, das quais a pars orationis "parte da fala" é a mais importante e também o elemento por excelência da estrutura profunda; tal percepção foi descrita da seguinte maneira: significatum "componente semântico, aquilo que é significado", modus significandi "interpretação semântica" e vox "expressão". Desse modo, assim como outros eruditos e a maioria dos linguístas modernos, Boetius reconheceu que todas as afirmações sobre a linguagem são, por fim, afirmações sobre significado; e a linguagem, por conta disso, se relaciona com aquilo que é significável, e tudo que é significável é passível de se conhecer. Portanto, para Boetius a gramática preocupase com o res "coisa" e suas propriedades e, por conta disso, o modus significandi e todas as suas variações adquiriram uma posição central no sistema semiótico, tendo em vista que é durante o ato de significar que nós indicamos nosso conhecimento e entendimento das coisas e suas propriedades (p. 176).

Com relação ao ponto de vista dos gramáticos medievais sobre a gramática, o autor afirma que consideravam a gramática fora da própria linguagem. Segundo os modistas, haveria uma gramática 
universal, uma atitude que se ajusta a todo o teor da vida intelectual medieval, que era dependente da estrutura da realidade; como resultado, as regras gramaticais eram independentes de qualquer língua natural usada para expressá-las e havia, portanto, um sistema gramatical válido universalmente para todas as línguas. Era a função dos filósofos da linguagem descobri-lo (p. 165)

Referente ao surgimento da escola modista, o autor atesta que toda uma atividade anterior de estudos da gramática culminou na doutrina gramatical deles: os gramáticos do século XII criticavam com sucesso o gramático latino Priscianus Caesariensis (ca. 500 a.C.), que escreveu o manual Institutiones grammaticae, e iniciaram o processo da mudança na teoria linguística; o início do século XIII nos apresenta elementos característicos de operações de correção como, por exemplo, a introdução da noção da gramática universal, extensão do conceito de modus significandi, a semantização concomitante das categorias linguísticas e o desenvolvimento da separação do estudo da gramática com suas associações humanísticas relacionadas ao estudo da literatura e sua transformação em uma ciência cada vez mais especulativa em associação com a lógica (p. 166).

O termo modus significandi foi utilizado entre 1260 e 1330 com independência pela gramática especulativa, mesmo ele também sendo comum para a filosofia e teologia. Inicialmente, o termo era oposto na gramática a significatum, ao passo que após 1280 o termo significatum foi substituído por modus significandi passivus e o termo modus significandi se torna modus significandi activus. Portanto, o termo sofre um desenvolvimento paralelo na gramática, teologia e filosofia; com relação à gramática, no início do período parece ter um conceito morfológico e no trabalho de Gerson (1426), é certamente de relevância sintática (KELLY, 1959, p. 159). 


\subsubsection{2 $O$ vernáculo como continuação da língua do Éden e a Etimologia vista como semântica da explicação}

Além da primeira perspectiva, temos um tema que se aproxima da tentativa de explicar a origem das línguas. Rischel afirma que esses eram os principais eventos tomados pelos linguistas como ponto de partida: a) o fato de Adão e Eva utilizarem palavras para nomear coisas, ou seja, havia uma língua original falada no Paraíso; b) após um período de monolinguismo, a língua se dividiu em várias línguas não inteligíveis por causa da construção da Torre de Babel. Esses eventos explicam o motivo pelo qual a língua hebraica foi tomada como língua original. Por conta disso, na Dinamarca, Peder J. Wandal publicou uma lista de palavras que comparava o dinamarquês e o hebraico (1651) e Peder Pedersen Syv (1631 -1702) escreveu uma monografia sobre a língua dinamarquesa com o título de Nogle Betænkninger om det Cimbriske Sprog $(1663)^{3}$. Os cimbros, segundo Tacitus em Germania (capítulo 37), eram um povo que vivia numa região ao norte da Alemanha perto do Mar do Norte; porém, Rischel (2002a) afirma que Syv compreendia este termo como simplesmente "germânico", ou seja, um estágio inicial de todas as línguas germânicas.

Syv afirmou que essa língua tinha muito mais em comum com o hebraico do que com o grego ou o latim e, portanto, era anterior a elas; porém, após a chegada de Odin, que veio da Ásia, na Escandinávia, ela se diferenciou do hebraico, o que causou uma mistura com a linguagem dos deuses (p. 109). Outro autor do mesmo período que trata desse assunto é o islandês Runolfur Jónsson (lat. Runolphus Jonas), em cuja obra Linguæ septentrionalis elementa tribus assertionibus adstructa (1651), que aborda as relações genéticas entre as línguas, afirma-se que uma vez que Odin falava o antigo nórdico no poema Hávamal, essa deve ter sido a língua falada por ele em sua

\footnotetext{
3 Trad. nossa: "algumas considerações sobre a língua dos cimbros"
} 
chegada na Escandinávia (HOVDHAUGEN, 1987, p 75). A crença desses autores do século XVII de que Odin tinha origem na Ásia devese ao prólogo da obra Edda em prosa do islandês Snorri Sturluson (1179-1121). Lá narra-se a trajetória de Odin, que tinha o dom da profecia (spadom), e, por conta disso, descobriu que seu nome iria ser famoso na parte norte do mundo e honrado por todos os reis. Por isso, ele partiu da Turquia (byria ferp sina af Tyrklandi) e só fez uma pausa quando chegou no Norte do que é chamado hoje em dia de "terra dos saxões" (oc peir gefa eigi stað ferpini, fyR en peir koma norðr i pat land, er nv er kallat Saxland). Depois foi para o norte, no que agora é chamado de "nação dos svea"4. Lá havia um rei, que era conhecido como Gylfi, e quando ele soube da viagem desses homens da Ásia, que eram chamados de æsir ${ }^{5}$, encontrou com eles e oferece a Odin o quanto bastasse de território (Eptir pat for hann norðr, par sem nv heitir Svípiođ. Par var sa konvngr, er Gylfi er nefndr. En er hann spyR til ferpar peira Ásiamanna, er er æsir voro kallađir, fór hann i moti peim ok bavd, at Opinn skyldi slikt vald hafa ihans riki, sem hann vildi sialfr). O texto original se encontra na edição de Finnur Jónsson (p. 3-6, 1931).

No que se diz a respeito das classificações das línguas, Hovdhaugen et al. comentam que Syv estava convencido de que o hebraico era a língua de Adão e que todos a falavam, de uma forma ou de outra, e que a primeira maior alteração ocorreu pro conta da mistura das línguas realizada por Deus na Torre de Babel; ele também as divide em quatro grupos: grego, latim (italiano ${ }^{6}$, espanhol e francês), línguas eslavas (russo, que segundo Syv era originalmente uma língua germânica, croata, tcheco e polonês) e as línguas címbricas (dinamarquês, sueco, norueguês, alemão, etc); o húngaro não foi analisado por ele porque ele acreditava que ela não pertencia a nenhum desses grupos, por ser proveniente da Ásia.

\footnotetext{
${ }^{4}$ Suécia

${ }^{5}$ um dos panteões dos deuses nórdicos, ao qual pertence Odin

6 vœlsk
} 
Hovdhaugen et al. também citam um dinamarquês anônimo de 1727 que, da mesma maneira, atestou que as línguas vieram de uma única só, aquela dada por Deus para Adão e Eva, mas não ousava dar um nome para ela e criticava aqueles que consideravam que era o hebraico. Na opinião dele nenhuma língua veio da outra, o que seria algo tão estranho quanto determinar que frutas, peixes, pássaros e animais das mesmas espécies vieram um dos outros. Na opinião dele, os europeus, isso inclui os dinamarqueses, eram filhos de Jafé, uma tradição aparentemente iniciada por Isidoro de Sevilla (580-636). Deus teria arranjado a língua original para formar cada uma das línguas existentes na época; para suportar tal argumentação foi realizada uma analogia com a música, ou seja, tendo em vista que um número infinito de melodias pode ser criado por meio de um conjunto finito de tons musicais, numerosas línguas poderiam ser formadas com base em um conjunto finito de "letras" (que representava no período os sons). Ele introduz certas formas de metáteses como die press, en perse ... die furcht, en frøgt ... das kraut, en urt ${ }^{7}$, ou seja, uma mistura de alemão e dinamarquês, como exemplos da maneira que Deus rearranjou os sons da língua original e assim ele conseguia provar como as línguas poderiam ser similares e ainda assim não derivadas diretamente uma das outras. Referente ao latim, francês e italiano, ele acreditava que tais línguas eram paralelas e mutualmente independentes (p. 67).

Realizaremos aqui um pequeno adendo sobre o que Isidoro atesta sobre Jafé. O autor publicou a obra Etymologiae (600-625), considerada a primeira enciclopédia escrita na cultura do Ocidente, que contém um compêndio sobre grande parte da erudição dos antigos mundos greco-romano e cristão primitivo (BARNEY, S. et al. 2006, p. 3). No livro 7 , capítulo 6 , em que há realizações de etimologias do nome de alguns povos, Isidoro atesta que Adam "Adão", de acordo com o São Jerônimo, significa homo "humano", terrenus "terráqueo" ou terra rubra "terra vermelha", pois da terra a carne foi moldada e o humus era o material utilizado para tal moldagem; os antigos acreditavam que as

\footnotetext{
7 "Uma prensa, uma prensa ... um temor, um temor ... uma erva, uma erva"
} 
raízes entre hebr.bibl. adamah "terra" ou "chão" e Adam estavam relacionadas. lapheth "Jafé", por sua vez, significa latitudo "largura, amplitude", pois dele nasceram as nações pagãs e muito ampla é "a multidão de crentes entre os pagãos" (ex gentibus multitudo credentium). No livro IX, capítulo 2, Isidoro também cita as tribos que surgiram por toda a Europa a partir dos filhos de Jafé: Gomer, a partir de quem surgiram os Galatae "gálatas", ou seja, os Galli "gauleses"; Magog, a partir de quem julga ter dado origem aos Scythae "citas" e Gothi "godos"; Madai, aos medos; lavan, aos lones "jônios", que também são os gregos, então mare lonium "mar jônico"; Thubal, aos Iberi "ibéricos", que também são os Hispani "habitantes da Hispânia, hispânicos", embora alguns suspeitam que os Itali também surgiram deles; Mosoch, aos Cappadoces "capadócios";8 Thiras, aos Thraces "trácios", cujo nome não foi muito alterado(quasiTiraces). No mesmo capítulo, Isidoro também afirma que talvez os godos sejam descendentes de Magog por causa da similaridade da última sílaba entre as duas palavras e que os antigos os chamam de Getae. Segundo ele, era um povo vigoroso e mais poderoso, com corpo massivo e alto e terríveis por conta das armas que usam. Percebemos, de fato, uma tradição que passou por Isidoro de Sevilha e chegou até a Dinamarca, apenas nos resta saber se realmente tal tradição foi iniciada por Isidoro.

Alguns autores escandinavos até mesmo se apropriaram da ideia de que havia um local onde uma língua primitiva e original era falada com o intuito de exaltar certo nacionalismo. Rischel (2002a) cita o patriotismo exacerbado do sueco Olaus Rudbeck (1630-1702), que julgou a Suécia na obra Atland eller Manheim (1679-1702) como o berço da civilização, ou seja, a própria Atlântida, onde a língua de Adão era falada (p. 109). Hovdhaugen et al. afirmam que a intenção de Rudbeck era mostrar que a ilha de Platão, Atlantis, era de fato a Suécia e que o sueco era a língua do paraíso e que sua obra é uma manipulação de fatos para argumentar essa conclusão. Ele também realiza comparações sistemáticas entre línguas por meio de uma lista de 
correspondências como sue. F e lat. $\mathrm{P}$, sue. $\mathrm{K}$ e lat. $\mathrm{C}$ e sue. $\mathrm{K}$ e lat. $\mathrm{G}$ como, por exemplo, sue. åker e lat. ager "terra, campo" ou sue. leka e din. lege "brincar". Seu filho, Olaus Rudbeck Jr., também seguiu os passos do pai para promover tais ideias de patriotismo exagerado. Ele tentou provar conexões entre a língua sami e o hebraico, gótico com o chinês e o finlandês com o húngaro, interpoladas com todos os tipos de etimologias de palavras hebraicas, que são comparadas com outras línguas semíticas, com o grego, italiano, gótico, anamita e ao que hoje chamamos de línguas bantu; por fim, está totalmente incerto quais línguas estão relacionadas (p. 73). Dois exemplos de etimologia entre o gótico e o chinês seriam: chin. cym, sue. thim, tima "tempo" e chin. dau, got. dau, du, dug "chuva" (RUDBECK, 1717, p. 64-67, In: HOVDHAUGEN, 2000). A caligrafia rúnica também foi considerada muito antiga tanto na Dinamarca quanto na Suécia, algumas vezes até mais antiga do que o alfabeto grego e latino e foi tomada como algo de orgulho nacional. Em 1650 o islandês Magnús Ólafsson of Laufás publicou o livro Specimen Lexici Runici em que a primeira entrada de cada palavra do dicionário era dada em alfabeto rúnico e latino.

De acordo com Hovdhaugen et al, no geral, a teoria dominante na Dinamarca era de que o hebraico era a primeira língua e a fonte principal de todas as outras línguas. Além de Wandal e Syv, também havia Henricus Muhle, que atestava que tudo poderia ser explicado como originário do hebraico, mas não tinha nenhum senso de cronologia e até mesmo assumia que uma palavra era emprestada do anglo-saxão para o grego, que poderia ser realizada uma comparação entre o umlaut/ablaut no alemão com as alterações vocálicas dos verbos hebraicos (MUHLE, 1692, p. 110-112, In: HOVDHAUGEN, 2000). Muhle também tinha a opinião de que o grego, o latim e o alemão tinham a mesma sintaxe gramatical, uma vez que que os textos poderiam ser traduzidos quase ao pé da letra de uma dessas línguas para a outra. Outro estudioso foi Ivar Abel (1720-1788), que publicou três estudos comparativos de qualidade variada. Ele assumiu que as línguas dos indígenas americanos tinham uma conexão com todos os grupos de 
línguas europeias, mas que tais indígenas eram primeiramente descendentes dos turcos. Ele tentou relacionar geneticamente esses grupos por meio de similaridades fonotáticas e até mesmo afirmou que, por conta das mesmas restrições fonotáticas em finlandês e em "brasileiro" (i.e. tupi), daria para afirmar solidamente uma relação entre essas duas línguas (ABEL, 1783, p. 25, In: HOVDHAUGEN, 2000, p. 69). Com relação à mudança linguística e semelhança genética, Rischel (2002a) afirma que por um longo tempo a mudança linguística foi entendida como algo que corrompe a língua e que os estudos comparativos foram distorcidos por fundamentalistas religiosos e crenças ingênuas sobre mitos migratórios (p. 109).

Com relação ao território sueco, Hovdhaugen et al. (2000) citam Georg Stiernhielm (1598-1672), que é considerado o fundador da Linguística Histórica-Comparativa sueca. Ele propôs, como base teórica, que todas as línguas existentes no mundo antigo vieram de uma só língua e que essas línguas vieram de Adão e Noé e da diversificação das línguas e também excluiu explicitamente as línguas da América e as ilhas caribenhas, porque os povos de lá devem ter sido originados naquela área e possivelmente não seriam descendentes de Adão e Eva (p. 71). Stiernhielm (1671) exclui tais línguas porque ele não detecta nelas nenhum traço de sistema, de coerência ou de familiaridade (p. iv). A classificação familiar proposta por ele se iniciou com os três filhos de Noé. Sem era o pai das línguas semíticas (hebraico, árabe e assírio) e Cam, do egípcio, etiópio, fenício, etc. Stiernhielm via a relação entre esses dois grupos e não acreditava que o hebraico era a língua original, mas sim um dialeto da língua comum. Jafé, o primeiro filho de Noé, segundo o relato da Gênesis, era o pai do latim, das línguas românicas, do grego, persa, germânico e eslavo. Tal grupo era chamado por Stiernhielm de citas e até mesmo as línguas frígia e trácia são atribuídas a esse grupo. Ele apontou a relação interna entre as línguas românicas, que se desenvolveram a partir dos dialetos do latim que, por sua vez, se desenvolveu de um dialeto dos citas (p. 71-72). Percebemos aqui que o ponto de vista de Stiernhielm se diferencia do 
de Isidoro de Sevilha e do dinamarquês anônimo, pois inclui mais grupos de línguas, além do germânico ou citas, como descendentes de Jafé. Os autores também afirmam que Stiernhielm forneceu umas das primeiras representações tabulares primitivas da relação entre as línguas germânicas. De acordo com Metcalf (2013), na representação de Stiernhielm, ele demonstra a emergência de uma "nova" (mas relacionada) língua para enfatizar que várias formações linguísticas (hoje em dia entendidas como dialetos) são ainda parte de uma "língua".

Para provar isso, propõe que falantes de brabantian, suevica "sueco" e mechlenburgian fossem levados a uma cidade, onde, segundo ele, no decorrer do tempo, desenvolveriam uma nova formação linguística unificada, que chamou de "lingua nova", diferente de cada uma das três formas originais e ainda assim germânica. Um dos grandes méritos desse autor é a clareza em que ele define "língua" e "dialeto" e também a afirmação de que todas as línguas estão sujeitas à modificação (p. 49-50). Segundo Stierhielm: "qualquer língua, mesmo aquela que não se mistura e não se contamina por outras, por simples deficiência ou virtude de um longo período de tempo, assume sucessivamente, enquanto ainda se permaneça por si só, uma outra aparência" (STIERNHIELM, 1671, p. viii, In: METCALF, 2013). Percebemos aqui uma visão de que a língua não é estável por natureza e de que vive em constante desenvolvimento. $O$ autor também atribui às línguas o envelhecimento, a morte e a ressurreição: "reconheço que as línguas sofrem envelhecimento, tornam-se obsoletas e morrem; por outro lado, renascem, entram num estágio de juventude, crescem e ficam com uma maturidade vigorosa" (p. ix).

Haquin Spegel (1645-1714) em seu dicionário Glossarium sveogothicum eller swensk ordabook de 1712 criticou tanto as especulações etimológicas de Stiernhielm quanto as de Rudbeck; ele acreditava que tentativas de relacionar línguas como sueco ou holandês ao hebraico, ao jardim do Édem ou aos filhos de Noé eram arbitrárias e heréticas (HOVDHAUGEN et al, 2000, p. 74). 
Com relação à Dinamarca, Rischel (2002a) também cita Hans Mikkelsen Ravn (1610-1663), que tinha um ponto de vista muito aceito sobre a mudança linguística na época, ou seja, Ravn acreditava que sua língua materna sofreu um declínio durante o tempo por causa das influências estrangeiras que a corromperam. Rischel cita também Oluf Borch (1626-1690), que se interessava pelas razões das quais as línguas se tornaram tão diferente após a Torre de Babel. Interessante na teoria de Borch era sua crítica às faltas de cuidado com relação aos fatores na mudança linguística, ou seja, ele antecipou percepções posteriores.

$\mathrm{Na}$ Noruega parece não ter nenhum representante que tratasse de fato as questões aqui abordadas. Mas, de acordo com Hovdhaugen et al. (2000), uma vez que por 300 anos não houve uma língua escrita norueguesa por conta da dominação política e cultura dinamarquesa, os dialetos noruegueses passaram a ser um tema de interesse por alguns eruditos, principalmente de clérigos como, por exemplo, o dinamarquês Jørgen Thomassøn, que serviu como vigário na Noruega e foi por volta de 1625 o primeiro a se interessar pelos dialetos, estabelecendo as correspondências sonoras básicas entre eles e o dinamarquês e comparando tal situação com a relação entre os dialetos do grego antigo (p. 33). Portanto, havia um interesse esporádico em diferenças dialetais e até mesmo na relação entre dialetos e a língua padrão já nesse período.

Com relação ao último ponto, Rischel (2002a) comenta que no período a Etimologia traçava a origem de uma palavra por análise comparativa de significados de palavras que indicavam pronúncias que sugeriam uma relação lógica entre elas. Isso novamente nos remete aos estudos dos modistas dinamarqueses, mas a ênfase era em propriedades universais de linguagem e não em uma história da língua (2002a, p. 108-109). 


\subsubsection{O pensamento comparativo na realização da Etimologia}

No que concerne à Etimologia, segundo Rischel (2002a), não havia exigências muito restritas referentes às similaridades gráficas ou fonéticas para considerar que duas línguas estavam relacionadas, como também não existiam critérios com base em uma rígida metodologia (comparação sistemática de línguas com formas parecidas), pois os eruditos estavam preocupados apenas com as normas ortográficas das línguas da Antiguidade e de eventuais línguas do período; por conta disso, no período não seria possível que eles assumissem que as línguas tendiam a mudar durante a história e, menos ainda, que tais mudanças tendiam a ser sistemáticas a irregulares. Por não haver nenhuma teoria explícita, levou muito tempo para entender que havia a necessidade de formular critérios operacionais por meio de uma base metodológica rígida. O autor conclui que não houve nenhum progresso metodológico considerável nas tentativas de realizar etimologia do século XVII até a obra comparativa realizada por Rask no século XIX ( $p$. 110), embora tenham existido interessantes antecipações da linguística comparativa, como já citado, com Jørgen Thomassøn (1625).

Além de Thomassøn, outro bom exemplo é o sueco Ericus Schroderus (Eric Schröder), que escreveu obra Lexicon LatinoScondicum de 1637, cuja introdução trata da linguística comparativa. Schröder é bem explícito sobre as comparações regulares entre línguas muito próximas geneticamente. Ele compara o gótico (i.e. o sueco para o autor) com o alto alemão, derivando o segundo do primeiro e, a partir disso, percebe a relação do alemão $p$ com o gótico $b$, como em beck/pech "piche, breu", e alemão b com gótico $f$ (que representa o [v]) ou também $g$ em graff/grab "túmulo", färgha/farb "cor", korgh/korb "cesto". Suas antecipações já eram uma premonição do conceito da segunda mutação consonantal como também percebeu a relação do alemão $t$ com o sueco $d$ em dufwa/taube "pombo", Dagh/tag "dia" e que o $t$ do sueco tinha várias correspondências no alemão, por causa da posição na sílaba, ou seja, "Gothicum $\mathrm{T}$ ab initio vocis fermè mutatur in 
Z" twå/zwey "dois", mas "in media voce, vel in calce fermè transit in D", pant/pffand "penhor, garantia", "vel in Germinum S", slott/schloß "castelo". A ideia da mutação consonantal também apareceu no gramático dinamarquês Eric Pontoppidan em 1663, que elucidou a mudança do $c$ para $h$ em palavras como collum/hals "pescoço", cornu/horn "chifre", etc (p. 111).

Após as obras citadas, houve uma grande pausa de mais de um século; entretanto, na metade do século XVIII, o sueco erudito Johan Ihre (1707-1780) publicou o livro De origine linguarum (1759), que parecia tradicional até mesmo com relação ao método etimológico do século XVII. No dicionário publicado em 1769 intitulado Glossarium Suiogothicum que, segundo Rieschel (2002a), é uma sequência da obra de Schröder, Ihre fornece traduções e explicações latinas com paralelos em dinamarquês e islandês e até mesmo em sua introdução há cognatos lexicais tirados de línguas como celta e iraniano; porém, mesmo com algumas etimologias boas e promissoras, há muitos erros etimológicos e simplificações de relação, como, por exemplo, a relação entre $t$ (sueco) e I (latim) no cognato tunga/lingua "língua". Ele também cria correspondências entre as letras do sueco e do latim, que apresentam correspondências com o desenvolvimento fonológico que futuramente seria conhecido como a segunda mutação consonantal, como "t por d", "h por k", "g por h", mas não faz nenhuma conexão sistemática. O autor conclui que, apesar do relativo sucesso em realizar etimologias naquele período, não há quase nenhum progresso metodológico e teórico do trabalho do século XVII de Schröder, pois ele se preocupa apenas com a grafia e não com as sistematizações fonéticas ou por qualquer medida de plausibilidade fonética, mesmo com o reconhecimento da relevância fonética para os estudos etimológicos em um período anterior referida, por exemplo, por Pontoppidan (1663) e também com a ênfase dada à fonética na enciclopédia de Diderot (1750-1772) no artigo Étymologie, alguns anos antes de Ihre. Mesmo que Rask não tenha dado tanta consideração ao trabalho de Ihre, Rischel afirma que as descobertas dele foram, de fato, 
de importância direta para o século XIX, inclusive para o próprio Rask (p. 111-112).

Teleman (2002) também afirma que no período entre o século XVI ao XVIII a palavra "etimologia" tinha dois sentidos. Um deles tinha relação com a estrutura da palavra, que é a parte flexional da palavra nas gramáticas atuais; o outro tinha a ver com o background histórico da palavra e sua relação com as outras línguas (p. 1382). O autor cita o "princípio etimológico" que, junto com o "princípio alfabético", "princípio de uso", "princípio do gênio da língua" e "princípio da desambiguação", era utilizado a favor do "princípio da padronização" como base para o estabelecimento de normas de ortografia (TELEMAN, 2002 p. 13801381).

O "princípio etimológico", de acordo com Teleman (2002, p. 1382), era primeiramente utilizado para fornecer argumentos para que as palavras fossem grafadas da mesma maneira quando for um afixo em derivações ou um lexema independente. Cita Syv (1663, 1685), que iguala a derivação com a flexão, e Laurel (1750), que tentou manter uma ortografia de certos sufixos flexionais de maneira uniforme, apesar da variação na pronunciação interligada foneticamente, por exemplo, para ele todos os verbos fracos deveriam ser grafados em -de (p. 1391). Nesse caso, o "princípio etimológico" dificilmente é separado do "princípio do gênio da língua". Esse princípio, embora seja de noção muito vaga, é entendido como sendo a natureza da língua como uma norma para a padronização; grosso modo, isso corresponde à sua gramática básica e, para seguir tal princípio, ortografias e formas de palavras duvidosas deveriam ser padronizadas de acordo com essas regras básicas. Syv acreditava que a escrita correta era aquela de acordo com as "regras e qualidades" da língua (TELEMAN, p. 1382). 


\subsubsection{Rasmus Rask}

\subsubsection{Algumas considerações sobre o capítulo Etimologia de Rasmus Rask (Om Etymologien overhovedet ${ }^{9}$ )}

Para Viaro (2011, p. 64), as ideias mais revolucionárias para o estabelecimento das etimologias científicas se devem a Rasmus Rask (1787 - 1832). O linguista dinamarquês contribuiu mais evidentemente para um rigor na utilização dos dados fornecidos pelas línguas, o que posteriormente seria assumido pela Linguística alemã (p. 71). Segundo Rischel (2002b), o método de Rask era uma complexa especulação que poderia ser resumida em dois objetivos inter-relacionados: a) apresentar a gramática e a fonologia no modo apropriado e b) posicionar a língua em sua relação apropriada com as outras línguas. Com esse estudo, estabeleceu virtualmente alguns dos campos atuais do estudo da linguística sistemática e comparativa (p. 124). A sua principal obra é a Undersögelse om det gamle Nordiske eller Islandske Sprogs Oprindelse ${ }^{10}$ de 1818, que foi premiado pela Academia Real Dinamarquesa de Ciências num concurso sobre a origem das línguas escandinavas. O objetivo de sua obra era identificar a origem do antigo nórdico ao compará-lo com outras línguas (extintas, mas documentadas ou ainda existentes) e tal conceito de "origem" não remetia à reconstrução, mas implicava que era possível apontar para uma outra língua conhecida como sendo a fonte de outras línguas conhecidas. No final da introdução, Rask (1818) afirma que não é possível descobrir a origem das línguas por meio de "raciocínio isolado", pois as regras não nos dizem como descobrir, mas sim quais são as propriedades que um idioma deve ter para ser a fonte do outro, ou seja, servem apenas como "pedras-de-toque". O único modo de encontrar a resposta para isso é por meio da comparação envolvendo línguas próximas (p. 10).

\footnotetext{
9 Trad nossa: sobre a Etimologia no geral

10 Trad nossa: investigação sobre a origem da antiga língua nórdica ou islandesa
} 
Segundo Rischel (2002b), a obra não teve tanta relevância nos movimentos posteriores de reconstrução do Indo-Europeu, porque o sânscrito não foi incluído no leque de idiomas utilizados na comparação; por outro lado, o escopo definido de sua tarefa permitiu que ele realizasse comparações mais aguçadas entre as línguas europeias, o que talvez não teria sido possível com a presença do sânscrito, tanto com relação aos cognatos lexicais quanto aos gramaticais (p. 125).

Rask afirma que não podemos culpar os gregos e romanos por não terem estudado a Etimologia, pois eles não tinham nenhuma noção sobre ela e tampouco havia predecessores que teriam deixado dados para trabalho e classificação. Para estudar etimologia são necessários tanto uma considerável intuição sobre todas as partes e cantos da língua (Indsigt $i$ alle Dele og Kroge af Sproget selv) em questão quanto uma extensiva familiaridade com as línguas relacionadas e com as línguas ancestrais, das quais é possível colher informações. As línguas ancestrais (Stammesprog) da Grécia e da Itália, entretanto, eram pouco conhecidas aos antigos, porque não havia significantes resquícios escritos (betydelige skrevne Lævninger) naquele período disponível a eles (p. 12)

$\mathrm{Na}$ obra Rask afirma que o etimólogo pode utilizar seus conhecimentos em línguas estrangeiras e sem uma competência nas línguas aparentadas o estudo etimológico seria fútil; e este é o principal erro no estudo da Etimologia pelos antigos: eles conheciam muito pouco ou nada sobre outras línguas, mas mesmo assim queriam realizar derivações a qualquer custo. Portanto, o etimólogo, equipado com tais conhecimentos, deveria se abster de derivar palavras de toda uma classe de línguas e, por isso, nunca afirmar que uma palavra é cita, sármata, gótica, cimbriana, céltica, etc. (p. 31). A respeito das semelhanças das línguas, Rask afirma que uma língua pode ter muitas semelhanças com uma outra tanto no vocabulário quanto em seu mecanismo e, mesmo assim, pode ser quase impossível descobrir a mínima concordância entre elas ao estudar um trecho de um texto 
traduzido e uma para a outra. Dessa maneira, é inapropriado tirar conclusões a respeito da concordância entre línguas desconhecidas com base nas traduções do Pai Nosso, como se tem feito há muito tempo, e como Adelund novamente sustentou ${ }^{11}$ (p. 37).

Ele julga necessário conhecer bem a língua para fazer etimologia como qualquer outro objeto de estudo e, para isso, não existe nenhum atalho (Gjenvej). Afirma que diferentes pontos de vista tomados por vários estudiosos ao olhar para um único objeto, que duas línguas diferentes têm, e também os diferentes modos em que as línguas apresentam características exatamente equivalentes, podem facilmente cegar aquele que não tem nenhum entendimento tanto nas estruturas das línguas (Sprogenes Bygning) quanto em suas essências mais íntimas (inderste Væsen) (p. 37).

Outros exemplos fornecidos por Rask para justificar que o etimólogo (Etymologen) tem que utilizar seus conhecimentos de línguas estrangeiras para seu próprio benefício, pois sem um entendimentosobre as línguas relacionadas é inútil (forgjæves) se dedicar à análise de línguas, são das palavras francesas vent "vento", nuit "noite" e sel "sal". Ele afirma que essas palavras, assim como outras que se tornaram irreconhecidas, e que seriam ainda mais se a ortografia francesa fosse mais adaptada à pronúncia, servem como uma advertência para que os estudantes das línguas sejam mais cautelosos em não condenar todas as semelhanças ou derivações como simples casos "estranhos ou engraçados" (Grillenfængeri) apenas porque nem todas as letras são parecidas nas palavras que se quer comparar e esclarecer. E, portanto, se aceitar (tilstaar) que essas três palavras são de origem latina, então não se poderá negar uma relação com ventus, nox (nocte) e sal e islandês vindur, nótt (alemão Nacht) e salt. Segundo ele, essa despreocupação era um erro na etimologia antiga (Gamles Etymologi) (p. 31).

11 Referência à obra Mithridates, oder allgemeine Sprachenkunde mit dem Vater Unser als Sprachprobe in bey nahe fünfhundert Sprachen und Mundarten (1806). 
No mesmo parágrafo ele também argumenta que apenas por meio uma investigação mais detalhada (nærmere Undersögelse) é possível saber se a semelhança entre várias palavras é fruto de um parentesco primitivo (oprindeligt Slægtskab) ou de de empréstimo em tempos posteriores (Laan i senere Tider) (p. 30).

O "esclarecedor das línguas" (Sprogforklaren), utilizado por Rask como sinônimo de etimólogo, equipado com tais conhecimentos, deve evitar deduções que indicam que uma determinada palavra faz parte de toda uma classe de línguas (en hel Sprogklasse) e, por isso, nunca indicar uma palavra como cita, sármata, gótica, címbrica ou celta, mas especificar claramente em qual ou quais línguas ela se encontra. Ele critica tais termos, pois, por experiência, foram na maioria dos casos inventados para embelezar (besmykke) uma opinião preconcebida (forudfattet Mening) de uma maneira que fique difícil de refutá-la, uma vez que não se sabe em qual língua ou em que tipo de língua se deve procurar a palavra em suspeita ou talvez para ganhar reputação por meio de erudição junto aos ignorantes ( $p .31-32$ )

Independente de quão misturadas duas línguas possam ser, Rask afirma que caso haja semelhança de vocabulários mais antigos (ældste Ordforrad) em cada uma delas, ou seja, se as primeiras palavras, que são as mais concretas, insubstituíveis e essenciais, forem comuns, tais línguas podem ser dadas como de mesma origem. Por por outro lado, nada se pode concluir das palavras técnicas, de cortesia e de comércio ou das daquelas que se associam às coisas do "outro", ou seja, de palavras provenientes de intercurso social, cultural e atividades de formação, que possam ter sido inseridas tardiamente ao vocabulário mais antigo, pois isso depende de muitas circunstâncias que apenas podem ser conhecidas pela história, ou seja, se os povos simplesmente emprestaram tais palavras ou se as desenvolveram por si próprio ( $p$. 35-36).

Vemos aqui uma distinção clara entre palavras herdadas e empréstimos e a argumentação de que apenas por meio da comparação 
entre línguas e da utilização de outras ciências como a História podemos desvendar qual a origem de uma determinada palavra, ideia que segue a mesma linha de nossa dissertação.

Rask propõe, portanto, evitar etimologias forçadas ou falsas e exemplifica, por exemplo, com o já citado Peder Syv, que explica a palavra Søndag "domingo" como "Sohntag", ou seja, at man da skal forsone sine Synder "que os pecados serão reconciliados" ao invés de remeter a palavra dinamarquesa ao islandês sunnudagr e ao alemão Sonntag, derivados da antiga palavra para "sol" sunna, alemão Sonne (p. 14). Ele também cita casos de palavras herdadas cuja palavra primitiva ou outras correspondentes, que poderiam explicá-la, estão perdidas, por exemplo, din. Kvæg "gado", que correspondente ao antigo islandês kvikr "que vive" (p. 32); nesse exemplo ele não considera que até mesmo seja possível que a palavra Kvæg seja uma derivação de kvikr, ou seja, a inexistência de uma sincronia anterior.

O autor também argumenta casos em que uma palavra é completamente estrangeira e entra na língua acidentalmente, por necessidade ou comodidade, por exemplo, din. Maskine, que vem do ale. Maschine, que vem do fr. machine, que vem do lat. machina e que, por fim, vem do gr. $\mu \eta x a v \eta ́$. Ele também comenta sobre palavras resultantes de uma blindt oversat "tradução cega", ou seja, um caso de decalque, por exemplo, din. Jordbeskrivelse do ale. Erdbeschreibung "geografia". Por fim, ele também cita casos de composição como forma de formação de uma palavra como, por exemplo, kjærkommen "bemvindo", composta de kjærlig "carinhoso" e komme "vir" (p. 32-33). Também encontramos no capítulo sobre etimologia um comentário sobre a semântica da palavra como indício de "boa etimologia". Rask afirma que quando a mesma palavra é encontrada em várias línguas, presume-se que ela pertença à língua na qual a palavra tem o significado mais insubstituível, concreto e geral como, por exemplo, sue. Pojke; din. Paag "menino" provavelmente provém do finlandês pojca "filho" (p. 40), o que é aceito por Hellquist (1922), hoje grafado poika. 


\subsubsection{Alguns exemplos dados por Rasmus Rask suas relações com a Linguística Histórica atual}

Relação entre substantivos da 4 a declinação do latim e da $3 a$ do grego antigo:

Anteriormente afirmamos que Rask atesta que é necessário conhecer bem as línguas para o estudo da Etimologia. Ele exemplifica com a quarta declinação do latim ao afirmar que para muitos ela parece representar uma grande discrepância do grego antigo, mas na verdade, concorda perfeitamente com ele, pois é nada menos do que uma contração da terceira classe do grego (p. 37) ${ }^{12}$. Os substantivos de $3^{a}$ declinação no grego antigo têm temas terminados por uma consoante (maioria), vogais ou ditongos e, para que seja possível reconhecer o tema da palavra, retira-se o -os do genitivo singular.

Rask parece ter percebido por meio da palavra do grego antigo ( $3^{a}$ classe) ixӨús "peixe", que tem a seguinte declinação:

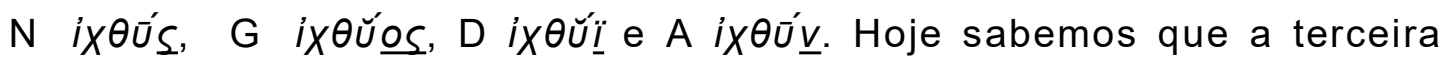
classe com tema vocálico em -ú- (sem contrações) segue tal paradigma: $\mathrm{N}-\varsigma, G-0$, $, \mathrm{D}-\breve{\imath}, \mathrm{A}-v^{13}$ e que o latim tem o seguinte paradigma na quarta classe: N -ŭs, G -ŭs, D -uĩ e A -um. De acordo com Beekes (2011), a terminação de acusativo do IE, que era um simples $-m$, era vocálica após uma consoante $(-m)$, o que resultou no grego a terminação -a; o latim, por sua vez, herdou apenas a nasalização -m (p. 187); compare gr. пó $\delta$-ă "pé" em ac.sing. (< IE *pódm) e latim uoc-em "voz" em ac.sing. (< ${ }^{*}$ wók$^{w}{ }^{w}$ ) (FORTSON IV, 2004, p. 104).

Rask se direcionava por meio das classes das declinações que existiam em seu período; no entanto, hoje sabemos que a quarta classe

12 F. Eks. den fjerde Dekl. i Latinen synes at være en stor Afvigelse fra Græsken, men stemmer dog fuldkommen overens dermed, da den er hverken mer eller mindre end en Sammendragelse af den tredie [...]

13 Os temas em consoante terão uma terminação de acusativo -ă. Exemplo de uma palavra com tema em -r пати́ 
do latim reflete os substantivos de tema em - $u$ do IE (considerado por Beekes como um substantivo de tema consonantal).

Fortson IV (2004) também afirma que tradicionalmente os substantivos atemáticos, que têm tema terminado em consoante, eram diferenciados daqueles com tema em - $u$ ou $-i$, mas essa diferenciação é desnecessária porque mascara o comportamento fundamentalmente idêntico desses dois grupos frente aos substantivos temáticos (com tema em -O-).

Com referência à formação dos temas nominais atemáticos, mais especificamente às classes de acento e ablaut, os substantivos atemáticos têm terminações adicionadas diretamente na raiz ou no sufixo sem a intervenção de uma vogal temática (p. 103) e consistem em três partes (raiz, sufixo e terminação), que podem se apresentar em diferentes graus de ablaut, dependendo principalmente da posição do acento, que pode cair em qualquer um desses três morfemas. De acordo com a teoria padrão, em qualquer forma de caso dada de um substantivo atemático, os morfemas átonos aparecem no grau zero, enquanto os morfemas tônicos em um grau mais forte que o zero: com vogal, geralmente $e$, mas também o ( $p$. 107). Também é possível ocorrer derivação interna (p. 110)

A respeito dos sufixos derivacionais atemáticos, que também fazem parte da formação dos temas nominais atemáticos, os sufixos mais prominentes terminavam em $n, r, s$, e $t$, formando assim tema em $n$, tema em -r, etc. Com relevância ao caso citado acima sobre Rask, há os temas em - $i$ e - $u$ que se formaram por conta do sufixo *-i- e *-u-, respectivamente, no grau zero $e^{*}$-ei $e^{*}$-eu no grau pleno. (p. 112-113).

Os substantivos de tema em $-u-$, como os de tema em -i-, são considerados consonantais porque o * $i$ é uma forma vocálica do glide * $y$ (grau zero), com grau pleno sendo -ey, igualmente com ${ }^{*} u$, que é forma vocálica de * $w$ (grau zero) e tem grau pleno em -ew. Além do mais, suas terminações se comportam como aqueles de tema em consoantes, compare a terminação de instrumental -bhi em todos os temas, menos 
em -o- (cf. Fortson IV, p. 113 e Sihler, 1995, p. 248 para visualizar as diferenças). Sihler (1995) também atesta que os temas em -i e -u são, na verdade temas -i/-ey/-oy/-ēy e $-u /-e w /-o w /-\bar{e} w$, respectivamente; além do mais, essa ordem de formas-tema é paralela aos temas em - $n$ e $-r$, mas a distribuição de graus é bastante diferente (p. 249).

Vejamos a tabela das formas no singular, de Sihler (p. 248):

\begin{tabular}{|c|c|c|c|c|c|}
\hline Stems: & Cons. & a-stems & $\mathrm{eH}_{2}$-stems & $i$-stems & $u$-stems \\
\hline Nom. & $-5,-0$ & $-0-5$ & $-e H_{2}-\theta$ & $-i-s$ & $-\mathrm{u}-\mathrm{s}$ \\
\hline Voc. & -0 & $-e-\theta$ & $-\mathrm{eH}_{2}-\theta$ & $-c y-0$ & -ew-0 \\
\hline Acc. & $-m$ & $-0-m$ & $-\mathrm{cH}_{2}-\mathrm{m}$ & $-i-m$ & $-\mathrm{u}-\mathrm{m}$ \\
\hline neut. & -0 & $-0-m$ & - & $-i=0$ & $-u-0$ \\
\hline Instr. & $\begin{array}{l}\text {-bhi, -mi } \\
-(e) H_{1}\end{array}$ & $-0-H_{1},-e-H_{1}$ & $\begin{array}{l}-\mathrm{eH}_{2}-\mathrm{bhi} \\
-\mathrm{eH}_{2}-\mathrm{ell}_{1} ?\end{array}$ & $\begin{array}{l}-\mathrm{i}-\mathrm{bhi} \\
-\mathrm{i}-\mathrm{HI}_{1}\end{array}$ & $\begin{array}{l}\text {-u-bhi, } \\
-u-H_{1}\end{array}$ \\
\hline Dat. & $-c y$ & $-0 ̄ y$ & $-e H_{2}-c y$ & -ey-ey & -ew-ey \\
\hline Gen. & $\begin{array}{l}-s, \\
-o s,-e s\end{array}$ & $-\bar{i}$, -osyo & $\begin{array}{l}-\mathrm{eH}_{2}-\mathrm{es} \\
-\mathrm{eH}_{2}-\mathrm{os}\end{array}$ & $-0 y-s$ & -ow-s \\
\hline $\begin{array}{l}\text { Abl. } \\
\text { Loc. }\end{array}$ & $\begin{array}{l}=G c n . \\
-i,-\infty\end{array}$ & $\begin{array}{l}-0 \bar{t}, \quad-\bar{a} t \\
-0-y,-c-y\end{array}$ & $\begin{array}{l}=\text { Gen. } \\
-e H_{-i}\end{array}$ & $=$ Gen. & $\begin{array}{l}=\text { Gen. } \\
-\bar{c} w-\rho\end{array}$ \\
\hline
\end{tabular}

Lembremos que a única forma temática ocorre com tema em $o$ e que $\mathrm{O}$ eH2 representa a vogal a posterior. Beekes afirma que esse tema deveria ser um tema consonantal, uma vez que ambas se comportam de maneira parecida (p. 190); ela servia para formar o feminino de adjetivos com tema em -o (p. 199). Fortson IV (2004) declara que esse tema é o sufixo que feminiza - $h_{2}$ adicionado à vogal temática ou simplesmente o grau pleno do sufixo que feminiza (p. 119).

No tocante às terminações dos casos na tabela acima vemos algumas variações no instrumental do tema atemático ao comparar com o tema em -o (cf. Fortson IV, p. 105 para atemática e 114 para temática). O dativo em -ōy, por sua vez, nada mais é, segundo Fortson IV, do que uma contração de *o-ei, portanto o sufixo originalmente seria *-ei, como nas formas dos atemáticos. O nominativo termina em -s e o acusativo em $-m$ (ou * $m$ pós consoantes). Substantivos animados atemáticos que terminam em ressonantes apresentam um grau alongado do tema e perdem o $-s$, por exemplo, 
gr. patếr "pai". De acordo com Fortson IV, é muito aceito que essas formas de singular originalmente tinham um grau pleno mais * $-s$, e que uma mudança sonora (Lei de Szemerényi) ocorreu no IE, fazendo com que o -s sofresse apócope em compensação ao alongamento da vogal: *ph ter-s > ph ${ }_{2} t \bar{r}$ (p. 104). De acordo com Beekes (2011), a classe temática em -o ocupa uma posição especial porque têm os temas como vogais (os temas em -i e - $u$ devem ser vistos como temas consonantais), não há mutações como ocorrem com as atemáticas e têm terminações especiais (p. 211).

Com relação aos temas, percebemos que onde há grau zero na forma com tema em o e, por isso o tema fica em $o$, temos os temas $i$ e $u$ nas formas com temas $i$ e $u$, ao passo que quando há o grau pleno no tema em $o$, ou seja, o tema fica em e, temos -ey e -ew nas formas com temas em $i$ ou $u$, respectivamente. Isso quer dizer que a forma em grau zero é apenas a forma vocálica das semivogais y e $w$.

A saber, Fortson IV afirma que a primeira classe do latim, com tema em a, reflete o tema em a do IE (p. 255), que é contraída do -eh; ; a segunda classe, com tema em $u$ (Pr.it. $\left.{ }^{*} O\right)$ reflete a o tema vocálico em o do IE, grupo de masculinos e neutros; a terceira classe dá continuidade tanto aos temas consonantais quanto ao tema em $i$, ao passo que o tema em $u$ origina a quarta declinação. A quinta declinação, por sua vez, não é um tipo herdado, mas uma combinação de várias formações, devido a mudanças sonoras, que vieram a ter um tema em e (p. 255).

Em suma, a única classe temática é a em o; o tema em a é atemática porque a terminação de caso é adicionada diretamente à laringal (p. 119) e a classas de tema em $i$ e $u$ também são porque o $i$ e $u$ são sufixos acrescentados em um grau zero e *-ei e *-eu são formas adicionadas em um grau pleno. A explicação para a não ocorrência de um tema em e se encontra em Beekes (2011, p. 215-216).

Com relação ao grego, a primeira classe, com tema em a, também reflete o tema em -eh, do IE; porém, diferentemente do latim, há 5 subtipos (SIHLER, 1995, p. 266), que não discutiremos aqui. O 
tema em -o reflete o tema em -o do IE (segunda declinação) (SIHLER, 1995, p. 256). O autor também apresenta comparações entre as diferenças de alguns casos entre latim e grego no singular de palavras com este tema (p. 256-259) e com tema em a (p. 266-270). De acordo com Fortson IV, as declinações com tema consonantal são mais simples do que no IE, já que as terminações não sofrem mais mutação vocálica (ablaut) (mas os temas às vezes sofrem, p.ex. kúōn "cachorro", tema kun-) (p. 235). Os substantivos de temas em $u$ entram na terceira classe do grego antigo.

Portanto, Rask afirma que a quarta declinação do latim, dos substantivos terminados em -us (com origem atemática de tema em $u$ ) é nada menos do que uma contração da terceira classe do grego, a qual está atribuída a palavra iX $\Theta \bar{U}_{S}$ (IE $d g^{n} u H-$, de acordo com Beekes, p. 2010, p. 606). Rask percebeu esse fenômeno num período muito anterior a tais estudos e sem a ajuda do sânscrito. Seu único erro foi afirmar que uma é contração da outra; na verdade, são dois processos de mesma origem (palavra de origem atemática com tema em $u$ ), que foram inseridas em classes diferentes em cada uma das línguas.

\section{Mudanças consonantais:}

Rask também contribuiu para mudanças consonantais e vocálicas ao criar sistemáticos estudos entre as línguas, como a troca de vogais (p. ex. a-e, a-o), troca de letras mudas (p.ex., j-g, h-g), troca de letras líquidas (p. ex., r-I, I-n), trocas mútuas de vogais e consoantes (p. ex. a-en, em, i,e-j), trocas mútuas de letras mudas e líquidas (p. ex., $\mathrm{m}-\mathrm{v}, \mathrm{f}, \mathrm{b}, \mathrm{l}-\mathrm{d}, \mathrm{t}$,$) , transposição de letras, incremento de letras no início de$ palavras e inserção de letras ou anexos no fim das palavras (p. 50-54). Segundo Rischel (2002b), essas correspondências são geralmente chamadas de "sound shifts", embora os elementos envolvidos nas comparações genéticas não sejam tipicamente sons (e nem mesmo fonemas), mas símbolos alfabéticos de línguas escritas extintas cujos valores fonéticos são, em princípio, hipotéticos e podem apenas ser 
deduzidos por reconstruções comparativas e internas (p. 125). Rask chamou tais "trocas de letras" de Bogstavovergange. Mas uma de suas demonstrações de correspondências regulares mais ilustres entre elementos de duas línguas como evidência de parentesco é a substituição do sistema de consonantes plosivas que separou o germânico das outras línguas indo-europeias. Rask fornece os seguintes exemplos da transição do grego e latim para o islandês (overgange fra Græsk og Latin til Islandsk) (p. 169):

$\pi$ se transforma em $f$, como em gr. ח\atús e isl. flatur "plano"; $\tau / t$ se transforma em $p$, como em gr. $r u$, lat. tu e isl. pú "tu"; $x / c$ [k] se transforma em $h[\mathrm{x}]$, como lat. cornu e isl. horn

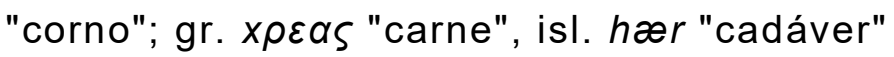

$\delta / d$ se transforma em $t$, como lat. dignus e isl. tíginn "elevado";

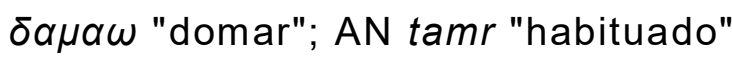

$\gamma / g$ se transforma em $k$, como em gr. yźvos, gena e isl. kyn "descendência, família" e "sexo, raça", respectivamente;

$\varphi / f$ se transforma em $b$, como em gr. $\varphi \varepsilon ́ \rho \omega$, lat. fero e isl. eg ber "eu carrego"

$\theta$ se transforma em $d$, como em gr. $\theta u ́ \rho a$ e ant. isl. dyr "porta", mas também gr. $\theta \varepsilon o s$ e lat. deus

$x$ se transforma em $g$, como em gr. Xútpa "panela" e isl. grýta "panela de barro"

Rask apenas percebe as diferenças por comparação; no entanto, foi por Jakob Grimm que tais correspondências foram conhecidas, as chamadas "Leis de Grimm". Como ele não estudou o sânscrito, não teria como ter exemplos ainda mais próximos do indoeuropeu, mas é a ele que devemos atribuir os primeiros esforços para realização da boa etimologia, ou seja, com base na comparação, 
mesmo com o fato de que ele não tinha quase nenhum trabalho predecessor.

Comentaremos apenas sobre a transformação de $\theta$ para $d$ citada acima. Hoje sabemos, de acordo com as leis fonéticas, que não foi o $\theta$ do grego que se transformou em $d$ no germânico e muito menos em $d$ no latim. Primeiramente, cada forma provém de um vocalismo a partir do IE *dh, compare scr. mádhu "mel, vinho", gr. $\mu \varepsilon \dot{\varepsilon u}$ "vinho", germ. "medu "hidromel" e, consequentemente, ing. mead, isl. mjöður, nor. mjød e ale. Met, mas ele está correto em afirmar a relação entre Өúpa e dyr "porta", apesar de não ser uma transformação, pois ambos provêm do IE *dhwō. Portanto: IE ${ }^{*} d h>$ (scr. $d h \cong$ gr. $\Theta \cong l a t . ~ f / d / b^{14} \cong$ germ. d).

De acordo com as leits fonéticas, o IE * $d h$ vira $f$ no latim quando se encontra no início de sílaba, portanto, foris "porta" e d no germânico, sendo o último um dos processos da Lei de Grimm.

Em segundo lugar, apesar de podermos relacionar o gr. $\theta \mathrm{com}$ o $d$ no germânico, não podemos relacionar com o $d$ do latim pois, como já dito, deveria ser um $f$, por ser inicial.

Portanto, a palavra "deus" provém de uma palavra que inicia $\mathrm{com}^{*} d$ no IE e não ${ }^{*} d h$ (ou $\theta$ como atesta Rask). De acordo com Mallory \& Adams (2006), essa palavra tem origem em IE *deiwós, que é um derivativo de tema em "o" de *dyeu- "céu, dia" e originou palavras que significam "deus" como, por exemplo, Olr. dīa, lit. dievas, hit. sius, skr. devá- e também "demônio", como em av. daēva-, que é um resultado de uma formação religiosa que degradou divindades anteriores para substituí-las por aquelas da nova religião pregada por Zaratustra ( $p$. 408-409); além do AN tivar "deuses" (< *teiwaz) que, segundo os manuscritos medievais, é a designação de um dos grupos de divindades com o singular em Týr, que parece corresponder "à divinda de" nórdica

14 De acordo com Fortson IV (2011, p. 205), ${ }^{*} \mathrm{dh}>$ f quando estava no início de palavra $\left({ }^{*} d h e{ }^{w} h-\right.$ "queimar" > fouēre "manter aquecido"); ${ }^{*} \overline{\mathrm{dh}}>\mathrm{b}$ depois de $u\left({ }^{*} h_{1}\right.$ rudh- "vermelho" > rubēre "enrubescer-se"), $r$ ("uerdho- > uerbum "palavra") ou antes de $r$ *ghladh-ro- > glabro- "liso") ou I ("sth2-dhlo- > stabulum ("stablum) "estábulo") e *dh > d em qualquer lugar no meio da palavra ( ${ }^{*}$ medhio- $>$ lat. medius). 
(REICHERT, 2002, p. 398) e é considerado na antiga literatura escandinava o deus do céu, da guerra e da assembleia e o único deus germânico cujo significado se desenvolve até o indo-europeu (SIMEK, 1983, p. 419). Óđinn parece ter substituído Týr em sua posição préeminente (REICHERT, 2002, p. 398). Na literatura islandesa medieval, tivar aparece no poema Prymskviða (estrofe 14).

Ernout \& Meillet [1932 (20016)] afirmam que a forma temática IE *deiwo designava pelos indo-europeus os seres "celestes" em geral, em oposição ao homem homō que é terrestre por natureza ( $p$ 171). A forma *deiwo- sofreu uma monotongação para *dēu- e em um certo estágio o *w/u sofreu apócope antes de vogais posteriores (no caso o "o"), mas não antes de vogais anteriores; por conta disso, o è se manteve na frente do $u<{ }^{*}$ wo e também o ē se transformou em e; portanto: *deiwo (IE) > ${ }^{*}$ deiw- (proto-itálico) $>{ }^{*}$ dēwos $>{ }^{*}$ deus $>$ deus (de VAAN, 2008, p. 167-168; BEEKES; 2011, p. 78).

A forma *dyeu- que, como já mencionado, também significava "dia", formou lat. dies "dia", Oir. dīa "dia" e gr. éndīos "no meio do dia" (MALLORY \& ADAMS, 2006, p. 301). A partir de *dyēus pḥatếr "pai do céu" também surgiram formações como lat. Jupiter, gr. Zeus patếr, skr. dyáuṣ pitā e também o adjetivo derivado *diwyós "divino" (lat. dīus, gr. dîos, skr. divyá-) (MALLORY \& ADAMS, 2006, p. 408-409). A forma *d(i)yēus "deus do céu; céu; dia"(que originou *deiwos) provém da raiz *dei- "brilhar", que está relacionada com o AN teitr "feliz, alegre" e gr. déato "é visto" e que deve ter sido primeiramente relacionada com a luminosidade do céu (MALLORY \& ADAMS, 2006, p. 329).

- IE *dei-"brilhar" $\rightarrow{ }^{*}$ dyeu-"céu, dia" $\rightarrow{ }^{*}$ deiwós $>$ "seres celestes" (Oir. dīa $\cong$ lit. dievas $\cong$ hit. sius, skr. devá- $\cong a v$. daēva- "demônio" $\cong$ germ. *teiwaz "deuses" $\cong$ Pit. *deiw[>*dēwos $>{ }^{*}$ deus $>$ lat. deus])

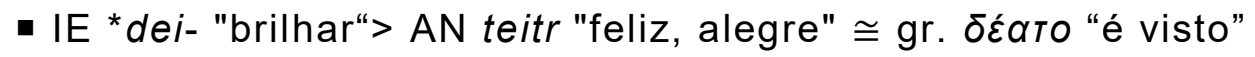




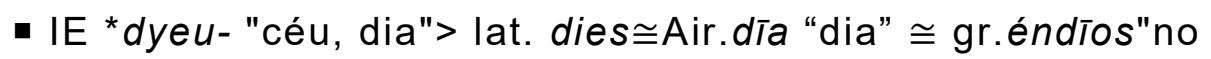
meio do dia"

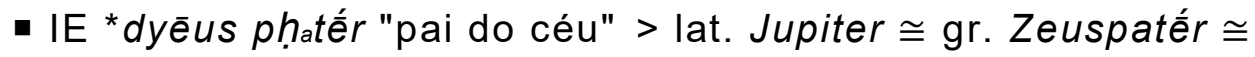
skr.dyáuṣ pitā

De acordo com Ernout \& Meillet [1932 (20016)], tal derivativo antigo "luminoso" está conservado em forma adjetiva em certas expressões consagradas como sub dīuō caelō "sob céu aberto"; em seguida, o "céu luminoso" foi considerado animado e deificado ou como inanimado e passou-se a dizer Deiuos, Deus, Deiua, Dĩua ou deiuom (p. 170).

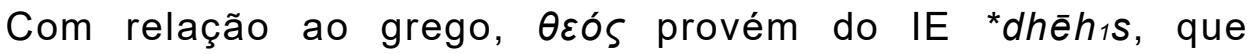
também originou arm. dik "os deuses", mas também é atestado em formas cognatas remanescentes como, por exemplo, lat. fēriae "dia festivo", skr. dhișána- "epíteto de vários deuses" (MALLORY \& ADAMS, 2006, p. 410), ou seja, a semelhança com deus é uma coincidência, assim como teotl em asteca (SIHLER, 1995, p.1). As leis fonéticas indicam que o IE *d se transforma em $\delta$ no grego (SIHLER, 1995, p. 147-148), por exemplo, IE *déḱm, lat. decem, mas got taihun; gr. ठદ́ka.

Mesmo assim, Rask estava um século à frente de seu tempo por conta de seu programa de pesquisas que envolvia a produção de gramáticas descritivas concisas de um grande número de línguas porque ele tinha a convicção de que a descrição sistemática de cada língua em acordo restrito com um conjunto comum de princípios analíticos é um pré-requisito para realizar uma análise interlinguística (RISCHEL, 2002b, p. 126).

\subsubsection{Outros nomes contemporâneos ou posteriores a Rasmus Rask}

Com importância secundária a Rask, há os estudiosos dinamarqueses Jakob Hornemann Bredsdorff (1790-1841) e Niels 
Matthias Petersen (1791-1862). Bredsdorff, junto com Rask, também considerava a influência entre línguas como um fator na mudança linguística, mas uma de suas contribuições mais importantes é a taxonomia das causas internas da mudança linguística; para tal, ele elaborou uma variedade de causas e propôs sugestões que estão muito além do pensamento dessa área no período. Ele também avançou no estudo das runas, pois distinguiu entre as runas do antigo Futhark e do novo Futhark e contribuiu com a primeira leitura essencialmente correta do chifre de Gallehus, objeto arqueológico encontrado na Dinamarca. Petersen escreveu um ensaio sobre as línguas norueguesa, dinamarquesa e sueca em 1829, traduziu as sagas, escreveu a primeira história literária científica dentro da filologia nórdica e questionou a relação histórica entre a língua escrita e falada.

Na Suécia se destaca Carl Fredrik Säve (1812-1876), que se especializou em dialetologia e foi o pupilo favorito de Petersen. Na Noruega, por sua vez, o principal nome é Ivar Aasen, que foi um pesquisador de línguas e se elevou a um alto nível de excelência por conta da aprendizagem dos empreendimentos de Rask. Ele se preocupou com a língua norueguesa que se sucumbiu por conta da norma escrita dinamarquesa e a sua grande descoberta se deve ao fato de que a língua ainda estava muito viva nos dialetos rurais noruegueses e, por conta disso, colocou como objetivo a criação de uma norma escrita com base em tais dialetos, o que levaria ao futuro nynorsk.

Nesse período o feroês, a língua nórdica mais negligenciada, também entra em cena: Venceslaus Ulricus Hammershaimb (1819-1909) publicou exemplares de texto e uma gramática experimental em uma ortografia fortemente de cunho etimológico que ele próprio criou com base na ortografia do islandês (RISCHEL, 2002b, p. 127-129). 


\subsection{A Etimologia e os processos etimológicos na Noruega}

Neste subcapítulo apresentaremos a fragilidade das obras etimológicas em língua norueguesa. Os dicionários etimológicos consultados foram: våre arveord de Bjorvand e Lindeman (2000), Norsk etymologisk ordbok (2013) de Yann de Caprona, Nynorsk etymologisk ordbok (1919) de Alf Torp e o Etymologisk ordbog over det norske og det danske sprog de Hjalmar Falk e Alf Torp (1900-1906). Os não etimológicos foram: Norsk ordbok de Tor Guttu (bokmål moderado), Norsk Riksmålsordbok ${ }^{15}$ (1937-1957) da Det Norske Akademi for Sprog og Litteratur, Bokmålsordboka e Nynorskordboka, ambos da Universidade de Bergen em conjunto com a Språkrådet e, por fim, o Norsk Ordbok 2014 (Nynorsk) da Universidade de Oslo. Todos esses dicionários estão disponíveis online e apenas os dois primeiros são pagos.

O dicionário våre arveord é uma coleção de artigos sobre as palavras norueguesas mais antigas. Estas podem ser herdadas ou palavras que entraram na língua há muito tempo que não são mais vistas como importadas (fremmendord). Como exemplo de verbete:

brøk m. "brutt tall" er et lånord fra mnt. brök(e) m. "brudd" som kommer av germ. *bruki-m. liksom mnl. brueke, nl. breuk, gs. bruki, gfris. breke, breze, fris, brek, geng. bryce, ght. bruh, ty. Bruch. Alle formene hører til et germ. sterkt verb, inf. *brekan- som vi ser i ty. brechen osv., se under brekke. Det dreier seg om et oversettelseslån fra mlat. fractio "brudd, brytning" (eng. fraction "brøk"), jf. frmo. som fraktur, fraksjon.

15 Apesar do termo riksmål ter sido substituído por bokmål a partir de 1929, o termo continuou a ser utilizado para designar a variante escrita mais conservativa, principalmente após 1938, que mantem pontos essenciais da tradição de escrita de 1917. A partir de 1953 o riksmål é normatizado pela Det Norske Akademi for Sprog og Litteratur com esse dicionário.

16 Brøk m. "número quebrado" [fração]é um empréstimo do MBA brök(e) m. "quebrado" que vem do germ. "bruki- m. assim como o m.hol. brueke, hol. breuk, AS bruki, AFris. breque, breze, frís. brek, IA bryce, AAA bruh, Ale. bruch. Todas as formas pertencem ao verbo forte alemão *brekan- (infinitivo), que vemos no Ale. brechen, etc. Consulte brekke. Trata-se de um decalque 
Apesar do raciocínio estar correto, uma vez que brøk é um empréstimo do médio baixo alemão brök(e) que, por sua vez, segundo o dicionário, "vem" do antigo germânico, preferimos desenvolver uma terminologia menos vaga e também aperfeiçoar as etapas sincrônicas. $\mathrm{Na}$ afirmação do verbete dá a entender, portanto, que a palavra do médio baixo alemão veio direto do antigo germânico, o que não poderia ocorrer porque há um período de aproximadamente 1300 anos entre essas duas sincronias. Portanto, isso vai contra os nossos pressupostos $^{17}$ porque temos o objetivo de definir uma nomenclatura sistematizada que seja aplicada tanto ao português quanto ao norueguês, para não falarmos de outras línguas.

No dicionário de Caprona (2013) encontramos muitas inconsistências terminológicas e processuais. Verbete pessimisme18:

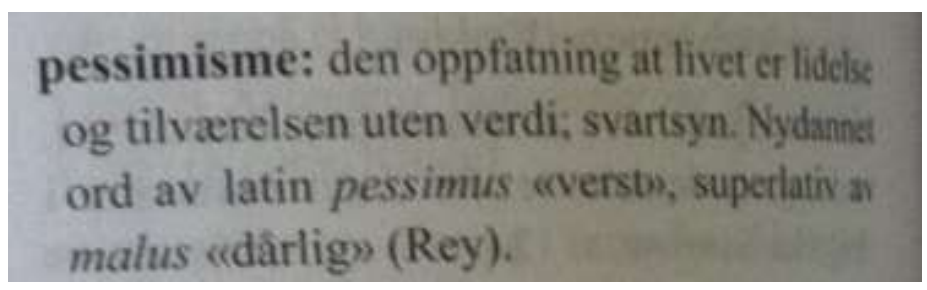

Verbete optativ ${ }^{19}$ :

do latim médio fractio "quebrado, quebra" (ing. fraction "fração"), compare palavras estrangeiras como fraktur, fraksjon.

17 Os pressupostos sobre étimo e origem aqui assumidos derivam de definições utilizadas pelo GMHP e pelo NEHiLP.

18 "Pessimismo: a compreensão de que a vida é sofrimento e a existência não tem valor; svartsyn (sinônimo). Neologismo do latim pessimus "pior", superlativo de malus "ruim" (Rey) (tradução nossa).

19 "Optativo: forma desejada. Do lat. optativus "que expressa um desejo", derivado de optare "desejar, escolher", sem Etimologia certa, que reconhecemos em palavras como adoptere, optere e opsjon (Kluge, E \& M)" (tradução nossa) 


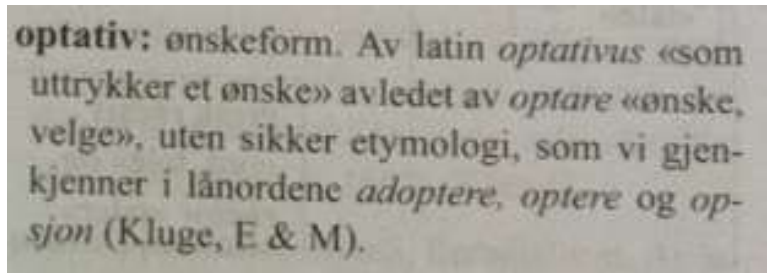

Verbete reaksjonær ${ }^{20}$ :

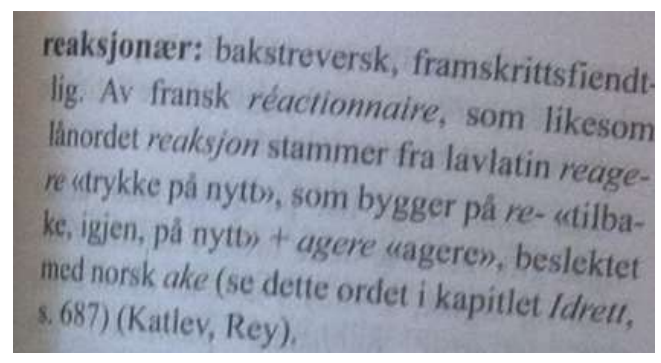

De acordo com o dicionário, a primeira palavra é um neologismo da palavra latina em forma superlativa pessimus "o pior", de malus "mau". O leitor compreende por esse verbete que a palavra foi criada na língua norueguesa; todavia, o LPR afirma que ela tem origem no francês em 1759. O mesmo ocorre com a palavra optativ, mas aqui o autor cita Kluge, E \& M. A palavra é dada como originária do latim optativus "que expressa um desejo", derivado do verbo optare "desejar, escolher", que tem etimologia incerta e é reconhecido em empréstimos como adoptere, optere e opsjon. Percebe-se que nesse caso o autor, na verdade, está buscando a origem da palavra e não o étimo.

No tocante à terceira palavra reaksjonær, ela é dada como av fransk "do francês" réactionnaire que, igualmente ao empréstimo reaksjon, é originária do baixo latim reagere "empurrar de novo". Aqui há dois problemas: falta de terminologia, quer dizer, a preposição av "do" é ambígua pois pode remeter tanto ao étimo quanto à origem, portanto o autor deveria utilizar "de étimo francês". O outro problema é afirmar que ela, assim como a palavra norueguesa reaksjon, deriva do

${ }^{20}$ Reacionário: "bakstreversk", "framskrittsfiendtlig". Do francês réactionnaire, que, assim como o empréstimo reaskjon, deriva do baixo latim reagere "impulsionar novamente", que se formou por meio de re- (de volta, novamente) + agere "agir", relacionado com o norueguês ake (consulta essa palavra no capítulo ldrett, p. 687) (Katlev, Rey) (tradução nossa). 
baixo latim reagere; não seria um problema realizar essa afirmação se ele estivesse falando de sua origem, uma vez que essa palavra se formou por derivação no latim medieval. De acordo com nossos pressupostos, o autor deveria afirmar que reaksjon tem étimo na língua que emprestou para o norueguês, assim como a palavra reaksjonær tem étimo francês; além do mais, que reactio deriva do particípio reactus, que é uma forma que sofreu analogia com o latim actio "execução, realização" ( $\leftarrow$ actus) (PARASCHKEWOW, 2004, p. 292).

Mas no verbete arbeid"21 "trabalho", que tem étimo do médio baixo alemão, o autor realiza um bom procedimento, apenas falta uma boa nomenclatura:

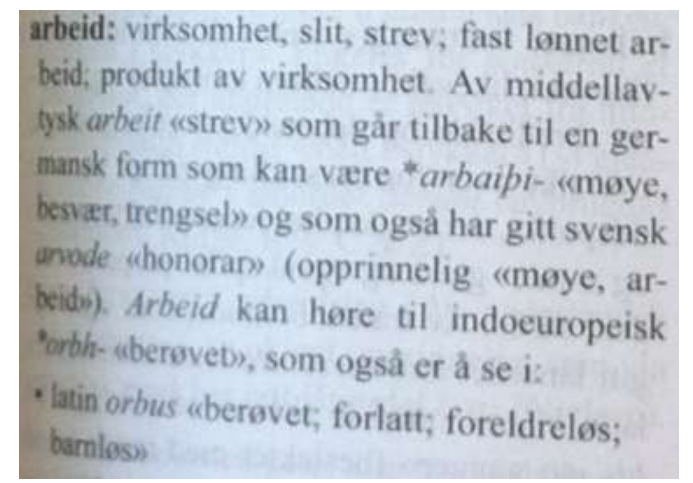

A respeito desses dois últimos dicionários, percebemos que ambos não colocam nem datação e nem o local de quando a palavra foi escrita pela primeira vez.

Exemplo do verbete dust ${ }^{22}$ no dicionário Nynorsk etymologisk ordbok de Alf Torp:

21 Trabalho: atividade, labor, labuta; trabalho com salário fixo; produto de uma atividade. Do médio baixo alemão arbeit "labuta", que remonta à forma germânica que pode ser *arbaipi- "esforço, aflição, incômodo" [...]. Arbeid pode pertencer ao indo-europeu *orbh- "aquilo que é tirado".

22 Dust (batalha em contos folclóricos), antigo nórdico dust "torneio"; do médio baixo alemão dust = médio alto alemão tjost, tjust, que vem do antigo francês joste, juste (francês joûte) "duelo em cavalos", que vem do latim juxta, que vem do latim juxtare "participar de torneio". 


\begin{abstract}
Dust $m$ (dyst, kamp, i folkeviser), gno. dust dystrend, turnering, gsv. diost, dust, da. dyst; fra mnt. dust ds. = mht. tjost, tjust, som er fra gfra. joste, juste (nfr. joute) ridderlig tvekamp. Dette av lat. juxta jevnsides, hvorav mlat. juxtare, turnere.
\end{abstract}

Torp apresenta que a palavra "vem" do antigo nórdico dust, com as formas cognatas diost e dust no antigo sueco e também apresenta a forma dinamarquesa dyst. Além do mais, afirma que a palavra "vem" do médio baixo alemão dust, que "é do" antigo francês joste, juste que, por sua vez, "é do" latim juxta.

Exemplo do verbete Kirke no dicionário Etymologisk ordbog over det norske og det danske sprog de Hjalmar Falk e Alf Torp (19001906):

\footnotetext{
Kirke, sv. kyrka, oldn. kirkja, kyrkja, laant fra ags. cirice, cyrice (eng. church) $=$ osax. kirika (holl. kerk), oht. kiricha (nht. Kirche). Skjønt ordet ikke er paavist i gotisk, maa dog en gotisk stamme ha formidlet dets optagelse fra den græske kirke; sml. det fra gotisk laante oslav.
}

O autor apresenta os cognatos da palavra: sue. kyrka e AN, kirkja ou kyrkja, misturando duas sincronias. Afirma que é um empréstimo do anglo-saxão cirice, cyrice (ing. church); cognatos também do AS kirka, AAA kiricha (ale. Kirche) [...]. Em seguida ele propõe a origem da palavra.

Outra palavra analisada desse dicionário foi arbeide "trabalho". O autor cita as cognatas dinamarquês antigo arbede, arbeid e sueco arbete, portanto ele não divide as sincronias. Afirma, também 
que a palavra é um empréstimo do médio baixo alemão arbeit, como já citado anteriormente.

Em todas essas obras citadas não há uma nomenclatura e nem uma definição do que é o étimo e a origem e também há anacronismos, pois, como exemplificado em arbeide, o antigo dinamarquês não poderia ser um cognato do sueco, uma vez que o primeiro pode ser o étimo do segundo já que o período de tempo entre as duas palavras é enorme.

Com exceção do dicionário de Caprona (2013), nenhum deles inserem uma introdução em que se explica o que se entende por Etimologia. O dicionário de Bjorvand e Lindeman, por exemplo, apenas apresentam um breve escopo do desenvolvimento das línguas germânicas a partir do germânico antigo. Também mostram as mutações consonantais germânicas (lei de Grimm e lei de Verner).

Com relação aos dicionários não etimológicos, apresentamos abaixo suas representações da etimologia. Escolhemos aleatoriamente quatro palavras de origem latina, duas que passaram pelo médio baixo alemão e duas herdadas, das quais uma remonta ao antigo nórdico e a outra é de origem norueguesa:

\section{Meditasjon "meditação":}

- fr. méditation, lat. meditatio; de •meditere (verbo) (Norsk Riksmålsordbok) substantivo verbal latino; meditere (Norsk Ordbok de Tor Guttu)

- do lat.; veja meditere (Bokmålsordboka)

- do lat.; ver meditere (Nynorskordboka)

- do lat. meditatio, de meditera (Norsk Ordbok 2014) 
Naturalisasjon "naturalização":

- fr. naturalisation (Norsk Riksmålsordbok)

- derivação francesa; ver naturalisere (Norsk Ordbok de Tor Guttu)

- Sem etimologia (Bokmålsordboka)

- Não há a palavra (Nynorskordboka)

- Não há a palavra (Norsk Ordbok 2014)

Regiment "regimento":

- ale. Regiment, fr. régiment, do lat. regimentum, forma paralela de regimen, compare regime (Norsk Riksmålsordbok)

- forma paralela francesa, latina de regime (Norsk Ordbok de Tor Guttu)

- do lat. (Bokmålsordboka)

- do lat. «controlar» (Nynorskordboka)

- do mlat. (Norsk Ordbok 2014)

Sedimentasion "sedimentação":

- de sediment (Norsk Riksmålsordbok)

- Não há etimologia (Norsk Ordbok de Tor Guttu)

- Não há palavra (Bokmålsordboka)

- Não há etimologia (Nynorskordboka)

- Não há (Norsk ordbok 2014) 
Desses dicionários apenas o Norsk Riksmålsordbok apresenta um possível caminho da entrada do léxico no riksmål, mesmo que não haja uma nomenclatura adequada como, por exemplo, nas palavras meditasjon e regiment. Os outros, por outro lado, afirmam erroneamente que a palavra veio do latim. O Norsk Ordbok não toma partido se regiment vem do francês ou latim e cita os dois. A respeito da palavra naturalisasjon, o Norsk Riksmålsordbok afirma que vem do francês e o Norsk ordbok, que é uma derivação francesa. Em vista disso, apenas o primeiro propõe de fato uma possível etimologia na língua norueguesa, já que o segundo cita a formação da palavra no francês. Porém, com o elemento lexical sedimentasjon, o dicionário de riksmål se equivoca ao afirmar que sedimentasjon é uma formação de sediment, pois o leitor pode entender que foi uma formação no próprio norueguês.

skje "ocorrer, acontecer":

- médio baixo alemão (ge)schên (Norsk Riksmålsordbok)

- médio baixo alemão (Norsk Ordbok de Tor Guttu)

- baixo alemão (ge)schen (Bokmålsordboka)

- baixo alemão (ge)schen (Nynorskordboka)

- do baixo alemão (ge)schen (Norsk ordbok 2014)

\section{tallerken "prato":}

- médio baixo alemão tallorken, diminutivo em -ken do médio baixo alemão tallôr, teller; dos romanos; comp.. fr. • tailloir, ital. tagliere "tábua de cortar", do verbo fr. tailler, ital. tagliare "cortar" (Norsk Riksmålsordbok)

- médio baixo alemão - diminutivo (compare alemão Teller), do francês tailloir (Norsk Ordbok de Tor Guttu) 
- por meio do médio baixo alemão, do fr. taillor ou it. tagliere "tábua de cortar" (Bokmålsordboka)

- baixo alemão tallorken, diminutivo de tallor, dos romanos, compare fr. tailloir, it. tagliere 'tábua de cortar" (Nynorskordboka)

- do baixo alemão tallorken, dimin. de tallor, do fr. tailloir 'tábua de cortar', til tailler 'cortar' (Norsk ordbok 2014)

No tocante ao verbo skje, todos os dicionários são bem sucintos ao afirmar que veio do médio baixo alemão, o que se diferencia muito do substantivo tallerken, pois esse último empréstimo eles explicam como uma palavra na forma diminutiva do médio baixo alemão. Os dicionários Norsk Riksmålsordbok e Nynorskordboka assumem que a palavra veio dos romanos e sugerem uma comparação com o francês tailloir "prato antigo onde se cortava carne", que é uma derivação de tailler "cortar". Com essa afirmação, os dicionários provavelmente indicam indiretamente que os romanos (falante do francês antigo) trouxeram essa palavra para o mundo dos falantes do médio baixo alemão. O Bokmålsordboka não decide se a palavra vem do francês talloir ou do italiano tagliere "tábua de cozinha". A melhor etimologia é do Norsk Ordbok 2014, pois apresenta os processos de maneira direta, com o possível caminho da palavra e também apresenta a sua derivação na língua francesa.

søknad "aplicação, solicitação escrita":

- não há (Norsk Riksmålsordbok)

- derivado de søke "buscar" (Norsk Ordbok de Tor Guttu)

- de søke (Bokmålsordboka)

- de søke (Nynorskordboka)

- de søkja (Norsk ordbok 2014) 
$\underline{\text { snø "neve": }}$

- não há (Norsk Riksmålsordbok)

- antigo nórdico snjór, snær (Norsk Ordbok de Tor Guttu)

- antigo nórdico snjór, snær (Bokmålsordboka)

- antigo nórdico snjór, snær (Nynorskordboka)

- antigo nórdico snjár, snjór, snær (Norsk ordbok 2014)

Com relação às palavras herdadas, os dicionários apenas citam a forma delas no antigo nórdico, como é o caso de snø ou apresentam a derivação na própria língua norueguesa, como é o caso de søknad.

Além da desorganização e da falta de nomenclaturas (étimo ou origem), nenhum desses dicionários apresentam a datação e o terminus a quo, que são de extrema importância para a deliberação da etimologia de uma determinada palavra.

Um outro ponto negativo atribuído a esses dicionários é a falta de um método etimológico ou de até mesmo uma explicação em que se explica o que é a Etimologia. Apenas o dicionário de Caprona (2013) realiza uma introdução sobre os processos etimológicos e define o que é a Etimologia:

A Etimologia é a ciência que estuda a descendência, origem, as condições de parentesco e a história do significado das palavras. Ela é utilizada também para esclarecer o significado básico de uma palavra [...] (p. 15)

Ainda na introdução, o autor mostra qual é o objetivo do dicionário: rastrear a origem de uma palavra dentro de um determinado tema. Cada tema é tratado em um capítulo e dentro dele são encontradas as palavras mais comuns. $O$ autor também esclarece que 
as explicações são de fácil compreensão e para serem lidas como uma "boa estória". Se houver várias hipóteses para a etimologia de uma determinada palavra, ele escolherá a melhor ou comentará as diferentes propostas através das fontes mais seguras como, por exemplo, Bjorvand \& Lindeman, Kluge, Rey, Ernoult \& Meillet e Chantraine. Além disso, o autor apresenta as diferentes formas que uma palavra pode ter para compreender melhor sua etimologia, por exemplo, a forma genitiva таıঠós "da criança" é mais facilmente relacionada com pedagog e pediatri do que a forma nominativa maĩs "criança". De acordo com o autor, para deixar o texto mais vivo, ele também explica a origem de expressões, topônimos ou nomes ligados a uma determinada palavra e adiciona fatos e anedotas e, também, afirma que uma parte importante da Etimologia é comparar uma palavra com suas cognatas da própria ou de outra língua e, por isso, também são realizadas, quando necessárias comparações com línguas como albanês, armênio e hitita, quer dizer, o autor entende aqui Etimologia como "origem" da palavra.

Por fim, o autor afirma que poderá haver explicações para cada tipo de leitor e que estes poderão escolher o que acham mais interessante: 1. descobrir o significado original, 2. por quais meios a palavra chegou no norueguês, 3. os desenvolvimentos de significado, 4. palavras cognatas em outros idiomas e eventuais palavras que 0 norueguês emprestou, 5. extensão em parentesco e 6. fatos/anedotas histórico-culturais ligadas à palavra em questão.

Porém, ao analisarmos as palavras escolhidas aleatoriamente acima, essas informações não foram passadas de maneira satisfatória. Da maneira que a palavra é apresentada, o leitor pensa que as palavras pessimisme e optativ se formaram no norueguês e, também, afirmar que a palavra norueguesa reaksjon é uma derivação do latim reagere está muito aquém do que propõe o ponto 2 .

Percebemos que o dicionário tem o objetivo de analisar a origem da palavra e não o étimo. No verbete kosmetikk "cosmético", por exemplo, que é citado de Katlev, Onions, Pfeifer, Rey e Chantraine, 


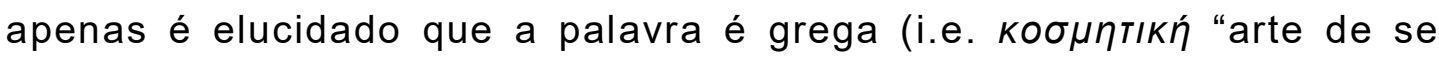

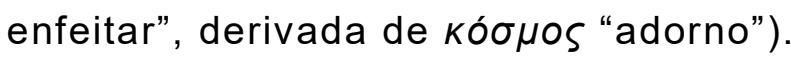

O dicionário, portanto, falha em não apresentar um método etimológico. Concluímos que o dicionário parece ter uma intenção muito mais de organizar hipóteses etimológicas já existentes para cada palavra (no âmbito da origem) do que, de fato, estudar e propor um método etimológico para as palavras norueguesas.

Em seguida o dicionário apresenta as leis fonéticas $e$ a genealogia das línguas, semelhante ao que Bjorvand \& Lindeman fazem na introdução do dicionário våre arveord.

Com relação a obras que tratam da língua norueguesa diacronicamente e não lexicográficas, não encontramos nenhuma que propusesse um método etimológico.

Por conta da falta de um método etimológico, justifica-se a utilização das propostas do NEHiLP no estudo de palavras norueguesas.

\subsection{Os dialetos e as duas formas oficiais de escrita do norueguês}

\subsubsection{Os dialetos}

\subsubsection{Introdução aos dialetos e às duas formas oficiais}

Neste capítulo demonstraremos como as duas variantes escritas norueguesas surgiram em um momento que só havia basicamente uma escrita no país (a escrita dinamarquesa), embora houvesse substratos dialetais em discurso direto para retratar o camponês norueguês ou até mesmo textos escritos em dialeto. Tal separação é importante para podermos indicar o terminus a quo e os étimos em cada uma dessas duas variantes. Apresentaremos as mudanças formais e ideológicas que contribuíram para que pudesse ocorrer essa separação, 
mas não nos prolongaremos nas mudanças ortográficas posteriores, realizadas em um momento em que a Noruega já havia oficializado essas duas variantes escritas.

Realizaremos aqui um breve comentário sobre o porquê da existência de duas línguas oficiais e tantos dialetos, todos de base germânica. Inicialmente comentaremos sobre os dialetos e por quais características eles são classificados. Em seguida, para motivos metodológicos referente à dissertação, apresentaremos as razões políticas e ideológicas e as mudanças formais que fizeram com que uma língua escrita, basicamente dinamarquesa, existente a partir do século XVI até o fim do século XIX, deu lugar a duas formas escritas, o riksmål e o landsmål que, num momento posterior, passariam a ser chamados de bokmål e o nynorsk. O surgimento dessas duas formas oficiais se deu em todo o século XIX e os debates entre os apoiadores de cada uma das vertentes é conhecido como den norske språkstriden "a guerra de idiomas norueguesa".

$\mathrm{Na}$ realidade, atualmente a Noruega tem três idiomas oficiais: os já citados bokmål e nynorsk, mas também o sami (subdividido em sami do sul, sami de Lule, e sami do norte). Os dois primeiros têm origens distintas, mas ambos são germânicos e de uso escrito; o terceiro, por sua vez, tem origem fino-ugriana e utilizado, em sua maior parte, nas regiões ao norte da Noruega como Finnmark e Nord-Troms.

Além dos idiomas oficiais, a Noruega tem centenas de dialetos. Apesar de haver algumas formulações de escrita para eles, são restritos à fala, já as duas línguas oficiais são utilizadas por documentos do Estado e pela mídia. De acordo com Jahr (1990, p. 7), a geografia norueguesa teve uma grande importância na formação dos dialetos, uma vez que os fiordes separavam e o mar unia as pessoas na região costeira aos tempos antigos; na parte continental, entretanto, havia altas montanhas, amplos planaltos e florestas, e grandes distâncias que criaram um bloqueio para o transporte e comunicação entre os habitantes de cada aldeia.

Outra causa é a utilização do idioma dinamarquês como língua oficial escrita do século XVI até início do XIX. Em 1814, quando o domínio dinamarquês acabou, as pessoas reconheciam apenas seus dialetos como $o$ 
verdadeiro norueguês e queriam que os alunos não utilizassem uma forma normatizada quando fossem para a escola. Esse foi o motivo mais importante para que o Odelstinget do Stortinget ${ }^{23}$ em 1878 determinasse que os alunos deveriam ter aulas em seus próprios dialetos. Em 1915 e 1917 esse princípio veio para as leis escolares e lá ainda se encontra (p. 8-9). No parágrafo $\S 5$ que trata das formas de fala no ensino fundamental do capítulo 2 da Lei sobre o ensino fundamental e médio, ou também conhecida como Lei da aprendizagem, determina-se:

"Nas aulas orais os alunos e o pessoal de ensino decidem por si próprios quais formas de fala utilizarão" (tradução nossa).

A importância dos dialetos na Noruega vai de encontro à maioria dos outros países europeus, que veem seu uso como algo rude e típico de pessoas não estudadas. Jahr (1990) descreve tal importância da seguinte maneira:

Na Noruega ser de um local é muito importante [...]. Identificar-se com o local de que se vem é importante para muitos noruegueses. Dessa maneira, o uso do dialeto está intimamente ligado a isso. Ele conta aos outros de onde viemos e faz com que sempre saibamos onde o lar, de fato, se encontra" (p. 7) (tradução nossa)

\subsubsection{Exemplos de dois dialetos}

Como exemplo de um dialeto que deve suas características à geografia por conta do isolamento temos o vallemål ${ }^{24}$, dialeto do município de Valle, na região Sørlandet e que se encontra no meio de Setesdal, que é um vale e também um distrito no condado de Aust-Agder. Por conta de tal isolamento, ele tem muitas características particulares, que podem ser conservação do antigo nórdico ou um desenvolvimento à parte e exclusivo:

a) preposições regidas por dativo, inexistente na maioria dos dialetos noruegueses; muitas delas apresentam uma conservação do antigo nórdico, p. ex., frå, AN frá "de"; av, AN af "de"; sjå, AN hjá "junto de", etc.

\footnotetext{
23 Stortinget é o parlamento norueguês. O Odelstinget era uma de suas câmaras.

24 www.vallemal.no
} 
b) ditongação ocasionada por fatores fonológicos: $i$ se transforma em í, pronunciado [æj]; e torna-se é, pronunciado [ej]; y torna-se $\dot{y}$, pronunciado [uj]; o torna-se ó, pronunciado [ow]; $u$ torna-se ú, pronunciado [ew] e $\varnothing$, por fim, torna-se $\varnothing$, pronunciado [øj]. Alguns ditongos ocorrem apenas nessa região, por isso não é uma conservação do antigo nórdico, p. ex., AN nýr [y:] "novo", IS nýr [i:], mas no dialeto ný'e (甘j); AN hví [i:] "por que", IS hví [i:], mas no dialeto kví [ej].

c) declinação de caso dativo na forma definida (TORP, 1990, p. 36)

- além da flexão de gênero do número um, ou seja, en, ei, ett, em masculino, feminino e neutro, respectivamente; também se flexionam, como no antigo nórdico, os números dois, três e o quatro, p. ex: no masculino tvei, trí (pronuncia ['trej]), fjouri hesta; AN tveir, prír, fjórir hestar, "dois, três, quatro cavalos"; no feminino tvæ, trjå, fjóre/fjóra (pronuncia-se [fjowre/fjowra]) bǿka, AN tvær, prjár, fjórar bækur "dois, três, quatro livros e no neutro tvau, trjú, fjågó (pronuncia ['fjogow]) hús, AN tvau, prjú, fjögur hús "uma, duas, três casas".

Por outro lado, como exemplo de dialeto também influenciado pela geografia, mas que não se manteve isolado e sim em contato, há o dialeto da cidade de Bergen. De acordo com estudiosos do dialeto (NESSE, 2003, p. 79), o bergensk se simplificou ou sofreu modificações morfológicas por conta do contato com o médio baixo-alemão no período da Liga Hanseática, que o influenciou com suas características e fez com que ficasse muito diferente dos dialetos das cidades ao seu redor. Algumas características: 
a) ausência do morfema de plural no predicativo do sujeito:

\begin{tabular}{|llll|}
\hline Bergensk: & di & $\mathrm{e}^{\prime}$ & avhengig \\
\hline & 3pp. & Verbo & $\mathrm{Q}^{25}$ (- morf.pl.) \\
\hline $\begin{array}{l}\text { Forma não } \\
\text { marcada: }\end{array}$ & de & er & avhengige \\
\hline & 3pp. & Verbo & Q (+ morf.pl.) \\
\hline Tradução: & eles & são & dependentes \\
\hline
\end{tabular}

b) apenas os gêneros comum e neutro ao invés de masculino, feminino e neutro. Na gramática normativa, tradicionalmente, denominados "artigos" e "pronomes adjetivos". Em todos os dialetos o den representa masculinos e femininos e o det representa os neutros:

\begin{tabular}{|llll|}
\hline Bergensk: & den & første & natten \\
\hline & $\left(\right.$ Det $\left.^{26} . \mathrm{M} / \mathrm{F}\right)$ & $(\mathrm{Q})$ & $\begin{array}{l}\text { (subs. gênero } \\
\text { comum) }\end{array}$ \\
\hline $\begin{array}{l}\text { Forma não } \\
\text { marcada: }\end{array}$ & den & første & natta \\
\hline & (Det. M/F) & $(\mathrm{Q})$ & $\begin{array}{l}\text { (subs. gênero } \\
\text { femin.) }\end{array}$ \\
\hline Tradução: & $a$ & primeira & noite \\
\hline
\end{tabular}

O substantivo natt, que é feminino em quase todos os dialetos, se comporta da mesma maneira que o masculino.

${ }^{25}$ qualificador
${ }^{26}$ determinante 
c) morfema -et ao invés de -a como marcador de pretérito dos verbos fracos da primeira conjugação:

\begin{tabular}{|c|c|c|c|c|}
\hline Bergensk: & me & snakket & om & jenten \\
\hline & $2 p p$. & verb.pret. & preposição & $\begin{array}{l}\text { (gênero } \\
\text { comum) }\end{array}$ \\
\hline
\end{tabular}

\begin{tabular}{lllll}
\hline Forma não & vi & snakka
\end{tabular}

marcada:

\begin{tabular}{|c|c|c|c|c|}
\hline & 2pp. & verb.pret. & preposição & $\begin{array}{l}\text { (subs. } \\
\text { gênero } \\
\text { femin.) }\end{array}$ \\
\hline Tradução: & nós & falamos & sobre & a menina \\
\hline
\end{tabular}

d) marcador de infinitivo te em vez de å:

\begin{tabular}{|llll|l|}
\hline Bergensk: & te & bruke & beinene & \multicolumn{2}{l|}{ sine } \\
& marc.infinitivo & verbo.inf. & subst.det.pl. & pron.poss. \\
\hline $\begin{array}{l}\text { Forma não } \\
\text { marcada: }\end{array}$ & å & bruke & beinene & sine \\
\hline & marc.infinitivo & verbo.inf & subst.det.pl. & pron.poss. \\
\hline Tradução: & $\varnothing$ & usar & as pernas & suas \\
\hline
\end{tabular}

Os dialetos são divididos grosso modo em quatro categorias baseadas na posição geográfica: østnorsk, vestnorsk (sørlandsk incluso), trøndersk (Nordmøre incluso) e nordnorsk (JAHR, 1990, p. 10). Muitas são as 
características e combinações das mesmas que atribuem um determinado dialeto a uma dessas categorias e muitas dessas características podem existir em mais de uma categoria, como uma forma de continuum.

\subsubsection{Algumas características gerais dos dialetos}

\section{A) Tom:}

Os dialetos noruegueses são tonais e podem ser divididos com base em dois tonemas: høytone (tom alto) e lavtone (tom baixo). O høytone se refere a um tom alto na primeira sílaba da palavra, ao passo que o tom na próxima sílaba é baixo; com relação ao lavtone, o processo é ao contrário. Essas duas categorias são separadas geograficamente com base na região de Trøndelag (centro da Noruega e onde está a categoria trøndersk): ao norte e ao oeste, como também em Sørlandet, estão os dialetos com høytone e ao leste e na própria região de Trøndelag há o lavtone. Isso quer dizer que os dois tonemas noruegueses são pronunciados diferentemente nesses dois cortes geográficos (HANSSEN, 2010, p. 59-61; JAHR, 1990, p. 10). Por exemplo, como na imagem a seguir retirada do Lingvistik 
TONEMA 1
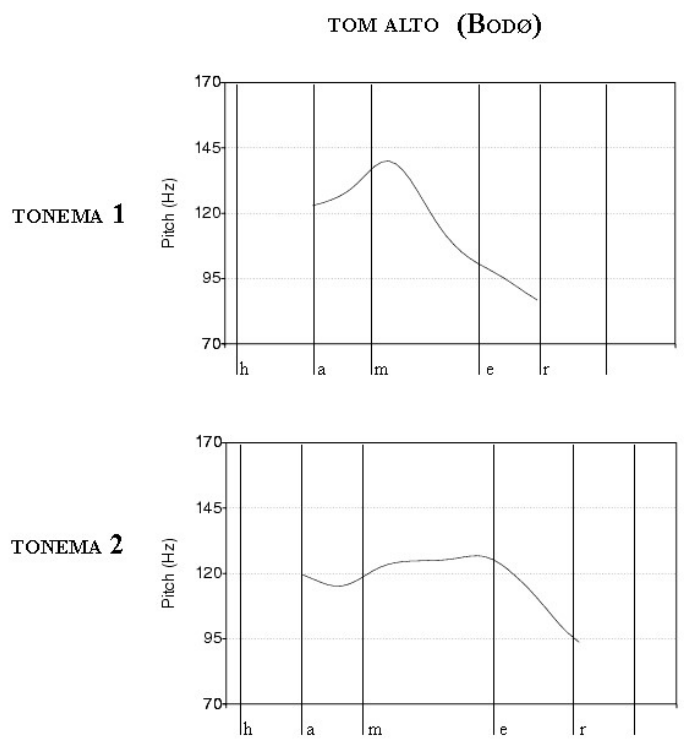

TOM BAIXO (LARVIK)
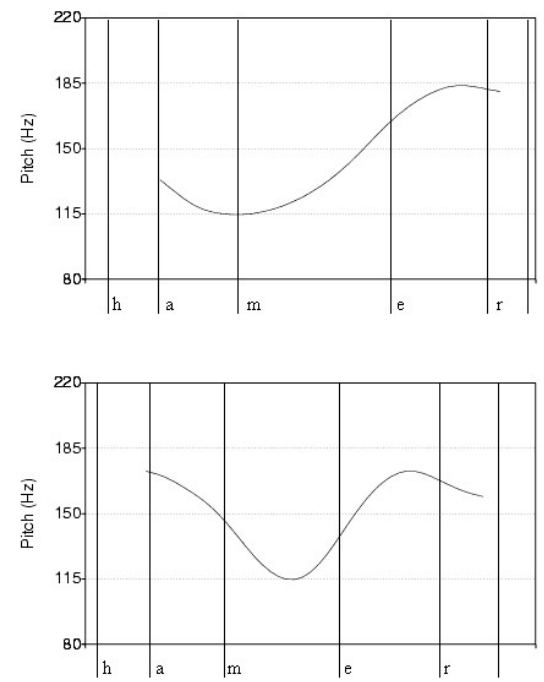

Mapa do corte geográfico dialetal na Noruega:

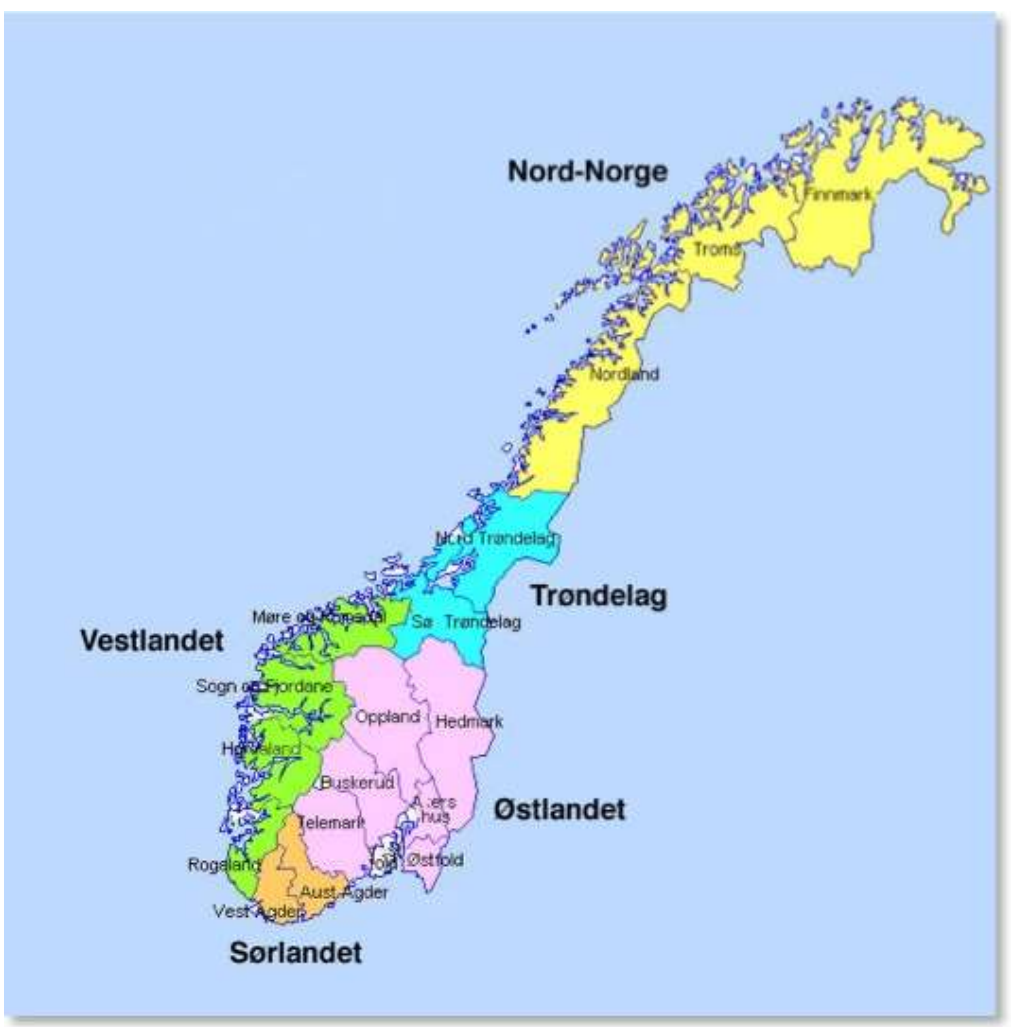




\section{B) Tjukk-L "L espesso"}

Tal característica existe em alguns dialetos noruegueses como, por exemplo, em toda a porção leste, em toda a região de Trøndelag, em Romsdal, em Nordmøre, na parte leste de Telemark, e também em alguns dialetos suecos, mas não em dialetos dinamarqueses (HANSSEN, 2010, p. 67-69). Temos, portanto, sol "sol" pronunciado como [so:[]

\section{C) Consoantes retroflexas e suas consequências}

Nos casos em que o $r$ é seguido das consoantes $I, t, d, n$ e $s$, ocorre a transformações destas da seguinte maneira $\mathrm{rl}[]$, $\mathrm{rt}[f], r d[q], r n[\eta]$ e $r s[]$, respectivamente. É um processo de assimilação que resulta na retroflexão (HANSSEN, 2010, p.70). Jahr afirma que tais características ocorrem ao leste da Noruega, em Trøndelag, na região Nord-Norge, em Romsdal, Molde e Ålesund. Portanto: gult [gut] "I truncado";surt = [sut] "azedo"; ferdig [fædi] "pronto"; perle [pæ:|ə] "pele"; bjørn [bjø:n] "urso" e forsynt [fo]ynt] "provido, fornecido".

\section{D) Palatalização das alveolares}

Tal característica não se encontra na parte sul da região Østlandet; em Vestlandet, por outro lado, se encontra apenas no Norte de Sognefjorden; está presente em toda a região de Trøndelag e na região Nord-Norge, com relativa presença no interior de Finnmark. Nesse processo ocorre a palatalização das consonantes alveolares $I, n, d$ e $t$ quando elas estão longas, ou seja, $I I, n n, d d$ e $t t$. Portanto ocorrem tais mudanças sonoras: vill pronuncia-se [vil] "selvagem", mann pronuncia-se [man] "homem", kvitt pronuncia-se [kvic, kvis] "branco" e vidde pronuncia-se [viłə] "amplidão". Muitos textos representam esses sons por dígrafos ou trígrafos com $j$ ou $i$, portanto, mannj "homem", danjs "dança" ou mainn, dains (HANSSEN, 2010, p. 75). É um desenvolvimento parecido com o lat. IIInn > esp. IIIn. 


\section{E) Palatalização das velares}

Jahr (1990) cita um outro tipo de palatalização que ocorre por toda a Noruega, mas que é mais difundido no oeste, a saber, a palatalização das oclusivas velares $k$ e $g$, que são empurradas para o palato diante das vogais $i \mathrm{e}$ (p. 15). Hanssen (2010) exemplifica com bakke (pronuncia-se [bacə]) "encosta", rike (pronuncia-se [ri:cə]) "reino", dagen (pronuncia-se [dajen]) "o dia", ringen (pronuncia-se [rinən]) "o anel" e banken (pronuncia-se) [bancən] "o banco", ou seja, $[\mathrm{k}]>[\mathrm{c}] ;[\mathrm{g}]>[\mathrm{j}] ;[\mathrm{n}]>$ [nj] e [nk] > [nc] (p. 76). Também é um processo que parece ocorrer com o latim vulgar, pois temos ocorre a passagem de ${ }^{*}[\mathrm{k}]>{ }^{*}[\mathrm{c}]>$ ${ }^{*}[\mathrm{ts}]>{ }^{*}[\mathrm{~s}]($ VIARO, 2011, p. 176) em palavras como, por exemplo, lat. centum > pt. cento e lat. lancěam > pt. lança quer dizer, o dialeto norueguês para no segundo estágio. Esse processo dialetal é comum em Vestlandet, antigamente também em partes da região Nord-Norge. A autora também afirma que em algumas partes da Noruega como, por exemplo, em Nord-Norge, em Trøndelag e em muitas cidades de Vestlandet, está ocorrendo um processo de forma hipercorretiva, pois muitos falantes não estão mais pronunciando a de maneira palatalizada, mas sim velarizada (p. 76).

\section{F) R gutural}

É um processo que ocorre na costa em Sørlandet e no Sul de Vestlandet. De acordo com Jahr (1990) é a característica linguística que está mais se avançando nos dias atuais, pois está se espalhando para o Norte da costa da região Vestlandet e da costa para o continente. Jahr afirma que o $R$ gutural surgiu como uma pronúncia de moda em Paris no século XVII e de lá se espalhou para muitas partes da Europa ocidental como, por exemplo, Dinamarca e Sul da Suécia (p. 15). Também encontramos esse som em várias regiões da Alemanha. Hanssen (2010) é da mesma opinião e afirma que o som está sendo usado por jovens em áreas que não utilizavam antes; por isso, o processo continua. $O$ autor também comenta que esse processo foi cartografado em 1900 e a partir daí é possível seguir sua expansão (p. 73). 


\section{G)Forma do infinitivo}

De acordo com Jahr (1990, p. 16), os dialetos noruegueses apresentam uma variedade de formas de infinitivo:

terminados em -e como em finne "encontrar". Existentes em algumas partes de Troms e Finnmark, em Aust-Agder da região Sørlandet e na parte norte de Vestlandet;

terminados em -a como em finna "encontrar". Existentes em VestAgder (região da Sørlandet) e no centro e sul da Vestlandet;

alguns terminam em -e (overvekt ${ }^{27}$ ), como finne, e outros em -a (jamvekt $\left.{ }^{28}\right)$, como væra "ser". Esse processo é conhecido como kløyvd infinitiv $^{29}$ "infinitivo cindido" e é realizado em Østlandet e Trøndelag. Também ocorre a apócope nas palavras overvekt, mas apenas em Trøndelag. Em Salten (Norland) também ocorre esse processo.

${ }^{27}$ Propomos a tradução como "sobrepeso", ou seja, a entonação ocorre em uma das sílabas.

${ }^{28}$ Propomos a tradução como "balanceado", ou seja, a entonação ocorria na primeira sílaba e na seguinte.

${ }^{29} \mathrm{O}$ kløyvd infinitiv ocorre nas regiões onde há o tonema 2 realizado em tom baixo em palavras de duas sílabas. Se consultarmos acima, veremos que o tom começa alto, desce e volta a ser alto. Para que seja possível entender o motivo pelo qual os infinitivos de alguns verbos terminam em $-a$ e outros em $-e$, é preciso ter em mente que o antigo nórdico tinha apenas a forma infinitiva em -a (finna, kasta, vera). A quantidade silábica do antigo nórdico, portanto, foi determinante para a ocorrência da redução em -e (overvekt "sobrepeso") ou da manutenção do -a (jamvekt) "balanceado" nas sincronias futuras. $O$ antigo nórdico tinha as seguintes quantidades silábicas: VK (sílaba curta), VVK, VKK (ambas sílabas longas) e VVKK (sílaba super longa) e os dialetos noruegueses, de modo geral, mantiveram apenas as formas $b$ e $c$, ou seja, não há sílabas curtas ou super longas. Essa diferenciação hoje em dia é demonstrada na grafia, quer dizer, se a vogal for longa, a consonante seguinte será curta (consoante simples) e se a vogal for curta, a consoante seguinte será longa (consoante geminada); a sílaba, portanto, sempre será longa. Com a remodelagem silábica, deixou de existir a diferença quantitativa entre uma palavra overvekt, que tinha a sílaba da raiz longa, e uma palavra jamvekt, que tinha sílaba da raiz curta com um certo acento na segunda sílaba (havia apenas uma consoante entre a vogal da raiz e a vogal da sílaba final como em fara "viajar"), pois todas passaram a ser overvekt. Por conta disso, ocorreu uma redução -a > -e nas palavras que eram outrora overvekt e uma manutenção nas que eram jamvekt, pois havia uma entonação na última sílaba por conta do tonema 2 e também havia uma distribuição de maneira balanceada entre a sílaba curta da raiz e a final, por isso o termo "balanceado (TORP \& VIKØR, 2000, p. 70). Os dialetos que seguem essa regra, quer dizer, que têm o kløyvd infinitiv, são geralmente chamados de jamvektsmål "dialetos balanceados" e essa regra é chamada de jamvektsregel. 
Exemplo dado por TORP \& VIKØR (2000, p. 70):

- AN kasta > dialeto kaste /'kaste/ "jogar" (infinitivo em -e, sílaba longa por conta do -st-). Com relação à apócope temos: kaste > /kast/; live > /liv/ "viver". É comum na região de Trøndelag. Estas são as palavras overvekt.

AN fara > dialeto fara /'far'a/ > /fa:ra/ "andar, viajar" (remodelagem, infinitivo em -a, perceba que a sílaba inicial, que antes era curta, ficou longa, antes tanto a vogal quanto a consoante eram curtas e, uma vez que nesses casos o antigo nórdico tinha uma certa entonação no -a da sílaba final por conta da distribuição balanceada do acento, o -a se manteve). Esta é uma palavra jamvekt.

Jahr (1990, p. 18) também afirma que nessa região ocorre um processo chamado de jamning "assimilação entre vogais" nos verbos em -a. Portanto, pode haver assimilação total ou parcial entre as vogais:

- AN koma l'kom'a/ "vir" (jamvekt) > dialeto kåmmå /'kom'o/ (assimilação total) > /'kom:o/ (remodelação silábica).

AN vita /'vit'a/ > vætta, vatta, ou våttå "saber" (assimilação parcial e total).

A intensidade aumenta gradualmente para o norte e nas regiões como Nord-Østerdalen e Indre Trøndelag, onde se encontra o foco dessa assimilação total (p. 18).

O -a- também podia ser impedido de sofrer a redução quando ele não era final. $O$ antigo nórdico tinha o seguinte modelo de conjugação do verbo (infinitivo, presente, pretérito, particípio):

$$
\text { kasta - kastar - kastađi - kastat }
$$

Com a redução vocálica, o kasta passou a ser kaste em alguns dialetos, mas o a das outras formas se manteve. Em outros dialetos não ocorreu 
essa redução vocálica em $e$, por isso, eles têm as formas acima demonstradas em -a.

Outras características definidoras são a sonorização do $p, t$ e $k$ em Sørlandet e em grande parte de Sørvestlandet, a negação nas formas ikkje, itte, inte ou ikke, o pronome pessoal em primeira pessoa singular representados como jeg, eg, je, i, jæ, aiæi, æig ou de primeira pessoa plural, como me, vi e oss e também a presença ou não do caso dativo.

\subsubsection{As línguas escritas oficiais: bokmål e nynorsk}

Trataremos agora sobre as duas línguas oficiais da Noruega, o bokmål (antigo riksmål) e o nynorsk (antigo landsmål). De acordo com o Språkrådet (Conselho do idioma norueguês), de 7 a $15 \%$ da população usa o nynorsk como língua escrita e o restante usa o bokmål; o nynorsk é a forma escrita estritamente predominante nos condados como Hordaland, Sogn og Fjordane, Møre og Romsdal, aos passos que os outros condados são neutros (escolhem qualquer uma das duas) ou usam o bokmål. Este é estritamente predominante nos condados Østfold, Vestfold e Finnmark. Para mais informações, consulte o Lovdata ${ }^{30}$.

Antes de comentarmos a origem das duas formas escritas é importante conhecer o momento político, que resultou na språkstrid "guerra de idiomas", ocorrido na Noruega. O período, no caso, é o "renascimento nacional", que se inicia em 1814.

\subsubsection{As línguas na Noruega antes de 1814}

A Noruega passou por uma dominação dinamarquesa do séc. XVI até o início do séc. XIX; consequentemente, a literatura norueguesa era muito escassa e se baseava apenas em alguns autores que escreviam em

${ }^{30}$ Disponível em: https://lovdata.no/dokument/SF/forskrift/2007-04-01-378 
dinamarquês, mas que incluíam um certo substrato norueguês dialetal como, por exemplo, os padres humanistas Absalon Pederssøn Beyer (1528-1575) e Peder Claussøn Friis (1545-1614). Segundo Haugen (1972), esse é o período inicial em que começaram a se desenvolver as línguas nacionais oficiais. A língua de aprendizagem ainda era o latim e a do comércio, o baixo-alemão médio; porém, as línguas escandinavas tornaram-se gradualmente línguas administrativas. $O$ sueco, no reino da Suécia e o dinamarquês na Dinamarca e Noruega. A região de Schleswig-Holstein continuava a utilizar o baixo-alemão (p. 351-352).

Como a presença dinamarquesa era intensa e bem estabelecida, tanto no âmbito político como no religioso, e a Noruega era muito pobre, cujas vilas eram pouco povoadas e distantes uma das outras, era de se esperar que haveria pouca resistência por parte dos noruegueses contra a obrigatoriedade de utilizar o dinamarquês, já esta língua era vista como superior e, ademais, era a língua em que a Bíblia tinha sido traduzida. Hognestad (2000) afirma que a Dinamarca obteve sua primeira oficina de impressão em 1482 com o alemão Johan Snell; a Noruega, por sua vez, apenas em 1643 na Christiania (atual Oslo) com os dinamarqueses Tyge Nilssøn e Christen Bang. Esse estabelecimento tardio de uma oficina de impressão na Noruega reflete o desinteresse da população pobre e dominada em reivindicar uma língua nacional.

De 1600 até 1800 os principais representantes da literatura norueguesa eram Dorothe Engelbretsdotter, Peter Dass e Ludvig Holberg, num período que abrange o Barroco, o Classicismo e o lluminismo norueguês. Com a parcial e gradual normatização da língua no reino, os dialetos passaram a ser vistos com maus olhos pelos dinamarqueses. Ao mesmo tempo que a tradição de escrita norueguesa morre, encontra-se pela primeira vez gêneros que têm como base os dialetos como, por exemplo, as canções folclóricas e populares. É o período também em que são criados glossários por funcionários públicos para que eles conseguissem compreender os dialetos noruegueses ou palavras antigas (p. 67). Segundo Torp e Vikør (2000), em todo esse período não havia nenhuma contestação e questionamento sobre a língua norueguesa, embora houvesse alguns norvegisme "norueguismos" em obras entre a metade do século XV e XIX. De acordo com Hoel, (1996) por volta de 1800 havia no mínimo quatro expressões linguísticas na Noruega (p. 29): 
1) Dinamarquês: língua da alta classe de Copenhagen, falada por dinamarqueses na Noruega

2) Høgtidsmålet "língua solene": pronúncia com base na escrita, (pronúncia de leitura) que os noruegueses tinham da língua escrita dinamarquesa. Era utilizada em eventos oficiais e formais, principalmente por padres, funcionários públicos e nas escolas

3) Den dana daglegtala "a fala culta do dia-a-dia": quer dizer, uma língua misturada chamada de dano-norueguesa com uma boa parte de inserção de elementos nativos e que a partir do século XVII foi a língua materna de parte da elite norueguesa

4) Dialetos: falares das aldeias utilizados pela grande parte da população e que se desenvolveu do antigo nórdico sem influência do dinamarquês

Torp \& Vikør (2000) também fazem uma classificação, mas consideram apenas o falar dos nascidos na Noruega e diferencia a parte dialetal em folkeleg bymål "dialetos populares de cidades", que são falados pelos artesãos e operários e bygdedialektane "dialetos das aldeias", falados pelos pescadores e camponeses (p. 127).

\subsubsection{As reflexões linguísticas na Noruega após 1814}

Segundo Torp \& Vikør (2000), a Noruega em 1814 tornou-se um Estado propriamente dito, mas com uma autonomia limitada devido a uma união com a Suécia, que obteve da Dinamarca por meio do tratado de Kiel. Nesse ano, a Suécia aceitou a Constituição e o Parlamento da Noruega por meio da Convenção de Moss; posteriormente, mas no mesmo ano, a união entre os reinos separados da Suécia e Noruega foi aprovada pelo parlamento, que duraria até 1905 sob um único rei, mas com constituições e leis separadas. Isso criou um 
ambiente para uma indagação linguística nacional, uma vez que a Noruega nesse momento se tornou uma nação independente e, ainda assim, utilizava o dinamarquês como língua escrita. Os principais pensadores sobre esse tema foram Henrik Wergeland (1808-1845), Peter Andreas Munch (1810-1863), Ivar Aasen (1813-1896), Peter Christen Asbjørnsen (1812-1885), Bjørnstjerne Bjørnson (1832-1903) e Knud Knudsen (1812-1895). Os "tempos modernos" se iniciam em 1907, quando ocorre o primeiro acordo ortográfico na Noruega, embora o landsmål tenha recebido sua primeira escrita oficial em 1901.

Esses pensadores se agruparam em duas correntes: uma formou a norma riksmål e a outra, a norma landsmål, que posteriormente chamariam bokmål e nynorsk, respectivamente. A diferença entre essas duas normas é o resultado de diferentes visões de uma língua nacional; por um lado, querem manter a linha dinamarquesa e, por outro, reviver uma língua norueguesa outrora perdida por conta da dominação dinamarquesa. O período que abrange desde o germânico até o final da dominação dinamarquesa está detalhado no subcapítulo 2.3.2.

Trataremos a seguir dos acontecimentos após 1814. Determina-se tais eventos como os mais importantes para o período de formação das duas formas escritas, com base em Torp \& Vikør (2000, 313-316):

1814: Noruega independente e união com a Suécia

1814-1858: foram publicadas inúmeras obras que defendiam a vertente que futuramente seria o bokmål e aquela que seria o nynorsk.

1862: ocorre a primeira reforma oficial na Noruega, em resumo, apenas convenções gráficas.

1869: ocorre o encontro escandinavo em Estocolmo e algumas medidas em comum foram adotadas.

1878: o Odelstinget aceita que a aula oral na barneskole (escola da primeira até a sétima série) poderia ocorrer no "próprio dialeto das crianças".

1884: o Parlamentarismo é inserido na Noruega 
1885: o Stortinget aceitou a igualdade das duas línguas escritas.

1887: o Kirke- og undervisningsdepartement "Departamento da Igreja e do Ensino" determina que a dannede dagligtale "falar culto do dia-a-dia" seja a norma utilizada para a pronúncia de leitura na escola.

1892: o Stortinget regulamenta por lei o direito de utilizar o landsmål como língua de aprendizagem nas escolas (Folkeskole), após determinação da diretoria de cada escola.

1893: o departamento dá o direito às crianças de utilizar as formas norueguesas no dano-norueguês que estão impressas no livro de leitura de Nordahl Rolfsen, pedagogo norueguês.

1901: o landsmål obtém sua primeira escrita oficial com base na norma de Hægstad (com a norma de midland como variante secundária).

1902: palavras como hovudmål "língua princípal" e sidemål "variante secundária" são inseridas no linguajar das escolas.

1905: a união com a Suécia é dissolvida.

1906: surge a Norigs Maalag31 "organização linguística da Noruega".

1907: a língua escrita dano-norueguesa recebe uma nova reforma ortográfica, que representa a principal quebra com o dinamarquês como base de norma (e a partir daqui começa a ser mais chamada de riksmål); além disso, a redação em variante secundária é introduzida no ginásio. Cria-se o Riskmaalforbundet ${ }^{32}$ "aliança do Riksmaal".

- 1910: o landsmål recebe uma outra reforma.

1917: ocorrem reformas tanto no riksmål quanto no landsmål.

- 1919: o Stortinget aceita a proposta da mudança de nome de ambas as formas escritas para bokmål e nynorsk.

31 Organização que tem o intuito de promover o landsmaal (nynorsk)

32 É uma organização que tinha o intuito de apoiar a posição do riksmål como língua escrita oficial. De início era esse o propósito principal, hoje em dia eles também apoiam a posição do riksmål e do bokmål moderado (forma mais conservadora do bokmål) 
A partir do período de união com a Suécia em 1814 começaram as reflexões sobre o fato da Noruega não ter uma língua própria. Segundo Vikør e Torp (2000), nos primeiros anos após essa união o sueco era visto como a principal ameaça contra uma independência linguística norueguesa. Uma proposta contra essa ameaça era manter o dinamarquês tão puro quanto possível sem influências suecas, mas gradualmente percebeu-se que a Suécia não tentaria influenciar o uso da língua e o medo de uma possível pressão parou de existir. $\mathrm{Na}$ verdade, a grande disparidade entre o dinamarquês e os dialetos falados pela maioria da população foi vista como um problema nacional apenas a partir de 1830. Henrik Wergeland (1808-45) foi o primeiro que tomou ciência sobre isso e, por conta disso, desejava colocar palavras e formas norueguesas na língua escrita de maneira gradual para fazer com que ela se tornasse verdadeiramente norueguesa. Ele, portanto, parte da frente moderada conhecida como fornorsking "ato de norueguizar" (p. 119-120). Em seu artigo Om norsk Sprogreformation (1832) "sobre a reforma linguística norueguesa" ele afirma (AMUNDSEN; SEIP, 1959, p. 296):

men nu er det virkeligheden af et selvstændigt Skriftsprog, som fremæsker Norges Aander

"mas agora deve-se tornar realidade uma língua escrita autônoma, que encoraje o espírito da Noruega" (trad. nossa)

O contraponto de Wergeland era Peter Andreas Munch (1810-1863), que apoiava que a língua era uma totalidade dependente que não poderia mudar sua nacionalidade apenas com a inserção de palavras e formas de uma outra língua. Ele refutou o fornorsking e sugeriu que fosse elaborada uma nova língua escrita com base em um dialeto norueguês que, em seguida, seria normatizado sob princípios etimológicos (TORP \& VIK $\varnothing R$, 2000, p. 120); tal ideal daria o pontapé inicial à målreising "edificação da língua".

Em seu artigo Norsk Sprogreformation de 1832 ele afirma (STORM, G. 1873, p. 25):

Vi raade Sprogreformatorerne [...]; de kunne da fornuftigere og mere 
konseqvent anvende deres Liebhaberi til at bringe en af vore reneste Almuedialekter $i$ en ordentlig Form sammenholdt med vort Oldsprog, istedetfor som nu skjændigen at forhuttle og sammenjaske vore Dialekter i vild Uorden.

"Nós aconselhamos aos reformadores [...]; eles poderiam utilizar de maneira mais sensata e mais consequente suas afeições para organizar um de nossos dialetos camponeses mais puros de uma maneira ordenada em confronto com nossa antiga língua, em vez do que acontece agora, pois miseravelmente balbuciamos nossos dialetos em uma desorganização selvagem". (tradução nossa)

Todo o trabalho de Munch era baseado na visão de que a Noruega tinha mil anos e que era necessário, para almejar um futuro nacional, estabelecer um vínculo comunicativo com a longínqua Idade Média em que o país era autônomo. Ele defendia que a antiga língua nórdica, que se afunilou em grande parte nos registros islandeses e noruegueses, deveria ser conhecida pelos pesquisadores dinamarqueses como oldnorsk "antigo norueguês" e não oldnordisk "antigo nórdico" (TORP \& VIKØR, 2000, p. 143). Os seguidores dessas duas vertentes obtiveram resultados mais decisivos do que os idealizadores.

\subsubsection{Ivar Aasen e a målreising}

Como principal nome da tendência radical målreising está Ivar Aasen (1813-1896), que foi o fundador do que levou à formação de uma das línguas oficiais atualmente na Noruega, o nynorsk. Ele compreendeu que os dialetos, principalmente por meio do estudo de seu dialeto nativo, o sunnmørsmål do município de Sunnmøre no condado de Møre og Romsdal, representavam um norueguês comum que se diferenciava sistematicamente das outras línguas escandinavas. Inspirado pelos ideais românticos que dominaram o país nesse período, empenhou-se em coletar os dialetos do oeste da Noruega e formular uma língua nacional (TORP \& VIKØR, 1993, p. 147). O anseio de Aasen está muito bem demonstrado no artigo Om vort skriftsprog (1836) "sobre nossa língua escrita": 
[...] dersom Norge gjennem disse Sekler havde hævdet sin politiske Selvstændighed, da skulde vort Hovedsprog ogsaa været Almuens ${ }^{33}$

[...] se a Noruega tivesse conquistado sua autonomia política durante esses séculos, nossa língua principal poderia ser aquela da gente comum" (trad. nossa).

A partir de seus trabalhos, surgiu o termo Landsmaal "língua do país" ou "língua da terra", que foi primeiramente registrado em uma carta de 2 de outubro de 184934. Em seu livro Prøver af Landsmaalet i Norge (1853) "Testemunhos da língua do país/da terra na Noruega", ele coleta 20 testemunhos dialetais com o objetivo de unificar os dialetos. Em um adendo aos dialetos registrados, Aasen propõe uma forma de escrita que é uma tentativa de formar uma língua comum norueguesa ou de unificar os falares camponeses em uma construção formal gramaticalmente unificada; portanto, ele queria fundar um landsmål comum para todos os dialetos (AASEN, 1853, p. 72). No entanto, as normas desse construto só foram publicadas em sua gramática (Norsk Grammatik, 1864) e em seu dicionário (Norsk Ordbog, 1873).

Algumas características da norma de Aasen são:

- Características ortográficas e gráficas (sem consequências para a pronúncia):

- escrita gótica;

- substantivos com a primeira letra maiúscula;

- aa em vez de å;

- hj quando houvesse na língua dinamarquesa e no antigo nórdico: Hjarta "coração", hjelpa "ajudar";

33 Disponível em http://www.aasentunet.no/1836+Om+vort+Skriftsprog.b7C_wJnW5O.ips (último acesso em 12 de agosto de 2015)

34 Disponível em http://www.aasentunet.no/iaa/no/ivar_aasen/brev_og_dagboker/brev_18281896/1846-1850/120+Olaus+Vullum\%2C+2.10.1849.b7C_xdzl3N.ips (último acesso em 3 de agosto de 2015) 
- gj, kj e skj antes de e, æ e ø: gjera, kjær;

\section{- Fonéticas:}

- $k v$ correspondente à escrita dinamarquesa e ao nórdico hv: kval "baleia", kvit "branco";

- mn correspondente à escrita dinamarquesa e ao nórdico, fn: namn "nome";

- rn correspondente à escrita dinamarquesa e ao nórdico: barn "criança";

Morfológicas:

- três gêneros (com três paradigmas no masculino e feminino) e um no neutro.

- dativo plural em -om;

- infinitivo do verbo terminando em -a;

- presente com -r nos verbos fracos (kastar "jogar"), mas ausente nos fortes (les "ler", skriv "escrever");

- pretérito em -ade, -de, -te e -dde em verbos fracos

Um dos seguidores de Aasen foi Arne Garborg, que em 1877 apareceu como um ideólogo da língua com o livro Den nynorske Sprog- og Nationalitetsbevægelse "o movimento nacional e linguístico do novo norueguês", cujo conteúdo apoiava o landsmål como a única expressão linguística adaptada à nacionalidade norueguesa; no mesmo ano ele criou o jornal Fedraheimen, que era a principal mídia de apoio ao målrørsla "movimento da língua" durante um pouco mais de uma longa década de discussão (de 1877 até 1891). Målrørsla é conhecido como o movimento que pleiteava elevar a escrita do nynorsk à sua total utilização e com todos os direitos. 


\subsubsection{Knud Knudsen e o fornorsking}

Segundo Torp \& Vikør (1993, p. 122), as bases ideológicas para a vertente moderada fornorsking foram realizadas por Knud Knudsen (1812-1895). De acordo com os autores, Knudsen era um ortofonista. De início, ele se dedicou à ortografia de algumas palavras com vogais dobradas como, por exemplo, deels "em parte", Priis "prêmio" e o e mudo após vogal longa. Com relação aos dialetos, de acordo os autores, Knudsen não apoiava a utilização dos dialetos como base para uma língua escrita porque eram limitados geográfico e socialmente; por outro lado, o melhor caminho seria representar na escrita a pronúncia do dia a dia que a alta classe norueguesa realizava da língua escrita dinamarquesa, e isso era o que Knudsen entendia por landsdyldige daglegtalen "falar do dia a dia válido para todo o país"; portanto, queria aos poucos segregar as características comuns dinamarquesas na escrita e substituir pelas características comuns norueguesas.

Em 1850 Knudsen concentrou-se em dar prestígio ao dannede dagligtale "falar culto do dia a dia" com a finalidade de apoiar a ideia de que as características norueguesas nessa pronúncia eram reconhecidas na língua do teatro, que era a forma de falar com maior prestígio naquele período. De início, com relação ao "escrever correto", ele se contentou em se dedicar às reformas que não tangiam a diferença entre a pronúncia "solene" (høgtid) e do "dia a dia" (dagleg); as palavras estrangeiras eram escritas mais de acordo com a pronúncia (p. 122).

Por conta disso, de acordo com Torp \& Vikør (2000) iniciou-se um debate sobre o modo de escrever, que não refletia a pronúncia do período, e uma solução foi dada em 1862, período em que se apresentou a primeira reforma oficial norueguesa, mas não era senão algumas mudanças em convenções gráficas (p. 186):

- supressão do e mudo

- fim das vogais duplas: ee > e; ii > i e uu > u como indicação de alongamento vocálico 
- supressão de $c$, ch e $q$ como representação do som [k], que passa a ser escrito apenas como $k$

- supressão de ph como representação do som [f], que passa a ser escrito apenas como $f$

Os autores afirmam que isso ocorreu por conta da agitação criada por Knudsen; em contrapartida, já a partir de 1844 ele afirmava que o den skriftrette høgtidstalen "o falar solene adequado para escrita" não era o falar natural de nenhum norueguês e só por isso já seria um bom motivo para uma reforma de escrita. Esta, portanto, deveria ter como ponto de partida a chamada den almindeligste Udtale af Ordene $i$ de Dannedes Mund "pronúncia mais corriqueira de palavras no linguajar culto", quer dizer, o Den dana daglegtala "a fala culta do dia a dia" e, a partir daí, começou a questionar as consoantes sonoras $(b, d, g)$ e o encurtamento de formas como bede "rezar, pedir" e fader "pai" para be e far, pontos que veremos a seguir.

Knudsen foi muito ativo nas questões linguísticas na década de 1850; se preocupava, entretanto, mais com a pronúncia; ele também foi consultor linguista do Det Norske Theater (Teatro Norueguês). Nessa época, o pessoal do teatro era formado em sua maioria por atores dinamarqueses porque a pronúncia norueguesa era vista como inaceitável nas apresentações. O objetivo do Det Norske Theater era tirar a hegemonia dos dinamarqueses e estabelecer tanto a profissão de ator para os noruegueses como uma dramaturgia genuinamente norueguesa. Knudsen, em vista disso, se esforçou para fazer com que as consoantes $p, t, k$ e outras características tornassem vistas como uma pronúncia normal. Além do mais, começou a influenciar os dramaturgos Henrik lbsen e Bjørnstjerne Bjørnson para a "norueguização" da língua escrita (TORP \& VIKØR, 2000 , p. 186-187).

Em 1869 outras mudanças ortográficas ocorreram por conta de um encontro escandinavístico em Estocolmo com o objetivo de propor uma aproximação entre a escrita dinamarquesa e a sueca; entre os enviados noruegueses, estavam Knudsen e Ibsen. Tal encontro propôs muitas 
modificações ortográficas nos três países. As mais importantes com relação ao dinamarquês foram essas:

1) supressão do $j$ antes de e, æ e æ: kjende > kende "conhecer, saber"; skjære > skære "cortar"; gjøre > gøre "fazer"

2) supressão do $d$ antes de $s$ : krands > krans "coroa" e tydsk > tysk "alemão"

3) $a i>a j, e i>$ ej e $ø i>\varnothing j$

4) $a a>a ̊$

5) substantivos em letra minúscula

6) $e>æ$ onde há motivos fonéticos ou etimológicos como base para isso

7) $0>$ å onde há motivos fonéticos ou etimológicos como base para isso

De acordo com Torp \& Vikør (2000, p. 187), Knusen apoiou toda sua vida para a realização dessas modificações, mas sem êxito. Os pontos 2,4 e 5 ocorreram apenas após a sua morte e os outros não foram realizados no norueguês até hoje, mas sim no dinamarquês, com exceção do ponto 7 .

Em 1876 foi publicada a obra de Knusen chamada de den landsgyldige norske uttale "pronúncias norueguesas válidas para o país", cujo conteúdo abordava que a pronúncia landsgyldig "válida para o país" era uniforme e não "acatada", pois as diferenças entre a pronúncia "culta" na Kristiania (atual Oslo), Bergen, Trondheim e Tromsø eram tão pequenas que não se poderia falar de diferenças dialetais, mas apenas de acentuação. Portanto, o argumento de Knudsen para apostar nessa pronúncia e não diretamente na Folkespraag "língua do povo" era prático: se tiver que construir uma língua com base na língua do povo, teria que favorecer uma pronúncia local ou construir uma língua que não existe em nenhum local, e foi isso que Aasen realizou. 
Knudsen também apoiava o futuro aprimoramento dessa possível língua escrita de acordo com a necessidade popular, algo que deveria ocorrer gradualmente. Era o caminho para chegar a uma língua escrita norueguesa que ele discordava, mas não o objetivo. Em frente aos conservadores ele sublinhou que para que essa "marcha" do landsmål pudesse parar, a característica dinamarquesa deveria ser removida do Bogmaal (TORP \& VIKØR, 2000, p. 189).

Como apresentado anteriormente, essa língua escrita até 1892 era conhecida de várias maneiras: Bogmaal "língua do livro", Skriftsprog "língua escrita", Bogsprog "língua do livro" e det skrevne Sprog "a língua escrita", ou seja, era o falar da classe culta norueguesa, o dano-norueguês, ou den dana daglegtala. A difusão de um nome para ela se iniciou em uma conferência realizada pelo poeta e dramaturgo Bjørnstjerne Bjørnson (1832-1910) em 1899, que a nomeou de rigsmaal "língua do reino", que era a "língua da cultura" (HAUGEN, 1968, p. 37). Esse termo era conhecido na academia norueguesa e dinamarquesa como uma variante da palavra rigssprog "língua do reino". É um decalque do alemão Reichssprache, uma denominação para o alto alemão padrão na forma escrita. Quando esse termo foi inserido ela apenas significava "língua comum livre de marcas dialetais" (HAUGEN, 1968, p. 38).

Torp \& Vikør (2000, p. 197) citam as algumas das propostas de Knudsen para diferenciar a língua escrita norueguesa do dinamarquês. Grande parte delas trata-se de modificações ortográficas:

1) utilização das consoantes surdas $p, t, k$ em vez das sonoras $b, d, g$

2) supressão de $d$ após I e $n$ : falle "cair" ao invés de falde; finne "encontrar" em vez de finde

3) supressão do $d$ e $t$ antes de s: besk "amargo" ao invés de bedsk; Pels em vez de Pelts

4) supressão de $j$ antes de e, æ e ø. skje > ske "ocorrer"; kjær > kær "querido"

5) supressão do e mudo no passado: nådde "graça, clemência" em vez de nåede 
6) fødde e bredde "nasceu, extendeu" em vez de fødte e bredte

7) troca $g$ por $v$ em palavras como Have > Hage "jardim"; Skov > Skog "floresta"; Torv > Torg "praça"

8) encurtamento de alguns verbos: drage > dra "puxar"; bede > be "pedir"; tage > ta "tomar"

9) "norueguização" de algumas palavras: kold > kald "frio"; Sne > Snø "neve"; råbe > rope "gritar, chamar alg."

10) inserção da declinação de plural norueguesa do feminino e neutro: Heste > Hester "cavalos" e Huse > Hus "casas"

11) supressão da pronúncia do -t em palavras neutras como como Huset "a casa" e em formas do particípio como sprunget "saltado"

12) remoção de alguns afixos alemães como: an-, be-, bi-, er-, for-, ge-, -het, -agtig, -bar, -inde, etc.

13) inserção dos ditongos au, ej, øy

14) introdução do a em diferentes terminações de flexão, tanto no substantivo (formas de plural como Fantar "ambulantes"), adjetivo comparativo e superlativo (kortare - kortast "mais curto - "o mais curto") e verbos (elskar - elska "amar")

15) realização do feminino como categoria gramatical

Essas formulações estão no livro Hvem skal vinne? (1886) "quem irá ganhar" de Knudsen. De acordo com Vikør \& Torp, as primeiras doze propostas eram entendidas por ele como adequadas para a "política atual" e as três últimas seriam objetivos mais distantes que eventualmente poderiam ser discutidas. Para os autores, as propostas mais radicais são a 13, 14 e 15. Os pontos 3 e 4 já reconhecemos do citado encontro em Estocolmo em 1869. Ele fez muita propaganda para a realização da utilização do ej e øy em vez de ei e øi , de æem vez de e e å em vez de o, mas para isso não encontrou apoio (p. 197-198).

Assim como Aasen, ele foi muito ativo e publicou muitos livros, revistas, panfletos e artigos. Todas essas publicações tratavam da questão da língua e aos 
poucos se juntaram como um núcleo referente à questão da "escrita correta", que tinha a haver com a base da escrita correta na transição do dinamarquês para o norueguês. Entre 1880 e 1890 suas ideias vieram rapidamente para esse debate, em paralelo com a rapidez com que o landsmål também veio para participar, juntamente com o estabelecimento das escolas e da aprendizagem de escrita e leitura.

\subsubsection{A reforma de 1907 (bokmål)}

Vikør \& Torp (2000, p. 201) dividem o uso da língua nesse período em três esferas: literatura, escola e geral (privado e público). As formas com consoantes $p, t, k$ e o encurtamento de verbos apareciam na literatura $\mathrm{e}$ parcialmente na imprensa, mas em pequeno grau e mais como um símbolo visível de orientação para o partido da esquerda (Venstre). Os autores também afirmam que com relação à literatura, havia apenas um mercado de livros compartilhado entre a Noruega e a Dinamarca; e, ademais, atores consagrados como Bjørnson, o mais obstinado e que mais utilizava características do norueguês, Ibsen, Kielland, Lie, Amalie Skram, etc. tinham que publicar seus livros por meio de uma editora dinamarquesa conhecida como Gyldendal e por conta disso, eles tinham que frequentemente pedir permissão ao diretor da editora, Niels Hegel, para usar algumas características do norueguês. Portanto, esse é um dos motivos pelo qual não se desenvolveu uma língua literária dano-norueguesa com base na acepção de Knudsen.

$\mathrm{Na}$ escola também era a escrita tradicional que dominava, mas em 1878 uma medida do Odelsting determinou que as aulas deveriam ocorrer no próprio dialeto das crianças; a questão da leitura, por outro lado, ainda não havia sido resolvido. Em 1885, o parlamento, Stortinget, mostrou um claro suporte à linha de "norueguização" de Knudsen no processo chamado de likestillingsvedtak "medida de igualdade" (ao landsmål) e em 1887 determinou-se que as crianças deveriam se sujeitar ao "falar culto do dia a dia" e dar preferência à pronúncia norueguesa onde fosse possível, ou seja poderia pronunciar as consoantes $p, t, k$ 
onde houvesse $b, d, g$ e também encurtar palavras que possibilitavam isso. Por exemplo:

Escrita: han lader fem være lige og bryder sig ikke om at broderen raaber og leder efter ham

Leitura: han lar fem være like og bryr seg ikke om at broren roper og leter efter ham

"para ele tudo é indiferente e não se importa que o irmão grite e o procure" (trad. nossa).

Tal medida agradou a alguns, mas não às crianças das aldeias, pois elas frequentavam aulas em dialeto e, quando tinham que ler alto, se deparavam com um texto basicamente escrito em dinamarquês que tinha que ser pronunciado em uma forma norueguesa que eles não conheciam. Em 1892 o pedagogo Nordahl Rolfsen publicou o primeiro volume de seu livro de leitura para as escolas (Læsebog for folkeskolen), cuja escrita, que tinha algumas variações entre $p / b, t / d, k / g$ e também encurtamentos como bror, far, mor (de broder, fader e moder) "irmão, pai, mãe", foi aceita pelo consultor linguístico da época, Moltke Moe (TORP \& VIKØR, 2000, p. 203; SKARD, 1979, p. 47). A partir daí, os alunos poderiam ler uma forma norueguesa que estava de acordo com a pronúncia deles, mas eles não podiam escrever tais formas; isso, entretanto, mudou em 1893 quando o Departamento da Igreja e do Ensino, em um comité formado por Aars, Hofgaard e Moe, formulou uma proposta que causou a liberação da utilização pelos alunos das formas contidas no livro de Rolfsen. E por conta disso fez-se necessária uma reforma oficial nesse bogsmaal.

A partir desse período até 1907 o principal porta-voz para tais reformas foi o já citado consultor linguístico Moltke Moe (1859-1913), filho do folclorista Jørgen Moe dos contos de Asbjørnsen og Moe. Ele encontrou muitos opositores, principalmente Johan Storm, que era o principal defensor do conservadorismo; portanto, Knudsen se encontrava entre Aasen e Storm (TORP \& VIKØR, 2000, p. 194).

Em 1907 ocorreu o marco definitivo para que a língua escrita até agora conhecida como riksmål fosse uma língua escrita "norueguesa" que deveria ser 
normatizada com base no falar "norueguês", a saber, o falar culto nas cidades. Os autores também afirmam que era difícil para os falantes saber quais modificações que deveriam ou que poderiam ser realizadas, ou seja, o conceito de liberdade de escolha foi pela primeira vez instituído (p. 123)

Torp \& Vikør (2000, p. 123) consideram que a reforma de 1907 (apenas no bokmål) foi consolidada rapidamente, uma vez que estava de acordo com o falar comum do dia a dia das classes cultas e, por tanto, não foi estigmatizado socialmente. Apenas representou um ajuste no uso da fala culta. Além do mais, os debates nos anos anteriores à reforma, junto com o pathos nacional, após o dissolvimento da união com a Suécia em 1905, fizeram com que muitos vissem essa reforma nacional de maneira positiva. Em 1910 quase toda a imprensa norueguesa usava essa nova forma de escrita, apenas os jornais conservadores Aftenposten e Bergens Aftenblad mantiveram a posição até 1923 (TORP \& VIKØR, 2000, p. 240-242).

Ocorreram as seguintes mudanças:

\section{Ortográficas:}

1) Inserção de consoantes para evitar homonímia (buk > bukk "cervo"; bal > ball "baile")

\section{Fonológicas:}

1) Ensurdecimento $b, d, g>p, t, k$. Após vogais longas, mas com exceções como, por exemplo, palavras compostas. Apenas na reforma de 1917 todas as palavras foram afetadas.

Obrigatório: dræbe > dræpe "matar"; aaben > aapen "abrir"; vide > vite "saber; kage > kake "bolo";

Obrigatório manter: skib "navio", vaaben "arma", arm "braço", saglig "adj. objetivo", aabenbar "evidente",, videnskap "conhecimento";

Optativo:eple/æble "maçã", bot/bod "multa", klok/klog "inteligente", bok/bog "livro". 
Morfológicas:

1) Plural em -er $(<-e)$

Obrigatório: na forma indeterminada do gênero comum; heste > hester "cavalos"

Optativo: em algumas palavras como dage/dager "dias"

2) Plural sem a terminação do gênero neutro na forma indeterminada Obrigatório: huse > hus "casas"

Optativo: em algumas palavras como blad/blade "folhas"

3) Passado e particípio de verbos fracos como no dinamarquês -ede dividido em três classes:

- Pass.-et e part. -et (kastede > kastet; fiskede > fisket "jogar; pesar") (tanto no pass. quanto no pret.)

- Pass. -te e part. -t (svarede > svarte e svaret > svart "responder") Pass. -(d)del e part. (d)d (boede > bodde e boet $>$ bodd; levede $>$ levde e levet > levd "morar, viver")

4) Supressão da forma do neutro em - $t$ nos adjetivos terminados em ig:

- et heldigt barn > et heldig barn; et ærligt menneske > et ærlig menneske "uma criança sortuda"; "um homem honrado"

5) Encurtamento de verbos e substantivos:

Optativo: drage $\approx$ dra; have $\approx$ ha; blive $\approx$ bli; tage $\approx$ ta (inf.); sagde $\approx$ sa (pass.); fader $\approx$ far, moder $\approx$ mor, broder $\approx$ bror

Obrigatório: i fjæder > i fjær, foder > fôr 


\subsubsection{A reforma de 1901 (nynorsk)}

Com relação ao landsmål, no ano de 1884, a esquerda conseguiu romper com a imposição do parlamentarismo e construiu um governo de mesma direção política com Johan Sverdrup, primeiro-ministro e reconhecido como fundador do parlamentarismo norueguês. Isso levou ao já citado suporte às ideias de Knudsen, mas também determinou em 12 de maio de 1885 que a língua popular (Folksprog) se igualasse à "nossa ordinária língua de livro e de escrita" (vort almindelige Skrift- og Bogsprog); no processo "medida de igualdade", citado anteriormente. Segundo Torp \& Vikør (2000), essa medida é vista como o reconhecimento formal da landsmål como língua oficial ao lado da língua de livro e de escrita (p. 170).

É curioso perceber que a declaração do parlamento compara o landsmål com uma skrift- og bogsprog, ou seja, uma "descrição de língua", a língua de livro e de escrita, uma língua ainda anônima. De acordo com Torp \& Vikør (2000, p. 170), em 1892 o landsmaal conquistou mais uma vitória, pois determinou-se pelo parlamento que os diretores das escolas tinham o direito de decidir qual das duas formas utilizariam. Em 1915 foi determinado e estabelecido por lei o sistema de votação, que permanece até hoje, sobre a língua da escola.

A primeira reforma ortográfica oficial do landsmål ocorreu em 1901. O Departamento da Igreja e do Ensino autorizou duas normas (TORP \& VIKØR, 2000 , p. 122). Os principais representantes foram Arne Garborg, Rasmus Flo e Marius Hægstad, divididos em dois grupos: Garborg e Flo elaboraram a norma de midland (junto com Steinar Schjøtt e Hans Ross), que era baseada no dialeto de Telemark utilizada por Steinar Schjøtt na tradução da obra em antigo nórdico Heimskringla (saga dos reis noruegueses); a segunda norma, de Hægstad, por sua vez, seria uma edição modificada da norma de Aasen. O Departamento decidiu autorizar a norma de Hægstad para uso escolar em 1901 e a norma de midland como variante secundária.

Norma de midland (FLO, 1906, p. 10-12): 
- baseada no dialeto de Vesttelemark;

- kløyvd infinitiv "infinitivo cindido";

- kløyvd svake honkjønn "substantivo cindido de gênero feminino": ei kiste - kista "caixão, cofre"(palavra overvekt) e sogu - sogo "causo, narração“ (palavra jamvekt) ;

- i e $u$ em vez de e e o nas determinações de flexões de feminino plural (indeterminado e determinado): kvister - kvistene >kvistir - kvistine "galhos" e kistor - kistone > kistur - kistune "caixão, cofre";

- formas adjetivas como opin "aberto" (p. 12) e de particípio como funni "encontrado";

- formas de passado como kasta (em vez de kastade) "jogou”;

De acordo com Torp \& Vikør, o -t mudo na forma neutra definida não é grafado como, por exemplo, produkte "o produto" e eple "a maçã" e há formas participais como gjengin "ido" (do verbo gaa); além do mais, uma forma especialmente inspirada no dialeto de Telemark é a utilização da vogal a no plural de antigas raízes consonantais: føtar "pés" e hendar "mãos" em vez das outras formas do landsmaal føter e hender (p. 176).

Norma de Hægstad:

- forma de passado dos verbos fracos kasta, em vez de kastade “jogou” (HÆEGSTAD, 1901, p. 37).

- supressão do -t das formas de particípio dos verbos fortes, então, funne (p. 31). Na norma de Aasen seria funnet e de midland, "encontrado".

- forma neutra de adjetivos terminados em - $n$ como opet ficam ope "aberto" (p. 21); 
- substantivos neutros terminados em vogais, na forma determinada como, por exemplo, augat "o olho", perdem o -t, auga (p. 18), assim como o pronome nokon "alguém" "alguém", que no neutro seria nokot, mas na norma fica noko "algo" (p. 26).

- formas do feminino plural (indeterminado e determinado) são: skaaler e skaalerne "tigelas, as tigelas"; e visor e visorne "canções, as canções" (p. 16 e 17).

- não há kløyvd infinitiv, os verbos no infinitivo terminam apenas em -a (p. 34)

Apenas em 1910 ocorreu a liberação da escrita do landsmaal (norma do Hægstad) para os alunos (VIKØR \& TORP, p. 242). Foram permitidas as seguintes formas:

- utilização da forma indeterminada em -e permitida para substantivos femininos fracos: ei vise/ei visa "canção"

- utilização dos verbos com infinitivo em -ere permitida na declinação em e (studerer/studerar; studerte/studera "estudar")

- Forma determinada de substantivos femininos e masculinos plurais poderia ser escrita sem a grafia do -r-: hestarne > hestane "os cavalos"; skålene > skålerne "as tigelas"; visone > visorne "as canções.

- cerca de 35 palavras poderiam receber um -y- em vez de -ju-/-jo(brjota > bryta "romper, quebrar"; bljug > blyg "tímido"; krjupa > krypa "arrastar-se"; ljon > lyn "relâmpago, raio")

\subsubsection{Outras reformas}

Não traremos detalhadamente dos acontecimentos posteriores; alguns pontos, entretanto merecem nossa consideração: na reforma ortográfica de 1917 , o sufixo -tion passou a ser escrito como -sjon por conta da "norueguização" de 
palavras importadas e em 1929 o Stortinget determinou que as duas formas escritas deveriam chamar bokmål e nynorsk.

Nas décadas seguintes também foram refletidas políticas de escrita como, por exemplo, o samnorsk, que durou de 1917 até 1966 e que tinha como objetivo elaborar uma forma comum para o bokmål e o nynorsk. Na reforma de 1938, que afetou ambas as normas, algumas mudanças foram realizadas para que o bokmål se aproximasse mais do nynorsk. Dois exemplos seriam: a terminação de feminino -a era obrigatório em mais de mil palavras (palavras do dia a dia, sobre o campo e a natureza, etc.), a terminação de plural determinado a era obrigatória em algumas palavras (barna "as crianças", dyra "os animais", etc.), mas optativa em todas as palavras terminadas em consoantes.

A partir de 1917 a diferença entre hovedformer "formas principais" e sideformer "variantes" foi inserida na ortografia norueguesa. As formas principais eram obrigatórias em livros didáticos para o ensino fundamental e ginásio; as variantes, por sua vez poderiam ser utilizadas pelos alunos (Språkråd, 2012, p. $3)^{35}$.

A forma do bokmål mais aproximada do nynorsk é conhecida como radikalt bokmål e aquela mais aproximada do riksmål, como moderat bokmå/36. Uma outra forma variante de nynorsk foi desenvolvida, conhecida como høgnorsk (alto norueguês), que rejeita a maioria das reformas oficiais realizadas para aproximar as duas formas escritas, como as de 1917 e 1938. O høgnorsk trocou, por exemplo, o sufixo que marca a determinação dos substantivos femininos fortes -i por -a, quer dizer, o -i ficou como variante; portanto, boka "o livro" e boki, como variante.

Por fim, após outras reformas, em 2012 a diferença entre hovudform e sideform no nynorsk foi abolida e a partir dessa data só é possível escrever boka "o livro" (entre outros exemplos). O mesmo processo de abolição ocorreu na reforma do bokmål em 2005. Se, por um lado, ela trouxe formas da sideform para a hovudform, pois agora se pode escolher entre -en (moderat bokmål) ou -a

\footnotetext{
${ }^{35} \mathrm{http}: / /$ www.sprakradet.no/globalassets/vi-og-vart/publikasjoner/ny-nynorskrettskriving.pdf

${ }^{36} \mathrm{http}: / /$ www.sprakradet.no/Vi-ogvart/Publikasjoner/Spraaknytt/Arkivet/Spraaknytt_1997/Spraaknytt_1997_1/Hvordan_ser_bokm aalet_ut/
} 
(radikalt bokmål) como sufixo que marca a determinação dos substantivos femininos fortes (boka/boken), por outro, baniu formas da sideform como: kløyvd infinitiv, alguns tipos de substantivos que no plural na forma indeterminada poderiam ser escritos como lærerer "professores", agora só podem ser escritos como lærere, entre muitos outros no âmbito da morfologia, fonética e grafia ${ }^{37}$. Muitos entendem o moderat bokmål como riksmål hoje em dia, tanto que há a já citada organização Riksmålsforbundet, que tem o objetivo de defender a posição dessa forma de escrita na vida social norueguesa: como língua escrita oficial, como língua de cultura e como língua comum falada em momentos que há a necessidade de uma comunicação entre membros de vários locais do país ${ }^{38}$.

\subsubsection{Quando se inicia o uso das duas formas escritas da língua norueguesa?}

Com base nessa análise podemos inserir um ponto de partida para aquilo que consideramos a língua norueguesa. A princípio, aceitaremos como "norueguês" os textos em nynorsk a partir de 1901 e em bokmål a partir de 1907. Anteriores ao ano de 1907, também podemos atribuir ao bokmål textos com bastante características sugeridas pelos participantes da "guerra de idiomas", pois apesar de tais características não terem sido oficialmente aceitas, muitos textos já as utilizavam; portanto, se houver apenas alguns norueguismos (norvegisme), como utilização aleatória do sufixo -a em infinitivos, não achamos que seja suficiente para afirmar que é um idioma escrita de base norueguesa. A respeito do landsmål, já havia muitos textos escritos anteriores à 1901.

Skard (1972) atesta que há mais "norueguismos" no registro jurídico, que manteve características que não são encontradas em outros registros como, por exemplo, conservação das vogais "a", "o" e "u" em posição átona e formas como deira "deles", e gamal "velho", nockor "alguém" em vez do dinamarquês deres, gammel e nogen. Uma menor quantidade de norueguismos é encontrada na literatura histórica e topográfica e ainda menos nas escrituras religiosas, pois

\footnotetext{
${ }^{37} \mathrm{http}$ ://www.sprakradet.no/globalassets/spraka-vare/norsk/rettskriving2005.pdf

$38 \mathrm{http}: / /$ riksmalsforbundet.no/organisasjon
} 
seguia o novo modelo dominante da literatura dinamarquesa de Reforma (p. 39). O autor (1972) também afirma que o perecimento da escrita norueguesa ocorre em 1525, mas após essa data ainda houve locais que mantinham registros nessa antiga língua escrita: os diplomas escritos em zonas rurais, principalmente nas partes sul e leste do país, e os jordebok ${ }^{39}$. O último diploma escrito em norueguês é de Telemark (1583 ou 1584) e muitos dos diplomas do lagman ${ }^{40}$ Jon Simonsson. Embora esses diplomas começassem a ser escrito em dinamarquês a partir de 1525, é possível encontrar formas norueguesas neles.

Encontramos um poema escrito em 1525 em dialeto norueguês (VENÅS, 1990, p. 35). Ele é considerado o mais antigo existente em norueguês (SKARD, 1973, p. 32):

Hans myn dreng quaat kant tv göra kant tv tryskia held kant tv mala held // kant tv den plogen aat drive ieegh giffv deegh eet paar vaska [hestar] deen // sommaren [du] hoos meegh bliue.

"Hans, meu garoto, o que tu podes fazer, você pode malhar ou pode pintar, ou você pode trabalhar com arado? Eu dou a ti alguns cavalos rápidos no verão em que estiver em minha companhia" [tradução nossa].

O livro de Venås trata sobre registros escritos em dialeto norueguês nesse período de escrita dinamarquesa.

No poema do padre Peter Dass (1647-1707) Nordlands Trompet vemos a utilização do dialeto da região do autor, Helgeland (Nordland). Alguns trechos:

1) AEg sa, min goe Granne: Bruch qvænna me me.

2) Aa sloe saa mi qvæn uti stykia.

3) Men nu vil æg vitta min kiære Landdrot

4) Hand sagde goe Skrivar, AEg hæve ey Sag ${ }^{41}$

39 Livro sobre registro de terras da Coroa, da Noruega e privadas.

40 Era aquele que memorizada as leis e recitar as leis no Thing (assembleia de homens livres).

41 1) Eu disse, meu bom vizinho: utilize o moinho comigo; 2) e destruiu meu moinho em pedaços; 3) mas agora eu quero saber, meu caro senhor da terra; 4) ele disse ao bom escrivão: eu tenho um caso/assunto (tradução nossa) 
Esse poema está de acordo com o dialeto da área do escritor. 1) Forma do substantivo forte de gênero feminino termina em -a (qvænna "o moinho"); 2) Plural neutro terminado em -a (stykia "os pedaços"); 3) a queda do $d$ em sílaba final pós-vocálica (me em vez de med "com"); 4) Infinitivos terminados em -a (vitta "saber"); 5) presente dos verbos fracos terminados em -e (æg hæve "eu tenho" 6). Palatalização (stykia em vez de styka "os pedaços"); 7).

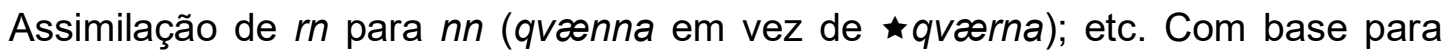
essas considerações utilizamos a obra de Jakobsen (1952, p. 43-45).

Como exemplo de textos em dinamarquês publicados na Noruega apresentamos um comentário sobre o estado de São Paulo no livro de Karl Andree (1873, Band II, p. 829-830):

San Paulo, en af Rigets vigtigste Provindser, tæller over $1 / 2$ Million Indbyggere [...]. Den har en frugtbar Jordbund og store Kaffeplantager. Byen Santos er en af de ældste $i$ Landet og har $i$ de senere Aar hævet sig stærkt ved Kaffeudskibning, der i 1864 til 1865 beløb sig til 328,139 Sække. [...]. Provindsialhovedstaden S. Paulo har 12.000 Indbyggere [...]. Richard Burton har som engelsk Konsul i Santos paavist, at der i Provindsen findes rige Lagere af Stenkul og Petroleum.

"São Paulo, uma das províncias mais importantes do país, conta com mais de meio milhão de habitantes [...]. Ele tem um solo muito produtivo e grandes plantações de café. A cidade de Santos é uma das mais antigas do país e, nos últimos anos, se desenvolveu intensamente com a exportação de café. Entre 1864 e 1865 chegou a Santos 328.139 sacas. [...]. A capital da província, São Paulo, tem 12.000 habitantes [...]. O cônsul inglês de Santos indicou que há na província ricas jazidas de carvão e petróleo". (trad. nossa)

E também um comentário sobre o Brasil e o Rio de Janeiro em um livro que trata brevemente sobre a Geografia, escrito por Geemuyden (1893):

Brasilien er en republik under navnet "Brasiliens forenede stater», idet hver af de tidligere provinser er en egen stat. Præsidenten vælges for 6 aar. Kongressen (stortinget) bestaar af to kamre. - Religionen er katholsk, oplysningen ikke er synderlig stor. [...] Rio de Janeiro, hovedstaden, ligger ved en havbugt, som er en af de skjønneste $i$ verden; folketallet siges at være 800.000. Den har en livlig og udbredt handel med kaffe paa alle verdensdele. 
Paa den anden side af vendekredsen sigger Santos, en by af Trondhjems folketal.

"O Brasil é uma república sob o nome de "Estados Unidos do Brasil", ao passo que cada uma das antigas províncias é um próprio estado. $O$ presidente é escolhido para governar por 6 anos. O Congresso consiste em duas câmaras. - A religião é católica e o acesso à informação não é especialmente grande. [...] O Rio de Janeiro, a capital, se localiza em uma baía, que é uma das mais bonitas do mundo. Diz-se que o número de habitantes é por volta de 800.000 . Há um comércio vivo e espalhado com café em todo o Continente. Do outro lado do trópico se encontra Santos, uma cidade com o número de habitantes de Trondheim." (trad. nossa)

Nesses dois está escrito basicamente na língua dinamarquesa, pois não encontramos nenhum caso de consoante surda em vez de sonora, muito pelo contrário: Rige "reino", frugtbar "fértil", lige "estar localizado", aaben "aberto", beløb "ascendeu-se a", vide "saber", etc. em vez de Rike, fruktbar, like, aapen, beløp, vite. As formas no pretérito são em -ede, por exemplo, svarede "respondeu", kastede "jogou" em vez de svaret e kastet. Também ocorre a manutenção da forma do neutro em -t nos adjetivos terminados em -ig: et uansvarligt menneske "um homem irresponsável" e as formas no plural indefinido heste "cavalos" e hunde "cães", exemplos do livro de Geemuyden.

Apesar do texto literário de LIE (1901, p. 5) ser de um período anterior à data convencionada por nós (1907), poderíamos considerar esse texto como rigsmaal:

Stod der ingen anden utvei aapen, var han evig fuld av undskyldninger, hvorav han sendte den ene frem for sig efter den anden som en feltherre sine hærlinjer indtil sidste reserve. Saa hadde han tilfældigvis faat vite gal lekse igaar, - saa var netop dette blad ute av boken hans, eller han hadde en ældre utgave (....)

"Se não houvesse nenhuma outra solução, ele vinha sempre cheio de desculpas, que chegavam uma após a outra como tropas de exército enviadas por um general até não houver nenhuma outra reserva. Então se ele tivesse eventualmente sabido sobre uma lição difícil no dia anterior, no mesmo momento a folha dela teria se perdido do livro ou ele teria uma tarefa mais antiga [...] (trad. nossa)"

Nesse trecho narram-se as desculpas dadas pelo aluno Svend Bidevind por causa dos exercícios. Consideramos esse texto como rigsmaal 
porque ele tem características como: utilização das consoantes surdas "p" (aapen "aberto"), "t" (vite "saber" ute "fora", utgave "exercício"), também há em outras páginas a forma em "k" (like "parecido") em vez das consoantes sonoras (aaben, vide, ude, udgave, lige). Também encontramos as formas hester "cavalos" (terminação em -er da forma indeterminada do gênero comum em vez de -e no dinamarquês). Outra característica existente é a forma de pretérito em -te e -dde (svarte "respondeu", bodde "morou") em vez de -ede e em ambos os casos). Encontramos também vários casos de supressão da forma do neutro em -t nos adjetivos terminados em -ig: et eller andet ubegripelig vis "de alguma maneira incompreensível” em vez de et eller andet ubegribeligt vis, além da palavra também ser escrita com "p" e não com "b".

Com relação ao landsmaal, encontramos atestações muito antes das primeiras atestações em rigsmaal. O seguidor de Aasen, Aasmund Vinje, publicou o primeiro jornal em landsmaal em 1858, conhecido como Dølen:

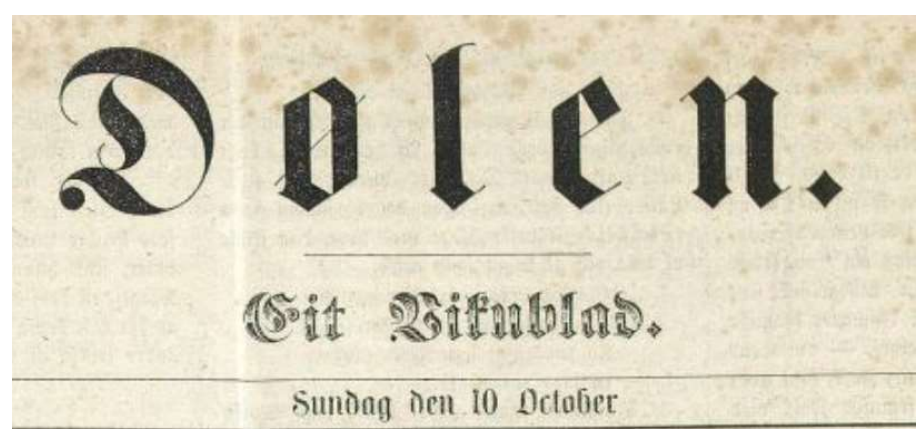


Artigo do dia 23 de janeiro de $1859^{42}$ :

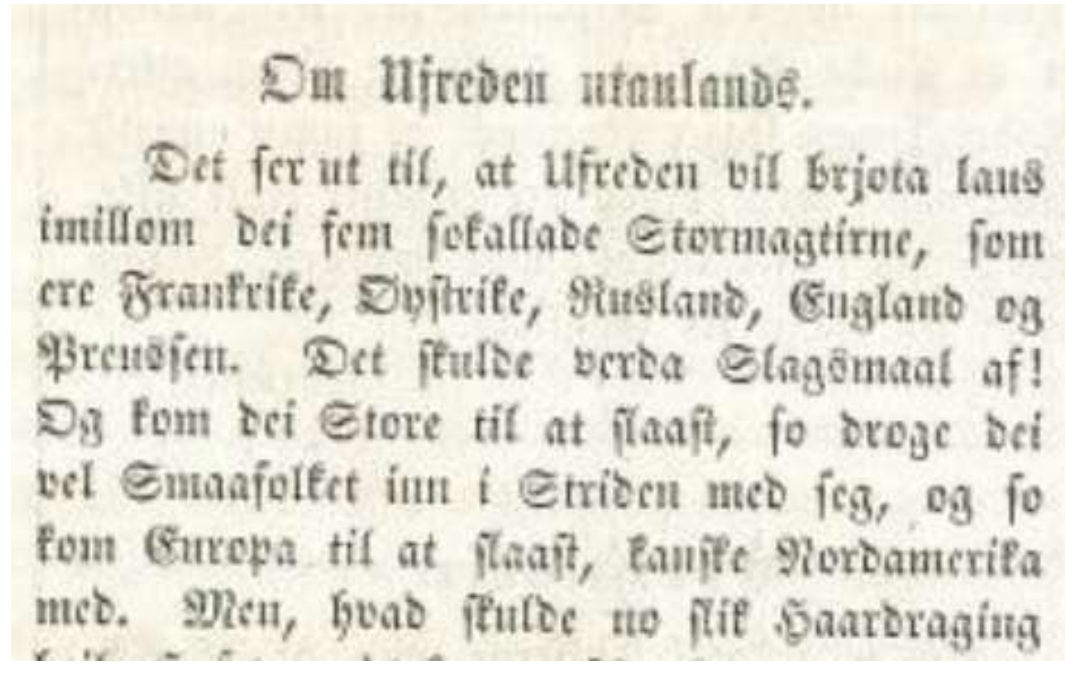

Sobre a guerra no estrangeiro

"Parece que a guerra vai eclodir entre os cinco, assim chamados, grandes poderosos: França, Áustria, Rússia, Inglaterra e Prússia. A partir daí teríamos uma batalha! $E$ então viriam os adultos para a batalha, como também suas crianças, e então a Europa entraria em guerra, talvez junto com a América do Norte [...]" (trad. nossa)

Percebe-se que nesse texto há muitas das propostas sugeridas por Aasen: infinitivo terminando em -a (brjota "romper", verda "tornar-se"), assim como outras características não citadas anteriormente como, por exemplo: utilização do dei "eles/elas" em vez de, o ditongo au (laus) em vez de $\varnothing$, o pronome reflexivo de terceira pessoa seg, que é grafado sig em rigsmaal e dinamarquês. Em outras partes desse artigo também encontramos a utilização da forma em feminino, por exemplo, ei Jord "terra", que é diferente da forma do dinamarquês e rigsmaal, pois estes utilizam o artigo comum (tanto para masculino como para feminino), en Jord. Também há o morfema - $i$ da forma definida singular do feminino, portanto, Soli "o sol" em vez de do morfema -en do rigsmaal e dinamarquês, Solen.

Concluímos que a língua escrita norueguesa (como um sistema que tem vários dialetos) nunca deixou de existir, pois, por menor que seja a

\footnotetext{
42 Disponível em: http://sedak.ikamr.no/2012/sed0012-aasentunet/sed0012004/01/\#/32/zoomed
} 
quantidade de registros, há várias canções populares e poemas. Podemos apenas considerar que tenha deixado de existir como língua política e de administração. O nynorsk (anteriormente landsmål) seria, portanto, uma expressão escrita formada a partir do cálculo de um denominador comum dos dialetos do Leste, que se normatizou e conseguiu atender à necessidade norueguesa de uma língua nacional. Delimitamos, como será demonstrado no subcapítulo 2.3.2, o norueguês escrito com textos a partir de 1901 (nynorsk) e 1907 (bokmål), embora possam haver textos com as características, que definimos como próprias do norueguês, em textos anteriores a essa data. 


\section{O MÉTODO ETIMOLÓGICO}

Definimos Etimologia como o estudo dos étimos e das origens do léxico, das estruturas sintáticas, dos elementos morfológicos e demais componentes morfológicos de uma determinada língua, tanto do ponto de vista da sua expressão (ortográfica, fonética, fonológica) quanto do seu conteúdo.

\subsection{A semelhança entre vocábulos}

Viaro (2011, p. 98-99) afirma que a semelhança entre vocábulos de duas línguas, tanto no significante, quanto no significado, deve-se basicamente a três fatores distintos: coincidência formal, empréstimo e semelhança por origem.

A coincidência formal entre palavras de duas línguas diferentes, segundo o mesmo autor, é mais corriqueira do que se possa imaginar. Caso haja palavras em línguas distintas com formas muito similares, mas nem documentos em sincronias pretéritas nem línguas afins servem para comprovar a afinidade entre elas, não é possível postular um étimo comum para as duas línguas, pois só é possível concluir que se trata de uma coincidência formal (p. 98). Ela pode ocorrer em vários processos. Fortson IV (2004) chama um desses processos de universais da linguagem, que englobam, por exemplo, a onomatopeia ou simbolismo do som e o baby-talk. Salmons (2012) acrescenta que no processo onomatopaico da imitação dos sons de animais as línguas tendem a utilizar frequentemente sons similares. Outro caso ocorre durante a aquisição da linguagem: as crianças tendem a produzir alguns sons parecidos e duplicá-los, por exemplo, papa, caca, mama (p. 12-13).

Outro processo citado por Fortson IV (2004) é o acaso, tendo em vista que há um número de sons limitados que a voz humana pode produzir e suas combinações também são limitadas. Por conta disso, são formadas certas palavras que coincidentemente lembram umas às outras em línguas coletadas aleatoriamente, como as palavras théos no grego e deus no latim (p. 1). Consideramos como reais similaridades acidentais e podemos exemplificar com a 
palavra inà "cachorro" da língua indígena de Oaxaca, sul do México, conhecida como mixteca de Chalcatongo. Ela se assemelha muito com a palavra japonesa para cachorro inu. Uma outra similaridade ocorre com as formas Mann "homem" no alemão e man "marido" no guajajara, língua indígena brasileira (SALMONS, 2012, p. 13-4). Viaro (2011) exemplifica com a palavra que significa "mau", cuja forma tanto no inglês quanto no persa é bad (p. 98). Ora, tanto o par mixteca e japonês quanto o par alemão e guajajara não tiveram absolutamente nenhum contato relevante entre os tempos. Os termos "cachorro" e "homem" fazem parte do vocabulário básico, que dificilmente é emprestado entre as línguas, ainda mais por aquelas que não sofrem nenhuma influência de outra. Já o par inglês e persa, apesar de haver maciça influência cultural do inglês em todo o mundo, também é uma coincidência formal, pois é provado que o persa médio tinha a forma vat que se desenvolveu em bad (SAMUELIAN, 1979, p. 135).

O empréstimo é um outro fator que leva à exigência de vocábulos parecidos ou idênticos. Segundo Viaro (2011), tal processo ocorre quando há comprovadamente um contato direto entre línguas, envolvendo ou não o bilinguismo ou quando há um prestígio e influência cultural de uma sobre a outra (nesse caso, não é necessário supor uma contiguidade espacial). O autor exemplifica o primeiro caso com o português e o espanhol nos séculos XVI e XVII e o segundo, com o português e o italiano no século XVI e com o francês durante toda a história até o início do século XX (p. 99). Outro exemplo relevante para essa dissertação é a influência que o latim eclesiástico medieval, que penetrava em todas as camadas e atividades da Idade Média, teve sobre os desenvolvimentos românicos do latim vulgar e, consequentemente, na formação das línguas neolatinas. O latim culto medieval supria as deficiências da pobreza e limitação das línguas românicas populares (MAURER JR., 1951, p. 37-38), com exceção da língua romena, que foi privada da fonte de empréstimos desse latim por ter ficado isolada da România ocidental por conta da retirada das legiões romanas da Dácia pelo imperador Aureliano em 270 d.C (BASSETTO, 2005, p. 136-137). Mas a influência desse latim culto não ocorreu apenas sobre a área do Romance, mas também sobre a Escandinávia, já que as línguas dos países nórdicos não tinham termos específicos para determinadas abstrações cristãs e, por conta disso, quando não criavam palavras novas, as tomava por emprestado. 
O terceiro ponto, segundo Viaro (2011), é a semelhança por origem. Campbell e Poser (2008) afirmam que para estabelecer uma hipótese plausível para uma relação genética é necessário eliminar o acaso, as onomatopeias, os universais e também o empréstimo.

Por outro lado, deve-se considerar a relação genética, a semelhança por origem, mas não com base nas similaridades entre as línguas, mas sim nas correspondências sistemáticas entre os sons das palavras comparadas, especialmente no vocabulário básico e na evidência gramatical padronizada ( $p$. 10-11). É de extrema importância que o método siga tais pressupostos tanto para a realização de uma reconstrução quanto para a determinação de um étimo.

Como já dito, as línguas românicas têm uma vantagem na determinação de um étimo pois há um terminus a quo ${ }^{43}$, já que os étimos são frequentemente documentados, algo diferente do que se passa com as línguas germânicas, em que há poucos registros das sincronias anteriores e eles se resumem em runas a partir do século IV ${ }^{44}$, quando havia uma certa unidade germânica. Esgotadas tais fontes, a única maneira é recorrer à reconstrução. $O$ filólogo alemão August Schleicher, que é considerado como um dos primeiros a trabalhar com o conceito de uma reconstrução linguística em sua obra Compendium der vergleichenden Grammatik der indogermanischen Sprachen (1861), utilizou as três vogais do indo-europeu $(a, i, u)$ e um total de quinze consoantes; contudo, futuramente seria apresentado um modelo de até 25 consoantes e 10 vogais. Porém, além da tentativa de reconstrução da língua "unificada" falada pelos povos germânicos, também se julga necessário a reconstrução do latim vulgar (ou, de um ponto de visto mais histórico, do protorromance). Embora haja, como já considerado, inscrições rúnicas de tempos muito remotos, quando havia uma certa unificação entre os germânicos, as fontes do latim vulgar são muito mais numerosas. Bassetto (2005) cita, por exemplo, inscrições populares, papiros antigos, gramáticos e mestres de retórica que faziam "correções" da forma vulgar, relatos de peregrinações, textos latinos tardios, textos cristãos e glossários (p. 110-135). O autor conclui, por fim, que a partir dos dados colhidos nas fontes é "possível reconstruir o latim vulgar, falado,

${ }^{43}$ Definido no subcapítulo 2.1.3.

${ }^{44}$ Consulte o capítulo 2.1.5. 
até um ponto razoável e mais ou menos completo, ainda que o recurso às fontes, incoerentes e incompletas, exija sempre muito critério e prudência" (2005, p. 138), mas tais fontes "não são suficientes para a reconstrução completa do latim vulgar" (p. 135). Portanto, "não existindo nenhum escrito totalmente em latim vulgar, por ter sido apenas falado, essas fontes indiretas, além de incoerentes, não conseguem cobrir seu universo." (p. 135). Além do mais, o autor destaca que as línguas românicas têm uma situação privilegiada, das quais se conhecem o terminus a quo e o terminus ad quem e, com isso, permite-se traçar com segurança a história externa e interna da evolução das línguas românicas, o que não acontece com a germanística e com a eslavística, às quais falta um conhecimento mais pormenorizado e documentado do terminus a quo (p. 138). O autor tem razão em afirmar isso, se também estiver considerando o registro do latim arcaico, clássico, medieval e vulgar, uma vez que as línguas germânicas têm um número de mais ou menos 6.000 inscrições rúnicas (ZILMER, 2005, p. 38), o que não é muito se compararmos aos registros do mundo românico. Por outro lado, a respeito das línguas germânicas, há inúmeros registros na maioria de seus dialetos, o que se torna possível conhecer o terminus a quo e realizar a reconstrução.

Por meio das correspondências sistemáticas entre as línguas, e não apenas se debruçando sobre os metaplasmos internos de uma determinada língua é possível determinar tanto a reconstrução do latim vulgar quanto do antigo germânico. A respeito das correspondências sistemáticas, Campbell e Poser (2008) afirmam que é importante ter em mente que elas são cruciais e não meras similaridades, que tais correspondências não necessariamente envolvem sons que são foneticamente similares e que as mudanças sonoras que levam a correspondências pouco parecidas sempre alteram as palavras cognatas de maneira que o parentesco não seja facilmente reconhecido até que as correspondências sistemáticas sejam compreendidas (p. 172-173).

Tomemos, como exemplo, as palavras do gótico sauhts "doença", haurn "chifre" e gulp "ouro". Suas formas nas línguas cognatas germânicas são: 
(germ. *suxti- >) Go. sauhts *[soxts] $\cong \mathrm{AAA} A \mathrm{AS}$ suht $\cong \mathrm{AFris.} \mathrm{sechte} \mathrm{\cong AN}$ sótt

(germ. * hurna) $>$ Go. haurn *[horn] $\cong$ rún. horna ${ }^{45}$ ( > AN/AS/AI/AFris./AAA horn)

(germ. * gulpa) $>$ Go. gulp $\cong$ rún. ${ }^{*}$ golda ( > AS/Al/AAA/AFris. gold $\cong$ AN gull ou goll)

Observando de maneira superficial, sem considerar as correspondências similares, ou metaplasmos, se realizaria as seguintes reconstruções: no primeiro caso, *suxti- ou *soxti-, no segundo caso *horna, já que todas as formas em sincronias posteriores estão em *[o] e, no terceiro, em *gulpa ou *golpa; tais reconstruções, no entanto, seriam errôneas. Por serem correspondências sistemáticas, é de grande ajuda para a investigação a comparação com outras palavras, cujas formas nas sincronias posteriores têm $o$ ${ }^{*}[\mathrm{o}], \mathrm{au}{ }^{*}[\mathrm{o}]$ ou $u *[\mathrm{u}]$ :

\begin{tabular}{|c|c|c|c|c|c|}
\hline Go & Rúnico & AN & Outras & Significado & \\
\hline sunus & $x$ & $\begin{array}{l}\text { sunr (ou } \\
\text { sonr) }\end{array}$ & $\begin{array}{l}\text { sunu } \\
\text { (Al/AS); } \\
\text { suno } \\
\text { (Fris.A.); } \\
\text { sun(u) } \\
\text { (AAA) }\end{array}$ & "filho" & $\begin{array}{l}\text { Manteve } \\
{ }^{*}[\mathrm{u}]\end{array}$ \\
\hline hunds & $\begin{array}{l}\text {-hudaz } \\
\text { (sec. III, } \\
\text { fecho de } \\
\text { Himlingjøje, } \\
\text { Din. } 200\end{array}$ & hundr & $\begin{array}{l}\text { hunt } \\
\text { (AI/AAA); } \\
\text { hund } \\
\text { (AS/Fris.A.) }\end{array}$ & "cachorro" & $\begin{array}{l}\text { Manteve } \\
{ }^{*}[\mathrm{u}]\end{array}$ \\
\hline
\end{tabular}

${ }^{45}$ Séc. V, Gallehus 


\begin{tabular}{|llll|l|}
\hline \multicolumn{2}{|c|}{ d.C.) } & & \\
\hline $\begin{array}{l}\text { waurd } \\
\text { *[word] }\end{array}$ & $\mathrm{X}$ & orð & $\begin{array}{l}\text { word palavra } \\
\text { (AS/Frs.A.); }\end{array}$ & $\begin{array}{l}\text { No Go. } \\
\text { Tornou-se } \\
\text { au *[o], } \\
\text { por causa } \\
\text { do } r \\
\text { posterior }\end{array}$ \\
& & wort & (AAA) & No Go. \\
& & & Tornou-se \\
au *[o], \\
auhsa
\end{tabular}

Desses exemplos, podemos concluir que o gótico sempre vai manter a vogal ${ }^{*}[u]$, quando posteriormente haver um -a ${ }^{*}[a]$ final, diferentemente das outras línguas parentes que transformam $\circ{ }^{*}[u]$ em *$[0]$ (Go. gulp $\cong$ as outras gold). Vemos, por outro lado, que há casos em que o gótico transforma o $u$ *[u] em au *[o], tendo ou não um -a *[a] final, mas nesse caso há uma condição: a existência de uma fricativa * $[X]$ ou um * $[r]$ posteriores (1. Go. sauhts $\cong$ outras suht,

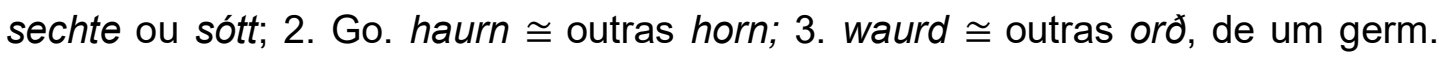

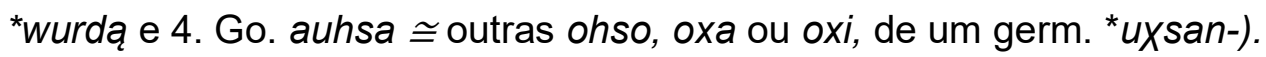

O a final, que gerou a apofonia de $u{ }^{*}[u]$ em $O{ }^{*}[0]$, sofreu apócope nas sincronias posteriores. Não encontramos outros registros no rúnico, que têm esse a final. Em todos os exemplos em que ele não existe, o $u{ }^{*}[u]$ permanece inalterado, como é o caso das palavras herdadas do rúnico (séc. III) hudaz- e germ. *sunu. A forma AN gull é uma variante de acordo com Haugen (1982, p. 33). Schuhmann (2009, p. 16) afirma que em alguns casos a mutação causada pelo a final não ocorria, o que permitiu a formação dessa variante. A forma variante AN sonr também ocorre posteriormente. 
A mutação de $u$ *[u] para $O{ }^{*}[0]$ causada pelo a *[a] final é conhecida como a-omlyd (TORP, A; VIKØR, S, 2000, p. 35) e a-Umlaut (RANKE, F.; HOFMANN, D., 1988, p. 30) ou simplesmente assimilação regressiva causada pelo $a{ }^{*}[a]$ final. A palavra horna, por ser um registro bem mais antigo, deixa o vestígio do a final, que posteriormente sofreria apócope; hundaz, por sua vez, não sofre a mutação porque há um travamento de nasal na coda silábica, o qual impede o processo (RANKE, F.; HOFMANN, D., 1988, p. 30).

Esses dados levaram às reconstruções de tais palavras como: *hurna, *suxti-, " uxsan-, "wurda-, " gulpa, *sunu e *hundaz (KROONEN, G., 2003). Pecebe-se que não há nenhuma reconstrução com a vogal curta $O$ *[o]. Por conta disso, é sabido que essa vogal não existia no proto-germânico e que a apofonia causada pelo $a *[a]$ final fez com que $0 u$ *[u] curto se transformasse em $O{ }^{*}[0]$ curto, por assimilação, preenchendo assim o espaço vazio existente entre as vogais do germânico, nesse ponto, $0 \circ$ *[o] curto não era um fonema propriamente dito, pois, uma vez que havia um a ${ }^{*}[a]$ final posterior, ele seria considerado apenas um alofone combinatório do $u$ *[u] curto, mas assim que o a *[a] final sofreu apócope por conta da passagem das tônicas para as sílabas iniciais, $0 O$ *[o] curto gradualmente passou de alofone para um fonema propriamente dito (TORP, A; VIKØR, S, 2000, p. 35-36). Outra prova de que esse $o$ *[o] curto não existia é a lista de palavras do gótico, língua registrada mais antiga, em que são contidas apenas palavras em $u{ }^{*}[u]$ curto. Para consultar as vogais (e consoantes) do proto-germânico, consulte Ringe (2006, p. 214).

\subsection{A língua, o dialeto e o sistema}

Definimos língua com base nas ideias de Saussure: "é um produto social da faculdade de linguagem e um conjunto de convenções necessárias, adotadas pelo corpo social para permitir o exercício dessa faculdade nos indivíduos" (SAUSSURE, 1916[2010] $]^{32}$, p. 17) e também:

[...] é a parte social da linguagem, exterior ao indivíduo, que, por si só, não pode nem criá-la nem modificá-la; ela não existe senão em virtude de uma espécie de contrato estabelecido entre os membros da comunidade. Por outro lado, o indivíduo tem 
necessidade de uma aprendizagem para conhecer-lhe 0 funcionamento; somente pouco a pouco a criança a assimila (p. 22)

Uma outra definição constantemente citada é a de Max Weinreich, que afirmou, em Ídiche $\left(1945\right.$, p. 13) ${ }^{46}$ :

אַ שפּראַך איז אַ דיאַלעקט מיט אַן אַרמיי און פَלאָט

$<$ a shprakh iz a dialekt mit an armey un flot>

"uma língua é um dialeto com um exército e uma marinha".

Falamos aqui de uma imposição de uma variedade linguística em meio a outras variedades (variação diatópica). Trata-se de um sistema em uma sincronia, que se impõe sobre os outros sistemas e que alça à condição politicamente conhecida como uma "língua". Consequentemente, devem ser aprendidas suas normas por aqueles que desejam ter poder e prestígio e fazer exercício de funções. Os outros sistemas, dentro desse espaço geográfico são considerados dialetos. Bem sabemos também que um dialeto nem sempre precisa ter a mesma origem da língua dentro desse espaço geográfico: basta lembrar do basco, que está dentro da Espanha e há pouco tempo não era conhecido como língua autônoma, mas como "dialeto".

A problemática entre o dialeto e a língua é bem complexa. Tomemos como exemplo o galego, que há pouco tempo não tinha o status de língua. Se não era considerado língua, seria um dialeto. Mas dialeto de qual língua? Do espanhol, devido ao espaço geográfico e político em que se encontra? Essa situação seria estranha porque ele é muito mais próximo do português quando consideramos a sua estrutura e a inteligibilidade mútua.

Se mantivermos em mente a afirmação de Weinreich, perceberemos que o sistema dialeto português ganhou força e foi imposto como língua, em oposição ao sistema dialeto galego (na

46 Weinreich teria ouvido essa afirmação de um estudante provavelmente chamado de Joshua Fishman, que assistia uma de suas palestras (BRIGHT, 1997, In: do COUTO, 2007, p. 323). 
sincronia galego-português), pois foi suportado pelo exército de $D$. Afonso Henriques, que iniciou a conquista dos territórios do sul e, assim, configurou geograficamente o que viria ser o estado português povoado por falantes de variantes dentro da sincronia português arcaico que se diferenciaria ainda mais do galego arcaico por conta das influências de substrato das regiões do sul.

Haugen (1976) afirma que por ser o desenvolvimento dos dialetos geográficos mais antigos do que a formação das nações atuais, as fronteiras nacionais não constituem geralmente as fronteiras dialetais e exemplifica com o caso dos dialetos do norte da Noruega que são semelhantes aos dialetos do norte da Suécia, por causa das isoglossas (p. 53-54).

Hock (1991) sugere um ponto de vista bem mais científico e menos social ao sugerir um uso técnico de que inglês vernáculo afroamericano e o inglês padrão são ambos dialetos da língua inglesa e que estão em pé de igualdade, se considerarmos num puro ponto de vista linguístico. O autor também afirma que as variedades da fala, cujas divergências são pequenas, são chamadas de diferentes dialetos de uma língua e língua seria uma união abstrata de tais dialetos, sejam eles de características normativas, vernáculas, urbanas ou rurais e regionais ou supraregionais. Por outro lado, as variedades da fala que diferem uma das outras notavelmente são consideradas línguas diferentes e conclui com o ponto de vista de que idealmente tudo está baseado na noção de mútua inteligibilidade. O autor ainda argumenta que o teste de mútua inteligibilidade nem sempre funciona, pois, o norueguês e o sueco, apesar de serem duas línguas normatizadas e tinham uma forte tradição literária, são mutualmente inteligíveis por muitos falantes (p. 380-381). Tal inteligibilidade ocorre porque ambas as línguas foram normatizadas mediante duas variedades dialetais, cada uma dentro de um espaço geográfico definido (por um lado, Noruega; por outro lado, Suécia), mas elas provêm de um sistema linguístico comum, chamado por Seip (1931) de Era das síncopes (p. 738) e por Haugen (1976) por Escandinavo comum (p. 132). 
Essa inteligibilidade ainda existente talvez seja explicada pelo fato de que durante todo esse longo período de tempo a partir da fragmentação dialetal não ocorreram influências significativas de superestrato ou substrato em ambas as regiões, mantendo algumas isoglossas intactas. Por fim, Hock (1991) assume que não há nenhuma demarcação evidente entre dialeto diferente e língua diferente. Em vista disso, não é um caso de "sim" ou "não", mas de um gradiente entre "menos" ou "mais"; além do mais, a inteligibilidade mútua depende não apenas de fatores linguísticos, mas também de fatores sociolinguísticos (p. 380-381).

Concluímos, ampliando a metáfora de Weinreich, dizendo que uma língua é um dialeto, que dentro de uma sincronia com outros dialetos, ganha um status político e social de maior relevância e, assim, com exército e marinha, se instala numa determinada região e, consequentemente, domina outros sistemas linguísticos, que nem sempre são mutualmente inteligíveis.

Por alguns momentos também utilizaremos o termo sistema. Este definimos como um conjunto de paradigmas fonológicos ou morfológicos e de regras sintáticas, associados a significados específicos e existentes numa determinada sincronia. Uma determinada sincronia também pode conter vários sistemas: a língua portuguesa na verdade é uma abstração que envolve sistemas conhecidos como português paulista, português carioca, português brasileiro, português angolano, português de Portugal, etc. A noção de sistema, por conseguinte, depende da abrangência da investigação. A sincronia atual da língua norueguesa, por sua vez, tem vários sistemas: os sistemas escritos normatizados bokmål e nynorsk, além dos sistemas diatópicos: sistema bergensk "de Bergen", sistema, trøndersk "de Trøndelag", sistema hallingmål "de Hallingdal", etc. Como a Noruega tem centenas de dialetos, tem, portanto, centenas de sistemas com variação diatópica. Ao comparar sistema com língua, Viaro (2015) afirma que a língua, diferentemente do sistema, perpassa o eixo da diacronia e da sincronia porque é sabidamente uma entidade política e não apenas 
cognitiva, em outras palavras, a língua tem sua parte Histórica e Psicológica (p. 96-97).

Diacronicamente, diremos que a fase anterior artificialmente recortada da língua portuguesa, entendida como unidade política, é o português arcaico, que também tinha muitos outros sistemas com variações diatópicas, diastráticas e diafásicas, pois, para dizer que a sincronia mudou, o sistema linguístico precisa mudar.

Como não houve uma língua escrita norueguesa antes do período da "guerra de idiomas norueguesa" (fim do séc. XIX), visto que o dinamarquês era a única língua escrita a partir de meados do séc. XVI, salvo algumas canções e anotações folclóricas, teria que ser realizada uma reconstrução dos dialetos noruegueses, com ajuda com documentos escassos em dialetos, para atestar as sincronias anteriores ao nynorsk, que é, como já demonstrado, uma criação do filólogo Ivar Aasen. Veremos essas sincronias no subcapítulo 2.3.2.

Com base em Saussure, fica evidente que não existe sistema em diacronia; portanto, a noção de sistema é eminentemente sincrônica. Isso não contradiz o fato de os sistemas serem dinâmicos. Apenas metodologicamente é possível congelá-los em uma determinada sincronia e, no meio de seu funcionamento, existirá sempre tanto a divergência natural quanto a convergência (causada, por exemplo, por tentativas preventivas ou por koiné, frutos de ações políticas e econômicas).

\subsection{As sincronias pretéritas das línguas portuguesa e norueguesa e as modificações formais}

Neste subcapítulo apresentaremos as sincronias tanto do português quanto do norueguês. As sincronias de uma língua são períodos que têm o testemunho de seu funcionamento. A respeito da língua latina, por exemplo, há testemunhos do período "arcaico", do período "clássico", do período "medieval", etc. 
Também se deve levar em consideração que a passagem temporal não ocorre apenas em diacronia, mas também em sincronia, uma vez que é possível perceber a mudança da língua durante a nossa vida. De acordo com Viaro (2015):

\begin{abstract}
Metodologicamente falando, a "sincronia atual" poderia definir-se como o período de tempo transcorrido entre a data de nascimento do falante mais iodoso de uma língua até o dia de hoje. Contudo, como esse critério não seria aplicável para as sincronias pretéritas, recorre-se às divisões arbitrárias, baseadas em dados da chamada "história externa" à língua. A mudança de um sistema para o outro configura-se, no jargão do Cours, um movimento temporal conhecido por diacronia (p. 96-97)
\end{abstract}

Portanto, uma abordagem teórica é fundamental para que seja realizada uma descrição sincrônica de um sistema e a compreensão de sua diacronia, em direção a um sistema subsequente, uma vez que são conceitos muito abstratos. O autor também postula que uma sincronia de uma língua em uso não é apenas teórica, abstrata e uniforme, mas pode ser entendida como real, concreta e múltipla. Os seus testemunhos seriam o elemento concreto, nos quais há como regra a multiplicidade (ainda mais quando um elemento normativo não é excessivamente forte). Para ser analisável, uma sincronia só pode ser artificial e conceitos como "português arcaico" e "português moderno" não são sistemas, mas períodos artificialmente recortados da mesma língua, que é entendida como unidade política. Haveria vários sistemas dentro de cada um desses recortes.

Por fim, o autor afirma que convém que as sincronias sejam verossímeis, uma vez que são períodos em que se situam teoricamente os contrutos artificiais dos sistemas e, assim, é possível realizar o teste popperiano da refutação. Por conta disso, a descrição das leis fonéticas é fundamental, já que podemos saber se uma certa afirmação é válida ou não no estudo etimológico, que varre sincronias pretéritas e diacronias rumo à sincronia atual (p. 98). 


\subsubsection{Do português}

Viaro (2015) elencou a respeito da transição do latim ao português seis sincronias (p. 98-99). Elas são arbitrárias, mas interligadas a eventos históricos importantes que provavelmente se integram a mudanças sociais e linguísticas. Em vista disso, cada palavra, sendo de origem latina, passou por todas essas sincronias. Estas são as sincronias pretéritas da língua portuguesa:

So - Do latim comum à formação da koiné latina (ou latim vulgar) (entre o século I a.C. e o século $V$ d.C.) ${ }^{47}$;

$\mathrm{S}^{1}$ - Do latim arcaico à formação do iberorromânico (entre o século III a.C. e o século $V$ d.C. $)^{48}$;

Essas duas sincronias são coexistentes, pois uma é importante para a história do português e outra, para a história do latim. Nesse momento, há a aprendizagem incompleta de segunda língua pelos povos da Gallaecia pré-românica, o que deixou algum vestígio nesse sistema latino arcaico que veio do Sul da península e, em seguida, a koinização dos dialetos latinos, formando o latim vulgar, que influenciou o latim arcaico já existente ${ }^{49}$ e permitiu a formação desse iberorromânico.

$S^{2}$ - Do iberorromânico à formação do iberorromânico do Noroeste Peninsular (entre o século VI e o IX);

$S^{3}$ - Do iberorromânico do Noroeste Peninsular à formação do galego-português (entre o século X e o século XIII);

47 O latim vulgar que foi levado pelos romanos para a Gália, com suas características sintáticas, fonéticas e morfológicas, se sobreporia à variante diatópica "ibérica" (com arcaísmo do período arcaico, primeiro passo do chamado "iberorromânico) como língua vernácula, mas não removeria todas as suas características arcaicas (Manual do NEHiLP, 2015, p. 119)

48 O latim arcaico é anterior ao latim vulgar no que se refere à Península lbérica meridional.

${ }^{49}$ Ele também pode ser entendido como uma koiné itálica, uma vez que os romanos o trouxeram quando entraram no sul da Península lbérica por volta de 218 a.C. e, a partir desse ponto, essa variante latina, que tinha certa conservação de uma forma mais antiga (do período de Plauto) entrou em contato com os falares autóctones já existentes na Península. Foi essa koiné que chegou na Gallaecia por volta da metade do século I a.C. 
$S^{4}$ - Do galego-português à formação do português antigo (entre o século XIV e o XVII);

$S^{5}$ - Do português antigo à formação do português moderno (entre o século XVIII e o século XXI);

O $\mathrm{S}^{0}$ ocorre simultaneamente ao $\mathrm{S}^{1}$ : é sincronia mais antiga e o $S^{5}$ é a sincronia que vai do português antigo até o período anterior ao nascimento do falante mais antigo da língua portuguesa. Ambas são sincronias pretéritas. Tais sistemas são atribuídos à língua portuguesa de hoje em dia, por ela ter sido formada a partir dessas modificações linguísticas em um determinado espaço geográfico. Nosso recorte não abrangerá as sincronias mais antigas que $\mathrm{S}^{0}$ e $\mathrm{S}^{1}$, ou seja, $\mathrm{S}^{-1}$ (do latim arcaico à formação do latim comum), $\mathrm{S}^{-2}$ (do itálico a formação do latim arcaico) e $\mathrm{S}^{-3}$ (do do-europeu à formação do itálico), pois teríamos que nos servir muito da reconstrução e também para nos mantermos apenas no escopo entre língua latina e língua portuguesa com seus respectivos sistemas.

As reconstruções das pronúncias de todos esses sistemas são encontradas em Viaro (2015).

\subsubsection{Do norueguês}

Com relação às línguas escritas oficiais da Noruega, propõese as seguintes sincronias pretéritas (as sincronias são parcialmente influenciadas pelos autores Skard (1972, 1973), Haugen (1982), Seip (1955), Antonsen (1975) e Nielsen (2000):

Primeiramente deve-se considerar que as sincronias a partir do germânico até as línguas nórdicas são bem discutíveis. Seguirei aqui o modelo proposto por Nielsen (2000). A principal discussão é se alguns ou todos os dialetos do germânico ocidental (i.e. alemão antigo, dialetos do alemão antigo, saxão antigo, inglês antigo, frísio antigo) deveriam 
ser considerados sucessores do rúnico primitivo $(R P)^{50}$, que são as inscrições rúnicas datadas do ano 150-200 a cerca de 450-550 d.C, seguidas de um período de transição entre 500 e 750 para o rúnico da Era viking. Há cerca de 60 inscrições desse tipo na Noruega (Skard, p. 25).

\section{Antes apresentaremos um mapa para localização geográfica}

do leitor:

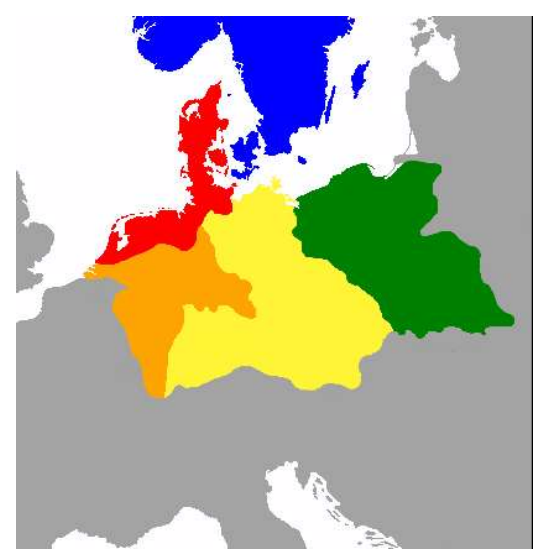

50 Kuhn (1955) afirma que a língua das inscrições rúnicas do início do período não era nem nórdico nem germânico do Oeste, mas comum a toda área germânica, com a exceção do gótico. Tal assumpção foi compartilhada por Antonsen, só que este em 1965 atribuiu tais inscrições ao germânico do Noroeste em vez de toda a área germânica. A razão para o surgimento desse novo termo era um conjunto de isoglossas que gradualmente demarcavam a fronteira (cronológica) entre o germânico e o germânico do Noroeste como, por exemplo, inovações na restruturação dos alofones de /i/ e /e/, a fonemização de [o] $>/ 0 /$ e da mudança de abertura $/ \bar{e}^{1} />/ \bar{a} /$ e na emergência do $/ \bar{e}^{2} /$. Antonsen também adverte sobre considerar a inscrições rúnicas mais antigas como "proto-escandinavo" ou "proto-nórdico" antecessor de todas as línguas escandinavas, uma vez que uma reconstrução baseada nas línguas escandinavas não seria idêntica à essa língua rúnica primitiva, mas sim a um nórdico comum que, por sua vez, é descendente da língua representada nessas inscrições mais antigas. Haugen (1976, p. 125) chama essa língua de Runic; alguns pesquisadores escandinavos, de urnodisk (em alemão urnordisch) e de língua inglesa de Proto-Nordic. Antonsen em 1975, por outro lado, mudou sua teoria em um aspecto: a língua das inscrições rúnicas mais antigas não seria antecessora de todos os dialetos do germânico Ocidental, mas apenas do germânico do tipo Ingveonic, ou seja, dos dialetos perto do mar do Norte, deixando, assim, os dialetos do antigo alto alemão fora desse escopo (Nielsen, 2000, p. 58-59). De acordo com Nielsen (2000), do total de 350 inscrições rúnicas entre III e VIII, 70 são de origem continental e 280 têm origem em território escandinavo. $\mathrm{O}$ autor, para evitar problemas de terminologia, sugere $\mathrm{O}$ termo Early Runic, traduzido nessa dissertação em rúnico primitivo. Ele também afirma que essas inscrições estão distribuídas numa área que compreende a Noruega e a Suécia, no Norte, respectivamente Trøndelag e Uppland, a ilha de Gotland e na Dinamarca (em Skåne e Slesvig), sendo o território medieval dinamarquês onde se encontra a maior concentração desses monumentos em Rúnico primitivo (p. 31-32). 
A cor azul apresenta os dialetos do germânico do Norte; a cor vermelha, germânico do Noroeste; Iaranja, germânico do Weser-Rêno (do Oeste); amarela, germânico do Elba (do Oeste) e verde, germânico do Leste. Designaremos como germânico do Ocidente quando considerarmos tanto o germânico do Noroeste quanto do Oeste. O único representante do germânico do Leste é o gótico.

É também um período em que ainda havia uma certa unidade de tribos germânicas entre o sul da Noruega e norte da Alemanha, embora algumas tribos já tivessem partido como, por exemplo, os godos que por volta do ano 200 estavam na área entre os rios Oder e Weichel a caminho do Mar Negro (SCHWARZ, p. 51), os marcomanos e os quados que já estavam na boêmia no século II, os francos que já se encontravam no Reno no fim do século III e estabeleceram um novo poder cristão sob Clóvis no fim do século $V$, os alamanos no oeste, etc.

Demonstraremos os desenvolvimentos no que diz respeito ao rúnico primitivo: sincronia $\mathrm{i}$ - que afetaram todos os dialetos do mundo germânico (continuum Norte-Oeste), com exceção do gótico, e que são evidenciados pelo rúnico primitivo (a partir do ano 100) e sincronia ii que afetaram apenas os dialetos do germânico do Norte e do Noroeste e que são evidenciados pelo rúnico primitivo (a partir do ano 200).

Há dois cânones no estudo do rúnico primitivo: Wolfgang Krause com a obra Die Sprache der urnodischen Runeninschriften (1971) e Elmer Antonsen com a obra A Concise Grammar of the Older Runic Inscriptions (1975) e ambas têm grandes divergências sobre esse assunto. Krause afirma que o rúnico primitivo é imediatamente predecessor do nórdico, mas não do germânico do Oeste (p. 18-20), assumindo, assim, haver um buraco linguístico entre a área dos falantes do urnordisch e da região do germânico do Oeste, que ficava ao sul da Jutlândia. Krause (1971) se baseia em a) o reflexo do ${ }^{*}-z$, que é mantido e representado pela letra rúnica $\psi$ (e como $-r$ em antigo nórdico), mas se perdeu em uma sincronia mais antiga no germânico do Oeste e b) formações de aoristo nas formas do indicativo pretérito 
singular de $2^{\mathrm{a}}$ pessoa como, por exemplo, IA bude e AAA buti vs. AN bauzt "tu ofereceste", embora não haja nenhum testemunho dessa forma no rúnico primitivo e, mesmo assim, ele reconstruiu como *bautst no $\operatorname{RP}$ (p. 126). O que Krause queria demonstrar, mesmo de maneira extrapolada, era a grande diferença do RP com relação aos dialetos do germânico do Oeste (NIELSEN, 2000, p. 147). Antonsen (1975), por sua vez, afirma que por meio de pontos de vista fonológico, morfológico e sintático, o germânico do Noroeste pode ser considerado língua paterna não apenas do escandinavo, mas também dos dialetos do germânico do Oeste do tipo Ingveonic, portanto, de acordo com o autor, não há características atestadas nas inscrições que contradiga isso (p. 26).

Portanto, Antonsen é da opinião que o germânico do Noroeste seria a sincronia anterior ao rúnico primitivo e ao germânico do tipo Ingveonic. Um problema, porém, não foi resolvido por ele no que diz a respeito da determinação do fim do período "germânico do Noroeste". Ele levanta dúvidas, por exemplo, se as isoglossas do germânico do Norte (alguns exemplos: medial $/ \mathrm{w} /$ antes de $/ \mathrm{u} />\varnothing ; / \mathrm{ht} />/ \mathrm{tt} / \mathrm{e} / \mathrm{j} /$ inicial > Ø) não refletiriam, na verdade, um dialeto tardio do "germânico do Noroeste" em vez de um dialeto separado do germânico do Norte. Ele não tinha dúvidas a respeito da língua das inscrições de Blekinge (período de transição que, em seguida, veremos ser a transição entre o rúnico primitivo e o nórdico primitivo), por exemplo, em que ocorre uma considerável ruptura no continuum do germânico do Noroeste para uma língua escadandinava discernível linguisticamente. Em seguida veremos que a teoria de Nielsen difere consideravelmente desse ponto de vista de Antonsen.

Sincronias do germânico até o médio-norueguês (com base em Nielsen, 2000 no que se refere): 


\subsubsection{SN $\mathrm{SN}^{1}-\mathrm{O}$ germânico do continuum Norte-Oeste}

Esta sincronia norteia a fase inicial do rúnico primitivo, período até aprox. 200 d.C. O germânico do continuuum Norte-Oeste é uma sincronia posterior ao germânico. Não iremos reconstruir as palavras dessa sincronia, mas sim dar exemplos de atestações, mesmo que em sincronias posteriores, para comprovar tal unidade, da qual o gótico não participou.

a) Germ. * $\bar{e}^{-1}$ se manteve no Go. gadēps "feito, ato", mas nos dialetos germânicos do Noroeste (e também do Sul) adquiriu uma qualidade sonora mais aberta como em AN dáđ, IA dæd, AAA tāt ${ }^{51}$. No sistema rúnico antigo Futhark a vogal também é mais aberta como, por exemplo, -mariz ("famoso", nom.m.s., bainha de Thorsberg, Schleswig, Alemanha, 200 d.C.), vide AS/AAA māri, mas Go. -mēreis. Também há a atestação dessa mudança mais ao sul na região da Boêmia, onde ocorreram as guerras marcomanas no século II e que tinha como líder Ballomar (170 d.C.), sendo o último elemento -mar "famoso" (Nielsen, p. 205). Portanto, de acordo com Nielsen esse processo antecede claramente o período do qual estamos tratando, que é de 200 a 500 d.C. (NIELSEN, 2000, p. 205).

b) como havia um espaço vazio no sistema de vogais curtas, quer dizer, faltava $O{ }^{*}[0]$ no sistema vocálico germânico, ocorreu uma mutação causada por a (a-umlaut) não acentuado que fez com que o *[o] não fosse mais um alofone de *[u] em distribuição complementar, mas um fonema *[o] por excelência; logo, percebe-se que ocorreu uma assimilação regressiva, cp. germ. "gulpa- "ouro" > AN ঋgoll (>

51 De acordo com Fortson IV (2004), o germânico tinha dois * ${ }^{*}:$ o * $\bar{e}^{-1}$ seria uma continuação do IE

${ }^{*} \bar{e}$ e $0{ }^{*} \bar{e}^{2}$ é considerado ter diferentes origens e nem todas explicadas. Ambas se mantiveram ${ }^{*} \bar{e}$ no gótico; nas línguas do continuum Norte-Oeste, por outro lado, o ${ }^{*} \bar{e}^{2}$ se manteve ${ }^{*} \bar{e}$ (Al/AAA hēr e AN hér) enquanto o o $\bar{e}^{1}$ se transformou em ${ }^{*} \bar{a}$ (p. 304). De acordo com van Coetsem (1994, p. 79), após a fixação do acento na primeira sílaba, o $\bar{e}^{2}$ surgiu no sistema de vogais longas como um produto reduzido do ditongo ei; ${ }^{*} \bar{e}^{-1}$, por sua vez, se abriu para ${ }^{*}[$ ] após a "fragmentação dialetal permanente". Esse * $\bar{e}^{1}$ recebeu um traço mais aberto por conta da introdução do $\bar{e}^{2}$, que realizou a abertura do ${ }^{*} \bar{e}^{-1}$ [æ] por motivos de distinção e, em sincronia posterior, se transformou em ā nas línguas germânicas do continuum Norte-Oeste. No Go., por outro lado, ocorreu a fusão do $\bar{e}^{-1} \operatorname{com} o \bar{e}^{-2}$ (p. 98-113, esp. 113). 
isl./no./din. gull, sue. guld), AS, IA e AAA gold, mas Go. gulp. A ocorrência do $O$ *[o] nos chifres de Gallehus (Møgeltønder, Dinamarca, séc. V) nas palavras holtijaz ${ }^{52}$ e horna e dohtriz "filhas" na pedra rúnica Tune (Østfold, Noruega, 200-450 d.C.) mostra que o o *[o] já tinha adquirido um status fonêmico no rúnico primitivo (NIELSEN, 2000, p. 206). É importante ressaltar que uma parte dos dialetos nórdicos, da parte leste, têm formas sem a mutação causada por a como, por exemplo, no sueco antigo hult (< germ. *hulta- "bosque"), ao passo que nos outros dialetos nórdicos seria holt e também no norueguês golv (< *germ. *gulva- "chão"), mas no dinamarques gulv.

C) transformação do germânico *-ō final não acentuado ${ }^{53}$ para u. No RP há as seguintes atestações: lapu ("convite" nom.f.s.; bracteata de Darum, Jutlândia, Dinamarca, 450-550 d.C., germ. < *lapō; no IE era *-ā, compare sanscr.ásvā "égua" e lat. filia "filha”), minu ("minha", pron.f.m.s. com tema em ā, pedra de Opedal, Hordaland, Noruega, 350 d.C., < *meinō) e liubu ("querida", nom.f.s. com tema em a, mesma que a anterior, < germ. *leubō). Correspondentes ao RP lapu, há IA. lađu, AN. Iǫ,, MAA. lat, Go. Lapons. No gótico o tema é em -ōn). No AN tanto lǫð quanto born ("crianças", nom.n.p.) sofreram primeiramente mutação causada pelo $u$, um processo exclusivo das línguas nórdicas, e em seguida, síncope, AN bǫrn < ${ }^{*} b o q r n u<$ germ. *barnō, compare IA bearn, AS./AAA. barn (nesses casos o - $u$ também sofre apócope após uma sílaba longa). A terminação germânica *-ō se encontra, portanto, no nom.f.s. com tema em $\bar{o}$ *lapō e *gebō "presente" e no nom.n.p. com tema em ā como RP *barnō. No Go., por outro lado, o descendente do germânico *-ō foi -a, cp. giba e barna.

d) germ. *ai e *au não acentuados sofreram monotongação em $\bar{e}$ e ō, respectivamente. Como exemplos no RP há: woduride ("cavaleiro furioso", dat.m.s. com tema em ā, Tune, Østfold, Noruega, 200-450 d.C.) e magoz (< germ. *magauz, "do filho", gen.s. com tema em $u$,

52 É um nome composto a partir de *Holta-gastiz. Compare AAA holtz, AS, Al holt "madeira". Gastiz seria "convidado".

53 Tem origem no IE *-ā 
pedra de Vetteland, Noruega, 350 d.C). Compare, por exemplo, AN degi $i^{54} \approx \mathrm{Al}$ dæge $\approx \mathrm{AS}$ dage $\approx \mathrm{AAA}$ tage "dia" (< germ. *dagai "dia", dat.s.) e AN sonar $\approx$ AS suno $\approx$ IA suna $\approx$ AAA fridoo (< germ. *sunauz "do filho" e < germ. *fripauz "da liberdade", ambos gen.s.) ${ }^{55}$. A terminação de 3 pessoa singular do subjuntivo de verbos fortes da classe IV também termina em -ai. Por exemplo: *beranan "levar": germ. *berai "leva" > Go. baírai $\approx(>\mathrm{PR}$ berē > AN beri) $\approx$ Al bere $\approx$ AAA bere. No Go. daga e sunaus como correspondentes dos exemplos acima (NIELSEN, 2000, p. 206).

Não evidenciadas pelo rúnico primitivo, mas que poderiam ser reconstruídas:

e) germ. inicial pl- permanece igual no gótico, mas se transforma em $\mathrm{fl}$ - nas outras línguas germânicas (AN flýja $\approx \mathrm{Al}$ flēon AFris. fliāa $\approx$ AS/AAA fliohan, mas Go. pliuhan (SCHIMIDT, 2007, p. 58; NIELSEN, 2000, p. 213).

f) enquanto o germ. $z$ (IE z ou $s$ (Lei de Verner)) $)^{56}$ é mantido no gótico em posição final como $s$, ele se torna $r$ no germânico do Norte e do Oeste. No germânico do Norte se torna $r$ em todas as posições, mas no do Oeste apenas medialmente (e em posição final acentuada), sendo que em posição final não acentuada $0-z$ desaparece em períodos mais antigos (NIELSEN, 2000, p. 213-214). Ex: germ. *dagaz (> Go. dags e AN dagr, mas IA dæg, AFris. dei, AS dag, AAA tag); germ.

$54 \mathrm{O}$-e final do RP se transforma regularmente em -i no AN

55 O germânico *-auz vira -o no RP que, em sincronia posterior, se transforma em -a. Em uma

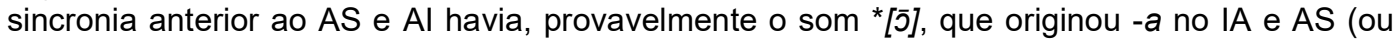
também o -o no AS).

56 De acordo com Nielsen (2000, p. 214), não é fácil datar a mudança do $z$ para o $r$. Ele critica as propostas de Schwarz $(1951,257)$ e afirma seguramente que tal mudança não foi implementada na Escandinávia até o final da sincronia do rúnico primitivo, pois não há confusão nas inscrições rúnicas entre as runas $\psi^{*}[z]$ e $R{ }^{*}[r]$ em posição medial e final. Na inscrição rúnica de By (500-550 d.C., Buskerud, Noruega), Antonsen (1975, p. 80) demonstra que há hrozaz (AN hrøra, AAA hruoren "mover rapidamente"), hroze (veja hrozaz) e azina (AAA arin, erin "chão", AN arinn "terra, plataforma"; compare latim area (IE *asynom)). De acordo com Nielsen (2000), no território do germânico do Oeste, a mudança deve ter ocorrido um pouco mais cedo, mas os rastros cronológicos não estão disponíveis (p. 214). Nielsen (2000) afirma que a queda no germânico Ocidental é bastante tardia e que não deve ter ocorrido até (ou depois) do século III a.D (p. 166-167 e p. 243); Grønvik (1998, p. 96-98 apud Nielsen, 2000, p. 266, nota 2) atesta que esse processo se completou no germânico do Oeste cerca de 200 a.D., o que, de acordo com Nielsen (2000, p. 266), é pouco provável. 
"maizan- "mais" (> Go. maiza, mas AN meiri, Al māra, AS, AAA mēro e germ. *deuza "animal selvagem" (> Go. dius, mas AN dýr, Al dēor, AS dior, AAA tior). A transformação de $z$ para $r$ também não está evidenciada no rúnico primitivo (NIELSEN, 2000, p. 213) O gótico, que mantém como $s$, demonstra a conservação, justificada por conta da precoce separação.

g) De acordo com Fortson IV (2004), havia uma tendência do

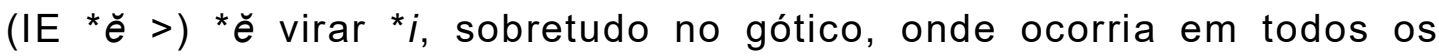
ambientes. Ringe (2006, p. 220-224) afirma que, com relação ao continuum Norte-Oeste, tal alternância ocorreu nos seguintes casos: 1) quando a sílaba seguinte tinha um $i$, sobretudo no indicativo e imperativo presente de verbos temáticos (em sua maioria parte, verbos fortes): (germ. *bero "eu levo" > IA bere; germ. *birizi "tu levas" > IA birst) ${ }^{57}$; 2) quando havia um *j não silábico na sílaba seguinte: IE *sédie- > germ. *set(j)an > germ. do continuum Norte-Oeste *sitjan- "sentarse" (> AN sitja, IA sittan, AAA sizzen) e IE *légh-ie- > germ. *leg(j)an "deitar-se" (> AN liggja $\approx$ IA licjan $\approx$ AS liggian $\approx$ AAA lickan/ligan $\approx$ Go. ligan $)$, mas IE * $h^{1} \bar{e} d->$ germ. *etan "comer" > $(>$ AN eta $\approx$ IA/AS etan $\approx$ AAA ezzan, mas Go. itan) e IE *uogogh-éie- > germ. *weganan "se mover" (> AN vega $\approx \mathrm{Al}$ wegan $\approx \mathrm{AS}$ gi-wegan $\approx$ AAA wegan, mas Go. ga-wigan) e 3) antes de uma nasal na coda da mesma sílaba (nasal mais consoante): IE * $b^{h}$ énd ${ }^{h}$-e- germ. $>{ }^{*}$ bendan ${ }^{58_{-}}>$germ. do continuum Norte-Oeste *bindan-59 "atar, ligar" (> AN binda $\approx$ Al/AS bindan $\approx$ AAA bintan; Go. bindan). As reconstruções do IE foram retiradas de Wodtko, Irslinger e Schneider (2008) e Kroonen (2013); do germânico de Kroonen (2013) e Ringe (2006).

${ }^{57}$ De acordo com Ringe, o IA foi o dialeto que melhor preservou essa alternância; o AN, por outro lado, nivelou todo o paradigma em favor do e (i.e. ber, berr); no AAA a alternância do *-ō final para * $u$ influenciou o nivelamento de *e para * $i$ (i.e. biru, biris)

${ }^{58}$ Nenhum autor cita diretamente essa reconstrução, mas a colocamos por motivos didáticos

59 Isso explica o motivo de haver duas vogais diferentes no infinitivo dos verbos fortes da classe III. Por exemplo, o já citado *bindan (sequência de ablaut: i, a, u e u) vs. *helpan- "ajudar" (e, a u e u) ou "werpan- "jogar" (RINGE, 2006, p. 224); no Go., por sempre se tornar $i$, é hilpan e wairpan, que se pronuncia ${ }^{*}[e]$. 
h) De acordo com Nielsen (2000, p. 215), o IE o de palavras com, por exemplo, tema em ō e que precede uma nasal simples em uma sílaba medial não acentuada, se desenvolve para Go. a: $1^{\text {a }}$ pes.pl.ind. IE *bheromes "levamos" > germ. *beromaz > Go. baíram60, ao passo que nos dialetos do continuum Norte-Oeste a vogal se mantém como o (> $u$ ) por conta da nasal seguinte (AN berum): germ. *dagamaz (> Go. dagam) $\approx$ *dagomaz ( $>$ *dagum $(>$ AN dogum $\approx$ IA/AS dagum $\approx$ AFris.

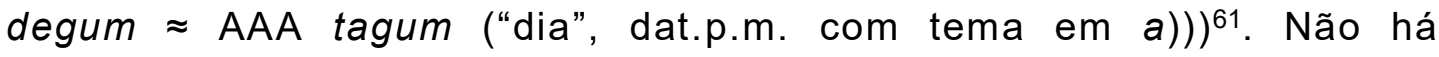
cognatas das palavras àcima no rúnico primitivo, mas há duas atestações em pedras rúnicas transicionais, que dizer, da sincronia posterior Era das síncopes: haborumz "he-goats" e hagestumz "corcéis" (< germ. *haboromz e *hagestomz, dat.p.m. com tema em a, pedra de Stentoften, Suécia, por volta de 600 d.C.)

Além de outras correspondências fonológicas entre o germânico do Norte e do Ocidente, Nielsen também exemplifica correspondências morfológicas, evidenciadas ou não no rúnico primitivo. Consulte Nielsen (2000) entre as páginas 205 e 208 para os paralelos evidenciados pelo rúnico primitivo e, na obra do mesmo autor, entre as páginas 210 e 215 para os paralelos que não são evidenciados.

Resumindo e com relação à cronologia: o processo a) ${ }^{*} \bar{e}^{1}>\bar{a}$ provavelmente antecede o ano de 200 d.C. e, de acordo com Nielsen (2000, p 272), deve ou não deve ter ocorrido independentemente em vários locais do mundo germânico do continuum Norte-Oeste e b) evolução a vogal faltante * [o] é secundária ao caso anterior. Também ocorreu uma simplificação das vogais utilizadas em sílabas não

${ }^{60}$ No AN e no IA

${ }^{61}$ Os substantivos de tema em o no IE viram de temas em a no germânico (masculino e neutro) e os de tema em $e h^{2}$ no IE viram de tema em ō no germânico (RINGE, 2006, p. 269; FORTSON IV, 2004, p. 305). Segundo Fortson IV (2004), as terminações de plural de substantivos temáticos (com tema em o) são nom.animado/voc. *- ōs (< ${ }^{*}$-o-es), ac.animado *-ons, nom.ac. não animado ${ }^{*}-\bar{a}\left(<{ }^{*} e-h^{2}\right)$, gen. ${ }^{*} \bar{o} m$, abl./dat./instr. ${ }^{*} o(i) b h$ - e loc. ${ }^{*}$-oisu (p. 114). Com referência ao dativo plural: IE *-o(i)bh- > Go. -am, mas nos outros dialetos germânico a forma om que, segundo Nielsen, é mantida como o $(>u)$; por isso supomos que a forma germânica deveria ser *dagomaz, com uma variante *dagamaz, que só deu origem no gótico. Com relação ao verbo germ. *beranan "levar", a forma em $1^{\text {a }}$ pes.pl.ind. *beromaz com variante *beramaz no Go. 
acentuadas no RP, que exibe um máximo de sete vogais. Algumas modificações são: c) ${ }^{*}-\bar{o}>{ }^{*}(-\bar{u})>{ }^{*}-u$ e d) ${ }^{*}-a i,{ }^{*}-a u>\bar{e}$ e $\bar{o}$, respectivamente. Em termos de cronologia, a mudança ${ }^{*}-\bar{O}>{ }^{*}-u$ precedeu a ${ }^{*} a u>\bar{o}$, que representam uma ordem de desenvolvimento chamada por van Coetsem (1994, p. 57-58) de relação counterfeeding. Com relação aos desenvolvimentos morfológicos não citados aqui, Nielsen (2000, p. 272-273) afirma que eles são difíceis de datar, da mesma forma que os paralelos fonológicos não atestados no rúnico primitivo, como por exemplo item e). Com relação ao item f), como a transformação de $z$ para $r$ não está evidenciada no rúnico primitivo (NIELSEN, 2000, p. 213), pois o RP apresenta apenas o -z- medial (Buskerud, Noruega, 500-550 d.C.), esse processo não se encaixa nessa sincronia.

Nielsen (2000) também apresenta paralelos entre o germânico do Noroeste e o nórdico; descarta, assim, os dialetos que formariam o antigo alto alemão. De acordo com o autor, tais inovações só podem ser posteriores às inovações gerais do germânico (com a não participação do gótico), acima apresentadas (p. 288-289).

\subsubsection{2 $\quad \mathrm{SN}^{2}-\mathrm{O}$ rúnico primitivo}

Esta sincronia trata de inovações que se apresentam no RP (rúnico primitivo), com participação ou não do germânico do Noroeste. O período é a partir de 200 d.C.

I) do continuum Norte-Oeste ao rúnico primitivo (inovações que se apresentam no RP e com participação do germânico do Noroeste) (a partir de 200 d.C.):

a) a única terminação de particípio passado forte atestada no rúnico primitivo é -inaz (IE *-enos) de faikinaz ("ameaçado", pedra de Vetteland, Noruega, 350 d.C.), haitinaz ("chamado, comandado", pedra de Kalleby, Suécia, 400 d.C.) e slaginaz ("assassinado", pedra de 
Möjbro, Suécia, 400-550 d.C). Reflexos do germ. *-inaz ocorreram principalmente no nórdico62, antigo inglês e antigo frísio (junto com reflexos do germ. *-anaz (<IE *-onos)). No Al há reflexos desse sufixo em binumini "tirado para longe de“, forsleginum „batido, morto“, no Afris. fenszen "pego", hvendsen "enforcado" (mutação do $i$ e palatalização). No AAA, Go. e alguns casos do AS e Al há reflexos do germ. *-anaz ((> AAA gibotan $\approx$ Go. budans $)<$ germ. *budanaz "comandado"); ((AS/AAA giboran e IA boren) < germ. *buranaz "carregado, trazido"), todos exibindo mutação causada por a, menos o gótico. Há, todavia, casos de *-inaz em Go. como, por exemplo, aigin "propriedade", adj. fulgins "escondido" vs. aigan "possuir", filhan "esconder" e pp. fulhans "escondidos", como também no AAA, pp. abasnitine "cortado" e talvez até mesmo no AS pp. bismitin "corrompido, poluído" e pp. kumin "vindo".

De acordo com Markey (1976), a seleção de uma alternância competitiva entre os dialetos não pode ser utilizada como evidência para agrupamento dialetal (p. 26, apud NIELSEN, 2000, p. 165), o que não ajuda para posicionar o espaço dialetal do RP dentro do mundo germânico. A origem do AN como, por exemplo, gripinn (< "apreendido, captura") parece ser *-inaz, mas como há uma mutação causada pelo a nos verbos fortes de classe II e IV no AN, assume-se que a terminação *-anaz já existia no nórdico. No entanto, muita dúvidas surgiram ao tentar posicionar o rúnico primitivo dentro da geografica dialetal germânica utilizando dessa característica (i.e. * ${ }^{*}$ inaz) (NIELSEN, 2000, p. 208-209 e 164-165).

b) vocalismo analógico causado por a nos casos dat./gen.m.s.singular com tema em $n$. Nomes como kepan ("de kepa", pedra rúnica de Belland, Noruega, 500 d.C.) e halaiban ("do pão", estela

62 Os particípios dos verbos fortes das classes II e IV são os únicos que têm a vogal *-o- na sílaba anterior à terminação (classe II: germ. *fruzanas "congelado" > AN frosinn; classe IV: germ. *buranaz "carregado" > AN borinn). O particípio da classe I tem a vogal *-i- (germ. "gripanaz "apreendido, tomado" > AN gripinn). De acordo com Nielsen (2000), a mudança do u de *buranaz e *fruzanas para o de frosinn e borinn só poderia ser explicada, de acordo com as leis fonéticas, se houvesse uma mutação causada pelo a $\left({ }^{*} u>{ }^{*} 0\right)$, portanto provavelmente havia o o sufixo *-anaz no nórdico, mas ele foi analogicamente substituído pelo reflexo de *inaz, após a mutação consonantal: *fruzanas $>$ *frozanas $>$ *frozinas $>$ frozinn e, consequentemente, * gripanaz $>\mathrm{X}>{ }^{*}$ gripinaz $>$ gripinn, como também as outras classes. 
rúnica de Tune, Østfold, Noruega, 200-450 d.C.) correspondem ao AN hana, Al honan, AS hanan "galo", em contraposição à terminação do IE *-en-, que é um elemento que aparece no AAA (hanen, -in), ABFranc. namin "nome", Go. gen. hanins e dativo hanin (NIELSEN, 2000, p. 209 e p. 155).

c) os substantivos com tema em a, que no gen.s.m./n. apresentam a terminação -as como, por exemplo, no rúnico primitivo godagas ("nome próprio" no genitivo, inscrição do penhasco Valsfjord, Noruega, 400 d.C.) e asugisalas ("nome próprio" no genitivo, cabo da lança Kragehul, Dinamarca, 300 d.C.), eram originalmente uma terminação pronominal idêntica não apenas ao sufixo da forma de escrita primitiva do IA, como em dægæs "do dia", mas também às formas pronominais em gen.s.m/n. como IA pæs e hwæs (que pressupõe um < *-as(a) < IE *-oso). O AAA tages e Go. dagis (gen.m.s. com tema em a), por outro lado, se relacionam com as formas pronominais correspondentes a, por exemplo, des, (h)wes e pis e his "daquele" e "de quem" (< * $\left.-e s(a)<I E{ }^{*} e s o\right)$; no AS há uma nuância entre dagas e dages. No AN o a sofreu síncope (por exemplo, dags "do dia"), mas as formas pronominais do islandês antigo pess e hvess apontariam para um vocalismo em e. Todavia, as formas pronominais do gen.s.m./n. em -a- são atestadas no sueco e dinamarquês antigos (hwass) junto com formas em -e-(hwess). (p. 150 e 209, consulte também BRØNDUM-NIELSEN, 1965, p. 387).

d) O sufixo de adjetivo forte do pronome possessivo masculino e singular em caso acusativo *-inō em minino ("meu", pedra rúnica de Kjølevik, Rogaland, Noruega, 450 d.C.) é, de acordo com Kruse (1971, p. 108) e Brøndum-Nielsen (IV 1962, p. 10), um reflexo acentuado de maneira fraca de *-āno ( ${ }^{*}$ minnanō, compare Go. meinana e AAA mīnan), mas se levarmos Brunner (1965, §324, apud NIELSEN, 200, p. 157) em consideração, a terminação deriva do IE *-inōm, que reflete no IA ǣnne "um" em ac.m.s. e, de acordo com Streitberg (1974, 269b, apud NIELSEN, 200, p. 157) no pronome demonstrativo do dialeto anglo do IA pene "aquele" na forma ac.m.s. Nielsen, portanto, afirma que é muito 
mais seguro conceber o sufixo IE *-inōm como uma herança não só de minimo mas também de hino ("isso", pron.dem. no caso ac.ms.s., pedra de molar de Strøm, Sør-Trøndelag, Noruega, 450 d.C.).

O autor também faz uma lista sobre inovações que ocorreram no germânico do Norte e do Noroeste, mas sem atestação no rúnico primitivo. Não iremos entrar em detalhe aqui, mas consideraremos duas:

a) O tema em $r$ (genitivo singular) do Go. fadrs "do pai", que corresponde ao IA fæder, AFris. feder, AS fader, AAA fater remete a um IE *pətrés/ós (com uma substituição do germânico do Ocidente do grau zero por um sufixo temática de grau pleno), ao passo que o $A I(A N)$ tem fǫður, que deriva de uma forma germ. *faðurz (IE < * $p ə t$ 'rs), compare o sânscrito pitúr no grau zero e latim patris no grau pleno. O importante é citar que, além do $\mathrm{AN}$, há paralelos nos dialetos de Mércia (i.e. feadur, fædor) e Nortumbria (-fadur, fador).

b) formas dos pronomes interrogativos e demonstrativos: AN peim "aqueles" e hveim "a quem", IA pǣm, hwǣm, AFris. thām, hwām (< vogal IE *-oi-). Essas formas, como dito acima, não são atestadas no rúnico primitivo, mas no rúnico da Era viking há paim (pedra Eggja, Noruega, 700) e uiam (pedra Rök, Suécia, 800). O vocalimso do e, representado no AS them $(u)$ e hwem(u), ABFranc. themo e AAA demu e (h)wemu, de acordo com Krahe, vem do IE *e-smō, mas Dal tem a opinião de que as formas monosilábicas apresentadas pelo AS têm vogais longas e (thēm, hwēm), por isso, são paralelas às formas do AN, Al e AFris $(\bar{e}<a i)$. Em contraste, o AAA themu "deve ser considerado como um invasor do Sul" (1971, p. 184 apud NIELSEN, 2000, p. 218).

Uma apresentação desses e outras características encontradas no RP e comparadas com os outros dialetos se encontra em Nielsen (2000) entre a página 149 e 167. Os mais relevantes foram comentados aqui. De acordo com o autor, o item b), c) e d) mostram um claro vínculo entre o RP e o AS, IA e AFris. O a), apesar de ser um pouco duvidoso, também pode ser interprestado assim. 
Há um outro item não citado aqui em que nas inscrições do RP o $n$ é deixado de fora antes de $d$ (ou $p$ ) (compare widuhudaz "cão da floresta", fecho de Himlingøje, Dinamarca, 200 d.C, se esperaria * widuhundaz); portanto, seria natural assumir que o $n$ foi omitido antes do -s no primeiro elemento dos nomes pessoais asugisalas ("convidado de deus", pedra rúnica Myklebostad, Noruega, 400 d.C.) e asugisalas ("nome próprio" no genitivo, cabo da lança Kragehul, Dinamarca, 300 d.C.), compare ansu- "deus". Seria, de acordo com o autor, uma convenção de ortografia (p. 248). Por outro lado, vale lembrar que no nórdico o $n$ cai antes de $s$ : germ. *gans "ganso" (> Al, AFris. gōs, AS *gōs/gās [> MBA gōs/gās], mas AAA gans e GO. gans) e germ. *ansu"deus" (> AI ōs, AS ās/ōs) (NIELSEN, p. 166 e 208). Compare os nomes Oswald e Anselm. De acordo com Harrison (1918), o primeiro é uma composição entre oss "deus" e w(e)ald "poder" (compare AN áss, óss, pl. æsir), mas Go.ans e AAA ans e o segundo é uma composição entre ans "deus" e helm "capacete".

Os dialetos do germânico do Noroeste trataram essa queda do $n$ (antes do $f, s$ e $p$ ) de maneira mais radical e sistemática e Nielsen (2000) afirma que a perda dessas nasais possívelmente ocorreram antes da partida dos anglos e dos saxões do Continente e também vincula essa mudança à criação de fonemas a partir do ą nasalizado ( $p$. 248). Não há, ainda segundo o autor, atestações seguras de queda do $p$ antes do $n$ no AN e o número de palavras que apresentanm a perda do $f$ é restrito a duas (AN fífl "monstro, gigante" e ADin. e ASue. toft "local para construção"). A queda do $s$, por outro lado, é mais comum no mundo nórdico, como já mostrado acima.

A respeito da cronologia dessa queda, Nielsen comenta o nome pessoal ąsmut, inscrito na pedra Sölvesborg (pedra rúnica da igreja de St. Nicolai em Sölvesborg, Suécia, 750-800 d.C.). Na inscrição utiliza-se a runa *ansuz (F), que serve para denotar o ą nasal e, por conta disso, indica que a perda do $n$ não poderia ter ocorrido muito tempo antes da composição dessa inscrição, ou seja, entre o ano 750 e 
800 d.C. e, consequentemente, não corrobora com a hipótese de que o desaparecimento do $n$ antes de $s$ foi um desenvolvimento compartilhado entre o germânico do Norte e do Noroeste. Discordando de Kuhn (1995, p. 41) que data a perda da nasal antes de fricativas no germânico do Noroeste à Era das grandes migrações, na assumpção de que o germânico do Norte estava parcialmente envolvido na perda mas, afirma que a perda da nasal antes de s (e f) é considerada um mudança tardia e independente no germânico do Norte e que os desenvolvimentos no germânico do Noroeste devem ter ocorrido anterior ao período suposto por Kuhn.

II) do continuum Norte-Oeste ao rúnico primitivo (inovações que se apresentam apenas no RP) (a partir de 200 d.C.):

a) o ditongo germânico *ai, que se torna *ā antes de ${ }^{*} h$ e ${ }^{*} r$, se manteve no RP faihido ("eu pintei", pedra de Vetteland, Rogaland, Noruega, 350 d.C.), mas aparece como monotongo em fahido (pedra rúnica Rö, Bohuslän, Suécia, 400 d.C.). De acordo com Karl Martin Nielsen, ocorreu um desenvolvimento *ai $>{ }^{*} \bar{a}$ antes de $\mathrm{h}$ e ele julga ser a única inovação peculiarmente escandinava (1975, p. 12 apud NIELSEN, 2000, p. 165). A mudança no Al e AFris de *ai > ${ }^{*} \bar{a}$, de acordo com Nielsen (2000), deve ser concebida como um desenvolvimento independente e sem conexão com o que ocorreu no NA e no RP (p. 165).

Conclui-se que o RP se distanciou do continuum Norte-Oeste e apresentou algumas inovações compartilhadas com o germânico do Noroeste, por conta provavelmente da imigração. Nielsen (2000) apresenta dois gráficos que explicam esses desenvolvimentos no mundo germânico:

Modelo estático (p. 288-290) ${ }^{63}$ :

63 I: inovações de todos os dialetos do germânico (com exceção do gótico) (a partir do ano 100); II: inovações dos dialetos do germânico do Norte e do Noroeste (a partir do ano 200); III: inovações do germânico do Ocidente (ano 300); IVa: inovações do germânico do Noroeste (após 


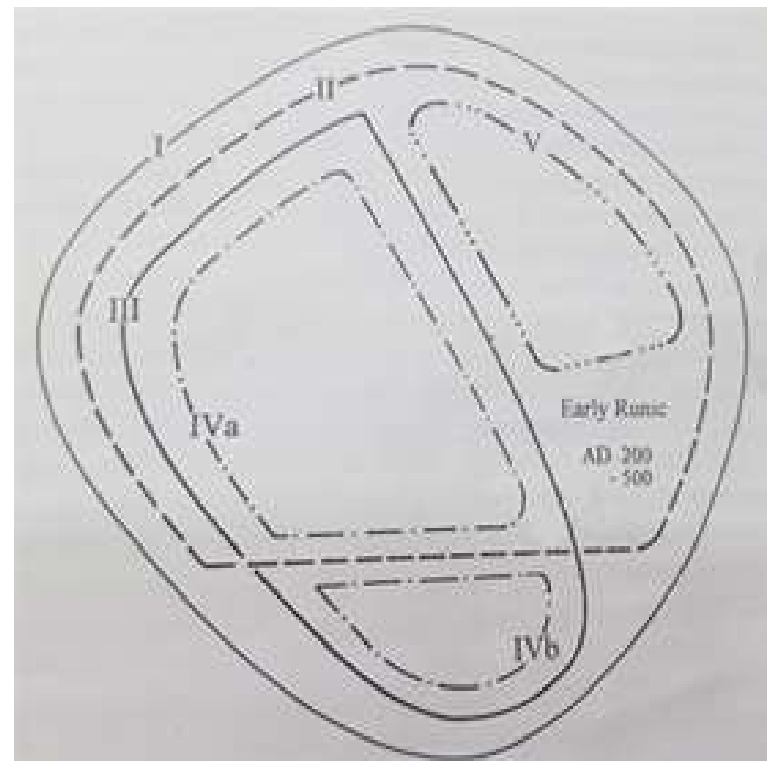

Nielsen apresenta algumas características principais, já discutidas aqui, em cada uma dessas áreas:

I. Germânico do Norte/Oeste (100 d.C.) - (1) $\bar{e}^{-1}>\bar{a}$, (2) [0] $>/ o /,(3)-\bar{o}>-u$ e (4) $-a i,-a u>-\bar{e},-\bar{o}$

II. II. Germânico do Norte/Noroeste (200 d.C) - (1) gen.d.m.s. com tema em $n$, -an; (2) gen.m.s. pronominal com tema em a, -as, (3) pronome interrogativo ou demonstrativo no caso dat.m. ou n.s. -aim, (4) gen.s. com tema em -r AN fǫður, IA (Angl.) feadur, fador.

III. III. Germânico do Oeste (cerca de 300) - (1) perda do germ. *-z não acentuado, (2) geminação consonantal antes de $j^{64}$, (3) pronomes demonstrativos utilizados em função relativa

ano 400); IVb: inovações no AAA (a partir ano 450) e V: inovações no germânico do Norte (ano $500)$.

${ }^{64}$ Geminação de consoantes (com exceção do $r$ ) antes de $j$ e após sílabas curtas como, por exemplo, em substantivos de tema em ja e jo (germ. "kunja "clã, família" (> IA cynn $\approx$ AS kunni $\approx$ AAA chunni $\approx$ AFris. kenn, mas AN kyn e Go. kuni) e nos verbos fracos da classe I, que são formados por um sufixo -j-: germ. *satjana "colocar sentado" > (IA settan $\approx$ AS settian $\approx$ AAA sezzen $\approx$ AFris. setta, mas NA setja e Go. satjan. Nielsen (2000) ainda afirma que tal inovação foi ao Norte em uma escala reduzida (p. 214-215). No rúnico primitivo há uma atestação: kunni (runas Weser Brake, Baixa-Saxônia, 300 d.C.), que está um pouco distante do ambiente 
IV. IV. Germânico do Noroeste (após 400 d.C.) - (1) ruptura do a para um ą nasalizado e outro não nasalizado, (2) perda da nasal antes de $f, s$, e $p$ com alongamento vocálico compensatório, (3) terminações uniformes no pres.ind.pl. e (4) $h$ - adicional ao pronome pessoal (nom.m.s.) "he".

V. IVb. Antigo Alto Alemão (após 450) - (1) mutação consonantal, (2) ditongação do $\bar{e}^{2}$ para $\bar{o},(3)$ introdução do $-e$ ao dat.m. ou $\mathrm{n}$. s. dos pronomes interrogativos e demonstrativos e (4) generalização dos pronomes monossílabicos em $-r$.

VI. V. Germânico do Norte (após 500) - (1) perda do j- e w-, (2) síncope do a, i e $u$, (3) ruptura e (4) introdução dos sufixos morfológicos do nórdico. 
Modelo dinâmico (NIELSEN, 2000, p. 290-293):

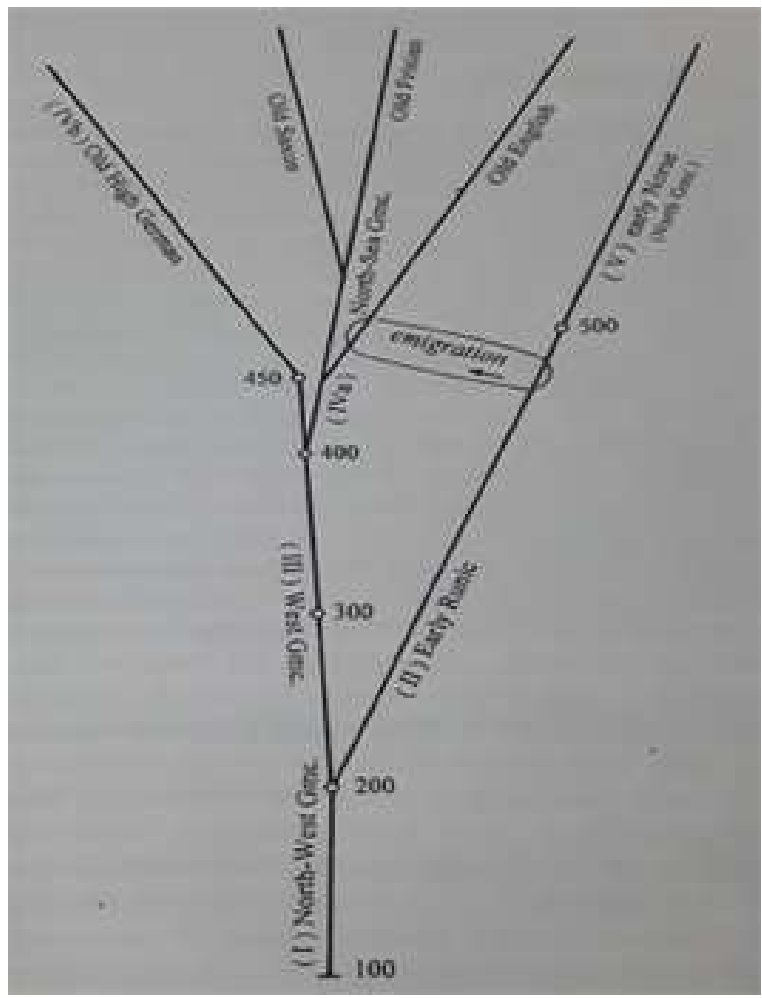

A respeito do modelo estático, Nielsen (2000) afirma que, por meio dele, é possível ver claramente que há três linhas que separam o AAA do rúnico primitivo, portanto, é o mais distante; o mais próximo, portanto, seria o germânico do Norte, que é separado apenas por uma linha (NIELSEN, 2000, 288-290).

O modelo dinâmico, por outro lado, tem a diferença em apresentar o momento em que o RP se diverge do continuum NorteOeste no ano 200 e, que passa a ser chamado de germânico Ocidental, embora haja características compartilhadas apenas entre o RP e o germânico do Noroeste, como também um desenvolvimento isolado do germânico do Oeste. Percebe-se também pelo gráfico que o nórdico primitivo seria o único sucessor do RP, por conta de uma característica do sistema vocálico não acentuado: rúnico primitivo -o, AN -a, mas germânico do Noroeste -e e -a, AAA -a e -o, que será demonstrado a seguir. Dessa maneira, no modelo estático as correspondências do rúnico primitivo são intermediárias em relação aos paralelos do 
germânico do Noroeste e do Oeste, tanto em espaço quanto em tempo; no modelo dinâmico, por sua vez, a primeira ruptura do continuum Norte-Oeste foi do rúnico primitivo. Vale reparar, vendo por um ângulo diferente, que poderia haver um continuum dialetal Norte-Oeste a partir do qual as características do rúnico primitivo e do germânico do Oeste começaram gradualmente a tornar-se visíveis (NIELSEN, 2000, p. 381).

O segundo modelo também permite explicar alguns paralelos que o IA compartilha com o rúnico primitivo. Em vista disso, seria possível criar a hipótese de que teria ocorrido uma imigração de falantes do rúnico primitivo entre 400 e 450 para as ilhas britânicas, participando, assim, da fusão de uma língua germânica independente. Uma convergência linguística tardia focada apenas na combinação de características do germânico do Oeste e do Noroeste ocorreu na Inglaterra e quando o IE surgiu após o ano 700, ele já era uma língua bastante homogênea. Mas mesmo assim o IA manteve um grau de variabilidade que se entrelaça tanto com a Escandinavia quanto com a região do mar do Norte na Alemanha (NIELSEN, 2000, p. 290-293). O germânico do Oeste se dissolveu com as inovações da parte sul (i.e. AAA) e as inovações do germânico Ocidental eram contemporâneas com as do rúnico primitivo.

O autor resume seus gráficos da seguinte maneira: o modelo estático é sincronico e orientado pela modelo da teoria de ondas, ao passo que o modelo dinâmico é diacrônico e foca na herança genética e nas quebras dialetais.

\subsubsection{3 $\quad \mathrm{SN}^{3}-\mathrm{A}$ Era das síncopes}

Esta sincronia se inicia no séc. VI e percorre até por volta da metade do séc. VIII. É a sincronia que tem como característica principal as síncopes do $a, i$ e $u$ após sílabas longas e, por isso, foi dado esse nome, seguindo a terminologia de Seip (1955, p. 19). Nielsen (2000) afirma que tais fenomenos como síncope, mutação vocálica e ruptura 
também ocorreram em outros dialetos do germânico (p. 256). Os seguintes estudiosos trataram do período de transição: Antonsen (1994, 1975), Grønvik (1998, 1987), Birkmann (1995), Schulte (1998), Isakson (2000) e Barnes (1998) e entre as apresentações de Linguística Histórica que ultrapassam o material evidenciado pelas inscrições rúnicas após 500 d.C. devem ser mencionados também Skautrup (1944), Seip (1955), Wessén (1995, 1975) e Haugen (1976).

Ocorreram, portanto, mudanças no nórdico primitivo (NP) ${ }^{65} \mathrm{e}$, assim, surgiu, um período de transição, chamado nessa dissertação de Era das síncopes ${ }^{66}$ (500-750), que faz a ponte entre o final do rúnico primitivo e o início da Era viking, que tem o alfabeto futhark mais jovem ${ }^{67}$ de dezesseis letras (NIELSEN, 2000, p. 95, 255).

Nielsen (2000) afirma que a essa sincronia pertencem as pedras rúnicas de Sölvesborg, do condado de Blekinge ${ }^{68}$, Suécia (por volta do ano 625, i.e., Gummarp, Istaby, Stentoften), a pedra rúnica de Björketorp, que está localizada a 35 milhas ao leste de Sölvesborg (ano 675) e a pedra rúnica Eggja (700, Sogndal, Noruega), que tem 180 runas em sua inscrição. $O$ autor também insere na análise dessas características transicionais as pedras rúnicas Glavendrup, Rønninge e Tryggevælde (Dinamarca, por volta do ano 900), que fazem parte de um período um pouco posterior, considerado como o início da Era viking; as duas primeiras são da região de Fyn e a terceira da região do Leste de Sjælland e todas têm características homogênicas (p. 95, 98).

Algumas características dessas pedras rúnicas apresentadas por Nielsen (2000, p. 95-98, 255-265) são:

65 Nórdico primitivo (tradução de Early Norse) para indicar a fase em que começaram a surgir características tipicamente nórdicas do período de transição do rúnico primitivo.

${ }^{66}$ Nielsen (2000) define o período de transição como o período em que as características mais antigas tipicamente nórdicas aparecem e cita Birkmann (1995), que afirma que esse período vai entre 500 e 750 d.C. (p. 268, nota 26). Esse termo também é utilizado por Skard (1973) e Seip (1955). Haugen (1976) chama esse período de Common Scandinavian e afirma que dura de 550 até 1050, ou seja, ele não separada em duas sincronias. Vikør \&Torp (2000, p. 113) inserem esse período no rúnico primitivo (i.e. eldre runetid), ou seja, não distinguem um período transicional.

67 Tradução proposta de Younger Futhark e Yngre Futhark, no inglês e norueguês respectivamente.

${ }^{68}$ Era território dinamarquês a partir do séc. IX, aproximadamente. 
a) os descendentes da runa ${ }^{*} j a \bar{r} a{ }^{*}[j]$, que é representada por ", * (Gummarp, Stentoften e Björketorp na Suécia; Eggja na Noruega ${ }^{69}$ ) e \ (Istaby, Suécia) passaram a denotar a, ou seja, o nórdico começou a perder a inicial *j- (rúnico primitivo *jāra > AN ár "ano"; mas AAA jār, IA gēar, AFris. jēr e Go jer). Há outras pedras desse período citadas por Nilsen (2000) na página 256. Ele também afirma que a perda desse $j$ provavelmente não ocorreu muito antes do ano 600 d.C.; a pedra rúnica de Vallentuna (Vallentuna, Suécia, 600 d.C.), que é arqueologicamente a mais antiga a ter tal característica, corrobora com tal afirmação.

b) perda do $w$ - antes de vogais arredondadas anteriores, que não se reflete, por exemplo, nas inscrições da região de Blekinge: na pedra rúnica de Gummarp (600-650) hapu(-)wolafa "lobo da batalha", mas há tal inovação em orte "formou" na pedra rúnica By (Buskerud, Noruega, 500-550 d.C.) e na pedra Sölvesborg (Sölvesborg, Blekinge, Suécia, 675 d.C.), porém não há na pedra de Tjürkö, wurte (Blekinge, Suécia, 500 d.C.). Essa característica também se encontra em inscrições a partir de 700 como upin ("Odin", IA Wōden, tema em a) e o particípio perfeito unin ("ganhado", IA wunnen), ambos no fragmento do crânio de Ribe (Dinamarca, 725 d.C.) e em ulfs ("do lobo", gen.m.s., em IA wulfes) em uma inscrição do início da Era Viking (Tryggevælde, Dinamarca, cerca de 900 d.C.). Primeiramente, Nielsen (2000) afirma que, ao menos que as formas com - $w$ sejam arcaísmos, uma variação deve ter ocorrido na Escandinávia durante um período dificilmente determinado; em segundo lugar, o princípio da perda do $w$ - deve ter sido um evento relativamente precoce, por conta da pedra rúnica By (500-550 d.C.), que é subsequente ao período das bracteatas (400$500)$.

c) mistura entre as runas $R r$ e $Y$ ( $(h) z$ : na pedra Istaby

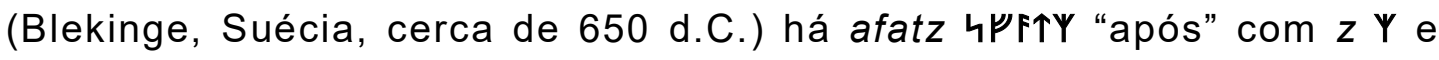
não $r$, como era esperado (< germ. *after). Isso sugere que nesse

${ }^{69}$ A antiga runa *ansuz $\mathrm{f}$ passou aparentemente a ser tuilizada para a nasal (NIELSEN, 2000, p. 98) 
período $\circ z$ estava se aglutinando com $\circ r$ em posição silábica final e seguido por uma obstruente. No fim dos primórdios da Era Viking, deixou de existir a distribuição etimologicamente correta de $-z{ }^{*}[-z]$ e $-r$ *[-r] como representações dos sons germânicos * ${ }^{*}[z]$ e ${ }^{*}[r]$ e, consequentemente, na pedra rúnica dinamarquesa de Tryggevælde

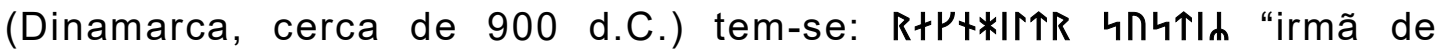
Ragnhild", onde se percebe que o - $\mathrm{R}$ (< germ. *rangnhildīz) e o - $h$ (< germ. *swestēr) estão sendo utilizados incorretamente, mas não se encontra tal erro em 4 n+l h suniz (< *suniwiz "filhos" em Glavendrup) e Rnt+h runaz (< "rūnoz "runas" em Glavendrup). Nielsen conclui que a mistura entre os dois sons não está entre os desenvolvimentos mais antigos e, ainda assim, é difícil sugerir uma data precisa para tal emergência.

d) a cisão do alofone */ð/ do fonema germânico *[d] e a fusão com o fonema ${ }^{*}[\theta]$ ainda não tinha se completado até o séc. VIII, momento em que formas como uipz "contra" e upin "Odin", inscritas no fragmento do crânio de Ribe (Dinamarca, 725 d.C.), testemunham a restruturação. A palavra NP uipz remonta ao germânico *wipra e a palavra upin, ao germânico *wodanaz. Em todas as línguas germânicas, menos o $\mathrm{AN}$, a última tem $d\left[{ }^{*} \mathrm{~d}\right]$, quer dizer, se reestruturou, e a primeira tem formas como ing. with (<IA/AS wip) e Go. wipra.

Outros exemplos são as palavras hagiradaz (nome pessoal, caixa de Garbølle, Sjælland, Dinamarca, 400 d.C.) e dohtriz ("filhas", runa Tune, Noruega, 200-450 d.C.) A primeira apresenta o $d /{ }^{*} \partial /$ (germ. $<{ }^{*}-r \bar{d} d a z$ "conselho", que deveria ser pronunciado [*d]) e, portanto, é um alofone do fonema $d\left[{ }^{*} \mathrm{~d}\right] \mathrm{da}$ segunda palavra. Por conta disso, apenas o antigo nórdico tem cognatas de ${ }^{*}$-rēdaz, cujo $d\left[{ }^{*} \mathrm{~d}\right]$ germânico é pronunciado [ $\left.{ }^{*} \mathrm{O}\right]$ (compare IA rǣ $\approx$ AS rād $\approx$ AFris. rēd $\approx$ AAA rāt, mas AN rađ); o gótico, por ser parcialmente uma boa fonte de conservação, tem a palvra -rēdan "aconselhar". No mesmo período 
havia prijoz ("três", runa Tune), que tem étimo no germ. *prī- (compare IA $p r \bar{i} \approx$ Afris. thrē $\approx$ AS thrīe $\approx$ AAA $d r \bar{\imath} \approx$ Go. preis).

e) apócope do $a, i$ e $u$, que são fundamentais para compreender a transição do RP para o nórdico. Podemos separar três processos aqui: a apócope dessas vogais $(-u>-\varnothing)$, suas retenções na pedra rúnica por conta de conservações (-u se mantem) e suas retenções porque sofreram o encurtamento vocálico de uma forma anterior longa $(-\bar{u}>-u)$. Atesta-se a síncope dessas vogais na posição final em sílabas não acentuadas e seguidas de sílabas longas.

\section{- Com relação ao a:}

Nas inscrições suecas de Stentoften, de Istaby e de Björketorp, que são atribuídas à região de Blekinge, há respectivamente, wolafz, -wulafz (ambas significando "do lobo" gen.s.com tema em a; < germ. *wufaz; compare AN úlfs) e hAerAmAlAlausz ("sem descanço"; < germ. *lausaz; compare AN lauss). Mas há conservações em hermAIAsAz na pedra de Stentoften. Após uma sílaba curta, o a se conserva em eka ("eu", Stentoften; compare AN ek e a forma -Ak na Björketorp). Na pedra rúnica norueguesa de Eggja, do mesmo período, ocorreu a síncope do a: fiskz ("peixe", nom.m.s. com tema em a, < germ. fiskaz; compare AN fiskr) e stain ("pedra”, ac.m.s. de tema em $a,<$ germ. *staina-; compare AN stein ${ }^{70}$ ), enquanto as pedras rúnicas em rúnico primitivo Tune ( $\varnothing$ stfold, Noruega, 200-450 d.C.) e Vetteland (Noruega, Rogaland, 350 d.C.) conservam o a na palavra staina. A respeito das pedras suecas: haukz passou por processo de síncope ("falcão", nom.m.s. com tema em a, pedra de Vallentuna, Suécia, 600 d.C.; < germ. *habukaz; compare AN haukr), mas a pedra de Ellestad (Söderköping) conserva o a após sílaba curta (eka "eu").

70 Propomos o desenvolvimento da seguinte maneira: germ. * staina $>$ RP staina $>$ NP stAin > AN stein 
Na Dinamarca, tanto as inscrições do crânico de Ribe (725 d.C.) upin ("Odin" < germ. *wodanaz; AN Ođinn) e o particípio perfeito unin ("ganhado" < germ. "wunnanaz, compare AN vinnandi) quanto a inscrição de mesmo período na pedra de Flemløse 1 [st]Ain ("pedra", nom.m.s. de tema em a, < germ. *stainaz; compare AN steinn, Fyn, Dinamarca, 725 d.C.) apresentam síncope e assimilação $\left({ }^{*}-n a z>{ }^{*}-n z>\right.$ $\left.{ }^{*}-n n^{71}\right)$.

Na pedra de Eggja há vários casos de a não acentuado como, por exemplo, o sufixo -a de gotna ("homens", marcador de tema em $n$, no caso gen.m.p.; compare AN gotna), que provém do sufixo -ō do proto rúnico, ou seja, a vogal não apenas deixou de ser arredondada, mas também se encurtou (NIELSEN, 2000, p. 98). Ele também é visto em runaz ("runas", caso ac.f.p. de tema em ō, Istaby, Björketorp, Glavendrup, < germ. "runōz; AN rúnar;). Uma palavra em que o a se mantém é stAbA ("bastões, ac.m.p. com tema em a, Gummarp, Suécia; < germ. "staban $(n)$ < "stabanz (compare Go. -ans dagans "dias" e AN daga, steina), por conta da nasal. O a também é visto na palavra stAinAz ("pedras, nom.m.p., com tema em a, pedra de Rävsal, Bohuslän, Suécia, 600-650 d.C.; < germ. "stainōz; compare Go. -ōs em stainōs e também AN steinar). Propomos: germ. * stainōz > RP stAinAz > NP ${ }^{*}$ stAinAR > AN steinar.

Nielsen explica que a vogal longa $\bar{o}$, ao ser encurtada, se identificou com a vogal curta não acentuada mais próxima foneticamente: a vogal a. Nesses casos ocorreu a manutenção do a por conta do encurtamento que passou a partir do $\bar{o}$. Vale considerar aqui que a transformação do $\bar{o}$ para o $\bar{u}$ ocorre quando não há influência de alguma nasalização ou consoante em seguida, compare lapu ("convite"

${ }^{71}$ De acordo com Nielsen (2000, p. 263), com base na palavra wulafz ("lobo", nom.m.s. com tema em a, Istaby, Suécia, 625 d.C.), assume-se que a forma stAin no nórdico primitivo foi inicialmente *stAinz (comparado com a terminação -az do RP). Portanto, propomos: germ. *stainaz > RP *stAinAz > *stAinz > NP stAinn > AN steinn. Nielsen (2000) afirma que tal assimilação ocorreu após 700 d.C., compare com a palavra upin "Odin" do fragmento do crânio de Ribe (725 d.C., < germ. *wodanaz). 
nom.f.s.; bracteata de Darum, Jutlândia, Dinamarca, 450-550 d.C., germ. < $\left.{ }^{*} / a p \bar{o}\right)$.

De acordo com Nielsen (2000), cronologicamente deve-se concluir que a síncope causada pelo a esteve em operação na Dinamarca, Noruega e Suécia antes e por volta do ano 600 e a conservação vista principalmente na inscrição de Ellestad (2000) sugere que a mudança não se concluiu em todos os lugares ao mesmo tempo (p. 9-12, 21, apud NIELSEN (2000, p. 260).

\section{- Com relação ao i:}

Com relação à síncope do $i$, na posição final e após sílaba longa, hAidz ("brilho", < germ. *haidiz), e barutz ("quebra”, $3^{a}$ p.s, < germ. *brikidi), ambas da pedra rúnica de Björketorp (675 d.C.) sofrem a síncope; por outro lado, há uma conservação do $i$ em hidez e bariutip na pedra de Stentoften (650 d.C.). A pedra de Eggja também passa por tal inovação: manz ("homens", nom.p. com tema consonantal; < germ. *manniz; compare AN menn).

O $i$ não acentuado é visto em trutin ("marido, senhor"; ac.m.s.com tema em a; Glavendrup, Dinamarca, 900 d.C.; < germ. *druhtiną; compare AN dróttinn, Al dryhten, AS druhtin e AFris. drochten) e em suniz ("filhos", nom.m.p com tema em $u$; Glavendrup, < germ. *sunīz < germ. *suniuiz, compare AN synir, AS/AAA suni). No primeiro, provavelmente por estar anterior a outra sílaba não acentuada e o segundo por vir de uma vogal longa $\left({ }^{*} i u i>{ }^{*} \bar{I}>\right.$ i) e também:

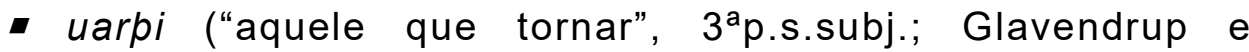
Tryggevælde, Dinamarca, 900 d.C.; < germ. *werdai, compare AN verði)

- traki ("aquele que arrastar", $3^{a}$ p.s.subj., Glavendrup e Tryggevælde; < germ. *dragai)

Essas duas últimas formas provêm do germ. *ai, compare Go. waírpai; 
- sati e karpi ("erigiu" e "fez", $3^{\text {a }}$ p.pret.s.ind. dos verbos fracos da Classe 1; Glavendrup, Tryggevælde e Rønninge). Propomos o seguinte desenvolvimento etimológico: AN setti < NP sati $<$ PR sate ${ }^{72}<$ germ. * satide ${ }^{73}$ e AN gerđi $<$ NP karpi $<$ PR *karpe < germ. * garwidē).

A respeito dos substantivos, há, por exemplo, a palavra welAdAude ("morte insidiosa", caso dat.m.s. com tema em a, Björketorp). Como parte integrante da composição, -dAude, que de acordo com Antonsen provém de um germ. *daupai, compare AN dauði, Al dēođe, AAA tōde, etc., portanto, em um monumento não tinha ocorrido a transição para $i$. Há, portanto, uma fusão que gerou ē a partir do reflexo de dois sufixos germânicos $\left({ }^{*}\right.$-aie $\left.{ }^{*}-\bar{e}\right)$ distintos (NIELSEN, 2000 , p. 162). Percebemos também, nos dois exemplos acima que a vogal ē resultou na vogal $i$ no rúnico de transição ou nórdico primitivo.

O sufixo -iz do patronímico hAeruwulAfiz (caso nom.m.s., Istaby) representa uma contração do germânico *-ijaz por meio de *īz, que tem uma vogal longa e explica porque não ocorreu a síncope, mesmo com a redução da vogal para -ĭz (Nielsen, 2000, p. 96).

Com relação ao hagestumz ("corcéis", caso dat.m.pl., Stentoften), de acordo com Nielsen, não há dúvidas de que o $e$ representa o $i$, compare germ. "hanhistaz "cavalo" e *hangistaz "corcel" (ambas no caso nom.m.s.). A respeito da inscrição rúnica de Eggja, há uma considerável variável entre $i$ e e em sílabas finais não acentuadas: made "friccionou", sakse "faca, espada"; huni "topo do mastro", misurki "malfeitor", wiltiz "selvagem", que, de acordo com Nielsen, seria uma variação influenciada por harmonia vocálica ( $i$ depois de uma vogal fechada e e, depois e uma não fechada). Tanto o sufixo de sakse quanto de huni remontam ao sufixo do germânico *-ai. Além do mais, made $\left(<\right.$ germ. ${ }^{*}$ mawide $\left.\bar{e}^{74}\right)$ é o pretérito singular indicativo de um verbo

\footnotetext{
72 Forma encontrada na pedra de Gummarp, por exemplo. Provavelmente pronunciado [ ${ }^{\star} \bar{e}$ ]

73 Nielsen afirma que a forma sate perdeu o $i$ medial não acentuado após sílaba curta, compare com a forma satido, $1^{a}$ p.sing.ind. na runa de Rö, Bohuslän, Suécia, 400 d.C.).

74 De acordo com Spurkland (2005, p. 70)
} 
fraco, similar ao sate $(<$ germ. * satide). Portanto, Nielsen afirma que o $\bar{e}$ e o $i$ se fundiram em posição não acentuada, resultando em $i$.

Nielsen afirma que há controversias se a síncope do a e do $i$ ocorreram no mesmo período ou se a do a foi um evento mais precoce. Grønvik (1987, p. 171) constata que o nórdico primitivo (diferentemente do gótico) preserva o - $i$ (e o $-u$ ) quando seguidos de uma sílaba curta após o período de início da síncope (apud NIELSEN, 2000, p. 260).

\section{- Com relação ao u:}

A respeito da síncope do $u$, ela ocorreu, como esperado, em posição final não acentuada e após sílaba longa como, por exemplo nas palavras sba ("profecia", nom.f.s., germ. < *spahu < "spahō, Björketorp, 625 d.C., compare AN spo), em que ocorreu um alongamento vocálico compensatório e na palavra fahi ("eu pinto", $1^{a}$ p.s., germ. < *fāhiu < *faihiu, pedra de Noleby, Västergötland, Suécia, 600 d.C.). Por outro lado, na palavra solu *[sōlu] ("sol", dat.f.s. com tema em ō; Eggja, Sogndal, Noruega, 700 d.C; AN sólu $\approx$ sól < solu < RP ${ }^{*}[$ sōlō] $<$ germ. *sōwulōi ${ }^{75}$ ) não houve a perda da vogal, por conta talvez, de acordo com Nielsen, de distinção. A síncope também não ocorreu após sílaba curta: alu ("mágica, proteção", ac.n.s., tema em $u$, pente de Setre, Noruega, 650-700 d.C. e pedra de Kinneve, Suécia, 600 d.C., compare AN Ql). No território dinamarquês pré-Era Viking ${ }^{76}$, o $-u$ também desapareceu após uma sílaba longa mas se conservou após uma curta: como exemplos de sílabas curtas em posição anterior ąsmu(n)t (nome pessoal, ac.m.s.) e sunu ("filho", ac.m.s. com tema em u, 750-800; < germ. *sunu-, compare AN son), ambas gravadas na pedra rúnica da igreja de St. Nicolai em Sölvesborg. De maneira similar, o - $u$ foi mantido em brupursunu ("filho do irmão", ac.m.s.), mas caiu posteriormente em kupumu(n)t (compare AN

\footnotetext{
75 Nossa proposta de desenvolvimento etimológico

76 A região conhecida como Skåneland, localizada no sul da península escandinava e que compreende as províncias atualmente suecas Blekinge, Halland e Scania, como também a ilha dinamarquesa de Bornholm, era território dinamarquês a partir, aproximadamente, do séc. IX. A data da pedra rúnica foi retirada em Nielsen (2000, p. 100).
} 
Gudmund, ac.m.s.), ambos na pedra rúnica de Fyn, Dinamarca, 790 d.C. A vogal, porém, foi sincopada um pouco depois nas pedras de Tryggevælde e Rønninge (compare sun, ac.m.s. 900 d.C.). As pedras suecas de Rök e de Kälvesten (825 d.C.) têm a forma não sincopada (sunu, ac.m.s.).

Outras formas em que se conserva o $u$ nas runas dinamarquesas do ano de 900 d.C. são: karpu ("fizeram", 3pes.pret.pl.ind., Glavendrup, 900; < terminação do germ. *-dēdun) (compare AN gørðu; Go. -dēdun, AAA -tun), raupum ("vermelho", Rønninge), fapur ("pai", ac.s.), brupur ("irmão", ac.s.) (compare AN fǫður, bróđur) (NIELSEN, 2000, p.95-100). O sufixo -ur deve provir de um sufixo do IE -or-, que se tornou -urquando precedido de $u$ : no germânico seria *faðorum e *brōporum (CAMPBELL, 1959, §631, apud NIELSEN, 2000, p. 99). Temos a hipótese de que o-u se manteve, por exemplo, em karpu e raupum por conta da nasalização posterior.

A síncope do u não ocorreu, por exemplo, na forma writu *[wrītu] ("escrevo", 1ª p.s.; < germ. "writō; fibula de Eikeland, Rogaland, Noruega, 500 d.C., compare AN ) porque o $u$ é reflexo do sufixo de $1^{a}$ p.s. do germânico, quer dizer, o -ō; o mesmo ocorre em gibu ("eu dou", bracteata de Sjælland II, Dinamarca, 450-550 d.C.; < germ. * gibō).

A respeito dessas três síncopes, Nielsen (2000) conclui que a síncope do $u$ é posterior à do $i$ e, especialmente, à do a (p. 261) e, apesar da evidência do sunu, Grønvik assume que o $i$ e o $u$ foram sincopados contemporaneamente após uma sílaba curta (1987, p. 171-172 apud NIELSEN, 2000, p. 261).

f) as inscrições rúnicas anteriores ao ano de 700 d.C. não indicam a implementação da mutação causada pelo $i$ das vogais anteriores. A síncope do fator condicionante $-i$ - em palavras como barutz ("quebra", $3^{a}$ p.s, Björketorp, Suécia, 675 d.C.) e manz ("homens", Eggja, Sogndal, Noruega, 700 d.C.), com cognatos no AN brýtr e męnn, sugere que a formação dos fonemas gerada pela mutação causada pelo $i$ ocorreu anteriormente ou, pelo menos, ao mesmo tempo que a síncope do $i$ nessas 
palavras. No geral, as inscrições do futhark mais jovem da Era Viking (início) não representam grafemicamente as vogais que sofreram a mutação (NIELSEN, 2000 p. 108 e 261), mas a inscrição no fragmento do crânico de Ribe (cerca de 725 d.C.) grafa ia (para æ) na palavra uiarki ["værk] ("dor", dat.m.s. < germ. "warki-, compare AN verk), que provavelmente representa o reflexo do a mutacionado pelo $i$ (STOKLUND, 1996, p. 206 e 1997, p. 26, apud NIELSEN, 2000, p. 261). Da mesma maneira, assume-se que a forma sincopada nAkdan ("nu", Eggja, Sogndal, Noruega, 700 d.C.) deve ter passado pela mutação do $u$ (apesar da escrita $\operatorname{com} A$ ), por conta da forma no AN nokviðr.

Nielsen (2000) conclui que a mutação causada pelo i e pelo u não deve ter sido iniciada após a síncope das vogais condicionantes (p. 261).

g) as atestações mais antigas da ruptura do e antes de a e $u$ não acentuado são: hAerAMA- (Björketorp, Suécia, 675 d.C.) e hAeru("espada", Istaby, Suécia, 625 d.C., compare AN hjör-). Magnússon (2008) apresenta as seguintes cognatas para hjör-: Al heoru, AS heru e Go. hairus (< germ. *heru). Compare a forma sem ruptura: herAmA("resto", Stentoften, Suécia, 625 d.C., mas AN *hjarm-). Outros exemplos são hialb ("ajuda", fragmento do crânico de Ribe, Dinamarca, 725 d.C., germ. < *helpō) e skialta ("escudo", Rønninge, Dinamarca, 900 d.C., compare AN skjaldar em gen.m.s. com tema em u). Tradicionalmente, a datação do processo de criação de fonemas a partir da ruptura se vinula com a síncope do a e do u (BRØNDUM-NIELSEN I, 1950, §93), mas a manutenção do -a- e -u- nas runas de Blekinge certamente não contradiz a interpretação de Steblin- Kamenskij, que afirma que a ruptura do AN não se deve ao desaparecimento das vogais traseiras não acentuadas (1957, p. 90-91, apud NIELSEN, 2000, p. 262). De acordo com Steblin-Kamenskij, o que de fato verifica-se é o surgimento de um alofone a partir do /ě/, o [ $\left.\mathrm{e}^{\mathrm{a}}\right]$, que consequentemente se transformou em um cluster fonêmico /ia/. O autor ainda explica que esse alofone em forma de ditongo coincide com o alofone não silábico de /i/ em 
tais combinações como /iū, iō/, como um resultado de mudança fonética gradual, portanto, a ruptura se deve à existência de tais combinações ( $p$. 90-91, apud NIELSEN, 2000, p. 262).

h) É evidente que ocorreu uma mudança drástica ao comparar as formas sufixais barutz (-z) ("quebra”, $3^{a}$ p.s., Björketorp, Suécia, 675 d.C.) e bariutip (-ip) (Stentoften, Suécia, 625 d.C.). No primeiro caso ocorreu a síncope do $i$, o que fez com que permitisse a aglutinação da fricativa dental com a consoante final do radical verbal; portanto, embora a síncope do $i$ não tenha ocorrido primeiramente após sílabas curtas no nórdico (compare sitiz "senta" na pedra Rök, Suécia, cerca de 825 d.C.), a incerteza criada a partir da primeira onda de síncope do $i$ criou a necessidade de haver uma nova terminação sufixal para substituir a plosiva alveolar (ou terminação zero), que alterna com a fricativa, representando as formas da $3^{a}$ p.s. Há basicamente duas explicações da inserção do $-z$ na $3^{a}$ p.s $s^{77}(<$ germ. -idi). De acordo com Nielsen (2000) o presente singular do nórdico passou de um modelo de três formas para um de duas formas: uma marcando a primeira pessoa (o falante) e o outro marcando a segunda e terceira pessoa. Independente da explicação sobre a introdução do $-z$ na terceira pessoa, poucas dúvidas surgem a respeito da cronologia da mudança, que acontece claramente nas inscrições de Blekinge (p. 264).

A síncope do a, $i$ e $u$ após sílabas longas esteve em uma posição pivô nos desenvolvimentos fonológicos e morfológicos mais drásticos nessa sincronia. Anteriores às mutações e síncopes, estão a queda do $j$-e especialmente a queda do $w$ - antes de vogais traseiras arredondas e, após 700 d.C., ocorreu a cisão do alofone $/^{*} \partial /$ de [*d] e a fusão com $\left[{ }^{*} \theta\right]$ e ainda posteriormente a coalescência do $-z\left[{ }^{*}-z\right]$ final não acentuado com o $\left.-r{ }^{*}-r\right]$.

77 a) mudança de -ð para -z (-R) (HAUGEN, 1976, p. 158; Bröndum-Nielsen VIII, 1973,§782,1) e b) transferência da terminação de $2^{a}$ p.s. para a $3^{a}$ p.s. (Krahe, II, 1969§69). Arlotto (1972, p. 154156) afirma que do ponto de vista semântico a terceira pessoa é mais indefinida (i.e. a parte sobre a qual se fala) do que a primeira e a segunda pessoa, uma situação que se adequa à observação tipológica de que a maioria das línguas no mundo tem a forma de terceira pessoa não marcada (apud NIELSEN, 2000, p. 264). 
No período de transação, portanto, começaram a desenvolver características nórdicas, mas o momento definitivo de quando isso ocorreu não é muito exato. Foi demonstrado no item e) que a síncope do a já ocorria antes e por volta do ano 600 d.C. Com relação à redução do ō para a, é de importância perceber que a inscrição de Stentoften tem runoz ("runas", ac.f.p. com tema em ō), ao passo que as inscrições de Björketorp e Istaby têm runaz; portanto, tanto o -oz quanto o -az são reflexos do germânico *ōz, e o AN -ar de rúnar é uma herança desse desenvolvimento. Há outros casos como: runo ("das runas", nos casos gen.f.p., Stentoften e Björketorp, < germ. *runō). No AN é rúna (gen.f.p.) e rúnar (ac.f.p.). Em outras palavras, há um paralelo direto da terminação em -a com tema em a com o germ. ${ }^{*}-\bar{o} z,{ }^{*}-\bar{o}$; e as variantes de Blekinge, acima citadas, sugerem que a mudança de -ō-para -a- era um processo em evolução.

Grønvik (1987) postula uma mudança com três estágios do RP para o nórdico (primitivo) no que se refere às formas do nominativo/acusativo masculino singular/plural com tema em a. A forma intermediária seria aquela em que o RP -a(-) (< germ. *-az; nom.m.s. com tema em a) é sincopado e a vogal -ō- não reduzida (RP ${ }^{*}$ dagoz< germ. *dagōz, nom.f.p. com tema em a) ${ }^{78}$; além do mais, nesse estágio no caso ac.m.p. com tema em a do RP ${ }^{*}$-an (< germ. ${ }^{*}$-anz) é retida a nasalização ( $\left.{ }^{*}-\tilde{a}\right)$ (p. 168-169 apud NIELSEN, 2000, p. 263). Em seguida, o RP *dagoz viraria *dagaz no NP, que, por sua vez, se transformaria em AN dagar. O germ. "stainaz sofreria tais leis: RP ${ }^{*}$ stAinAz $>{ }^{*}$ stAinz $>$ NP stAinn > AN steinn.

Nielsen (2000) conclui que o início do sistema nórdico esteve, de acordo com Grønvik, intrinsicamente atado à apócope do a e, portanto, é um ponto de vista que ele não sente a necessidade de discordar (p. 263).

${ }^{78}$ No exemplo dado por Grønvik ele utiliza a palavra runoz que, apesar de não ter tem em a, mas em $\bar{o}$, tem a mesma terminação de nom.p. (compare germ. * ${ }^{*}$ runōz). O autor exemplifica com a fibula de Eikeland (Rogaland, Noruega, 500 d.C.), que exibe o nome pessoal wiz com a sincopado (< germ. *wizaz) e também a palavra runoz (NIELSEN, 2000, p. 270, n. 37) 
O fator mais importante para comprovar que apenas o AN seria uma continuidade do RP é a vogal o. Demonstraremos tal comprovação a seguir.

De acordo com Nielsen (2000, p. 79), as vogais não acentuadas do IA, com base nos manuscritos mais antigos, eram: [i], $[æ],[u]$, e [a] e do AS, [i], [æ] / [a], [u], e [a] / [o].

Comparação entre o desenvolvimento da vogal * ${ }^{*} \overline{-}$ do germânico com a vogal correspondente do antigo nórdico e com o inglês e saxão antigos, que não era acentuada:

\begin{tabular}{|l|l|l|l|l|}
\hline Germ. & RP $>$ AN & IA & AS & AAA \\
\hline$*-\bar{n} 7^{79}$ & $-0>-a / \varnothing$ & $*(-a)^{80}>-æ(-e)^{81}$ & $*(-a)>-e$ ou $-a^{82}$ & $*(-a)>-a$ \\
\hline$*-a i^{83}$ & $-e>-i$ & $*(-\bar{\varepsilon})>-æ(-e)$ & $*(-\bar{\varepsilon})>*-e$ ou -a & $-e$ \\
\hline$*-e^{1}$ & $-a$ & $*(-a)>-æ(-e)$ & $*-a>-e$ ou-a & \\
\hline$*-\tilde{o}^{84}$ & $-0>-a$ & $*(-\bar{\jmath})>-a$ & $*(-\bar{\jmath})>-$ ou -a & -0 \\
\hline
\end{tabular}

79 Terminação de casos como nom.s.f. de tema em $n$, ac.s.f. de tema em ō e $1^{a}$ pess.pret.ind. Portanto, a forma germânica em nom.s.f. com tema em $n{ }^{*}$ tungōn originou IA tunge, AFris. tunge, AS *tunge ou *tunga, AAA zunga, mas RP *tungo (> AN tunga). Há o correspondente lamo (em forma n.s.f. com tema em $n$, de Udby, Skovgårde, Dinamarca, c. 200 d.C.). Como exemplo de ac.s.f. em ō há germ. *runōn que originou IA *rune (há, por exemplo, giefe), AS ${ }^{*}$ runal*rune (há, por exemplo, geБa), AAA *runa (há gëba), mas RP runo > PN *runa > AN rún. Essa terminação provém do IE *ām (Sanscr. Ásvām "égua" e lat. filiam). Com relação à $1^{\text {a }}$ pess.pret.ind: IA *tawode (mas há fremede), AS *tōida ou *tōide (há fremida), AAA *zawita, mas PN tawido (> AN *táđa). Essas reconstruções foram tiradas de Nielsen (2000, p. 77-79).

80 Nielsen (2000) inclui o estágio do germânico do Noroeste *(-a) antes de se tornar -æ(p. 101).

$81 \mathrm{Na}$ versão (Moore) da Nortúmbria (norte da Inglaterra e sudeste da Escócia) do hino de Caedmon, o típico -es do IA era escrito inicialmente como -aes ou -æs: -ricaes "do reino", metudæs "de Deus", -cynnæs "do parentesco" e não rices, metodes e cynnes, portanto, gen.sing. -æs (< *as). Posteriormente o -æ seria escrito -e.

82 No manuscrito Heliand S é -e (thiorne, ine, ire giboren) e no Heiland C, -a (thiorna, ira, giboran).

83 Terminação do dativo masculino singular com tema em a. No RP há woduride "cavaleiro furioso", cuja segunda parte da composição teria origem no germ. *ridai. Não existente em inscrições rúnicas, porém reconstruído há *dage "dia", que gerou o AN degi. No IA corresponde a *ride (há, entretanto, dage "dia", cyninge "rei" ou *dagæ/cyningæ). No AS Heliand C há cuninga e no Heliand S há cuninge. No alemão antigo, por sua vez, tage, cuninge. 


\begin{tabular}{|l|l|l|l|l|}
\hline$*-a u^{85}$ & $-0>-a$ & $*(-\bar{\jmath})>-a$ & $*(-\bar{\jmath})>-0$ ou $-\mathrm{a}$ & $-\bar{o}$ \\
\hline
\end{tabular}

Com base nessa tabela, percebe-se que o germânico *-ōn (no Go. tuggō "língua") se mantém como -o no RP (200-550), que se transformou em -a na sincronia posterior (600-900 d.C.); ao passo que aparece como *-æ nos primeiros textos do IA. No AS, por sua vez, há as terminações -e ou -a, que serão explicadas abaixo. O germânico *-õ (no Go. tuggōnō) corresponde ao rúnico primitivo -o, que virou -a no período de transição; no germânico do Noroeste, por outro lado, se transformou em * $-a\left({ }^{*}-\bar{\jmath}\right)$, tendo em vista que no IA/AS há a terminação a (com cognata -o no AS), no AAA -o foi conservado.

O germânico *-ai, que vira *-æ no IA e AS, se funde com o-æ, originado do germanico do Noroeste *-a $\left(<-\bar{n} n\right.$ ou $\left.-e^{1}\right)$; no RP, por sua vez, é inscrito como -e (> AN -i).

De acordo com Nielsen (p. 83) é possível determinar um sistema vocálico não acentuado do germânico do Noroeste, mas é óbvio que tal sistema não poderia ter existido até o reflexo fronteado de * $-a$ $\left(<-\bar{n}\right.$ ou $\left.-\mathrm{e}^{1}\right)$ ter se fundido com o descendente de *ai.

Com relação à mudança do -o para o -a (em sincronia anterior -̄), pode ser interpretado como um processo tardio em cadeia: no IA foi completado no tempo da emergência dos primeiros textos (cerca de 700), ao passo em que no AS não foi concluído até o séc. IX e XX (Klein, 1977, p. 528-9, apud NIELSEN, 2000, p. 83). A fusão do germânico *-a e *-ai nas línguas germânicas do Noroeste deve, portanto, ter sido antecedida por um sistema vocálico não acentuado

${ }^{84}$ Terminação do caso gen.pl. de radical em $n$. No RP há arbijano "dos herdeiros" que teria origem em um germ. *arbijanon. No IA há gumena "dos homens" e tungena "das línguas" e no AS gumono e tungono, mas há também gumona, no AAA, por sua vez, hanono "dos galos". Por exemplo, no manuscrito Heiland S é -a (uuillia, kuninga, gumona) e no Heliand C, -o (uuilleo, cuningo, gumono).

85 Terminação do caso gen.sing.(masc.) de radical em $u$. Há no RP magoz "do menino", que é herança do germ. "magauz. No IA corresponde a *maga (com atestação em suna "do filho") e no AS suno ou *suna e no AAA *suno. 
consistente de cinco vogais: /i, æ, a, o, u/, compare com a forma do AAA. O AAA não passou por tal fusão.

Na bracteata de ouro de Undley, Suffolk, Inglaterra (fim do séc. V) está inscrito gægogæ mægæ medu. Eichner (1990) compreende a primeira parte como "será destinado" (< germ. "ga-gō-gai; verbo em 3ap.pr.s.subj.), mægæ (mǣgæ) (dat.m.s. com tema em a) e medu (nom.f.s. com tema em ō) (p. 315-318, apud NIELSEN, 2000, p. 91). Portanto, de acordo com Nielsen, se a transliteração de Odenstedt (1983, 1990) de f como $æ$ e a tradução de Eichner estiverem corretas, a bracteata de Undley carregará o momento da evolução desse sistema vocálico não acentuado no germânico do Noroeste, quer dizer, há a terminação *-ai, que deu origem à terminação verbal em gægogæ e também ao dativo da palavra mægæ. Uma vez que ocorreu um fronteamento da vocal não acentuada a $\left(<\right.$ germ. $\left.{ }^{*} \bar{e}^{1}\right)$ para $æ$ em gæ- $(<$ germ. do continuum Norte-Oeste *ga-; RP magoz "filho", AS/AAA māg "parente", mas Go. mēgs "genro"), a inscrição mostra que nesse tempo uma fusão deve ter ocorrido entre os reflexos não acentuados do germânico *-a e *-ai, sugerindo, assim um sistema não acentuado de quatro unidades $\left(/ \mathrm{i}, æ\left(<^{*}-a i \mathrm{e}^{*}-a\right),(\mathrm{a}<) \overline{\mathrm{j}}, \mathrm{u} /\right)$. O $-u$ de medu (mēdu) remonta ao germânico * $-\bar{o}$ e a síncope desse -u só ocorreria em tempo posterior (compare IA mēd "recompensa").

Geograficamente, há dois textos no AS que marcam as duas formas apresentadas: textos do grupo -e e -a da parte leste e sudeste da área (Ostfália e Engern) e textos do grupo -a e - 0 , da parte sudoeste (Vestfália). De acordo com Klein (1977, p. 529, apud Nielsen, p. 82), o sistema fonológico desses dois sistemas era respectivamente /-i, -æ(e), -a, -u/ e /-i, -a, -o, -u/ e ambos seriam reflexos de um sistema vocálico mais antigo /-i, -æ, $-\bar{\jmath},-u /$, que teria origem em um sistema de cinco vogais ainda anterior /i, æ, a, o, u/. Decisivo para a diferença do número de vogais não acentuadas, em comparação com o AAA que tinha cinco $(/-\mathrm{i},-e,-a,-0,-\mathrm{u} /)$, foi o fronteamento do -a para -æ, que se fundiu com o -e /-æ/ (< germ. *ai; germ. *dagai "dia” no caso dat.m.s. 
com tema em a > AAA tage, IA dæge). A fusão entre os reflexos do germânico *-ai e *-a ocorreu em toda a área do AS, sendo representados por -a no grupo de textos do tipo "a" e -e no grupo de textos do tipo e.

Dois textos, Heliand $S$ e Heliand $C$, demonstram essas diferenças: em palavras em que há -æ $\left(<\right.$ germ. $\left.{ }^{*}-\bar{o} n,-e^{1}\right)$ no Heliand $S$, há -a no Heliand $C$ e em palavras em que há -a (< germ. *-õ ou *-au) no Heliand S, há -o no Heliand C. Nielsen (2000) afirma que no grupo -e, a do AS (Heliand $S$ ) a transformação ${ }^{*}-a>^{*}$-æ foi seguida da mudança de -o para -a fazendo com que esse modelo de AS parecesse com o grupo vocálico do primórdio do IA e também do primórdio do AFris. Aparentemente houve uma forma ${ }^{*}-\bar{\jmath}\left(<\right.$ germ. $\left.{ }^{*}-\tilde{o}\right)$ antes de dar origem ao -a do germânico do Noroeste.

Conclui-se que ao assumir que lamo, runo e tawido derivam do germânico *-ōn e que arbijano e magoz dos, respectivamente, germ. -õ $e^{*}$-au, as vogais do germânico do Noroeste -e, -a (-a, -o) não poderiam ter origem no RP, em que ocorreu uma fusão. De acordo com Samuels (1972), não é possível que as línguas do germânico do Noroeste (e o AAA) pudessem reviver distinções vocálicas consistentes uma vez perdidas pela fusão (p. 34, apud NIELSEN, 2000, p. 89). Portanto, uma vez que a distribuição das duas vogais do IA é etimologicamente determinada, $æ$ como desenvolvimento do germ. (*-on) e a do germânico *-õ e *-au, o vocalismo do IA (germânico do Noroeste) não poderia ser originado do rúnico primitivo no que se refere ao $\bar{o}$ (p. 102). Nielsen também conclui que o AAA é muito mais conservador do que as outras línguas do germânico do Ocidente no que diz respeito à preservação do comprimento silábico, mas, ao mesmo tempo, muito mais inovativo em desenvolver um sistema longo que correspondente completamente com o sistema curto (p. 89-90). Nielsen (2000) explica a hipótese de haver uma forma comum tanto para o nórdico quanto para o germânico do Noroeste, mas afirma que as informações demonstradas pelas runas de Blekinge, Eggja, entre outras, evidenciam uma transição gradual do RP para o nórdico, que é o sucessor legítimo (p. 103). 


\subsubsection{4 $\mathrm{SN}^{4}-\mathrm{A}$ Era dos Vikings}

Este é o período (do séc. VIII até 1050) em que os dialetos começaram a se fixar em suas áreas: os dinamarqueses olhavam mais para o Oeste (Inglaterra e França), os suecos para o Leste (Báltico e Rússia) e os noruegueses para o oeste e Norte (SEIP, 1931, p. 38). O autor também apresenta as inovações linguísticas desse período. Inicialmente ele cita o aparecimento dos artigos definidos enclíticos e da forma reflexiva (kalla "chamar" > kallast "ser chamado"). Com relação aos vocalismos, o autor cita:

Mutação causada por consoante palatal (mutação do $g, k$ e $n g$ ): é parecido com a mutação causada por i. Ocorre em casos que um $i$ surge em vez de ĕ (PG slaginaR, compare alemão geschlagen) ou do $\bar{e}$, que é mais antigo (compare AN degi de germ. ${ }^{*}$ dagē). $\mathrm{O} i$ influencia o a, que vira e. Portanto, genginn "ido", tekinn "tomado, mas malinn "pintado" e farinn "viajado". Esse processo ocorre especialmente na parte oeste da Escandinávia (Noruega e Islândia).

Mutação causada pelo -R: é uma assimilação de contato e tem a mesma consequência que a mutação causada pelo $i$. A palatal R, que no PG surgiu de um $\mathrm{s}$, influencia por assimilação de contato a vogal anterior. Tal processo ocorreu antes da mesclagem entre os dois $r$ (o-R e o $r$ mais antigo). Portanto: germ. "glaza "vidro" (compare AN e isl. gler, mas din. glar) e do PG "suR "porca" formou-se sýr no AN e isl. Essa modificação não orreu em todo o norte. No sueco há em alguns dialetos, no dinamarquês não há.

Mutação do causada pelo u: ele já ocorreu em período anterior após sílabas longas e, em seguida, caiu. Uma vez que o u após consoantes curtas se manteve após o ano de 800 , essa nova mutação causada pelo u dificilmente aconteceu antes do séc. IX. Além do mais, ela ocorreu em sua maior parte na parte Oeste.

Monotongação: ei (do antigo ai) torna-se ē e au e ey tornam-se $\varnothing$ longo. É um processo compartilhado pelas línguas 
germânicas e, antes de virem para o norte, já havia ocorrido no antigo saxão e antigo frísio; por conta disso, é um processo que foi do sul para o norte. Em 800 já ocorria no noroeste da Alemanha, em 900 na Dinamarca (rispi, na runa de Asferg, 970-1020, corresponde ao AN reisti "elevou"), etc. Por volta do ano 1000 a monotongação já havia dominado a Dinamarca. Na Suécia ela ocorre no Sul após o ano 1000, no centro um pouco mais tarde (stin, na runa $U 1143$ do tipo Ingvar, entre 1036 e 1041, corresponde ao AN steinn "pedra"). Segundo Skard, o processo se concluiu por volta de 1200, com exceção de algumas áreas no Oeste, Norte e Leste. A respeito da Noruega, na Era Viking esse processo não foi de grande importância. Uma ocorrência é a monotongação das formas superlativas mestr e flestr (compare com a forma comparativa meiri e fleiri). Ambas as palavras significam mais, mas o primeiro tipo é incontável e o segundo é contável. Portanto, a monotongação é um processo muito mais do Leste do que do Oeste.

Ruptura do e: na Era Viking a ruptura foi realizada em palavras como mioðr "hidromel" < meðuR, com a provável apócope do $u$ após sílaba curta. Em palavras que restaram o a e o $u$ final acredita-se que a ruptura ocorreu por volta do ano 900 , pois os escaldos rimam blađ "folha" e fjađrar "da pena (do pássaro".

Fechamento sonoro: o nasalisado ó vira ó no fim da Era Viking. Tem-se essa hipótese por conta da utilização da runa ansuz f (a) após o ano 1000 no lugar da vogal o, que resultava numa uma confusão. A palavra Ólafr (< ólafr), por exemplo, vém de *AnulaibaR e Ósló (< óss) de *ansuR-).

Abertura sonora $e>æ$ : os escaldos separam nas rimas o e original (por exemplo, no pronome ek "eu" (de eka)) e o e (æ) gerado na mutação do a causada pelo $i$ (como em ferð "viagem", de *farði). Mas o e original que fica entre $v$ e $r$ (como, por exemplo, sverठ "espada) ou que fica após $v$ e parcialmente após $b, r$, l em "sílaba fechada" (como, por exemplo, vegr "caminho") soa sempre como æ já em poemas anteriores ao ano 1000 . Isso pressupõe uma mudança de e para $æ$, que 
também se apresenta na língua escrita antes do ano 1200. Dessa maneira, isso mostra que o e nessa posição se abriu e recebeu uma pronuncia que corresponde à de hoje em dia (compare com sua forma original em palavra como no alemão Schwert "espada") (Skard, 1973, p. 59). Essa abertura sonora ocorreu em diferentes dialetos; no dinamarquês e sueco ocorreu de maneira universal antes do ano 1000 (SEIP, 1955, p. 48).

Com relação aos consonantismos, os autores citam a aférese do $h$ (antes de $r, l$ e $n$ ). O processo ocorreu no dinamarquês já por volta de 800 , mas no islandês ainda se mantém. Nos manuscritos mais antigos de norueguês a aférese ocorreu em todas essas posições. A aférese do $v$ ocorreu já por volta de 800 na parte Oeste, mas o $v$ se mantém em expressões fixas e também em alguns dialetos do sul e sudeste da Noruega (Agder, Telemark, Viken) e também no sueco e dinamarquês. O v também some após sílaba longa: Noregr "Noruega" (< *Norđvegr) e mais raramente Norvegr (SKARD, 1973, p. 59). Seip e Skard apresentam outras quedas, que não consideraremos aqui (1955, p. 49 e 1973 , p. 59, respectivamente).

Alguns processos assimilatórios são, por exemplo uma nasal junto com um plosiva vozeada: mp > pp (lat. campus > AN kappi "luta"); $\mathrm{nt}>\mathrm{tt}$ (germ. *wintruz > AN vetr, mas din. vinter "inverno" e nk > kk (germ. *brinkaz > AN brekka, mas din. brink "beirada), por outro lado, AN drekka, din. drikke, sue. dricka e ale. trinken. Esses processos ocorreram muito mais no nórdico do Oeste. No dinamarquês e sueco e partes dos dialetos noruegueses do leste esses processos ocorrem mais no final das sílabas. O processo ht > tt (nátt "noite" e átta "oito") é geral e ocorre no período anterior, da Era das Síncopes.

Assimilações progressivas que ocorrem em toda a área nórdica: Ip, np para II, nn (gull "ouro", annarr "segundo", mas ale. Gold e ander). E também as mudanças de IR, nR e $\mathrm{SR}$ para II, nn e ss ocorrem em toda a área nórdica, principalmente em nom.s.m. de substantivos, adjetivos e particípios fortes: stóll "cadeira" (< *stolR), heill "saudável" 
(<*heilR), heitinn "chamado" (< *heitinR $<$ haitina $R<$ germ. *haitandz), etc. (SKARD< 1973, p. 60). Seip apresenta muitos outros processos entre as páginas 50 e 53 (1955).

De acordo com Skard (1973) e Seip (1955), a separação entre o Oeste e o Leste já se iniciou no período anterior, uma vez que a parte Leste tem formas sem a mutação causada pelo a (hult em sue., mas holt em nor. "madeira") (p. 28, 65; p. 59). A mutação causada por consoante palatal, a causada pelo $u$ e as assimilações são mais fortes no oeste, ao passo que a ruptura é mais frequente no Leste. Por outro lado, a fronteira entre essas duas configurações linguísticas não é rígida: a monotongação tão frequente no Leste não se aplica na ilha sueca de Gotland e ela é presente nos dialetos noruegueses do Leste.

\subsubsection{5 $\quad \mathrm{SN}^{5}-\mathrm{O}$ antigo nórdico}

Esta sincronia percorre de 1050 até 1350. Seip (1955) divide esse período em três fases: primórdios do nórdico antigo (1050 até 1150), norma de Trønder e norma de Bergen (1150-1300) e do antigo nórdico até o médio norueguês (1300-1370). Skard (1973) coloca essas três fases em um único grupo: o antigo nórdico. Indrebø (1951) segue basicamente o mesmo raciocínio, mas considera desde o 700 até 1350 como den norrøne tid "a era nórdica", dentre o qual há o vikingtidi "era dos vikings", de 700 até 1050 e o gamalnorsk "norueguês antigo", de 1050 até 1350. A única diferença de Skard para Indrebø é que ele inicia a era viking em 800. Haugen (1976), por sua vez, chama o periódo de 500 até 1050 de common scandinavian e de 1050 até 1350, de old scandinavian. Torp \& Vikør (1993) chamam todo o período de 700 até 1350 de norrønt (p. 32) e o divide em duas fases: yngre runetid "era das runas mais novas" (700-1050) e klassisk norrøn tid era nórdica clássica (1050-1350).

Os autores também afirmam que o período nórdico clássico foi de grande importância literária na Noruega, apesar de terem sido os 
islandeses aqueles que mais contribuíram para a nova escrita, uma vez que eram designados pelos próprios reis noruegueses para escreverem suas bibliografias. Uma norma escrita, na verdade, não existia nesse período e a maior parte das escrituras eram realizadas em mosteiros e chancelarias, onde se iniciaram algumas convenções, mas mais variadas, uma vez que havia muitos centros políticos, econômicos e religiosos. Apesar dessa variedade, até aproximadamente 1350, é considerado que os letrados na Noruega escreviam em um idioma, hoje chamado de gammalnorsk mål "antigo nórdico norueguês", que não se diferenciava muito do gammalislandske mål "antigo nórdico islandês", uma vez que foram os próprios noruegueses que colonizaram a Islândia em 874. Essa, portanto, era a língua das sagas islandesas e norueguesas.

Seip (1931) afirma que a língua escrita se mudou abruptamente por volta de 1370. Até esse momento, não se podia falar de língua nacional na Noruega, muito pelo contrário, os manuscritos refletiam o crescimento das divergências dialetais e cada centro tinha sua própria tradição de escrita (HAUGEN, 1976, p. 189). Segundo o autor (p. 190), os manuscritos mais antigos da Noruega se originaram em Nidaros (atual Trondheim), a sede do arquebispo (de 1152) e de alguns reis, e em Bergen, apesar de Hákon V Magnusson (1299-1319) ter consagrado Oslo como capital e movido a chancelaria real para lá em 1299; por conta disso, havia duas tradições diferentes nesse período: de Trondheim e de Oslo. Seip (1931, p. 342) afirma também que antigamente a Noruega tinha uma língua mãe (gammalnorsk mål) utilizada como uma língua escrita, mas esta nunca teve tempo e tranquilidade para desenvolver-se de maneira homogênea sob a influência de uma língua falada central, devido às concorrências já citadas entre as tradições e entre os tais centros políticos, econômicos e religiosos. Além dos conflitos internos, a influência política do sueco e do dinamarquês também bloquearam o desenvolvimento dessa nova formação linguística nativa no final do século XIV. 
Neste período ocorreram muitas reduções vocálicas em posição atona. Nesta posição, e após uma sílaba longa, o a pode sofrer um afrouxamento para æ. Isso ocorreu, por exemplo, na palavra fulæ "horrível" em uma inscrição rúnica (Trondheim, ac.f.sg. ou gen.m.sg.) (< fúla). Seip cita o manuscrito islandês (i.e. Livro de sermões do antigo islandês) em que ocorrem reduções: elle por ella "senão", feóre por færa "viajar" (eó $=æ$ ). Tais reduções em pequenas palavras átonas ocorrem no norueguês em um período posterior. Seip cita outras reduções que envolvem o norueguês do leste (1955, p. 72). A realização da mutação causada pelo $u$ também foi variada em certas áreas, o que causou uma variação dialetal: nas partes mais antigas do livro de sermões do antigo nórdico foram utilizadas formas sem mutação como stuð (em vez de stoð "apoio"). No livro de sermões do antigo islandês há em alguns sermões casos sem a mutação, pois são uma versão do livro de sermões do antigo norueguês. Conclui-se que os noruegueses têm menos mutação causada pelo $u$ do que os islandeses, mesmo que ambos dialetos sejam do Oeste.

Skard (1973) também cita que após 1300 encontram-se formas de plural com redução: manædær "meses", formas pronominais como annær "segundo, outro" e hennær "dela" e verbos orkæ "influenciar, afetar", orkær (no pres.), orkædæ (no pass.), orkæt (no part.). O norueguês do leste começa a enfraquecer as vogais cheias que se encontram no sufixo de palavras com duas sílabas quando a primeira sílaba é longa, mas mantém a vogal cheia quando ela é curta e isso explica a jamvektslov "lei balanceada", que justifica a existência em alguns dialetos de dois tipos de verbos: uns que termina em com - $e$ e outros que terminam com - $a$. O enfraquecimento fez com que a vogal final a (e $u$ ) tenha se afrouxada e, assim, passada a ser pronunciada como um e puxado para $\varnothing$ : "vogal média" que foneticamente se transcreve como $ə$.

Essa forma de redução parece ter começado em Oppland e tal tendência ficou mais forte por volta de 1200 , de maneira que se disseminou em toda a área do Leste. 
O norueguês do Oeste segue um outro princípio. Antes de 1300 parece ter havido uma tendência sob desenvolvimento, especialmente no bergensk, e em um dialeto do Leste, no Sul de Østfold, que seguiu o modelo do norueguês do Oeste. Neste caso o comprimento da raiz não teve nenhuma influência na redução. A distribuição ocorreu de maneira que a redução se realizou após uma raiz curta ou longa, nas áreas com dialetos que terminam apenas com e (há regiões no Sul e no Norte e, também, o dialeto de Bergen), ou não se realizou em nenhuma situação, nas áreas com dialetos que terminam com -a (parte sudoeste) (p. 91-92). Processos de redução após 1300 são apresentados por Seip (1955) no período entre o antigo nórdico e norueguês médio (p. 252-253).

Uma outra característica dialetal são: $t n>n n, t l>l l, h v>v$, manutenção de $v r$ (SEIP, 1955, p. 83), que ocorreram no Sudeste. Outras assimilações são comentadas pelo autor nas pagínas 78 e 79 . Outros desenvolvimentos são:

Harmonia vocálica: encontra-se nas pedras rúnicas de 1050 até 1150. Há uma assimilação progressiva uma vez que a qualidade vocálica na sílaba final é determinada pela vogal da sílaba anterior: vogais altas na raiz pedem $i$ e u (himni "céu" no dat.sg.ind., guðum "deus" no dat.pl.ind.) e vogais baixas pedem e e o (lande "terra, pais" no dat.sg.ind. < landi, toco "tomaram, pegaram" < toku) (SKARD, 1973, p. 90-91).

Mais processos de síncope.

Jamning (assimilação entre vogais): prep. ifir em vez de yfir "sobre"; firir em vez de fyrir "na frente de". Junto com a jamvektslov "lei de balanço", esse processo teve uma grande importância em alguns dialetos: assimilação parcial entre vogais: vita > veta "saber"; e total: vita > vata, våtå "saber" (SKARD, 1973, p. 93)

Mutação causada pelo $u$ : novamente ocorre esse processo com a consequente queda do $u$, só que nas regiões onde não havia ocorrido anteriormente como, por exemplo, na costa e nas cidades 
(SKARD, 1973, p. 93). Uma forma especial de mutação causada pelo u é conhecida como mutação por conta de consoante labial, quer dizer, ocorre a labialização do $i$ : silfr > sylfr "prata", etc. Seip atribui esse processo ao período das normas de Bergen e de Trondheim (1955, p. 123).

Mutação progressiva causada pelo $j$ : processo mais comum no nórdico do Leste, uma vez que se iniciou no sueco por volta de 1050 e no dinamarquês por volta de 1100 . No norueguês é mais comum nos dialetos do leste e no Islandês e Feroês nunca ocorreu. Exemplo: fjall > fjæll "montanha" e jafn > jæfn "o mesmo" (Skard, p. 93). Seip também atribui esse processo ao período das normas (p. 122-123)

- Motongação: ocorrem casos de monotongação no norueguês do Leste e do sudeste e, apesar de haver casos no islandês, isso se deve por conta da origem norueguesa do escriba. No ano de 1200 há muitos exemplos de monotongação, principalmente antes de uma consoante longa ou combinação de consoantes, mas também há vários casos antes de consoante não geminada, ou seja, sílaba longa: gleyma > gløma "esquecer"; draume > drøme "sonhar" e seint > sent "atrasado". Após 1300, uma vez que o norueguês do leste ganhou força, essa simplificação ficou ainda mais comum.

- Epêntese: ela pode ocorrer em várias posições, mas no antigo nórdico é mais comum antes do $r$ (Olafr > Olaver). Após 1300 esse processo começou a se difundir. A qualidade da vogal é indeterminada, uma vez que algumas vezes correspondem com a vogal da sílaba ou anterior e, mais frequentemente, insere-se um e ou æ. $\mathrm{Na}$ parte oeste (Voss e parcialmente em Hardanger) e na Islândia há bastante casos com u, já na parte Leste, a (Skard, 1973, p. 94). Seip apresenta esse processo em várias fases: nos primórdios (p. 68 e 72), na fase das normas (137-141) e no antigo nórdico (257-259).

- Tjukk L "L espesso": o $-r ð$ antigo se desenvolveu diferentemente no norueguês do leste e do oeste: no do leste o $r$ e o $\delta$ se assimilaram para a velar 
caiu e portanto ficou -or. Seip (1955) apresenta esse processo na página 177 .

Seip afirma que em 1152 o arcebispado foi inserido em Trondheim-Nidaros e isso possibilitou o desenvolvimento de uma língua escrita mais normatizada. Trondheim sempre tinha sido a sé para o rei e Bergen, a cidade residencial. Portanto, foi a língua escrita em Trondheim e no Oeste da Noruega que tornou o modelo padrão. Seip faz uma lista dos manuscritos mais antigos e aqueles a partir do séc. XIV entre as páginas 87 e 95. A partir do séc. XIV começaram a aparecer os diplomas, que são cerca de 80 escritos em norueguês ( $p$. 96). Nos manuscritos mais antigos utiliza-se uma norma do oeste e uma norma de Trondheim (p. 102).

Ainda restam muitos outros processos de menor documentação que não foram considerados aqui. Apesar de serem pouco documentados, eles são muito importantes para a determinação da sincronia.

\subsubsection{6 $\quad \mathrm{SN}^{6}-\mathrm{O}$ médio norueguês}

Esta sincronia se inicia em 1350 e termina em 1523. Torp e Vikør (1993) alegam que a partir de 1370 apareceram novas características que apenas podem ser explicadas pelo fato da língua falada ter sofrido significantes alterações, que em seguida refletiriam na escrita, e que por isso seria vista por estudiosos do séc. $X I X$ e $X X$ como uma nova sincronia, chamada de mellomnorsk, cuja escrita era muito mais instável do que a do antigo norueguês. Essa transição também é sempre vista relacionada à grande epidemia conhecida como Svartedauden "peste negra" (1349-50) que assolou a Noruega, uma vez que dizimou grande parte dos letrados, por exemplo, padres e funcionários da chancelaria. Por conta disso, a maioria dos eruditos nascidos após a peste não conseguiu receber instrução mediante a escrita tradicional, como as gerações anteriores, de maneira que emprestavam características da 
língua falada para a escrita (p. 116-117). Haugen (1976) também assume que grande parte do clero foi afetado pela peste (p. 286). Ademais, a partir de 1400 ocorreram modificações na língua escrita, mas estas não tiveram relação com a língua falada, pois começaram a aparecer nos documentos noruegueses elementos suecos e dinamarqueses e, até mesmo, textos totalmente fundamentados nessas duas línguas. Isso seria uma consequência da união nórdica entre Noruega, Dinamarca e Suécia, conhecida como União de Kalmar (13971521), com o centro da Dinamarca. Por conta disso, uma gradual transição para o dinamarquês como língua escrita se iniciou a partir de 1400, uma vez que os dinamarqueses obtiveram cada vez mais integração na administração norueguesa e até os próprios noruegueses começaram a escrever em uma forma misturada entre os dois idiomas, sem que haja qualquer tipo de normatização em cada um desses idiomas (p. 117).

Portanto, esse período chamado anteriormente de intermediário, que abrange 1350 até aproximadamente 1550 (1325Indrebø e Seip; -1523 Skard, -1550 Haugen e Vikør -1536), grande parte dos acadêmicos estão em consenso por chamar de mellomnorsk ou middle scandinavian. Venås (2002, p. 35) também atesta que é um momento em que ocorreram grandes modificações linguísticas, que causaram o desenvolvimento para um "novo norueguês"; foi o período em que o sistema flexional sintético cedeu lugar para um novo sistema analítico. Ele também cita o grande número de palavras importadas do médio baixo alemão por conta dos milhares diplomas da Liga Hanseática.

Alguns desenvolvimentos sonoros considerados por Skard Indrebø (1951), (1973):

a) Mudança no acento e na quantidade vocálica. No norueguês a partir desse período a quantidade de uma vogal e uma consoante seguinte são dependentes: se uma vogal for longa, a consoante seguinte será curta e se a vogal for curta, a consoante seguinte será longa, mas ambas não podem ser tanto curtas quanto longas ao mesmo 
tempo igual ocorria na sincronia anterior. Anteriormente era [V:K], [VK:], [VK] e [V:K:] e a partir desse período apenas [V:K] e [VK:].

b) No período anterior a qualidade era a mesma seja a vogal curta ou longa e a partir dessa sincronia as vogais curtas ficaram mais abertas e reduzidas $\mathrm{e}$ as vogais longas ficaram fechadas (para a reconstrução do AN foi utilizado RANKE \& HOFFMANN (1988) e BARNES (2008)):

\begin{tabular}{|c|c|c|c|c|c|}
\hline \multicolumn{3}{|c|}{ Longas } & \multicolumn{3}{|c|}{ Curtas } \\
\hline $\begin{array}{l}\text { sól ['so:l] } \\
\text { "sol" }\end{array}$ & $>$ & sol ['s $\underline{u l}]$ & $\begin{array}{l}\text { golf *['golv] } \\
\text { "chão" }\end{array}$ & $>$ & golv ['g \\
\hline $\begin{array}{l}\text { hús *['hu:s] } \\
\text { "casa" }\end{array}$ & $>$ & hus ['hㅂ:s] & $\begin{array}{l}\text { tunga *['tunga] } \\
\text { "língua" }\end{array}$ & $>$ & tunge tunə] \\
\hline $\begin{array}{l}\text { tré *['tre:] } \\
\text { "árvore" }\end{array}$ & $>$ & tre [tre:] & $\begin{array}{l}\text { hestr *['hestr] } \\
\text { "cavalo" }\end{array}$ & $>$ & ['hæst] \\
\hline
\end{tabular}

c) Redução vocálica em posição átona. Em médio norueguês ocorre a maioria das reduções em posição átona: $a, i$ e $u(o)>æ$ ou $e$. A redução ocorre com mais frequência na terceira sílaba do que na segunda, em sílaba aberta do que em sílaba fechada, após prefixo longo do que prefixo curto. Alguns dialetos reduziram significante ao ponto de serem confundidos com formas dinamarquesas; o dialeto de Trøndelag, por exemplo, teve um desenvolvimento em que a vogal final sofreu apócope após sílaba longa: bíta > bit "morder" e vísa > vis "canção".

d) mutação causada pelo u (INDREB $\varnothing, 1951$, p. 226; SKARD, 1973, p. 144) em outros contextos.

e) simplificação de ditongo, que é um processo mais comum nos dialetos do Leste, com possíveis influências diretas do sueco (SKARD, 1973, p. 144)

f) epêntese: foi nesse período que ficou quase uma regra 
indicar a epêntese na escrita, uma vez que ela já estava sendo pronunciada por muito tempo: ákr > åker "campo".

g) queda do $r$ de plural em adjetivos, no artigo determinado (enclíticos) e pronomes: AN spakir > spake "sábio, esperto" (adj. nom.pl); AN prestarnir > prestane "os padres" e peir > dei "eles". Na forma nominativa singular, o $r$ cai em quase todos os lugares: AN svart(e)r > svart "negro" e e hest(e)r > hest "cavalo". Nos verbos fortes e verbos terminados em -ja ocorre a queda em todos os dialetos (com exceção daqueles da parte sudeste): ég kemr > eg kjem "eu venho" e ég telr > eg tel "eu conto", mas as classes do tipo kasta ocorre a queda apenas no Oeste e no Norte: ég kastar > eg kasta "eu arremeço, jogo".

h) queda definitiva do $\delta$ em algumas posições que tinha se iniciado no AN.

i) queda do $\mathrm{m}$, especialmente no norueguês do oeste, que atinge a terminação do dativo (i.e. -um; e onde o dativo foi mantido), de maneira que aparecem as formas hono (AN honum, honom, "ele" no dativo"), preposições gjøno (AN < (í)gegnum) "por meio de") e myllo (AN < (í)millum "entre").

j) queda do $-n$, que começou por volta de 1200 .

k) $\delta>d$. Nem sempre o $\delta$ caia em sílaba final após vogal em posição átona: em alguns dialetos ocorreu o desenvolvimento $\delta>d$ como em AN svarađi > svarde (svarte) "respondeu" (cai em AN kastaði > kasta "jogou, arremeçou"). Essa transição também começou no AN e não veio a terminar no médio norueguês (SKARD, 1973, p. 146).

I) em palavras tônicas ocorre o desenvolvimento $p>t$; nas átonas, $p>d$. O primeiro se iniciou por volta no início de 1300 e foi completamente realizado antes de 1450: ping > ting "coisa". O segundo, por exemplo: pú > du "tu", etc. (SKARD, 1973, p. 146; INDREB $\varnothing, 1951$, p. 229-230). A escrita $\delta$ desaparece por volta de 1300 e é substituída por $d$ ou $d h$; a escrita $p$, por sua vez, mantém-se por mais tempo, mas foi substituída por th por volta de 1500.

i) hv $>$ v. A queda do $h$ - se iniciou na área do germânico ocidental, onde ele caiu por volta de 800 (*hwaz > waz "o que"). A 
queda ocorreu no dinamarquês por volta de 1250 e, no sueco no fim do séc. XIV. A respeito do norueguês, a queda se iniciou no Sudeste, no séc. XIV ou mais cedo, uma vez que está mais perto da antiga fronteira com a Dinamarca. A partir daí a tendência se espalhou para o oeste e para o norte, o que fez com que trombasse em uma outra tendência: a mudança $h v>k v$, pois o $k$ - reforça esse som inicial no cluster, diferentemente do $h$ - que estava caindo nas regiões mais ao sul; portanto, ocorreu um reforço $h v>k v$ para manter os sons mais claros. Em consequência disso, no período final do médio norueguês, separouse o dialeto do sudeste, com a queda do $h$ - e o resto do país com o kvmantido, com exceção de algumas áreas intermediárias que têm a pronuncia [gv-] com escrita $h v$ (SKARD, 1973, p. 146-147; INDREB $\varnothing$, 1951, p. 233-234).

\subsubsection{7 $\quad \mathrm{SN}^{7}-\mathrm{A}$ era dinamarquesa}

Este período (1523-1848) é chamado por Indrebø de nynorsk (norueguês novo), que inclui as fases reformasjonstidi "era da reforma" de 1525 até 1814 e etter 1814 "após 1814". Seip pouco contribui para esse período. Skard não nomeia os próximos periódos, mas os divide em inúmeros períodos datados, que se inicia a partir de 1523. Haugen designa como modern scandinavian (1550 até atualmente) e Vikør \& Torp como moderne norsk (1536 até atualmente), que é separado em dansketid "era dinamarquesa" (1536-1814), nasjonal renessanse "renascimento nacional" (1814-1907) e moderne tid "tempos modernos" (1907 até atualmente). Nessa dissertação propomos, com base em um ponto de vista mais linguístico do que político, a data da era dinamarquesa até 1848, que é a data da primeira grande obra de Ivar Aasen (i.e. det norske Folkesprogs Grammatik), a partir de cujo momento se iniciou as discussões de uma escrita legitimamente norueguesa.

Venås (2002) certifica que todas as línguas nórdicas
continentais na época da Reforma, baseadas em critérios internos,


obtiveram um estágio significantemente diferente da língua conhecida pelas fontes escritas da Idade Média, de maneira que se justifica designar um novo período a partir da Reforma, que é aquele que permanece até os dias de hoje. Uma característica comum desse período é a substituição de um meio de expressão caracterizado em terminações flexionais por uma ordem fixa das palavras com amplo uso de preposições e palavras gramaticais; isto nos indica que havia um estágio sintético que passou para um estágio analítico (p. 36-37).

Segundo Vikør \& Torp, nesse período no ano de 1536, ocorreu a dissolução da antiga igreja católica pela substituição da religião de Estado luterana e a abolição do Conselho do Reino Norueguês pelo rei Christian III da Dinamarca e Noruega e, assim, todo o poder de regência passava para esse rei e, consequentemente, para o Conselho do Reino Dinamarquês.

Como consequência linguística, o dinamarquês foi a única língua permitida a ser utilizada na Noruega: a Bíblia veio a ser traduzida para esse idioma em 1550 e isso fez com que influenciasse e causasse a impressão na população de que essa era a língua escrita mais "correta" e que merecia "maior respeito". Mas ela ainda não estava normatizada no século XVI, de maneira que elementos tanto dela quanto do norueguês eram comuns; porém, gradualmente surgiu uma língua escrita mais formalizada, baseada no modo de fala de prestígio de Copenhagen. A necessidade de normas surgiu somente no século XVIII, uma vez que o ensino obrigatório público foi inserido, com o ensino de leitura para a plebe (1739). A maioria dos funcionários públicos após 1660 eram dinamarqueses e, naturalmente eles falavam o dinamarquês, preferencialmente aquele da variante de Copenhagen, mas com o tempo a administração pública ficava cada vez mais influenciada pelos "nascidos na Noruega", quer dizer, homens noruegueses de pais dinamarqueses; por conta disso, iniciou-se uma tendência que utilizava a língua falada dinamarquesa com pronúncia norueguesa, especialmente em assuntos formais e, por conta disso, parece ter surgido no final do século XVIII uma língua falada muito 
comum no círculo aristocrático, aceita como "bela", até mesmo para os dinamarqueses e que era o embrião para o bokmål moderno, uma das línguas oficiais da Noruega e a mais utilizada (TORP e VIKOR, 1993, p. 117-118).

Como a língua escrita nesse período era basicamente o dinamarquês, teríamos que procurar registros escritos informais que representassem de alguma maneira os dialetos noruegueses a fim de estabelecer as características e desenvolvimentos dessa sincronia. Portanto, essa sincronia determinada pelos autores é muito mais mais política do que linguística. Seria relevante realizar um estudo, com base no médio norueguês escrito, em reconstruções de como os dialetos noruegueses poderiam ser nesse período de domínio dinamarquês e comparar com os dialetos atuais para determinar exatamente os cortes sincrônicos desse período político.

\subsubsection{8 $\mathrm{SN}^{8}-\mathrm{A}$ era norueguesa}

Da mesma maneira que a anterior, esta sincrônia (1848 atualmente) também é de cunho muito mais político do que linguístico e é nesta começam as reflexões e as discussões para o ressurgimento de uma língua escrita norueguesa, como apresentadas no subcapítulo 1.4. No início desse período, obviamente, a maioria dos textos ainda são escritos em dinamarquês, mas são introduzidos textos escritos com base nos dialetos que, num momento posterior, seriam sistematizados e postos em uma única norma, o landsmaal (nynorsk).

Colocamos esse período como a sincronia atual porque é nele que surgem os primeiros textos escritos em dialetos e também ocorrem as reformas na escrita, que representam o modo de falar norueguês, seja com base no fornorsking de Knud Knudsen seja com base no målreising de Ivar Aasen, embora haja, como já considerado, textos dispersos e de cunho informal em dialetos nas sincronias anteriores.

Em nossa pesquisa consideramos um texto como norueguês 
apenas se nele houver características suficientes para isso, uma vez que houve uma transição gradual de implementação dessas características na escrita e muitos meios de comunicação se recusavam a utilizá-las como, por exemplo, alguns jornais e editoras. A respeito do landsmaal (nynorsk) é muito mais fácil determinar uma vez que ele é norueguês por excelência, pois ele não foi formado por meio de uma adaptação. Por outro lado, para que um determinado texto possa ser considerado riksmaal (bokmål) nesse período de transição, devem haver as seguintes características no texto, que basicamente são aquelas impostas na reforma de 1907:

1) Ensurdecimento $b, d, g>p, t, k$.

Obrigatório: dræbe > dræpe "matar"; aaben > aapen "abrir"; vide > vite "saber; kage > kake "bolo";

Obrigatório manter: skib "navio", vaaben "arma", arm "braço", saglig “adj. objetivo", aabenbar "evidente",, videnskap "conhecimento";

Optativo:eple/æble "maçã", bot/bod "multa", klok/klog "inteligente", bok/bog "livro".

2) Plural em -er $(<-e)$

Obrigatório: na forma indeterminada do gênero comum; heste > hester "cavalos"

Optativo: em algumas palavras como dage/dager "dias"

3) Plural sem a terminação do gênero neutro na forma indeterminada Obrigatório: huse > hus "casas"

Optativo: em algumas palavras como blad/blade "folhas"

4) Passado e particípio de verbos fracos como no dinamarquês -ede dividido em três classes: 
- Pass.-et e part. -et (kastede > kastet; fiskede > fisket "jogar; pesar") (tanto no pass. quanto no pret.)

- Pass. -te e part. -t (svarede > svarte e svaret > svart "responder")

- Pass. -(d)de e part. (d)d (boede > bodde e boet > bodd; levede > levde e levet > levd "morar, viver")

5) Supressão da forma do neutro em -t nos adjetivos terminados em ig:

et heldigt barn > et heldig barn; et ærligt menneske > et ærlig menneske "uma criança sortuda"; "um homem honrado"

6) Encurtamento de verbos e substantivos:

Optativo: drage $\approx$ dra; have $\approx$ ha; blive $\approx$ bli; tage $\approx$ ta (inf.); sagde $\approx s a$ (pass.); fader $\approx$ far, moder $\approx$ mor; broder $\approx$ bror

Obrigatório: i fjæder > i fjær; foder > fôr

A discussão sobre a passagem do dinamarquês para o riksmål e a formação do nynorsk está no subcapítulo 1.4 .

Portanto, uma determinada palavra na língua portuguesa pode ter a origem nas cinco sincronias pretéritas da língua portuguesa (étimo de herança) ou ser um empréstimo (étimo de empréstimo) ou decalque (étimo de decalque), entre outras maneiras que uma palavra pode entrar na língua.

Com relação ao bokmål, as palavras vão provavelmente ter étimo de empréstimo (do dinamarquês), a não ser que seja uma tradução direta para o bokmål de uma outra língua diferente do dinamarquês. Também é possível que a palavra tenha sido apenas utilizada em textos dinamarqueses publicados da Noruega (influência de substrato), de maneira que seja possível rastreá-la até a sincronia mais 
antiga do norueguês, o que seria uma palavra herdada. Com relação ao nynorsk, uma palavra pode ser toda rastreada até a sincronia mais antiga do norueguês, ser uma criação com base nos dialetos, o que no caso seria um neologismo, ou ter entrado na língua por meio de empréstimo ou decalque.

\section{4 Étimo (de herança, de língua anterior e de empréstimo), a origem e o terminus a quo}

\subsubsection{Definição do étimo}

Define-se o étimo como a palavra (localizável ou reconstruída) na sincronia pretérita mais recente que corresponda à forma de um item pesquisado na sincronia atual. Esse étimo pode ou não ser atribuído à mesma língua da palavra que está sendo pesquisada. Além do mais, ele pode ter a mesma forma e/ou significado da palavra pesquisada, mas com mais frequência isso não ocorre. A Etimologia é a busca e/ou a coleta do étimo, com base no sentido de étimo. A origem de uma palavra, por sua vez, não se confunde com o étimo da palavra, pois é um conceito mais vago. Diferentemente do étimo, a origem de uma palavra pode remontar a etapas anteriores à sincronia pretérita imediatamente anterior à sincronia estudada ${ }^{86}$.

Escolhemos nomear o étimo de palavras herdadas como étimo de herança, que se distingue do étimo de palavras emprestadas, designado étimo de empréstimo.

No que se refere ao primeiro tipo, chamamos de sincronia atual a linha de tempo posterior à data de nascimento do mais antigo falante vivo de uma determinada língua até o dia de hoje. Qualquer dado anterior a esse período de tempo pertencerá a uma sincronia pretérita. Por ser um construto metodológico passível de diferentes

${ }^{86}$ Esta definição foi retirada com base no manual do NEHiLP, 2004, p. 20 
recortes, nesta dissertação a sincronia imediatamente pretérita à atual é a sincronia do português antigo (ou seja, $\mathrm{S}^{4}$, cf. subcapítulo 2.3.1 desta dissertação). Dependendo da pesquisa, um outro pesquisador pode definir outras sincronias como, por exemplo, uma sincronia imediatamente pretérita à atual como o português do séc. XIX. Os recortes podem ser arbitrariamente homogêneos (i.e., por décadas, séculos, etc.), ou então recortes de diferente extensão com base em eventos históricos de impacto social que supostamente possam ter influenciado no vocabulário e na estrutura de uma língua ${ }^{87}$.

De acordo com a definição acima, o étimo de herança de uma determinada palavra se encontra ou é reconstruído em uma sincronia mais recente que corresponda com sua forma. Se ao analisarmos a palavra água ['agwa] na sincronia atual $\left(S^{5}\right)$, perguntássemos qual seria o seu étimo de herança, de acordo com essa definição, teríamos a resposta *['agwa] (português antigo, $S^{4}$ ), com as seguintes grafias (exemplos retirados de Cunha, 2007):

\section{Aagua:}

E entam frey Gill tornou-sse ao moesteiro com sua aagua [...] (Cronica da Ordem dos Frades Menores, sec. XV)

\section{Agoa:}

[...] e emcheo aquellas vazilhas de agoa [...] (Cronica da Ordem dos Frades Menores, sec. XV)

O mortal se tolhe per peemdemça, ligeyra e per contriçom e per agoa beemta. (Tratado de confissom, Chaves, 8 de agosto de 1489)

\section{Agua:}

[...] muitas barcas hiam contra a agua. (Vida e feitos de Júlio César) (sec. XV)

${ }^{87}$ Manual do NEHiLP, 2014, p. 20 


\section{Aguoa:}

Trazem o leyte seco a maneyra de hũa pasta. ho qual lançam em aguoa $[\ldots]$ (séc. XV)

Percebe-se que as grafias aagua, agoa, agua e aguoa representam a reconstrução fonética *['agwa] da sincronia 4, que provavelmente não é muito diferente da pronúncia do português atual $\left(\mathrm{S}^{5}\right)$ ['agwa].

Porém, tanto em dialetos do português moderno quanto no português antigo e no galego-português e, possivelmente, no iberorromânico do noroeste peninsular, há a variante com metátese, *['awga]. Algumas abonações (exemplos retirados de Cunha (2007) e do corpus TMILG (Tesouro Medieval Informatizado da Lingua Galega):

\section{Auga:}

Sincronia do galego-português:

[...] é como Santa Maria tolleu a auga da fonte ao cavaleiro [...] (Cantiga de Santa Maria, 48, 1264-1284)

Sincronia do português antigo:

[...] se ffoy a hũu peego d'auga muy fria [...] (Vida de sam Bernardo, séc. $X V$ )

\section{Aaugua:}

Sincronia do português antigo

O abbade dê aaugua aas maãos aos hospedes. (Regra de nosso padre o muy bem aventurado sam Beeto Abade, séc. XV)

\section{Algua:}

Síncronia do galego-português: 
[...] e o cervo do monte a augua volvia [...] (Lírica profana galegoportuguesa, cap. 05, 1240-1300)

Síncronia do português-antigo:

[...] esta fonte çara-se em guisa que nõ corre algua della. (Orto do Esposo, séc. XIV)

\section{Augoa:}

Sincronia do português-antigo

[...] quãta uez que emtrarem na ygreia que deytem da augoa beemta [...] (Tratado de confissom, Chaves, 8 de agosto de 1489)

\section{Augua:}

Sincronia do português-antigo

[...] e que moyra ante que receba a augua do bautismo [...] (Crónica da tomada de Ceuta por el rei D. João I, séc. XV)

\section{Auguoa:}

Sincronia do português-antigo

E auya dhuuma parte a caua com muyta auguoa, e da outra era toda seca [...] (Crónica del rei dom Joham I de boa memória e dos reis de Portugal o décimo: parte primeira, séc. XV)

Por meio da reconstrução, temos a hipótese de que essa variante já existia desde a sincronia 2 (iberorromânico do noroeste peninsular). Portanto, ao indagarmos sobre o étimo do item lexical auga na sincronia atual, que existe nos dias de hoje em dialetos portugueses, e que também é a forma padrão do galego, temos como resposta *['awga] na sincronia $\mathrm{S}^{4}$.

Em vista disso, de acordo com nossos pressupostos, o étimo do elemento lexical na sincronia $S^{5}$ se encontra na sincronia $S^{4}$, que tem o étimo na sincronia $S^{3}$, que, por sua vez, tem o étimo na sincronia $\mathrm{S}^{2}$, etc. 
Exemplifiquemos também com o elemento lexical chão. $O$ étimo do português atual tem a pronúncia reconstruída *['t]ẽw] com as seguintes grafias na sincronia 4: chão (O livro de Vita Christi), chãao e chaão (obras de Gomes Eanes de Zurara) e chãão (Orto do esposo) com pronúncia reconstruída *['t]ẽw] nessa sincronia. A reconstrução de

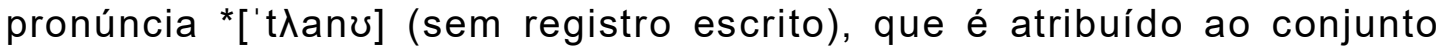
de sistemas conhecido como iberorromânico $\left(\mathrm{S}^{1}\right)$, tem como étimo planum, na sincronia 0 (conjunto de sistemas do latim). É importante frisar que não devemos confundir o étimo da sincronia do conjunto de sistemas do latim $\mathrm{S}^{0} \mathrm{com}$ a origem do elemento lexical, como apresentaremos no subcapítulo 2.4.4.

Uma vez que apenas as línguas ibéricas do Noroeste (português, galego e leonês) têm uma forma substantiva, cria-se a hipótese de que quando os romanos chegaram na Península Ibérica no séc. III a.C. esse elemento lexical latino era ainda apenas um adjetivo, que só foi se substantivar no mínimo a partir do séc. I a.C., quando chegaram à Gallaecia. Fora da península ela não se substantivou até os dias de hoje.

No que tange à palavra auga, exemplificada anteriormente, o étimo do elemento lexical na sincronia 4 (português antigo) seria $\mathrm{S}^{3}$ (galego-português) *['awga], com as abonações auga e algua, que por sua vez tem étimo na sincronia 2 *['agwa], sem abonações. Em vista disso, foi na sincronia 2 que ocorreu a metátese.

Representação do elemento lexical chão:

$\mathrm{S}^{4}$ chãao, chaão ${ }^{88}$, chãão ${ }^{89}$ e chão ${ }^{90}$ *['tfão]: no conjunto de sistemas conhecidos como português antigo

88 Zurara, Gomes Eanes de. Crónica do conde D. Duarte de Meneses. Edição diplomática de Larry King. Lisboa: Faculdade de Ciências Sociais e Humanas da Universidade Nova de Lisboa, 1978. Manuscrito do século XV do Arquivo Nacional da Torre do Tombo, Lisboa, Livraria, 520. [Citam-se, nas transcrições, os números da página e da linha] (CUNHA, 2007)

89 Orto do esposo: texto inédito do fim do século XIV ou começo do XV. Edição crítica com introdução, anotações e glossário de Bertil Maler. Rio de Janeiro: Instituto Nacional do Livro, 1956. 2 v. ORTO do esposo: correções dos vols. I e II, estudo das fontes e do estado da língua, glossário, lista dos livros citados e índice geral. Stockholmo: Almqvist e Wiksell, 1964. v. 3. Manuscrito CCLXXIII/198, da Biblioteca Nacional de Lisboa, designado pelo editor ms. A, 
$\mathrm{S}^{3}$ chão e chãa ${ }^{91}$ *['t $\left.\mathrm{a} \overline{\mathrm{a} o}\right]:$ no conjunto de sistemas conhecido como galego-português

$S^{2}$ *['tJano] no conjunto de sistemas conhecido como iberorromânico do Noroeste

$S^{1}{ }^{*}[$ 't $\lambda$ anv] no conjunto de sistemas conhecido como iberorromânico

$\mathrm{S}^{0}$ plānum no conjunto de sistemas latino

Em vista disso, o elemento lexical *['tfāo] da sincronia 3 tem étimo na sincronia 2 (sistema iberorromânico do noroeste peninsular) *['tıano]. Há várias cognatas para a palavra chão nas línguas românicas:

- Iberorromânico ocidental: gal. chan ${ }^{92}$, ast. Ilanu 93 , cast. Ilano ${ }^{94}$, arag. plan

- Iberorromânico oriental: catalão pla95; valenciano pla;

- Galorromânico meridional: gascão, não há (atual: gasc. sòu); provençal, não há (atual: prov. sòl ${ }^{96}$ )

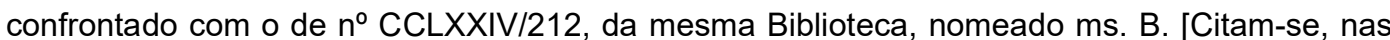
transcrições, os números da página e da linha.] (CUNHA, 2007)

90 Vita Christi em lingoagem português. Edição fac-similar e crítica. Rio de Janeiro: Casa de Rui Barbosa, 1957-1968. 2 v. Incunábulo de 1495, cotejado com os apógrafos por Augusto Magne. [Citam-se, nas transcrições, feitas diretamente do fac-símile do Incunábulo de 1495, os números do fólio e da linha, adotando-se o critério de fazer preceder o número da linha da letra $b$, para a segunda coluna do fólio reto, $c$, para a primeira coluna do fólio verso, e $d$, para a segunda coluna do fólio verso.] (CUNHA, 2007)

91 Afonso X. Cantigas de santa Maria. Editado por Walter Mettmann. Coimbra: Universidade de Coimbra, 1972. v. 4. Texto do século XIII. [Citam-se, nas transcrições, os números da poesia e do verso, de acordo com o critério de numeração adotado pelo editor] (CUNHA, 2007)

$92 \mathrm{O}$ vaso caeu ao chan (informação de nativos). Chan aqui tem o sentido idêntico ao pt. chão

${ }^{93}$ Sentido de chão: tarren (El xarron cayeu nel tarren). Como adjetivo: Ilanu (el tarren elye llanu), mas também pode ser um substantivo como, por exemplo, el llanu ta plagao de praos com arboles frutales "o campo está ocupado por campos de árvores frutíveras".

94 Sentido de "chão": suelo (el jarrón se cayó al suelo). Terra é usado para "Terra" e em alguns casos como "piso", dependendo da sentença. Llano tem o sentido adjetival de pla no catalão, mas também pode ser um substantivo que significa "campo llano".

${ }^{95}$ Sentido de chão: terra (el gerro ha caigut a terra). Pla tem o sentido de uma reta com relação a uma perspectiva geométrica, ou do adjetivo plano: aquest pla és perfecte "esta reta é perfeita", el sòl és pla (o solo é plano). Há também a forma sòl dada no exemplo anterior, que significa "solo".

${ }^{96}$ Sentido de "chão": sòl (lo vas es tombat al sòl, com consequência no presente). 
- Galorromânico setentrional: francês antigo plain (de acordo com o TLF, em 1155 tinha o sentido de "qui presente une surfasse plane, unie"; no atual sol, a partir de 1538, de acordo com o LPR);

- Retorromânico oriental: friulano plàn ${ }^{97}$;

- Retorromânico ocidental: rumantsch grischun/alto engadino (puter) plaun; subselvano plàn; sobremirano plang; baixo engadino (válader) plan.

- Italorromânico: piemontês pian ${ }^{98}$; emiliano (bolognese) $)^{99}$ pian; ital. Piano

A forma na sincronia $S^{1}$ tinha como variante nos territórios mais ao sul a cognata $\left.{ }^{*}\left[{ }^{\prime} \lambda a n\right\}\right]$, que perdeu $O{ }^{*}[t]$ inicial, que geraria futuramente Ilano em espanhol. De acordo com Teyssier (2001), a inicial latina $\mathrm{p} /$ - sofreu, de primeiro encontro, a palatalização do $I$. Esse fenômeno ocorreu na zona que compreendia o galego-português, o leonês e o castelhano, e ainda uma pequena parte do território entre a Catalunha e Aragão. Em castelhano, por outro lado, posteriormente, a consoante inicial cairia e isso faria com que resultasse apenas o I palatal, transcrito $/ /[\lambda]$. O mesmo processo ocorreu na parte oriental do leonês, mas na parte ocidental, junto com o galego-português, a evolução foi mais profunda: a consoante inicial seguida de I palatal deu origem à africada [t $\mathrm{t}]$, transcrita em galego-português como ch-. O autor também afirma que a zona moçárabe não sofreu tal processo metaplasmático e, por conta disso, o galego-português e o leonês ocidental isolam-se dos vizinhos do Leste e do Sul. Apesar de nos exemplos haver palavras do asturiano em II- $[\lambda]$, nos dialetos mais ao

97 Sentido de "chão": tiáre ou tiere (El vâs al còle pár tiáre); plàn teria um sentido parecido com piano em italiano

98 Mas no sentido de "chão": tèra (ël vas a l'é drocà na tèra); pian tem sentido de "superfície, camada, nível": I soma al pian dij babi "estamos no mesmo nível que os sapos", quando algo vai muito mal.

${ }^{99}$ Sentido de chão: tera/teraa (al vescovo l'è casche a teralal ves l'è casche' in teraa). 
oeste, perto da Galícia, há regiões em que tais palavras começam com ch- [t] $(p .16)$

$\mathrm{Na}$ definição acima, postula-se que "o étimo pode ter a mesma forma da palavra pesquisada, mas com mais frequência terá aspecto e/ou significado distintos". De fato, o étimo de grau $S^{1}$, antes da

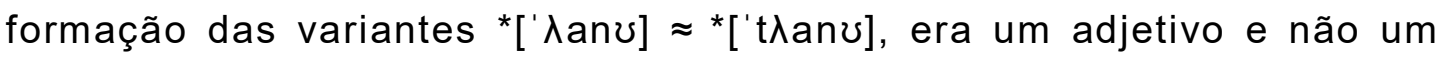
substantivo. Por conta disso, na discussão etimológica podemos retratar essa substantivação do adjetivo, que afetou o português, o galego e o asturiano; todas as outras línguas e dialetos utilizam essa palavra na forma adjetival.

Em síntese, as sincronias mostram todo o trajeto gráfico, fonético, fonológico e morfológico que uma determinada palavra sofreu até a atualidade. A forma do elemento lexical na sincronia latina $\left(\mathrm{S}^{0}\right)$ é, de fato, a que mais chama a atenção do leitor que se prende apenas à sincronia do português atual e do latim. 
Propomos a seguinte representação para a representação das sincronias:

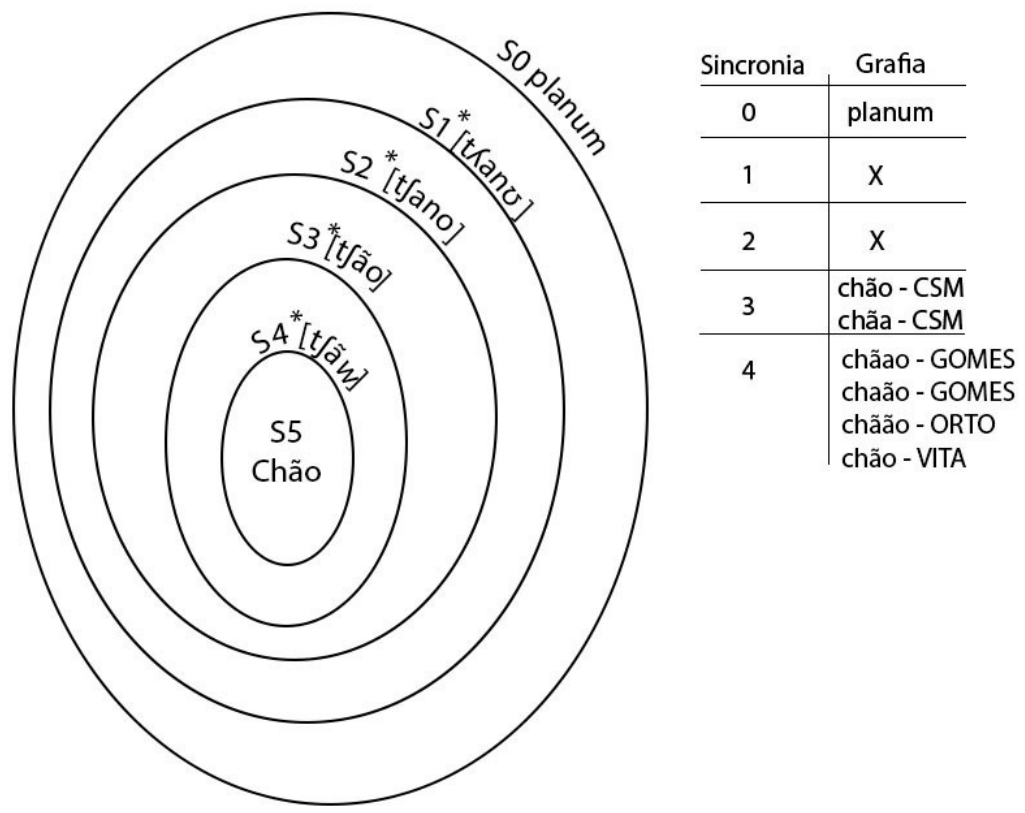

\subsection{2 Étimo de empréstimo ou de decalque}

O étimo de empréstimo ou de decalque, como o próprio nome já indica, não é criado nas sincronias anteriores. Não sendo herdada, a palavra provém de um outro sistema em determinada sincronia. Por conta disso, a palavra futebol tem étimo de empréstimo no inglês football.

Também vale considerar que uma palavra emprestada pode conter diferentes acepções, que nem sempre tem o étimo na mesma língua. Isto significa que a acepção $X$ da palavra $A$ pode ter étimo no alemão ao passo que a acepção $Y$ da mesma palavra $A$ pode ter étimo no inglês. Um exemplo ocorre, como está registrado na parte de análise, com a palavra deflação, que tem duas acepções: financeira e geológica; a acepção da primeira, que tem sua origem no inglês, veio para o português ou do alemão ou do inglês, já a acepção da segunda, 
que tem sua origem no alemão, pode ter chegado ao português por meio do espanhol, francês, inglês ou alemão. Portanto, consideramos que uma palavra pode ter várias acepções e cada uma delas tem o seu étimo.

\subsubsection{Terminus a quo}

Durante o estudo etimológico de uma determinada palavra é importante encontrar a primeira ocorrência documentada de cada uma de suas acepções. Embora seja impossível conhecer a datação exata da formação ou surgimento de uma determinada palavra, em suas várias acepções, é possível investigar as datações mais antigas de cada uma delas. A esse registro mais antigo chamamos de terminus a quo. Ele é, portanto, a primeira abonação de um determinado elemento lexical dentro de todas as sincronias que compõem uma língua.

Tanto palavras emprestadas quanto palavras herdadas têm terminus a quo e este também pode se encontrar em sincronias anteriores. Tomemos, por exemplo, o terminus a quo de casa, que se encontra na sincronia denominada galego-português $\left(\mathrm{S}^{4}\right)$ :

En casa do ric' estava un crerigo d'avengeo que ao capelan disse [...] (CSM, 75, séc. XIII)

Entendemos que seja possível inserir o terminus a quo nessa sincronia anterior porque ela faz parte da formação da língua em estudo, o português.

Há, no entanto, algumas palavras cuja formação ou surgimento é mais facilmente reconhecido, os termos técnicos, os quais, em grande maioria, são registrados, mas só depois de um certo tempo passam a ser utilizados pelas pessoas que fazem parte do ambiente ao qual a palavra pertence (não necessariamente se popularizando e se tornando conhecidos por leigos). Por outro lado, as palavras populares são 
normalmente formadas antes de serem registradas e, não raros os casos, muitas palavras nunca são registradas por se manterem apenas na esfera de uso coloquial.

Segundo Viaro (2011), a datação do limite mais antigo tem sua importância porque só por esse meio teremos certeza de que a palavra já estava sendo usada numa determinada sincronia; portanto, se ela foi registrada no momento de sua criação ou empréstimo, ou apenas séculos depois, é uma questão que se coloca apenas hipoteticamente (p. 107). O terminus a quo também não se delimita ao lema, mas prolonga-se para as acepções de uma palavra, para as variantes ortográficas e também para as suas flexões. Tanto a penúltima quanto a última são importantíssimas para a reconstrução das sincronias pretéritas, além de serem úteis para o estudo de irregularidades (das flexões) e para a Paleografia (das variantes ortográficas). O terminus a quo só é relevante quando há uma transcrição do seu contexto de uso, quando há um vínculo da obra em que esse contexto se encontra e, por fim, quando há uma referência da localização da mesma obra.

\subsubsection{Origem}

A origem, por sua vez, pode remontar a etapas anteriores às sincronias pretéritas. Portanto, uma palavra na língua portuguesa pode ter origem na língua latina e ao mesmo tempo ter um étimo de empréstimo em uma língua vernácula. Isso acontece muito com palavras cultas difundidas pelo francês como, por exemplo, lat. alimentum $>\mathrm{fr}$. aliment (1120) - pt. alimento (1584). Em vista disso, ao determinamos a origem de um elemento lexical, propomos que ela deva remontar à língua em que criou tal elemento, que pode ser tanto a língua em estudo (i.e. gourmetização, que tem origem no próprio português) quanto outros idiomas.

Voltando ao elemento lexical água. Sabemos que o étimo da sincronia $S^{1}$ é aquam na sincronia $S^{0}$. Se levarmos em considerações 
propostas de estudos do IE e de outros ramos como, por exemplo, do germânico, veremos que há cognatas no gótico aha "rio, águas" e AAA aha "riacho, rio, água", como apresentam Lehmann (1986) e Seebold (2008), respectivamente. Lehmann (1986) e Kroonen (2013) propõem a forma no germânico * $a h^{w} \bar{o}$, que gerou também IA á "rio", IA ēa "rio", "água", AS aha. De acordo com Kroonen, é uma isoglossa germânicoitálica, que tem sido considerada com originária de uma língua não IE (Beekes, 1998). Ringe (2006, p. 96), ademais, afirma * $a h^{w} \bar{o}$ "rio" provém de um pós-IE *ák ${ }^{\mathrm{w}} e h_{2}$ "água corrente" e sugere a comparação com o latim aqua.

Lehmann (1986) também afirma que a única cognata explicita é aqua do latim, mas que também há especulações de que possa ter cognatas em nomes de rios de outras línguas como, por exemplo, lituano Akelé, ilírio Aquilo, venético Aquileia, rio Окá na Rússia.

De Vaan (2008) afirma que no proto-itálico o elemento lexical tem a forma * $a k^{w} \bar{a}$ e não fornece nenhuma cognata no úmbrico e no osco. Procuramos por elas e não as encontramos além de utur no úmbrico, que remete ao verbo *ued- "brotar", "jorrar" do IE, que teria, entre muitas formas derivadas, a forma *ud-or-, que deu origem à forma

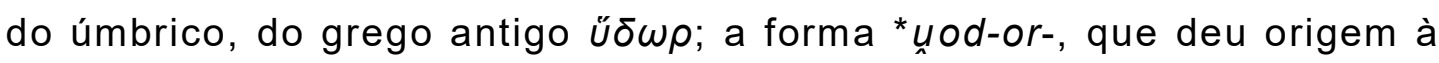
forma germânica *uadara- (> IE waeter $\cong A A A$ wazzar $\cong A S$ watar $\cong A N$ vatn) e do russo antigo voda "água".

Kroonen (2013) também afirma que é mais possível que o germânico * $a h^{w} \bar{o}$ seja uma variante do IE, compare o hitita hapa- "rio", sanscrito áp-, avéstico ap- < ${ }^{*} h_{2} e p$-, lat. amnis "rio, corrente" $<{ }^{*} h_{2} e p n i$ e irlandês antigo ab, aub "rio" < * $h_{2} e p H o n-\left(c^{*}{ }^{*}-p H->{ }^{*}-b\right.$ - como em sânscrito píbati ("beber" < IE *pi-ph - -é-. De acordo com o autor, * desenvolveu para * $k^{w}$ - no germânico e no latim e compara com *agra-, *aujō- e *ēgja-. Rix (2001, p. 311), por outro lado, afirma que a forma original do IE é * $h_{2} e p$ - "água" e esta derivou uma forma * $h_{2} a p$ - (a partir desta surgiram áp- no védito, talvez hāppa no hitita "para a água", ap- 
no avéstico "água", āp- no tocário $A$ e no tocário $B$, etc.) e também uma forma ?*h2p-h3on- (a partir dela surgiram as formas hapā no hitita, amnis no latim "rio, corrente"; $a b$, oub, aub "rio" no irlandês antigo); mas não há uma forma no germânico. Ringe (2006, p. 98) afirma que consoante * $b$ é rara no germânico, e também no IE, tanto que as formas * $h_{2}$ ébō "rio" e "píbeti "ela está bebendo" não sobreviveram no germânico. Em vista disso, a hipótese de Kroonen é rechaçada.

Rix (2001) complementa que as formas do hitita ekuzileukzi, akuanzi "beber" (< ${ }^{*} h 1 \mathrm{eg}^{\text {uh }}{ }_{-}$) se relacionam com lat. èbrius "bebado e muito pouco com lat. aqua e gótico ahva, uma vez que a transformação de um $h_{1}$ e- para a- no latim e no germânico não seria regular. De acordo com Beekes (2011, p. 147), $h_{1}$ e desenvolvia em e no latim e $i$ no germânico. Um outro elemento trata-se de que no germânico e latim temos ${ }^{*} k^{w}$ e não ${ }^{*} g^{w h}$. Em vista disso, é possível excluir aqua e as cognatas germânicas.

Kroonen (2013) também cita uma forma germânica derivada *a(g)wjō, que teria formado IA ey "ilha", IA ieg, èg, ig "ilha", MBA ōge, ōch, ou(we), MAA ouwe "prado", "península" "rio". Ringe (2006, p. 109) registra a forma derivada germânica como *ahwjắ "ilha" > *agwjắ > *aujō.

Concluímos que, de fato, a forma pós-IE ák ${ }^{w} e h_{2}$ "água corrente", que teria originado o germânico * $a h^{w} \bar{o}$ "rio" e o proto-itálico " $a k^{w} \bar{a}$ "água", são cognatas. Em vista disso, a origem formal da palavra água ocorreu em uma etapa posterior do IE, que Beekes define como um período de isoglossas, talvez por conta de um empréstimo de alguma língua fora do IE; porém, tanto * $a k^{w} \bar{a}$ quanto ${ }^{*} a h^{w} \bar{o}$ também poderiam ser duas formas que seriam dois vestígios das descendentes de uma forma anterior, que teria gerado muitas outras que não deixaram vestígios nas línguas de hoje.. A origem do significado ocorreu, de fato, no proto-itálico, que deu uma nova acepção, de "água". A origem formal é, portanto, a língua que criou a forma da palavra. 
Em vista disso, distingue-se a origem formal (significante) da origem semântica (significado), pois elas podem remeter, como visto acima, a caminhos completamente diferentes.

Continuando com o item lexical deflação, a sua origem é alemã, uma vez que foi nessa língua que ocorreu a derivação a partir do verbo latino deflare "assoprar removendo" e inseriu a acepção geológica "de erosão". Por isso, tem tanto a origem formal quanto a origem semântica no alemão. Não encontramos nem em dicionários nem em corpora uma atestação da palavra deflatio no latim.

A respeito da sua acepção financeira, a origem semântica é inglesa, embora a origem formal continue sendo alemã. $O$ inglês tomou emprestada do alemão a palavra com a acepção geológica no ano de 1891 e apenas em 1909 inseriu a acepção financeira, que foi para o alemão só em 1920:

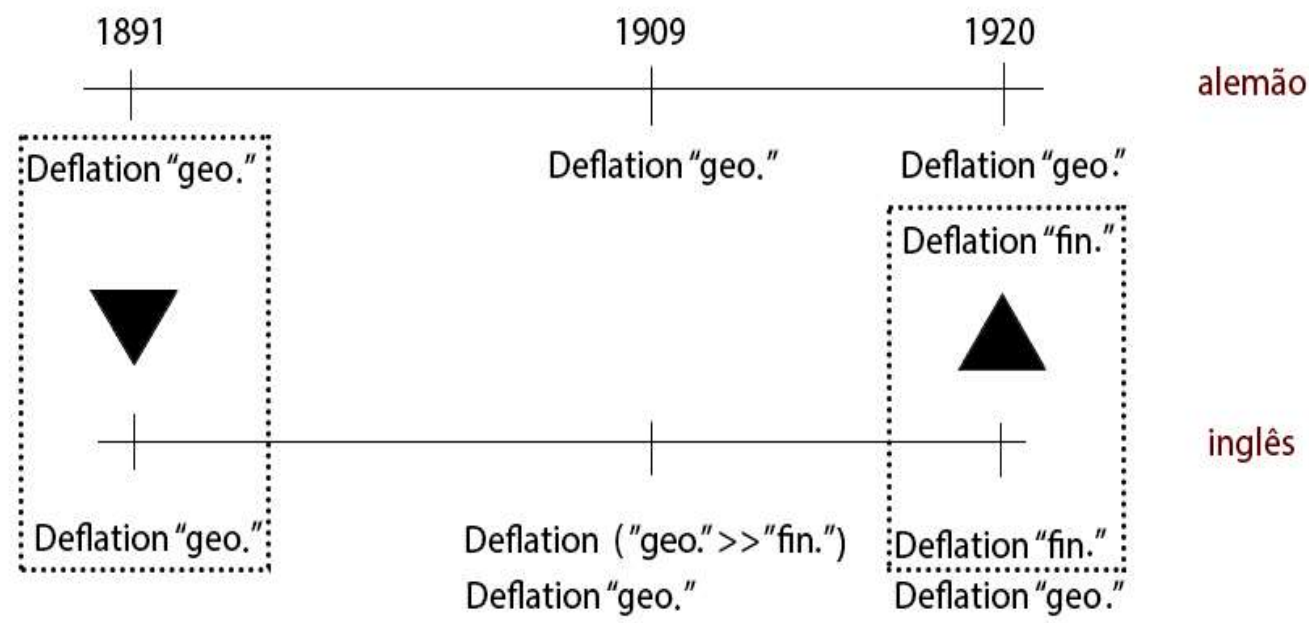

Para exemplificar nas línguas escandinavas, tomemos como exemplo a palavra nor. koke "ferver, cozinhar, fazer comida, cozer", cujas cognatas nas línguas escandinavas são din. koge (ant.din. kōgæ) e sue. koka (ant.sue. kōka). 
Segundo Bjorvand e Lindeman (2000), a palavra é um empréstimo do médio baixo-alemão kōken que tem origem no lat. coquere (p. 471). O verbo é restrito apenas nas línguas do germânico ocidental, sendo as formas escandinavas um empréstimo do médio baixo-alemão, que é um empréstimo antigo do latim (DUDEN, p. 462); compare AAA kohhōn, AHol. coken, AFranc. kokia (KLUGE, 2002). O germânico tinha a palavra "seupan "borbulhar, ferver", formando as cognatas AN sjóđa, IA sēođan (ing. seethe), AAA siodan, Got. sieden, etc. No islandês moderno a palavra é sjóða, indicando que continuou com a forma e significado do AN, ao passo que o norueguês utiliza a forma koke, mas há também a cognata syde "borbulhar intensamente" ou sodd "sopa de carne". Portanto, no período de contato com o médio baixo-alemão, as línguas escandinavas continentais emprestaram essa palavra, junto com outras referentes à alimentação como, por exemplo, frokost "café da manhã" (MBA vrôkost, AN dagverđr "de valor para o dia", isl. morgunmatur "comida da manhã", morgunverður), kjøkken "cozinha" (MBA kokene, do mlat. cucina; AN e isl. éldhus "sala onde se acende o fogo") e tallerken "prato" (MBA tallorken, diminutivo de tallor, de origem românica, fra. tailloir, ita. tagliere; AN diskr, skutildiskr, skutill, isl. diskur).

Concluímos que tenha ocorrido um empréstimo do latim para o antigo frâncico (kokia) e a partir dele, para outras línguas germânicas ocidentais, surgindo, assim, koken no MBA, que emprestou para as línguas escandinavas. Não acreditamos que essa palavra tenha vindo do estágio anterior, pois não a encontramos em nenhum corpus do antigo saxão. Portanto, a palavra tem origem latina e étimo baixoalemão médio.

No português, cozinhar (terminus a quo 1364, datação de Houaiss), tem étimo de empréstimo do francês (que surgiu no séc. XIII, de acordo com LPR), sendo um decalque (cuisin- $\geq$ cozinh- e -er $\geq$-ar), pois o francês é a primeira língua a atestar essa palavra e é um decalque porque tanto cuisine quanto cozinha são palavras herdadas do latim vulgar *cocina. Isto nos mostra que ocorreu um decalque do 
radical e do sufixo. Também não poderíamos desconsiderar que cuisiner e cozinhar sejam derivações separadas; não haveria, desse modo, uma influência do francês. Outra possibilidade é a existência de uma forma no latim vulgar *cocinare, que se espalhou para as outras línguas. A penúltima hipótese é menos provável porque senão talvez encontrariamos abonações mais antigas que séc. XIII (como ocorre no francês) e a última também é porque o francês no período era uma língua de cultura, inclusive na culinária. Portanto, a palavra provavelmente tem étimo francês e origem formal e semântica também no francês, já que é uma formação de cuisin- mais o sufixo -er, caso não haja uma forma *cocinare no latim vulgar; o português, portanto, apenas teria traduzido. Com relação à palavra cozinhar com acepção de "enrolar alguém", esta teria a origem semântica diferente, ao passo que a origem formal seria a mesma.

Propomos nessa dissertação, como mostrado anteriormente que uma palavra tem a origem do seu significante e do seu significado; portanto as mudanças de significante, desde que haja uma regularidade das leis fonéticas para a origem de um significado. Analisemos a palavra pt. esp. it. casa "casa", fr. chez "em casa de", "no país de", "no local de trabalho de", "em", "entre" e ing. chez "at the home of".

Com relação ao étimo de herança da palavra casa ['kaza], o étimo de sincronia 4 (galego português) apresenta um $z$ apical (i.e. $z$ *['kaza]) com grafias cas, casa e cassa que, de acordo com as leis fonéticas ocorridas nas sincronias anteriores, não apresenta diferença fonética nas sincronias 3,2 e 1 . O étimo de língua latino $\left(\mathrm{S}^{0}\right)$ apresenta uma consoante surda e apical (i.e. casam *['kașam]), mas possivelmente deveria haver uma variante *['kazam]. Conforme a linha La Spezia-Rimini ${ }^{100}$ do latim vulgar, que marca um número de isoglossas que diferenciam as línguas românicas abaixo e acima dela. Abaixo dessa linha estão os dialetos que mantêm $0{ }^{*}[s]$ latino e suas

100 Essas isoglossas dividem o norte da Itália a partir da cidade de La Spezia (Ligúria) e segue até Rimini (Emilia-Romanha), segundo os estudos de Linguística Românica (BASSETTO, Vol. I, 2013, p. 251) 
consoantes plosivas na posição intervocálica $\left({ }^{*}[\mathrm{p}],{ }^{*}[\mathrm{t}]\right.$ e * $\left.[\mathrm{k}]\right)$; acima, os dialetos que sonorizam essas consoantes.

O idioma de origem de uma determinada palavra é aquele em que a palavra foi criada. A palavra casa remete à palavra casa no latim, que, segundo o Oxford Latin Dictionary (1968), significava "uma morada pequena e humilde", "cabana", "casebre". O latim, por outro lado, tinha a palavra domus para "a construção em qual uma pessoa vive, casa, morada". Por mais difícil que seja qualificar semanticamente os objetos e compará-los entre as sincronias, como, por exemplo, a palavra casa que no séc. III tinha uma acepção, comparada com a acepção de casa no Brasil do século XXI, podemos aceitar que hoje em dia casa faz referência a uma moradia vista de maneira geral (que difere de mansão, cabana, barraco, etc.) e que no período latino, casa era onde moravam as pessoas mais humildes.

A palavra domus, por sua vez, tinha um sentido mais geral, que hoje é empregado pela palavra casa. Para saber exatamente quando ocorreu a mudança de sentido (de moradia simples para moradia geral) seria necessário um estudo aprofundado em textos latinos mas pode-se ter a certeza de que tal mudança semântica ocorreu anteriormente ao isolamento do romeno, que se iniciou no século III e terminou pelo menos no século XVIII. Como objeção a uma possível hipótese de que a palavra romena casă poderia ser um empréstimo após o fim do isolamento romano, há uma atestação da palavra no manuscrito de Coresi (1577) de Psaltirea Scheiana (1482), Mss. 449 B.A.R. no salmo V, 9: [...] eu [...] întrău în casa ta $[\ldots]^{101}$ (p. 11) ${ }^{102}$.

Também para estes estudos é muito importante pesquisar em fontes mais antigas. Duarte Nunes de Lião no capítulo VII da obra Origem da Lingoa portuguesa (1606) que trata, entre outras coisas, da Corrupção per impropriedade de significaçaõ alhea, afirma: "e como

${ }^{101}$ Eu entro para tua casa (trad. nossa)

102 Disponível em: http://digital-library.ulbsibiu.ro/dspace/handle/123456789/204 
nefta palaura cala, que lignificando proprieamente na lingoa latina as choupanas, ou choças, que laõ as calas rufticas, chamamos calas, alsi as que laõ grandes \& reas como as do campo" (p. 40). Portanto, a origem do significante da palavra casa é bem mais antiga que a origem do significado com referência à língua portuguesa.

Tomaremos como base algumas obras etimológicas para investigar a origem do significado. De Vaan (2008) afirma que casa no latim significava "cabana, casebre" e cita Walde-Hoffmann (1930-1954) que declara que casa reflete um desenvolvimento dialetal de *kat-ja (a partir de "kat- "trançar"). De Vaan (2008) certifica que isso é concebível, mas uma conexão com palavras europeias para "cabana, local de moradia" ("ket-, "kot-) também seria aceita: av. kata- "câmara", AEE котьсь "cell, nest", ATch. kot "booth, stall" (market), Al heađor "incarceration, jail". Mesmo assim, de acordo com de Vaan (2008), por conta do -a- e do -s- após essa vogal curta pode ser possível que casa seja um empréstimo.

Pokorny (1959) afirma que a palavra surgiu a partir de *kat"ligar ou tecer; corrente, rede" e que a partir dela surgiram derivativos como catēna "cadeia, corrente" (< *cates-nā), cassis "capacete de metal emplumado" (por causa da forma catēna, seria de preferência uma formação a partir *kat-s-is do que *ka-ti-s) e talvez casa "cabana primitiva" (originalmente a partir de um leve entrelaçado, provavelmente dialetal a partir de *catiā, como osco Bansae de Bantiae). De acordo com o autor, essa palavra também estaria relacionada com a língua galesa cader "fortaleza", antigo irlandês cathir "cidade", talvez AN hadda "anel, alça de chaleira" ("hapipōn: catēna, mas completamente incerto), AS heađor "prisão, encarceramento". O autor ainda fornece vários exemplos em línguas eslavas e algumas já foram citadas acima (Vol II, p. 534)

Concluímos que a origem formal dessa palavra pode ser:

*kat- $\rightarrow$ *kat-ja (Walde-Hoffmann)

${ }^{*}$ ket ou *kot- $\rightarrow{ }^{*}$ kat-ja (de Vaan) 
${ }^{*}$ catịa (Pokorny)

A palavra francesa chez, por outro lado, se apresenta a partir de uma outra hipótese.

O LPR afirma que a palavra chez tem o étimo em chies na data de 1190 e que no francês antigo chiese (ou chese) significava "maison, habitation". O TLF cita que a primeira atestação da palavra chez (em forma chiés) no sentido preposicional (i.e. "na habitação de") está na obra Couronnement de Louis, que é uma canção de gesta do ciclo de Guilherme d'Orange, portanto, é datada entre 1130 e 1160. Na obra há o trecho: chiés Simon fustes le lepros ostelez "na casa de Simon os leprosos foram alojados" (LANGLOIS, 1984, p. 24 e p. 747). O TLF afirma que chez vem do latim casa e que a irregularidade do final da palavra é explicada pela posição pretônica que essa palavra tinha diante de um substantivo ao ser utilizada de maneira preposicional. $O$ FEW também afirma que a palavra é do séc. XII. O francês antigo também tinha a palavra chiese (ou chese) com o sentido de "mansion, habitation".

Portanto, a palavra latina casa sofreu, por conta das leis fonéticas, a transformação para chiese/chese e, por ser uma palavra que tem um locativo de essência, o que permite facilmente que ela se transforme em um advérbio ou preposição, se transformou na preposição ches/chies, mas como já demonstrado acima, o substantivo chese parece ter se mantido até o séc. XIV. Afirmaremos, portanto, de acordo com nossa hipótese, uma vez que não encontramos em documentos na sincronia latim comum o mesmo processo de transformação da palavra casa de substantivo para preposição, que a palavra ches/chies (que futuramente seria chez) continua a ter origem de significado latina ou anterior ao latim, mesmo que a origem de significante seja diferente daquele da sincronia anterior, ou seja, da sincronia latina comum. 
Convém certificar que essa transformação de casa para a classe de preposição ocorre em muitas outras línguas: cabo-verdiano (na ká Mimita "na casa da Mimita"), catalão (a ca l'Albert "na casa do Alberto"), galego (vai cas Rosa "vai para a Rosa"), italiano (ca' d'Andrea "na Andrea", mas raro, aragonês (boy ta ca Pilar) "vou para a Pilar", friulano (čhadaldiaul "casa do diabo, com o diabo, inferno"). Com relação às línguas nórdicas, temos um processo parecido com a preposição nbok. dan. e sue. hos "junto de", "em casa". De acordo com Bjorvand e Lindeman (2000), elas são uma forma átona de hus "casa" e, portanto, o significado original seria "na casa de alguém". Vemos aqui também um enfraquecimento da palavra em posição anterior ao substantivo que segue.

\subsubsection{Um estudo de caso para apresentar o étimo e a origem em uma palavra norueguesa}

Estudaremos a palavra rettighet (grafia atual). De acordo com o dicionário Bokmålsordbok da Universidade de Bergen (NbUiB):

Rettighet (etter I.ty.) frihet, privilegium - politiske, økonomiske rettigheter

"Rettighet (do baixo alemão) liberdade, privilégio - direitos políticos, econômicos (trad. nossa)"

Em uma carta escrita em médio norueguês no dia 6 de maio de 1353 (Diplomatarium Norvegicum, Vol. 2. N. 319103), período em que a Noruega já sofria forte influência do médio baixo-alemão (SKARD, 1973, p. 158), por conta da Liga Hanseática, encontra-se a forma rettighæit. Trata-se de uma carta escrita em nome do rei Magnus VI da Suécia e 
Noruega ${ }^{104}$. Há também a forma rettigheit em uma carta escrita em Bjerke (Noruega) em 1 de fevereiro de 1436 (Diplomatarium Norvegicum, Vol. 5. N. 655 $\left.{ }^{105}\right)$.

Com relação ao médio baixo-alemão, que era a principal língua do comércio nesse período (da Liga Hanseática), encontra-se a forma cognata rechticheit em uma carta escrita na data de 1342 (carta retirada do livro publicado pela Dem Vereine für lübeckische Geschichte und Alterthumskunde, 1873, p.30). Também há a cognata do médio altoalemão rechticheit nas canções de Rumelant v. Sachsen (século XIII) e de Heinrich Frauenlob (fim do século XIII), encontrada no Mittelhochdeutsche Begriffsdatenbank (MDHBDB).

Uma das conclusões possíveis é de que a palavra norueguesa rettighæit tem étimo médio baixo-alemão ou médio alto-alemão. O grau de certeza é maior para o primeiro caso, tendo em vista que os reis, padres, nobres e mercadores trocavam cartas em médio-norueguês, médio-dinamarquês e médio baixo-alemão, demonstrando que havia uma compreensão desses três idiomas nessas esferas, pois são idiomas muito próximos; além disso, há várias atestações dessa palavra nos diplomas da Liga Hanseática.

Vemos que o médio alto-alemão, por sua vez, também influenciou as línguas escandinavas, mas isso ocorreu em período posterior. Como a primeira atestação nessas cartas está em antigo norueguês, descarta-se a possibilidade de ter sido criada no antigo dinamarquês ou antigo sueco.

Com relação à formação da palavra, a argumentação de que a própria língua norueguesa poderia ter derivado essa palavra a partir de rettig- integrado ao sufixo importado -heit não se sustenta, porque há

\footnotetext{
104 A carta trata-se de uma troca dos "regalos da manhã" (Morgengave, Morgengabe: dote que o marido destina à esposa). Em vez da rainha Blanca possuir a região governada pela tesouraria de Tunsberg como um feudo pessoal, ela teria Bahus, Malstrand e Elvesyssel, com exceção de Ranrike, Vettahered e Borgesyssel.

105 Disponível em:

http://www.dokpro.uio.no/perl/middelalder/diplom_vise_tekst.prl?b=5257\&s=n\&str=rettigheit
} 
apenas a forma rett nas línguas escandinavas e não trettig e o sufixo heit tem origem no oeste germânico (Schmidt, 2007, p. 58):

germ. * ${ }^{*}$ hehta $>\mathrm{AS}$ reht $(\cong \mathrm{AAA}$ reht $\cong \mathrm{AN}$ réttr $>\mathrm{LEsc}$ rett $)>$ MBA reht

IE $h^{3}$ reǵ- $\rightarrow$ adj. ${ }^{*} h^{3}$ reg-to- $>$ (av. rāšta- $\cong$ lat. rectus $\cong$ gr.

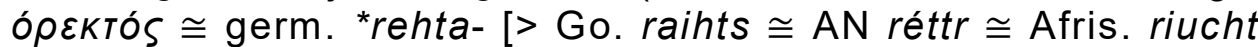
$\cong \mathrm{AS}$ reht $\cong \mathrm{AAA}$ reht]) (com base em KROONEN, 2013, p. 408)

O sufixo -ig também tem origem germânica. Ringe (2006, p. 295) afirma que um número de sufixos inovativos, que terminam em *ga-, ficaram muitos produtivos no germânico e que o mais importante para a história do inglês foi *-a-ga- (exemplo, "stainagaz "pedregoso", "mōdagaz "bravo" e *hailagaz "sagrado"). Também há exemplos reconstruíveis em *-u-ga- (exemplo, *handugaz "capaz, esperto") e em *-i-ga ("mahtīgaz "poderoso").

Procuramos por palavras com alguns desses sufixos nas runas e encontramos alssualtuhr, interpretada pelos runólogos como allsvaldugr "todo poderoso" (G 306M, programa rundata e SN/EDAL, 2013 , p. 5). Há as cognatas do segundo elemento -valdugr em AS, que é giweldig). Seip (1955) afirma que o sufixo -agr se encontra apenas na palavra heilagr "sagrado" e que sua manutenção ocorreu por ser sagrada e que -ugr tem origem a partir de uma metafonia do -agr causada por $-u$. O -igr também pode ser um desenvolvimento causado por palatalização em casos gramaticais em que há um $i$ final, porque há as variantes auđigr e auðugr "rico" (p. 207). Também é possível que tenha existido originalmente um sufixo em $i$ por conta de algumas palavras que têm um $i$ no gótico como, por exemplo, gabeigs "rico". De acordo com Orel (2003), seria possível a existência das duas variantes no período do germânico. Possivelmente o autor sugeriu a variante com - $u$ - por conta da variante do AN: 
germ. $\quad{ }^{*}$ geநanan $\rightarrow$ germ. $\quad{ }^{*}$ gabigaz $\approx{ }^{*}$ gabugaz (> Go. gabeigs $\approx$ gabigs $\cong \mathrm{AAA}$ kebic $\approx$ kepic $\cong \mathrm{IA}$ gifig $\cong \mathrm{AN}$ göfugr $\approx$ göfigr) ${ }^{106}$

No próximo exemplo, Orel (2003) considera a possível existência apenas da palavra *maxtigaz, ou seja, não havia um $\star$ maxtugaz:

germ. "magh-ti-107 "poder" $\rightarrow$ *maxtigaz (> Go. mahteigs $\cong \mathrm{AAA}$

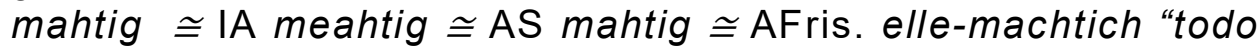
poderoso" AN máttigr)

Nesse caso vemos a manutenção do sufixo inicial -igaz. Ocorre também um prolongamento regular no AN -ht- > -tt- (NOREEN, 1903, p. 91). Outro exemplo de tal manutenção é na palavra nauđigr "necessário, forçoso", que é herdada de "nauđigaz e tem as cognatas $\mathrm{MAA}$ notec $\cong \mathrm{MBA}$ nodech $\cong \mathrm{IA}$ níedig $\cong \mathrm{AFris}$. nodich (com base nos exemplos de VRIES, 1977, p 405).

Orel (2003) propõe uma variação entre *-igaz e *-ugaz. As outras cognatas têm a terminação em -ig. Hægstad (1909) afirma que nas línguas do germânico do oeste resultaram-se os sufixos -ig, -îg e ag (p. 45).

Um exemplo em que as línguas do germânico do oeste apresentam herança da terminação em *-agaz é:

germ. *blōđagaz $\approx$ *blōđigaz "sangrento" (> AAA bluotag $\approx$ bluotig $\cong A S$ blōdag IA blódig $\cong A F r i s$. blōdich $\cong A N$

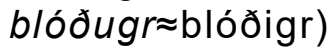

O que importa saber aqui é que o sufixo -igr quase não é produtivo no AN. Com relação ao $-u g r$ vemos produtividade nessa sincronia, como também casos gerados por metafonia [-agaz > -ugaz 
por metafonia causada por $u$, seguida de manutenção] ou mantidos do antigo-ugaz:

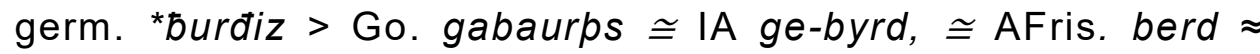

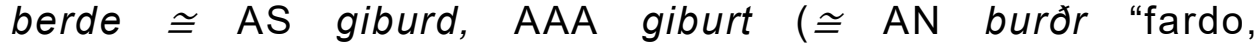
nascimento" $\rightarrow$ burðugr "nascido em berço de ouro")

germ. *xantjanan > IA hentan "seguir" $\cong$ (AN henta "ajustar, ser apropriado" $\rightarrow$ hentugr "apropriado")

AN glens "brincadeira, piada" $\rightarrow$ glensugr "engraçado"

AN dreyra "sangrar“ $108 \rightarrow$ dreyrugr "sangrento"

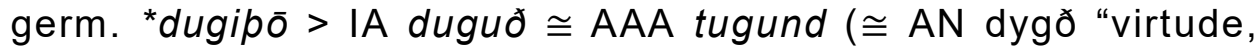
honestidade" $\rightarrow$ dyguđr "honesto")

Há outros casos como hold "carne" $\rightarrow$ holdugr "corpulento, robusto"; mál "língua" $\rightarrow$ málugr "falador, tagarela", snjór "neve" $\rightarrow$ snjóugr "coberto de neve" e skyn "percepção, informação" $\rightarrow$ skynja "investigar" $\rightarrow$ skynjugr "compreensivo, sensato, esperto". Nesses casos não há cognatas em outras línguas germânicas. Portanto, há casos em que a forma derivada só existe no AN, seja seu sentido ou sua forma (mál com o sentido de "língua", henta com o sentido de "ser apropriado", dreyra com o sentido de "sangrar", as formas hold "carne", glens "gracejo" e skyn) ou ocorreu a derivação apenas no AN (snjór $\rightarrow$ snjóugr; dygð $\rightarrow$ dyguðr e burðr $\rightarrow$ burðugr).

A palavra ferðugr "pronto" tem as cognatas MAA vertec $\approx$ vertic $\cong \mathrm{MBA}$ verdich $\cong \mathrm{MHol}$. vaerdich. De acordo com de Vries (p. 118) essa palavra do $\mathrm{AN}$ foi emprestada ou influenciada pelo MBA. O mesmo ocorre com a palavra AN sálugr "pobre, miserável" que, de acordo com de Vries (p. 461), é empréstimo do MBA salich "contente, devoto, favorável, miserável". Nesses casos percebemos que o empréstimo

108 Literalmente "deixar cair" (< germ. *drauzian), mas no Go. gadrausjan "precitipar-se" e AAA "pingar". 
ocorreu pela língua escrita, uma vez que os escrivães se preocuparam em "substituir", "traduzir" todos os morfemas emprestados pelos nativos.

Encontramos, no entanto, algumas formações exclusivamente em -igr como: orð $\rightarrow$ orðigr "comunicativo, eloquente", no AAA encontramos worteclîche "com palavras" no dicionário de Lexer; snúđr "pressa" $\rightarrow$ snúđigr "rápido", no MBA snud "pressa". Se havia uma palavra MAA *wortec e uma palavra MBA *snudich, que teriam sido emprestadas ao AN, não sabemos e, portanto, precisaria ser realizada uma pesquisa mais aprofundada.

Além do mais, a respeito do sufixo -het, ele tem origem no oeste germânico (Schmidt, 2007, p. 58), como apresentado na nota 78 . A palavra do AN heidr (< germ. *haiduz "modo, maneira; estado, condição"), portanto, não passou por um processo de gramaticalização em que viraria um sufixo. As línguas do germânico do Oeste, que passaram por tal processo, provavelmente entendiam as palavras como: cind- + -heit "essência/posição/cargo de criança", ou seja, "infância"

Ressalta-se que é importante o conhecimento de outras línguas cognatas para poder analisar uma língua específica. Percebe-se que a palavra rettighet, com um grande grau de certeza, não foi criada no AN pelo fato de que este sistema utilizava com mais frequência o sufixo -ugr (esperaria um $\star$ rettug) e, além disso, a segunda parte da palavra (-het) é uma forma gramaticalizada, que ocorreu apenas nas línguas germânicas do oeste. Em suma, não havia a base *rettig nas línguas escandinavas; por outro lado, o antigo alto-alemão tinha rehtic ${ }^{109}$ e o médio alto-alemão, as formas rehtec $\approx$ rihtec (LEXER, M. Mittelhochdeutsches Handwörterbuch). Com relação ao médio baixoalemão, não encontramos a palavra rehtec ou rihtec, mas a composição rechtigheyt ${ }^{110}$ em 1368 e a forma rechticheit no dicionário de Schiller \&

109 Com base em SEEBOLD (2008), Fragmentos de Mondseer (Matthäusevangelium). Disponível em: http://titus.uni-frankfurt.de/texte/etcs/germ/ahd/monsee/monse.htm

110 Diplomatarium Norvegicum, Vol. 8, N. 84 (Maio de 1368, não cita o local, em médio baixoalemão) 
Lübben (1875, Bd. III, p. 434). Pela forma da palavra podemos concluir que a derivação em rechtigheit ocorreu no médio alto-alemão, que a emprestou para o médio baixo-alemão. Portanto, a palavra norueguesa, nesse caso, tem o étimo médio baixo-alemão e origem médio altoalemã.

\subsection{A discussão etimológica: herança, empréstimo, decalque, derivação, entre outros}

De acordo com Viaro \& Bizzocchi (2016, no prelo), a discussão etimológica:

[...] se detém na argumentação de cada proposição etimológica, na variação (diatópica, diafásica, diastrática, diacrônica) da forma e do significado da palavra e nos cognatos interlinguísticos (e eventualmente nas suas disparidades formais ou semânticas). São considerados pertinentes os comentários fundamentados sobre a atualidade da palavra ou sobre sua raridade, seu grau de especialização, sobre seu uso ou desuso. Também são pertinentes questões sintáticas que envolvam aspectos morfossintáticos de concordância (como gênero, número ou regências específicas), assim como da participação da palavra em lexias.

Nesta mesma discussão e também de acordo com os autores, classificam-se os vocábulos em cultos ou eruditos (cultismos) e vulgares ou populares (vulgarismos). Além do mais, tais categorias se referem à origem do vocábulo e não ao seu uso, quer dizer, podem haver palavras herdadas, como escorreito, que só ocorrem no registro ultraformal e também cultismos, como operário, que são de amplo uso em todos os níveis da linguagem. Há também gradações: semicultismos, que surgem a partir de hibridismos de elementos cultos e vulgares, seja por combinação ou por vulgarização da forma grecolatina e semivulgarismos, ou seja, vocábulos existentes na língua desde seus primórdios, que surgiram no período conhecido como "latim 
cristão", quase sempre conectados à Igreja, disseminados na fala popular, porém, com baixa frequência de uso e também restritos a certos gêneros discursivos em que a fala era mais controlada. Por conta disso, é necessário conhecer bem as sincronias pretéritas. Metaplasmos irregulares, como no caso de escola, cabido, cônego e missa indicam os chamados semivulgarismos. Há casos, por fim, inclassificáveis como os neologismos fonológicos (poperô, tilim-tilim) e as derivações de silgas (ufologia, petista, aidético) e os nomes próprios (amperímetro, kantiano), bem como as recomposições (reprografia, informática, metrô, minissaia e showmício).

Apresentaremos processos que podem ser discutidos na etimologia:

\subsubsection{Herança}

Os vernáculos ou hereditários são vocábulos herdados diretamente do sistema linguístico numa sincronia imediatamente anterior, sem a intervenção de outro sistema qualquer (VIARO \& BIZZOCHI, 2016, no prelo). Com relação à neologia fonológica, os autores não fornecem exemplos ou qualquer explicação.

\subsubsection{Empréstimo}

O empréstimo, de acordo com os autores, é aplicado a tudo aquilo que não é criado em sincronia nem é herdado. À vista disso, seria um elemento lexical proveniente de outro sistema numa determinada sincronia. Bizzocchi (2013) realiza um vasto desenvolvimento tipológico referente ao empréstimo, assim como também o faz com as palavras herdadas.

Viaro \& Bizzocchi (2016, no prelo) também afirmam que, salvos uns poucos casos (status, habitat), palavras do grego e do latim já 
ingressam plenamente "nacionalizadas" ao português, ao passo que alguns estrangeirismos (muitas vezes utilizado como sinônimo de empréstimo), ou estão nacionalizados na grafia (futebol, abacaxi) ou não (pizza, bonbonnière).

Outros processos de empréstimo citados pelos autores é a retroversão, em que a palavra de um sistema $\mathrm{A}$ é admitida pelo sistema B e, tempos depois, retorna para A: fetiche \ fr. fétiche ("feitiço" >> "fetiche") \ feitiço. Também pode ocorrer com palavras cultas: fr.ant. tparformer ing. perform $>$ fr. performer.

A entrada na língua de um cultismo com a forma fonética do idioma a partir do qual foi importado produz muitas vezes uma divergência entre a forma assumida por esse cultismo e a que seria esperada se ele proviesse diretamente do grego ou latim: gr. $\varphi \rho \varepsilon ́ v \eta \sigma / S$ - lat. phrenēsis - fr. frénésie p pt. Frenesi. Bizzocchi (2013) chama esse processo de Empréstimo de cultismo estrangeiro sem adaptação grafo-fonética (p. 20); tais palavras mantêm seu status de cultas.

Outro tipo ocorre quando uma língua importa um semicultismo, que mantém o caráter semiculto na língua-alvo, de acordo com Viaro \& Bizzocchi (2016, no prelo): lat. necessarĭus $>$ fr. nécessaire (com adaptação da terminação) - pt. nécessaire na acepção de "bolsa ou estojo feminino para utensílios de toalete". Bizzocchi (2013) chama esse processo de Empréstimo de semicultismo estrangeiro (p. 24). Quando a palavra entra por transmissão oral de um cultismo indireto, isto é, a partir de outra língua que não o grego e o latim, Viaro \& Bizzocchi (2016, no prelo) afirma que pode ser reproduzida na grafia a pronúncia dessa palavra pela língua. Bizzocchi (2013) chama esse processo de Empréstimo de cultismo estrangeiro com reprodução gráfica da pronúncia original (p. 25): fr. estime - ing. esteem [Is'ti:m] (e não $\star$ estime [Is'tajm]).

Por fim, de acordo com Viaro \& Bizzocchi (2016, no prelo), cultimos podem ser emprestados acompanhados de desinência, que se incorporam ao radical da palavra na nova língua: fr. privé $\$ pt. privé, 
com a manutenção da desinência de particípio -é $[e]$ e não $\star[\varepsilon]$. Tendo em vista que é um elemento francês e não latino, ele confere aos termos portugueses um caráter híbrido, isto é, semiculto ( $p . X Y Z$ ). Bizzocchi (2013) confere a esse processo o nome de Empréstimo de cultismo estrangeiro acompanhado de desinências (p. 25).

\subsubsection{Decalque}

O decalque é a tradução de um vocábulo (ou dos elementos que o compõem) de um sistema diferente do estudado por equivalentes do sistema em questão. Viaro \& Bizzocchi (2016, no prelo) exemplifica com a palavra relação, que não seria uma palavra herdada e tampouco um mero empréstimo, porque não se trata de uma mudança fonética regular, mas sistemática. Portanto seria um tradução parcial, ou para nós decalque parcial. Exemplos:

- francês †estrangier $\geq$ estrangeiro;

- inglês goalkeeper $\geq$ goleiro;

- esp. cañón $\geq$ canhão

Rash (1989, p. 18), por outro lado, não concorda que processos desse tipo sejam decalques, mas hybrid loan ou loanblend (cita Haugen, 1953, p. 390 e 402 e T.E. Hope 1971, p. 578 "parcial morphemic substitution"). Trata-se da substituição parcial de morfemas da língua de empréstimo e esse processo ocorre em derivativos e componentes analisáveis.

Betz $(1949 ; 1959)$ separa os decalques em dois tipos de acordo com a intensidade: Lehnübersetzung "tradução de empréstimo" (Ioan translation para Weinreich (1953) e exact para Haugen (1956)), que é a tradução de elemento por elemento, e o Lehnübertragung "transferência parcial mais livre" (Loan rendition para Weinreich e approximative para Haugen). Rash (1989, p. 19) afirma que uma palavra 
estrangeira proporciona a base para a tradução, mas o resultado não corresponde exatamente ao termo original. Haugen (1956) insere o tipo exact e approximative dentro da classificação borrowed creation. Exemplos de Lehnübersetzung seriam:

- AI. Großvater (s fr. grand-père "avô)

- Go. adj. *armahaírts"111 ( $\leq$ lat. misericors $\leftarrow$ miser "pobre, miserável" + cors "de coração") $\geq$ AAA armherz (séc. IX) > [ irbarmen "ter misericórdia" (sec. IV) < *ir-bi-armen ou *ir-abarmen ${ }^{112} \cong$ Go. *ga-arman ${ }^{113}$ ( $\leq$ lat. miseseri)] > MAA barmherze $\approx$ barmherzic $\rightarrow$ MAA barmherzekeit $\approx$ barmherzkeit $\approx$ barmherzickeit > ale. Barmherzigkeit).

- lat. regnum coelorum "reino do céu" $\geq$ himinríki, em que himinn significa "céu" e ríki, "reino"

- MBA dōmkerke $\geq$ AN dómkirkja "catedral".

Exemplos de Lehnübertragung:

- ing. hovercraft "máquina de pairar" (em pt. "aerobarco") $\geq$ ale. Luftkissenboot "barco de almofada de ar"

- ing. jukebox "caixa de desordem"114 $\geq$ ale. Musikkiste "caixa de música"

111 Há atestação apenas do plural armahairtei. É uma composição de arma- "pobre" (Nom.sing. *arms) e -hairto "coração". A terminação -s em *-hairts é marca de adjetivo no caso nominativo e singular. Lehmann (1986) cita as teorias de Raumer (1845, p. 345) e Kluge (1909), que afirmam que tanto o gótico quanto as línguas germânicas do Ocidente têm essa palavra como um decalque do latim misericors. Carr (1939, p. 3-4), por outro lado, sugere que o AAA armeherz foi emprestado do Go. uma vez que essa palavra não existe no baixo alemão e por cor conta do -e-, e também -a-, após arm-. Osthoff (1894) propôs que, nas palavras de Lehmann, o proto-germânico armoz por si só adquiriu o significado de "misericordioso" e adicionou o sufixo -hairts para seguir o modelo latino. De acordo com Lehmann, mais crédito tem a proposta de Üçok (1938, p. 36), que afirma que *arma-hairts é um decalque dos modelos gregos e latinos, uma vez que aos germânicos faltavam as gentilezas de presentear (p. 43). Isso provavemlente se sustenta porque os góticos foram os primeiros que tiveram contato com os ensinamentos da Bíblia.

112 De acordo com o DUDEN, o - $b$ - é resto de um prefixo bi- ou ab-. Kluge (na entrada erbarmen) afirma que seria um prefixo ab-, como no Al of-earmian "ter pena ou compaixão".

113 Há atestação de 3p.pres.s. armaip e 3p.pret.pl. gaarmaida.

$114 \mathrm{O}$ dicionário de Oxford (CD-ROM) afirma que juke vem da língua africana Gullah e significa "desordem". 
Para Haugen (1956), além do borrowed creation também há o borrowed extention, que são chamados por Betz (1949) de Lehnbedeutung, também conhecidos como semantic loan or extension "extensão ou empréstimo semântico". Nesse caso, o significado de uma palavra estrangeira é inserido a uma palavra nativa e, assim, concede à palavra nativa um novo significado. Há dois tipos: analogical extension "extensão analógica" (Haugen, 1953, chama de synonymous extension) e a substitutive extension "extensão substitutiva" (Haugen, 1953, chama de homonymous extension "extensão homônima"). A extensão analógica, por sua vez, também tem dois tipos: semantic analogy "analogia semântica" (chamada por Haugen, 1953, de homologous extension) e phonetic analogy (chamada por Haugen, 1953, de homophonous loan extension):

- analogia semântica: o modelo estrangeiro é lembrado apenas semanticamente (exemplo: lat. faciem ("face" e "visão") $\geq$ ale. Gesicht ("visão" >> "face").

Outros exemplos são lat. nuclěus ("caroço" >> "núcleo de uma célula ou de um átomo") $\geq$ ale. Kern (ambas as acepções, cf. Kernphysik, "Física Nuclear") e ing. star ("corpo celeste" >> "pessoa famosa") $\geq$ pt. estrela ${ }^{2}$ "pessoa famosa" $\equiv$ estrela1 "corpo celeste" < lat. stellam "corpo celeste"

- analogia fonética: a similariedade é puramente fonética: fr. banquette $\geq$ ale. Bancket

A analogia fonética é diferente dos empréstimos regulares (pure loanwords), que são palavras inteiras derivadas de uma outra língua e adaptadas para uso nativo. Tanto a forma fonêmica e seu significado são importados para a língua recipiente: parole, service, visite, discours, etc. (Rash, 1989, p. 18).

Um outro tipo é o Lehnschöpfung (Betz, 1949), que corresponde não ao tipo borrowed de Haugen, mas de Native (de 
subtipo induced). De acordo com Betz, é uma recriação independente da forma para a tradução de uma palavra estrangeira" e ela sempre ocorre, de acordo com Rash (1989), quando o loan translation ou o loan rendition não é possível por conta de razões formais e semânticas ( $p$. 19)

Nesta presente dissertação analisaremos apenas os internacionalismos, que em grande parte se encaixam na categoria chamada por Bizzocchi (2013) de tradução de cultismo (p. 21) e por Rash (1989) de hybrid loan (p. 18). Entendemos que é de fato uma tradução e chamaremos de decalque de cultismo, no caso decalque parcial de cultismo, pois trata-se da tradução dos morfemas de um vocábulo estrangeiro por equivalentes nacionais. De acordo com Bizzocchi, esse processo ocorre quando há a substituição a partir de palavra grega, latina ou de cultismo criado em outra língua, quer dizer, a substituição de qualquer morfema da palavra culta por outro, de natureza semiculta ou vulgar, com significado equivalente. O autor exemplifica o tipo de decalque total como lat. superponere > pt. sobrepor e de decalque parcial como lat. emotio > pt. emoção. O sufixo -ção é um equivalente nacional, que substitui o latino -tionem, e, por isso, é um sufixo herdado, abstraído de palavras herdadas como canção e lição, por exemplo.

A respeito dos sufixos fr. -tion, it. -zione e esp. -cíon, não podemos considera-los como equivalentes nacionais, uma vez que são empréstimos do latim -tionem e, em seguida, sofreram adaptação ortográfico. Estas mesmas línguas têm seus correspondentes nacionais (como -ção no português): fr. -son, it. -gione e esp. -zone. Nas línguas germânicas também ocorre o empréstimo do sufixo latino, com possível adaptação ortográfica, como no norueguês que passa de -tion para sjon em 1917. Ademais, o ator afirma que essas palavras que surgem por decalque são consideradas semicultismo, quer dizer, a palavra emoção seria considerada um semicultismo; por conta disso, se alguma língua emprestar essa palavra do português, a palavra também será um semicultismo. Em suma, todos as palavras terminadas com esses 
sufixos surgem por meio do decalque de cultismo (ou de semicultismo, quando vem por meio indireto, quer dizer, passou por uma língua intermediária antes de chegar na língua-alvo).

Bizzocchi (1998, p. 124) também cita a categoria empréstimos de restituição, nos quais parte de um vulgarismo ou semicultismo estrangeiro é traduzido por elementos cultos gregos ou latinos:

ing. feed back $\geq$ retroalimentar

fr. opérationnel $\geq$ operacional (sufixo -el volta para -al)

Este é o processo inverso do decalque de cultismo citado acima.

Viaro \& Bizzocchi (2016, no prelo) também cita outros processos etimológicos, que não comentaremos nessa dissertação, pois não são relevantes a ela.

\subsubsection{Derivação}

A diferença básica entre o étimo e a derivação é que na primeira a mesma palavra sofre mudanças fonéticas e semânticas sem nenhum aumento ou decréscimo de elementos de formação como, por exemplo, os prefixos e sufixos; ao passo que na segunda trata-se claramente de palavras distintas (VIARO, 2011, p. 99). Por conta disso, uma palavra pode ser derivada de uma palavra com étimo de empréstimo e, mesmo assim, ter origem na língua que criou a derivação. A palavra gourmet tem étimo francês, mas a palavra gourmetização é portuguesa:

fr. gourmet $\vee$ gourmet $\rightarrow$ gourmetização 
Tomemos também, como exemplo, a palavra norueguesa djervhet "valentia". Ela é formada pelo substantivo djerv "valente" e pelo sufixo -het, que é formador de substantivos; portanto:

$$
\text { djerv } \rightarrow \text { djervhet (derivação morfológica) }
$$

Tal palavra tem cognatas em outras línguas escandinavas como, por exemplo: nbok. djervhet $\cong$ sue. djärvhet $\cong$ din. djærvhed $\cong$ nyn. djervheit ( $\approx$ djervskap), mas tanto no AN quanto no isl. é dirfð.

Para a formação de substantivos abstratos, o nynorsk, que segue relativamente os modelos dos dialetos noruegueses, utiliza o sufixo -skap, junto como os sufixos -dom e o -leik, que foram muito produtivos após a era das síncopes, por terem um certo peso sonoro e serem mais recentes (SKARD, 1973, p. 101)115. A língua precisava de novos sufixos para criar palavras abstratas por conta do irreconhecimento dos sufixoss. Dessa forma, nessa mesma Era das síncopes, os sufixos herdados -skap, -dom, -leik, mas também o -ing, ganham mais produtividade. Além da síncope, outros fatores importantes que contribuíram para a perda de reconhecimento de relação entre a palavra derivada e a palavra original foram a mutação consonantal e o bryting (quebra vocálica), ou seja, o que antes era "sōkīni "busca" e sōkian "buscar", acabou se transformando em sókn e sœkja (p. 29-31). O sufixo -he(i) $t^{116}$, no século XIV, também contribuiu para a substituição dos antigos sufixos.

115 Segundo Seip (1934), o período da síncope fez com que o AN perdesse uma grande quantia de prefixos e sufixos pois eles se simplificaram de tal maneira que os falantes não mais os reconheciam e, por conta disso, não eram mais produtivos; os falantes não conseguiam, por exemplo, reconhecer na palavra stjórn "controle, poderio" o sufixo formador de abstratos -īni (stjórn < *[steurīni]). Outros sufixos que perderam essa capacidade foram -īn, -ipō e -pi.

116 No dinamarquês completamente, mas nos dialetos noruegueses apenas em algumas condições (AASEN, 1864, 267; Seip, 1934, p. 89), ao passo que no islandês nada ocorreu. Segundo Skard (1973), esse sufixo veio para substituir os antigos sufixos -dom, -skap e -leik (p. 155). O islandês não passou por esse processo porque estava isolado do continente em que ocorria o fenômeno 
Skard (1973) afirma que a alta frequência da ocorrência da palavra alemã rettigheit nas cartas dos reis (p. 155), ajudou na divulgação do sufixo. O médio baixo-alemão e o médio alto-alemão tinham várias palavras formadas a partir de -heit ${ }^{117}$, pois tal sufixo teve sua origem apenas nas línguas do germânico do Oeste.

Como havia muita troca cultural por conta do comércio, cujas palavras representavam abstrações, essas línguas escandinavas acabaram por emprestar esse sufixo: o dinamarquês, como já dito, foi a língua que mais dele se utilizou, pois não só criou derivações com o adjetivo, mas também com o particípio, ex. Forrykthed "demência, demência":

$\mathrm{MAA}$ ver- + -rücken $\rightarrow \mathrm{MAA}$ verrücken $\cong \mathrm{MBA}$ vor- + -rucken $\rightarrow$ MBA vorrucken ( $\geq$ din. forrykke $\left.{ }^{118}\right)$

No caso acima, as palavras MAA verrücken e MBA vorrucken tinham apenas o sentido de "puxar do lugar que se encontra" e não é possível afirmar com certeza, sem um estudo de datação, quem emprestou para quem; o MBA emprestou essa formação para o dinamarquês. A forma participal no MAA, no entanto, se desenvolveu em uma nova acepção ${ }^{119}$ que influenciou o dinamarquês:

ale. verrückt ("movido para outro lugar" >> "louco") $\geq$ din. forrykt (ambas as acepções)

comercial da Liga Hanseática, no qual participavam principalmente a Dinamarca, a Noruega e o norte da Alemanha.

117 De acordo com Kluge (CD-ROM, 2002) há as variantes -keit e -igkeit no alemão, que foram geradas a partir dos adjetivos terminados em -ig (MBA -ec: -ec-heit = ec-keit; ig-keit). No AAA era -heit, no AS -hed, IA -had e AFranc. -hed(e) (do germânico do oeste *-haidu "tipo e modo; aparência). Ela ocorre também no Go. haidus "jeito e modo", no AN heiðr "honra, dignificade", no IA had "entidade, pessoa, rank, linhagem", etc.

118 De acordo com o Ordbok over det danske Sprog e Den danske Ordbog, é um empréstimo do médio alemão.

${ }^{119}$ A partir do séc. XVI ganhou a acepçao de "enlouquecido". Esse último sentido foi fortalecido por sinnverrückt "cujo senso foi puxado do lugar" e construções similares (Kluge, sobre a acepção verrückt) 
Em seguida, o dinamarquês realizou uma derivação:

din. forrykt $\rightarrow$ forrykthed "loucura"

Os verbos MAA rücken e MBA rucken ${ }^{120}$ tinham cognatos em outras línguas germânicas:

germ. rukjan-121/*rukk/gōn ${ }^{122}>$ [ASue. rykk(i)a (> sue. rycka $)^{123}$ $\cong \mathrm{AN}$ rykkja (> nyn. rykkje) $\cong A D$ rykkja (> din. rykke) $\cong A A A$ rucchen].

A respeito do sufixo, havia no AAA as variações AAA fir-/far- > ale. ver-; AS for- > MBA vor-. De acordo com Kluge, esse prefixo era diferenciado no gótico em três maneiras: faur- fra- e fair- e essa tríade representa a relação com as línguas fora do germânico: ai. pura, prá e pári; gr. parà, pró e perì; I. (por-), pro e per, etc. Possivelmente, esses prefixos remetem ao "per- "ir para o outro lado" do IE. No caso em questão, é o significado do faur- do gótico que importa. A ele pertencem as funções que podem ser imputadas aos pontos de partida marcados espacialmente de maneira significativa ("para o outro lado, em um outro local", portanto, verschlafen "dormir demais" e versetzen "mudar de local, deslocar"). Ao fra pertencem as palavras verarbeiten "usar, utilizar", verbrauchen "gastar, consumir" e verschwinden "desaparecer" e também para expressar contrariedade como, por exemplo, verspielen "perder", vergehen "passar, decorrer" e verlernen "desaprender". A respeito do fair-, não há nenhuma correspodência funcional. Uma vez que a coincidência desses três casos é antiga, separará-los no alemão moderno não teria sentido.

120 De acordo com Kluge (CD-ROM)

121 Hellquist (1922, p. 665)

122 Kroonen (p. 417)

123 Hellquist (1922, p. 665) 
Em suma, o significado original de verrückt era "movido para outro lugar" e a partir do século XVI começou a ter o sentido de "louco". De fato, no dicionário de LEXER (1872) sobre o médio alto-alemão, não encontramos nenhuma entrada com o significado de "louco". O dinamarquês tomou esse novo significado do alemão e criou um substantivo por derivação.

A língua escrita da Noruega, que logo seria dominada pela Dinamarca, também adotou essas formações com tais afixos; nos dialetos noruegueses, por outro lado, tais afixos parecem não ter causado influência, salvo em alguns casos, por isso temos a formação atual do nynorsk em djervskap. Skard (1973) afirma que esse sufixo ficou tão produtivo que é praticamente impossível determinar se uma determinada palavra foi formada com base no norueguês ou se foi um empréstimo (p. 155).

O item lexical djerv não poderia ter vindo do médio baixoalemão porque a forma nessa língua era derve (de VRIES, 1977, p. 77; FICK, A.; FALK, H.,1909, p. 202). Portanto, não apenas o sufixo deve ser considerado para um estudo etimológico, mas também a base em que ele foi inserido.

O item lexical djervhet serve como um exemplo de derivação, pois foi formado em uma das línguas escandinavas em contato com o médio baixo-alemão no período da Liga Hanseática por meio de uma raiz nativa e um sufixo importado. Poderia ter sido formada no sueco, que exerceu influência entre 1319 e 1355, no dinamarquês, que exerceu influência de 1397 até 1814 (com a participação da Suécia até 1523, devido à União de Kalmar) (TORP, A; VIKØR, S., 2000, p. 117) ou até mesmo no norueguês, provavelmente na cidade de Bergen, porque foi lá que o médio baixo-alemão foi utilizado como língua falada, ou seja, onde havia mais Kontor "escritórios" da liga hanseática (TORP, A; VIKØR, S., 2000, p. 300). Portanto, seria necessária uma investigação etimológica para saber em qual das línguas escandinavas tal palavra foi criada por derivação e, consequentemente, emprestada para as outras línguas 
escandinavas. Uma hipótese é possível: em uma das três línguas escandinavas a palavra foi criada e as outras duas tem o étimo de empréstimo que remete à língua que a formou.

\subsection{Levantamento da amostragem para análise e o método de pesquisa}

Exemplificamos com 9 palavras da língua portuguesa sufixadas em ção e que têm cognatos na língua norueguesa.

Tomamos como base as palavras do Dicionário Houaiss Eletrônico (DHE), que fornece informações sobre a etimologia e a datação mais antiga. As palavras norueguesas foram coletadas em quatro dicionários: o Bokmålsordboka (NbUiB), o Norsk ordbok de Tor Guttu (NTG), que tratam do bokmål, o Norsk Riksmålordbok (ROB), que pega palavras do período do riksmål e o Nynorskordboka (NyUiB), que trata do nynorsk.

Como textos muito antigos noruegueses e portugueses não são acessíveis manualmente, foi necessária a busca de textos online. Apesar de haver uma ampla acessibilidade a esses textos, nem sempre eles são digitalizados e, por impossibilitarem por conta disso a busca de palavras pelo ctrl + F, dificultam nosso trabalho. Por conta disso, foi utilizado o programa Abbyy FineReader 12, que digitaliza o texto escaneado por meio da tecnologia Optical Character Recognition (OCR). Dessa forma é possível buscar por palavras terminadas em X-sjon (ou X-tion em textos mais antigos), mas nem sempre o reconhecimento chega perto do aceitável, uma vez que a maioria desses textos são manuscritos e, por isso, há uma considerável variação de grafia, fazendo com que o OCR não reconheça os caracteres de maneira adequada. Uma maneira aceitável de tentar resolver esse problema é fazer várias buscas com caracteres possíveis que estão representando erroneamente o "-tion" como, por exemplo, "cion", "rion", ou apenas fazer a realização da busca em "ion" ou "io". Uma vez que esse encontro vocálico -io- não é comum nas línguas escandinavas, a não ser quando utilizado em palavras desse tipo, tal problema pode ser satisfatoriamente resolvido. 
Uma maneira muito melhor, porém, muito mais demorada, de resolver o problema da má leitura dos caracteres é treiná-los no texto. Trata-se de um programa que reconhece um caractere do manuscrito que, em seguida, é combinado, por meio do usuário, a um caractere representativo; obviamente que não precisa realizar o treinamento do texto inteiro, de 3 a 5 páginas já pode ser suficiente para garantir um treinamento adequado com base na grafia do copiador, mas é sabido que tal grafia pode variar até mesmo em caracteres iguais. Embora haja seus pontos negativos, tal procedimento é muito mais positivo pois sem ele não seria possível a busca dentro de tais documentos, uma vez que eles não são acessíveis, estão em grande quantidade e são muito antigos, o que não seria possível o manuseamento deles.

Também utilizamos a Biblioteca Nacional Norueguesa (Nasjonalbibiothek), que possui digitalizados todos os livros publicados na Noruega até o ano de 2000. Como o campo de pesquisa é muito bom, quer dizer, tem um reconhecimento de OCR satisfatório, foi possível buscar as palavas por esse meio.

O Google Books nos ajudou a buscar textos de português e de outras línguas românicas e germânicas. Também podemos citar as dezenas de corpora utilizados, que estão listados na parte da bibliografia.

\subsection{Obras, dicionários e corpora utilizados}

Para a realização dessa pesquisa é necessária uma bibliografia que tenha livros escritos em várias fases da língua portuguesa e norueguesa, Google Books, obras lexicográficas como dicionários atuais e antigos e sites que têm corpora online de textos de difícil acesso em papel.

Aqui estão indicadas sistematicamente obras que podem ser utilizadas durante a pesquisa, em subgrupos: A) dicionários atuais para um panorama semântico mais preciso de alguma palavra em questão, tanto no português, quanto no norueguês; B) dicionários em sincronias anteriores; C) obras de cunho etimológico; D) obras em idiomas do mesmo tronco linguístico do português e do 
norueguês; E) corpora para a investigação da existência de alguma palavra, em toda a diacronia, a ser datada ou retroagida. Todas elas estão citadas na bibliografia.

A) Poderão ser utilizados os dicionários Grande Dicionário Houaiss da Língua Portuguesa (versão online), Novo Dicionário Eletrônico Aurélio, o Dicionário Contemporâneo da Língua Portuguesa de Caldas Aulete, o Moderno Dicionário da Língua Portuguesa da Michaelis; para o bokmål podem ser utilizados o dicionário online Bokmålsordboka, fornecido pela Universidade de Bergen, o dicionário online Norsk ordbok de Tor Guttu e o Lexin Bokmålsordbok fornecido pelo Utdanningsdirektoratet; para o nynorsk, o dicionários onlines Nynorskordboka e o Norsk Ordboka 2014, ambos, fornecidos pela Universidade de Oslo e o Lexin Nynorskordbok, fornecido pelo Utdanningsdirektoratet.

B) Os possíveis dicionários em sincronias anteriores da língua portuguesa a serem utilizados são as obras de Jerônimo Cardoso como, por exemplo, o Hieronymi Cardosi Lusitani de Monetis tã Graecis quā Latinis. Item de Ponderibus \& Mësuris ad praesentem vsum redactis, Anacaephaleosis, o Index Totius Artis de António Vélez, o Diccionario Lusitanico-Latino de Nomes Proprios de Pedro de Poiares, as obras de Rafael Bluteau, como o Vocabulário Portuguez, o Prosodia in vocabularium bilingue, Latinum, et Lusitanum digesta, o Thesouro da lingua portugueza, ambos de Bento Pereira, o Diccionario da língua portugueza de Antonio de Moraes Silva, o Diccionário Etymológico, Prosódico e Orthográfico da Língua Portugueza de J. T. Silva Bastos; para o norueguês, podem ser utilizados o Norsk Riksmålsordbok da Det Norske Akademi for Sprog og Litteratur o Ordbog over det gamle Norske Sprog de Johan Fritzner, o Ordbog over det norske Folkesprog de Ivar Aasen, o Ordbog over det danske Sprog (dinamarquês, eletrônico), que dá uma visão geral entre 1700 e 1955, o Ordbog til det ældre danske Sprog de Otto Kalkar (dinamarquês). 
C) Obras de cunho etimológico possíveis de serem consultadas são, para o português, o Dicionário Etimológico Nova Fronteira da Língua Portuguesa de Antônio Cunha, Etimologia e Por Trás das Palavras, ambos de Mário Eduardo Viaro, o Dicionário Etimológico da Língua Portuguesa de J. P. Machado; outras obras de palavras do tronco latino também podem ser utilizadas como, por exemplo, o Dictionnaire Étymologique de la langue Latine de Alfred Ernout e Antoine Meillet, para a língua latina, o Romanisches Etymologisches Wörterbuch de Meyer-Lübke, para línguas latinas em geral, o Breve Diccionario Etimológico de la Lengua Castellana de J. Corominas, para o castelhano, o Dizionario Etimológico della Lingua Italiana de M. Cortelazzo e P. Zolli, para a língua italiana. Para o norueguês podem ser utilizados o Etymologisk ordbog over det norske og det danske sprog de Hjalmar Falk e Alf Torp, o Nynorsk Etymogisk Ordbok de Alf Torp, o Våre Arveord de Harald Bjorvand e Fredrik O. Lindeman, o Dansk Etymologisk Ordbog de Edwin Jessen, o Dansk Etymologisk Ordbog de Niels $A$. Nielsen, sendo os dois últimos para a língua dinamarquêsa. Outras obras etimológicas de línguas do tronco germânico possíveis de serem utilizadas são o Svensk Etymologisk Ordbok de Elof Hellquist (online), o Etymologisk Svensk Ordbok de Frederik A. Tamm e A. Noreen, ambos para o sueco, o DWDS (online), o Etymologisches Wörterbuch der deutschen Sprache de Friedrich Kluge, o HerkunftsWörterbuch da Duden, os últimos três para o alemão, o Oxford Dictionary of English Etymology de Charles Onions, o Klein's Comprehensive Etymological Dictionary of the English Language: Unabridge de Ernest Klein, ambos para o inglês, o o Altnordisches Etymologisches Wörterbuch de Jan de Vries, para o nórdico antigo.

D) Obras de outros idiomas de mesma raiz também podem ser consultadas, como é o caso do Dicionário Electronico de la Lengua Española da Real Academia, para o espanhol, o Vocabolario della Lingua Italiana de Nichola Zingarelli, para o italiano, o Le Petit Robert do Robert Le Petit, para o francês e o Dicionário e-Estraviz, para o galego. Para o norueguês, podem ser utilizados o Svenska Akademiens Ordbok, 
para o sueco, o Deutsches Universalwörterbuch da Duden, para o alemão e o Longman Dictionary of Contemporary English da Logman Group, para o inglês.

E) Os corpora para consulta de palavras em toda a diacronia do português são: o Corpus do Português dos Professores Mark Davies e Michael J. Ferreira, as Cantigas de Santa Maria, o Corpus informatizado do português medieval (CIPM), as obras disponibilizadas pelo GMHP, como o corpus literário do português, o DICIWeb e o Corpus Histórico do Português de Tycho Brahe. A maioria desses corpora fornecem maneiras de pesquisar tanto por uma determinada palavra em um século específico, quanto pela frequência das palavras em ordem cronológica nas obras contidas neles que são de várias áreas literárias. Para o norueguês, podem ser utilizados os corpora Diplomatarium Norvegicum (textos de 1050 até 1570), o Regesta Norvegica (833-1390), o Medieval Nordic Text Archive (textos de aprox. 1200), Oslo-korpuset av taggede norske tekster (atual), o Tekstsamlingen do Dokumentasjons-prosjektet, o KorpusDK (atual), o Arkiv for danks Litteratur (século anterior e atual) e o Studér Middelalder på Nettet (medieval), sendo os três últimos dinamarqueses.

\subsection{Grau de certeza}

\subsubsection{Introdução}

Já em 1922 foi dada a primeira sugestão sobre os graus de certeza nos étimos por Jespersen (p. 307):

It's of course, impossible to say how great a proportion of the etymologies given in dictionaries should strictly be classed under each of the following heads: (1) certain, (2) probable, (3) possible, (4) improbable, (5) impossible - but I am afraid the first two classes would be the least numerous. 
De acordo com Viaro \& Bizzocchi (em prelo), é possível definir o grau de certeza por meio de um número e, para isso, é necessário confirmar a aplicação regular das leis fonéticas em cada sincronia. Os autores definem os seguintes graus de certeza:

\begin{tabular}{|c|c|c|c|c|}
\hline $\begin{array}{l}\text { Grau de } \\
\text { certeza }\end{array}$ & Número & $\begin{array}{l}\text { Aplicação das } \\
\text { leis fonéticas }\end{array}$ & $\begin{array}{l}\text { Tipos de } \\
\text { dados }\end{array}$ & Significado \\
\hline Certo & [1] & Regular & $\begin{array}{c}\text { Não } \\
\text { reconstruídos }\end{array}$ & Mantido \\
\hline Provável & [2] & Regular & Reconstruídos & Mantido \\
\hline Provável & [2] & $\begin{array}{l}\text { Irregular (em } \\
\text { apenas um } \\
\text { locus) }\end{array}$ & $\begin{array}{c}\text { Não } \\
\text { reconstruídos }\end{array}$ & Mantido \\
\hline Possível & [3] & Regular & $\begin{array}{c}\text { Não } \\
\text { reconstruídos }\end{array}$ & Não mantido \\
\hline Possível & [3] & Regular & $\begin{array}{c}\text { Não } \\
\text { reconstruídos }\end{array}$ & Não mantido \\
\hline Possível & [3] & $\begin{array}{l}\text { Irregular (em } \\
\text { apenas um } \\
\text { locus) }\end{array}$ & Reconstruídos & Mantido \\
\hline Improvável & [4] & $\begin{array}{l}\text { Irregular (em } \\
\text { apenas um } \\
\text { locus) }\end{array}$ & $\begin{array}{l}\text { Reconstruídos } \\
\text { ou não }\end{array}$ & Não mantido \\
\hline Improvável & [4] & $\begin{array}{l}\text { Irregular (em } \\
\text { mais de um } \\
\text { locus) }\end{array}$ & $\begin{array}{l}\text { Reconstruídos } \\
\text { ou não }\end{array}$ & Mantido \\
\hline Impossível & [5] & $\begin{array}{l}\text { Irregular (em } \\
\text { mais de um }\end{array}$ & $\begin{array}{c}\text { Reconstruídos } \\
\text { ou não }\end{array}$ & Não mantido \\
\hline
\end{tabular}


Resumidamente (sendo i = número de loci irregulares):

\begin{tabular}{|c|c|c|c|c|c|c|c|c|c|c|c|c|}
\hline $\begin{array}{l}\text { Regularidade } \\
\text { das leis } \\
\text { fonéticos }(i \leq 1)\end{array}$ & \multicolumn{2}{|c|}{ Sim } & \multicolumn{2}{|c|}{ Sim } & \multicolumn{2}{|c|}{ Sim } & \multicolumn{2}{|c|}{ Sim } & Não & Não & Não & Não \\
\hline Reconstrução & \multicolumn{2}{|c|}{ Sim } & \multicolumn{2}{|c|}{ Sim } & \multicolumn{2}{|c|}{ Não } & \multicolumn{2}{|c|}{ Não } & Sim & Sim & Não & Não \\
\hline $\begin{array}{l}\text { Manutenção do } \\
\text { significado }\end{array}$ & \multicolumn{2}{|c|}{ Sim } & \multicolumn{2}{|c|}{ Não } & \multicolumn{2}{|c|}{ Sim } & \multicolumn{2}{|c|}{ Não } & Sim & Não & Sim & Não \\
\hline $\begin{array}{l}\text { Número de loci } \\
\text { irregulares }\end{array}$ & 0 & 1 & 0 & 1 & 0 & 1 & 0 & 1 & $>1$ & $>1$ & $>1$ & $>1$ \\
\hline Grau de certeza & [2] & [3] & [3] & [4] & [1] & [2] & [3] & [4] & [4] & [5] & [4] & [5] \\
\hline
\end{tabular}

De acordo com Viaro \& Bizzocchi (2016, em prelo), os graus de certeza são acrescidos de + quando há uma atuação analógica. Por exemplo, se uma proposição etimológica de grau 4 não segue as leis fonéticas porque necessita de uma explicação de cunho etimológico, os autores afirmam que sua notação será [4+], o que equivaleria a algo como [4,5]. Se houver duas explicações analógicas, o resultado será $[4++]$ ou $[4,75]$, etc. A respeito das substituições, decalques e empréstimos, ao contrário, nunca terão um grau de certeza menos que 3 , mas, inversamente serão acrescidos de -. Dessa maneira, se uma notação tiver valor [3-], isso quer dizer que teremos algo parecido com [2,5] e [3--] algo como [2,25], etc.

Porém, com referência ao grau de certeza para palavras com étimo de empréstimo, das três características acima citadas apenas o caráter semântico deve ser considerado, uma vez que o empréstimo é feito em sincronia. 


\subsubsection{O terminus a quo e outros elementos que podem fortalecer/enfraquecer a determinação do étimo de empréstimo ou de decalque}

Com relação ao étimo de empréstimo, a coleta dos termini a quo de uma determinada palavra nas línguas cognatas é o primeiro procedimento que se deve realizar para descobrir o caminho que ela percorreu entre as línguas. No entanto, além desse procedimento de coleta, propomos outros procedimentos que podem de alguma maneira fortalecer ou enfraquecer a hipótese no caminho percorrido por ela:

(1) verificar se a palavra é atribuída a algum tema, que é difundido exclusivamente por alguma(s) língua(s). Um estudo sobre o tema pode determinar em que momento a língua, que domina determinado tema, influenciou de maneira mais massiva outras línguas. Duden (2014) afirma, por exemplo, que um grande número de empréstimo de palavras italianas para o alemão ocorreu entre os sécs. XV e XVI por causa dos negociantes italianos que viajavam para outras cidades ( $p$. 68). Outro exemplo é a Psicologia, tema muito trabalhado pelos alemães, e muitas palavras desse tema são empréstimos do alemão entre no fim do séc. XIX e início do séc. XX;

(2) a representação escrita do item lexical em correspondência com sua pronúncia. Eventualmente essas palavras podem vir emprestadas junto com o objeto ou a ideia;

(3) levar em conta o radical (sua forma e significado);

(4) cruzamentos panromânicos, como apresentado por Freitas (2013, p. 443);

(5) a semântica da palavra. Suas acepções podem ajudar na determinação do caminho percorrido por ela. 
Iremos exemplificar com a palavra fascismo em seu sentido original. Hoje em dia fascismo ou fascista tem outros sentidos (i.e. sinônimo de "reacionário" ou "autoritário") e não necessariamente com a ideologia original. No que diz a respeito ao ponto 2, de línguas de influência em determinados temas, ele acaba sendo irrelevante no estudo dessa palavra, pois o fascismo descrevia a situação que ocorria apenas na nação italiana e, consequentemente, a palavra muito provavelmente tem sua origem na língua dessa nação. De acordo com a Encyclopædia Brittanica Ultimate Reference Suite, o fascismo foi uma ideologia política e movimento em massa que dominou muitas regiões da Europa central, sul e do Leste entre 1919 e 1945. O primeiro líder europeu fascista foi Benito Mussolini, que sugeriu essa palavra para seu partido. Ela é uma derivação da palavra latina fasces (feixe de varas) usado como símbolo de uma autoridade penal na Roma antiga. Por conta do contexto histórico-social, é fácil concluir que a palavra tem origem italiana e, além do mais, as datas da primeira aparição nos outros idiomas apresentam a italiana como sendo a primeira. Os dicionários de norueguês não datam essa palavra. O Dizionario interattivo Etimologico de Zanichelli (2000) afirma que a primeira abonação ocorreu em 1919 por Benito Mussolini.

A respeito do terminus a quo de cada uma das palavras temos:

\begin{tabular}{|l|l|l|l|l|}
\hline Dicionário & Língua & Palavra & Étimo & Datação \\
\hline Houaiss & Port. & fascismo & it. fascismo & 1921 \\
\hline Corominas & Esp. & fascismo & $\begin{array}{l}\text { It. fascismo } \\
\text { (p. 329) }\end{array}$ & X \\
\hline Zanichelli & It. & fascismo & $\begin{array}{l}\text { X (deriv. de } \\
\text { fascio) }\end{array}$ & 1919 \\
\hline $\begin{array}{l}\text { Le Petit } \\
\text { Robert }\end{array}$ & Fr. & fascisme & it. fascismo & 1921 \\
\hline Caprona & Nor. & fascisme & it. fascismo & X \\
\hline
\end{tabular}




\begin{tabular}{|l|l|l|l|l|}
\hline NbUiB & Nor.Bok. & fascisme & it. fascismo & X \\
\hline Katlev & Din. & fascisme & $\begin{array}{l}\text { Derivado do } \\
\text { latim fascis- }\end{array}$ & X \\
\hline SAO & Sue. & Fasc(k)ism & it. fascismo & 1922 \\
\hline Dud.Herk. & Ale. & Faschismus & it. fascismo & X \\
\hline Kluge & Ale. & Faschismus & it. fascismo & X \\
\hline Ety.Woord. & Hol & fascisme & It. fascismo & 1923 \\
\hline Chr.Woord. & Hol & fascisme & it. fascismo & 1923 \\
\hline Oxford & Ing. & fascism & it. fascismo & X \\
\hline
\end{tabular}

O primeiro registro em que há a palavra fascisme na Biblioteca Nacional é o jornal Nordre Bergenhus Amstidende de 17 de novembro de 1922:

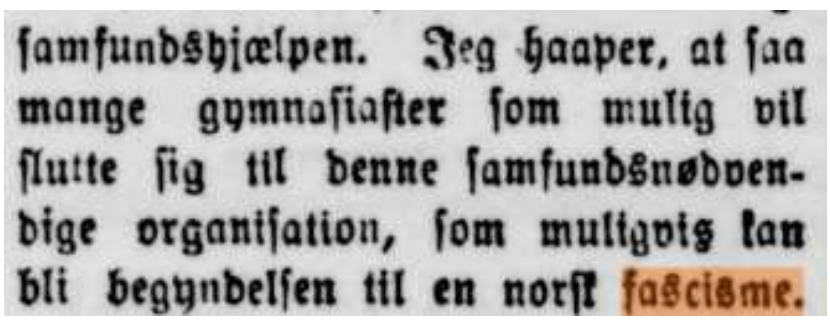

"Eu (Ole Jakob Skattum ${ }^{124}$ ) desejo que muitos alunos de ginásio que querem se associar a essa organização necessária para a sociedade, que possivelmente pode se tornar o início de um fascismo norueguês" (trad. nossa).

A respeito do português, encontramos por meio do Google Books a primeira atestação em 1922 na revista portuguesa Illustração portugueza:

124 Geógrafo (presidente da Norsk Geografisk Selskap), educador, político do partido Frisinnede Venstre (esquerdaliberal de mente aberta) e reitor da escola Vestheim 
"[...] (em 1819 e 1820), tornaram-se, agora, o fascismo, principal, se não o único arbitro dos destinos dos governos d'aquele paiz".

O Houaiss data em 1921 e não especifica o local de onde tirou essa informação.

Como foi uma palavra de rápida divulgação, há várias hipóteses para determinar por onde a palavra chegou tanto ao norueguês quanto ao português: se chegou ao português via espanhol (cuja primeira atestação é, de acordo com nossa pesquisa no Google Books, de 1921125), via francês (também 1921) ou diretamente do italiano (mais provável). É visível que nas línguas escandinavas a palavra chegou um ou dois anos depois e possivelmente direto do italiano por causa da rápida difusão da palavra e dos meios midiáticos

A respeito do primeiro procedimento, o item lexical fascismo é de um tema político e social. Nem o italiano nem qualquer outra língua é a principal representante de empréstimos de palavras cujas acepções são políticas e sociais no início do séc. XX; em vista disso, o alemão, o francês e o inglês também poderiam divulgar palavras de cunho político e social nesse período. $O$ procedimento 1 não se aplica para esta palavra.

O procedimento 2 , a relação entre escrita e pronúncia (em uma sincronia em que se sabe de fato qual era a pronúncia), pode ajudar a determinação de um étimo. Vejamos sons de -sci- nas línguas românicas com a mesma palavra cognata: fr. fascinant [fasi'nã], esp. fascinante [faști'nante], pt. fascinante [fasi'nẽti], mas no it. affascinante [affa]i'nante]. O alemão grafa palavras com -sz- (Faszination, Disziplin, konfiszieren] porque as emprestou em um período em que o -sc- do francês era pronunciado *[ts], mas na palavra mais recente Faschismus temos [] e não * Faszismus, que é o mesmo caso com o ing. fascism ['fæ]Izəm]. No francês há, para fascisme, tanto a pronúncia [fafism] quanto a [fasism], no holandês, norueguês português também há essa variação de [i] ou [si], o dinamarquês pronuncia ao modo francês com [si] como também o islandês: fasismi ['fa:șismi] . Portanto, concluímos que o elemento lexical tem

125 La Reforma social : revista mensual de cuestiones sociales, económicas, políticas, parlamentarias, estadísticas y de higiene pública. 
origem italiana e é o étimo de possivelmente todas as línguas apresentadas porque elas produzem o som [i]], grafado -sci- no italiano, em uma combinação de consonantes que não corresponde ao som que naturalmente reproduziriam. Outra conclusão que podemos tomar é a de que ele provavelmente entrou meu meio da oralidade por conta da pronúncia "à italiana" e a pronúncia com [s] no português, por exemplo, começou a ser reproduzida por conta da influência da língua escrita. O único problema que pode ocorrer na determinação do étimo em itens lexicais como essa é se a língua a qual a palavra foi emprestada modificar o som original por conta da escrita.

Também é muito importante considerar o radical do elemento lexical, pois ele pode ser um vernáculo de uma língua específica e aqui trata-se do procedimento 3. No caso de fascismo, há o radical fasci-, que vem de fascio "feixe", o que remonta totalmente ao italiano e não ao francês faix, português feixe ou espanhol feje.

O procedimento 4 tem a ver com a hipótese de Freitas (2013) sobre os cruzamentos panromânicos. Na hipótese de Freitas postula-se que não há "em duas ou mais línguas românicas o mesmo empréstimo latino, uma vez que tende a ocorrer primeiro em uma das línguas, e desta, passar a outras” (p. 443). Com relação aos elementos lexicais internacionais e de grande divulgação, também é possível aplicar essa hipótese muito além do mundo românico, possivelmente como um cruzamento panromânico e pangermânico.

Como definidores do grau de certeza, podemos utilizar, junto a esse procedimento, o prestígio de uma língua (francês, por exemplo), a proximidade geográfica (espanhol) e, obviamente, o terminus a quo. No que tange ao elemento lexical fascismo, confirma-se a hipótese do panromanísmo, pois surgiu em uma única língua que passou para as outras línguas românicas, mas também espalhou também para o mundo germânico. O prestígio e a proximidade geográfica não são relevantes nesse caso, uma vez que esse elemento lexical foi emprestado para as outras, não por ser prestigioso, mas por necessidade de expressão desse novo modelo político. Além do mais, como ocorreu num período de grande propagação de mídia, o espaço geográfico teve pouco efeito. 
A semântica da palavra, procedimento 6, também é importante para definir o étimo de uma palavra. Durante o empréstimo da palavra, pode ocorrer apenas a transmissão de uma de suas acepções, que pode sofrer transformação na língua receptora e, novamente, ser emprestada para outras línguas em contato. Portanto, é importante saber o significado da palavra em cada uma das línguas cognatas. No caso da palavra fascismo, ela surgiu com apenas uma acepção e, assim, passou para as outras línguas. 


\section{$3 \quad$ Análise}

A análise está dividida em duas partes. Na primeira parte se apresenta os dados coletados em todas as línguas cognatas. O terminus a quo e os procedimentos que podem fortalecer/enfraquecer a determinação do étimo estão elencados e discutidos na segunda parte. Nela também apresentaremos a ficha de Etimologia do elemento lexical tanto para um dicionário português quanto para um norueguês (tanto bokmål quanto nynorsk). O modelo da ficha é o seguinte:

\section{Elemento lexical (gênero)}

Acepção do elemento lexical

Hipótese 1 do caminho percorrido pela elemento lexical

Hipótese 2 do caminho percorrido pela elemento lexical Etc...

Comentários (se necessário)

Ano da primeira abonação. Obra da primeira abonação

Trecho em que o elemento lexical ocorre (apenas para o norueguês, pois no português já foi citado na análise)

Origem do significado da acepção

Origem do significante da acepção

Étimo de empréstimo

Localização da obra

Ao lado de cada hipótese colocaremos sua porcentagem. Quando houver um colchete entre uma língua e sua datação, na sequência de línguas por quais o elemento lexical passou, isso significará que essa língua pode ter sido ou não um intermédio por qual o elemento lexical passou. Por exemplo:

pt. 4 esp. $\triangleleft[$ [it.] $\triangleleft$ fr. 
No exemplo acima temos a hipótese de que o francês foi o ponto de partida do elemento lexical que, em seguida, surgiu no espanhol, sendo ou não o italiano uma língua intermediária. Nesta representação, o étimo do elemento lexical no português só pode ser espanhol. Exemplo de uma hipótese apresentada na análise da palavra navegação:

20\% ( din. na Noruega navigation $1766 \triangleleft$ din. navigation 1707 ale. Navigation 1589 ४ hol. navigatie $1549 \triangleleft$ [fr. navigation 1538] \ pt. navegação 1499)

Neste caso, o elemento lexical tem a primeira abonação na língua portuguesa e o dinamarquês emprestou do alemão. Como o holandês não está em colchetes, o étimo da palavra alemã só pode ser holandês (tendo em vista que é a primeira abonação do alemão é uma tradução de uma obra holandesa); o holandês, por sua vez, uma vez que o francês apresenta os colchetes, pode ter étimo francês e português.

Um exemplo de porcentagem seria:

$$
\begin{aligned}
& 25 \% \text { pt. } 4 \text { esp. } \\
& 25 \% \text { pt. } \triangleleft \text { it. } \\
& 25 \% \text { pt. } \triangleleft \text { fr. } \\
& 25 \% \text { pt. } \triangleleft \text { ing. }
\end{aligned}
$$

No exemplo acima temos 4 hipóteses e, como não conseguimos encontrar dados que reforçam uma delas, cada uma tem $25 \%$ de chances de ser verdadeira. Se, por outro lado, a primeira abonação for uma tradução de alguma dessas obras, por exemplo, uma obra de língua italiana, afirmaremos que há $100 \%$ de chances de ser um empréstimo do italiano.

Abaixo da ficha do norueguês bokmål e caso a obra seja anterior à cerca de 1907, que foi o ano, como apresentado no subcapítulo 1.4.2.5, em que ocorreu o primeiro acordo ortográfico para o bokmål, colocaremos indícios linguísticos para comprovar se a obra está, de fato, escrita em norueguês. Esta adaptação ortográfica não ocorreu repentinamente e muitos jornais ainda não a 
utilizavam após o ano de 1907; por outro lado, já havia pensadores e linguístas que utilizavam elementos noruegueses muito antes desse ano.

A respeito do nynorsk, por não ter sido uma norma que surgiu de uma base dinamarquesa e, portanto, desde seu início já era norueguesa, não é necessária tal a apresentação de qualquer indício. 


\subsection{Aberração/Aberrasjon}

\subsubsection{Apresentação dos dados}

\subsubsection{Mundo germânico}

Norueguês

Significados em dicionários atuais (a partir de 1901 em nynorsk e 1907 em bokmål):

\begin{tabular}{|c|c|c|c|}
\hline Dic. & Significado & Etimologia & Datação \\
\hline $\mathrm{NbUiB}$ & $\begin{array}{l}\text { 1. (astron.) mudança } \\
\text { aparente na posição } \\
\text { de uma estrela por } \\
\text { causa do movimento } \\
\text { da luz e da terra; } \\
\text { 2. Diferença entre um } \\
\text { objeto e a imagem } \\
\text { do mesmo quando } \\
\text { os raios de luz dele } \\
\text { são quebrados por } \\
\text { meio de uma lente; } \\
\text { 3. (biol.) modificação } \\
\text { anormal em um } \\
\text { cromossomo durante } \\
\text { a divisão das células }\end{array}$ & $\begin{array}{l}\text { Do lat. aberrare } \\
\text { "divergir, } \\
\text { discrepar" }\end{array}$ & Não consta \\
\hline NyUiB & $\begin{array}{l}\text { 1. Igual } \\
\text { 2. Erro na imagem } \\
\text { refletida por uma }\end{array}$ & $\begin{array}{l}\text { Do lat. aberrare } \\
\text { "divergir, }\end{array}$ & Não consta \\
\hline
\end{tabular}




\begin{tabular}{|c|c|c|c|}
\hline & $\begin{array}{l}\text { lente } \\
\text { 3. } \text { Igual }\end{array}$ & discrepar" & \\
\hline NTG & $\begin{array}{l}\text { 1. Igual } \\
\text { 2. Igual (aberração } \\
\text { esférica e cromática) } \\
\text { 3. Igual }\end{array}$ & $\begin{array}{l}\text { Do latim "desvio, } \\
\text { discrepância" }\end{array}$ & $x$ \\
\hline ROB & $\begin{array}{l}\text { 1. (lit., fis.) desvio a } \\
\text { diferentes pontos de } \\
\text { encontro de raios de } \\
\text { luzes que vêm de } \\
\text { uma mesma fonte e } \\
\text { passam por uma } \\
\text { lente ou são } \\
\text { refletidos de um } \\
\text { espelho } \\
\text { 2. (astron.) modificação } \\
\text { de lugar notável da } \\
\text { estrela em } \\
\text { consequência do } \\
\text { movimento } \\
\text { simultâneo da luz e } \\
\text { da Terra }\end{array}$ & $\begin{array}{l}\text { do latim aberratio } \\
\text { ("engano, } \\
\text { equívoco, erro"; } \\
\text { "perder-se") }\end{array}$ & $x$ \\
\hline
\end{tabular}

\section{Obras em dinamarquês publicados na Noruega}

O primeiro registro deste elemento lexical está no jornal Den Norske Rigstidende de 10 de novembro de 1831, mas faz parte de uma listagem de livros dinamarqueses publicados em setembro de 1831: Begyndelses-Grundene af Læren om Aberrationen, ved H. J. Hansen. En astronomisk Monographie [...] 
"Fundamentos iniciais do ensino da aberração, com H. J. Hansen. Uma monografia astronômica [...]" (trad. nossa).

A segunda abonação ocorre no livro sobre política e economia de Strøm (1833) e não tem nenhuma acepção técnica:

[...] i det man, ved en Aberration fra hiint hovedprincip lod seg forleede til at udviide $[\ldots]$ (p. 38)

"Enquanto, em um desvio do princípio fundamental, deixou-se levar a ampliar [...]" (trad. nossa)

No mesmo período, há outros registros em jornais com um sentido mais geral, de desvio, como por exemplo em Aberration i Anskuelsen "aberração no entendimento" (Den Constitutionelle 10.03.1836) e [...] som en Aberration fra de naturlige Forholde "como uma aberração das relações naturais" (Den Constitutionelle 06.04.1836), Aberrationer fra Sandheden "desvios da verdade" (Morgenbladet, 20.08.1847), etc.

Em 1841 atesta-se pela primeira vez o elemento lexical com acepção astronômica nos livros noruegueses, se não considerarmos a citação do jornal acima, na obra de Arago (1841, tradução de Langberg):

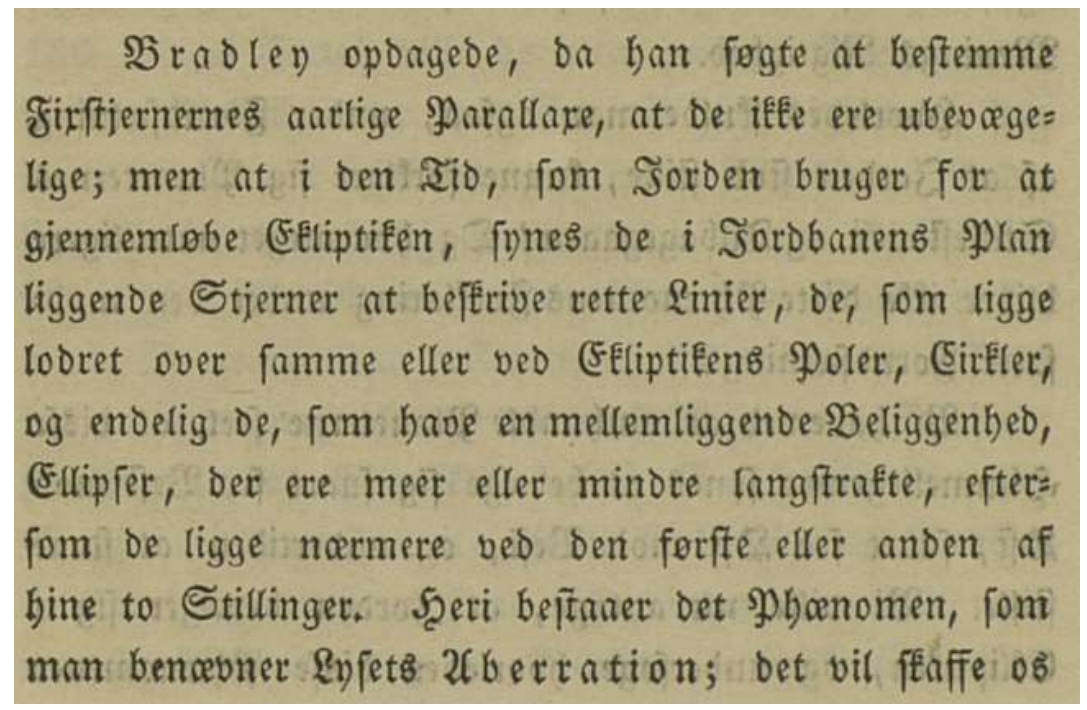

"Bradley, se empenhando em determinar as paralaxes anuais das estrelas fixas, descobriu que elas não são imóveis; mas que parecem descrever, durante o período em que a Terra usa para atravessar sua órbita, tais como 
aquelas que estão no plano dessa órbita, linhas retas; que estão em um plano perpendicular a essa órbita, a descrever círculos e que estão em planos intermediários, a descrever elipses mais ou menos alongadas, de acordo com o fato de estarem mais ou menos perto de uma ou de outra dessas posições. Trata-se do fenômeno chamado de Aberração da Luz [...] (trad. nossa)

No jornal Morgenbladet, edição de 21 de junho de 1851, informa-se sobre o famoso escritor sueco de sua época Carl Jonas Love Almqvist, que fugiu da Suécia por suspeita de fraude e tentativas de envenenamento do usurário Johan Jacob von Scheven a quem ele devia 18.000 riksdaler:

[...] maatte han ved deres Udklækkelse eller Udførelse have været besat af en dæmonisk Aberration eller Manomani, til hvilken man maa søge et Modstykke $i$ Goethes Faust eller Eugen Arams historie [...]

"[...] ele teria com sua imaginação ou realização sido possuído por uma aberração demoníaca ou Manomani a qual deve-se buscar um equivalente no Fausto de Goethe ou na história de Eugene Aram [...]" (trad. nossa)

Como uma acepção de "erro" encontramos no livro sobre o surgimento da saga dos reis, de Gjessing (1873):

I Frisbogen er $i$ dette Cap. det Granmar tiltænkte Sæde udeladt ved Aberration fra [...] (p. 27)

"No livro de Fris e nesse capítulo, o sítio destinado ao Granmar é omitido por erro [...]" (trad. nossa)

Em algumas obras encontramos a preferência pelo uso da forma nórdica em vez da forma latina: dicionário dano-norueguês-francês de Sundby (1883), abaixo citado, e o manual de física de Schiøtz (1881), em que aparece: den sfæriske Afvigelse (Aberration).

$\mathrm{Na}$ acepção óptica, a primeira abonação está no livro de Arndtsen (1853):

Dette benævner man her som ved huuspeilene den sphæriske Aberration. ( $p$. 70)

"Isso chama-se aqui como em espelhos côncavos de aberração esférica." (trad. nossa) 


\section{Obras lexicográficas}

No dicionário de palavras estrangeiras de M. C. Hansen (1851) atestase o seguinte:

Aberration, en, Forvildelse; Afvigelse fra den lige Retning

"Aberração, gen.com. variação, discrepância do caminho ou da direção" (trad. nossa)

Nos dicionários de inglês-dano-norueguês-inglês:

\begin{tabular}{|l|l|l|l|l|}
\hline Inglês & $\begin{array}{l}\text { Dano- } \\
\text { Norueguês }\end{array}$ & Autor & Tipo & Ano \\
\hline Aberration & $\begin{array}{l}\text { Afvigelse } \\
\text { "discrepância", } \\
\text { Vildfarelse } \\
\text { "erro, engano" }\end{array}$ & Geelmuyden & Geral & 1855,1872 \\
\hline
\end{tabular}

No dicionário de francês-dano-norueguês de Sundby (1883/1884):

\begin{tabular}{|l|l|l|l|l|}
\hline Francês & $\begin{array}{l}\text { Dano- } \\
\text { norueguês }\end{array}$ & Autor & Tipo & Ano \\
\hline Aberration & $\begin{array}{l}\text { (Estrela; de } \\
\text { estado normal) } \\
\text { Afvigelse; } \\
\text { Forvildelse }\end{array}$ & Sundby & Geral & $1883 / 1884$ \\
\hline
\end{tabular}

Concluímos que a abonação com acepção astronômica ocorre no ano de 1831 e com acepção geral, já a partir de 1833. A acepção óptica surgiu apenas 
em 1853. Os dicionários bilíngues, por outro lado, não atestam esse elemento lexical.

\section{Cognatas em outras línguas germânicas}

Dinamarquês (publicado na dinamarca)

O corpus Renæssancens Sprog i Danmark cita apenas Pedersen (1510) como obra que tem a cognata correspondente, porém, apenas na forma latina aberratio, que teria como tradução villfarelse "erro", "engano", "desvio".

Pelo Google Books encontramos o elemento lexical em um artigo de Horrebow (1747) publicado em uma revista chamada:

Om Fixstiernernes Aberrationer som nu, efterat deres rigtige Theorie og Aarsage er funden, bør kaldes Refractioner eller Anaclases. (p. 107)

"Sobre as aberrações das estrelas fixas que agora, depois que suas teorias e causas foram encontradas, devem ser chamadas de refrações ou anáclases" (trad. nossa)

No capítulo XII. Forklaring over adskillige fremmede Sprogs Ord, som i Almindelighed bruges og indføres udi Breve [...] og Skrifter [...] "Explicação sobre diferentes palavras de línguas estrangeiras que no geral são utilizadas e inseridas em cartas [...] e escrituras [...], do livro Arithmetica aurea mercatoria de Arnoldus Bondesøn (1755) não há registro desse item lexical.

Com acepção astronômica ele ainda aparece no léxico de conversação de Kofod (1816):

Sex Aar efter bekjendtgjorde han [James Bradley] sin Opdagelse af Lysets Aberration [...] (p. 504)

"Seis anos depois ele [James Bradley] publicou sua descoberta sobre a aberração da luz [...]" (trad. nossa)

$\mathrm{Na}$ enciclopédia concisa de palavras, expressões e modos de falar estrangeiros de Meyer (1837), temos:

Aberration, en, Forvidelse; Afvigelse fra Banen el. fra den lige Retning (om Planeter og Lystraaler) 
"Aberração, gênero comum, perde-se, extraviar-se, induzido, imoral, equivocado; variação, discrepância do caminho ou da direção (de planetas e raios de luz)" (trad. nossa)

$\mathrm{Na}$ tradução dinamarquesa da obra Kosmos (Band I) (1847) de Alexander von Humboldt, ocorre a tradução de Abirrung des Lichtes por (Lysets) Aberration. Essa obra tem o mesmo tema da obra de Arago, acima citada e Abirrung é uma formação alemã de mesmo sentido.

O elemento lexical tem a acepção no Almennyttigt Dansk Konversations-Lexikon (1849-1860, mas o volume 1 é de 1849) de: Forvildelse, Afvigelse fra Banen eller den lige Retning (Se Lysets Aberration) "perde-se, extraviar-se", "induzido", "imoral", "equivocado"; "variação, discrepância do caminho ou da direção (veja Aberração da Luz)" (trad. nossa). No verbete Astronomi, dentro da acepção 1) Den sphæriske Astronomi "a astronomia esférica" afirma-se que se ocupa com as aparições no céu [...] com o ensino sobre aparições gerais como Nutation, Aberration, Parallaxe.

$\mathrm{Na}$ acepção óptica, a primeira abonação encontrada no dinamarquês está na obra de Hompel (1849):

Derimod tjener Iris som et kunstigt Diaphragma til at indskrænke den altfor stærke sphæriske Aberration [...]

"Entretanto, a íris serve como um diafragma artificial para reduzir a aberração esférica muito forte [...]" (trad. nossa) (p. 47).

\section{$\underline{\text { No sueco }}$}

De acordo com o Svenska Akademiens Ordbok, o primeiro registro da cognata correspondente aberration é de 1745 , na obra de Anders Johan von Höpken, com a acepção da astronomia e da física.

Retrodatamos este item lexical porque encontramos uma abonação mais antiga na revista Kungliga Svenska Vetenskapsakademiens Handlingar, edição de 1744, feita por Wargentin:

[...] af fix-stiernornas så kallade aberration, hvilken den berömlige Engländaren Herr Bradley nyligen uptäckt [...] (p. 139) 
"[...] da então chamada aberração das estrelas fixas, que o famoso inglês Mr. Bradley recentemente descobriu [...]" (trad. nossa)

Na acepção física e geométrica encontramos o terminus a quo também na revista Kungliga Svenska Vetenskapsakademiens Handlingar, edição de 1753, com o título de Geometriska Aberrationer de A. G. Kästner (p. 126).

No inglês:

De acordo com Oxford (CD-ROM, 2010), a cognata correspondente aberration apareceu no inglês no final do séc. XVI e tem apenas uma acepção:

A fact, an action or a way of behaving that is not usual, and that may be unacceptable

De acordo com o dicionário etimológico de Murray (1888-1933), no período havia muitas acepções, que podem ser resumidas. O primeiro registro é de 1594 e tem a acepção de a wandering from the path of rectitude, or standard of morality; morality irregularity, quer dizer, tem a acepção de "engano, infração, distração, desvio" e é a terceira acepção:

Error in religion and aberration in manners.

Encontramos, no entanto, uma abonação cinco anos mais antiga no corpus Early English Books, que se encontra em uma obra de $1589^{126}$ de Job Throckmorton:

[...] M. Some in his calme conceite can wel afforde it to be, for it semeth he dare goe noe farther then to An aberration of the Christian Church (...)

"[...] M. Some em seu pacífico pensamento pode bem permitir que isto assim seja, pois parece que ele não se atreve a ir mais longe do que a Uma aberração da Igreja Católica [...]" (trad. nossa)

De acordo com The Christian Research Institute (CRI), a aberração é diferente da heresia, que é o falso ensinamento dos elementos básicos que

126 M. Some laid open in his coulers VVherein the indifferent reader may easily see, hovve vvretchedly and loosely he hath handeled the cause against M. Penri. Done by an Oxford man, to his friend in Cambridge. 
fundamentam a fé histórica cristã, que dizer, as heresias são ensinamentos que abertamente negam uma de suas doutrinas fundamentais (trindade, Jesus Cristo como divindade, ressurreição). Por outro lado, quando um ensinamento não nega manifestamente a teologia bíblica, mas é igualmente perigoso e inconsistente com a confissão ortodoxa da fé, ele é denominado aberração. O autor do trecho acima, Job Throckmorton (1545-1601), de acordo com Auchter (2001), era um protestante inglês, de visão puritana, membro do Parlamento, que autorizou as sátiras anticlericais de um autor anônimo (ou autores) cujo pseudônimo era Martin Marprelate. Esse autor (ou autores) anônimo escreveu os tratados de Marprelate, que circularam ilegalmente na Inglaterra e no País de Gales entre os anos de 1588 e 1589 tinham como principal objetivo atacar o episcopado do anglicanismo.

Concluímos que o termo aberração nesse caso, é uma conduta da igreja católica que desvia e é inconsistente com a verdadeira fé, do ponto de vista do protestantismo puritano, ou seja, condiz com a acepção dada por Murray (i.e. wandering from the path of rectitude, or standard of morality; morality irregularity).

A primeira acepção do dicionário de Murray é a wandering away, a straying. A segunda (1610-1631), a deviation or divergence from a direct, prescribed, or ordinary course of mode of action; quer dizer, tem o sentido de "partida". A quarta (1823), a wandering of the intellect, an abnormal state of any intellectual faculty, ou seja, erro de julgamento, uma lacuna de imaginação; a quinta, deviation from the ordinary or normal type of any natural production.

A acepção óptica surgiu apenas em 1753 na Cyclopaedia, Supplement, Vol 1 de Ephraim Chambers:

Aberration, in optics, is used to denote that error or deviation of the rays of light, when inflected by a lens or speculum, whereby they are hindred from meeting or uniting in the same point.

A acepção astronômica é, de acordo com o dicionário, the displacement of the true position of a heavenly body to na observer on the earth, occasioned by the joint effect of the earth's motion, and the non-instantaneous transmission of light; hence also called aberration of light. Como primeiro registro está a obra de Lardner, Astron. (1856): 
The apparent displacement produced by aberration is always in the direction of the earth's motion.

Na Biblioteca Nacional da Noruega, diferentemente, encontramos a obra de Maupertuis, Camus, Clairaut, Le Monnier e Celcius (1738):

This Aberration of the fixt Stars seemed at first subject to so great Varieties, that it was not till after a long Course of Observation that Mr. Bradley discovered the Theory (...) (p. 69)

No ano seguinte, o item lexical também aparece no artigo de Smith (1739) na revista Philosophical Transactions:

It may be imagined, perhaps, at first View, that (if our Reasoning is just) the Errors of refracting Telescopes, occasioned by different Refrangibility of Light, may be corrected by a like Artifice: But the Aberration of the Rays from the principal Focus it here so grat (...) (p. 334)

Esta é a revista em que apareceu pela primeira vez as primeiras observações do astrônomo James Bradley (1693 - 1762) do que viria a ser conhecido como aberração da luz. Essa descoberta foi evidência conclusiva para o movimento da Terra e, por isso, corrigiu as teorias de Aristarchus e Kepler. Ela foi anunciada pela primeira vez por James Bradley na edição de janeiro de 1727 dessa mesma revista ${ }^{127}$, mas não encontramos no artigo aberration.

No dicionário inglês que explica termos difíceis de Coles (1717), aberration significa going astray, quer dizer, ainda não havia a acepção acima.

Concluímos que esse elemento lexical com a acepção de "comportamento não aceitável" surgiu no final do séc. XVI, mas a acepção científica apenas em 1739 e foi transportada para o domínio da óptica e física, uma vez que aparece na obra de Chambers (1753).

\section{No alemão}

Nem no Duden (Das Herkunftswörterbuch) nem no Kluge há uma cognata correspondente como entrada.

127 Disponível em http://rstl.royalsocietypublishing.org/content/35/399-406.toc 
No corpus Deutsches Textarchiv, o primeiro registro é de 1764. Ao procurar no Google Books, a primeira obra a registrar essa cognata é a revista de medicina Sammlung von Natur- und Medicin- wie auch hierzu gehörigen Kunstund Literatur-Geschichte (1718) de Johan Kanold:

Die hiervon erfolgende, und gewiss sehr gemeine, metaschematismi morborum in abdomine, die angustiae asthmaticae Pectoris, Vertigines, Sufurrus \& Gravitates capitis, u.d.g.m. sind offt kräfftiger zum Beweis obiger aberration (...) (p. 773)

"A metaschematismi morborum in abdomine, a angustiae asthmaticae pectoris, vertigines, Sufurrus \& Gravitates capitis, u.d.g.m., que ocorrem a partir disso e que são certamente muito cruéis, são sempre mais evidentes para a aberração acima [...]" (trad. nossa)

Na Enciclopédia Universal de Zedler (1731-1754) não encontramos nenhuma citação de Aberration.

A obra Erklärung über das ... 1734 in der Grafschafft Schackenburg ... gefundene güldene Horn [...] de Gutacker (1736), que relata sobre a descoberta por Erich Lassen de um dos itens arqueológicos rúnicos mais famosos, o segundo chifre de Gallehus, tem essa cognata. Ao descrever o terceiro círculo do objeto arqueológico, temos:

Das ander Thier mit 2. Köpfen ist ein Monstrum naturae, woraus die Druiden wegen Unvollkommenheiten und aberration der Natur ein Ormen (...) (p. 17)

"O segundo animal com duas cabeças é um Monstrum naturae, de que os druidas por conta de suas imperfeições e aberração da natureza, um augúrio [...]" (trad. nossa).

Com acepção científica, a primeira atestação está num artigo que é uma continuação de um outro, Fortsetzung des im vorigen Stücke abgebrochnen Auszuges, aus den Schriften der kaiserl. Petersburg-Akademie (1751):

[...] Abhandlung von der aberration der Fixsterne (p. 354).

"(...) tratado da aberração das estrelas fixas" (trad. nossa)

A respeito da acepção óptica, encontramos o seguinte trecho por meio do Google Books na obra Göttingische Anzeigen von gelehrten Sachen (97. Stück. 13 de agosto de 1763): 
[...] und es ist möglich, durch die Vereinigung zwei verschiedener durchsichtiger Köper die Aberration zu vermeiden, die aus der verschiedenen Brechbarkeit der Strahlen entsteht. (p. 783)

"[...] e é possível, por meio da unificação de dois corpos diferentes e transluzentes, evitar a aberração que é gerada a partir da distinta refrangibilidade dos raios." (trad. nossa)

No holandês

O banco de etimologia afirma que, de acordo com Philippa (20032009), a cognata aberratie aparece pela primeira vez em 1658 com o sentido de afdwaling "desvio" e em 1853 com a acepção de "aberração da luz". É um empréstimo do francês aberration (1624) do latim aberratio. N. van der Sijs (2001) também afirma que o item lexical com a acepção de "desvio" é de 1658 e vem do francês.

O WNT (Woordenboek der Nederlandsche Taal); no entanto, afirma que o item lexical com acepção de "desvio" surgiu apenas em 1888; com a acepção de "aberração da luz", concorda com os outros.

Pelo Google Books encontramos uma abonação com a acepção astronômica em um artigo de Struyck (1761):

In het berekenen van deeze Plaatsen, is de Parallaxis, Aberratie en Refractie [...] (p. 305)

"No cálculo desses locais, a paralaxe, aberração e refração [...]" (trad. nossa)

\subsubsection{Mundo românico}

\section{Português:}

Os dicionários de língua portuguesa atestam a etimologia desse elemento lexical da seguinte maneira:

\begin{tabular}{|l|l|l|}
\hline Dicionário & Étimo & Datação \\
\hline Houaiss (online) & $\begin{array}{l}\text { lat. aberratio, onis, } \\
\text { "processo de se afastar }\end{array}$ & $\begin{array}{l}1813 \quad \text { (Diccionario da } \\
\text { Lingua Portugueza [...] por }\end{array}$ \\
\hline
\end{tabular}




\begin{tabular}{|l|l|l|}
\hline de, desvio do bom & Antonio de Morais Silva \\
caminho", der. do v. & (2a edição), Lisboa [= \\
aberrare "errar longe, & MS $^{2}$ ]. \\
extraviar-se", de $\quad$ ab- & \\
"afastamento" + errare & \\
"errar, vagar"; na acepção & \\
de "desvio do juízo" é & \\
decalque do fr. aberration & \\
(1733). &
\end{tabular}

O dicionário cita 9 acepções. Da primeira até a quinta tratam-se de desvios, quer dizer, de padrão, de regularidade, de natureza, de moralidade, de bom senso. A sexta acepção é do campo astronômico: desvio angular aparentemente de um astro na direção do observador, provocado pela composição da velocidade da luz e da velocidade do nosso planeta; aberração da luz, aberração das fixas. A sétima trata-se da óptica: desvio dos raios luminosos que atravessam um sistema óptico, provocando uma distorção na imagem. A acepção oito é da medicina e a nove, é da teratologia, corpo de conformação anômala. Também são citadas várias locuções: aberração da luz, aberração das fixas, aberração de esfericidade, aberração esférica, aberração geométrica, aberração planetária, etc.

A primeira versão do dicionário de Antonio de Moraes Silva, Diccionario da Lingua Portugueza composto pelo padre D. Rafael Bluteau, reformado, e accrescentado por Antonio de Moraes Silva (1789) não tem a entrada desse elemento lexical. Ele foi inserida apenas na segunda edição de $1813 \mathrm{com}$ a acepção de movimento apparente das estrellas fixas. Houaiss apenas cita a data e a obra, como acima demonstrado. Na terceira (1823) e quarta edições (1831) descrevem-se a mesma acepção. Não tivemos acesso às edições seguintes. $\mathrm{Na}$ oitava (1890), por outro lado, há a acepção: (do Lat. aberratio) (t. astr.) Movimento apparente das estrellas fixas; (t. De opt.) Aberração da luz; dispersão de seus raios; (t. med.) desmancho na disposição dos orgãos e no exercício das suas funcções. 
No Corpus Lexicográfico do Português não encontramos aberração, apenas a forma latina aberratio, como por exemplo, Bento Pereira em sua obra Prosodia (1697) afirma que aberratio significa "o desvio do caminho direito", com base em Cícero; em sua outra obra Thesouro (1697), desvio e sincada são traduzidos por declinatio, aberratio.

No vocabulário de Bluteau (1728, p. 689) não há aberração, mas aberratio, que aparece nas seguintes entradas: allucinaçam, desvarîo, digressam, distracçam (mentis aberratio) e divertimento e desattençaõ (mentis aberratio). Bluteau cita Cícero nessas entradas. Este item lexical é entendido por ele como "variedade do juízo", "quando o orador aparta do seu principal assumpto", quer dizer uma digressão, é uma "cousa que diverte os sentidos, ou o pensamento de qualquer seria occupaçaõ".

No Diccionario de Carlos Folqman (1755), a entrada distracçam é entendida como "inquietação, ou divertimento do pensamento; mentis aberratio, ou avocatio".

Em Parvum Lexicon (1798) de Pedro José da Fonseca, aberratio é traduzido por "desvio, apartamento".

Nenhuma das obras do Corpus Lexicográfico prova a existência desse elemento lexical no período até 1798 .

Nos dicionários de etimologia da língua portuguesa encontramos as seguintes atestações:

\begin{tabular}{|l|l|l|l|}
\hline Dicionário & Forma & Étimo & Datação \\
\hline Cunha (1999) & Aberração & $\begin{array}{l}\text { Do fr. aberration, } \\
\text { deriv. do latim } \\
\text { aberratione- }\end{array}$ & $\begin{array}{l}\text { XIX (“desvio, } \\
\text { desacerto, } \\
\text { deslocamento") }\end{array}$ \\
\hline
\end{tabular}

Por meio do Hathitrust Digital Library, pudemos encontrar a abonação em um livro mais antigo e, assim, retroagir o terminus a quo dado pelo Houaiss e 
pelo Cunha a respeito da acepção científica óptica. Nele há o artigo Elogio Historico de João Le Rond D'alembert, escrito por Francisco de Borja Garção Stockler, contido na obra Memorias da Academia Real das Sciencias de Lisboa, Tomo I (1797):

Este grande Geometra tinha affirmado contra a expressa decisão de Newton, que a aberração de refrangibilidade nos Telescopios podia destruir-se, combinando na composição das suas lentes diversas materias [...] (p. 572).

A respeito de aberração com uma acepção não científica, por meio da Hereoteca Digital Brasileira, a encontramos no artigo Particularidades e observaçoens, sobre os Ministros de Finança de França, que tem sido mais celebres, desde 1660, até 1791; 1 volume, 8o Londres, 1811 na parte de Literatura e Sciencias na edição de fevereiro de 1812 do Correio Braziliense:

Não saõ somente os Ministros de Finanças os que tem experimentado ésta aberraçaõ do juizo nacional; tem-se ella extendido até os reys, a todos os objectos do Governo, e aos objectos que Ihe saõ extranhos, Luiz XIV., tem sido exaltado, e quase adorado: quando empregava a uma vaã magnificencia, a substancia de seus subditos; quando fazia correr o sangue humano por guerras injustas [...] (p. 165).

\section{Espanhol:}

Nos Corominas encontramos a seguinte entrada:

\begin{tabular}{|l|l|l|l|}
\hline Dicionário & Forma & Étimo & Datação \\
\hline $\begin{array}{l}\text { COROMINAS } \\
(1984)\end{array}$ & Não consta & Não consta & Não consta \\
\hline
\end{tabular}

O Corominas apenas cita aberrar, que vem do lat. aberrare "desviar-se do caminho.

Ao pesquisar no Google Books a obra mais antiga que cita a acepção astronômica é a de Zuñiga (1743):

Si las observaciones de la segunda operacion se quieren corregir tambien 3 $1 / 2$ ", que padeciò mas de Aberracion de la luz à 31 de Julio [...] (p. 16) 
Como primeiro registro de aberração com a acepção não científica temos a tradução da obra do abate francês Barruel (1813):

De este modo al miesmo tiempo em que el filosofismo celebraba sus triunfos, debia el orgullo de la secta verse humillado por la aberracion y extravagancia mais impía del mais querido de los iniciados. (p. 219)

A acepção óptica é do ano de 1781, na obra Elementos de matemática de Benito Bails:

Como hemos tomado $P$ y $P^{\prime}$ para representar la aberracion media, la aberracion que se destruye, por medio de la fórmula antecedente, es la de los rayos intermedios. (p. 523)

Italiano:

\begin{tabular}{|c|c|c|c|}
\hline Dicionário & Forma & Étimo & Datação \\
\hline ZINGARELLI & aberrazióne & $\begin{array}{l}\text { Voc. culto, lat. } \\
\text { aberratione }(m) \text { V. } \\
\text { aberrare }\end{array}$ & 1750 \\
\hline Deli & aberrazióne & $\begin{array}{l}\text { Voc. culto. Lat. } \\
\text { aberrare "desviar- } \\
\text { se, errar, afastar-se" } \\
\text { (comb. de ab "de" e } \\
\text { errare "vagar"), com } \\
\text { der. aberratione }(m) \\
\text { "distração, } \\
\text { diversão". A difusão } \\
\text { de aberração } \\
\text { influenciou } \\
\text { certamente o fr. e o }\end{array}$ & $\begin{array}{lr}1750 \text { (F. Algarotti, } \\
\text { “irregularidade de } \\
\text { orgãos } \\
\text { funções"); } 1772 \\
\text { (D'Alb. "desvio } \\
\text { aparente dos } \\
\text { astros de suas } \\
\text { posições"); } 1819 \text { (Il } \\
\text { Conciliatore, } \\
\text { "desvio moral, } \\
\text { perda") e } 1829\end{array}$ \\
\hline
\end{tabular}




\begin{tabular}{|l|l|l|l|}
\hline & $\begin{array}{l}\text { ing. aberration, } \\
\text { usado em inúmeras } \\
\text { acepções. }\end{array}$ & $\begin{array}{l}\text { (Tram. "defeito na } \\
\text { formação ou } \\
\text { imagem de parte } \\
\text { de um sistema } \\
\text { óptico"). }\end{array}$ \\
\hline
\end{tabular}

O Zingarelli cita quatro acepções: 1) sinônimo de degeneração, perversão, desvio da norma; 2) med. anomalia, irregularidade dos orgãos e de suas funções; 3) fís. Defeito na formação da imagem de parte de um sistema óptico e 4) astron. Desvio aparente dos astros de suas posições devido a composição vetorial da velocidade da luz com a do observador.

Nos corpora utilizados não encontramos aberração. No Google Books, por outro lado, encontramos datas mais antigas:

Artigo XII da obra de Lioni (1722), com acepção óptico:

Per venir a capo del Problema, era d'uopo correggere nelle lenti sferiche l'aberrazione (p. 390)

"Para resolver o problema, era necessário corrigir a aberração nas lentes esféricas" (trad. nossa)

Del Faggiol (1739), com acepção astronômica:

[...] l'aberrazione del Manfredi: cioè intanto che il terrestre spettatore [...] ( $p$. 27)

"[...] a aberração de Manfredi: isto é, enquanto que o espectator terrestre [...]" (trad. nossa)

Aqui se faz referência ao astrônomo bolonhês Eustachio Manfredi, a quem, de acordo com Gualandi e Bònoli (2004, p. 479), se deve o termo "aberração". Os autores citam o artigo "Chi fu il primo a parlare d'aberrazione?" de G. H. D'Arturo (Coelum, III, 1933), da qual não tivemos acesso. Os autores afirmam que isto está provado na obra de Manfredi chamada De annuis 
inerrantium stellarum aberrationibus, de 1729. De fato, Manfredi utilizou essa cognata correspondente, mesmo que em latim, antes de Bradley, pois este não a utilizou no artigo de 1727 e que só foi utilizada primeiramente por Smith em 1739, como mostrado acima. Conclui-se que a ideia parece ter sido introduzida primeiramente por Manfredi, mas o terminus a quo em italiano deve-se a Del Faggiol (1739).

Com relação à acepção não científica, encontramos uma atestação mais antiga na obra L'elviennesi o sai lettere provinciali filosofiche (tomo III, 1786):

[...] non ravvisar che allievi deliranti, e nel più alto grado di aberrazione! Perdonate, Cavaliere, perdonate un errore, a cui il mio cuore non ha avuto parte $[\ldots]$ (p. 267).

“[...] não reconhecer senão alunos delirantes e no mais alto grau de aberração! Perdoe, Cavaliere, perdoe um erro que o meu coração não tinha parte" (trad. nossa)

\section{Francês:}

Nos dicionários de francês (incluindo os etimológicos):

\begin{tabular}{|l|l|l|l|}
\hline Dicionário & Forma & Étimo & Datação \\
\hline $\begin{array}{l}\text { Le Petit Robert } \\
(2014)\end{array}$ & Aberration & $\begin{array}{l}\text { Lat. aberratio, par } \\
\text { l'anglais }\end{array}$ & $\begin{array}{l}1753 ; \\
\text { "afastamento" } \\
1633\end{array}$ \\
\hline
\end{tabular}

O Französisches Etymologisches Wörterbuch (FEW) afirma que aberratio significa "ação de vaguear para lá e para cá" (1624) e que vem do inglês.

O Le Trésor de la Langue Française informatisé afirma que o primeiro registro é de 1624 action de s'écarter "desviar, afastar-se de" (Philippe d'Aquin ${ }^{128}$, Discours des sacrifices de la loy mosaïque, 52 ds R. hist. Litt. Fr., I, 52) e também o coloca como a primeira acepção: 
Un desvoyement et aberration du vray chemin.

"Um desvio e aberração do caminho verdadeiro" (trad. nossa)

O dicionário afirma que essa acepção é uma derivação do latim aberrare ou do próprio francês *aberrer e que também há no latim medieval aberratio "erro, pecado" (1081, Gebehardus, Ad Hermannum, 2 ds Mittellat. W. s.v.), já no latim clássico havia apenas o significado de "possibilidade de diversão, desvio".

Em 20 de junho de 1733 surge, de acordo com o TLFi, a segunda acepção, que é do campo da astronomia, com o sentido de "fenômeno causado pelo efeito de que as estrelas são vistas da Terra em uma direção diferente da posição que elas realmente se encontram" (Volt., éd. Moland Corresp., I ,354):

[...] par le moyen du feu et à calculer l'aberration de la lumière.

"[...] por meio do fogo e calcular a aberração da luz" (trad. nossa)

O FEW também coloca essa data como terminus a quo. Essa acepção, de acordo com o TLFi, vem do inglês e é o termo que exprime o fenômeno descrito pelo astrônomo inglês James Bradley em 1728, talvez por intermédio do latim científico (lat. aberratio empregado pelo astrônomo italiano Manfredi em 1730).

Em março de 1775 aberration surge com a acepção de "ação de se desviar das regras", que seria a terceira acepção (a) para o TLFi:

[...] toutes les aberrations auxquelles il peut être sujet dans la pratique (...)

"(...) todas as aberrações que podem estar sujeitas na prática [...]" (trad. nossa)

Esta acepção também está de acordo com FEW, que afirma que é "desvio de imaginação, erro de julgamento, falta de direção" 
O TLFi também cita uma terceira acepção (b), que surgiu em 1835 com a acepção de senso moral, quer dizer, erro de julgamento. O FEW cita a mesma data e explica que o sentido é de "aberração momentânea da mente, dos sentidos".

De acordo com o TLFi, é difícil determinar a formação dessa acepção: como extensão da primeira acepção seria pouco provável; talvez, o emprego figurativo das acepções 2 e 4, mas mais provavelmente é um empréstimo do sentido figurativo do inglês aberration (dep. 1594 "engano, infração, distração, desvio" - domínio moral - e dep. 1610-1631 com sentido 1, dep. 1823 com sentido $3 b)$.

De acordo com o TLFi, o item lexical em 1798 aparece com a quarta acepção, a da óptica. O FEW tem a mesma opinião. O TLFi afirma que ela surgiu pela transposição de Chambers ao domínio da física em 1753 (Chambers, Cycl. Supp.), que também passou ao latim científico (1760, Samuel Klingenstierna, De aberratione luminis in superficiebus et lentibus sphericis refractorum, $d s$. Philosoph. Transacations, t. 51, part. II, no LXXXVI, p. 944) e então para o francês em 1798.

\section{Latim:}

Além da cognata no latim científico, podemos citar as acepções dadas por Lewis (2002) e pelo dicionário de Glare (1968):

Um alívio de alguma coisa, uma diversão; talvez apenas em Cicero (e em apenas duas passagens):

[...] sive hanc aberrationem a dolore delegerim. (ad Att., 12, 38)

"[...] ou preferisse desse divertimento (desvio) da tristeza." (trad. nossa)

[...] verumtamen aliam aberrationem a molestiis nullam habemus. (ad Fam. $15,18)$

"[...] entretanto, não temos nenhuma outra distração de nossos problemas" (trad. nossa) 
Os dicionários também afirmam que o verbo aberro significa: 1) vaguear para longe, dispersar, se perder; 2) dispersar-se de um assunto, uma digressão de discurso; 3) desviar de um propósito; 4) afastar de, divergir de (um padrão, um modelo), variar, discordar; 5) errar, fazer um erro e 6) se livrar de.

Não encontramos essa cognata em DuCange (1883-1887).

\subsubsection{Determinação do étimo}

Terminus a quo (mais antigo ao mais novo)

\begin{tabular}{|c|c|}
\hline \multicolumn{2}{|c|}{ Mundo romano } \\
\hline Francês & $\begin{array}{l}1624 \text { "ação desviar, partir, afastar"; } \\
1733 \text { (astr.) } \\
1775 \text { "ação de desviar-se de regras" } \\
1798 \text { (óptica) } \\
1835 \text { "desvio de senso moral, erro } \\
\text { de julgamento" }\end{array}$ \\
\hline Italiano & $\begin{array}{l}1722 \text { (óptica) } \\
1739 \text { (astr.) } \\
1786 \text { "desvio moral" }\end{array}$ \\
\hline Espanhol & $\begin{array}{l}1743 \text { (astr.) } \\
1781 \text { (óptica) } \\
1813 \text { "desvio de regras" }\end{array}$ \\
\hline Português & $\begin{array}{l}1797 \text { (opt.) } \\
1812 \text { "desvio moral, de regras" } \\
1813 \text { (astr.) }\end{array}$ \\
\hline \multicolumn{2}{|c|}{ Mundo Germânico } \\
\hline Inglês & $\begin{array}{l}1589 \text { "desvio de conduta, de } \\
\text { moralidade" } \\
1739 \text { (astr.) } \\
1753 \text { (óptica) }\end{array}$ \\
\hline Holandês & $\begin{array}{l}1658 \text { (Philippa), } 1888 \text { (WNT) } \\
\text { "aceção de desvio"; } \\
1761 \text { (astron.) }\end{array}$ \\
\hline Alemão & $\begin{array}{l}1718 \text { (med.teratologia) "desvio de } \\
\text { padrão, de forma física padrão" }\end{array}$ \\
\hline
\end{tabular}




\begin{tabular}{|l|l|}
\hline & $\begin{array}{l}1751 \text { (astr.) } \\
1763 \text { (ópt.) }\end{array}$ \\
\hline Sueco & 1744 (astron.) \\
\hline Dinamarquês & 1747 (astron.) \\
& 1849 (óptica) \\
\hline Dinamarquês na Noruega & 1831 (astron.) \\
& 1833 (desvio [de um princípio]) \\
& 1853 (óptica) \\
\hline Bokmål & 1910 (desvio) \\
& 1910 (ópt.) \\
& 1915 (astr.) \\
\hline Nynorsk & 1911 (astr.) \\
& 1918 (ópt.) \\
\hline
\end{tabular}

1) A respeito das línguas de influência em determinados temas, a primeira acepção de "desvio" remete a um desdobramento da forma latina e, por isso, poderia ser de qualquer língua românica e até germânica. Tanto a acepção astronômica quanto a acepção óptica, por outro lado, são científicas e há maior possibilidade de ter sido originada em línguas científicas como, por exemplo, inglês, francês e alemão.

2) A relação entre escrita e pronúncia não nos proporciona nenhuma pista para a investigação do étimo, uma vez que cada língua pronuncia o radical aberr- da usa maneira.

3) O radical do item lexical é aberr- e remete ao latim; portanto, não seria um radical exclusivo de nenhuma língua descendente.

4) Aqui a hipótese dos cruzamentos panromânicos de Freitas (2013) se confirma. Tanto a acepção astronômica (latim científico) quanto a de desvio (com seus desdobramentos) são empréstimos do latim, que ocorreram em apenas uma única língua, ou seja, francês e inglês, respectivamente. Entendemos, por outro lado, que seria extremamente possível que outras línguas emprestassem em momentos diferentes o termo emprestado por essas línguas caso a obra latina tenha grande relevância para tradução. 
5) Por meio dos caminhos semânticos conseguimos rastrear e confirmar ou negar atestações dos dicionários utilizados.

Além do terminus a quo, os procedimentos 1) e 5) foram importantes para a definição da etimologia.

\subsubsection{Fichas}

\subsubsection{Para o português}

\section{Aberração s.f.}

Acepção: "desvio"

25\% ( 4 it. 17864 [fr. 1755 "ação de desviar-se de regras"] 4 ing. aberration "desvio de conduta, 1589" — lat. aberratio "desvio de conduta", acepção 4 do dicionário de latim)

25\% ( 4 fr. 1755 "ação de desviar-se de regras" 4 ing. aberration "desvio de conduta, 1589" \ lat. aberratio "desvio de conduta", acepção 4 do dicionário de latim)

$25 \%$ ( 4 ing. aberration "desvio de conduta, 1589"

lat. aberratio "desvio de conduta", acepção 4 do dicionário de latim)

25\% ( lat. aberratio "desvio de conduta", acepção 4 do dicionário de latim)

Comentário: não encontramos nenhum indício que nos dê uma certeza por qual língua esse item lexical chegou ao português, já que o terminus a quo não é uma tradução. A hipótese é de que o inglês tenha emprestado o item lexical do latim e, em seguida, difundido para os outros idiomas. Afirmar que a aberração veio diretamente do inglês ou do latim medieval, ou teve intermédio do francês e italiano seria apenas uma especulação.

1812. Particularidades e observaçoens, sobre os Ministros de Finança de França, que tem sido mais celebres, desde 1660, até 1791

Origem do significado da acepção: latina

Origem do significante da acepção: latina 
Étimo de empréstimo: 25\% latim medieval, 25\% francês, $25 \%$ inglês e $25 \%$ italiano

Local: Heremoteca digital

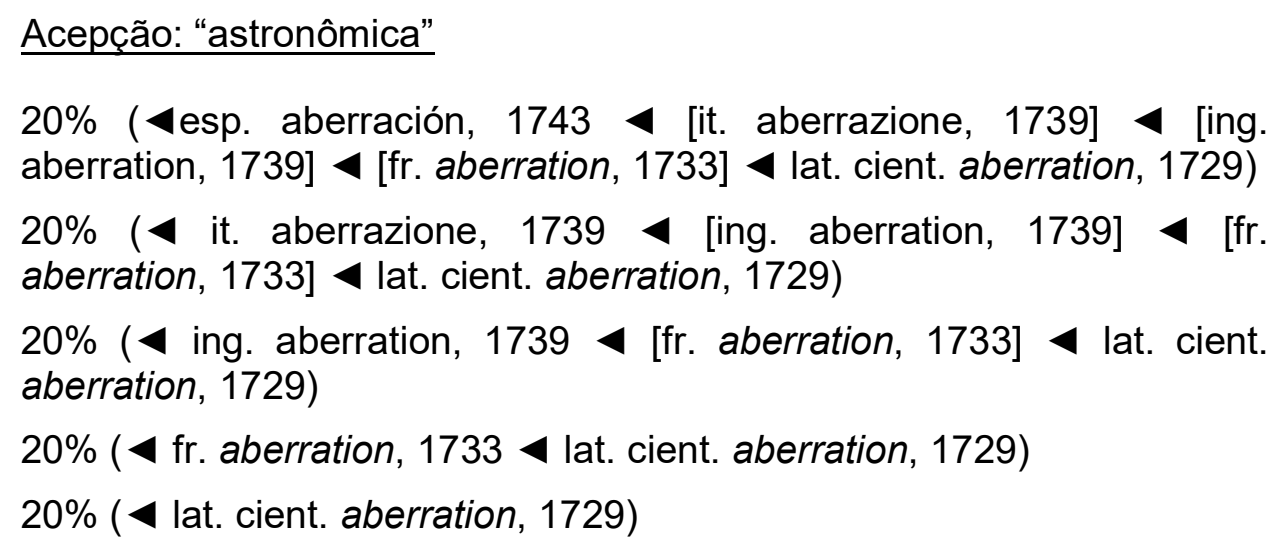

Comentário: A primeira abonação em português não é tradução, portanto, pela falta dela não sabemos qual foi a língua intermediária. As opções aqui são muitas e o autor da segunda edição de Bluteau (i.e. Antônio de Moraes) pode ter lido sobre esse termo em qualquer uma dessas línguas. Os colchetes indicam que pode ter um intermédio da língua.

1813. Diccionario da Lingua Portugueza composto pelo padre D. Rafael Bluteau, reformado, e accrescentado por Antonio de Moraes Silva $\left(2^{a}\right.$ edição)

Origem do significado da acepção: latina científica Origem do significante da acepção: latina científica Étimo de empréstimo: 20\% latim científico, 20\% francês, $20 \%$ inglês, $20 \%$ italiano e $20 \%$ espanhol

Local: Dicionário do Houaiss

Acepção: "óptica"

25\% ( 4 fr. aberration $1798 \triangleleft$ [esp. aberración 1781] 4 [ing. aberration, 1753] \it. aberrazione, 1722) 25\% ( esp. aberración $1781 \triangleleft$ [ing. aberration, 1753] \it. aberrazione, 1722) 
$25 \%$ ( 4 ing. aberration, $1753 \varangle$ it. aberrazione, 1722)

$25 \%$ ( $\triangleleft$ it. aberrazione, 1722 )

Comentário: as obras etimológicas afirmam que foi o inglês que tomou uso da cognata com acepção astronômica e começou a utilizá-la na acepção óptica (Chambers), mas encontramos uma atestação em italiano de 1722, o que invalidaria tal proposição. Também podem ser duas utilizações (inglês e italiano) coincidentes, mas a italiana não teria feito uso da astronômica porque esta ainda não existia. Aceitaremos como primeira abonação a italiana, que hipoteticamente poderia ter emprestado para o inglês.

1797. Elogio Historico de João Le Rond D'alembert, escrito por Francisco de Borja Garção Stockler

Origem do significado da acepção: italiana

Origem do significante da acepção: latina científica

Étimo de empréstimo: $25 \%$ francês, $25 \%$ espanhol, $25 \%$ inglês, $25 \%$ italiano

Local: Google Books

\subsubsection{Para o norueguês}

\section{Aberrasjon s.m.}

Acepção: "desvio de conduta"

Bokmål:

$50 \%$ ( 4 din. da Noruega aberration, $1833 \varangle$ din. ??? 4 fr. aberration, 1775 \ing. aberration "desvio de conduta, 1589" \ lat. aberratio "desvio de conduta", acepção 4 do dicionário de latim)

$50 \%$ ( 4 din. da Noruega aberration, $1833 \varangle$ din. ??? 4 ing. aberration "desvio de conduta, 1589" \ lat. aberratio "desvio de conduta", acepção 4 do dicionário de latim)

Comentário: os dois trajetos estão apresentados acima, mas o elemento lexical é $100 \%$ de étimo dinamarquês. Consideramos uma 
intermediação com o dinamarquês da Dinamarca por motivos de obviedade, pois como já existia no dinamarquês da Noruega, provavelmente haveria no dinamarquês da Dinamarca, mas não encontramos um exemplo em nenhum dos corpora. O elemento lexical não pode ter vindo do francês, porque de acordo com - Le Trésor de la Langue Française informatisé, a cognata francesa com acepção de "desvio de conduta" só apareceu em 1775 (a acepção de "desvio de caminho, afastamento" é de 1624) e, portanto, ainda de acordo com o dicionário, é provavelmente um empréstimo do sentido figurativo do inglês aberration com acepção de 1594 "desvio de conduta", no nosso caso 1589, porque retroagimos.

1910. Jean Jacques Rousseau. 1 de Gerhard Gran

Citação: [...] naar han betragter frøken Lamberciers straf som aarsaken til sine aberrationer $[\ldots]^{129}$

Origem do significado da acepção: latina

Origem do significante da acepção: latina

Étimo de empréstimo: dinamarquês

Local: Nasjonalbibliothek

Característica de texto em bokmål nessa obra:

- Consoantes surdas: aapen "aberto", vite "saber", kake "bolo", klok "inteligente" e bok "livro";

- Plural indefinido em -er: hester "cavalos"; veier "caminhos"

- Tempo pretérito em -et (kastet "jogar"), -te (svarte "responder") e -dde (bodde "morar")

- Supressão da forma do neutro em -t nos adjetivos terminados em -ig: et heldig barn "uma criança sortuda"

- Encurtamento de verbos e substantivos: ha "ter", dra "ir, viajar", bli "tornar-se", far "pai", etc.

129 Quando ele encara o castigo da senhorita de Lambercier como a causa de suas aberrações [...] (trad. nossa) 
Nynorsk:

Não consta

Acepção: "astronomia"

Bokmål:

20\% ( din. na Noruega Aberration, 18314 din. Aberration, 1747 sue. aberration, $1744 \varangle$ ing. aberration, $1739 \varangle$ fr. aberration, 1733 lat. cient. aberration, 1729)

20\% ( din. na Noruega Aberration, 18314 din. Aberration, 1747 ing. aberration, $1739<\mathrm{fr}$. aberration, $1733<$ lat. cient. aberration, 1729)

20\% ( 4 din. na Noruega Aberration, 18314 din. Aberration, $1747 \varangle$ ing. aberration, $1739<\mathrm{fr}$. aberration, $1733<$ lat. cient. aberration, 1729)

20\% ( 4 din. na Noruega Aberration, 18314 din. Aberration, 1747 fr. aberration, $1733 \varangle$ lat. cient. aberration, 1729)

20\% ( din. na Noruega Aberration, 18314 din. Aberration, 1747 lat. cient. aberration, 1729)

Comentário: como o elemento lexical aberração com essa acepção já havia na Noruega em textos em dinamarquês, consideramos que naturalmente seria um empréstimo dessa língua, portanto a hipótese é de 100\% de que o étimo seja dinamarquês. Por conta da primeira abonação em dinamarquês ser do ano de 1747 e, também, por não ser nenhuma tradução, fica incerto saber por qual caminho a o elemento lexical chegou nessa língua. A melhor hipótese está dada acima. O fato de ter sido divulgada pelo inglês (artigo de Smith e teoria de Bradley) indica que é muito possível que tenha passado pelo inglês, que tomou emprestado do francês (artigo de Voltaire). Mas também não podemos excluir que esse elemento lexical tenha entrado na língua dinamarquesa por conta do artigo em francês de Voltaire.

03 de abril de 1915. Jornal Bergens tidende

Citação: S. har aabenbart ingen anelse om, at vi i aberrationen og i fiksstjernernes aarlige parallakse har fuldgyldige beviser for jordens løp 
om solen ${ }^{130}$. (p. 13)

Origem do significado da acepção: latina científica

Origem do significante da acepção: latina científica

Étimo de empréstimo: $100 \%$ do dinamarquês

Local: Nasjonalbibliothek

Característica de texto em bokmål nessa obra:

- Consoantes surdas: aapen "aberto", vite "saber" e bok "livro";

- Plural indefinido em -er: hester "cavalos";

- Tempo pretérito em -et (kastet "jogar"), -te (svarte "responder") e -dde (bodde "morar")

- Supressão da forma do neutro em -t nos adjetivos terminados em -ig: et heldig aar "um ano favorável"

- Encurtamento de verbos e substantivos: ha "ter", dra "ir, viajar", bli "tornar-se", far "pai", etc.

Nynorsk:

20\% (4 din. na Noruega Aberration, 18314 din. Aberration, 1747 sue. aberration, $1744 \varangle$ ing. aberration, $1739 \varangle$ fr. aberration, 1733 lat. cient. aberration, 1729)

20\% ( din. na Noruega Aberration, 18314 din. Aberration, $1747 \triangleleft$ ing. aberration, $1739<\mathrm{fr}$. aberration, $1733<$ lat. cient. aberration, 1729)

20\% (4 din. na Noruega Aberration, 18314 din. Aberration, 1747 ing. aberration, $1739 \triangleleft \mathrm{fr}$. aberration, $1733<$ lat. cient. aberration, 1729)

20\% ( 4 din. na Noruega Aberration, 18314 din. Aberration, 1747 fr. aberration, $1733 \triangleleft$ lat. cient. aberration, 1729)

20\% ( din. na Noruega Aberration, 18314 din. Aberration, 1747 lat. cient. aberration, 1729) 
Comentário: nesse período ainda não havia sido registrado o elemento lexical em bokmål e, por isso, temos a hipótese de que ele é um empréstimo do dinamarquês.

1911. Stjernegransking i gamall og ny tid de Sigurd Einbu

Citação: James Bradley [...] fann i 1728, at det merkelege stadskiftet, denne sjerna hadde, kom av aberrrationen av ljoset. (p. 40) ${ }^{131}$

Origem do significado da acepção: latina científica

Origem do significante da acepção: latina científica

Étimo de empréstimo: $100 \%$ do dinamarquês

Fonte: Nasjonalbibliothek

\section{Acepção: "óptica"}

\section{Bokmål:}

25\% ( 4 din. na Noruega aberration, $1853 \triangleleft$ din. aberration, $1849 \triangleleft \mathrm{fr}$. aberration, $1798 \varangle$ ale. Aberration $1763 \triangleleft$ ing. aberration, $1753 \varangle$ it. aberrazione)

25\% ( din. na Noruega aberration, $1853 \triangleleft$ din. aberration, 1849 ale. Aberration $1763 \triangleleft$ ing. aberration, $1753 \triangleleft$ it. aberrazione)

25\% ( din. na Noruega aberration, $1853 \varangle$ din. aberration, 1849 ing. aberration, $1753 \triangleleft$ it. aberrazione)

25\% ( $\triangleleft$ din. na Noruega aberration, $1853 \triangleleft$ din. aberration, $1849 \triangleleft$ it. aberrazione)

Comentário: já havia a difusão desse item lexical em dinamarquês em livros publicados na Noruega. De acordo com o Le Trésor de la Langue Française informatisé, essa acepção surgiu pela transposição de Chambers ao domínio da física em 1753, mas o encontramos no italiano na acepção da física e ótica na obra de Leoni (1722). Se este item lexical passou antes pelo francês ou alemão, ou se veio direto do inglês para o dinamarquês, não conseguimos descobrir.

1910. Lærebog i fysik for realgymnasiet og tekiske skoler. 2 de D. Isaachsen e G. Holtsmark

131 James Bradley [...] descobriu em 1728 que a evidente mudança de estado que essa estrela tinha vinha da aberração da luz. (trad. nossa) 
Citação: [...] randstraalernes og centralstraalernes foreningspunkter kaldes den sfæriske avvikelse eller sfæriske aberration ${ }^{132}$. (p. 118)

Origem do significado da acepção: italiana

Origem do significante da acepção: latina científica

Étimo de empréstimo: $100 \%$ dinamarquês

Local: Nasjonalbibliothek

Característica de texto em bokmål nessa obra:

- Consoantes surdas: aapen "aberto", vite "saber", klok "inteligente";

- Plural indefinido em -er: ganger "vezes

- Tempo pretérito em -et (opdaget "descobrir")

- Encurtamento de verbos e substantivos: ha "ter", dra "ir, viajar", bli "tornar-se", far "pai", etc.

Nynorsk:

25\% ( 4 nbok. aberration, $1910 \varangle$ din. na Noruega aberration, 1853 din. aberration, $1849 \varangle$ fr. aberration, $1798 \varangle$ ale. Aberration 1763 ing. aberration, $1753<$ it. aberrazione)

25\% ( nbok. aberration, $1910 \varangle$ din. na Noruega aberration, 1853 din. aberration, $1849 \varangle$ ale. Aberration $1763 \varangle$ ing. aberration, 1753 it. aberrazione)

25\% ( 4 nbok. aberration, $1910 \varangle$ din. na Noruega aberration, 1853 din. aberration, $1849 \varangle$ ing. aberration, $1753 \varangle$ it. aberrazione) 25\% ( 4 nbok. aberration, $1910 \varangle$ din. na Noruega aberration, 1853 din. aberration, $1849 \varangle$ it. aberrazione)

Comentário: neste caso podemos afirmar que o elemento lexical é um empréstimo do bokmål porque esse manual de física, em que há a abonação do elemento, é uma tradução do mesmo manual acima, em bokmål para essa acepção. Nas páginas informa-se que a Studentmaallaget envia "uma tradução em landsmaal do livro de Isaachsen

132 Os pontos de união do raio da borda e do raio raio central são chamados desvio esférico ou aberração esférica. (trad. nossa) 
e Holtsmark" e que o livro foi traduzido de acordo com a $5^{\text {a }}$ edição pelo tradutor Sverre Havig.

1918. Lærebok i fysik for realgymnasiet og dei tekniske skulane. 2 de D. Isaachsen e G. Holtsmark

Citação: [...] og avstandet millom desse punkt vert kalla det sfæriske avviket (den sfæriske aberration) ${ }^{133}$ (p. 115)

Origem do significado da acepção: italiana

Origem do significante da acepção: latina científica

Étimo de empréstimo: 100\% norueguês bokmål

Local: Nasjonalbibliothek

\section{Origem do significante:}

Aberratio em latim é uma derivação de aberro que, por sua vez, se originou a partir da composição entre o prefixo ab- "para longe" e do verbo errare, portanto, aberrare. De acordo com Ernout \& Meillet (1932 [20016]), erro significa, em primeiro lugar, "vaguear", "ir a uma aventura" (daí errantes, Cic. N.D. 3, 51) e, em segundo lugar, numa acepção moral, "desviar-se da verdade", "errar". É um elemento lexical arcaico (proto-itálico) e clássico; portanto, panromânico, com exceção do romeno. Aberrare, portanto, seria "vaguear para longe" e aberratio, aquilo que "desvia-se do caminho".

De acordo com de Vaan (2008), erro tem a forma *ers-āje- no proto-itálico e *h1ers-o/h2- "erro" no indo-europeu, com cognatas no armênio eram "borbulhar; ser incansável" < *ersā; no gótico airzeis "errado", "enganado", airzjan, AAA irren "estar enganado", "levar ao erro" < *erz-(i)io-.

133 [...] a distância entre esse ponto é chamada de desvio esférico (aberração esférica) (trad. nossa) 


\subsection{Adoção/Adopsjon}

\subsubsection{Apresentação dos dados}

\subsubsection{Mundo germânico}

Norueguês

Significados em dicionários atuais (a partir de 1901 em nynorsk e 1907 em bokmål):

\begin{tabular}{|l|l|l|l|}
\hline Dic. & Significado & Etimologia & Datação \\
\hline NbUiB & de adoptere "adotar"134 & $\begin{array}{l}\text { do lat. ad "para, } \\
\text { até" e optare } \\
\text { "escolher" }\end{array}$ & Não consta \\
\hline NyUiB & $\begin{array}{l}\text { sinônimo: } \\
\text { Adotar. }\end{array}$ & $\begin{array}{l}\text { adoptering. } \\
\text { do latim. Veja } \\
\text { adoptere135 } \\
\text { "adotar" }\end{array}$ & Não consta \\
\hline NTG & det å adoptere "adotar" & $\begin{array}{l}\text { lat. vsubst. } \\
\text { adoptere136 }\end{array}$ & Não consta \\
\hline ROB & det å adoptere(s) "adotar" & do latim adoptare & Não consta \\
\hline
\end{tabular}

Analisaremos apenas a acepção de "adotar como próprio filho".

134 De acordo com o dicionário, adoptere "adotar": 1) tomar para si como um próprio filho; 2) aprovar, autorizar, admitir. Exemplos: 1) "adotar uma criança", "mandar para adoção de pais adotivos"; 2) "adotar uma proposta"

${ }^{135}$ Basicamente o mesmo sentido da anterior.

136 Segue parcialmente o modelo dos outros. 1a) tomar para si como um próprio filho; 1b) adotar uma proposta, systemet er adoptert fra England, "o sistema adotou da Inglaterra", ou seja, nos modelos ingleses; 2) mandar à adoção. Nesse caso o norueguês utiliza o advérbio bort "para longe". Adoptere bort sitt barn "mandar seu filho à adoção". 


\section{Livros em dinamarquês publicados na Noruega}

A primeira atestação do item lexical está no livro de Henrik Steenbuch (1815). Ela se encontra no parágrafo § 6 "Sucessão é linear e paternal" (p. 23).

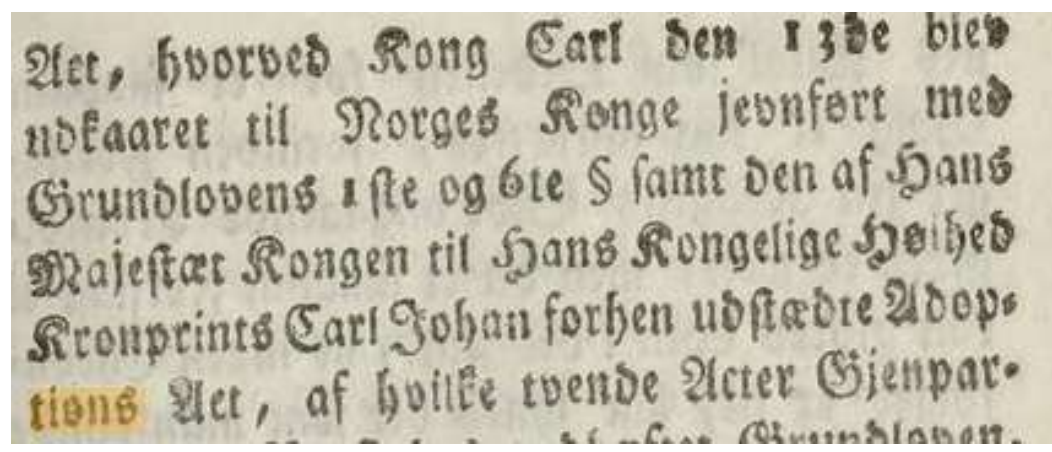

"[...] mediante a qual o rei Carlos XIII foi coroado rei da Noruega de acordo com as leis constitucionais $1^{\mathrm{a}}$ e $6^{\mathrm{a}}$ - parágrafo a linhagem de adoção emitida anteriormente pela Sua Majestade para o príncipe Carl Johan [...]" (trad. nossa)

O livro de P. J. Collet (1859) afirma:

Adoption eller Antagelse af Fremmede i Barns Sted, med den Virkning, at de indtræde $i$ den Adopterendes Familie, omtales ei $i$ vor nugjældende Lovgivning (p. 316)

"A adoção ou admissão de estranhos no local dos filhos, com o efeito de que eles ingressam na família adotiva, é mencionada em nossa legislação atualmente vigente" (trad. nossa)

\section{Livros escolares}

No livro de texto sobre História Geral de Albert Lassen (1837) há três citações de Adoption. Todas as acepções são de de "adoção real" como, por exemplo:

Riget faar ved Adoption em Række af gode Keisere $i$ det andet Seculium ( $p$. 794)

"O reino recebe pela adoção uma série de bons imperadores no século II." (trad. nossa) 
No livro de texto sobre a história do mundo para ensino médio de Nissen (1870) adoption é citado uma vez, com o sentido de que Augusto tomou Nero como seu filho.

\section{Manuais}

Há no manual sobre a religião cristã (PETRI, 1854)" uma atestação de adoption em que afirma-se:

[...] at Christus blot ved Adoption er Guds Søn (Adoptianismus) [...] (p. 90)

[...] que Cristo apenas pela Adopção é filho de Deus (adocionismo) (trad. Nossa)

\section{Bíblia}

Esse elemento lexical não aparece na Bíblia. Tomemos por motivos de comparação a Vulgata, que tem 5 registros de adoptatio:

[...] ut adoptionem filiorum reciperemus (Galatas 4:5)

[...] adoptionem filiorum expectantes [...] (Romanos 8:23)

[...] accepistis Spiritum adoptionis filiorum (Romanos 8:15)

[...] quorum adoptio est filiorum (Romanos 9:4)

[...] in adoptionem filiorum per lesum Cristum (Efésios 1:5)

Nenhuma tradução para o dano-norueguês (dinamarquês da Noruega), para o bokmål ou para o nynorsk utilizou adoption (adopsjon), por outro lado utiliza-se elementos lexicais como: udkaarelse, sønlig udkaarelse (1870, dinamarquês), barnekaar ${ }^{137}$ (1904, bokmål), banekår (1930, bokmål), få rett til å være Gud/hans barn, å bli/være Guds barn ${ }^{138}$ (bokmål, 2011); få barneretten ${ }^{139}$, barnekår (1938, nynorsk), å vera/bli Guds born ${ }^{140}$, retten til å vera Guds born, få rett til å vera hans born (2011, nynorsk).

\footnotetext{
137 Tradução literal: condições de criança, filho

138 Tradução literal: ter direito de ser a criança de Deus/dele, tornar-se/ser a criança de Deus.

139 Tradução literal: obter o direito de criança, de filho

140 Tradução literal: ser/tornar-se filho de Deus, o direito de ser filho de Deus, obter o direito de ser filho dele
} 
Como a Bíblia tinha o intuito de ser alcançada pela população não tão letrada, era de se esperar que fossem utilizados elementos lexicais mais transparentes ou de cunho popular.

\section{Obras lexicográficas}

No dicionário de palavras estrangeiras de M. C. Hansen (1851) atestase o seguinte: Adoption, en, Antagelse i Barns Sted "adoção, aceitação no lugar do filho" (trad. nossa).

Nos dicionários de inglês-dano-norueguês-inglês como de Geelmuyden (1855, 1872) e Brynildsen (1892), a cognata correspondente inglesa adoption tem as correspondentes Adoption, Antagelse e Anvendelse.

No dicionário latim-dano-norueguês:

\begin{tabular}{|l|l|l|l|l|}
\hline Latim & $\begin{array}{l}\text { Dano- } \\
\text { norueguês }\end{array}$ & Autor & Tipo & Ano \\
\hline Adoptio & Adoption & Johansen & Geral & 1887 \\
\hline Adoptatio & $\begin{array}{l}\text { Adoption, } \\
\text { antagelse i } \\
\text { barns sted }\end{array}$ & Johansen & Geral & 1887 \\
\hline
\end{tabular}

No dicionário de francês-dano-norueguês de SUNDBY (1883/1884):

\begin{tabular}{|l|l|l|l|l|}
\hline Francês & $\begin{array}{l}\text { Dano- } \\
\text { norueguês }\end{array}$ & Autor & Tipo & Ano \\
\hline Adoption & $\begin{array}{l}\text { Adoptering, } \\
\text { Antagelse, } \\
\text { Knæsatning, } \\
\text { Udkaarelse } \\
\text { (bibl.), ÆEtledning }\end{array}$ & Sundby & Geral & $1883 / 1884$ \\
\hline
\end{tabular}


Concluímos que adoption tem dois sentidos básicos (1. de adoção familiar e 2. de aceitação, admissão). Nesta análise estudaremos apenas a primeira acepção.

\section{Cognatas em outras línguas germânicas}

\section{Dinamarquês (publicado na Dinamarca)}

Tanto no ODS quanto no dicionário etimológico de Katlev (2000) não há nenhuma entrada para adoption, apenas adoptere (p. 447). No dicionário de Kalkar (2000) não encontramos nenhuma entrada. No dicionário de palavras estrangeiras de Meyer (1844, p. 14) há a entrada Adoption como Antage/se $i$ Barns Sted.

No dicionário de Matthias Moth, que coletou palavras por todo o país, inclusive Noruega, nos anos entre 1697 e 1719, não há uma entrada para tal elemento lexical.

Com base no corpus sobre a língua do renascimento na Dinamarca (Renæssancens Sprog i Danmark), nos dicionários de latim-dinamarquês de Tursen (1561), de Pedersen (1510), Smith (1563) e de Colding (1626) encontramos apenas entradas: adoptiuus (som tages til søn "pego como filho"), Filius adoptiuus (vdkaaret barn "criança escolhida") e adoptatio (Vdkaarelse "escolha"). Também não encontramos registros de adoption no corpus de textos entre 1500-1700. Tampouco encontramos formas flexionadas do verbo adoptere, mas sim com o verbo udkaare.

A primeira abonação com a acepção de "adoção de filho" se encontra em Holberg (1745):

Neronis Adoption eller Antagelse udi Søns Sted blev av Raadet samtykket.

"A adoção ou a tomada de Nero em posição de filho foi aprovada pelo conselho" (trad. nossa) 


\section{$\underline{\text { No sueco }}$}

No dicionário Svenska Akademiens Ordbok (SAO) ${ }^{141}$ não encontramos uma cognata correspondente. Pelo Google Books, por outro lado, foi possível encontrar o primeiro registro virtual dessa cognata: Romerska Folkets Hemseder (de Hr. D' Arnay, 1777), que é uma tradução do francês. Trecho:

[...] en blott adoption: foerst, att den som adopterade, skulle vara aeldre ean den som adopterades [...] (p. 340)

"[...] uma simples adoção: em primeiro lugar, aquele que adotou deveria ser mais velho do que o adotado" (trad. nossa).

No inglês:

De acordo com Oxford (CD-ROM, 2010), a cognata correspondente adoption tem os seguintes significados:

1. The act of adopting a child

2. The decision to start using something such as an idea, a plan or a name

3. (BrE, politics) the act of choosing somebody as a candidate for an election

De acordo com o dicionário, ela surgiu no inglês médio e vem do latim $\operatorname{adoptio}(n-)$, de ad- "para" + optio(n-) "escolha", do radical optare "escolher"

De acordo com o dicionário etimológico de Murray (1888), essa cognata veio diretamente ou por meio do francês para a língua inglesa. Com a acepção de the action of voluntarily taking into any relation; of taking into sonship ela aparece pela primeira vez em John Wyclif Rom. VIII. 23 (1382).

Foi encontrada, entretanto, um registro mais antigo no Corpus of Middle English Prose and Verse:

[...] and maki him his zone be adopcioun (Ayenbite of Inwyt de Michael of Northgate, 1340, p. 101, manuscr. British Museum MS. Arundel 57, vol. 1)

“[...] e fez dele seu filho por adoção" (trad. nossa)

${ }^{141}$ Disponível em: http://g3.spraakdata.gu.se/saob/ 
Esta é uma prosa confessional escrita no dialeto de Kent e, de acordo com Thomson (1907, p. 396), foi realizada com base em um original francês por um "tradutor muito incompetente".

No alemão

De acordo com DHW (das Herkunftswörterbuch, 2014), Adoption significa Annahme an Kindes statt "aceitação como filho (trad. nossa)" e tem origem no século XVI, como empréstimo do latim adoptio.

A primeira abonação possível de determinar com o Google Books é da obra Der neü Layenspiegel von rechtmässigen ordnungen [...] (1512):

Aber ain schlechte Adoption mag beschehen [...] (folio xxxviii-b)

"Mas uma adoção ruim pode ocorrer [...]" (trad. nossa)

$\mathrm{O}$ único elemento lexical que encontramos no século $\mathrm{XV}$ que se refere a adoção é adoptiuus, em um poema chamado Ehebüchlein (parte 3, página 53, capítulo 3, linha 8) de Albrecht von Eyb (1420 - 1475).

\section{No holandês}

O banco de etimologia afirma que, de acordo com Philippa (20032009), a cognata correspondente adoptie aparece pela primeira vez em 1616 com o sentido de aaneming (als kind) "tomar como criança" (trad. nossa), citando o Woordenboek der Nederlandsche Taal (WNT):

[...] by adoptie, contract van houwelick, testament oft andere wettighe dispositie (VI. Placcaertb. 2, 657)

"[...] por adoção, casamento, testamento e outras disposições legais" (trad. nossa) 


\subsubsection{Mundo românico}

\section{Português:}

Os dicionários de língua portuguesa atestam a etimologia desse item lexical da seguinte maneira:

\begin{tabular}{|c|c|c|}
\hline Dicionário & Étimo & Datação \\
\hline (online) & lat. adoptǐo,ōnis & $\begin{array}{l}\text { XV (ver Cunha, } \\
\text { Índice do Vocabulário do } \\
\text { Português Medieval) }\end{array}$ \\
\hline
\end{tabular}

O Houaiss define três acepções:

1. (jur.) processo legal que consiste no ato de se aceitar espontaneamente como filho de determinada pessoa, desde que respeitadas as condições jurídicas para tal

2. (p. ext.) aceitação espontânea de (pessoa ou animal, ger. doméstico) como parte integrante da vida de uma família, de uma casa

3. (p. ext.) aceitação, admissão do que antes era externo, alheio, estranho ou não era conhecido ou cogitado.

O dicionário define a etimologia da seguinte maneira: lat. adoptio, onis "adoção", de adoptatio, onis "adoção, perfilhamento", ver opt-; f.hist. sXV adoçõ, sXV adopçom.

De acordo com o Corpus do Português, o terminus a quo se encontra na obra Sacrammental de Clemente Sanches de Vercial (1488):

A outra chamã adopcio que he quando alguû toma por filho a outra que tem padre \& esta em seu poderio \& este non pasa a ho poderyo do que ho perfilhou \& esta sse pode fazer por autoridade doutro qual quer juiz que a ja jurdiçon \& mero er mixto jmperio. Porem de sse alguû tomasse por filho a outro ë ssua cassa oulamte algûas testemunhas seria nëguû tal adopçio ou arrogaçõ darlhe liçëça que case $[\cdots]$ 
Ainda de acordo como Corpus do Português, nesse mesmo período, entre 1400 e 1500, havia outras formas: adopçom, adopçam e adopcio. Concluímos que não é um elemento lexical herdado pois o português não esperaria um radical adop- e sim au- ou oo-. Como havia também várias formas de grafia para o sufixo (i.e. -çom, -çam, -cio e -çio) não podemos concluir nada sobre qual língua poderia ter emprestado para o português, uma vez que essas grafias eram comuns nesse período (i.e. liçã, liçam, liçõ; cançã, cançõ, cançion), quer dizer, não havia uma forma padrão e o escriba simplesmente escrevia da maneira que ele falava.

O vocabulário histórico-cronológico do português medieval (VHCPM), de Cunha, apresenta a primeira atestação em 1495 (Vita Christi em lingoagem português).

No vocabulário de Bluteau (1728, p. 689) encontramos a seguinte entrada para adoção:

ADOPC,AM,Adopçâm, ou Adoptação. Perfilhamento. A acção de adoptar a alguém por filho. Para elte acto ser legitimo, o adoptante hâ de ser de condição livre, hâ de passar de dezouto annos, não há de ser molher, \& há de ser capaz para a geração. Do parentesco por adopção. [...]

Antes desse período havia outros elementos lexicais que supriam esse significado como, por exemplo, perfilhamento, citada no dicionário escolar de latim-português de Jerónimo Cardoso (1562) como correspondente do latim adoptio(onis). Na tradução ao português das regras de São Bento (séc. XV) temos (junto com o latim):

Reçebestes spiritu de adopçom e de perfilhamento de filhos [...] (VHCPM) Accepistis spiritum adoptionis filiorum [...]

No vocabulário de Bluteau tem-se que perfilhamento é sinônimo de adopção. O Corpus do Português apresenta esse sinônimo em 1300 (Terceyra Partida de Afonso X - 1300):

[...] como deue ser feita a carta. do perfilhamëto do homë que esta ë poder de seu padre natural 
Também há filhamënto na mesma obra:

[...] assi como diz ëno Titulo dos filhamëtos, ou lhi desse, ou lhi prometesse algûã herdade

No século XIV também há filhaçom e afilhamëto. Como não há a formação filhamënto na língua latina, tem-se a hipótese de que seja um item lexical que se formou em alguma língua do romance.

\section{Espanhol:}

Nos Corominas encontramos a seguinte entrada:

\begin{tabular}{|c|c|c|c|}
\hline $\begin{array}{l}\text { Dicionári } \\
\text { o }\end{array}$ & $\begin{array}{ll} & \text { Form } \\
\text { a } & \end{array}$ & Étimo & Datação \\
\hline $\begin{array}{l}\text { COROMINAS } \\
(1984)\end{array}$ & Adopción & $\varnothing$ & $\varnothing$ \\
\hline
\end{tabular}

No Corpus do espanhol encontramos a primeira atestação da cognata correspondente no século XIII (siete partidas de Afonso X, que viveu entre 1252 e 1284):

Adopçio en latin tanto quiere dezir en romançe como porhijamento. E este porhijamiento es vna manera que establesçieron las leyes por la qual pueden los onbres ser hijos de otros maguer non lo sean natural mente.

Aqui também encontramos um sinônimo de adopción, que é porhijamiento.

$\underline{\text { Italiano: }}$

\begin{tabular}{|l|l|l|l|}
\hline Dicionário & Forma & Étimo & Datação \\
\hline ZINGARELLI & adozióne & di ăd e ŏptio & 1347 \\
\hline
\end{tabular}




\begin{tabular}{|l|l|l|l|}
\hline Deli & adozióne & lat. adoptāre & 1347 \\
\hline
\end{tabular}

De acordo com o Deli, esse item lexical se encontra em alguma obra de Bartolomeo da S. Concordio (1262-1347).

O Tesoro della lingua Italiana delle Origini (TLIO) afirma que essa cognata com o ato de "adotar um filho" foi registrada pela primeira vez na obra Cronia deli Imperadori (1301), p. 178.4:

[...] e la generacion de la mare descendi da Enea, e fo nievo de lulio Cesaro, e per adotion el foy fyo.

Elementos lexicais com o sufixo grafado em -tion eram comuns no séc. XIII e XIV.

- Obra Patto del Sodano (1225, ven.): indition;

- Sermone de Pietro da Bescapè (1274, lomb.): devotion, fornication, mention, oration;

- Opere volgari de Bonvesin da la Riva (XIII, mil.): attention, condition, creation, desperation, intention oration, perdition, tribulation, etc.

- Scritti spirituali veneti (XII, ven.): consolation, salvation Mas também havia a grafia -zione:

- Rosa fresca de Celo d'Alcamo (1231-1250, tosc.): maladizione

- Rime de Bonagiunta Orbicciani (XIII, lucch.): menzione

- Rime de Ruggieri Apugliese (XIII, sen.): destruzione, konsolazione;

- Rettorica de Brunetto Latini (1260-1261): accusazione, affezione, aflizione, azione, comparazione, constituzione, contenzione, deliberazione, etc..

- Trattati morali de Andrea da Grosseto (1268, tosc.): benedizione, cauzione, circunspezione, cogitazione, comparazione, compensazione, concluzione, etc. 
E também as em -gione:

- Breve di montieri (1219): rasgione

- Promemoria riguardante (1230-1231, tosc. pis.): scomunicagio(n)e

- Frammento d'um libro di conti di mercanti di panni (1247, tosc. prat.): pisgione, rasgione

- Poesie de Abate di Tivoli (1230-1250, tosc.): isperagione, stagione

- Rime de Bonagiunta Orbicciani (XIII, lucch.): istagione, pensagione

Essa última forma é herdada, mas as duas primeiras são de itens lexicais que vêm por empréstimo, que pode ser tanto do latim (-tio) como do francês (-tion). Portanto, não é possível determinar se adotion é um empréstimo do francês ou do latim.

Francês:

Nos dicionários de francês (incluindo os etimológicos)

\begin{tabular}{|l|l|l|l|}
\hline Dicionário & Forma & Étimo & Datação \\
\hline $\begin{array}{l}\text { Le Petit Robert } \\
(2014)\end{array}$ & adoption & lat. jur. adoptio & XIII \\
\hline TLF & adoption & lat. adoptio & 1279 \\
\hline
\end{tabular}

Entre seus significados, o TLF afirma que o sentido de action d'adopter foi primeiramente registrado em 1279 , na obra Somme le Roil42 de Flère Laurent: fil par adoption "filho para adoção".

Em todas as edições do dicionário latino-gálico de Robert Estienne (1539, 1543, 1549 e 1552) afirma-se que essa cognata tem o significado de adoptio ou adoptatio no latim.

O FEW (Französisches Etymologisches Wörterbuch) constata que a acepção de "ação de adotar uma criança legalmente" existe desde o séc. XIII; a

${ }^{142}$ Em ms Chartres, fo 29 ro ds GDF. Compl. 
acepção de "graça especial que, no batismo, os cristãos viram crianças de Deus" (séc. XII); "preferência dada a um estilo, a uma maneira de ver (desde 1789).

Latim:

1. Adopção para uma família, de uma pessoa.

Quae deinde causa cuique sit adoptionis [...] (Cic. De Domo Sua, I, 34)

"Qual é então a causa da adoção de cada [...]" (trad. nossa)

2. Aplicado ao processo de enxerto; a uma planta enxertada (GLARE); transformação de plantas (LEWIS). Termo muito utilizado em Plínio, naturalis (livro 15, 41; livro 16, 1; livro 17, 129).

\subsubsection{Determinação do étimo}

Terminus a quo (mais antigo ao mais novo)

\begin{tabular}{|c|c|}
\hline \multicolumn{2}{|c|}{ Mundo Romano } \\
\hline Francês & 1279 \\
\hline Espanhol & Segunda metade séc. XIII \\
\hline Italiano & 1301 \\
\hline Português & 1488 \\
\hline \multicolumn{2}{|c|}{ Mundo Germânico } \\
\hline Inglês & 1340 \\
\hline Alemão & 1512 \\
\hline Holandês & 1616 \\
\hline Dinamarquês & 1745 \\
\hline Sueco & 1777 \\
\hline
\end{tabular}




\begin{tabular}{|l|l|}
\hline Dinamarquês na Noruega & 1815 \\
\hline Nynorsk & 1889 \\
\hline Bokmål & 1912 \\
\hline
\end{tabular}

Por conta da datação, fica bem evidente que o francês foi a primeira língua a utilizar esse elemento lexical por meio de uma tradução do latim científico, mas não necessariamente foi ele que o emprestou para o português.

1) A respeito das línguas de influência em determinados temas, é difícil fazer qualquer conclusão porque este item lexical já era utilizado no latim, no âmbito jurídico e, por conta disso, não foi nenhuma língua vernácula que se apropriou dele e deu a ele uma acepção técnica.

2) A relação entre escrita e pronúncia não nos proporciona nenhuma pista para a investigação do étimo, uma vez que cada língua pronuncia o radical adopt- da sua maneira. Desconfiamos que o empréstimo da cognata italiana adotion pudesse provar um empréstimo francês, mas vimos que também poderia ser um empréstimo latino e o fato do italiano ter outros itens lexicais terminados com o sufixo -tion (junto com -zion) no séc. XIII apenas indica variantes gráficas para representar o som compreendido pelo escriba.

3) O radical é adopt- e remete ao latim; portanto, não seria um radical exclusivo de nenhuma língua descendente.

4) Neste item lexical o cruzamento panromânico de Freitas não se confirma, uma vez que, por ter uso jurídico e de grande uso social (i.e. ato de adotar), ela poderia ter sido emprestada do latim para cada língua românica separadamente.

5) A questão semântica é pouco relevante para descobrir o caminho que o elemento lexical percorreu até o português e o norueguês uma vez que ele manteve sua acepção original.

No presente caso, apenas os termini a quo são relevantes para a etimologia desse elemento lexical. 


\title{
3.2.3 Fichas
}

\subsubsection{Para o português}

\author{
Adoção (s.f.) \\ $25 \%$ ( 4 it. adotion 13014 [esp. adopçio 1250-1300] \[fr. adoption \\ 1279] 4 lat. adoptio \\ 25\% ( $\triangleleft$ esp. adopçio 1250-1300 \[fr. adoption 1279] \ lat. adoptio) \\ $25 \%$ ( $\triangleleft$ fr. adoption $1279<$ lat. adoptio) \\ $25 \%$ ( $<$ lat. adoptio)
}

Comentário: o elemento lexical pode ter chegado no português por meio dessas quatro línguas. Como ocorre a adaptação dos sufixos durante o empréstimo e nenhum vestígio da língua de empréstimo é deixado nele, não é possível determinar com certeza qual foi a língua que o emprestou. Mesmo que a primeira abonação italiana registrada seja adotion, sem o -p-, entre 1351-1374 já havia adoption (obra trionfi de Francesco Petrarca) e adozione (1333, pis.; 1336, fior.; 1342, pis.).

1488. Sacrammental de Clemente Sanches de Vercial

Origem do significado da acepção: latina

Origem do significante da acepção: latina

Étimo de empréstimo: $25 \%$ latim, 25\% francês, 25\% espanhol, 25\% italiano

Local: Corpus do português 


\subsubsection{Para o norueguês}

\section{Adopsjon (s.m.)}

\section{Bokmål}

25\% ( din. na Noruega adoption 1815 din. adoption $1745 \varangle$ ale. Adoption 1512 ing. adopcioun 1340 fr. adoption 1279 lat. adoptio)

25\% ( din. na Noruega adoption $1815 \varangle$ din. adoption $1745 \varangle$ ing. adopcioun $1340 \varangle$ fr. adoption 1279 lat. adoptio)

25\% ( din. na Noruega adoption 1815 din. adoption $1745<\mathrm{fr}$. adoption $1279<$ lat. adoptio)

25\% ( din. na Noruega adoption $1815 \varangle$ din. adoption $1745 \varangle$ lat. adoptio)

Comentário: apesar de haver quatro hipóteses de trajeto, em todos eles o étimo é dinamarquês. O elemento lexical já estava sendo utilizado por muito tempo no dinamarquês e, por isso, consideramos que o étimo de empréstimo no bokmål é do dinamarquês. Como não estamos lidando com traduções, qualquer uma das quatro opções acima de entrada na língua é possível.

1912. Jornal Trondhjems Adresseavis de 01 de abril de 1912

Trecho: Arbeidet gjælder en lov om egteskapers indgaaelse og opløsning og om adoption 143

Origem do significado da acepção: latina

Origem do significante da acepção: latina

Étimo de empréstimo: 100\% dinamarquês

Local: Nasjonalbiblioteket

Comentário: esta obra por estar na data de 1912 nos livra da necessidade de análise para definir se a entendemos como escrita em norueguês.

143 O trabalho refere-se a uma lei sobre a celebração casamento, separação e sobre adoção (trad. nossa) 


\begin{abstract}
Nynorsk
25\% ( nbok. adoption $1912 \varangle$ din. na Noruega adoption 1815 din. adoption $1745 \varangle$ ale. Adoption 1512 ing. adopcioun $1340<\mathrm{fr}$. adoption 1279 lat. adoptio)

25\% ( nbok. adoption 1912 din. na Noruega adoption 1815 din. adoption 1745 ing. adopcioun 1340 \&r. adoption 1279 lat. adoptio)

25\% ( nbok. adoption $1912 \varangle$ din. na Noruega adoption $1815 \varangle$ din. adoption $1745 \varangle$ fr. adoption $1279 \varangle$ lat. adoptio)

25\% ( nbok. adoption $1912 \varangle$ din. na Noruega adoption 1815 din. adoption 1745 lat. adoptio)
\end{abstract}

Comentário: apesar de haver quatro hipóteses de trajeto, em todos eles o étimo é norueguês bokmål. Esse elemento lexical já estava sendo utilizada há alguns anos no nessa norma e, por isso, consideramos que o étimo de empréstimo vem dela. Igualmente com o caso do bokmål acima, como não estamos lidando com traduções, qualquer uma das quatro opções acima de entrada na língua é possível.

1916. Tru og liv: ei kristendomslæra for lærarskularne de Håkon

Wergeland

Trecho: Han [Jesus] er den einaste som kjenner Faderen av di han er den einaste som er «Sonen». Me andre er det etter adoption [...]”. 144

Origem do significado da acepção: latina

Origem do significante da acepção: latina

Étimo de empréstimo: $100 \%$ dinamarquês

Local: Nasjonalbiblioteket

\title{
Origem do significante:
}

De acordo com Ernout \& Meillet (1932 [20016]), adoptio é uma derivação de optio "faculdade ou liberdade de escolher" e inicialmente significava "escolha" e, pela língua do direito, recebeu a acepção "adoção", que é oposto à naturalis. Optio seria um substantivo verbal de um suposto *opiō "eu escolho", que

144 Ele "Jesus" é o único que reconhece o Pai porque ele é o único que é o "Filho". Nós somos filhos a partir da adoção (trad. nossa) 
tem vestígios em P. F. 222, 24 praedotiont (I. praedopiont?), praeoptant. *Opio foi substituído pelo frequentativo (p. 464). De acordo com Sloman (2016), a partir do radical do supino formava-se verbos frequentativos: iacio "eu jogo", cuja forma no supino é iactum $\rightarrow$ iacto "eu arremeço".

Optō, por sua vez, e também de acordo com os autores, significa "escolher" (compare proto-itálico, Ru. 852, opta ocius: rapi te... mauis na trahi); significado antigo, tomado pela língua da poesia imperial e no uso comum e clássico "escolher em sua mente, desejando" e daí surgiu optatio (Cícero) por meio do particípio optatus e a derivação adopto, que recebeu um sentido técnico da língua do direito "adotar" e, a partir do particípio, adoptatio "adopção, perfilhamento" (p. 464).

Em suma, tanto o substantivo optio ( $\leftarrow$ *optus), que derivou adoptio e que é um deverbal de *opio quanto o verbo opto ( $\leftarrow$ *optum, supino de *opere), que derivou optatio e, consequentemente, por derivação adoptatio, têm acepções parecidas de acordo com Ernout \& Meillet (1932 [20016]). 


\subsection{Argumentação/argumentasjon}

\subsubsection{Apresentação dos dados}

\subsubsection{Mundo germânico}

\section{Norueguês}

Significados em dicionários atuais (a partir de 1901 em nynorsk e 1907 em bokmål):

\begin{tabular}{|l|l|l|l|}
\hline Dic. & Significado & Etimologia & Datação \\
\hline NbUiB & $\begin{array}{l}\text { Apresentação de } \\
\text { argumentos; meio com que } \\
\text { se argumenta, prática de } \\
\text { demonstrar provas }\end{array}$ & X \\
\hline NyUiB & $\begin{array}{l}\text { Apresentação } \\
\text { argumentos; meio com que } \\
\text { se argumenta } \\
\text { NTG }\end{array}$ & $\begin{array}{l}\text { Utilização de argumentos } \\
\text { Substantivo } \\
\text { verbal latino de } \\
\text { argumentere }\end{array}$ & $X$ \\
\hline ROB & $\begin{array}{l}\text { Ação de argumentar; meio } \\
\text { com o qual se argumenta }\end{array}$ & X & $X$ \\
\hline
\end{tabular}

Podemos admitir, portanto, uma única acepção para argumentasjon em norueguês, que seria a prática de demonstrar provas, uma coleção de argumentos, etc. No português também temos essa acepção. De acordo com Houaiss: 1) arte, ato ou efeito de argumentar; 2) troca de palavras em 
controvérsia, disputa, discussão; 3) conjunto de ideias, fatos que constituem os argumentos que levam ao convencimento ou conclusão de algo. Todas essas acepções também resumiremos em uma só.

\section{Livros em dinamarquês publicados na Noruega}

A primeira atestação do elemento lexical está em um livro de Bredo Henrik von Munthe af Morgenstierne (1808, p. 22):

Jeg har saa gode Tanker om Recensentens juridiske Kundskaber, at jeg ikke tvivler paa, at han jo føler det Urimelige i en saadan Tiltale; og dog er Recensentens Argumentation imod mig af selvsamme Beskaffenhed (p. 2223)

"Eu aprecio os conhecimentos jurídicos do crítico. Não duvido que ele sinta, de fato, uma insensatez em uma acusação como essa. Todavia, a argumentação do crítico contra mim é de mesma natureza" (tradução nossa)

Outros excertos são:

Mod Argumentationerne for Emancipationen følgte især Mauguin at paavise, at de engelske Kolonier havde lidt ved Emancipationen; at Sukkerproductionen havde formindsket sig [...] (jornal Den Constituionelle, 12 de junho de 1836) ${ }^{145}$

"De encontro às argumentações pela emancipação, Maugin veio a demonstrar que as colônias inglesas sofreram por conta da emancipação; que a produção de açúcar diminuiu [...]" (trad. nossa)

\section{$\underline{\text { Manuais }}$}

No manual sobre a história da Igreja de Heinrich Guerike (1842) há o seguinte trecho:

Dette Concil udtalte Anathemaet over alle, der forfærdigede Christusbilleder, som om de (ifølge en besynderlig Argumentation) enten vare Nestorianske eller Eutychianske Kjættere (....) (Vol. 1, p. 268)

"Esse conselho declarou que todos aqueles que elaboraram imagens de Cristo se tornassem anátemas, como se eles (de acordo com uma curiosa argumentação) fossem hereges nestorianos ou eutiquianos [...]" (trad. nossa)

145 Disponível em http://www.nb.no/nbsok/nb/b9ecc2bf8336f71e930c824245aa3023?index=158 


\section{Obras lexicográficas}

No dicionário de palavras estrangeiras de M. C. Hansen (1851) o verbete argumentation tem o significado de Bevisførelse (demonstração, argumentação, prática de provas).

Vejamos na tabela as entradas em dicionários de inglês-danonorueguês-inglês:

\begin{tabular}{|c|c|c|c|c|}
\hline Inglês & $\begin{array}{l}\text { Dano- } \\
\text { norueguês }\end{array}$ & Autor & Tipo & Ano \\
\hline \multirow[t]{2}{*}{ Argumentation } & $\begin{array}{l}\text { Bevisførelse; } \\
\text { Ordstrid "briga } \\
\text { em palavras" }\end{array}$ & Geelmuyden & Geral & 1855, 1872 \\
\hline & $\begin{array}{l}\text { Begrundelse, } \\
\text { Bevingeførelse } \\
\text { "linha de } \\
\text { argumentação" }\end{array}$ & Brynildsen & Geral & 1892 \\
\hline $\begin{array}{l}\text { Dano- } \\
\text { norueguês }\end{array}$ & Inglês & & & \\
\hline \multirow[t]{2}{*}{ Argumentation } & $\begin{array}{l}\text { Argumentation, } \\
\text { reasoning }\end{array}$ & Larsen & Geral & 1880 \\
\hline & $\begin{array}{l}\text { Argument(ation), } \\
\text { reasoning }\end{array}$ & Brynildsen & Geral & 1892 \\
\hline
\end{tabular}


Nos dicionários de dano-norueguês-francês:

\begin{tabular}{|l|l|l|l|l|}
\hline $\begin{array}{l}\text { Dano- } \\
\text { norueguês }\end{array}$ & Francês & & & \\
\hline Argumentering & Argumentation & Sundby & Geral & 1883 \\
\hline
\end{tabular}

No dicionário de latim-dano-norueguês de Johanssen (1885):

\begin{tabular}{|l|l|l|l|l|}
\hline Latim & $\begin{array}{l}\text { Dano- } \\
\text { norueguês }\end{array}$ & & & \\
\hline Argumentatio & Bevisførelse & $\varnothing$ & Geral & 1887 \\
\hline
\end{tabular}

Dicionários de Dano-Norueguês-Francês:

\begin{tabular}{|l|l|l|l|l|}
\hline $\begin{array}{l}\text { Dano- } \\
\text { norueguês }\end{array}$ & Francês & & & \\
\hline $\begin{array}{l}\text { Argumentering, } \\
\text { Bevisførelse }\end{array}$ & Argumentation & $\varnothing$ & Geral & $\begin{array}{l}\text { Sundby, } \\
1883\end{array}$ \\
\hline
\end{tabular}

Conclui-se que em todas essas obras não há nenhuma diferenciação radical de acepção. Este elemento lexical desde seu aparecimento teve um sinônimo (i.e. bevisføre/se), que nada impediu sua contínua utilização. 


\section{Outras cognatas nas línguas germânicas}

Dinamarquês (publicado na Dinamarca)

Não encontramos registro da cognata correspondente em nenhum dos dicionários utilizados. No Google books, o primeiro registro se encontra no artigo Mod detaf Kammeradadvocat [...] da revista Astraea (Vol. 1, 1797):

Gartman junior har endelig ved sit Brev af 2. Octbr. 1793 saavelsom ved sin Paastand om Boets Extradition, afgiort ved Eragtning af 9 Novbr. 1793, erkiendt Ugyldigheden af Kammeradvocatens Argumentation under dette Nummer (p. 292).

"Gartman junior, finalmente, com sua carta de 2 de outubro de 1973, assim como sua alegação sobre a extradição de Boets, determinada pela decisão de 9 de novembro de 1793, reconheceu como inválida a argumentação dos advogados da câmera sob esse número". (trad. nossa)

\section{No sueco}

De acordo com o SAOB, o elemento lexical argumentation foi primeiramente reportado em 1721 no sueco, na obra de Andreas Rydelius chamada Nödiga förnufftz öfningar: 2 uppl. 1-5), com um sentido mais ligado à lógica de "conclusão, dedução"; apenas a partir de 1802 que ele passou a ter o sentido de "desenvolvimento de uma prova" com a obra de Carl Gustaf Leopold chamada Samlade skrifter: 1-3 (2 uppl.), 4-6. Sthm 1800-02. 2 uppl. 1814-33).

No inglês:

De acordo com Oxford (CD-ROM, 2010), a cognata correspondente argumentation já existia no Late Middle English e chegou via francês antigo, que emprestou do latim argumentatio( $n$-), derivado de argumentat- "conduzido como um argumento" que, por sua vez, vem de argumentari.

O dicionário de MURRAY \& BRADLEY (1901) fornece três acepções para esse item lexical: 1) ação ou operação de inferir uma conclusão de proposições como premissas; emprego metodológico ou apresentação de argumentos; raciocínio lógico ou formal; 2) intercâmbio de argumentos, discussão, debate e 3) uma sequência ou cadeia de argumentos, um processo de raciocínio, 
que seria igual a argument. Tomaremos essas três acepções como uma só. $\mathrm{O}$ terminus a quo dessa item lexical, de acordo com os autores, se encontra na obra de William Caxton, Vitas Patrum (W. de W. II 293 b.) de 1491.

(...) thou sekest it by argumentacyon.

[...] você busca isto pela argumentação. (trad. nossa)

Consideraremos, portanto, que essa obra de 1491 é o terminus a quo de argumentation em inglês.

\section{No alemão}

O Herkunftswörterbuch (DUDEN) afirma que a cognata correspondente significa Beweisführung "argumentação, arguição, demonstração de provas", de origem latina com o mesmo significado e que entrou na língua alemã no séc. XVI. O dicionário etimológico de Pfeifer (DWDS) sustenta que esse elemento lexical surgiu na língua no início do século $\mathrm{XVI}$, com o sentido de Beweisführung e Begründung "fundamentação, prova" e veio do latim argumentatio.

Encontramos seu terminus a quo no Google Books com a obra Confessio odder Bekantnus des Glaubens etlicher Fürsten und Stedte [...] (1530):

Es ist warlich ein fein argumentation / als wenn einer Spreche von einem beklagten im halsgericht / wilchem das leben gefristet were [...] (página 7 do cap. von vergebung der sunden)

"É certamente uma boa argumentação. Como se alguém falasse de um réu em um tribunal, a quem a vida tivesse sido levada de maneira miserável" (trad. nossa)

\section{No holandês}

No Etymologiebank encontra-se os dados de van der Siljs (2001, Chronologisch Woordenboek), P.A.F. van Veen en van der Siljs (1997, Van Dale Etymologisch woordenboek) e Woordenboek der Nederlandsche Taal (WNT), que afirmam que a esse elemento lexical surgiu em 1573, com o significado de bewijsvoering "argumentação, disputa, demonstração". Ele seria um empréstimo do francês argumentation que, por sua vez, emprestou do latim argumentationem, derivação de argumentari. O WNT afirma que o sentido sua acepção é "ação de 
argumentar, também com o pensamento sobre a natureza ou o valor dos termos utilizados ou para utilizar argumentos; argumento ou evidência sobre a natureza e conteúdo" e cita a obra de Wielant (Pract. Civ. 31 [ed. 1573]).

\subsubsection{Mundo românico}

Português:

O dicionário Houaiss atesta a etimologia desse elemento lexical da seguinte maneira:

\begin{tabular}{|l|l|l|}
\hline \multicolumn{1}{|c|}{ Dicionário } & \multicolumn{1}{|c|}{ Étimo } & \multicolumn{1}{|c|}{ Datação } \\
\hline Houaiss (online) & $\begin{array}{l}\text { Lat. argumentatio, onis, } \\
\text { "raciocínio lógico, } \\
\text { demonstração" }\end{array}$ & \begin{tabular}{l} 
Tratado da Sphera) \\
\hline
\end{tabular} \\
\hline
\end{tabular}

Nos dicionários de etimologia da língua portuguesa encontramos as seguintes atestações:

\begin{tabular}{|l|l|l|l|}
\hline Dicionário & Forma & Étimo & Datação \\
\hline Cunha (1999) & argumentação & do lat. argumentatio & XVI \\
\hline VHCPM (2007) & $\varnothing$ & $\varnothing$ & $\varnothing$ \\
\hline
\end{tabular}

O Corpus do Português cita a mesma datação e obra considerada por Houaiss:

E que a tal argumentaçam nam valha: vemolo craramente nas partes das sobreditas quartas. (Tratado da Spheracom suas anotações, NUNES, 1537) 
Ao buscar esse elemento lexical no corpus lexicográfico, não o encontramos nem nas obras de Jerônimo Cardoso (1569-1570) nem na de Velez (1599). Na obra de Agostinho Barbosa (1611), disputa é a tradução de disputatio, argumentatio e dispectatio. Barbosa tem como corpus as obras clássicas. Na obra de Bento Pereira, Prosodia, de 1697, há argumentatio com a acepção de argumento comprido. No verbete meditação da obra Thesouro (1697) de mesmo autor, argumentaçam em português corresponde à argumentatio em latim. $\mathrm{Na}$ obra de Pedro José da Fonseca (1798), o verbete argumentatio está traduzido como disposição, e explicação do argumento. O autor afirma que todas essas acepções são para compreender as obras de Cícero. Estas três obras estão de acordo com o dicionário de Lewis (2002): argumentatio é tanto uma condução de provas como a própria prova. Em Carlos Folqman (1755) não há a entrada para esse item lexical; há, por outro lado, a entrada argumento que, segundo o autor, se traduz por argumentum e argumentatio, como é esperado em Cícero, em que argumentatio também tem o sentido de "prova". Folqman exemplifica com: Argumentum, ou argumentationem ad dialecticas rationes conformare ${ }^{146}$.

Na obra de Bluteau, Vocabulário (1712-1728), há a seguinte acepção:

argumentaçam.(Termo Dialectico) He hum dos nomes, que daõ os Logicos à terceyra operaçaõ do Entendimento, \& val o mesmo, que oraçaõ, que os homens inventaraõ para o discurso, no qual se infere huma cousa da outra. Na Argumentaçaõ distinguem os Logicos Antecedente de consequente, \& de consequencia. Cicero Ihe chama Argumenti explicatio, onis. Fem. Argumentatio, no dito orador quer dizer syllogismo, ou argumento, \& naõ Argumentaçaõ, que he explicaçaõ do argumento.

Concluímos que o terminus a quo é, como afirmado por Houaiss, a obra de Pedro Nunes de 1 de dezembro de 1537, Tratado da Sphera. Citação da obra não fornecida pelo Houaiss:

E auemos mais de notar que esta argumentação não concrude. Estes dous arcos sam iguaes [...] (p. bii, p. 29 do documento).

146 Moldar argumento, ou argumentação, para as razões dialéticas. (trad. nossa) 
O dicionário de Houaiss também não indica que essa obra é uma tradução para o português da obra latina Sphaera mundi (1230) de Giovanni Sacrobosco.

\section{Espanhol:}

Nos Corominas encontramos a seguinte entrada:

\begin{tabular}{|l|l|l|l|}
\hline \multicolumn{1}{|c|}{$\begin{array}{l}\text { Dicionári } \\
\text { O }\end{array}$} & Forma & Étimo & Datação \\
\hline $\begin{array}{l}\text { COROMINAS } \\
(1984)\end{array}$ & argumentación & $\begin{array}{l}\text { Deriv. de argüir } \\
\text { (tomado del lat. } \\
\text { arguere) }\end{array}$ & $\begin{array}{l}1457 \quad \text { (Palencia, } \\
\text { Perfección, p. } \\
351 a \quad \text { (Nougué, } \\
\text { Bhisp. LXVI) }\end{array}$ \\
\hline
\end{tabular}

No Corpus do Espanhol, a primeira atestação está no livro introductiones latinae de Antonio de Nebrija (1481).

Com relação à acepção no período, argumentaçion é, de acordo com o dicionário de Palencia (1490), la que faze alos afirmantes enla disputaçion. $\mathrm{Ca}$ el argumento es la mesma sentençia que da fe: \& la argumentation explica la sentençia por la oraçion o razonamiento: delos argumentos hay vnos probables \& necessários (fol. XXXv). No dicionário também se afirma que silogismo \& induçion "son dos espécies de argumentaçión" e que "ca silogismo en griego quiere dezir en latin argumentaçion ineuitable. es silogismo postrera conclusion dela proposiçion \& dela assumpto \& de la confirmaçion". Não há a atestação desse elemento lexical no dicionário de Nebrija (1495).

Afirmamos, portanto, que o terminus a quo no espanhol se encontra na obra Tratado de la perfección del triunfo militar de Palencia (1457), como demonstra o Corominas. 
Italiano:

\begin{tabular}{|c|c|c|c|}
\hline Dicionário & Forma & Étimo & Datação \\
\hline ZINGARELLI & $\begin{array}{l}\text { Argomentazione } \\
\text { (o } \\
\text { argumentazione) }\end{array}$ & $\begin{array}{l}\text { Voc. culto lat. } \\
\text { argumentatione }(m) \text {, } \\
\text { da argumentum } \\
\text { "argomento" }\end{array}$ & $\varnothing$ \\
\hline Deli & Argomentazióne & $\begin{array}{l}\text { vocábulo culto do } \\
\text { lat. argumentu(m) } \\
\text { (de arguere } \\
\text { "demonstrar") }\end{array}$ & $\begin{array}{l}\text { 1481, C. Landino } \\
\text { ("modo de } \\
\text { argumentar") }\end{array}$ \\
\hline
\end{tabular}

O corpus OVI dell'italiano antico nos mostra que o primeiro registro da cognata correspondente argomentazione se encontra em 1313-1314, no dialeto fiorentino, na obra La Sfera di Alfragano de Zucchero Bencivenni. Tal obra seria uma versão de Bencivenni do Sphaera mundi (1230) de Giovanni Sacrobosco.

O TLIO atesta a mesma obra como terminus a quo e, além disso, sugere a seguinte acepção: ragionamento volto a dimonstrare una tesi (attraverso la discussione di argomenti in sucessione logica). Exemplifica com:

Doviamo sapere che se alcuno argomentasse in questo modo la sua argomentazione non varebbe in questo modo: (Sfera di Alfragano de Zucchero Bencivenni, Pt. III, cap 3, p. 129: 13)

"Devíamos saber que se alguém argumentasse deste modo sua argumentação não variaria na seguinte maneira: questi due archi sono iguali" (trad. nossa)

Analisamos uma versão editada por Wolfgang Hopyl de 1489 e há, de fato, esse elemento lexical:

Et notanduz q non valet talis argumẽtatio. Isti duo arcus sũt eqles [...] (B.ii, p. 15 do documento online) 
Francês:

Nos dicionários de francês (incluindo os etimológicos)

\begin{tabular}{|c|c|c|c|}
\hline Dicionário & Forma & Étimo & Datação \\
\hline $\begin{array}{l}\text { Le Petit Robert } \\
(2014)\end{array}$ & $\varnothing$ & latin argumentatio & $\begin{array}{lr}\text { XIV (obras } & \text { de } \\
\text { Eustache } & \\
\text { Deschamps } & \\
\text { ação, arte } & 1) \\
\text { argumentar; } & 2 \text { de } \\
\text { coleção } & \text { de } \\
\text { argumentos } & \text { que } \\
\text { tendem a uma } \\
\text { conclusão }\end{array}$ \\
\hline TLF & argumentacion & $\begin{array}{l}\text { Empréstimo do } \\
\text { latim argumentatio, } \\
\text { derivado de } \\
\text { argumenter }\end{array}$ & $\begin{array}{l}\text { 1291-1328 } \\
\text { (argumentacion, } \\
\text { no sentido de ação } \\
\text { de argumentar, } \\
\text { L'Ovide moralisé, } \\
\text { XI, 193, IGLF. }\end{array}$ \\
\hline $\begin{array}{l}\text { GODEFROY- } \\
\text { Complement (1891- } \\
1902)\end{array}$ & argumentacion & $\varnothing$ & $\begin{array}{l}\text { Ação, arte de } \\
\text { argumentar. } \\
\text { (Oresme, } \\
\text { 147) }{ }^{148 ;}\end{array}$ \\
\hline FEW (2003) & $\varnothing$ & $\begin{array}{l}\text { Emprestado do } \\
\text { latim argumentatio } \\
\text { "argumentação, } \\
\text { argumentos" }\end{array}$ & $\begin{array}{l}\text { env. 1320, Tobler- } \\
\text { Lommatzsch; } \\
\text { GIPar, } \\
\text { Oresme, 1350; }\end{array}$ \\
\hline
\end{tabular}




\begin{tabular}{|l|l|lr|l|}
\hline & $\begin{array}{l}\text { derivado de } \\
\text { argumentari Ação de } \\
\text { Roques }\end{array}$ & $\begin{array}{l}1380 . \quad \text { argumentar } \\
\text { arg }\end{array}$ \\
\hline
\end{tabular}

Ao procurar pelo elemento lexical no Frantext, encontramos a primeira atestação em 1370, na obra de Nicole Oresme, Le Livre de Ethiques d'Aristote, p. 287.

Tanto o TLF quanto o FEW sugerem uma obra mais antiga. O primeiro coloca um período de tempo possível e o segundo afirma que é de 1320, de acordo com o dicionário etimológico de Tobler \& Lommatzch (1925-2002), mas não tivemos acesso a esse dicionário. Tomaremos, portanto, como relevantes para essa pesquisa as informações do TLF, que registra a obra L'Ovide Moralisé como terminus a quo. De acordo com Arlima ${ }^{149}$ (Archives de Littérature du Moyen Âge), é uma obra anônima antigamente atribuída ao Philippe de Vitry e a "Crestien Li Gois", mas tais afirmações parecem ser infundadas. Diferentemente do TLF, o Arlima afirma que a obra foi composta entre 1317 e 1328. Com base nos tomos de Boer (1915-1938), que apresentou todo o poema de 72.000 versos octossílabos, tivemos acesso ao verso (p. 122, vers. 192, Tomo IV, Livro XI, 1936) em que aparece o elemento lexical:

Par lor argumentacion 193

Menoit à redargucion 194

"Pela argumentação deles

Leva à impugnação" (trad. nossa)

O autor cita no primeiro livro da obra (1915, Tomo 1, p. 44-47) que dos 19 manuscritos encontrados, 10 fazem parte do séc. XIV, 5 do séc. XV, 1 do séc. XIV ou XV e 3 sem data. Tentamos ter acesso aos manuscritos com base nas informações do Arlima, que descreve os manuscritos insere a localização de todos eles ${ }^{150}$, mas não tivemos acesso a eles nas bibliotecas como, por exemplo,

\footnotetext{
$149 \mathrm{http}: / / \mathrm{www}$. arlima.net/mp/ovide_moralise.html\#mss

150

http://archive.wikiwix.com/cache/?url=http\%3A\%2F\%2Fwww.arlima.net\%2Fmp\%2Fovide_moral ise.html
} 
na Bibliothéque Nationale de France, na área do Mandragore, que é uma base de manuscritos, uma vez que todos os links para os manuscritos estavam quebrados $^{151}$. Por conta disso, confiaremos na informação do TLF de que o argumentation surgiu entre 1291 e 1328 mesmo que não tenhamos provas concretas para isso.

Latim:

As seguintes acepções foram recolhidas referentes a esse item lexical, de acordo com Lewis:

1) Uma condução de provas

i. Nam argumentatio nomine uno res duas significat, ideo, quod et inventum aliquam in rem probabile aus necessarium, argumentatio vocatur et ejus inventi artificiosa expolitio (Cic. Inv. 1, 40)

"Pois a argumentação significa duas coisas sob um único nome; quer dizer, qualquer discussão a respeito de qualquer coisa que é provável ou necessária é chamada de argumentação; e também é o polimento sistemático de tal discussão [...]" (trad. nossa)

ii. Est ergo (ut supra dictum est) explicatio argumenti argumentatio (de Partitionibus Oratoriae, cap. 13, 46)

"Portanto, como dito acima, a explicação dos argumentos é a argumentação" (trad. nossa)

2) A própria prova

Etiamme in tam perspicuis rebus argumentatio quaerenda est aut conjunctura capienda? (Cic. Rosc. Am. 35)

Mesmo em casos tão evidentes, deve-se procurar por argumento ou obter conjecturas? (trad. nossa)

\footnotetext{
151 http://mandragore.bnf.fr/jsp/rechercheExperte.jsp
} 


\subsubsection{Determinação do étimo}

Terminus a quo (mais antigo ao mais novo)

\begin{tabular}{|c|c|}
\hline Mundo romano & \\
\hline Francês & $1291-1328$ \\
\hline Italiano & $1313-1314$ \\
\hline Espanhol & 1457 \\
\hline Português & 1 de dezembro de 1537 \\
\hline Inglês & 1491 \\
\hline Alemão & 1530 \\
\hline Holandês & 1573 \\
\hline Sueco & 1721 \\
\hline Dinamarquês & 1797 \\
\hline Dinamarquês na Noruega & 1808 \\
\hline Nynorsk & 1 de agosto 1869 \\
\hline Dialeto norueguês & 1893 \\
\hline Bokmål & 1907 \\
\hline
\end{tabular}

Inserimos o campo dialeto norueguês acima para indicar que esse item lexical já havia sido inserido no sistema den dana daglegtala "fala culta do dia-adia", utilizado pelo autor Hans Jæger. Esse sistema, como considerado no subcapítulo 1.4.2.1. sobre as línguas na Noruega antes de 1814, é uma mistura do dano-norueguês com uma boa parte de inserção de elementos nativos e que a partir do século XVII foi a língua materna de parte da elite norueguesa. De acordo com Språkrådet ${ }^{152}$ (Conselho linguístico estatal da Noruega), ele, assim como

152 vart/Publikasjoner/Spraaknytt/Arkivet/Spraaknytt_2002/Spraaknytt_2002_2/Polfarernorsk/ 
outros autores (i.e. Fridtjof Nansen e Roald Amundsen), desprezava a sociedade burguesa com suas convenções e regulamentos e, por conta disso, escreveu três romances onde tentou ajustar a escrita com a sua fala, a den danadaglegtala "fala culta do dia-a-dia". Apesar dessa língua falada ter muitos elementos do dinamarquês, adaptados com uma pronúncia norueguesa, consideramos como norueguês e não dinamarquês, sendo, assim, uma etapa anterior ao bokmål, que tem a normatização escrita dessas modificações, e Jæger em suas obras representou essas modificações na escrita num período bem anterior à obrigatoriedade da utilização de tais modificações na escrita (ano de 1907). E mesmo que essa forma não seja tão radical como, por exemplo, os dialetos do leste, que proveram a base para o landsmål, consideramos ainda assim que seja um tipo de dialeto norueguês, mesmo com muitas influências dinamarquesas.

A primeira abonação do italiano é uma tradução do latim científico e a do francês é uma obra religiosa, só que não é uma tradução. Concluímos que não é possível saber, pela falta de mais informações que os manuscritos poderiam fornecer, qual dessas obras surgiu primeiro.

1) A respeito das línguas de influência em determinados temas, a acepção de "condução de provas" não remete a nenhum tema específico, provavelmente tenderia a ir na direção do Direito e da Retória, que são áreas muito difundidas na língua latina.

2) A relação entre escrita e pronúncia não nos proporciona nenhuma pista para a investigação do étimo, uma vez que cada língua pronuncia o radical argument- da sua maneira.

3) O radical do elemento lexical é argument- e remete ao latim; portanto, não seria um radical exclusivo de nenhuma língua descendente.

4) Neste elemento lexical os cruzamentos panromânicos de Freitas não se aplicam, pois vimos que não foi uma língua que espalhou para todas as outras, mas sim que pode ter havido duas frentes principais (i.e. francês e italiano). Até mesmo para o português ele não veio diretamente de uma língua vernácula e sim diretamente da tradução do latim, cuja obra traduzida é a mesma da qual o italiano emprestou. 
5) A questão semântica é de pouca relevância para esse item lexical porque ele permaneceu basicamente a mesma ("condução de provas" ou "a própria prova").

No presente caso, apenas o terminus a quo de fato ajuda na determinação do étimo. O procedimento (1) é parcialmente relevante.

\subsubsection{Fichas}

\subsubsection{Para o português}

\section{Argumentação s.f.}

$100 \%$ ( 4 lat. cient. argumentatio)

Comentário: Verificamos que a primeira abonação aparece na obra de Pedro Nunes, que é uma tradução da obra latina Sphaera mundi (1230) de Giovanni Sacrobosco

1 de dezembro de 1537. Tratado de sphera com a Theorica do Sol e da Lua. E ho primeiro liuro da Geographia de Claudio Ptolomeo Alexandrino.

Origem do significado da acepção: latina

Origem do significante da acepção: latina

Étimo de empréstimo: 100\% latim científico

Local: Biblioteca Nacional de Portugal

Discussão a respeito das informações do Houaiss:

O Houaiss afirma que argumentação vem do latim e a primeira abonação se encontra no ano de 1537. Nossa pesquisa está de acordo com essas informações. 


\subsubsection{Para o norueguês}

\section{Argumentasjon, s.m.}

Nos dialetos noruegueses:

16,66\% ( 4 nyn. argumentation, $1869 \triangleleft$ din. na Noruega. argumentation 1808 \in. argumentation 1797 \ue. argumentation 1721 \ol. argumentatie, 1573 《 ale. Argumentation 1530 ४ ing. argumentation, 1491 \&r. argumentation, 1291-1328 \& latim medieval argumentatio)

16,66\% ( 4 nyn. argumentation, $1869 \triangleleft$ din. na Noruega. argumentation 1808 \&in. argumentation 1797 ४ hol. argumentatie, 1573 ale. Argumentation 1530 ४ ing. argumentation, 1491 \&r. argumentation, 1291-1328 4 latim medieval argumentatio)

16,66\% ( 4 nyn. argumentation, $1869 \$ din. na Noruega. argumentation 1808 < din. argumentation 1797 \ale. Argumentation $1530<\mathrm{ing}$. argumentation, 1491 fr. argumentation, 1291-1328 latim medieval argumentatio)

16,66\% ( 4 nyn. argumentation, $1869 \triangleleft$ din. na Noruega. argumentation $1808<$ din. argumentation $1797<$ ing. argumentation, 1491 fr. argumentation, 1291-1328 \ latim medieval argumentatio)

$16,66 \%$ ( nyn. argumentation, $1869 \triangleleft$ din. na Noruega. argumentation 1808 din. argumentation 1797 \r. argumentation, 1291-1328 \ latim medieval argumentatio)

16,66\% ( 4 nyn. argumentation, $1869 \triangleleft$ din. na Noruega. argumentation 1808 \in. argumentation 1797 \ latim medieval argumentatio)

Não há indícios concretos para demonstrar o caminho exato que o item lexical levou para chegar até o norueguês. Temos a hipótese de que o étimo é $100 \%$ norueguês nynorsk porque esse item lexical é atestado desde 1869 nas obras de Aasmund Olavsson Vinje, como demonstrado abaixo; o ponto de partida foi o latim medieval. É possível que ele tenha chegado ao dinamarquês pelo alemão, pelo sueco, pelo inglês, pelo francês ou diretamente do latim medieval.

1893. Syk kjærlihet: roman de Hans Jæger

Trecho: Deres svar paa defensors uigjendrivelie argumentation var taushet ${ }^{153}$

${ }^{153}$ A resposta deles sobre a argumentação incontestável do defensor foi o silêncio (trad. nossa) 
Origem do significado da acepção: latina

Origem do significante da acepção: latina

Étimo de empréstimo: 100\% norueguês nynorsk

Local: Nasjonalbiblioteket

\section{Bokmål:}

$16,66 \%$ ( 4 din. na Noruega. argumentation $1808 \triangleleft$ din. argumentation 1797 sue. argumentation 1721 \ol. argumentatie, 1573 ४ ale. Argumentation $1530<\mathrm{ing}$. argumentation, 1491 - fr. argumentation, 1291-1328 \ latim medieval argumentatio)

16,66\% ( din. na Noruega. argumentation $1808<$ din. argumentation $1797 \varangle$ hol. argumentatie, $1573 \varangle$ ale. Argumentation $1530 \varangle$ ing. argumentation, 1491 \&r. argumentation, 1291-1328 ४ latim medieval argumentatio)

16,66\% ( din. na Noruega. argumentation 18084 din. argumentation 17974 ale. Argumentation $1530<\mathrm{ing}$. argumentation, 1491 ४ fr. argumentation, 1291-1328 4 latim medieval argumentatio)

$16,66 \%$ ( din. na Noruega. argumentation $1808<$ din. argumentation $1797 \varangle \mathrm{ing}$. argumentation, $14914 \mathrm{fr}$. argumentation, 1291-1328 latim medieval argumentatio)

16,66\% ( 4 din. na Noruega. argumentation 18084 din. argumentation 1797 fr. argumentation, 1291-1328 4 latim medieval argumentatio)

16,66\% (《 din. na Noruega. argumentation $1808<$ din. argumentation 1797 \&atim medieval argumentatio)

1907. Forkjel og vurdering: artikler om kirkestriden de M. J. Gjessing

Trecho: [...] naar man ser hen til den Argumentation, som vedkommende Prest benytter sig av. ${ }^{154}$

Origem do significado da acepção: latina

Origem do significante da acepção: latina

Étimo de empréstimo: $100 \%$ dinamarquês

Local: Nasjonalbiblioteket 
Comentário: temos a hipótese de que o item lexical é 100\% de étimo dinamarquês porque ele já estava em uso há muito tempo no dinamarquês escrito na Noruega. Rechaçamos a hipótese de que teria étimo no norueguês landsmaal (nynorsk) porque havia um conflito contra essa norma.

Discussão a respeito das informações dos dicionários do bokmål:

Os dicionários $\mathrm{NbUiB}$ e o ROB nada afirmam sobre o étimo desse item lexical. O NTG apenas sugere que ele é um substantivo verbal de argumentere, o que estaria correto se estivéssemos tratando da língua latina e não da norueguesa.

Nynorsk:

$16,66 \%$ ( 4 din. na Noruega. argumentation $1808 \triangleleft$ din. argumentation 1797 sue. argumentation 1721 hol. argumentatie, 1573 ४ ale. Argumentation 1530 ४ ing. argumentation, $1491<\mathrm{fr}$. argumentation, 1291-1328 4 latim medieval argumentatio)

16,66\% ( 4 din. na Noruega. argumentation $1808 \triangleleft$ din. argumentation 1797 hol. argumentatie, 1573 ale. Argumentation 1530 ४ ing. argumentation, $1491 \varangle \mathrm{fr}$. argumentation, 1291-1328 4 latim medieval argumentatio)

16,66\% ( 4 din. na Noruega. argumentation $1808 \triangleleft$ din. argumentation 1797 ale. Argumentation 1530 ४ ing. argumentation, 1491 ४ fr. argumentation, 1291-1328 - latim medieval argumentatio)

16,66\% ( 4 din. na Noruega. argumentation $1808<$ din. argumentation 1797 ing. argumentation, 1491 fr. argumentation, 1291-1328 latim medieval argumentatio)

$16,66 \%$ ( 4 din. na Noruega. argumentation 18084 din. argumentation 1797 fr. argumentation, 1291-1328 \ latim medieval argumentatio)

16,66\% ( $\triangleleft$ din. na Noruega. argumentation $1808 \triangleleft$ din. argumentation 1797 ४ latim medieval argumentatio)

Comentário: o elemento lexical surgiu primeiramente no landsmål do que no riksmål ou bokmål e, por isso, concluímos ser um empréstimo do dinamarquês. 
1 de agosto 1869. A. O Vinjes skrifter i Utval. B. 5 : Innanlandsk politik publicado pela Det Norske Samlaget em 1889

Trecho: [...] Hammarstad slog meg og i eit Ordskifte om vaare politiske Stormenn til Jordi med denne sama Argumentation: «Ja, du ser, at du ikki kann berga deg» ${ }^{155}$

Origem do significado da acepção: latina

Origem do significante da acepção: latina

Étimo de empréstimo: $100 \%$ dinamarquês

Local: Nasjonalbiblioteket

Discussão a respeito das informações do dicionário de nynorsk:

O NyUiB nada afirma sobre o étimo desse elemento lexical e, portanto, nossa pesquisa ajuda nesse sentido.

\section{Origem do significante:}

O elemento lexical latino argumentatio é uma derivação a partir do particípio argumentatus do infinitivo passivo do verbo argumentor (-aris, -ari, -atus sum) "aduzir prova, argumentar". De acordo com Ernout \& Meillet 1932 [20016], argumentor é um denominativo de argumentum "prova", "argumento", "justificação", "razão" (p. 46).

Fortson IV (2004) afirma que um sufixo homófono acentuado era utilizado para formar verbos denominativos, que derivam de substantivos ou de outras partes da fala como, por exemplo, ing. to head, to chair). No IE esses verbos eram formados ao adicionar o sufixo *-ie/o- diretamente à raiz de um substantivo. Portanto, a partir de ${ }^{*} h_{1} n_{n} h_{3} m n$ - "nome", formava um verbo denominativo * $h_{1} n_{n} h_{3} m n$-ie/- "nomear", que reflete no hitita lamn-iya-zzi "nomes" (lamn- "nome", com I substituído pelo $\mathrm{n}$ ), grego onomaínō "eu nomeio" (< prégrego *enomn-ie/o-) e germânico *namnjan "nomear" (compare no gótico namnjan e no AAA nemnen). De acordo com o autor esses verbos se tornaram extremamente produtivos na maioria das línguas filhas do IE. Por exemplo, o

155 Hammarstad bateu em mim e em uma discussão sobre nossos aristocratas políticos de Jordi falou com a mesma argumentação: "sim, você vê que você não pode se salvar" (trad. nossa) 
grego criou muitos denominativos a partir de substantivos cuja raiz terminava em $i d$-; a combinação resultante pré-grega *id-ie/o se tornou (por meio de mudanças fonéticas regulares) gr. -ize/o e isso então foi reanalisado como um sufixo denominativo separado. Este sufixo foi até o inglês (i.e. -ize) (p. 90)

Sihler (1995) afirma que a inserção do sufixo é mais transparente no védico, pois o -ya- fica preservado em todas as posições, ao passo que tanto no grego quanto no latim, e outras línguas IE, ele permanece disfarçado pela perda do -y- intervocálico, contração e outras mudanças fonéticas. O autor também registra que as funções dos denominativos eram das mais variadas: de factivo (escravizar), incoativo (envelhecer), agentivos (verbos com acepção de, por exemplo, agir como um determinado animal), instrumentativos (forçar, telefonar), locativos (centrar, alistar), etc. (p. 511). De acordo com o autor, o tipo do IE, que permaneceu produtivo, é geralmente encontrado na $4^{\mathrm{a}}$ conjugação (portanto, finire "terminar" de finis "fim", etc.). Este tipo tratava originalmente substantivos de tema em -a e alguns com tema em -o, e de uma formação factiva deadjetival (i.e. novare "renovar"). Porém, isto se propaga além das bases funcionais em latim, que forma derivativos com base em todas os temas como, por exemplo, levare "elevar" (de levis "leve"), laudare "louvar, elogiar" (de laus "louvor"), nominare "nomear" (de nomen "nome"). Há também denominativos intransitivos, que são sempre depoente, como, por exemplo, laetari "ser feliz" (de laetus "feliz"), embora há muitas exceções a essa generalização (p. 514-515).

O item lexical argumentum, por sua vez, é uma composição a partir do verbo arguo ("eu provo", "eu demonstro", "eu mostro", "eu indico") mais o sufixo mentum "meio, resultado de". Arguo, por fim, provém de um proto-itálico *argu"brilhante" que, por sua vez provém do IE * $h_{2} e r g ́-u$ - "branco", com cognatas no hitita arkuunae-zi "fazer um apelo" (<* arkuue/a-zi < *arkuie/a-, Melchert 1998, < IE *h2orǵ-u-ie- "deixar claro", Kloekhorst 2008: 206); sânscrito árju-na "branco, claro";

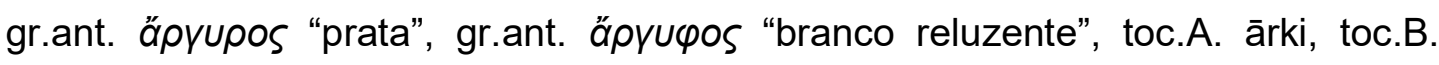
ārkwi "branco" (de VAAN, 2008, p. 53). De acordo com o autor, provavelmente arguo é um verbo denominativo que significaria "deixar brilhante, clarear", que surgiu a partir do adjetivo *argu- "brilhante" (p. 53). 


\subsection{Deflação/Deflasjon}

\subsubsection{Apresentação dos dados}

\subsubsection{Mundo germânico}

Norueguês

Significados em dicionários atuais (a partir de 1901 em nynorsk e 1907 em bokmål):

\begin{tabular}{|c|c|c|c|}
\hline Dic. & Significado & Etimologia & Datação \\
\hline $\mathrm{NbUiB}$ & $\begin{array}{l}\text { Queda de preço e aumento } \\
\text { no valor do dinheiro, } \\
\text { contrário a inflasjon }\end{array}$ & Pelo ing. do lat. & Não consta \\
\hline NyUiB & $\begin{array}{l}\text { (diminuição do montante de } \\
\text { dinheiro e outras medidas } \\
\text { que levam a) queda do } \\
\text { preço e aumento do valor } \\
\text { do dinheiro }\end{array}$ & $\begin{array}{l}\text { Pelo ing. do lat. } \\
\text { de- e flatus } \\
\text { "vento" }\end{array}$ & Não consta \\
\hline \multirow[t]{2}{*}{ NTG } & $\begin{array}{l}\text { 1. Redução do } \\
\text { montante do dinheiro } \\
\text { para estabilizar o } \\
\text { valor do mesmo; } \\
\text { queda e medida } \\
\text { econômica de dim } \\
\text { 2. Erosão causada pelo } \\
\text { vento }\end{array}$ & $\begin{array}{l}\text { De de- II e latim } \\
\text { flatus "vento", } \\
\text { quer dizer } \\
\text { "diminuição da } \\
\text { força do vento" }\end{array}$ & Não consta \\
\hline & $\begin{array}{l}\text { 1. (financ.) transição da } \\
\text { inflação para uma }\end{array}$ & De. Lat. deflare & \\
\hline
\end{tabular}




\begin{tabular}{|l|l|l|l|}
\hline OB & $\begin{array}{l}\text { condição financeira e } \\
\text { de crédito normal } \\
\text { (indicado com queda } \\
\text { de preço e efeito de } \\
\text { redução econômico) }\end{array}$ & & \\
{$[\ldots]$} & & \\
2. Erosão causada por & & \\
vento & & \\
\hline
\end{tabular}

Trataremos das duas acepções, que também existem no português.

Livros em dinamarquês publicados na Noruega

A primeira atestação do elemento lexical com a acepção geográfica está na enciclopédia Illustreret norsk konversations leksikon (1908):

Defi'nitiv (lat.), afgjort, bestemt, endelig (modsat terimistisk og provisorisk, s. d.).

Deflation, se Denudation.

Defle'ktor, nautisk instrument, hvormed foretages imnasknrrelition no deviationsundersagelse ombord

"Deflation, veja denudation" (trad. nossa)

Denudation, de acordo com a enciclopédia, significa na geologia a retirada de partes que ficam na superfície da crosta.

O livro, apesar de ser de 1908 está escrito basicamente em dinamarquês pois encontramos muitas características dinamarquesas:

1) Uso das consoantes sonoras: aaben (em vez de aapen) "aberto", mod (em vez de mot) "contra", kage (em vez de kake) "bolo"; 2) utilização da terminação -e na forma indeterminada do gênero comum: gange (em vez de ganger) "vezes" e penge (em vez de penger) plural de "dinheiro"; 3) plural com a terminação do gênero neutro na forma indeterminada: huse (em vez de hus); 4) passados e particípios de verbos fracos terminados em -ede como kastede (em 
vez de kastet) "jogou" e svarede (em vez de svarte "respondeu"); 5) uso do sufixo neutro - $t$ nos adjetivos terminados em -ig como et heldigt (em vez de et heldig) "um ... sortudo" e 6) verbos e substantivos não encurtados: drage "puxar", have "ter" e broder "irmão".

No período em que se escrevia dinamarquês não foi encontro o elemento lexical com a acepção financeira.

\section{Cognatas em outras línguas germânicas}

\section{Dinamarquês (publicado na Dinamarca)}

A respeito dos dicionários, a cognata está atestada no dicionário online de palavras estrangeiras de Meyer (1924) tanto na acepção de geologia quanto na de economia.

No Google Books há a obra Økonomisk revue (vol. 4, 1921) em que se encontra a cognata no sentido econômico:

At gjennomføre en deflation av pengeværdien uten at gjøre [...] (p. 524)

"Realizar uma deflação do valor do dinheiro sem fazer [...]" (trad. nossa)

O terminus a quo da acepção geológica foi encontrada na obra de Bøving-Petersen (1912):

[...] af Vindens "æoliske" Virksomhed, den saakaldte Deflation eller Bortblæsning. (p. 85)

"[...] do efeito "eólico" do vento, que é chamado deflação ou sopro para fora" (grifo e trad. nossos)

\section{No sueco}

No sueco encontramos a primeira atestação com a acepção econômica em 1920 no jornal Anglo-Swedish Trade:

Bankmännen frukta [...] en deflation [...] (p. 101)

"O banqueiro temia [...] uma deflação [...]" (trad. nossa). 
A acepção geológica não foi encontrada.

No inglês:

No Oxford (CD-ROM, 2010) se apresentam duas acepções para a cognata correspondente deflation: 1) a redução no montante de dinheiro na economia de um país para que os preços caiam ou permaneçam os mesmos e a ação do ar sendo removido de algo e 2) a ação do ar sendo removido de alguma coisa. O primeiro registro é do séc. XIX (no sentido de "liberar o ar de algo inflado").

O dicionário etimológico de Murray não apresenta essa cognata.

No Google Books o registro mais antigo com a acepção econômica é, de fato, de 1920. Um exemplo é o livro High Prices and Deflation de Edwin W. Kemmerer:

The hardships therefore and the resulting political difficulties of carrying through a program of price level reduction through deflation (...) (p. 63)

No corpus pago de jornais antigos Newspapers encontramos esse item lexical em uma data bem mais antiga:

Theirs would be the irresponsible power to say then "the common good" requires an inflation of the currency, decreasing prices, and when a deflation, increasing prices! (The Commoner, 24 de dezembro de 1909, p. 15)

O primeiro registro da acepção geográfica está na revista Scottish Geographical Magazine (Volume 7, 1891), na parte de Book review:

The disintegration of rocks in a desert is confined to their exposed surfaces, and were "deflation" or the transporting action of the wind to cease, denudation would quickly come to an end (p. 504).

${ }^{156}$ Disponível em: https://www.newspapers.com/image/49594187/?terms=deflation\%2Bprices 
No alemão

O terminus a quo da cognata correspondente Deflation com o sentido geográfico está na obra de Johannes Walther (1891):

Bei seiner hohen Bedeutung glaube ich, dass es nützlich ist, diesen Denudationsprocess mit einem besonderen Namen zu bezeichnen, und so schlage ich vor, das Wort „Deflation“ für die denudierende Thätigkeit bewegter Luft zu gebrauchen (p. 382)

"Por conta de sua grande importância eu acho que é relevante indicar esse processo de denudação com um nome especial e, então, proponho utilizar a palavra "Deflação" para o efeito denudante do vento agitado." (trad. nossa)

No dicionário de Meyers Konversations-Lexikon (IV Band, 1894) afirmase que Deflation significa Denudation "desnudação", quer dizer, há apenas a acepção geológica.

Com a segunda acepção encontramos a primeira abonação no jornal alemão Die Uhrmacher-Woche de 23 de outubro de 1920:

Die Rückkehr zur effektiven Goldwährung ist nicht zu empfehlen, weil sie eine plötzliche Deflation (Papierwertsteigerung) zur Folge hätte (...)

"O retorno ao padrão-ouro efetivo não é recomendável pois ele teria como consequência uma deflação repentina (aumento do valor mobiliário) [...]" (trad. nossa)

\section{No holandês}

O Woordenboek der Nederlandsche Taal (WNT) afirma que há duas acepções:

1. (geo.) efeito removedor do veto no solo

2. (econ.) aumento em valor do dinheiro

Como étimo da acepção geológica registra-se que o item lexical veio do inglês deflation (1893), que por sua vez vem do alemão Deflation (1891, primeiro relatado pelo acadêmico alemão J. Walther). Como primeiro registro: Gedaanteverand. Aarde de Escher (1916). A respeito da segunda acepção, vem do francês déflation (1909), também no ing. deflation (1920) e no ale. Deflation (início do séc. XX). Como primeiro registro Financ. D. Ondern. de V. Ketel (1944). 
M. Philippa e.a. (2003-2009) cita datas anteriores. A acepção geológica entra na língua em 1913 (Baale) diretamente do alemão (1891), ou por meio do inglês, pelo geólogo John Walther, que divulgou esse elemento lexical, uma analogia com outro elemento lexical técnico, a erosão. Imediatamente após sua introdução, ela foi entendida no alemão como oposição à Inflation. Em agosto de 1891 o elemento lexical foi introduzido no inglês com a acepção de "esvaziamento de algo que está inchado". Em 1920, após a Primeira Guerra Mundial e, consequentemente, a crise monetária, deflation no inglês recebe primeiramente um sentido econômico, que ocorre também no francês em 1922. O holandês tem essa acepção, que veio talvez pelo francês, emprestado do inglês. Afirma-se que o primeiro registro ocorreu em 1929 com Kramers II.

Não entendemos o motivo do dicionário afirmar que "imediatamente após sua introdução", ela foi entendida no alemão como oposição à Inflation, pois a introdução na língua foi em 1891, quer dizer, foi um elemento lexical criado por John Walther, e o mesmo elemento lexical com acepção econômica só apareceu em 1920.

\subsubsection{Mundo românico}

\section{Português:}

Os dicionários de língua portuguesa atestam a etimologia desse elemento lexical da seguinte maneira:

\begin{tabular}{|l|l|lr|}
\hline Dicionário & \multicolumn{2}{|c|}{ Étimo } & \multicolumn{2}{|c|}{ Datação } \\
\hline Houaiss (online) & ing. deflation (1893) na & $1926 \quad$ (Cândido de \\
acp. geológica e (1920) na & Figueiredo & Novo \\
& acp. econômica, der. de to & Diccionário da Língua \\
& deflate 'diminuir a força', & Portuguesa) & \\
& do lat. deflatum,supn. de & & \\
& deflarer 'soprar por & & \\
& cima',der. de flo 'soprar, & \\
\hline
\end{tabular}


bafejar'; ver inch-

No dicionário de Houaiss há duas acepções: 1) (econ.) ato ou efeito de frear a inflação com medidas monetárias (redução do meio circulante) ou financeiras (controle do crédito, enquadramento de preços etc.); 1.1.) (econ.) redução do papel-moeda em circulação, a fim de provocar o aumento do poder aquisitivo de uma moeda avaliada em ouro ou em mercadoria 2) (geo.) transporte pelo vento de pequenos detritos desagregados que se encontram nas anfractuosidades das rochas.

Pela pesquisa sabemos que, diferentemente do que fala Houaiss, deflação com acepção geológica entrou em 1891.

Nos dicionários de etimologia da língua portuguesa encontramos as seguintes atestações:

\begin{tabular}{|l|l|l|l|}
\hline Dicionário & Forma & Étimo & Datação \\
\hline Cunha (1999) & Deflação & $\begin{array}{l}\text { Do ing. deflation, } \\
\text { palavra criada por } \\
\text { oposição a inflation }\end{array}$ & Séc. XX \\
\hline VHCPM (2007) & Não consta & Não consta & Não consta \\
\hline MACHADO (1900) & Deflação & Do inglês & 1920 \\
\hline
\end{tabular}

Nos dicionários mais antigos não encontramos esse item lexical.

Com base na Hermenoteca, retrodatamos o item lexical para 1920 (jornal A Federação, 11 de dezembro de 1920):

[...] conforme o fluxo e refluxo dos descontos, afim de evitar as crises commerciaes e bruscos movimentos de inflação e deflação de crédito 
A respeito da acepção geográfica, curiosamente não encontramos nenhum resultado no período das outras línguas (até o primeiro quarto do séc. $X X)$. No Corpus do português encontramos apenas um resultado, que não está datado e só a o título da obra: erosão dos solos, quer dizer, não tem relevância para essa dissertação.

No Google Books, também não encontramos nada muito antigo. O terminus a quo da acepção geológica é o dicionário de Freire (1954).

Não encontramos nenhuma abonação mais antiga nos acervos da Folha e da Veja.

\section{Espanhol:}

Nos Corominas encontramos a seguinte entrada:

\begin{tabular}{|l|l|l|l|}
\hline Dicionário & Forma & Étimo & Datação \\
\hline $\begin{array}{l}\text { COROMINAS } \\
(1984)\end{array}$ & Não consta & Não Consta & Não Consta \\
\hline
\end{tabular}

Encontramos a entrada deflación no dicionário da Real Academia Española, que afirma que é um termo da economia (descenso del nivel general de precios) e que vem do fr. déflation, que por sua vez vem do ing. deflation.

No ano de 1923 encontramos o primeiro registro tanto do elemento lexical com sentido da Geografia quanto da Economia:

[...] el defensor más caluroso de la denudación por deflación, considera que así se forman también los oasis [...] (Revista del Instituto Histórico y Geográfico del Uruguay, Vol 3, 1923, p. 176).

[...] 330 milillones, se rebajaría a 132 mil millones y esto es mucho más lógico que uma deflación progressiva. (La Comunidad económica mundial y la amenaza de su decadencia, Vicent Gay y Forner, 1923, p. 296) 
Italiano:

\begin{tabular}{|c|c|c|c|}
\hline Dicionário & Forma & Étimo & Datação \\
\hline ZINGARELLI & deflazióne & $\begin{array}{l}\text { 1. fr. déflation, } \\
\text { do inglês } \\
\text { deflation } \\
\text { "sgonfiament } \\
\text { o", } \\
\text { contraposto } \\
\text { a inflation } \\
\text { "gonfiamento } \\
\text { " } \\
\text { 2. (geo.) de lat. } \\
\text { deflare } \\
\text { "assoprar" }\end{array}$ & $\begin{array}{l}\text { 1. } 1931 \text { (econ.) } \\
\text { condição do } \\
\text { sistema } \\
\text { econômico } \\
\text { caracterizada } \\
\text { pela redução da } \\
\text { circulação } \\
\text { monetária e, } \\
\text { consequenteme } \\
\text { nte, diminuição } \\
\text { do nível geral } \\
\text { dos preços } \\
\text { 1913 (geol.) } \\
\text { remoção, pelo } \\
\text { vento, formada } \\
\text { de grânulos de } \\
\text { areia para a } \\
\text { desintegração } \\
\text { de rochas. }\end{array}$ \\
\hline Deli & deflazióne & $\begin{array}{l}\text { 1. Ingl. deflation } \\
\text { (1920 nessa } \\
\text { acepção), } \\
\text { propr. } \\
\text { "sgonfiament } \\
\text { o", de } \\
\text { inflation } \\
\text { "inflazione", a } \\
\text { palavra } \\
\text { chegou até o } \\
\text { italiano } \\
\text { provavelment } \\
\text { e através do } \\
\text { fr. déflation } \\
\text { (1922). } \\
\text { 2. Mesma } \\
\text { definição do }\end{array}$ & $\begin{array}{l}\text { 1. } 1919 \text { (A. } \\
\text { Cabiati: SLI X, } \\
\text { 1984, 118). } \\
\text { Mesma } \\
\text { definição do } \\
\text { Zingarelli } \\
\text { 2. } 1913 \text { (geol.) } \\
\text { Mesma } \\
\text { definição do } \\
\text { Zingarelli }\end{array}$ \\
\hline
\end{tabular}




\section{Zingarelli}

Não compreendemos o motivo pelo qual o Deli afirma que a obra no italiano é de 1919 ao passo que a cognata correspondente provavelmente veio do francês (1922), que por sua vez veio do inglês (1920), quer dizer, é anacrônico. Por conta disso preferimos escolher a primeira abonação encontrada no Google Books, o livro La deflazione dei salari de Biondi (1921).

Nem nos corpora nem no Google Books encontramos uma datação mais antiga.

\section{Francês:}

Nos dicionários de francês (incluindo os etimológicos):

\begin{tabular}{|l|l|l|l|}
\hline Dicionário & Forma & Étimo & Datação \\
\hline $\begin{array}{l}\text { Le Petit Robert } \\
(2014)\end{array}$ & déflation & $\begin{array}{l}\text { Do alemão } \\
\text { Deflation; do latim } \\
\text { deflare "remover ao } \\
\text { soprar" }\end{array}$ & 1909 \\
\hline TLF & déflation & $\begin{array}{l}\text { No inglês há desde } \\
1891\end{array}$ & $\begin{array}{l}\text { 1. (fin.) } 1909 \\
\text { 2. (geo.) } 1932\end{array}$ \\
\hline
\end{tabular}

Le Petit Robert apenas cita a acepção geológica e também que o primeiro registro está no ano 1909, em uma entrada na Larousse mensuel de Claude Augé (1907-1910). Verificamos a fonte e de fato o elemento lexical está registrado no mês de março (no 25, p. 420). Nesta entrada não se encontra nenhuma informação sobre a acepção financeira. Porém, pelo Google Books encontramos uma obra um ano mais antiga em que se registra essa acepção (i.e. La Presqu'ile du Sinai de Raymond Weill, 1908): 
En somme, la démolition du terrain se poursuit par le double mécanisme de l'érosion et de la déflation [...] (p. 59)

"Em suma, a demolição do terreno continua pelo duplo mecanismo de erosão e de deflação" (trad. nossa)

O TFL afirma o contrário: que a acepção financeira é de 1909, ou seja, mais nova que a acepção geológica, de 1932. Constatamos essas afirmações como erradas.

O terminus a quo da abonação financeira está na obra de Yves-Guyot \& Raffalovich (1921), que se chama Inflation et Déflation.

Latim:

Não consta, mas há a forma verbal deflo no dicionário de Gaffiot (1934), que afirma que o significado é "remover assoprando" e cita a obra de Varro (116 a.C. - 27 a.C.), De Re Rustica, 64:

Amurcam cum ex olea expressa, qui est umor aquatilis, ac retrimentum conditum in vas fictile. Id quidam sic solent tueri; diebus $X V$ in eo quod est levissimum ac summum deflatum ut traiciant in alia vasa [...]

"A amurca, espremida das olivas e que é um fluído aquoso, é armazenada com junto com os sedimentos em um vaso de barro. Alguns têm o costume de fazer assim para preservar: após quinze dias os sedimentos que, estando mais leves, sobem até o topo são assoprados para fora [...]" (trad. nossa)

Também encontramos essa cognata correspondente na obra lexicográfica de Estienne (1552):

Deflo/ deflas, deflare - souffler. 


\subsubsection{Determinação do étimo}

Terminus a quo (mais antigo ao mais novo)

\begin{tabular}{|c|c|}
\hline \multicolumn{2}{|l|}{ Mundo Romano } \\
\hline Francês & $\begin{array}{l}1908 \text { (geo.) } \\
1921 \text { (fin.) }\end{array}$ \\
\hline Italiano & $\begin{array}{l}1913 \text { (geo.) } \\
1921 \text { (fin.) }\end{array}$ \\
\hline Espanhol & $\begin{array}{l}1923 \text { (geo.) } \\
1923 \text { (fin.) }\end{array}$ \\
\hline Português & $\begin{array}{l}1954 \text { (geo.) } \\
1920 \text { (fin.) }\end{array}$ \\
\hline \multicolumn{2}{|l|}{ Mundo Germânico } \\
\hline Alemão & $\begin{array}{l}1891 \text { (geo.) } \\
1920 \text { (fin.) }\end{array}$ \\
\hline Inglês & $\begin{array}{l}1891 \text { (geo.) } \\
1909 \text { (fin.) }\end{array}$ \\
\hline Holandês & $\begin{array}{l}1913 \text { (geo.) } \\
1929 \text { (fin.) }\end{array}$ \\
\hline Sueco & 1920 (fin.) \\
\hline Dinamarquês na Noruega & $\begin{array}{l}1908 \text { (geo.) } \\
\text { Não encontramos (fin.) }\end{array}$ \\
\hline Dinamarquês & $\begin{array}{l}1912 \text { (geo.) } \\
1921 \text { (fin.) }\end{array}$ \\
\hline Bokmål & $\begin{array}{l}1920 \text { (geo.) } \\
1920 \text { (fin.) }\end{array}$ \\
\hline Nynorsk & $\begin{array}{l}1951 \text { (geo.) } \\
1927 \text { (fin.) }\end{array}$ \\
\hline
\end{tabular}

Por conta da datação, fica bem evidente que o inglês foi a primeira língua a utilizar deflation na acepção financeira. No que tange a acepção 
geológica, pode ser tanto originária no inglês quanto no alemão. Só que definimos como um elemento lexical alemão, porque o próprio autor (Johannes Walther) atribui a ele em sua obra de 1891 a invenção desse elemento lexical.

1) A respeito das línguas de influência em determinados temas, encontramos geólogos importantes em toda a Europa. A The Encyclopedia of Geology cita como principais geólogos: Agassiz, Cuvier, Darwin, Du Toit, Hall, Hutton, Lyell, Murchison, Sedgwick, Smith, Steno, Suess, Walther e Wegener, quer dizer, 9 falantes de inglês (maioria quase absoluta da Austrália), 3 de alemão, 1 de francês e 1 dinamarquês. Portanto, há mais probabilidades de termos que vêm da geologia serem do inglês. Como a geologia é uma área absolutamente ampla, para esse estudo ser mais pontual teríamos que compreender quais escolas são mais influentes no tema geologia sedimentária e, especificamente, estratigrafia. Influentes na época em que aparecem a maioria das abonações desse item lexical foram: Gignoux (francês), Grabau (inglês norteamericano), Walther (alemão), quer dizer, não encontramos uma exclusividade de apenas uma língua no estudo desse tema. Esse item lexical com acepção financeira se encontra no tema da economia, que tem pensadores das mais diferentes nacionalidades. Por conta disso, esse definidor é irrelevante para o seu estudo.

2) A relação entre escrita e pronúncia não nos proporciona nenhuma pista para a investigação do étimo, uma vez que cada língua pronuncia o radical defl- da sua maneira.

3) O radical do item lexical é defl- e remete ao latim; portanto, não seria um radical exclusivo de nenhuma língua descendente.

4) O elemento lexical (e suas duas acepções) não são formações no latim; em vista disso, não é possível aplicar a hipótese de Freitas.

5) A questão semântica nos ajuda a descobrir o trajeto percorrido pelo elemento lexical (com suas duas acepções), quer dizer, o elemento apareceu pela primeira vez com a acepção geológica, que foi emprestado para o inglês. No inglês ele recebeu uma nova acepção e, em seguida, foi emprestado para o alemão e para outras línguas. 
No presente caso, além do terminus a quo, o procedimento (5) é relevante para a etimologia desse elemento lexical.

\subsubsection{Fichas}

\subsubsection{Para o português}

\section{Deflação (s.f.)}

Acepção geológica:

25\% ( esp. deflación $1923 \varangle$ fr. deflation 1909 ing. deflation 1891 ale. deflation, 1891)

$25 \%$ ( 4 fr. deflation 1909 ing. deflation 1891 ale. deflation, 1891)

$25 \%$ ( 4 ing. deflation $1891<$ ale. deflation, 1891)

$25 \%$ ( 4 ale. Deflation, 1891)

Comentário: aqui as possibilidades são muitas. Como a primeira abonação no português ocorreu de maneira tardia, é muito difícil dizer qual língua que passou esse elemento lexical para o português, já que a primeira abonação não é uma tradução. Outro ponto para se considerar é que nenhuma dessas cognatas tem um terminus a quem (quando a palavra deixa de ser usada) anteriormente à inserção na língua portuguesa. Todas essas línguas são científicas, portanto, $25 \%$ de chances para cada uma.

Comentário 2: o alemão fez uma derivação do verbo latino deflo e inseriu uma nova acepção, mais especificamente, restringiu a acepção original apenas para a acepção geológica.

1954. Dicionário da Língua Portuguesa (Laudelino Freire)

Origem do significado da acepção: alemã

Origem do significante da acepção: alemã (derivação a partir do verbo latino deflare)

Étimo de empréstimo: 25\% francês, 25\% espanhol, 25\% inglês e 25\% alemão

Local: Acervo da Folha 
Acepção financeira:

$50 \%$ ( 4 ale. deflation $1920 \triangleleft$ ing. deflation, 1909)

$50 \%$ ( 4 ing. deflation, 1909)

Comentário: são duas por conta das datações. Descartamos que esse item lexical possa ter étimo nas últimas línguas românicas porque os termini a quo delas são mais recentes.

Comentário 2: esse elemento lexical ganhou essa acepção no inglês talvez por conta da analogia com uma acepção anterior, também existente na língua inglesa: "a remoção do ar de alguma coisa". Como exemplo temos o nondeflation inner tube que "reduz as chances de punção e esvaziamento de ar" (The New York Times, 3 de maio de 1908, p. 30). Ela tem origem inglesa pois não tem nada a ver com o significado do latim.

1920. Artigo da Folha llustrada

Origem do significado da acepção: inglesa

Origem do significante da acepção: empréstimo do alemão para o inglês ou derivação do inglês com base no verbo latino deflare

Étimo de empréstimo: $50 \%$ inglês, $50 \%$ alemão

Local: Acervo da Folha

Discussão a respeito das informações do Houaiss:

O Houaiss apenas insere um terminus a quo (1926) e não indica a qual acepção está se referindo. No campo etimologia ele insere informações já contidas em outros dicionários a respeito do inglês, que a primeira abonação da acepção geológica é 1892 e da econômica, 1920 e (ambas estão erradas de acordo com nossa pesquisa), portanto não entendemos o motivo do Houaiss não ter pelo menos inserido dois termini a quo. O dicionário não define qual é, na verdade, o étimo desse elemento lexical português e apenas cita o significado dos componentes do item lexical latino deflate "soprar por cima", que é uma composição formada pelo prefixo de- e o verbo flo "soprar, bafejar". No que tange a obra de Machado, ele apenas cita que vem do inglês (1920) e não cita em qual acepção e a de Cunha, apenas que é do séc. XX. A origem do significante da 
acepção pode ser alemã ou inglesa porque pode ter ocorrido tanto um empréstimo do elemento lexical alemão com acepção geológica e a inserção do significado financeiro quanto a uma inserção desse novo significado financeiro inglês no significante que já havia nesse idioma com a acepção de "ação do ar sendo removido de alguma coisa".

\subsubsection{Para o norueguês}

\section{Deflasjon (s.m.)}

Bokmål:

Acepção geológica:

33,33\% ( 4 din. na Noruega. deflación $1908 \varangle$ fr. deflation $1909 \varangle$ ing. deflation 1891 ale. Deflation, 1891)

33,33\% ( din. na Noruega. deflación 1908 ing. deflation 1891 ale. Deflation, 1891)

33,33\% ( din. na Noruega. deflación 1908 ale. Deflation, 1891)

Comentário: como esse elemento lexical já estava difundido nos jornais noruegueses escritos em dinamarqueses, temos a hipótese de $100 \%$ de que foi o dinamarquês que passou para o bokmål. A respeito dos caminhos para chegar até o dinamarquês há as três possibilidades acima.

1920. Aschehougs konversationsleksikon. 2: Blindeundervisning-

Détaille

Trecho: Denudation [...] vindens d. (deflation) $[. . .]^{157}$

Origem do significado da acepção: alemã

Origem do significante da acepção: alemã (derivação a partir do verbo latino deflare)

Étimo de empréstimo: $100 \%$ dinamarquês

Local: Nasjonalbiblioteket

Esta obra por estar na data de 1920 nos livra da necessidade de análise para definir se a entendemos como escrita em norueguês.

157 Denudação [...] d. do vento (deflação) [...] (trad. nossa) 
Acepção financeira:

$50 \%$ ( 4 ale. deflation $1920 \varangle$ ing. deflation, 1909)

$50 \%$ ( 4 ing. deflation, 1909)

Comentário: são duas possibilidades por conta das datações.

22 de abril de 1920. Artigo o jornal Trondhjems Adresseavis

Trecho: [...] idet det under deflationen er krediitorerne, kapitalisterne, som tjener paa debitorernes bekostning ${ }^{158}$ (p. 4)

Origem do significado da acepção: inglesa

Origem do significante da acepção: empréstimo do alemão para o inglês ou derivação do inglês com base no verbo latino deflare Étimo de empréstimo: $50 \%$ inglês e 50\% alemão

Local: Nasjonalbiblioteket

Esta obra por estar na data de 1920 nos livra da necessidade de análise para definir se a entendemos como escrita em norueguês

\section{Discussão a respeito das informações dos dicionários:}

O dicionário NbUiB afirma que este elemento lexical vem do inglês que, por sua vez, vem do latim. Ambas as afirmações não estão corretas, pois a forma do elemento lexical surgiu no alemão.

O NTG cita também apenas a acepção financeira, afirma que é uma derivação de deflatus e desconstrói esse elemento lexical de maneira totalmente errônea: de- II "redução, "privação" e flatus "vento". O erro ocorre ao afirmar de uma maneira que o leitor possa vir a pensar que o elemento lexical é uma criação norueguesa a partir de deflatus; ele, na verdade, é uma formação que se assimilou com a ideia anterior existente na língua inglesa (i.e. da ação do ar sendo removido de algum lugar, quer dizer, também não é bem exata com a acepção do latim clássico) e em seguida ganhou a acepção de "remoção da quantia de dinheiro na economia de um país", mas também pode ter ocorrido,

158 "[...] enquanto sob a deflação são os credores, os capitalistas, que se beneficiam às custas dos devedores"(trad. nossa) 
como já mencionado acima, o empréstimo do significante alemão e, em seguida, a inserção do novo significante inglês. Percebe-se, portanto, que ocorreu um empréstimo do latim deflatus com acepção clássica "removido assoprando", que recebeu um novo sentido tanto no alemão (para "erosão") quanto no inglês ("ação do ar sendo removido de alguma coisa").

O segundo erro é afirmar que -flatus significa "vento", uma vez que ele é a forma participial de flo "assoprar", quer dizer, é um particípio que anda nesse caso junto com o afixo e não um elemento lexical por si só que se juntou com o afixo de-, portanto, o dicionário comete um erro anacrônico. O ROB, por sua vez, cita as duas acepções e afirma que deflare significa "voar para longe", o que não está incorreto, mas pode fazer o leitor pensar que esse elemento lexical foi criado no norueguês com base no verbo latino deflo e, assim, desconsiderar todas as considerações etimológicas realizadas até agora.

\section{Nynorsk:}

\section{Acepção geológica:}

33,33\% ( bokm. deflation, 1920 din. na Noruega. deflación 1908 fr. deflation 1909 ing. deflation 1891 ale. Deflation, 1891) 33,33\% ( bokm. deflation, 1920 din. na Noruega. deflación 1908 ing. deflation 1891 ale. Deflation, 1891) 33,33\% ( bokm. deflation, 1920 din. na Noruega. deflación 1908 ale. Deflation, 1891)

Comentário: esta cognata já existia no bokmål, portanto temos a hipótese de que foi esta norma que passou para o nynorsk.

1951. Norsk allkunnebok. 3 bandet de Sudmann

Trecho: Deflasjon: den geol. verksemda til vinden ${ }^{159}$

Origem do significado da acepção: alemã

Origem do significante da acepção: alemã (derivação a partir do verbo latino deflare)

Étimo de empréstimo: 100\% bokmål 
Local: Nasjonalbiblioteket

Acepção financeira:

$50 \%$ ( $\triangleleft$ bokm. deflation, $1920 \triangleleft$ ale. deflation $1920 \triangleleft$ ing. deflation, 1909)

$50 \%$ ( $\triangleleft$ bokm. deflation, $1920 \varangle$ ing. deflation, 1909)

Comentário: esta cognata já existia no bokmål, portanto temos a hipótese de $100 \%$ de que foi esta norma que passou para o nynorsk.

1927. Engelsk-norsk ordbok

Trecho: [...] deflate [...] ion [...] fig. deflasjon, nedgang $i$

(penge)setelmengd (tidt:) auke i pengeverdet ${ }^{160}$

Origem do significado da acepção: inglesa

Origem do significante da acepção: alemã

Étimo de empréstimo: 100\% bokmål

Local: Nasjonalbiblioteket

Discussão a respeito das informações dos dicionários noruegueses:

O dicionário NyUiB também afirma que a cognata vem do inglês, que por sua vez vem do latim. Este dicionário repete o que o NTG afirma (comentado acima) no que diz respeito ao elemento lexical deflatus.

\section{Origem do significante:}

O elemento lexical deflation é uma formação a partir do particípio do verbo latino deflo que, por sua vez, é uma composição a partir do prefixo de"para longe" e do verbo flo "assoprar", portanto, "assoprar para fora". Ernout \& Meillet $1932\left[2001^{6}\right]$ afirmam que flo também tinha um sentido técnico "derreter [metal]". Uma de suas derivações é deflo (raro): "soprar" e "ignorar".

De Vaan (2008) afirma que flo provém do IE * $b^{h} l e h_{1}-I^{*} b^{h} / h_{1}$ " "assoprar". Se flare (de flo) estiver relacionado com fleo "chorar", "lamentar" (de flere), a raiz era provavelmente ${ }^{*} b^{h} / h_{1-}$. O particípio pretérito pode refletir diretamente ${ }^{*} b^{h} / h_{1}$-to-, como Schrijver postula, mas pode ser secundário. O pretérito é explicado por

160 "[...] deflate [...] ion [...] fig. Deflação, queda na quantia de cédula, (sempre:) aumento no valor do dinheiro (trad. nossa) 
Schrijver (1991, p. 402) a partir de ${ }^{*} b^{h} / h_{1}-C-$, o grau zero do presente da raiz do IE (aceito por Meiser, 1998), porque ele espera *falje/o- como resultado do segundo mencionado. Rix (2001) reconstrói como * $b^{h} I_{h}$-ie-, mas não explica como *flaje$>$ flā- surge dessa pré-forma. Alternativamente, pode-se diferenciar "assoprar" de "chorar", uma vez que os significados são suficientemente diferentes e, assim, reconstruir IE ${ }^{*} b^{h} l_{h}$ - para flare; ainda assim, deixaria sem explicação o germânico *ē em AAA blāen, Go. blesan "assoprar". 


\subsection{Gravitação/Gravitasjon}

\subsubsection{Apresentação dos dados}

\subsubsection{Mundo germânico}

Norueguês

Significados em dicionários atuais (a partir de 1901 em nynorsk e 1907 em bokmål):

\begin{tabular}{|c|c|c|c|}
\hline Dic. & Significado & Etimologia & Datação \\
\hline $\mathrm{NbUi}$ & $\begin{array}{l}\text { Força de atração } \\
\text { universal entre } \\
\text { todas as massas do } \\
\text { universo. Sinônimo: } \\
\text { tyngdekraft }\end{array}$ & $\begin{array}{l}\text { Nova formação } \\
\text { latina a partir de } \\
\text { gravis "pesado". }\end{array}$ & $x$ \\
\hline NyUi & $\begin{array}{l}\text { Força de atração } \\
\text { universal entre } \\
\text { todas as massas do } \\
\text { universo. } \\
\text { Especialmente: } \\
\text { força de atração da } \\
\text { terra. Sinônimo: } \\
\text { tyngdekraft }\end{array}$ & $\begin{array}{l}\text { Nova formação } \\
\text { latina a partir de } \\
\text { gravis "pesado". }\end{array}$ & $x$ \\
\hline NTG & $\begin{array}{l}\text { Força de atração } \\
\text { entre massas }\end{array}$ & $\begin{array}{l}\text { de lat. nova } \\
\text { formação < } \\
\text { gravitere }\end{array}$ & $x$ \\
\hline $\mathrm{ROB}$ & $\begin{array}{lr}\text { (Fis.) força } & \text { de } \\
\text { atração } & \text { entre }\end{array}$ & $\begin{array}{l}\text { Lat. construção } \\
\text { nova gravitatio de }\end{array}$ & $x$ \\
\hline
\end{tabular}




\begin{tabular}{|l|l|l|l|}
\hline & massas. & gravitare & \\
\hline
\end{tabular}

\section{Livros em dinamarquês publicados na Noruega}

A primeira atestação do elemento lexical está na revista Provinzialblade de 1779 (II Bind, No. 20,1779, p. 160) ${ }^{161}$ da cidade de Bergen:

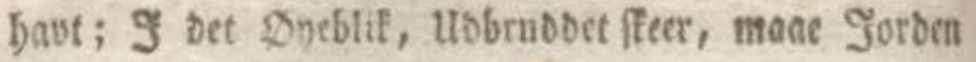 fole set faume, foum foregaser med en sanon,

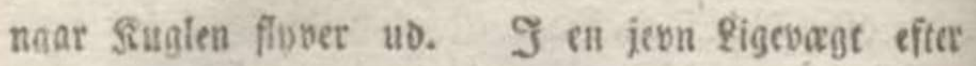 (Grabitations 2obene, ligefom Sanonen ex pan Ravet.}

"[...] no momento em que a explosão ocorre, a terra sente o mesmo que acontece com um canhão quando a bala é disparada. De acordo com as leis da gravitação, em um equilíbrio, da maneira que o canhão está [...]" (trad. nossa)

\section{Livros escolares}

O livro de física para middelskolen de $\mathrm{H}$. Christie (1871) cita que a gravitação universal (den almindelige Gravitation) é uma atração entre corpos, e é universal e o livro de geografia matemática para o ginásio (JOHANSSEN, p. 1883) afirma que a formação de atração é chamada de tyngdekraft ou gravitation (p. 44), mas também tygnde (p. 49)

\section{Manuais}

No manual sobre mecânica de Christopher Hansteen (1838) está atestado:

Tyngden paa Jorden er altsaa et specielt Tilfælde af den almindelige Tiltrækning; og af denne Grund kalder man ogsaa denne almindelige Kraft, den almindelige Tyngde eller Gravitation.

"O peso na terra é também um caso especial da atração universal e, 
por esse motivo, é também chamada de força universal, peso universal ou gravitação". (trad. nossa)

No manual sobre física de Schiøtz (1881) há basicamente o termo almindelige Gravitation "gravitação universal”.

\section{Obras lexicográficas}

No dicionário de palavras estrangeiras de M. C. Hansen (1851) encontramos a seguinte explicação para o elemento lexical:

Gravitation, Tyngdekraft, trykket af et Legemes eiendommelige Tyngde; Legemernes Henstræben til (Jordens, Solens) Middelpunkt, gravitere

"Gravitação, "força do peso", empurrado pelo peso particular de um corpo; atração dos corpos para o centro (da Terra, do Sol), gravitar" (trad. nossa)

As entradas em dicionários de inglês-dano-norueguês-inglês:

\begin{tabular}{|c|c|c|c|c|}
\hline Inglês & $\begin{array}{l}\text { Dano- } \\
\text { norueguês }\end{array}$ & Autor & Tipo & Ano \\
\hline \multirow[t]{2}{*}{ Gravitation } & $\begin{array}{l}\text { Faldkraft, } \\
\text { Gravitation, } \\
\text { Tygning }\end{array}$ & Larsen & Geral & 1888 \\
\hline & tyngdekraft & Brynildsen & Geral & 1892 \\
\hline $\begin{array}{l}\text { Dano- } \\
\text { norueguês }\end{array}$ & Inglês & & & \\
\hline Gravitation & gravitation & Larsen & Geral & 1888 \\
\hline Gravitation & Gravitation & Brynildsen & Geral & 1892 \\
\hline
\end{tabular}


No dicionário de LARSEN (1888), os termos tyngde e tyngdekraft estão traduzidos para gravity e force of gravity, respectivamente; no de Brynildsen (1892), o termo tyngdekraft é gravitation ou force of gravity.

No dicionário alemão-dano-norueguês de Kaper (1885) :

\begin{tabular}{|l|l|l|l|l|}
\hline Alemão & $\begin{array}{l}\text { Dano- } \\
\text { norueguês }\end{array}$ & Autor & Tipo & Ano \\
\hline Gravitation & Tyngdekraft & Kapper & Geral & 1885 \\
\hline
\end{tabular}

Concluímos que há vários sinônimos para o termo gravitation e que o terminus a quo é de 1779.

\section{Cognatas em outras línguas germânicas}

Dinamarquês (publicado na Dinamarca)

Não encontramos nenhuma obra no Google Books e nos corpora que seja mais antiga que aquela acima citada publicada na Noruega.

\section{$\underline{\text { No sueco }}$}

O dicionário Svenska Akademiens Ordbok (SAO) consta que a cognata correspondente foi primeiramente registrada no sueco em 1728 no livro de Mårten Triewald Notification, om trettijo publique föreläsningar öfver nya naturkunnigheten e que é um elemento lexical do neolatim derivada de gravitare.

No inglês:

De acordo com Oxford (CD-ROM, 2010), a cognata correspondente gravitation tem os seguintes significados:

1. A force of attraction that causes objects to move towards each other. 
O dicionário afirma que esse elemento lexical é da metade do século XVII e vem do neolatim gravitatio( $n$-), derivação do verbo gravitare, que é uma derivação de gravitas, que significa "peso". O dicionário de Murray \& Bradley (1901) afirma que gravitation tem terminus a quo em cerca de 1645 e que tal elemento lexical está registrado na obra The Harleian Miscellany, or a Collection of scarce, curious, and entertaining Pamphlets and Tracts, as well in Manuscript as in Print, found in the late Earl of Oxford's Library (Vol. V, 1810). Na indagação se encontra:

The sea is wide and deep, yet not as the air, that compasseth the sea and land; nor so passible in any part as the air is supposed to be in some parts thereof: for, if the opinion be true, that gravitation is from the magnetism of the earth, then, the more remote from the earth, the less is the gravity (...) (p. 501)

Portanto, gravitation não foi utilizada primeiramente por Isaac Newton, mas foi consideravelmente divulgada por sua teoria.

$\underline{\text { No alemão }}$

Nenhum dos dicionários e corpora nos forneceram uma data mais antiga do que aquela encontrada pelo Google Books com o livro Nova telluris, das ist: Neue Betrachtung der Erde [...] (1712), tradução da obra de William Whiston, sucessor de Isaac Newton. Entre vários trechos escolhemos:

[...] das Gesetz der gravitation, oder druckenden Triebes / auf eben denselben zielend / entdecket: und vice versa, wo das Gesetz der Gravitation, oder schwermässigen Druckung bekant ist [...] (p. 150)

Tradução da parte correspondente de Whiston (1696):

[...] the Law of Gravitation tending towards the same is discovered; and vice versa, where the Law of Gravitation is known [...] (p. 25)

O dicionário etimológico de Kluge afirma que Gravitation entrou na língua alemã no sec. XIX e que é uma formação neoclássica correspondente a gravitas. Na versão online do Deutsches Wörterbuch von Jacob Grimm und Wilhelm Grimm afirma-se que Gravitation é uma cognata correspondente do francês. De acordo com nossa pesquisa, ela é do séc. XVIII e veio do inglês. 
Aqui faremos duas observações. Primeiro, por ser um livro de tradução do inglês, cujo termo foi primeiramente utilizado na língua inglesa, afirmaremos que o étimo é inglês. Segundo, o elemento lexical gravitation aparece várias vezes em minúsculo, diferentemente dos outros substantivos alemães, que estão, por regra, em maiúsculo; portanto, isso provavelmente ocorre porque o tradutor via Gravitation como sendo um elemento lexical estrangeiro.

\section{$\underline{\text { No holandês }}$}

O banco de etimologia cita Philippa (2003-2009), que afirma que gravitatie significa zwaartekracht "força do peso", que veio para o holandês em 1832. O dicionário também afirma que é um neologismo internacional (inglês em 1645, de acordo com o dicionário de Oxford e francês, 1717, de acordo com Rey), considerado como um elemento lexical neolatino, gravitatio, formado a partir do verbo gravitare que, por sua vez, é formado com base no latim gravitas "peso, gravidade" que, por fim, é uma derivação de gravis "pesado".

Outras obras citadas pelo banco como, por exemplo, G.J. van Wyk (2003), N. van der Sijs (2001), P.A.F. van Veen em N. van der Sijs (1997) também afirmam que a cognata correspondente surgiu em 1832, diretamente do neolatim. O WNT, diferentemente, cita a data de 1847 da obra Kunstwdt., com base em Kramers.

\subsubsection{Mundo românico}

\section{Português:}

Os dicionários de língua portuguesa atestam a etimologia desse elemento lexical da seguinte maneira:

\begin{tabular}{|l|l|l|}
\hline Dicionário & Étimo & Datação \\
\hline Houaiss (online) & $\begin{array}{l}\text { fr. gravitation (1717) 'id', } \\
\text { do ing. gravitation (c1645) }\end{array}$ & \begin{tabular}{l} 
Portugal Médico, 1726) \\
\hline
\end{tabular} \\
\hline
\end{tabular}




\begin{tabular}{|l|l|}
\hline 'id', este do lat. cien. \\
gravitation-, gravitatio; \\
popularizado em fr. pelas \\
traduções das obras de \\
Sir Isaac Newton.
\end{tabular} \mid

Não encontramos nenhuma atestação mais antiga tanto no Corpus do Português quanto no Google Books. Também não há nada sobre o elemento lexical no Vocabulário Português e Latino de Bluteau.

Nos dicionários de etimologia da língua portuguesa encontramos as seguintes atestações:

\begin{tabular}{|l|l|l|l|}
\hline Dicionário & Forma & Étimo & Datação \\
\hline Cunha (1999) & gravitação & $\begin{array}{l}\text { Do fr. gravitation, } \\
\text { deriv. do lat. cient. } \\
\text { gravitatio, a partir do } \\
\text { lat. gravitas -atis. }\end{array}$ & \\
\hline VHCPM (2007) & X & X & X \\
\hline
\end{tabular}

Não tivemos acesso ao documento de 1726 intitulado Portugal médico ou Monarquia médico-lusitana de Brás Luís e Abreu, citado por Houaiss. O Corpus do Português só atesta esse elemento lexical no século XIX.

Também não encontramos nenhuma entrada nos dicionários que fazem parte do Corpus Lexicográfico do português. 


\section{Espanhol:}

Nos Corominas encontramos a seguinte entrada:

\begin{tabular}{|l|l|l|l|}
\hline Dicionário & Forma & Étimo & Datação \\
\hline $\begin{array}{l}\text { COROMINAS } \\
(1984)\end{array}$ & gravitación & $\begin{array}{l}{[\ldots] \text { aunque no fué }} \\
\text { creado por Newton, } \\
\text { como suele decirse, } \\
\text { su difusión se debe } \\
\text { realmente a este } \\
\text { gran físico }[\ldots]\end{array}$ & $\varnothing$ \\
\hline
\end{tabular}

De acordo com o Corpus do Espanhol, a atestação mais antiga é de 1728, contida na obra Texto Critico Universal de Benito Jerómino Feijoo:

[...] como se haya penetrado bien lo que hemos dicho de las dos fuerzas de gravitación, y elasticidade del Aire; advirtiendo, que em algunos fenómenos es causa únicamente la gravitación [...]

$\underline{\text { Italiano: }}$

\begin{tabular}{|l|l|l|l|}
\hline Dicionário & Forma & Étimo & Datação \\
\hline ZINGARELLI & gravitazione & $\begin{array}{l}\text { ingl. gravitation, de } \\
\text { gravitate "gravitare" }\end{array}$ & 1731 \\
\hline Deli & gravitazione & $\varnothing$ & 1731 \\
\hline
\end{tabular}

Apesar desses dois dicionários datarem gravitazione como sendo do ano de 1731, encontramos no Google Books uma abonação mais antiga no artigo Metodo d'investigare l'Orbite de' Pianeti [...], contido no Giornale de Letterati D'Italia (tomo secondo, Anno MDCX, articolo XV, p. 455, 1710):

[...] e perciò questa forza $B \mathrm{~m}$, ovvero $C \mathrm{c}$ è la gravitazione del Pianeta verso il Sole $S$ [...]. 
"[...] e então essa força B m ou C c é a gravitação do planeta em direção ao sol S [...]" (trad. nossa)

\section{Francês:}

Nos dicionários de francês (incluindo os etimológicos)

\begin{tabular}{|l|l|l|l|}
\hline Dicionário & Forma & Étimo & Datação \\
\hline $\begin{array}{l}\text { Le Petit Robert } \\
(2014)\end{array}$ & gravitation & $\begin{array}{l}\text { lat. scient. } \\
\text { gravitatio, de } \\
\text { gravitas }\end{array}$ & 1717 \\
\hline TLF & gravitation & $\begin{array}{l}\text { Empr. à l'angl. } \\
\text { gravitation (ca } \\
1645)\end{array}$ & 1717 \\
\hline
\end{tabular}

TLFi afirma que o terminus a quo de gravitation se encontra na obra de Hartsœker (bib. Anc. Et Mod., VII, p. 306 ds BRUNOT t. 6, p. 548, note 3). FEW fornece outra data, 1722. Não tivemos acesso ao conteúdo dessa obra citada pelo TLFi.

\section{Latim:}

Não encontramos nenhum resultado para gravitatio nos dicionários de Du Cange (1883), Glare (1968) e Lewis (2002).

A abonação mais antiga encontrada em latim ocorre na obra de Deusingii (1643):

Scholastici actum primum in corporibus gravibus gravitatem absolutè vocant, actum secundum gravitationem solent appellare. (p. 140)

"Os eruditos chamam o primeiro ato em corpos pesados de gravidade absoluta, o segundo ato eles tendem a chamar de gravitação." (trad. nossa) 


\subsubsection{Determinação do étimo}

Terminus a quo (mais antigo ao mais novo)

\begin{tabular}{|c|c|}
\hline \multicolumn{2}{|l|}{ Mundo Romano } \\
\hline Francês & 1711 \\
\hline Italiano & 1710 \\
\hline Português & 1726 \\
\hline Espanho & 1728 \\
\hline \multicolumn{2}{|l|}{ Mundo Germânico } \\
\hline Inglês & 1645 \\
\hline Alemão & 1712 \\
\hline Sueco & 1728 \\
\hline Dinamarquês na Noruega & 1779 \\
\hline Dinamarquês & $\begin{array}{l}\text { Não achamos nada mais antigo que } \\
1779 \text { (Dinamarquês na Noruega) }\end{array}$ \\
\hline Holandês & 1832 \\
\hline Nynorsk & 1889 \\
\hline Bokmål & 1908 \\
\hline
\end{tabular}

Por conta da datação, fica bem evidente que o inglês foi a primeira língua a utilizar este item lexical por meio de uma tradução do latim científico.

1) No que tange às línguas de influência em determinados temas, nenhuma conclusão podemos tomar porque o elemento lexical tem uma acepção científica astronômica e qualquer país que tenha astrônomos significativos poderia ter derivado o elemento lexical gravitas para criar um novo termo que explicasse o fenômeno descoberto ou que necessita de explicação. Além do mais, também é muito provável que o elemento lexical em estudo tenha sido 
primeiramente registrado em latim científico, já que esta era a principal língua científica entre os séc. XVI e XIX

2) A relação entre escrita e pronúncia não nos proporciona nenhuma pista para a investigação do étimo, uma vez que cada língua pronuncia o radical gravit- da sua maneira.

3) O radical do elemento lexical é gravit- e remete ao latim; portanto, não seria um radical exclusivo de nenhuma língua descendente.

4) Neste elemento lexical o cruzamento panromânico de Freitas (2013) se confirma, uma vez que foi o inglês que o emprestou do latim científico e o divulgou para as outras línguas, mesmo que o francês tenha também contribuído em anos posteriores.

5) A questão semântica é pouco relevante para descobrir o caminho desse item lexical até o português e até o norueguês uma vez que ele manteve sua acepção original.

No presente caso, apenas o terminus a quo é relevante para a etimologia de gravitação.

\subsubsection{Fichas}

\section{Para o português}

\section{Gravitação s.f.}

25\% ( it. gravitazione $1710 \varangle$ [fr. gravitation 1702] ४ [ing. gravitation 1645] \lat cient. gravitatio, 1643)

25\% ( fr. gravitation 17024 [ing. gravitation 1645] \ lat cient. gravitatio, 1643)

25\% ( ing. gravitation 1645 lat cient. gravitatio, 1643)

$25 \%$ ( 4 lat cient. gravitatio, 1643)

Comentário: como a primeira abonação não é nenhuma tradução e o elemento lexical era difundido em todas essas quatro línguas até 1726 , esses 
quatro caminhos são possíveis. Por conta de uma data mais antiga e pelo alemão sempre ter sido uma língua científica, também é possível que seja um étimo de empréstimo dessa língua e, assim, cada uma das hipóteses teria, nesse caso, $20 \%$.

1726. Portugal médico ou Monarquia médico-lusitana de Brás Luis e Abreu

Origem do significado da acepção: latina

Origem do significante da acepção: latina

Étimo de empréstimo: $100 \%$ dinamarquês

Local: Houaiss

Discussão a respeito das informações do Houaiss:

O Houaiss indica a obra e a data da primeira abonação (1726, Portugal médico ou Monarquia médico-lusitana) e afirma que o elemento lexical vem do inglês gravitation (cerca de 1645), que por sua vez vem do latim científico gravitatio. É um termo, segundo o dicionário, popularizado em francês pelas traduções das obras de Sir Isaac Newton. As considerações de Houaiss estão parcialmente corretas, mas a o elemento lexical, como vimos, não necessariamente vem do inglês. $O$ termo pode sim ter sido popularizado por conta das traduções, mas não é algo que devemos tomar como único, pois há muitos artigos do final do séc. XVII na famosa revista científica Philosophical Transactions of the Royal Society of London em que aparece esse termo. Portanto, os principais divulgadores foram o inglês e o francês. Porém, a respeito do português, não temos nenhuma prova de que o termo veio diretamente dessas duas línguas, como também não temos nenhuma prova de que veio diretamente do italiano, latim científico ou alemão. 


\subsubsection{Para o norueguês}

\section{Gravitasjon (s.m.)}

\section{Bokmål:}

25\% ( din. na Noruega. gravitation 17794 din. gravitation ??? sue. Gravitation, $1728 \$ [ale. gravitation 1702] \ [ing. gravitation 1645] \ lat cient. gravitatio, 1643)

25\% ( din. na Noruega. gravitation 17794 din. gravitation ??? 4 ale. gravitation $1702 \varangle$ [ing. gravitation 1645] \ lat cient. gravitatio, 1643) 25\% ( 4 din. na Noruega. gravitation 17794 din. gravitation ??? 4 ing. gravitation 1645 lat cient. gravitatio, 1643)

25\% ( 4 din. na Noruega. gravitation $1779 \varangle$ din. gravitation ??? 4 lat cient. gravitatio, 1643)

Comentário: o elemento lexical já estava sendo utilizado por muito tempo no dinamarquês e, por isso, consideramos que o étimo de empréstimo no bokmål é do dinamarquês. Mesmo que não tenhamos encontrado uma forma mais antiga no dinamarquês da Dinamarca, temos a hipótese de que ela exista. De todos esses empréstimos, o alemão é o único que tem o terminus a quo em uma tradução do inglês, portanto é o único que podemos garantir que tem étimo de empréstimo inglês.

1908. Lærebok i fysik for realgymnasiet og tekniske skoler. 1

Trecho: men gravitationen vil ogsaa være konstant naar avstanden er konstant ${ }^{162}$

Origem do significado da acepção: latina

Origem do significante da acepção: latina

Étimo de empréstimo: $100 \%$ dinamarquês

Local: Nasjonalbiblioteket

Comentário: Esta obra por estar na data de 1908 nos livra da necessidade de análise para definir se a entendemos como escrita em norueguês. 
Discussão a respeito das informações dos dicionários de bokmål:

O dicionário NbUiB afirma que o elemento lexical é uma nova formação latina a partir de gravis "pesado". O NTG e o ROB afirmam que é uma nova formação latina a partir de gravitere. Os dois últimos estão corretos, pois ocorreu de fato uma derivação desse verbo latino, mas todos não estão de acordo com o que entendemos por etimologia. Nenhum dos dicionários inseriram a primeira abonação.

Nynorsk:

25\% ( din. na Noruega. gravitation 1779 din. gravitation ???

sue. Gravitation, 1728 [ale. gravitation 1702] \ [ing. gravitation 1645] \ lat cient. gravitatio, 1643)

25\% ( din. na Noruega. gravitation 17794 din. gravitation ??? 4 ale. gravitation $1702 \varangle$ [ing. gravitation 1645] \ lat cient. gravitatio, 1643) 25\% ( din. na Noruega. gravitation 17794 din. gravitation ??? ing. gravitation 1645 lat cient. gravitatio, 1643)

25\% ( din. na Noruega. gravitation $1779 \varangle$ din. gravitation ??? 4 lat cient. gravitatio, 1643)

Comentário: este elemento lexical entrou no landsmaal (nynorsk) antes de entrar no riksmål (bokmål), portanto concluímos que o étimo dela é dinamarquês.

1889. Fri Forhandling: ymse Stykkje (paa norsk og dansk) um Tru og Tanke de Arne Garborg

Trecho: Det er altso dette, som tilslutt vert den sanne Lov um Tyngdi: eit aalment gjensidigt Tildrag millom alle Ting, Himmeldraget, "Gravitationen". 163

Origem do significado da acepção: latina Origem do significante da acepção: latina Étimo de empréstimo: $100 \%$ dinamarquês

${ }^{163}$ É, portanto, isso que por fim se torna a verdadeira lei do peso: uma atração comum entre todas as coisas, a atração do céu, "a gravitação" (trad. nossa) 
Local: Nasjonalbiblioteket

Discussão a respeito das informações do dicionário de nynorsk:

O dicionário NyUiB também afirma erroneamente que gravitatio é uma formação a partir de gravis. Da mesma maneira que os outros, ele também não cita nenhuma abonação.

\section{Origem do significante:}

O elemento lexical latino gravitatio é um substantivo deverbal formado a partir do particípio gravitatus do verbo gravitare, que é uma derivação a partir do substantivo gravitas "peso". Este último se formou a partir do adjetivo gravis "pesado" e o sufixo -tas, que cria substantivos que indicam estado.

O sufixo -tas/-tatis, de acordo com Pike (2011), é universalmente entendido como uma herança do IE *-tāt-. Há, por exemplo, no grego antigo -ThS, тптоS, no védico -tāt- (junto com uma variante de tema em i, -tāti-) e no avéstico tāt- (p. 1-2). Segundo o autor, a literatura recente sobre esse sufixo tem pouco a dizer e apenas repete a longa e não apoiada ideia de que o sufixo continua o * $t e h_{2}-t$, que reflete uma raiz -t secundária construída em um abstrato ${ }^{*} t e h_{2}$ (MIGNOT, 1972, P. 13; RIEKEN, 1999, p. 93-94; RINGE, 2006, p. 61-62 e FORTSON, 2010, p. 125); ele também apresenta outras teorias (p. 5).

O elemento lexical gravis, por sua vez, tem a forma ${ }^{*} g^{w} r a(w)-u$ no proto-itálico com a cognata no osco bravús que pode, de acordo com de Vaan (2008), significar pesado (< * $\left.g^{w} r e h_{2}-u-o-\right)$. A forma no IE seria * $g^{w} r e h_{2}-u$ - "pesado",

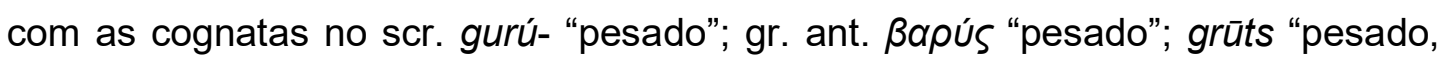
difícil, grávida" (< * $g^{w} r h_{2}$-u-to-); Go. f.pl. karujos "pesado, opressivo"; toc.B. krāmär "pesado" e toc.A. krāmärts "pesado" (p. 272). 


\subsection{Infecção/Infeksjon}

\subsubsection{Apresentação dos dados}

\subsubsection{Mundo germânico}

Norueguês

Significados em dicionários atuais (a partir de 1901 em nynorsk e 1907 em bokmål)

\begin{tabular}{|l|l|l|l|}
\hline Dic. & Significado & Etimologia & Datação \\
\hline NbUiB & $\begin{array}{l}\text { Matérias infecciosas (de } \\
\text { microorganismos) penetram } \\
\text { em um organismo e } \\
\text { causam doenças. }\end{array}$ & Do lat. infisere & $\mathrm{X}$ \\
\hline NyUiB & $\begin{array}{l}\text { Matérias infecciosas (de } \\
\text { microorganismos) penetram } \\
\text { em um organismo e } \\
\text { causam doenças. }\end{array}$ & $\begin{array}{l}\text { Do lat. tardio } \\
\text { infisere }\end{array}$ & $\mathrm{X}$ \\
\hline TG & $\begin{array}{l}\text { 1. Matérias infecciosas (de } \\
\text { microorganismos) penetram } \\
\text { em um organismo e } \\
\text { causam doenças: se } \\
\text { contagiar por infecção } \\
\text { 2. doença de infecção: ter } \\
\text { uma infecção. Sinônimo: } \\
\text { betennelse }\end{array}$ & $\begin{array}{l}\text { 1. Pegar infeção (que } \\
\text { consiste de bactérias ou } \\
\text { organismos parecidos) } \\
\text { 2. Doença, condição }\end{array}$ & $\begin{array}{l}\text { ty. infection fra lat. fr. } \\
\text { infectio }\end{array}$ \\
\hline ROB & $\mathrm{X}$ & $\mathrm{X}$ \\
\hline
\end{tabular}




\begin{tabular}{|l|l|l|l|}
\hline $\begin{array}{l}\text { doentia, inflamação gerada } \\
\text { dessa maneira }\end{array}$ & & \\
\hline
\end{tabular}

Não distinguiremos essas duas acepções.

Livros em dinamarquês publicados na Noruega

A primeira atestação do elemento lexical está no jornal Morgenbladet, edição do dia 09 de abril de 1824:

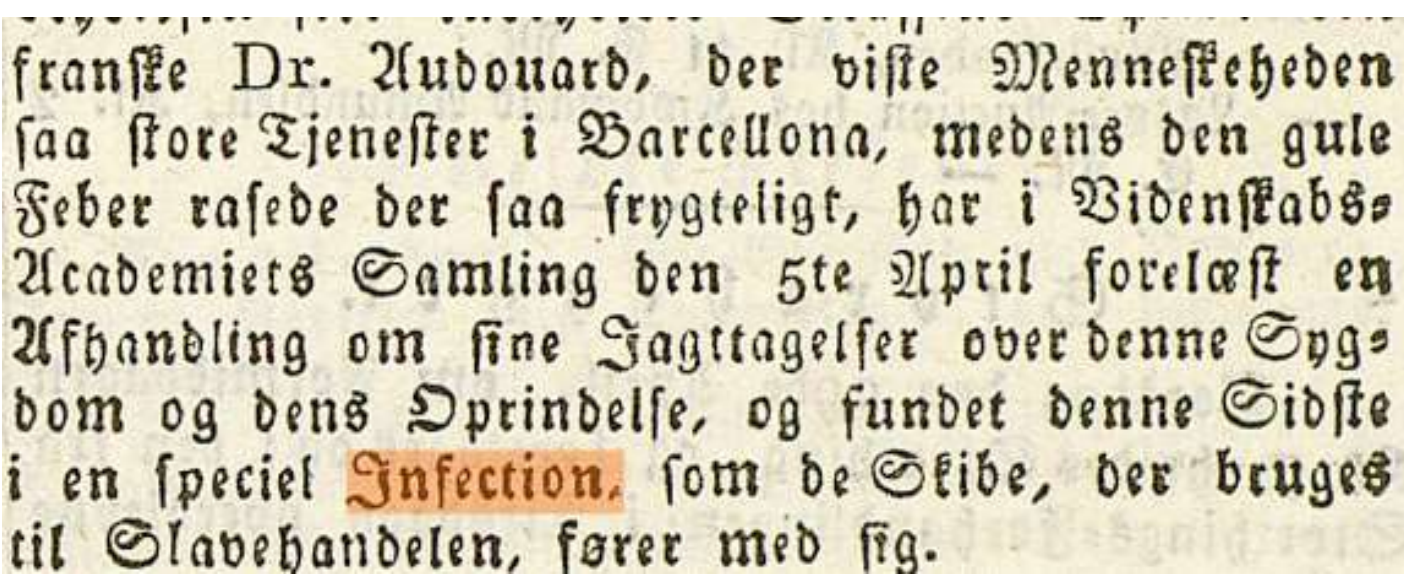

"[...] enquanto a febre amarela se disseminava lá terrivelmente, um estudo foi lido no encontro da Academia de Ciências no dia 5 de abril a respeito dos aspectos dessa doença e sua origem. E a origem foi encontrada em uma infecção especial, que é carregada pelos navios do tráfico negreiro" (trad. nossa)

Em um livro de atos que fazem referência à epidemia de cólera na Noruega em 1853, temos trechos como:

Med Antagelsen af en saadan Luftsmitte (Infection) [...] (p. 158)

"Admitindo de que um tal contágio pelo ar (infecção)" [...] (trad. nossa)

Jeg maa derfor ogsaa i Forbindelse med Conradis Bemærkning anföre, at Roche senere omhandler Infection fra Luften, som han anseer for det eneste Medium, hvorigjennem Contagiet kan virke [...] (p. 66) 
"Por conta disso, eu devo, de acordo com a observação de Conrad mencionar que Roche posteriormente trata da infecção do ar, que ele considera como o único meio pelo qual o contágio pode ser realizado [...]" (trad. nossa)

$\mathrm{Na}$ notícia do jornal Fredriksstad Tilskuer de 16 de abril de 1878 registra-se a notícia de uma infecção relacionada à água contaminada:

Det Udbrud af Nervefeber, der nylig har fundet Sted i Drammen, er antageligt en ved Drikkevandets Infektion fremkaldt Epidemi.

"O acesso de febre tifoide, que recentemente ocorreu em Drammen, é provavelmente uma epidemia provocada por uma infecção de água potável" (trad. nossa)

\section{Obras lexicográficas}

No dicionário de palavras estrangeiras de M. C. Hansen (1851) o verbete infection tem o significado de Smitte e smitsom Syge "contágio" e "doença contagiosa".

Vejamos na tabela as entradas em dicionários de inglês-danonorueguês-inglês:

\begin{tabular}{|c|c|c|c|c|}
\hline Inglês & $\begin{array}{l}\text { Dano- } \\
\text { norueguês }\end{array}$ & Autor & Tipo & Ano \\
\hline $\begin{array}{l}\text { Contagion, } \\
\text { infection (of } \\
\text { disease) }\end{array}$ & sygdomssmitte & Larsen & Geral & 1880 \\
\hline Infection & $\begin{array}{l}\text { Smitte, } \\
\text { Smitstof, } \\
\text { smitsom } \\
\text { Sygdom }\end{array}$ & Geelmuyden & Geral & 1855,1872 \\
\hline $\begin{array}{l}\text { Dano- } \\
\text { norueguês }\end{array}$ & Inglês & & & \\
\hline Infektionssygdom & Infectious & Larsen & Geral & 1880 \\
\hline
\end{tabular}




\begin{tabular}{|l|l|l|l|l|}
\hline & disease & & & \\
\hline
\end{tabular}

Nos dicionários de dano-norueguês-francês:

\begin{tabular}{|l|l|l|l|l|}
\hline $\begin{array}{l}\text { Dano- } \\
\text { norueguês }\end{array}$ & Francês & & \\
\hline $\begin{array}{l}\text { Befængelse, } \\
\text { Inficering, } \\
\text { Kropsmitte }\end{array}$ & Infection & Sundby & Geral & 1883 \\
\hline $\begin{array}{l}\text { Infektions- } \\
\text { sygdom }\end{array}$ & $\begin{array}{l}\text { Maladise, } \\
\text { contagieuse }\end{array}$ & & & \\
\hline
\end{tabular}

No dicionário de alemão-dano-norueguês de Kaper (1885)

\begin{tabular}{|l|l|l|l|l|}
\hline Alemão & $\begin{array}{l}\text { Dano- } \\
\text { norueguês }\end{array}$ & & \\
\hline Infektion & Smitte & Kaper & Geral & 1885 \\
\hline
\end{tabular}

Nota-se que o item lexical latino concorria com correspondentes germânicas e que também surgiu uma forma mesclada, com radical latino e sufixo germânico (i.e. inficering). Aparentemente a língua dano-norueguesa tinha muitos sinônimos para representar a acepção de "infecção".

\section{Outras cognatas germânicas}

Dinamarquês (publicado na Dinamarca)

Nos dicionários de 1510 até 1626 não encontramos o registro da cognata infektion. No dicionário de Smith (1520) afirma-se que siuge, modgang e forderuilsæ correspondem aos elementos lexicais latinos infectio, corruptio, 
interemptio, pestis, pernicies, etc. (Smith, 1520). No dicionário das obras do escritor Ludvig Holberg (1684-1754) também não a encontramos.

O dicionário de palavras estrangeiras de Meyer (1837) mostra a seguinte definição para infection (infektion ou inficering): é um smitte (sinônimo, contágio) (na aquisição de substâncias nocivas e parcialmente desconhecidas no corpo); doença contagiosa; elas podem ser agudas (como o tifos, etc.) e crônicas como, por exemplo, a sífilis.

O terminus a quo foi encontrada no Google Books na obra de Callisen (1809):

[...] men dette troer Commisionen at maate allene tilskrives en føregaaende Infektion førend Vaccinationen har giort sin Virkning. (p. 63)

“[...] mas isso a comissão acha que se atribui apenas a uma infecção antes da vacinação ter dado efeito" (trad. nossa)

\section{No sueco}

A cognata correspondente, de acordo com o dicionário SAOB, aparece pela primeira vez no sueco em 1656 no jornal Nyia aviser:

Gvdh beware wår armee för thenne (dvs. pesten) och annor infection.

"Deus proteja nosso exército disso (quer dizer, a peste) e outra infecção" (trad. nossa)

No inglês:

De acordo com Oxford (CD-ROM, 2010), a cognata correspondente infection já havia no inglês médio tardio e tem origem no latim tardio infectio( $n$-), do latim inficere "dip in, taint", derivado de in- "into" + facere "put, do".

O dicionário de MURRAY \& BRADLEY (1901) afirma que ela tem terminus a quo em 1398 numa tradução para o inglês realizado por John Trevisa da obra em latim de Bartholomeus Anglicus (1203 - 1272) chamada De Proprietatibus rerum "sobre as propriedades das coisas".

Não tivemos acesso ao manuscrito da obra traduzida por Trevisa, mas por meio do Middle English Dictionary conseguimos obter as transcrições. 
Realizaremos aqui uma comparação do elemento lexical nas obras latinas e na inglesa:

Trecho 1 (Of infection of the eie through indurate bloud)

Tradução inglesa de 1398:

The yzen hauep anopir passioun pat vnhiztip ham \& is infeccioun of blood.

"Os olhos têm outra enfermidade que o deixa feio e, por isso, é uma infecção do sangue" (trad. nossa)

Tradução inglesa 1582 (Livro 7, capítulo 17, obtida no Early English Books): bloud.

The eien haue another passion that defileth them, and that is infection of

Versão latina do séc. XIII ou XIV164, da Universidade de Victoria

Não encontramos o trecho. Essa é a versão mais antiga que tivemos acesso e parece estar incompleta ao comparar com a versão latina abaixo.

Cópia latina de 1471 (Köln ${ }^{165}$, Livro 7, cap. 17, p. 118 do documento online):

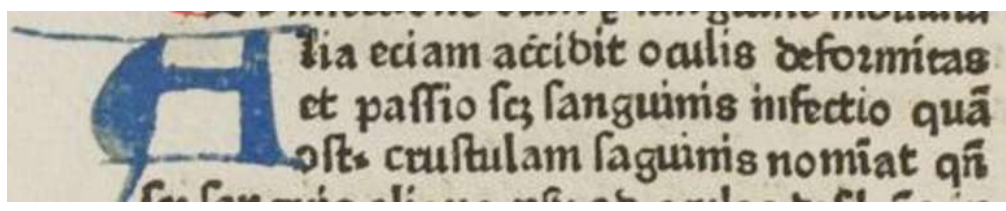

No manuscrito da versão latina de 1488, de Heinrich Knoblochtzer ${ }^{166}$, tal trecho ocorre no capítulo 16.

164 Disponível em: http://spcoll.library.uvic.ca/Digit/bart/introduction.htm

165 impressão de Jan Veldener, Johann Schilling. Disponível em: http://digital.ub.uniduesseldorf.de/ink/content/zoom/4091798

166 Disponível em: http://digital.ub.uni-duesseldorf.de/urn/urn:nbn:de:hbz:061:1-112875 
Versão francesa, cerca de $1487^{167}$ de Jean Syber (Livro 7, cap. 16, slide 150):

Une aultre maladie et laidure vient a loeil du sang corrompu qui se essẽble [...]

$\underline{\text { Versão espanhola de } 1494^{168}}$ de Fray Vicente de Burgos (Livro 7, cap. 16):

[...] no menos al ojo outra fuziedad y enfermedad de sangre corrõmpida $q$ se ayuta $[\ldots]$

Neste trecho percebe-se que o espanhol e o francês utilizam o elemento lexical corromper para indicar o sentido de "infecção".

Trecho 2 (Of the soule reasonable)

Versão inglesa de 1398:

Wyn \& opir licour takep infeccioun of a vessel pat is afoystid.

Versão inglesa de 1582 (Livro 3, capítulo 13):

As wine and other licour taketh infection of a vessel that is sustie

Versão latina do séc. XIII ou XIV169, da Universidade de Victoria

Não encontramos o trecho.

Cópia latina de 1471 (Köln, Livro 3, cap. 13, p. 13 do documento online):

[...] vinũ alius quicũqz liquor ex vase corrupto oõtrahit infectione

167 Disponível em: http://bibliotheque-numerique.bibliotheque-agglo-stomer.fr/collection/659-leproprietaire-des-choses/. Há traduções desde 1372, realizada por Jean Corbechon, mas não tivemos acesso a esses manuscritos.

168

Disponível em: https://play.google.com/books/reader?id=o5uY3F0BDOUC\&printsec=frontcover\&output=reader \&hl=pt_BR\&pg=GBS.PT146

169 Disponível em: http://spcoll.library.uvic.ca/Digit/bart/introduction.htm 
Versão francesa, cerca de 1487 de Jean Syber (Livro 3, cap. 13, slide 45):

[...] ainsi que le vin qui est bon de soy mais quant il est mis en vng maul, uais vaisseau il en trait vne mauluaise faucur [...]

Versão espanhola de 1494 de Fray Vicente de Burgos (Livro 5, cap. 13):

[...] como veemos enel vino et cada vn licor que avn que puro y bueno sea seuio es muchas vezes por la ynfeçion del vaso podrido ynfector gastado et por esto quando [...]

Nestre trecho há uma correspondência entre as versões inglesas e a latina e uma correspondência entre a francesa e a espanhola, embora as quatro apresentam uma certa relação.

Trecho 3 (Of the skinne)

$\underline{\text { Tradução inglesa de } 1398}$

Não apresentamos o trecho porque não tivemos acesso à obra completa.

Tradução inglesa 1582 (Livro 5, capítulo 64):

Sometime of infection of humours, as it fareth in leprous, and in the that haue the Morpheu.

Versão latina do séc. XIII ou XIV (na parte XXVI do livro):

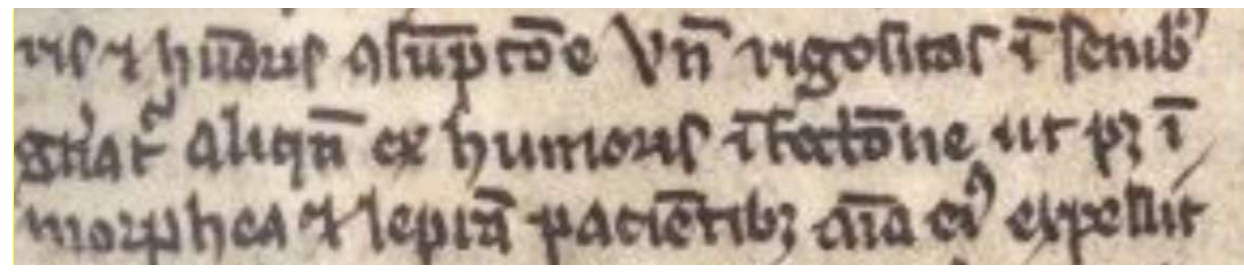


Cópia latina de 1471 (Köln, Livro 5, cap. 64, p. 91 do documento online):

\section{cortugacōe; Dt in lemibs* qñ ;er bnmoris in fectione Dt in morpheam et in leprã paciēti bus s nam natura materiá imfectam erpellit}

Versão francesa, cerca de 1487 de Jean Syber (Livro 5, cap. 64, slide 120):

[...] qui vient par dedens sicõe par degastement de lumeur substancialle qui fait froncer et rider la pel/elle la corrompt et la fait [...]

Versão espanhola de 1494 de Fray Vicente de Burgos (Livro 5, cap. 64):

[...] por causa intrinseca como por guasto de humor sustãçial q la haze affugar $y$ encoger et corrompe et haze [...]

Neste trecho também há uma grande correspondência entre o inglês e o latim, que se diverge um pouco das versões espanhola e francesa, que não utilizam infecção.

Trecho 4 (Of fleame)

Tradução inglesa de 1398

Não apresentamos o trecho porque não tivemos acesso à obra completa.

Tradução inglesa 1582 (Livro 4, capítulo 9):

Ther be ome anne, of vnkindly, fleames. Same is sower, colde and dry, through minglyng of melancholy, some is salte, hot and dry, through infection of red Cholera. 
Versão latina do séc. XIII ou XIV (na parte XXVI do livro):

Não encontramos o trecho no manuscrito.

Cópia latina de 1471 (Köln, Livro 4, cap. 9, p. 44 do documento online):

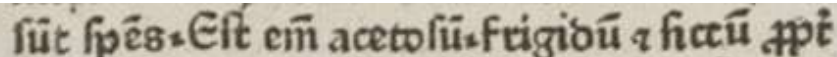 meläcolie abomíttionēs falfü calioü $q$ ficcum

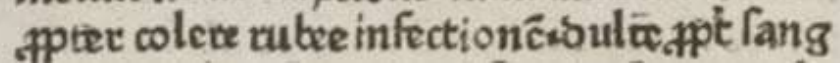

Versão francesa, cerca de 1487 de Jean Syber (Livro 4, cap. 9, slide $67)$ :

Ilz sont quatre especes de fleume nõ naturel, car il est aigre et froid et sec porce quil est mesle auec melancolie. Il est salle et chault et sec pource que il est mesle avec la colle rouge q le corrompt.

Versão espanhola de 1494 de Fray Vicente de Burgos (Livro 4, cap. 9)

Es denotar que iij son los espeçie d fiema no natural / es a saber agria et fria et seca por la mixtiõ hecha com colera / et et salada cali ete et seca por la ynfeçion de la colera ruuia [...]

Neste trecho há também relação entre o inglês eo latim, ao passo que o francês e o espanhol são mais próximos, mas apenas o espanhol utiliza a cognata.

Trecho 5 (Of touching)

Tradução inglesa de 1398

De tast demep bittir swete for infexioun of pe roof of pe moup.

Tradução inglesa 1582 (Livro 3, capítulo 21):

And the tast yt supposeth bitter to be swéete, through infection of the roofe of the mouth (...) 
Versão latina do séc. XIII ou XIV (na parte XXVI do livro):

Não encontramos o trecho no manuscrito

Cópia latina de 1471 (Köln, Livro 3, cap. 21, p. 30 do documento online):

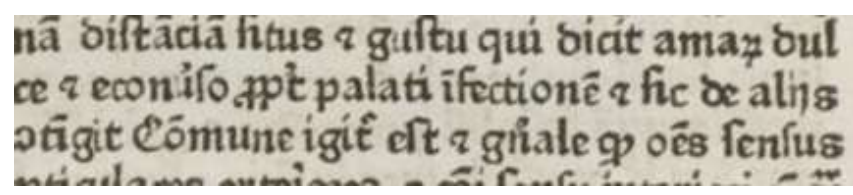

Versão francesa, cerca de 1487 de Jean Syber (Livro 3, cap. 21, slide 53):

Não apresenta nenhuma cognata relacionada ao termo estudado, apesar de haver grande relação com as outras partes do capítulo.

Versão espanhola de 1494 de Fray Vicente de Burgos (Livro 4, cap. 21)

[...] ao menos haze el gusto por la ynfeçiõ del paladar algũa vez juzgãdo le dulçe o amargo [...]

Aqui também há uma relação entre o inglês e o latim, ao passo que o francês apresenta uma certa disparidade. O espanhol, por sua vez, está mais próximo e utiliza a cognata.

Concluímos que esse elemento lexical é um empréstimo do latim científico para o inglês; e, também, que o francês e o espanhol traduziram de uma fonte diferente. É interessante perceber também a preferência em utilizar palavras flexionadas de corromper para expressar o sentido estudado aqui, mesmo que já houvesse, como veremos em seguir, o registro de uma cognata francesa em uma obra de 1314 (tradução da obra latina de Mondeville). O uso das flexões mostra que corromper seria um sinônimo de infecção. 
O dicionário etimológico de Onions está de acordo com as atestações anteriores, ou seja, o elemento lexical é de XIV (John Trevisa) e tem étimo no antigo francês ou no latim tardio.

\section{No alemão}

Apenas o das Herkunftswörterbuch (DUDEN) anota uma datação aproximada (séc. XVI). Encontramos o terminus a quo da cognata no Google Books na obra de Hundt (1529):

Dieweyl die andere vrsach der pestilentz / aufz voranderûg der lufft in ihrer selbstendigkeyt und qualitetê durch die vormischung der faulen dunst / und bredem des erdtreych vnd wasser also in der lufft eine infection machen / welche den menschlichen coerper die aller ferligeste ist. [...] (p. 3-4)

"Enquanto as outras causas da pestilência por conta da modificação do ar em sua pureza e qualidade devido ao ar impuro e o vapor do solo e água produzem uma infecção no ar que é perigosa aos corpos humanos [...] (trad. nossa)

Não encontramos nenhuma obra mais antiga no Deutschen Textarchiv (DTA).

\section{No holandês}

No Etymologiebank encontra-se os dados de M. Philippa e.a. (20032009), que cita a obra de van den Werve (1553) como o primeiro registro de infectie, que significa besmetting (met ziekten) "contaminação (com doenças)" (trad nossa). Na entrada também afirma-se que é um empréstimo do francês infection (1314 em Rey), que é uma denominação médica relacionada à "manchado (com pensamentos nefastos)", uma expansão de significado do latim cristão a partir do latim tardio infectio "tingimento, mancha, mácula, contaminação, que é uma derivação do latim clássico inficere "pintar, tingir, manchar, contaminar". 
O próprio banco de dados realiza uma retrodatação ao citar que no etymologiewiki ${ }^{170}$ desde 2011 já havia sido descoberto que o terminus a quo da cognata está em 1485 na mesma obra de Bartholomeus Anglicus citada anteriormente, ou seja, a De Proprietatibus rerum, que foi traduzida para o holandês em 1485 com o título Van den proprieteyten der dinghen (livro 5) 171: $^{17}$

[...] onderwijlen van infectien der humoren als lazerie (p. 102v)

[...] qñz ex humoris infectione vt in morpheam et in leprā pacientibus (edição de Colônia: Veldener \& Schilling, 1471, Livro 5, cap. 64, p. 91 do documento online)

(...) às vezes a partir da infeção dos humores como nos leprosos [...] (trad. nossa)

O WNT coloca como terminus a quo uma data muito mais nova, 1664.

Huizenga (2008) afirma que a obra em latim Chirurgia Magna do italiano Lanfranco de Milão teve três independentes traduções para o holandês médio. A primeira tradução data do séc. XIV e foi realizada em Flandres, a segunda é da metade do séc. XV em Guelders e a terceira, um pouco após a metade do séc. XV (na parte noroeste da Holanda) (p. 428).

\subsubsection{Mundo românico}

\section{Português:}

Os dicionários de língua portuguesa afirmam que a etimologia deste elemento lexical é a seguinte:

\begin{tabular}{|l|l|l|}
\hline Dicionário & Étimo & Datação \\
\hline Houaiss (online) & $\begin{array}{l}\text { Lat. infectio, onis "ação de } \\
\text { tingir, tintura", p ext., } \\
\text { "mácula, desonra, } \\
\text { estupro". José Pedro }\end{array}$ & \\
\hline
\end{tabular}

$170 \mathrm{http}: / / \mathrm{www}$. etymologiewebsite.nl/

171 Disponível em: http://wemal.let.uu.nl/digitaleedities.html 


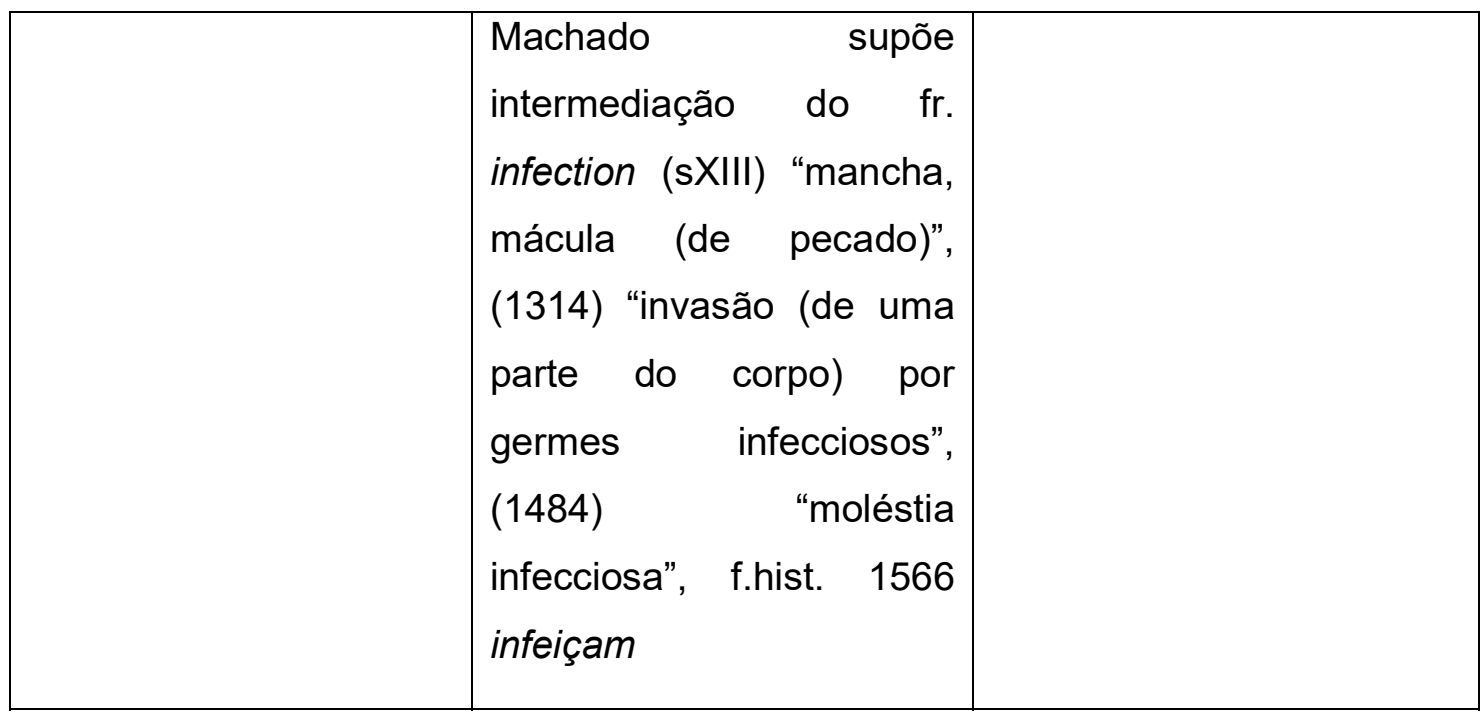

Não encontramos nenhuma atestação mais antiga tanto no Google Books e no Vocabulário histórico-cronológico do português medieval não há o registro dessa cognata porque provavelmente não existia. De acordo com 0 dicionário etimológico de Cunha, ela foi primeiramente registrada no século XVI como infeição; portanto, está de acordo com Houaiss.

Ao consultar o Corpus Lexicográfico, constatamos que no dicionário de Jerónimo de Cardoso não há nenhuma entrada para infecção; mas há a forma latina infectio, que é traduzida por tingidura (edição de 1562), siue infect9, us. Ho tingir e tingidura por infectio $(1570,1694)$. Com relação à infectus, há dois sentidos: cousa corrompida ou por fazer e cousa tingida $(1570,1694)$.

No dicionário de Barbosa (1611) e de Pereira (1697) também não há nenhuma entrada para infecção, apenas tingidura, que significa infectus. No segundo há inficionar com o sentido latino de inficio, corrompo.

O dicionário de Bluteau (1713) cita:

INFECC,AM. Qualidade de cousa infecta. Vid inficionado. Contagio, onis. [...] Alterado da Infecção, maligna [...]

Ainda no dicionário de Bluteau há na entrada contaminar registro da forma infeçaõ e na entrada impureza, infecçaõ. 
Na obra de Feijó (1734) infecçaõ é explicado como qualidade de cousa inficionada.

No corpus do português encontram os o terminus a quo com sentido de "algo corrompido":

[...] o filho de Deus perfeito satisfazedor pollo pecado nem perfeito estruidor do pecado se nom fosse destruidor e purgador da coruçom e do tingimento e infeiçom que se segue do pecado (Corte Imperial, séc. XV)

Com relação à acepção de contaminação com germes infecciosos, e como não encontramos nenhuma data mais antiga, consideramos o terminus a quo citado por Houaiss: Crónica do felicissimo rei D Manuel composta por Damião de Góis (1566):

[...] Portugueses, que seriam atte quarenta, por q hos mais erã já mortos de doença, por há terra ser de mãos ares, \& doentia, da q I infeiçam Pero danhaia faleçeo dahi a poucos dias [...] (livro II, fol. 16)

No dicionário do Houaiss não há essa citação, apenas a localização da obra.

Nos dicionários de etimologia da língua portuguesa encontramos as seguintes atestações:

\begin{tabular}{|l|l|l|l|}
\hline Dicionário & Forma & Étimo & Datação \\
\hline Cunha (1999) & Infecção & $\begin{array}{l}\text { Infeição. Do lat. } \\
\text { tardio infectio -onis }\end{array}$ & $\mathrm{XVI}$ \\
\hline VHCPM (2007) & $\mathrm{X}$ & $\mathrm{X}$ & $\mathrm{X}$ \\
\hline
\end{tabular}




\section{Espanhol:}

Nos Corominas encontramos a seguinte entrada:

\begin{tabular}{|l|l|l|l|}
\hline Dicionário & Forma & Étimo & Datação \\
\hline $\begin{array}{l}\text { COROMINAS } \\
(1984)\end{array}$ & infección & $\begin{array}{l}\text { Infición, Garcilaso; } \\
\text { lat. infectio; de aqui } \\
\text { el derivado } \\
\text { inficionar que se } \\
\text { usó antes em lugar } \\
\text { de infectar }\end{array}$ & \\
\hline
\end{tabular}

O dicionário de Nebrija traduz o elemento lexical infectio como teñidura ou tintura (Dictionarium hispano-latinum, 1495) e por la tintura (Dictionarium latino-hispanicum, 1492).

Ao pesquisar no corpus do DiCCA-XV, encontramos em 1440 (manuscrito original de 1417) a obra chamada Tratado de la Lepra de Enrique de Villena em que se registra:

Lepra perseuerans erit. E tal como esta ya auia fuerça de transpassar su ynfecçion em outra cosa. por esto mando que fuese quemada la ropa e lo que çerca.

Nesse caso, entretanto, ainda não há o sentido de infecção causada por bactérias, mas sim de uma condição em que acreditava-se que as mulheres menstruadas sofriam e que originava o mau-olhado.

Na edição impressa da tradução espanhola da obra de Bartholomeus Anglicus (de proprietatibus rerum), por Vicente de Burgos (1494) há o termo, como demonstrado acima na parte do inglês. A obra original, de acordo com Surget (1980) é do séc. XIV. (p. 8). 
Italiano:

\begin{tabular}{|c|c|c|c|}
\hline Dicionário & Forma & Étimo & Datação \\
\hline ZINGARELLI & infezióne & $\begin{array}{l}\text { Palavra culta, lat } \\
\text { tardio infectare }\end{array}$ & 1363 \\
\hline Deli & óne infezi & $\begin{array}{l}\text { Palavra culta, lat. } \\
\text { tardio infectione(m), } \\
\text { de infectus } \\
\text { "infectado", } \\
\text { intensivo de inficere, } \\
\text { lit. meter (fazer) } \\
\text { dentro (in-), misturar } \\
\text { porque } \\
\text { originalmente } \\
\text { refere-se ao } \\
\text { processo de pintura, } \\
\text { por em um banho } \\
\text { de tinta, "tingir, } \\
\text { impregnar" e então } \\
\text { "infectar, } \\
\text { corromper". Do } \\
\text { particípio passado } \\
\text { infectu(m) surgiu } \\
\text { infetto e do tardio } \\
\text { infectione(m) } \\
\text { ("tingir, tintura", sec. } \\
\text { IV/V d.C., Teodoro } \\
\text { Prisciano, médico), } \\
\text { surgiu infezione. }\end{array}$ & $\begin{array}{l}1363 \text { (Matteo } \\
\text { Villani), } \\
\text { contaminazione, } \\
\text { contagio, anche } \\
\text { fig. }\end{array}$ \\
\hline
\end{tabular}


No Corpus OVI dell'Italiano antico encontramos um registro mais antigo (1321-1330, Vite di eremiti dalle "Vite dei santi Padri" de Domenico Cavalca), mas não tem a acepção medicinal:

Credo veramente che ti venga puzza e orrore di tanti mali, e non solamente gli tuoi orecchi, ma eziando l'aria riceva infezione di questo parlare.

"Acredito piamente que a ti venha o fedor e o horror de tantos males e não apenas por tuas orelhas, mas até mesmo o ar recebe a infecção dessa conversa" (trad. nossa)

Este trecho, no entanto, tem a acepção de corrompimento e não medicional. O Corpus OVI também apresenta como primeira obra a registrar essa acepção a Cronica de Matteo Villani (por volta de 1348 e 1363), de acordo com o OVI:

[...] perché parea che questa impestifera infezione s'appiccasse per la veduta e per lo toccamento [...]

"[...] uma vez que parecia que esta infecção pestífera se transmitia pela visão e pelo toque [...]" (trad. nossa)

Francês:

Nos dicionários de francês (incluindo os etimológicos)

\begin{tabular}{|l|l|l|l|}
\hline Dicionário & Forma & Étimo & Datação \\
\hline $\begin{array}{l}\text { Le Petit Robert } \\
(2014)\end{array}$ & infection & bas latin infectio & $\begin{array}{l}\text { XIII (pensamento } \\
\text { impuro); 1314 } \\
\text { (corrupção, } \\
\text { putrefação) }\end{array}$ \\
\hline TLF & infection & $\begin{array}{l}\text { Fim sec. XIII } \\
\text { (impureza, } \\
\text { pecado); 1314 } \\
\text { (invasão de um } \\
\text { órgão por germes } \\
\text { infecciosos) Henry }\end{array}$ \\
\hline
\end{tabular}




\begin{tabular}{|l|l|l|l|}
\hline & & & $\begin{array}{l}\text { de Mondeville, } \\
\text { Chirurgie, éd. A. } \\
\text { Bos. par.2058, } \\
2107 .\end{array}$ \\
\hline $\begin{array}{l}\text { GODEFROY- } \\
\text { Complement (1891- } \\
\text { 1902) }\end{array}$ & Infection & $\begin{array}{l}\text { H. de Mondeville, } \\
\text { Chirurgie, f. 95 v6 }\end{array}$ \\
\hline FEW (2003) & Infection & $\begin{array}{l}\text { Pensamento, } \\
\text { sentimento impuro } \\
\text { (Job); decadência } \\
\text { das células por } \\
\text { germes infecciosos } \\
\text { (H. de Mondeville) }\end{array}$ \\
\hline
\end{tabular}

Percebemos uma concordância em todas essas obras. O elemento lexical inicialmente não tinha o sentido de "contaminação por bactérias", mas a partir do início do séc. XIV ganhou tal sentido. O terminus a quo no francês seria a tradução da obra latina de H. de Mondeville chamada Chirurgie, contida em Bos (1896, Vol. II, p. 188):

Melancolie innaturel, non pas porrie, est double: l'une occupe, aussi comme universelment, tout le cors, et ceste est double: car l'une occupe tant seulement la char, et fait lepre; [l'autre occupe tant seulement le cuir, et ceste est double: la .I. occupe tout le cuir, et fait uterique noire]; l'autre occupe la seule partie du cuir, et fait morfea noire ou autres infections noires ou cuir, et aucune fois chancres et pustules et neus et leur semblables.

O trecho acima seria uma tradução do original latino de 1312. Este trecho da versão latina de Mondeville está no livro de Hirsch \& Gurlt (1892, p. 329):

Melancholia innaturalis non putrefacta est duplex: alia occupat quase universaliter totum corpus et haec est duplex: uma occupat solam carnem et facit lepram, alia occupat solam cutem, et haec est duplex: prima ocupat totam et facit icteritiam nigram, alia occupat solam partem et facit morpheam nigram aut ceteras nigras cutis infectiones et aliquando cancro et pustulas et nodos et similis. 
De acordo com Clarke (1931), a obra foi traduzida para o francês por volta de 1314. Pilcher (1895) afirma que ele foi o cirurgião de Felipe, o Belo e de seu sucessor, Luís $\mathrm{X}$ e que sua obra é o primeiro tratado medieval sobre cirurgia, mas foi substituído pela obra mais famosa Chirurgia magna de Guy de Chaliac.

\section{Latim:}

Nos dicionários de Lewis (2002) e de Glare (1968), apenas o primeiro apresenta a cognata infectio, que tem a acepção de "tintura" no latim tardio (i.e. infectio capillorum, Theodorus Priscianus, séc. IV); além dessa acepção, também havia uma acepção de "não realização de alguma coisa coisa", porém, cada uma tinha uma origem diferente, como está demonstrado abaixo na origem do significante.

\subsubsection{Determinação do étimo}

Terminus a quo (mais antigo ao mais novo)

\begin{tabular}{|l|l|}
\hline Mundo Romano & $\begin{array}{l}1314 \text { (da obra em latim de } \\
\text { Mondeville) }\end{array}$ \\
\hline Itancês & $\begin{array}{l}1348-1363 \\
\text { (houve uma tradução da obra de } \\
\text { Lanfranc em 1309) }\end{array}$ \\
\hline Espanhol & $\begin{array}{l}1440 \\
\text { (houve uma tradução por Vicente de } \\
\text { Burgos da obra de Bartholomaeus } \\
\text { (sec. XIV), edição impressa em } \\
1494\end{array}$ \\
\hline Português & 1566 \\
\hline Mundo Germânico & 1380 (da obra em latim de Lanfranc) \\
\hline Inglês &
\end{tabular}




\begin{tabular}{|l|l|}
\hline Alemão & 1529 \\
\hline Holandês & $\begin{array}{l}1485 \text { (da obra de Bartholomeus } \\
\text { Anglicus) } \\
\text { (havia traduções do Lanfranc no } \\
\text { séc. XIV, que não encontramos) }\end{array}$ \\
\hline Sueco & 1656 \\
\hline Dinamarquês & 1809 \\
\hline Dinamarquês na Noruega & 1824 \\
\hline Bokmål & 1892 \\
\hline Nynorsk & 1918 \\
\hline
\end{tabular}

Não faremos distinções de significados extremamente precisos e técnicos dentro da própria acepção de "doença, contágio"; apenas a diferenciamos da antiga acepção latina de "tingidura" e de uma pré-acepção "doença na alma". O inglês médio, por exemplo, é citado por reconhecer duas acepções que envolvem o sentido de "doença, contágio", com subacepções: 1) a) a morbid condition of a bodily part, a humor, etc. (1398); (b) an infectious disease; also, any kind of disease (1425); (c) something which causes disease or death, infection in the air, poison, any morbific agent (1425) e 2) (a) contaminated state or condition, filthiness; rustiness [1st quot.] (1398); (b) something which contaminates, filth (1398); (c) mental or spiritual contamination (1443). Portanto, não tomaremos essa diretriz.

Percebe-se que há a tradução de três obras latinas que resultam no surgimento desse elemento lexical em traduções vernáculas: De proprietatibus rerum de Bartholomaeus Anglicus (1235), Chirurgia Magna (1296) de Lanfranc de Milan e Chirurgia (1312) de Henri de Mondeville.

De acordo com de Moulin (1988), Lanfranc foi a ponte entre os cirurgiões parisienses e italianos e suas atividades formam a base da cirurgia francesa (p. 46-47). McCallum (2008) também atesta que, com Henri de Mondeville, ele foi o fundador da escola de cirurgia francesa do séc. XIV. 
Bartholomeus Anglicus, embora não tenha sido um cirurgião, foi precursor da enciclopédia e autor de um dos livros mais lidos do medievo (STEELE, 1893, p. 1). Concluímos que os três livros foram muito populares em um período muito próximo na Europa.

Houve muitas traduções de todas essas obras e não tivemos acesso a elas. No que diz respeito à obra de Lanfranc, além das citadas acima (i.e. inglês em 1380, italiana de 1309 e holandesas do séc. XIV), sabemos que houve traduções para o alemão no séc. XIV e XV por conta do artigo de Keil e Müller chamado Deutsche Lanfrank-Übersetzugen des 14. und 15. Jahrhundert (1971), mas também não tivemos acesso a ele. Com relação à obra de Mondeville, além da tradução francesa de 1314, há dezenove manuscritos que carregam o nome do autor como, por exemplo, em inglês no ano de 1392. A maioria desses manuscritos se encontram na Bibliothèque Nationale, embora haja alguns holandeses no British Museum, uma tradução para o provençal em Florença, etc. (CLARKE, 1931, p. 474-475).

No que tange a obra de Bartholomaeus Anglicus, Surget (1980) afirma que a primeira tradução para o vernáculo foi para o italiano (tradução de Vivaldo Belcazer, 1309), em seguida para o francês (tradução de Jean Corbechon, 1372), para o provençal (oferecida a Gaston III, 1391), e então a versão inglesa de Trevisa (1398). Houve também a versão espanhola de Vicente de Burgos, anônimas tanto em flamengo quanto em anglo-normando ao mesmo tempo em que os manuscritos latinos continuam sendo copiados e distribuídos por toda a Europa (p. 8-9)

Em 1470, funcionava pela primeira vez a máquina de impressão de Gutemberg. Entre os anos 1470-1480 o livro já havia sido impresso na Basiléia (1470 e 1475) e em Colônia (1472 e 1475). Em Lyon na data de 29 de julho de 1480 foi produzida a primeira edição do texto original de Bartholomaeus Anglicus. A primeira edição do Le Propriétaire des choses, traduzido por Corbechon, surgiu em 1482 (SURGET, 1980, p. 17). Também surgiu a versão de Guillaume Leroy (1486) (p. 45), de Jean Syber (1487) (p. 55). Houve também edições entre 1480 e 1500 como, por exemplo, em Nuremberg (1483, 1492), Strassbourg (1491). A 
versão flamenga surgiu em 1479, a holandesa, em 1485 e a espanhola em 1494 , em Toulouse.

É visível a dificuldade em fazer uma gênese de todas as versões dessas três grandes obras e, assim comparar o elemento lexical, uma vez que não temos acesso à maioria delas. Por conta disso, consideraremos o que temos em mão, uma vez que não é possível afirmar que esse elemento esteja registrado nas obras não acessadas.

1) Por ser inicialmente um elemento lexical de cunho técnico (tintura), que com o tempo passou a ser utilizado em outras áreas (no plano moral, alma corrompida) e, em seguida, no plano medicinal, nada podemos dizer sobre seu tema, pois foi um desenvolvimento que ocorreu dentro do próprio latim. Por outro lado, ao receber a acepção medicinal no latim e, em seguida, ser emprestada para as línguas vernáculas, conhecer quais regiões da Europa estudavam, por exemplo, a medicina poderia esclarecer a determinação de qual foi a primeira língua que utilizou esse elemento lexical e, possivelmente, passou para as outras línguas vernáculas. Como visto acima, a França e a Itália eram países que estudavam a cirurgia e a medicina. Mas, contra isso, podemos argumentar que infecção não necessariamente poderia surgir apenas em temas relacionados à cirurgia e à medicina, mas também, por exemplo, em anotações de viagens, em uma a narrativa que alguma infecção dizimou parte da tripulação. Concluímos que aplicar um tema a esse elemento lexical é muito difícil e apenas gera especulações.

2) A relação entre escrita e pronúncia não nos proporciona nenhuma pista para a investigação do étimo, uma vez que cada língua pronuncia o radical infec- da sua maneira.

3) O radical é infec- e remete ao latim; portanto, não seria um radical exclusivo de nenhuma língua descendente.

4) Neste elemento lexical os cruzamentos panromânicos de Freitas não se aplicam, pois vimos que não foi uma língua que o espalhou para todas as outras, mas sim que houve duas frentes principais (i.e. francês, que traduziu Mondeville; inglês, que traduziu Lanfranc, sem contar as traduções diretas do latim para espanhol, holandês e italiano que não tivemos acesso). Portanto, o que 
houve, na verdade, foi um elemento lexical latino científico que foi traduzido para as outras línguas em épocas diferentes, mas isso não significa que não tenha também ocorrido empréstimos dele entre as vernáculas.

5) A questão semântica poderia ajudar ainda mais se tivéssemos tido acesso a todos os manuscritos das três obras acima citadas. Talvez uma separação ainda mais radical da acepção do elemento lexical (i.e. infecção no corpo, infecção no ar, infecção em uma substância, no queijo, por exemplo) pudesse ajudar melhor na determinação do caminho até o português e o norueguês.

No presente caso, apenas o definidor (1) é relevante para a etimologia desse elemento.

\subsubsection{Fichas}

No português

\section{Infecção s.f.}

25\% ( esp. infección $1440 \$ [it. infezione 1348-1363] \[fr. infection $1314]<$ lat. cient. infectio)

$25 \%$ ( $\triangleleft$ it. infezione 1348-1363 4 [fr. infection 1314] $<$ lat. cient. infectio)

$25 \%$ ( 4 fr. infection $1314<$ lat. cient. infectio)

$25 \%$ ( $<$ lat. cient. infectio)

1566. Crónica do felicissimo rei D Manuel composta por Damião de Góis

Origem do significado da acepção: latina

Origem do significante da acepção: latina

Étimo de empréstimo: $25 \%$ francês, $25 \%$ espanhol, $25 \%$ italiano e $25 \%$ latim científico

Local: Houaiss

Discussão a respeito das informações do Houaiss: 
O dicionário não deixa muito claro qual seria o étimo do elemento lexical, pois afirma que o latim tinha infectio na acepção de "ação de tingir, tintura" e, consequentemente, "mácula, desonra, estupro" e cita Joaquim Machado que supõe intermediação do fr. infection (sXIII) "mancha, mácula (de pecado)", (1314) "invação (de uma parte do corpo) por germes infecciosos" e (1484) "moléstia infecciosa".

\subsubsection{No norueguês}

\section{Infeksjon, s.m.}

\section{Bokmål:}

$20 \%$ ( 4 din. na Noruega. infektion $1824 \varangle$ din. infektion, 18094 sue. infection, $1545 \varangle$ [ale. Infection, 1529] \[hol. Infectie, 1485] 4 [ing. infection 1380] 4 [fr. infection 1314] 4 latim cient. infectio)

20\% ( din. na Noruega. infektion $1824 \varangle$ din. infektion, $1809 \varangle$ ale. Infection, $1529 \varangle$ [hol. Infectie, 1485] 4 [ing. infection 1380] 4 [fr. infection 1314] 4 latim cient. infectio)

20\% ( din. na Noruega. infektion $1824 \varangle$ din. infektion, $1809 \varangle$ hol. infectie, $1485 \varangle$ [ing. infection 1380] $\varangle$ [fr. infection 1314] \ latim cient. infectio)

$20 \%$ ( din. na Noruega. infektion $1824 \varangle$ din. infektion, $1809<$ ing. infection $1380 \varangle$ [fr. infection 1314] \latim cient. infectio) 20\% ( din. na Noruega. infektion $1824 \varangle$ din. infektion, $1809<\mathrm{fr}$. infection $1314 \varangle$ latim cient. infectio)

Comentário: como esse elemento lexical já estava difundido nos jornais noruegueses escritos em dinamarqueses, concluímos que foi o dinamarquês que passou para o bokmål. A respeito dos caminhos para chegar até o dinamarquês as possibilidades são muitas e não deixa de ser algo totalmente especulativo, pois não encontramos traduções como terminus a quo para que pudéssemos afirmar com certeza.

1892. Illustreret verdensgeografi: skildringer og livsbilleder: lande og folk. 1

Trecho: Men em stor fordel [...] frembringe hurtigere og sterkere gjæring 
ved ostens infektion ved gjærbakterier vilde vise sig praktisk ${ }^{172}$

Origem do significado da acepção: latina

Origem do significante da acepção: latina

Étimo de empréstimo: dinamarquês

Local: Nasjonalbiblioteket

Comentário: a obra apresenta várias características de que está escrita na língua norueguesa: ensurdecimento (ut "fora", trakt "funil"), plural em -er (trakter "funis"), passado em -et (glimret "brilhou"), plural sem a terminação do gênero neutro na forma indeterminada (sine statelige nybygde hus "as casas estatais recém-construídas dele) e encurtamento de verbos e substantivos (ha "ter", dra "andar", ta "pegar").

Discussão a respeito das informações dos dicionários de bokmål:

Os dicionários NbUiB e NTG afirmam que o elemento lexical vem do latim infisere e apenas o ROB sugere uma intermediação com o francês ou alemão. Eles também não indicam sua datação. Por meio de nossa pesquisa, determinamos o étimo e a datação.

Nynorsk:

20\% ( $\triangleleft$ nbok. infektion $1892 \triangleleft$ din. na Noruega. infektion $1824 \triangleleft$ din. infektion, $1809 \varangle$ sue. infection, $1545 \varangle$ [ale. Infection, 1529] 4 [hol. Infectie, 1485] \ [ing. infection 1380] \[fr. infection 1314] \ latim cient. infectio)

20\% ( 4 nbok. infektion $1892 \varangle$ din. na Noruega. infektion $1824 \triangleleft$ din. infektion, $1809 \triangleleft$ ale. Infection, $1529 \triangleleft$ [hol. Infectie, 1485] 4 [ing. infection 1380] \ [fr. infection 1314] \ latim cient. infectio) 20\% ( 4 nbok. infektion $1892 \triangleleft$ din. na Noruega. infektion $1824 \triangleleft$ din. infektion, $1809 \triangleleft \mathrm{hol}$. infectie, $1485 \triangleleft[$ [ing. infection 1380] $\triangleleft$ [fr. infection 1314] 4 latim cient. infectio) 20\% ( 4 nbok. infektion $1892 \varangle$ din. na Noruega. infektion $1824 \triangleleft$ din. infektion, $1809 \triangleleft$ ing. infection $1380 \triangleleft[\mathrm{fr}$. infection 1314] 4 latim cient. infectio)

172 Mas uma grande vantagem [...] para produzir fermentação mais rápida e mais forte com a infecção do queijo pelas bactérias de fermentação se mostraria prática. (trad. nossa) 
20\% ( nbok. infektion $1892 \varangle$ din. na Noruega. infektion $1824 \varangle$ din.

infektion, $1809 \varangle \mathrm{fr}$. infection $1314 \varangle$ latim cient. infectio)

Comentário: este elemento lexical já existia no bokmål, portanto temos a hipótese de que foi ele que emprestou para o nynorsk por meio do contato.

1918. Den Nye rettskrivning: reglar og ordlistor. II: Landsmål de Den

Departementale rettskrivningskomite

Trecho: infeksjon, ein ${ }^{173}$

Origem do significado da acepção: latina

Origem do significante da acepção: latina

Étimo de empréstimo: 100\% bokmål

Local: Nasjonalbiblioteket

Discussão a respeito das informações do dicionário de nynorsk:

O dicionário NyUiB também afirma que o elemento lexical vem do latim infisere e não sugere nenhuma datação.

\section{Origem do significante:}

De acordo com Ernout \& Meillet 1932 [20016], o adjetivo factus "feito" é antônimo de infectus "não feito", cujo neutro infectum é utilizado na gramática (Varrão) para designar o tempo do presente (que marca a ação não concluída) por oposição ao tempo do perfeito, perfectum. Infectus é arcaico e clássico; porém, com exceção de alguns casos em textos jurídicos, não sobreviveu à língua imperial, que viu o desenvolvimento de imperfectus. A homonímia com infectus, do verbo inficiō, também foi uma desvantagem (p. 210).

No entanto, o infectio estudado aqui é o resultado desse último citado pelos autores. Este elemento lexical é o resultado da derivação a partir do particípio infectus, do verbo inficere. De acordo com os autores, inficio, cujo significado original devia ser "colocar dentro", se especializou, em um momento seguinte, na língua dos tintureiros e adquiriu o significado de "colocar em molho,

173 Infecção, uma (trad. nossa) 
em um banho, numa tinturaria" e, consequentemente, "tingir", "colorir", "impregnar" (p. 212). Por conta da associação entre o prefixo in- com o radical fact- veio a ocorrer a apofonia com influência de sílaba fechada e, como em muitos outros casos, o a passa para e, ou seja, infect-. Percebe-se que no período contagio era um elemento lexical para algo que, grosso modo, seria a atual "infecção". 


\subsection{Libração/Librasjon}

\subsubsection{Apresentação dos dados}

\subsubsection{Mundo germânico}

Norueguês

Significados em dicionários atuais (a partir de 1901 em nynorsk e 1907

em

bokmål):

\begin{tabular}{|l|l|l|l|}
\hline Dic. & Significado & Etimologia & Datação \\
\hline NbUiB & Não consta & Não consta & Não consta \\
\hline NyUiB & Não consta & Não consta & Não consta \\
\hline NTG & Não consta consta \\
\hline ROB & $\begin{array}{l}\text { Movimento oscilatório da } \\
\text { lua, pelo qual algumas } \\
\text { partes, que normalmente } \\
\text { não são vistas, são } \\
\text { observadas. }\end{array}$ & $\begin{array}{l}\text { Lat. libratio "ato } \\
\text { de pesar" }\end{array}$ & \\
\hline
\end{tabular}

Livros em dinamarquês publicados na Noruega

A primeira atestação desse elemento lexical está no jornal Den Norske Rigstidende do dia 13 de abril de 1821:

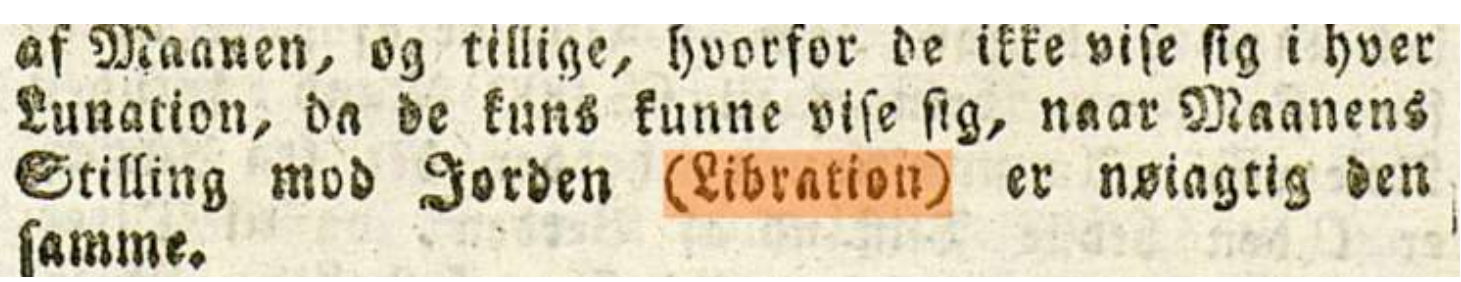


"da Lua, e também porque eles não aparecem em cada lunação (referência aos vulcões), uma vez que eles apenas podem aparecer quando a posição da lua contra a Terra (Libração) é exatamente a mesma" (Trad. nossa)

É sabido que a libração da lua foi descoberta pelo astrólogo polonês Johannes Hevelius, que a mapeou (BURNS, 2001, p. 138). Esse trabalho se encontra na obra Selenographia, sive Lunae descriptio (1674). No entanto, de acordo com a Encyclopedia online Treccani, a libração é um fenômeno que ocorre por conta da rotação e da translação da lua, o que faz com que a lua não se mostre para um observador da Terra sempre o mesmo hemisfério e, por efeito desse fenômeno, a parte da lua visível para a Terra é um pouco mais que a metade (cerca de 59/100) da superfície total. A enciclopédia também afirma que a libração foi descoberta por G. Galilei que o chamo de titubazione e, em seguida, descrito e estudado por G. B. Riccioli, J. Hevelius, F. M. Grimald e G. Cassini.

Kopal (1969) afirma que Galileo Galilei foi o primeiro que detectou o deslocamento periódico dos pontos lunares alternadamente em direção ao limite leste e ao limite oeste da superfície visível da lua. Afirma que na obra Dialogo sopra i due massimi sistemi del modo (1632) Galilei deu à afirmação de Salviati duas causas possíveis: quer dizer, a libração em latitude e a libração diurna enquanto o grosso do fenômeno que ele observou ocorria graças à libração em longitude. $\mathrm{O}$ autor também afirma que a libração foi reconhecida como tal por Riccioli e Hevelius entre 1638 e 1641 e em 1654, em uma carta de Hevelius a Riccioli, o astrônomo expressou a opinião de que a verdadeira causa da libração observada em longitude é a não uniformidade do movimento da Lua em sua órbita (implícita, na verdade, na segunda lei de Kepler conhecida desde 1609) (p. 2223).

Independentemente de quem leva o crédito por ter descoberto esse fenômeno, analisaremos quem de fato utilizou o termo libração para explicá-lo, mas como a própria enciclopédia afirma que Galilei o explicava com o termo titubação e Kopal, que cita a explicação de Hevelius a Riccioli, temos a hipótese de que pode ter sido de fato Hevelius o criador desse termo. 


\section{Obras lexicográficas}

No dicionário de palavras estrangeiras de M. C. Hansen (1851) temos a seguinte explicação para a palavra:

Libration, en, Dinglen, svaiende Bevægelse

"Libração, oscilação, movimentação que se encurva" (trad. nossa)

Nos dicionários utilizados para analisar as outras palavras não encontramos definições para libration.

\section{Cognatas em outras línguas germânicas}

Dinamarquês (publicado na dinamarca)

A respeito dos dicionários, o elemento lexical está atestado no dicionário de palavras estrangeiras de Meyer (1837) ${ }^{174}$ :

Libration: en, Dinglen, Svaien, svaiende Bevæelse (Maanens)

É praticamente a mesma definição do dicionário de Hansen (1851), acima citado. Em nenhum dos outros dicionários utilizados encontramos uma entrada para esse elemento lexical. No Grand Dictionnaire Royal Danois et François (1759) ${ }^{175}$ não há o elemento lexical Libration, mas sim Svæven:

Stiærnes Svæven - mouvement de libration

A falta de atestação, por ser um grande dicionário, provavelmente nos mostra que esse elemento lexical não existia ainda na língua dinamarquesa em 1759. A tradução também não está ao pé dá letra, pois em dinamarquês significa "movimento dos astros", quer dizer, stiærne "astro, estrela" é posto como sinônimo de libration em francês.

\footnotetext{
174 Disponível em https://books.google.dk/books?id=EjZVAAAAcAAJ\&printsec=titlepage\&hl=pt-

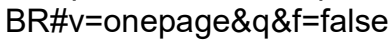


Não encontramos nada mais antigo no Google Books e nos corpora utilizados.

\section{No sueco}

O dicionário Svenska Akademiens Ordbok (SAO) ${ }^{176}$ consta que tal cognato correspondente foi primeiramente registrada no sueco em 1795 no livro de Astronomie 1-2 de Daniel Melanderhjelm.

$\underline{\text { No inglês }}$

No Oxford (CD-ROM, 2010) não há uma entrada para libration, ao passo que o dicionário etimológico de Murray (1903) postula três acepções para esse elemento lexical:

1. A. The action of librating; motion like that of the beam of a balance oscillating upon its pivot; swaying to and fro. B. The state of being balanced or in equipoise; equipoise, balance

2. Astron. A real or apparent motion of an oscillating kind. Libration of the moon: an apparent irregularity of the moon's motion which makes it appear to oscilatte in such a manner that the parts near the edge of the disk are alternately visible and invisible

3. † Weighing

O dicionário afirma que a primeira atestação é de 1603, mas com a segunda acepção apenas em 1669 na obra Philosophical Transactions IV de John Flamstead: If the Libration of the Moon be known, the protraction of the Star's way in this Appearance will be facile. O Google Books mostra o mesmo resultado.

\section{No alemão}

Não encontramos o cognato alemão nem nos dicionários de etimologia nem nos dicionários antigos da língua alemã. No Deutsche Textarchiv (DTA), por

176 Disponível em: http://g3.spraakdata.gu.se/saob/ 
outro lado, há obras em que ela é citada. Como primeiro registro há o livro de Erasmus Francisci, das eröffnete Lust-Haus der Ober- und Nieder-Welt (1676):

Solche libration, oder Hin- und Wieder-Bewegung (...) von dem Mond (...) (p. 420)

"Tal libração, ou o movimento ocasional [...] realizado pela lua [...]" (trad. nossa)

\section{No holandês}

O dicionário de N. van der Sijs (2001) afirma que libratie é o balancear aparente de corpos celestes e tem como primeiro registro a data de 1824 , do francês. P.A.F. van Veen e N. Van der Sijs (1997) fazem o mesmo comentário, mas descrevem melhor o possível caminho do elemento lexical: fr. libration < latim libratio "equilíbrio", de librare "balancear", de libra "balança".

\subsubsection{Mundo românico}

\section{Português:}

Os dicionários de língua portuguesa atestam a etimologia desse elemento lexical da seguinte maneira:

\begin{tabular}{|l|l|l|}
\hline Dicionário & Étimo & Datação \\
\hline Houaiss (online) & $\begin{array}{l}\text { lat. libratio "ação de } \\
\text { nivelar, nivelamento; } \\
\text { movimentor regular, } \\
\text { oscilação" }\end{array}$ & \\
\hline
\end{tabular}

No dicionário de Houaiss há duas acepções: 1) fis. Movimento oscilatório de um corpo cuja tendência de movimento é rotacional, não contendo, porém, energia suficiente para efetuar uma rotação completa e 2) astr. oscilação, aparente ou real, de um corpo celeste. Trataremos apenas da segunda acepção, que é a existente no norueguês. 
Nos dicionários de etimologia da língua portuguesa encontramos as seguintes atestações:

\begin{tabular}{|l|l|l|l|}
\hline Dicionário & Forma & Étimo & Datação \\
\hline Cunha (1999) & Libração & Não consta & 1813 \\
\hline VHCPM (2007) & Não consta & Não consta & Não consta \\
\hline
\end{tabular}

Ao pesquisarmos no corpus lexicográfico, encontramos as informações abaixo.

Bento Pereiro na obra Prosodia (1697) afirma que o elemento lexical latino libratio significa pezo, pezadura, igualdade.

A obra Vocabulário de Bluteau (VOL, 5, 1716) define libraçaõ da seguinte maneira:

He hum movimento com suspensão, \& alternativa inclinação de huma parte para outra. Com oculos de longa mira se tem observado na Lua hü movimento, a que os Astronomos chamàrão de Libração, que consiste, em que as maculas deste Planeta hora apparecem por huma banda, \& hora por outra, em hum tempo visiveis por estarem no Hemisferio da Lua, que olha para a terra, \& em outro tempo invisiveis, por estarem no Hemispherio opposto. Porèm ainda não assentàrão os Astronomos a certeza deste movimento, \& fazem pouco caso delle. Libratio, onis. Fem. Acha se esta palavra em Vitruvio no cap. 18. do livro 10. em sentido que se póde accommodar a este, porque falla o dito Author na acção de pôr huma cousa em equilibrio.

Este elemento lexical também está citado na entrada systéma. Bluteau explica que Systéma é um elemento lexical excogitado pelos astrônomos e vale o mesmo que coordenação, composição, disposição, situação e colocação dos grandes corpos do mundo respectivamente, ao centro do universo com suposições e hipóteses que servem de fundamento para explicar e determinar todos os fenômenos, aparências, movimentos e mudanças do planetas e orbes celestes. Ele estabelece que há três sistemas principais: ptolemaico, copernicano e thyconico. Em seguida escreve: 
[...] no Systema Ptolemaico [...] està o globo terraqueo, immovel, no centro do mundo, rodea o ar este dous elementos, \& he o ar cercado do elemento do fogo, debazxo do concavo do Ceo da Lua. Chama Ptolomeo a esta primeyra parte do seu Systema Regiaõ elemental. A segunda parte do dito Systema, chamada região Etherea, começa do Ceo da Lua até o primeyro movel inclusive, \& entre estes dous esfericos limites se encerrão outros nove Ceos, a saber, o de Mercurio, de Venus, do Sol, de Marte, de Jupiter, de Saturno, o Ceo, a que chamão Firmamento, em que estão as Estrellas fixas, \& os dous ceos crystallinos, hum de Libraçaõ, que se move do Oriente para o Occaso, \& outro de Trepidaçaõ, que vay do Norte para o Sul [...]

$\mathrm{Na}$ entrada céo, Bluteau define os doze corpos celestes e em quarto lugar está o segundo Ceo Cristallino, que também é [...] excogitado, para explificar o movimento de libraçaõ, ou trepidação, que leva a Esphera celeste de hum Polo para outro, donde nace a differença, que em varios tempos se chama na mayor declinaçã̃ do sol.

A respeito da acepção latina, Bluteau a cita na entrada librar, que é suspender, como em balança, que em Latim he Libra. He ter huma cousa hum certo movimento, como se se quizera pôr em equilibrio, inclinando quase insensivelmente hora para hüa parte, hora para outra. Librare, $(O$, avi, atum Ovid. Columel. Vid. Libração. Na entrada sobre Stâtica o autor também o cita: divide.se a Statica em Acrostatica, que contempla a libração dos corpos suspensos no ar $[\ldots]$.

No dicionário Parvum Lexicon de Fonseca (1798), libratio significa movimento de libração em Vitruvius.

Não encontramos registros mais antigos no Google Books ou no Corpus do português. 


\section{Espanhol:}

Nos Corominas encontramos a seguinte entrada:

\begin{tabular}{|l|l|l|l|}
\hline Dicionário & Forma & Étimo & Datação \\
\hline $\begin{array}{l}\text { COROMINAS } \\
(1984)\end{array}$ & libración & $\begin{array}{l}\text { De libratio "ação de } \\
\text { nivelar, balancear" }\end{array}$ & 1640, Nieremberg \\
\hline
\end{tabular}

Corominas cita apenas o sentido que não é da astrologia. No Google Books, por outro lado, a encontramos como primeira abonação com acepção da astrologia na obra De Los Reyes (1650):

El cielo vndecimo es el primer moble, que com igual, y rapido mouimiento se mueue sobre los polos del mundo em espacio de veiente y quatro horas, arrebatando tras si todos los inferiores Orbes, los quales se mueu e del Ocaso, al Oriente, sobre los polos del Zodiaco cõ próprio mouimiento. Siguese la decima esfera, que sin el curso com que sigue al primer moble, tiene outro proprio de libracion, com el qual se mueue de Septentrion a Medio dia, y de Medio dia al Septentrion.

No entanto, não consideramos essa abonação como aquela que tem a acepção astronômica relacionado com a libração da lua. Tal abonação se encontra na obra traduzida do francês de Ladvocat (1754):

Hevelke, ó Hevelio (Juan) Regidor [...] Este es el que descubriò uma especie de movimiento de libracion em la Luna [...] (p. 302).

Italiano:

\begin{tabular}{|l|l|l|l|}
\hline Dicionário & Forma & Étimo & Datação \\
\hline ZINGARELLI & librazióne & $\begin{array}{l}\text { Voc. culto, lat. } \\
\text { libratione(m), da } \\
\text { libratus }\end{array}$ & 1631 \\
\hline
\end{tabular}




\begin{tabular}{|c|c|c|c|}
\hline Deli & librazióne & Não consta & $\begin{array}{l}\text { Leggera } \\
\text { oscillazione (av. } \\
\text { 1642, E. Diodati), } \\
\text { (Astron.) } \\
\text { "apparente } \\
\text { leggerissima } \\
\text { oscillazione della } \\
\text { luna per cui è } \\
\text { osservabile dalla } \\
\text { Terra più che metà } \\
\text { della sua } \\
\text { superficie (1630- } \\
\text { 31, G. Galilei, che } \\
\text { scoprì il } \\
\text { movimento e lo } \\
\text { chiamò } \\
\text { titubazione). }\end{array}$ \\
\hline
\end{tabular}

Zingarelli afirma que há duas acepções: 1) (astrom.) ligeira oscilação da lua, devido à órbita elíptica que desenha ao redor da terra; 2) (raro) balancear, oscilar.

Não encontramos as referências para a obra de data 1642 acima citada, mas provavelmente não tem a ver com nossa acepção pois o primeiro a utilizá-la provavelmente foi Hevelius, em latim e em 1647. Além do mais, como afirma o Deli, encontramos cartas e obras de Galileo Galilei em que ele cita o elemento lexical librazione, mas que não é um termo para a explicação do fenômeno lunar. Para tal, ele utiliza o termo titubazione em uma carta de 1637 intitulada, que se encontra nas Opere di Galileo Galilei de 1744, tomo II:

[...] si scopriranno altre mutazioni in confermazione di questa, che possiamo quasi chiamare Titubazione della Luna [...] (p. 49)

"[...] você vai descobrir outras mutações na confirmação desta, que podemos quase chamar de titubação da lua [...]" (trad. nossa) 
Trechos em que aparece o elemento lexical librazione na obra Dialogo sopra i due massimi sistemi del modo (1632):

Accaderà, per la quarta maraviglia, che il giorno della massima obbliquità sarà l'istesso che quello del passaggio fatto per linea retta, e nel giorno della librazione apparirà l'arco del viaggio piu che mai incurvato. (p. 340)

"Acontecerá, pela quarta maravilha, que o dia da máxima obliguidade será o mesmo que aquele do curso feito pela linha reta, e no dia da libração o arco do curso aparecerá mais encurvado do que nunca". (trad. nossa)

Com a acepção de libração lunar encontramos a primeira abonação em uma obra de F. A. di C. (1724):

[...] a Luna deve far intorno alla Terra come questa intorno al Sole, ch' alle volte presenta al medesimo le parti Settentrionali, ed alle volte l'Australi, il che contribuisce parimente a dette librazioni della Luna. (p. 92-93)

"[...] a lua deve estar em torno da Terra como esta está em torno do sol, que às vezes apresenta as mesmas partes setentrionais e, às vezes, as partes austrais, que contribui da mesma maneira à dita librações da lua" (trad. nossa)

\section{Francês:}

Nos dicionários de francês (incluindo os etimológicos)

\begin{tabular}{|c|c|c|c|}
\hline Dicionário & Forma & Étimo & Datação \\
\hline $\begin{array}{l}\text { Le Petit Robert } \\
(2014)\end{array}$ & libration & latin libratio & 1547 \\
\hline TLF & libration & $\begin{array}{l}\text { Empr. Do lat. libratio } \\
\text { "nivelamento" (cp. } \\
\text { Vitruve) TLL); } \\
\text { "movimento regular, } \\
\text { balanceamento" e } \\
\text { em baixo latim fig. } \\
\text { "equilíbrio". Como } \\
\text { termo de }\end{array}$ & $\begin{array}{l}15471 . \\
\text { "nivelamento" (Jean } \\
\text { Martin, trad. } \\
\text { l'Architecture de } \\
\text { Vitruve, B4 } \\
\text { vo ds GDF. Compl.); } \\
\text { 2.a) } 1704 \text { astron. } \\
\text { (Trév.); b) } 1867\end{array}$ \\
\hline
\end{tabular}




\begin{tabular}{|l|l|l|l|}
\hline & $\begin{array}{l}\text { astronomia, a língua } \\
\text { inglesa atesta } \\
\text { libration of the moon } \\
\text { em 1669. }\end{array}$ & phys. (Littré); 3. \\
& & "balanceamento \\
& & harmônico, \\
& & equilíbrio" \\
& (Boulainvilliers, \\
& & Réfutation des \\
& & erreurs de Benoît \\
& & de Spnioza, p. 203) \\
\hline
\end{tabular}

Godefroy, na parte Complemént, afirma que libration significa nivellement e cita como primeira ocorrência a obra traduzida de 1547 por J. Martin (Vitruve). FEW faz o mesmo comentário (1547, Jan Martin, Vitruve, Anotations, Db.).

Encontramos, diferentemente, a primeira abonação com a segunda acepção (astronômica) no Le lovrnal des Scavans (24 de janeiro de 1667):

Les Astronomes trouueront dans cet ouurage plusieurs choses tres remarquables touchant le diametre apparent du Soleil \& des autres Astres, le mouuement de libration de la Lune, les éclipses, les parallaxes, \& le refractions [...] (p. 14)

"Os astronomos encontram nesse livro várias coisas muito notáveis no tocante ao diâmetro aparente do sol e dos outros astros, ao movimento de libração da lua, aos eclipses, às paralaxes e às refrações [...]" (trad. nossa)

\section{Latim:}

Tanto o dicionário de Oxford e de Lewis propõem dois sentidos básicos para libratio:

1. Nivelamento:

Fortasse qui Archimedis libros legit, dicet non posse fieri veram ex aqua librationem (Vitr. 8, 5, 3)

"É possível que algum leitor dos trabalhos de Arquimedes diga que não pode ocorrer nivelação por meio da água" (trad. nossa)

2. Posição horizontal, nível: 
circa terrae librationem (Vitr. 6, I, 5).

"no nível da terra" (trad. nossa)

Como primeira atestação do sentido de libração da lua, há a obra de Johannes Hevelius chamada Selenographia, sive Lunae (1647). Neste tratado Hevelius mostrou a diferença entre seu trabalho e o de Galileo Galilei e criticou a qualidade das representações da lua em Sidereus nuncius (1610). Trecho da obra:

\section{SELEN OGR APH I A.}

hujus motus, quodlibet punetum, fub meridiano conftitutum, ab eodem dimovetur, aliudque admovetur, quemadmodum facilè intelligitur. Atque fic cum motu Librationis Lunæ elt comparatum. Nametfi propterea, non omnino de loco de-

Atque sic cum motu Librationis Lunae est comparatum. (p. 237)

"E então é comparado com o movimento de libração da lua." (trad. nossa)

\subsubsection{Determinação do étimo}

Terminus a quo (mais antigo ao mais novo)

\begin{tabular}{|l|l|}
\hline \multicolumn{2}{|l|}{ Mundo Romano } \\
\hline Francês & 1667 \\
\hline Italiano & 1724 \\
\hline Português & 1716 \\
\hline Espanhol & 1754 \\
\hline Mundo Germânico & 1669 \\
\hline Inglês & 1676 \\
\hline Alemão & 1795 \\
\hline Sueco &
\end{tabular}




\begin{tabular}{|l|l|}
\hline Holandês & 1824 \\
\hline Dinamarquês na Noruega & 1821 \\
\hline Dinamarquês & 1837 \\
\hline Bokmål & 1922 \\
\hline Nynorsk & 1976 \\
\hline
\end{tabular}

1) A respeito das línguas de influência em determinados temas, nenhuma conclusão podemos tomar porque, como considerado no ponto (1), o elemento lexical tem uma acepção científica astronômica e qualquer país que tenha astrônomos significativos poderia ter se apropriado desse elemento lexical latino e dado a ele uma nova acepção de acordo com o estudo astronômico.

2) A relação entre escrita e pronúncia não nos proporciona nenhuma pista para a investigação do étimo, uma vez que cada língua pronuncia o radical libr- da sua maneira.

3) O radical do elemento lexical é libr- e remete ao latim; portanto, não seria um radical exclusivo de nenhuma língua descendente.

4) Aqui a hipótese dos cruzamentos panromânicos de Freitas (2013) não se confirma, porque seria extremamente possível que tanto o francês (1667) quanto o italiano (1724) emprestassem esse elemento lexical da obra latina de Hevelius, já que era uma obra muito conhecida, quer dizer, não necessariamente o francês emprestou essa palavra para o latim.

5) A questão semântica é pouco relevante para essa análise, uma vez que a acepção do elemento lexical estudado não se mudou durante o tempo.

No presente caso, apenas o terminus a quo é relevante para a etimologia desse elemento lexical. 


\subsubsection{Fichas}

\subsubsection{Para o português}

\section{Libração (s.f.)}

25\% (ale. Libration, 1676 [ing. libration, 1669] \[fr. libration, 1667] 4 lat. cient. libratio "da lua", 1647)

$25 \%$ ( 4 ing. libration, $1669 \varangle$ [fr. libration, 1667] 4 lat. cient. libratio "da lua", 1647)

25\% ( fr. 1667 lat. cient. libratio "da lua", 1647)

$25 \%$ ( 4 lat. cient. libratio "da lua", 1647)

Comentário: a primeira abonação está na obra de Bluteau, portanto, esse elemento lexical pode ter sido emprestado por ele tanto do francês quanto diretamente do latim científico. Que ele tenha utilizado uma edição alemã (1676) ou inglesa (1669) também não é de se descartar.

1716. Vocabulário de Bluteau

Origem do significado da acepção: latim científico

Origem do significante da acepção: latim científico

Étimo de empréstimo: $25 \%$ francês, 25\% latim científico, $25 \%$ alemão, $25 \%$ inglês

Local: Vocabulário online de Bluteau

\section{Discussão a respeito das informações do Houaiss:}

O dicionário apenas afirma que o elemento lexical vem do latim libratio "ação de nivelar, nivelamento; movimento regular, oscilação", o que não deixa de estar correto, mas não afirma que o elemento lexical também pode ter vindo do francês. A datação também está correta. 


\subsubsection{Para o norueguês}

\section{Librasjon, s.m.}

Bokmål:

33,33\% ( din. na Noruega libration, $1821 \varangle$ ale. Libration,1676 4 [fr. libration,1667] \ lat. cient. libratio "da lua", 1647) 33,33\% ( din. na Noruega libration, $1821 \varangle$ fr. libration, $1667 \varangle$ lat. cient. libratio "da lua", 1647) 33,33\% ( din. na Noruega libration, 1821 lat. cient. libratio "da lua", 1647)

Comentário: a obra em dinamarquês está em um jornal da Noruega de 1821 e só encontramos a primeira abonação em dinamarquês na Dinamarca anos depois. Provavelmente há na Dinamarca uma obra mais antiga que essa da Noruega. É possível que tenha passado para o dinamarquês diretamente do francês, pelo alemão e até mesmo pelo latim científico, mas temos a hipótese de que há $100 \%$ de chances do étimo do bokmål ser dinamarquês Outro comentário relevante é a etimologia dada por $\mathrm{ROB}$, que está presente no início dessa análise: que vem do latim "ato pesar", quer dizer, não houve no dicionário uma preocupação em investigar todo o caminho desse elemento lexical, mas apenas citar a acepção existente no latim clássico, o que vai totalmente contra nosso entendimento sobre Etimologia.

1922. Aschehougs konversationsleksikon. 6: Kassette-Löwen

Citação: Libration, Maanens, se Maanen. ${ }^{177}$

Origem do significado da acepção: latim científico

Origem do significante da acepção: latim científico

Étimo de empréstimo: $100 \%$ dinamarquês

Local: Nasjonalbiblioteket

\section{Característica de texto em bokmål nessa obra:}

177 Libração: da lua, consulte lua (trad. nossa) 
Não é necessário avaliar, pois a obra é de 1922.

Discussão a respeito das informações dos dicionários de bokmål:

Apenas o ROB atesta esse elemento lexical, que teria vindo do latim. A respeito de sua origem ele está correto, mas não determina o étimo de acordo com nossos pressupostos.

Nynorsk:

33,33\% ( nbok. libration, 19224 din. da Noruega libration, 1821 ale. Libration, 1676 [fr. libration, 1667] \ lat. cient. libratio "da lua", 1647)

33,33\% ( nbok. libration, 1922 din. da Noruega libration, 1821

fr. Ibration, 1667 lat. cient. libratio "da lua", 1647)

$33,33 \%$ ( nbok. libration, 1922 din. da Noruega libration, 1821

lat. cient. libratio "da lua", 1647)

Comentário: o manual de escola em nynorsk é uma tradução realizada por Truls S. Ringnes do manual Matematisk geografi: for gymnaset em bokmål de Akexander (1974) e, por isso, o étimo é norueguês bokmål.

1976. Matematisk geografi for gymnaset

Citação: Librasjon til månen fører til at ein frå jorda kan observere 59\% av måneoverflata (p. 206) ${ }^{178}$

Origem do significado da acepção: latim científico

Origem do significante da acepção: latim científico

Étimo de empréstimo: 100\% bokmål

Local: Nasjonalbiblioteket

Discussão a respeito das informações do dicionário de nynorsk:

O dicionário de nynorsk não atesta um cognato correspondente.

178 A libração da lua faz com que alguém possa observar a partir da Terra apenas $59 \%$ da superfície da lua (trad. nossa) 


\section{Origem do significante}

O elemento lexical latino libratio é uma derivação a partir do particípio libratus, de librare "nivelar, balancear" que, segundo de Vaan (2008), existe desde Catão, o Velho (234-149 a.C.) na língua latina. Esse significante ganhou um significado científico com Hevelius, o de balanceio da lua. Librare, por sua vez, é uma derivação de libra "medida de peso", termo existente desde Plauto (254-184 a.C.).

De acordo com o autor, libra remete a um proto-itálico *leipra "medida de peso" e não há nenhuma forma para o IE. 


\subsection{Navegação/Navigasjon}

\subsubsection{Apresentação dos dados}

\subsubsection{Mundo germânico}

Norueguês

Significados em dicionários atuais (a partir de 1901 em nynorsk e 1907 em bokmål):

\begin{tabular}{|l|l|l|l|}
\hline Dic. & Significado & Etimologia & Datação \\
\hline NbUiB & $\begin{array}{l}\text { arte de navegar; } \\
\text { aprendizagem de como se } \\
\text { determina a posição e o } \\
\text { curso de um navio ou avião }\end{array}$ & X & X \\
\hline NyUiB & $\begin{array}{l}\text { arte de navegar; } \\
\text { aprendizagem de como se } \\
\text { determina a posição e o } \\
\text { curso de um navio ou avião }\end{array}$ & $\begin{array}{l}\text { do latim "viagem } \\
\text { de navio" }\end{array}$ & $\mathrm{X}$ \\
\hline NTG & $\begin{array}{l}\text { navegar; aprendizagem de } \\
\text { navegar }\end{array}$ & $\begin{array}{l}\text { fr., der. lat. de } \\
\text { navigere }\end{array}$ & $\mathrm{X}$ \\
\hline ROB & $\begin{array}{l}\text { arte de navegar; } \\
\text { aprendizagem de navegar }\end{array}$ & lat. navigatio & $\mathrm{X}$ \\
\hline NO2014 & Aprendizagem de navegar & \multicolumn{1}{|c|}{$\mathrm{X}$} & $\mathrm{X}$ \\
\hline
\end{tabular}


Percebe-se que há basicamente dois significados: "arte de navegar" e "aprendizagem em navegar". Apenas no NbUiB e no NyUiB vemos a inclusão de "avião" como objeto em que se navega.

Com relação ao verbo correspondente, navigere/navigera "navegar", em todos os dicionários significa a) determinar o curso ou a posição e b) conduzir o movimento de um navio ou de uma aeronave (como um condutor).

O ROB exemplifica com um texto de Wergland (30 de junho de 1831):

skibsbygningskunsten, navigationen, er den tidsalderens triumf? "É a arte de construir navios, a navegação, o triunfo da época?" (tradução nossa)

Não compreendemos o motivo pelo qual o ROB não colocou também a definição de navegação como "a arte de construir navios", uma vez que exemplifica dessa maneira.

Percebemos que esse termo não é utilizado com o sentido de "andar de navio", maneira utilizada nas línguas latinas.

\section{Livros em dinamarquês publicados na Noruega}

Com relação ao período anterior, encontramos a primeira atestação desse elemento lexical no jornal Norske Intelligenssedler de 15 de outubro de 1766:

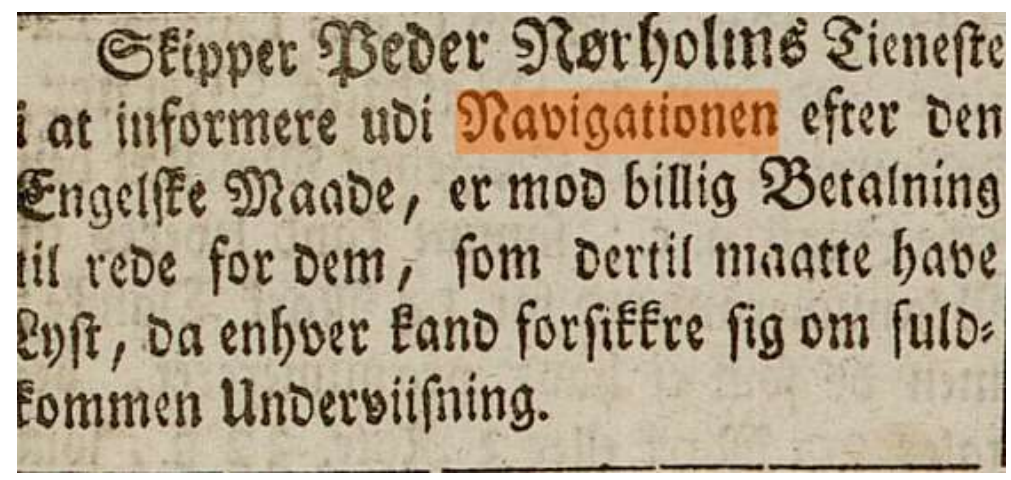


"O serviço do marinheiro Peder Nørholms em informar sobre a navegação de acordo com o modelo inglês está disponível por meio de um custo barato [...]" (trad. nossa)

Em 1771, em um livro de registros cronológicos sobre as regulações reais de Martinus Nissen (1771), publicado em Trondheim, encontramos o seguinte

trecho:

Forord. af 15de Febr. 1768. befaler: at alle de, som $i$ henseende til Commercien og Navigationen, Skibs-Byggeriet og Saltvands-Fiskeriene [...]

"A regul. de 15 de fevereiro de 1768 ordena: todos aqueles relacionados ao comércio, à navegação, à construção de navios e pescas em salgada [...]" (trad. nossa)

O elemento lexical também é encontrado em uma tradução realizada por Henrich Dedechen em Bergen do livro de John Mair (1775). O livro desse autor $^{179}$ trata sobre o método das partidas dobradas, que é utilizado na Contabilidade. O autor tinha o intuito, de acordo com o título, em aplicar o método italiano de Contabilidade nos livros de Copenhagen. No final do livro há um apêndice, que também foi traduzido, onde se encontra a "explicação de várias palavras e modos de falar estrangeiros utilizados no comércio". E lá se encontra Navigation traduzido como Skibsfart "viajar de navio", que é um elemento lexical dinamarquês de origem herdada.

Na mesma cidade, Bergen, também havia a moderna e internacional revista Provinzialblade, publicada por Claus Fasting (1778), um funcionário público, autor, crítico e redator da cidade. Encontramos Navigationsakt (p. 82) "Atos de Navegação", Engelske Navigationsakt "Atos ingleses de Navegação", Navigationskonsten "arte da navegação" (p. 212) e Navigation:

[...] hvor der gives Underretning av de dueligste Lærere i Astronomie, Geographie, Navigation o.s.v.

"[...] onde são dadas informações sobre os professores mais competentes em Astronomia, Geografia, Navegação, etc." (p. 278) (trad. nossa)

${ }^{179}$ Book-keeping Methodised: or, a Methodical Treatise of Merchant-accompts, according to the Italian Form [...] (Dublin, 1772) 
Os Atos de Navegação foram uma série de leis atribuídas para restringir o comércio de carga inglês aos navios ingleses entre o século XVII e XVIII. O Grande Ato de Navegação de 1651 tinha como objetivo atingir a Holanda, a maior rival comercial da Inglaterra (Enciclopédia Britannica Ultimate Reference Suite).

No século XVIII há mais abonações. No livro de Lyder Sagen (1824) encontramos o termo Navigationskole "escola de navegação", que é, de acordo com o autor, um sinônimo de Styrmandsskole "escola de capitão" (p. 623). A Navigationskole de Bergen era da seguinte maneira definida pelo o autor:

De, der bestemtes til Søefarten, besøgte en saare maadelig Navigationskole og lærte nogle mekaniske Beregninger af en eller anden Styrmandsbog [...]

"Aqueles que decidiam ir para a "navegação" frequentavam uma Escola de Navegação muito ruim e aprendiam alguns cálculos mecânicos por meio de um ou outro "livro de capitão" [...] (trad. nossa)

Percebe-se que há uma pequena diferença de significado entre Søefarten e Navigation; o primeiro parece ser "a atividade de viajar no mar" e o segundo, um termo consagrado relacionado à matéria de estudo. O sentido técnico de Navigation-, como alguém que precisa adquirir habilidades para realizar, é reforçado quando é posto como sinônimo de Styrmand-, que significa "capitão". O termo Styrmand é posto muitas vezes nos dicionários como sinônimo de Navegation.

Nesse ponto encontramos o elemento com o sentido de "matéria a ser estudada" ou como parte integrante de composições que têm a ver com o estudo dessa matéria.

\section{Livros escolares}

No livro de texto sobre História Geral de Albert Lassen (1837) há nove citações de Navigation, mas todas como formas compostas Navigationsact. No livro de texto sobre Geografia de Carl N. S. Platou (1840) há apenas o termo 
Navigationsact, no de Geelmuyden (1851) há duas: Navigationskole e Navigationslov "Lei da Navegação" (p. 156) e no de Daa (1859), apenas uma, Navigationsskole. No livro de texto de Nissen (1870) há várias menções do Navigationsact. No livro de Lütke (1875), que explica as palavras e também fornece anotações sobre tais palavras do livro de Petersen ${ }^{180}$, que serve para treinar a leitura de textos, afirma-se que a cognata francesa navigation deve ser entendida como Søfart (p. 19).

No livro de leitura de Schjøth (1889) para a middelskolen, que é uma reestruturação do Verdenshistorie "história do mundo" de Nissen e Daa, há apenas o termo Navigationsakt "atos de navegação".

No livro de P. A. Munch (1840) sobre os eventos mais importantes na história do mundo também há apenas esse elemento lexical. No livro de leituras de H. Smith Hjort (1847) há apenas uma atestação do elemento Navigationsskole.

Na seleção de trechos de leitura noruegueses e dinamarqueses para o exame da middelskole de Broch (1888) há uma passagem do escritor dinamarquês Ole Drachmann, em que há uma nota explicando para os alunos que navigation significa styrmandskunst:

[...] og Oles navigation var reel. (p. 248)

"[...] e a navegação de Ole era real" (trad. nossa)

Nos livros escolares são encontradas, portanto, apenas as composições que têm a ver com a matéria "navegação" e tal cognata, em francês, é explicada como søfart e, em dinamarquês, como styrmandskunst, ou seja, o sentido original francês de "ação de viajar de navio" só é representado pelo elemento herdado søfart, ao passo que a forma do elemento emprestado é entendido como algo técnico, como "arte de pilotar o navio".

180 Escritor de manuais escolares 


\section{Manuais}

No manual sobre navegação de Geelmuyden \& Wille (1892) há por volta de 60 atestações do elemento lexical e todas tem o sentido técnico e de doutrina como, por exemplo: da man i Navigationen som Regel kunbruger 5 Decimaler [...] (p. 14) "visto que se usa na navegação, por regra, apenas 5 decimais [...]. Basicamente o elemento vem acompanhado pela proposição $i$ "em" nesse livro para indicar "na doutrina da navegação".

Procuramos também por Seilads e encontramos várias entradas, que significam a "ação de navegar": Dette kan for enhver kortere Seilads ske [...] (p. 79) "Pode acontecer em navegações mais curtas [...]". Nesse caso entendemos como um sinônimo de Navigation.

\section{Obras lexicográficas}

A navegação como "ação de navegar" parece corresponder no período, entre outros elementos lexicais, como ao já citada Seilads, ao elemento Farten, como é demonstrado no dicionário de frases inglês-norueguês de Hedley Laycock (1852, p. 61):

Is the navigation of this coast very difficult?

Er Farten paa denne Kyst meget vanskelig?

No dicionário de palavras estrangeiras de M. C. Hansen (1851) há os verbetes Navigation, Navigations-Act e Navigations-Skole:

Navigation, en, Skibsfart, Styrmandskunst. Navigations-Act, en, den engelske Søfarts-Lov. Navigations-Skole, Søskole, Sømandskole. (p. 209)

Navegação, uma, "viagem de navio", doutrina da pilotagem. Ato de Navegação, um, lei inglesa da "viagem no mar. Escola de Navegação, "escola do mar", "escola do marinheiro" (trad. nossa)

No livro den norske Søret: en Haandbog for Søfarende, Skibsredere og Handlende "direitos de navegação: um manual para marinheiros, armadores e 
comerciantes" de Hjelm-Hansen (1862) há duas atestações de Navigation: Kyndighed i Navigationen (p. 9) "especialista na navegação" e Prøve $i$ Navigationen "prova em navegação" (p. 10). Há também uma abonação para Navigations-Examen "exame de navegação" (p. 9). Como "ato de navegar" encontramos Seilads (p. 10) e Søfarten (p. 14)

Vejamos na tabela as entradas em dicionários de inglês-danonorueguês-inglês:

\begin{tabular}{|c|c|c|c|c|}
\hline Inglês & $\begin{array}{l}\text { Dano- } \\
\text { norueguês }\end{array}$ & Autor & Tipo & Ano \\
\hline \multirow[t]{3}{*}{ navigation } & $\begin{array}{l}\text { Fart, } \\
\text { Navigation, } \\
\text { Seilads, } \\
\text { Søfart }\end{array}$ & Clausen & $\begin{array}{l}\text { Especializado } \\
\text { (marítimo) }\end{array}$ & 1875 \\
\hline & $\begin{array}{l}\text { Beseiling, } \\
\text { Søfart, } \\
\text { Navigation }\end{array}$ & Larsen & Geral & 1888 \\
\hline & $\begin{array}{l}\text { Beseiling, } \\
\text { Skibsfart }\end{array}$ & Brynildsen & Geral & 1892 \\
\hline $\begin{array}{l}\text { Dano- } \\
\text { norueguês }\end{array}$ & Inglês & & & \\
\hline Navigation & navigation & Clausen & $\begin{array}{l}\text { Especializado } \\
\text { (marítimo) }\end{array}$ & 1875 \\
\hline Skibsfart & navigation & Lund & Escolas $^{181}$ & 1881 \\
\hline
\end{tabular}

${ }^{181}$ Vocabulário inglês para as Middelskoler e para as Borgerskole. Middelskole era o modelo de escola fundada a partir de 1869. Após passar por três anos na allmueskole (escola geral), os alunos poderiam frequentar por seis anos essa escola, que tinha uma grade de latim e de inglês; em seguida, poderiam ir para o ginásio. O Borgerskole era o modelo de escolas fundado 


\begin{tabular}{|l|l|l|l|l|}
\hline Navigation & navigation & Larsen & Geral & 1888 \\
\hline Navigation & navigation & Brynildsen & Geral & 1892 \\
\hline Skibsfart & navigation & Grüner & Comércio & 1892 \\
\hline
\end{tabular}

No dicionário de Clausen (1875) também encontramos muitas composições como: Navigations-bog "livro de navegação", Navigationskundskaber "conhecimentos em navegação", Navigations-instrumenter "instrumentos de navegação", Navigations-love "leis de navegação", Navigationslærer "professor de navegação", Navigations-skole "escola de navegação", Navigations-tabeller "tabelas de navegação" (p. 335), ou seja, isso demonstra que o termo é muito técnico.

Com relação ao vocabulário inglês para as Middelskoler e para as Borgerskole de James Lund (1881), percebemos que os alunos não tinham um conhecimento sobre o elemento Navigation e, por conta disso, há uma entrada que o explica como sendo sinônimo de Skibsfart "viagem de navio".

No dicionário de dano-norueguês-inglês de Larsen (1888), há também as seguintes composições: Navigationsakt "Navigation Act", -bog "book of n.", elev "pupil of n.", -eksasen "examination of n.", Navigationskundskaber "knowledge in n.", Navigationslove "n. laws", Navigationslærer "teacher of n.", Navigationskole "nautical academy" Navigationstabeller "navigation tables".

No dicionário de norueguês-inglês de Brynildsen (1892) os resultados são parecidos com o de Larsen e no dicionário de palavras estrangeiras com autor desconhecido (1892) há as atestações Navigation como Seilads, Styrmandskunst e Navigations-skole como Sømandskole (p. 150).

No dicionário latim-dano-norueguês de Johansen e de francês-danonorueguês de Aaholm: 


\begin{tabular}{|l|l|l|l|l|}
\hline Latim & $\begin{array}{l}\text { Dano- } \\
\text { norueguês }\end{array}$ & Autor & Tipo & Ano \\
\hline Navigatio & $\begin{array}{l}\text { Seilads, } \\
\text { Søreise }\end{array}$ & Johansen & Geral & 1887 \\
\hline
\end{tabular}

\begin{tabular}{|l|l|l|l|l|}
\hline Francês & $\begin{array}{l}\text { Dano- } \\
\text { norueguês }\end{array}$ & Autor & Tipo & Ano \\
\hline navigation & Navigation & Aaholm & Geral & 1861 \\
\hline
\end{tabular}

No livro de Aaholm percebemos que a entrada é muito pobre, pois fr. navigation não significa apenas Navigation em dano-norueguês.

$\mathrm{Na}$ lista de palavras de francês-norueguês (landsmaal) para o ginásio (RAKNES, 1914, p. 90) encontramos a seguinte atestação:

\begin{tabular}{|l|l|l|l|l|}
\hline Francês & $\begin{array}{l}\text { Dano- } \\
\text { norueguês }\end{array}$ & Autor & Tipo & Ano \\
\hline navigation & $\begin{array}{l}\text { Sjøreis, sigling, } \\
\text { ferdsel, } \\
\text { skipsføring }\end{array}$ & Raknes & $\begin{array}{l}\text { Lista de } \\
\text { palavras } \\
\text { (ginásio) }\end{array}$ & 1914 \\
\hline
\end{tabular}

Vemos aqui que o autor traduz por meio de quatro sinônimos o sentido original da cognata francesa navigation para os alunos leitores de landsmål.

Já no dicionário de mão alemão-dano-norueguês de Kaper (1885) a entrada Navigation em alemão se apresenta como Navigation, Sejlads e 
Styrmandskunft e também há as formas compostas Navigations-lehrer (Navigationslærer) e Navigations-schule (Navigationsskole).

\begin{tabular}{|l|l|l|l|l|}
\hline Alemão & $\begin{array}{l}\text { Dano- } \\
\text { norueguês }\end{array}$ & Autor & Tipo & Ano \\
\hline Navigation & $\begin{array}{l}\text { Navigation, } \\
\text { Sejlads, } \\
\text { Styrmandskunft }\end{array}$ & Kapper & Geral & 1885 \\
\hline
\end{tabular}

Veremos nas páginas seguintes que o significado de Navigation na língua alemã também é específico como no dinamarquês e norueguês, tanto que nesse dicionário a tradução dano-norueguesa não saiu do âmbito técnico.

$\mathrm{Na}$ enciclopédia norueguesa sobre conhecimentos gerais de JOHNSEN (1884), há duas entradas que tratam de navegação: Marine- og Postdepartamentetet "Departamento da Marinha e de Correios" e Navigation. Na primeira há a informação de que, além de muitas coisas, tal departamento trata dos Navigations- og lodsvæsenet, ou seja, dos fundamentos da navegação e da praticagem [...] (p. 427). Na entrada Navigation, afirma-se que ela significa Skibsfart "viagem de navio" e Sjømandsvidenskab "ciência do marinheiro". Também são citados a Navigationskole e o Navigationsakt (p. 574).

Dicionário de dinamarquês para landsmaal:

\begin{tabular}{|l|l|l|l|l|}
\hline Dinamarquês & Norueguês & Autor & Tipo & Ano \\
\hline Navigation & Skipsstyring & Vidsteen & Geral & 1907 \\
\hline
\end{tabular}

Concluímos que não há nenhuma entrada que nos permite afirmar que Navigation tem um sentido de "viajar de navio". Descobrimos vários sinônimos, principalmente por meio das obras que têm o inglês como língua componente. $\mathrm{O}$ 
inglês, assim como o dinamarquês, também tem acepções específicas e com uso técnico, principalmente nas formas compostas.

Conseguimos provar essa especificidade também por meio de traduções.

\section{Traduções}

Analisamos Mémoires de Garibaldi (Josef Garibaldi.EnSelvbiografi, de 1861) de Alexandre Dumas, "as viagens de Gulliver"182, Gullivers Rejser (1878) de Jonathan Swift (1878) e Les Grands voyages et les grands voyageurs (1878) de Júlio Verne (Jordens Opdagelseshistorie. [1] : De store Reisers og de store Reisendes Historie, eller Jordens Opdagelseshistorie fra de ældste Tider til Udgangen af det 17de Aarhundrede, de 1879).

$\mathrm{Na}$ autobiografia de Garibaldi há duas atestações de Navigation, ambas com o significado de "doutrina de navegação" (DUMAS, 1861, p. 42 e 44). Também colocamos a passagem original em francês (DUMAS, 1860, p. 92):

[...] havde det mindste Bekjendtskab til Navigation eller Geografi [...] [...] eût la moindre connaissance en navigation, la moindre notion géographique

"[...] tinha o mínimo de conhecimento sobre navegação ou geografia [...]" (trad.

nossa)

Nas viagens de Gulliver há uma atestação para Navigation em dinamarquês (1878, p. 4), que corresponde ao inglês navigation (1776, Part 1, p. 2): [...] til at lære Navigation og andre Dele af Mathematiken "aprender navegação e outras partes da Matemática".

$\mathrm{Na}$ versão original em inglês há mais duas atestações, que não correspondem ao Navigation do dinamarquês:

182 Texto extraído do livro Into Several Remote nations of the World. In Four Parts. By Lemnuel Gulliver, first a Surgeon, and then a Captain of several SHIPS(1776), de Jonathan Swift. 
1) [...] experienced in the navigation of those seas (1776, Part II, p. 3)

[...] erfaren i Sjøfarten på disse Farvande $(1878, p .116)$ e 2)

2) [...] The Author shews his Skill in Navigation (1776, Part II, p. 78)

[...] Forfatteren viser sin Dygtighed i Sjøvæsenet (1878, p. 170).

A primeira, como já dito, significa "viagem no mar" e a segunda, "essência do mar". Ambos os elementos lexicais são sinônimos de Navigation. Também não esperaríamos uma cognata inglesa com o sentido de "viajar de navio", já que nesse idioma ela também tem um sentido técnico.

Com relação ao livro de Júlio Verne, encontramos sete casos em que Navigation está de acordo com a forma francesa navigation. Três deles são utilizados no sentido de "doutrina de estudo". Um termo significa a "ação técnica de navegar":

[...] la hauteur du soleil et d'appliquer l'astrolabe aux besoins de la navigation. (1878, p. 119)

[...]Solens Høide ved at anvende Astrolabiet $i$ Navigationens Tjeneste [...] (1879, p. 135)

"[...] a altura do sol ao aplicar o astrolábio para necessidades da navegação" (trad. nossa)

No francês original se encontra também l'art de la navigation (1878, $\mathrm{p}$. 315), que está traduzido para o dinamarquês apenas como Navigation (1879, p. 352), ou seja, é a "doutrina", que também é encontrada em [...] $i$ alt, hvad der vedkom Navigationen (1879, p. 379), que está no original como [...] toutes les branches connues de la navigation [...] (1878, p. 341); em português, "em tudo que concerne a navegação" (trad. nossa).

Alguns casos em que o francês original navigation não corresponde com o dinamarquês: Après six jours de navigation [...] (1878, p. 8) e no dinamarquês Efter seks Dages Seilads [...] (1879, p. 10) "depois de seis dias de navegação"; La navigation continua dans les conditions meilleures [...] (1878, p. 11), dinamarquês [...] gik det bedre med Reisen [...] (1879, p. 12) "melhorou com a navegação"; [...] après une longue et périlleuse navigation [...] (1878, p. 335), em 
dinamarquês [...] efter en lang og farlig Reise [...] (1879, p. 373) "depois de uma longa e perigosa navegação". Compare a tradução se analisarmos o verbo francês naviguer "navegar" em frases como:

[...] navigué tout ce qui avait été navigué jusqu'à lui [...] (p. 120)

[...] havde beseilet alle de dengang kjendte Have [...] (p. 135-136)

"navegado tudo que tinham navegado naquele período" (trad. nossa)

[...] nous navigâmes plus de cinquante lieues en vain (p. 356)

$[\ldots]$ vi [...] seilede over femti Mile sydover [...] (p. 394)

"navegámos mais de cinquenta léguas para o sul" (trad. nossa)

Isso nos mostra que beseile e seile são utilizados para representar "navegar de barco", portanto, está de acordo com as formas que vimos anteriormente como, por exemplo, no dicionário de inglês-dano-norueguês em que há Beseiling para o sentido de "viajar de barco", sendo, assim, Navigation um termo técnico que lida com a doutrina, comércio ou posicionamento de um navio.

Exemplo da uma divulgação de uma escola de navegação em jornais noruegueses (Lillesands-Posten, 29 de agosto de 1878):

\section{Navigationsskole.}

Undertegnedes Navigationsskole

i Lillesand begynder saa snart 3 a 4

Elever melde sig.

Indmeldelse kan ske hos $\mathrm{Hr}$.

Kjøbmand A. M. Andersen.

Sophus Simonsen. 


\section{Cognatas em outras línguas germânicas}

\section{Dinamarquês (publicado na Dinamarca)}

De acordo com o Ordbog over det Danske Sprog (ODS), a primeira atestação da cognata dinamarquesa ocorre no livro de H. O. Pflug (1707).

No dicionário etimológico de Katlev (2000) não há nenhuma entrada para navigation, apenas navigere (p. 447). O dicionário ODS afirma que ela tem origem no latim navigatio, que é uma derivação de navigere. No dicionário de palavras estrangeiras de Meyer (1837, p. 365) há a entrada Navigation como Skibsfart, Seilads, Søfart e Styrmandskonst.

No dicionário de Matthias Moth, que coletou palavras por todo o país, inclusive Noruega, nos anos entre 1697 e 1719, afirma-se que a cognata (na forma navigasion) tem origem francesa e significa Seilaß, Søkonst e Sømandskab. No dicionário de latim-dinamarquês de Tursen (1561), disponível no corpus da língua dinamarquesa na época da Renascença, Nauigatio representa Seylaß em dinamarquês e Nauigare como ath seyle; no de Pedersen (1510), que também faz parte do corpus, por sua vez, só há nauigare como at segle. Não encontramos nenhuma entrada em que há a cognata dinamarquesa Navigation.

Também não encontramos textos com essa cognata no corpus de textos entre 1500-1700, mas há, por exemplo, Seiladtz no livro de Sthen (1578), que também se encontra no corpus. A seguir um trecho de uma oração presente no livro:

[...] skin $d u$ for oss $i$ denne vor Skibs reise oc Seilatz, som en salig Naadestierne

[...] brilhe para nós em nossa viagem de navio e navegação, como uma bemaventurada estrela de graça (trad. nossa) [...]

Concluímos que esse elemento lexical, de fato, entrou na língua dinamarquesa em 1707. 


\section{No sueco}

De acordo com o Svenska Akademiens Ordbok (SAO) o primeiro registro da cognata sueca navigation é de 1617. Tal registro trata-se de uma carta enviada pelo político sueco Johan Skytte em que se consta: till alle frije commerciers och navigations "a todos os comércios e navegações livres". Esta carta está registrada no livro Rikskanseleren Axel Oxenstiernas Skrifter och Brefvexling, X (1900, p. 198).

No inglês:

De acordo com Oxford (CD-ROM, 2010), a cognata inglesa navigation tem os seguintes significados:

1. the skill or the process of planning a route for a ship or other vehicle and taking there.

2. The movement of ships or aircraft

$\mathrm{O}$ elemento lexical tem origem no começo do século $\mathrm{XVI}$, com o significado de "travel on water". Ele vêm do francês ou do latim navigatio(n-), do verbo navigare, de navis "ship" e + agere "drive".

O dicionário etimológico de Onions (1966) também afirma que este elemento é do século XVI, com origem no francês (antigo) ou latim e o dicionário etimológico de Skeat (1956) afirma que a primeira ocorrência aparece em Macbeth (1606), Shakespeare, o que é errôneo como mostrado abaixo.

As seguintes acepções semânticas e suas abonações são definidas no dicionário etimológico de Murray (1908), que afirma que o elemento lexical veio do francês (uma cognata já existia no francês no séc. XIV) ou do latim:

1. The action of navigating; the action or practice of passing on water, esp. the sea, in ships or other vessels; sailing. 
Esta acepção tem a primeira abonação em 1533, na obra de Thomas Elyot chamada The castel of health. O dicionário cita o trecho (livro 2), mas o encontramos completo no corpus Early English Books:

Nauigation or rowynge nigh to the lande, in a clame water, is expediēt for them that haue dropsies, lepries, palsepes, called of the vulgar people, takynges, and fransies (p. 52)

2. The art or science of directing the movements of ships on the sea including more especially the methods of determining in a ship's position and course by the principles of geometry and nautical astronomy.

Esta acepção é de 1559 (Cunningham, Cosmographical Glasse).

O dicionário também afirma que há uma terceira acepção entre 15271599, que significa a voyage; an expedition or journey by sea or water (In this nauigation ... was discouered, that these Islands nothing set by golde), em R. Thorne in Hakluyt Voy.

Também havia uma quarta acepção, que não é relevante para essa análise. A quinta tem, que de acordo com o autor não era mais utilizada no período em que o dicionário foi publicado (1908), tem a ver com o shipping business; trade or intercourse carried on by sea or water, como no trecho this Navigation is very necessary that the lower Oestreich being fertill, may supply the upper ... with wine and corne (1617, Moryson, Itin. I. 21). A sexta acepção indica que navegação também poderia significar a passage or course by which one may sail e, no período, também é rara; a sétima, a natural inland channel e, por fim, a oitava que é um attributive, as navigation branch, channel, deck, limit, season como, por exemplo, a navigation act or law, a legal enactment regulating navigation or shipping; a navigation coal, steam-coal, etc. Como exemplo o autor cita a obra de Blackstone Comm., de 1765 e cita o trecho the navigation-acts.

De acordo com o livro, já citado anteriormente, de John Mair (1772), o elemento lexical navegação era difícil de ser compreendido, uma vez que é um 
verbete registrado no merchant's dictionary; or, the abstruse words and terms that occur in merchandise [...]. Na entrada apresenta-se Navigation como sendo the art of sailing "arte de navegar" e também sea-trade "comércio do mar" (p. 407).

Das acepções acima citadas apenas a primeira e a segunda têm relevância para essa pesquisa, já que são as duas que existem na língua norueguesa.

No alemão:

De acordo com DHW (das Herkunftswörterbuch, 2014), Navigation é a "determinação do curso e local em uma viagem por mar, ar ou pelo espaço". Esse substantivo é atestado desde o século XVI e foi emprestado do latim navigatio "Schifffahrt".

Nos corpora encontramos a tradução da obra do cartógrafo holandês Lucas Janszoon Waghenaer (1589) chamada Der erst Theil dess Spiegels der Seefart / von Nauigation des Occidentischen Meers [...]. A holandesa original chama Teerste Deel vande Spieghel der Leevaerdt, vande nauigatie der Westersche Zee [...] (1584).

No holandês:

O holandês tem a seguinte atestação para a cognata navigatie (van Dale, online):

1. (kennis, nodig voor) van een schip of vliegtuig naar een bep. doel. "1. (conhecimento, necessário para) de um navio ou avião para um determinado propósito" (trad. nossa)

O banco de etimologia nos fornece muitas informações de vários dicionários. Philippa (2003-2009) afirma que a cognata navigatie aparece pela primeira vez em 1549 com o sentido de scheepvaart "navegação, ato de navegar", 
citando o WNT (Woordenboek der Nederlandsche Taal). O WNT cita como primeira abonação:

[...] aengaende andere partien vander Navigatie, als Schippers, Bootgesellen, Kostumen ende Rechten van der Zee (Gr. Placaetb. 4)

"[...] que tem relação com outras partes da navegação, como capitães, camaradas do barco, costumes e leis do mar" (trad. nossa).

De acordo com Philippa e.a. (2003-2009), até o século XVIII a cognata tinha o significado de scheepvaart "transporte marítimo" e scheepvaartwezen "doutrina de transporte marítimo", mas no século XIX esse significado ficou obsoleto e se formou o significado atual stuurmanskunst "arte de pilotagem", por meio de um empréstimo renovado do francês ou empréstimo semântico do inglês navigate. Philippa também afirma que o termo com a acepção de scheepvaart foi emprestado do francês, do elemento lexical com a acepção que, de acordo com o TLF (Trésor de la langue française), surgiu em 1538, ou seja, "ação de viajar sobre a água", mesmo já existindo desde 1284 o sentido "viagem pelo mar".

\subsubsection{Mundo românico}

\section{Português:}

Os dicionários de língua portuguesa atestam a etimologia desse elemento lexical da seguinte maneira:

\begin{tabular}{|l|l|l|}
\hline Dicionário & Étimo & Datação \\
\hline Houaiss (online) & lat. navı̆gatǐo,ōnis & 1385 \\
\hline Aurélio (2009) & lat. navigatione & $\varnothing$ \\
\hline Michaelis (1998) & lat. navigatione & $\varnothing$ \\
\hline
\end{tabular}


Houaiss afirma que este elemento se encontra na obra Descobrimentos Portugueses (1944) de João Martins da Silva Marques. Como não tivemos acesso a essa obra, não pudemos citar o trecho do livro que apresenta essa e nem sua acepção.

Não encontramos nenhuma atestação mais antiga no Corpus do português.

No vocabulário de Bluteau (1728, p. 689) encontramos a seguinte atestação para navegação:

O andar por agua, \& particularmente no mar. Aquelle que inventou efta Arte, enlinou aos homens o modo de andar por hum elemento, pelo qual ló andavão os peixes. Defta melma Arte, $q \sim$ antes de inventada poderia parecer luperior à natureza, resultarão grandes conveniencias para o commercio [...]

Vemos aqui a "navegação" sendo vista como uma arte e doutrina, da mesma maneira que ocorre com o material das línguas germânicas acima apresentado.

Nos dicionários de etimologia da língua portuguesa encontramos as seguintes atestações:

\begin{tabular}{|l|l|l|l|}
\hline Dicionário & Forma & Étimo & Datação \\
\hline Machado (1995) & nauegaçam & lat. navigatione- & 1510 \\
\hline Cunha (1999) & nauegaçam & lat. navigatio & XIV \\
\hline VHCPM (2007) & X & X & $X$ \\
\hline
\end{tabular}


De acordo com o Corpus do Português, o documento mais antigo com essa cognata se encontra em Mosteiro de Santa Maria da Vitória do século XV $(1499)^{183}$ e tem a acepção voltada ao "arte, ofício de viajar ao mar":

[...] Dom Manuel [...] daquém e dalem maar em Africa Senhor de guine e da conquista nauegacam e comércio d'etiopia arabia persia e jndia [...]

Na obra de João de Barros (Décadas da Asia, do séc. XVI) afirma-se:

[...] convém que saibamos como no título da real Coroa destes reinos, se compreendem três cousas distintas ûa da outra [...] a primeira é conquista, a qual trata da milícia; a segunda navegação, a que responde a geografia, e a terceira comércio, que convém da mercadoria.

Entendemos o trecho acima que navegação tem a acepção de "arte, ofício", que trata da análise do espaço para que ocorra a navegação.

Alguns trechos do Diário de bordo de Fernão de Magalhães (cerca de 1525), retirado do Corpus do Português:

Trecho 1: [...] e tem mays indústria na arte da navegação [...]

Trecho 2: [...] e home entendido na arte da navegação [...]

Trecho 3: [...] e a navegação do mar perigosa [...]

Trecho 4: Não tem navegação mays q algûas almadias pequenas e poucas [...]

Trecho 5: [...] por q hyão enfadados daquela longa e duvidosa navegação [...] Trecho 6: [...] podem ser mil e oytocëtas leoguas pouocomays ou menos, segundo a navegação fezerão do estreyto de magalhães.

\section{Espanhol:}

Nos Corominas encontramos a seguinte entrada:

\begin{tabular}{|l|l|l|l|}
\hline Dicionário & Forma & Étimo & Datação \\
\hline COROMINAS (1984) & navegación & $\varnothing$ & 1440 \\
\hline
\end{tabular}

183 Apesar do Corpus do Português não datar, determinamos essa data porque o primeiro rei a utilizar essa Titulatura foi o D. Manuel I de Portugal em 1499. 
De acordo com Corominas, a atestação da cognata espanhola se encontra na obra Visión deleitable de Alfonso de la Torre. Acreditamos seja esse o trecho a qual Corominas se refere (retirado do corpus do espanhol):

ANSI como sobre el andar delos caminhos por la tierra \& la nauegaçión por la mar.

A respeito da acepção "arte da navegação", encontramos entradas no Corpus do Espanhol. A mais antiga é de 1520, obra de Bartolomé de las Casas chamada Brevísima relación de la destrucción de África:

[...] mandó poner mucha diligencia sobre que se hicese arte de navegar, $y$ encomendólo a dos médicos [...] Martín de Bohemia, que decía haber sido discípulo de Juan de Monte Regio, grande astrónomo, los cuales hallaron esta cierta manera de navegación, de que agora usamos por el altura del Sol $[\ldots]$

Italiano:

\begin{tabular}{|l|l|l|l|}
\hline Dicionário & Forma & Étimo & Datação \\
\hline ZINGARELLI & navigazione & navigatiōne $(m)$ & 1308 \\
\hline Deli & navigazione & $\varnothing$ & $1304-1308$ \\
\hline
\end{tabular}

De acordo com o Deli, a cognata italiana se encontra em Dante. Com base no corpus OVI dell'Italiano antico, a cognata se encontra na obra Convivio (IV, cap. 28). Trecho:

[...] la naturale morte è quasi a noi porto di lunga navigazione e riposo.

[...] a morte natural é como se fosse nosso porto de longa navegação e ropouso. 
Francês:

Nos dicionários de francês (incluindo os etimológicos):

\begin{tabular}{|l|l|l|l|}
\hline Dicionário & Forma & Étimo & Datação \\
\hline $\begin{array}{l}\text { Le Petit Robert } \\
(2014)\end{array}$ & navigation & lat. navigatio & 1265 \\
\hline TLF & navigation & lat. navigatio & 1284 e 1538 \\
\hline DAUZAT (1993) & navigation & $\varnothing$ & $\begin{array}{l}\text { XIII (J. De } \\
\text { Meung) }\end{array}$ \\
\hline LAROUSSE & navigation & $X$ & 1265 (de Meung) \\
\hline
\end{tabular}

TLF afirma que navigation tem duas etimologias:

1) 1284: sentido de "viagem sobre o mar" e atesta o livro Art de Chevalerie de Jean de Meung, que é uma tradução da obra $D e R e$ Militari de Flavius Vegetius. Trecho tirado do livro de Robert (1897):

Mais puis la natevité de navigacion, c'est a dire puis que li tans de nagier est commenciés $[. .$.$] (p. 169)$

"Mas depois do nascimento da navegação, quer dizer, depois que começamos ir ao mar" (trad. nossa)

2) 1538: sentido de "ação de viajar sobre a água" e "arte e ofício do navegador" e atesta que tirou tal informação do dicionário de Robert Estienne Dictionarium latinogallicum.

As edições afirmam o seguinte:

(1539 e 1549) - Nauigation, Nauigatio. Selon que les nauigations aurons cousté, Quanti nauigationes constiterint (p. 401 e 325) 
(1543) - Nauigatio, nauigationis, verbale, Nauigation (p. 469)

(1552) - Nauigatio, nauigationis, Verbale. Cic. Navigation, Navigage

No dicionário de Nicot (1606) há a seguinte entrada:

Navigation , Nauigatio.

Selon que les navigations auront cousté, Quanti nauigationes constiterint. ${ }^{184}$

Latim:

Apesar do Dictionnaire Étymologique de la Langue Latine de Ernout \& Meillet não tratar do verbete navigationem, o Lexicon Totius Latinitates de Forcellini atesta sua existência no período de Cícero. Procuramos algumas atestações no período:

[...] nulla enim post hiemen fuit ante eam diem navigatio (Cicero, Epistulae ad Familiares, livro 10, 33)

"[...] pois foi o primeiro dia desde o inverno que a navegação foi possível" (trad. Nossa)

[...] eosdem aiebant nuntiare te prima navigatione transmissurum (Cicero, Epistulae ad Quintum, livro 2, 4)

"você tinha a intenção de atravessar tão breve quanto a navegação fosse possível" (trad. nossa)

Isso nos mostra que a língua latina já tinha um elemento lexical com o sentido de "viajar pelo mar" e que ele não foi uma criação de nenhuma língua romana.

184“"Dependendo de quanto a navegação irá custar" (trad. nossa) 


\subsubsection{Determinação do étimo}

Terminus a quo (mais antigo ao mais novo)

\begin{tabular}{|c|c|}
\hline \multicolumn{2}{|l|}{ Mundo Romano } \\
\hline Francês & $\begin{array}{l}1284 \text { "viagem ao mar"; } \\
1538 \text { "ação de viajar na água" e } \\
\text { "arte e ofício de navegador" }\end{array}$ \\
\hline Italiano & $\begin{array}{l}\text { 1304-1308 "ato de navegar" } \\
\text { Não encontramos nada no período } \\
\text { com acepção de "arte de navegar" }\end{array}$ \\
\hline Português & $\begin{array}{l}1385 \text { "sem acepção"; } \\
1499 \text { "arte, ofício de navegar"; }\end{array}$ \\
\hline Espanhol & $\begin{array}{l}1440 \text { "ato de navegar"; } \\
1520 \text { "arte de navegar" }\end{array}$ \\
\hline \multicolumn{2}{|l|}{ Mundo Germânico } \\
\hline Inglês & $\begin{array}{l}1533 \text { "ação de navegar"; } \\
1559 \text { "arte ou ciência de direcionar } \\
\text { os movimentos dos navios no mar" }\end{array}$ \\
\hline Holandês & 1549 \\
\hline Alemão & 1589 \\
\hline Sueco & 1617 \\
\hline Dinamarquês & 1707 \\
\hline Dinamarquês na Noruega & 1766 \\
\hline Bokmål & 1892 \\
\hline Nynorsk & 1916 \\
\hline
\end{tabular}

1) A respeito das línguas de influência em determinados temas, espera-se que navegação seja um elemento lexical necessário para línguas de regiões que se utilizam desse meio de comércio. Mesmo assim, teríamos um grande número de regiões (Portugal, Espanha, França, Holanda, norte da Alemanha, Dinamarca, etc.) e não poderíamos fazer uma hipótese mais certeira. 
O ideal provavelmente seria relacionar países com tradição de navegação com países que foram importantes divulgadores de cultura e literatura. De acordo com Maurer Jr. (1951), a França tinha um grande centro ou centros de irradiação, onde criavam e, sobretudo, dissipavam inovações de forma e estrutura linguística. No período em que se formavam as línguas românicas, a França teve sua hegemonia pela rica literatura nela florescente e pela cultura latina (universitária, teológica, filosófica, etc) (p. 218) e esse período de influência é anterior ao apogeu de navegação de Portugal e Holanda, por exemplo. Em suma, a França, com sua literatura e cultura de divulgação, poderia ter registrado esse elemento lexical muito antes do período em que regiões como Holanda, Portugal, Espanha e norte da Alemanha tivessem escrito alguma coisa sobre a navegação.

2) A relação entre escrita e pronúncia pode nos ajudar nos empréstimos dentro da Península Ibérica. Alguma língua desse local emprestou o elemento lexical, que sofreu metamorfismo $-i->-e-e$, assim, passou a ser registrado na grafia; em seguida, este elemento foi emprestado para outras línguas da Península. De certa maneira, isto está relacionado com o procedimento (3) abaixo. Também é possível que alguma dessas línguas da Península Ibérica tenha herdado a palavra latina navigatio (e por isso a forma é herdada, como seria possivelmente navegação e, então, não seria um metamorfismo), em que ocorreu a influência da pronúncia na escrita. Em seguida, o elemento lexical que surgiu, com pronúncia herdada, foi emprestado para as outras línguas.

3) O radical é navig- e remete ao latim; portanto, não seria um radical exclusivo de nenhuma língua descendente. O radical naveg-, por outro lado, não remete ao latim e nos fornece informações importantes. Uma vez que todas as línguas da Península Ibérica têm a forma com -e- (arag. ast. cast. gal. navegación, cat. navegació, oc. navegacion e pt. navegação) pode-se criar a hipótese de que a vogal -e- no radical naveg- sofreu um metamorfismo ${ }^{185}$ após o empréstimo do latim ou do francês, uma vez que ocorreu em um radical culto a passagem do latim -r- para -e-, que é comum a todas as línguas vernáculas; as outras línguas mantêm o $-i$ - que caracterizam o radical como culto. Também é

185 i.e. modificação fonética que ocorre em um cultismo por analogia com metaplasmos que ocorrem em palavras herdadas 
possível que esse elemento lexical seja herdado no português, uma vez que por meio do desenvolvimento fonético de navigat- resulta-se um navegaç- (mas também, de acordo com o metaplasmador do NEHilP, naviguez-, navigaç-, navilze naviaç-). O problema é que esse elemento surgiu apenas tardiamente na línguas portuguesa (1385) e espanhola (1440). A primeira hipótese, portanto, seria a mais provável: em alguma das línguas ibéricas (provavelmente o português por ter a atestação mais antiga) ocorreu o empréstimo de navigatio (latim) ou navigation (francês) e, talvez, por ser muito utilizada, ele sofreu um metamorfismo e, em seguida, emprestou para os outros dialetos.

Por outro lado, há outros elementos lexicais anteriores à entrada do termo navegação, mas com o mesmo radical. As mais antigas, de acordo com o Corpus do Espanhol, é nauegar (siete partidas, 1252-1284). Com base no Corpus do Português e no VHCPM, navegar, navegantes, navegam existem desde o séc. $\mathrm{XV}$. Portanto, podemos concluir que navegação possa ser uma derivação na própria língua portuguesa (em 1385) com base no verbo navegar, que possivelmente existia antes dessa data (encontramos navegar apenas em 1419). A respeito do verbo navegar, não o encontramos no séc. XIII, o que pode implicar um empréstimo do espanhol nauegar, que existe desde o séc. XIII (Siete partidas), e isso fez com que pudesse formar a cognata navegação no português; além do mais, ela não seria um empréstimo do espanhol, porque surgiu apenas em 1440, ou seja, depois do português. O empréstimo do verbo navegar diretamente do latim, seguido de metamorfismo, também seria possível.

4) Aqui a hipótese dos cruzamentos panromânicos de Freitas (2013) não se confirma. O elemento lexical apareceu primeiramente no francês (1265), que foi a língua de divulgação de cultura, mas não temos nenhuma prova de que a cognata no italiano (1304-1308) não tenha sido um empréstimo direto do latim e possa também ter emprestado às outras línguas (até mesmo a alguma língua ibérica como português ou espanhol, que teria realizado o metamorfismo). Com relação ao português, caso não seja um empréstimo do francês seguido de metamorfismo, também poderia ser uma derivação na própria sincronia do português antigo. O espanhol, assim como as outras línguas ibéricas, por sua vez, provavelmente emprestou a cognata correspondente do português por conta da presença do -e- no radical e por apresentar abonação posterior, mas também 
é possível que o espanhol tenha derivado a partir do verbo navegar (que existe desde o séc. XIII) e tenha emprestado para outras línguas românicas, menos o português em que a cognata aparece anterior a 1440. As línguas românicas que têm o radical com - $i$ - poderiam ter emprestado a cognata francesa ou latina.

5) Por termos estudados as acepções do elemento lexical, conseguimos definir os caminhos que elas tomaram em outras línguas. A acepção básica, "ato de viajar", pode ter sido um empréstimo do latim com metamorfismo (no caso do português) e sem metamorfismo (no caso do francês) ou até mesmo uma derivação em cada uma dessas línguas a partir do verbo (navegar e naviguer), mas o surgimento da acepção "arte de navegar" foi criada na língua portuguesa (1499), que possivelmente emprestou para o francês (1538) e, este, para o inglês (1559), mas também é possível que o próprio português tenha emprestado diretamente para o inglês, por ser uma grande potência de navegação no período.

Além do terminus a quo, os procedimentos 3) e 5) também nos ajudam para a definição do étimo desse elemento lexical.

\subsubsection{Fichas}

\subsubsection{Para o português}

\section{Navegação s.f.}

Acepção: "arte de navegar"

( 41499 nova acepção criada para a navegação, $1385 \leftarrow$ navegar esp. navegar).

( 1499 nova acepção criada para a navegação, $1385 \leftarrow$ navegar lat. navigare $\left.{ }^{186}\right)$.

( 1499 nova acepção criada para a navegação ${ }^{187}, 1385$ 4r. navigation $1284 \varangle$ lat. navigatio). 
( 1499 nova acepção criada para a navegação ${ }^{188}$, 1385 lat. navigatio).

Comentário: o elemento lexical com a acepção "arte de navegar", independente do trajeto (derivação no próprio português, empréstimo do francês ou latim com processo de metamorfismo), é uma criação da língua portuguesa. A origem do significado é portuguesa e do significante, latina. $O$ português parece ter sido a primeira língua a utilizar o elemento com essa acepção, com base em [...] Dom Manuel [...] daquém e dalem maar em Africa Senhor de guine e da conquista nauegacam e comércio d'etiopia arabia persia e jndia [...].

1499. Mosteiro de Santa Maria da Vitória do século XV

Abonação não disponibilizada pelo Houaiss

Origem do significado da acepção: portuguesa

Origem do significante da acepção: latina

Étimo de empréstimo: formada no português

Local: Corpus do português

\subsubsection{Para o norueguês:}

\section{Navigasjon (s.m.)}

20\% ( din. na Noruega navigation 1766 din. navigation 1707 sue. navigation 1617 [ale. Navigation 1589] \[hol. navigatie 1549] 《 [fr. navigation 1538] ४ pt. navegação 1499)

20\% ( din. na Noruega navigation $1766 \varangle$ din. navigation 1707 ale. Navigation 1589 hol. navigatie 1549 [fr. navigation 1538] \ pt. navegação 1499)

20\% ( din. na Noruega navigation $1766 \varangle$ din. navigation 1707 hol. navigatie 1549 [fr. navigation 1538] \ pt. navegação 1499)

20\% ( din. na Noruega navigation 1766 din. navigation $1707 \varangle \mathrm{fr}$. navigation 1538 pt. navegação 1499) 20\% ( din. na Noruega navigation $1766 \varangle$ din. navigation 1707 pt. navegação 1499)

${ }^{188}$ Com processo de metamorfismo: -i- > -e-. 
Comentário: o elemento lexical do bokmål tem étimo dinamarquês porque ele já estava sendo utilizada por muito tempo na Noruega. Se teve intermédio para o dinamarquês do sueco, alemão ou holandês não conseguimos descobrir. É muito provável que foi o francês que emprestou para as línguas germânicas. De acordo com as abonações, foi o holandês a primeira a utilizar e a primeira abonação do alemão é uma tradução do holandês, portanto, a cognata alemã tem étimo holandês. É possível que o francês tenha emprestado o elemento do português, pois, como vimos, foi a primeira língua a utilizar com a acepção de "arte de navegar".

1892. Illustreret verdensgeografi: skildringer og livsilleder: lande og folk. 1 de Yngvar Nielsen

Trecho: I den navigation som hørte med til jægteseilasen, dannet de det første grundlag 189

Origem do significado da acepção: portuguesa

Origem do significante da acepção: latina

Étimo de empréstimo: dinamarquês

Local: Biblioteca Nacional norueguesa

Consideramos que a cognata está em um texto norueguês, mesmo anterior 1907, porque ele tem as seguintes características:

- ta, drar em vez do din. tage, drage "pegar", "ir, viajar"

- skog, brøt, ute, aapen, bak, like em vez do din. skov, brød,ude, aaben, bag e like "floresta, rompeu, fora, aberto, atrás, igual"

- supressão do morfema - $t$, que marca adjetivos neutros, em elementos lexicais terminados em -ig como, por exemplo, almindelig, rimelig, em vez de almindeligt, rimeligt "comum, justo"

189 Eles construíram o primeiro fundamento na navegação que estava ligada à "viagem de navio para caça" (trad. nossa) 
- far em vez de fader "pai"

Nynorsk:

20\% ( nbok. navigation 1892 din. na Noruega navigation 1766 din. navigation 1707 sue. navigation 1617 《ale. Navigation 1589] 4 [hol. navigatie 1549] \ [fr. navigation 1538] \ pt. navegação 1499)

20\% ( nbok. navigation 18924 din. na Noruega navigation 1766 din. navigation 1707 ale. Navigation $1589 \varangle$ hol. navigatie $1549 \varangle$ [fr. navigation 1538] \ pt. navegação 1499) 20\% ( nbok. navigation 1892 din. na Noruega navigation 1766 ४ din. navigation 1707 hol. navigatie $1549<$ [fr. navigation 1538] « pt. navegação 1499)

20\% ( nbok. navigation 18924 din. na Noruega navigation 1766 din. navigation 1707 fr. navigation 1538 pt. navegação 1499) 20\% ( nbok. navigation 1892 din. na Noruega navigation 1766 din. navigation 1707 pt. navegação 1499)

1916. Utvalde skrivter. 1 de Rasmus Steinsvik:

Trecho: eg veit ikkje um dei lærer navigation av dette slaget paa skipperskulane ${ }^{190}$

Origem do significado da acepção: portuguesa

Origem do significante da acepção: latina

Étimo de empréstimo: bokmål

Local: Biblioteca Nacional norueguesa

\section{Origem do significante:}

De acordo com Malllory \& Adams (2006, p. 249), o elemento

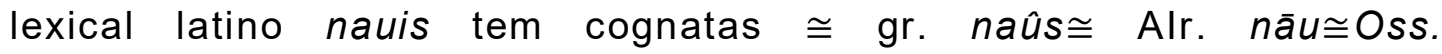

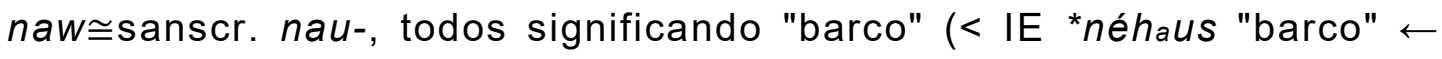
*(s)néha- "nadar").

No latim:

$$
\text { nauis" navio" + agĕre } \rightarrow \text { *nauagere > nauigare }
$$

190 Eu não sei se eles ensinam navegação desse modo nas escolas de navio (trad. nossa) 
nauigare $>$ nauigatus + io $\rightarrow$ nauigatio

O verbo nauigare se formou a partir da metafonia a/i do radical e da mudança da conjugação, como ocorre com outros verbos como:

- sedere "sentar, estar sentado" X sedare "acalmar, assentar, fazer sentar, apaziguar"; "parar, seder" (ERNOUT \& MEILLET, [1932 $(20016)$ ], p. 609-610);

- placere "agradar, satisfazer" X placare "tentar concordar, aceitar, agradar" (ERNOUT \& MEILLET, [1932 (20016)], p. 511);

- dicere "dizer, declarar" X dicare "dedicar, devotar, consagrar, atribuir"

De acordo com Ernout \& Meillet 1932 (20016)], tais verbos da primeira conjugação apresentam um aspecto causativo e, portanto, "navegação" poderia ter um sentido de "fazer mover-se o navio". 


\subsection{Plastinação/Plastinasjon}

\subsubsection{Apresentação dos dados}

\subsubsection{Mundo germânico}

\section{Norueguês}

Este elemento lexical não está registrado em nenhum dicionário norueguês. Além do mais, nem Google Books nem na Biblioteca Nacional norueguesa foram encontrados resultados sobre ele. Na web, por outro lado, foram encontrados 32 resultados e a maioria é do ano de 2002. São eles:

Metoden som von Hagens bruker for å konservere de døde kroppene, kalles plastinasjon [...] (jornal NRK, 27 de fevereiro de 2002 ${ }^{191}$ ).

"O método que von Hagens utiliza para conservar os corpos mortos, chamado de plastinação [...]" (trad. nossa)

Den tyske legen Günther von Hagens har brukt sin lidenskap for menneskets anatomi til å gjøre karriere som kunstner. Med utgangspunkt i en teknikk han startet å utvikle $i$ 1977, kalt plastinasjon [...] (Jornal Dagens Medisin, 11 de março de $2004^{192}$ ).

"O médio alemão Günther von Hagens tem utilizado sua paixão pela anatomia humana para fazer carreira na arte. Com ponto de partida em uma técnica que ele começou a desenvolver em 1977, chamada plastinação" [...] (trad. nossa)

Plastinasjon kaller han [von Hagens] teknikken, som på mange måter er en slags variant av utstopping. (jornal VG, 24 de março de 2010)

"Plastinação é chamada por ele [von Hagens] a técnica que de várias maneiras é um tipo de variante taxidermia." (trad. nossa)

191 Disponível em https://www.nrk.no/viten/doden-pa-utstilling-1.1850595

192 Disponível em http://www.dagensmedisin.no/artikler/2004/03/11/vil-du-bli-et-vakkert-lik/ 


\section{Cognatas em outras línguas germânicas}

$\underline{\text { No Dinamarquês (publicado na dinamarca) }}$

Também não foram encontrados registros nem em dicionários nem no Google Books. No Google há 29 resultados para esse cognato correspondente, que foi introduzido pela primeira vez em 2008 na língua dinamarquesa:

De er blevet præserveret ved hjælp af en metode kaldet plastination. (Revista Aniston, 29 de setembro de $2008^{193}$ ).

"Eles foram preservados com ajuda de um método chamado plastinação" (trad. nossa)

\section{No sueco}

Também não foram encontrados registros nem em dicionários nem no Google Books. No Google há 29 resultados para esse cognato correspondente, que foi introduzido pela primeira vez em 2006 no sueco:

Plastination. Tysken Gunter von Hagen tar ett ovanligt grepp i sitt konstskapande, när han torkar människolik, preparerar dem med plast och sedan visar upp muskler och organ för allmänheten (site de notícias Mynews, 17 de novembro de $2006^{194}$ ).

"Plastinação. O alemão Gunther von Hagen se engaja de maneira incomum em sua arte, quando ele seca antropomorfos, prepara-os com plástico e, em seguida, mostra os músculos e órgãos para o público" (trad. nossa).

No inglês:

Nos dicionários de inglês esse cognato também não está registrado. A primeira abonação encontrada está em um resumo de 1981 da revista Acta Anatomica (Vol. 111, no. 1-2, p. 140):

[...] recommended as a most useful dehydration method for plastination and paraffinization.

193 Disponível em http://aniston.dk/bodies-udstilling-i-koebenhavn.49911.html

194 Disponível em http://www.mynews.se/Plastination-goer-doeden-till-konst,170404.html 
Em um website que trata da vida do cientista, o Body Worlds, afirma-se que ele descobriu e desenvolveu o processo de plastinação entre 1977 e 1995 e que sua primeira maior publicação foi em 1979 e chama-se Impregnation of Soft Biological Specimens with Thermosetting Resins and Elastomers. Entretanto, nesse artigo o elemento lexical não é citado. $O$ autor também patenteou nos EUA ${ }^{195}$ e na Grã-Bretanha ${ }^{196}$ sua descoberta e em nenhuma das patentes ele foi citado. Há apenas o seguinte trecho nas patentes norte-americanas:

The chest and abdominal cavity of the rat were opened. All details of the plastic-impregnated anatomical structure were fully preserved including the eyes, the plexus, brachialis, the vessels of the mesentery, but also the individual hairs of the fur.

\section{No alemão}

Não encontramos a cognata correspondente em nenhum dicionário até agora utilizado. No DUDEN (Deutsches Universalwörterbuch), por outro lado, ela é citada como método de conservação.

A primeira abonação do cognato alemão também é da mesma revista que a abonação inglesa citada acima. Trecho de um resumo de M. F. Lischka, $R$. Mayr, W. Mayerhoffer da revista Acta Anatomica (1981, Vol. 111, no. 1-2, p. 92):

Mit einem neuen Kunststoffimprägnationsverfahren "Plastination" [1] können erstmals (...)

"Com um processo de impregnação de plástico (sintético) "plastinação" [1], pela primeira vez podem [...]" (trad. nossa)

Também analisamos a primeira patente alemã DE 2710 147, que foi criada em 1978, e não encontramos a abonação dessa cognata. Porém, encontramos a descrição do processo: 
Es liegt eine plastifzierte Maus vor, deren Brust- und Bauchhöhle eröffnet ist. "Está à disposição um rato plastificado, cuja cavidade do peito e barriga está aberta" (trad. nossa)

Também há uma patente austríaca (AT360272 (B)), mas a cognata não foi encontrada nela.

Como não há mais dados, podemos concluir que há $50 \%$ de chances desse elemento lexical ter sido criado no inglês e $50 \%$, no alemão. O fato de o inventor ser alemão não justifica uma preferência pela por um elemento lexical alemão, uma vez que ele mesmo publicou seu principal artigo em inglês.

\section{$\underline{\text { No holandês }}$}

A cognata correspondente holandesa também não se encontra nos dicionários holandeses. No Google Books a primeira atestação é de Lundelin \& James-Kester

Professor Von Hagens en zijn team verwijderen vuil uit de voorkant van een mannenlichaam op een fluorescerend rooster alvorens tot de plastinatie [...] (p. 74)

"Professor Von Hagens e sua equipe removem sujeira da frente de um corpo humano por meio de uma grade fluorescente antes da plastinação (....)" (trad. nossa)

\subsubsection{Mundo românico}

\section{Português:}

Da mesma maneira que as línguas germânicas, nenhum dicionário de português reconhece uma cognata plastinação. Buscamos em acervos de revistas e jornais como, por exemplo, da Veja (1998), Estadão (1997), Folha de São Paulo (2003), no Corpus do Português e também no corpus de Portugal chamado Linguateca com mais de 1 bilhão de palavras, que existem em jornais, revistas brasileiros, portugueses e de Moçambique. 
$\mathrm{O}$ primeiro registro se encontra num pedido de credenciamento em 1991 pela Universidade Federal do Rio de Janeiro do curso de pós-graduação em Anatomia Humana, em nível de mestrado. Além disso, para aprimorar a qualidade do mesmo está a uma das seguintes medidas:

Criação de um laboratório de plastinação, que é um novo método de conservação de cadáveres, inicialmente desenvolvido na Alemanha e já em uso na USP e na UFF'197

Embora, muito possivelmente essa cognata esteja registrada numa data anterior a essa, uma vez que segundo o documento já havia o laboratório de plastinação na USP e na UFF, tomaremos como terminus a quo a data de 1991.

\section{Espanhol:}

Também não encontramos uma cognata correspondente no espanhol em nenhum dos dicionários de espanhol até agora consultados. Pelo Google Books encontramos como primeiro registro um documento da Universidade Nacional Autonoma de Mexico chamado de Metas Minimas de Trabajo (1988):

Asimismo se pretende la adaptación de um espacio para el Laboratorio de plastinación [...] (p. 32)

No Corpus do Espanhol encontramos na data de 1998 e no Corpus da Real Academia Española na data de 2002, portanto o terminus a quo é 1988.

Italiano:

Também não há o registro de uma cognata italiana em dicionários italianos. No Google Books o primeiro registro está no livro Enciclopedia Medica Italiana (1984):

197 Disponível em http://livros01.livrosgratis.com.br/cd005487.pdf 
[...] è oggi possible ottenere la conservazione di pezzi com gradi di consistenza i più disparati: dall'estremamente duro al notevolmente morbido e plastico (plastinazione) (p. 2063).

(...) hoje é possível obter a conservação de partes com graus de consistência de maneiras muito diversas: do extremamente duro ao notavelmente suave e plástico. (trad. nossa)

\section{Francês:}

Como em todos os outros casos, não encontramos o registro de uma cognata francesa nos dicionários franceses. Não temos acesso ao Frantext por ser de uso apenas de assinantes. Como registro mais antigo, encontramos no Google Books o livro La Plastination: de la Theorie a la mise em Application, de Philippe Poncot (1993).

Também há uma patente francesa (FR2382855), mas não foi encontrada uma abonação desse item lexical.

\subsubsection{Determinação do étimo}

Terminus a quo (mais antigo ao mais novo)

\begin{tabular}{|l|l|}
\hline \multicolumn{2}{|l|}{ Mundo Romano } \\
\hline Italiano & 1984 \\
\hline Espanhol & 1988 \\
\hline Português & 1991 \\
\hline Francês & 1993 \\
\hline Mundo Germânico & \\
\hline Inglês & 1981 \\
\hline Alemão & 1981 \\
\hline
\end{tabular}




\begin{tabular}{|l|l|}
\hline Holandês & 1998 \\
\hline Bokmål & 2002 \\
\hline Sueco & 2008 \\
\hline Dinamarquês & 2008 \\
\hline Nynorsk & Não consta \\
\hline
\end{tabular}

1) A respeito das línguas de influência em determinados temas, tanto a língua inglesa quanto a alemã são línguas de ciência já no séc. XX e ainda nos dias de hoje.

2) A relação entre escrita e pronúncia não nos proporciona nenhuma pista para a investigação do étimo, uma vez que cada língua pronuncia o radical plastin- da usa maneira, uma vez que o elemento lexical entrou pelo meio escrito e não oral.

3) O radical do elemento lexical é plastin- e ele não tem significado algum em nenhuma das línguas românicas ou germânicas. Trata-se de uma invenção que utiliza um radical plast-, um interfixo -in- e o sufixo -ação. O que confirma mais ainda essa hipótese é não haver nenhum registro de forma verbal anterior às abonações do substantivo, quer dizer, plastinieren e to plastinate "plastinar" surgem depois de plastination.

4) Não aplicaremos aqui os cruzamentos panromânicos de Freitas. Por ser um elemento lexical inventado, obviamente ela teria um ponto de partida apenas na língua que o criou.

5) Uma vez que ele tem uma única acepção para todas as línguas, este campo de semântica não é relevante para o estudo da etimologia.

Apenas terminus a quo ajuda de alguma maneira na definição da etimologia do elemento lexical em estudo. O procedimento (1) proporciona duas opções: o inglês e o alemão, mas também há elementos lexicais científicos do séc. XX criados, por exemplo, no italiano. 


\subsubsection{Fichas}

\subsubsection{Para o português}

\section{Plastinação (s.f.)}

33,33\% ( esp. plastinación 1988 [it. plastinazione 1984] ४ ing. plastination 1981 ou ale. Plastination 1981)

33,33\% ( it. plastinazione 1984 ing. Plastination 1981 ou ale. Plastination 1981)

33,33\% ( ing. plastination 1981 ou ale. Plastination 1981)

1991. Pedido de credenciamento em 1991 pela Universidade Federal do Rio de Janeiro do curso de pós-graduação em Anatomia Humana, em nível de mestrado

Entrada não disponibilizada no Houaiss

Origem do significado da acepção: alemã ou inglesa

Origem do significante da acepção: neologismo com sufixo latino Étimo de empréstimo: $50 \%$ alemão, 50\% inglês

Local: http://livros01.livrosgratis.com.br/cd005487.pdf

Comentário: O significante da acepção é um neologismo, pois tem um radical plast-, que remonta ao "plástico", junto com um interfixo -in- e o sufixo latino -tion. 


\subsubsection{Para o norueguês}

\section{Plastinasjon (s.m.):}

Bokmål:

50\% ( hol. plastinatie 1998 ing. plastination 1981 ou ale.

Plastination

50\% ( ing. plastination 1981 ou ale. Plastination 1981)

2002. Jornal online NRK, 27 de fevereiro de 2002

Entrada não disponibilizada nos dicionários noruegueses

Origem do significado da acepção: alemã ou inglesa

Origem do significante da acepção: neologismo com sufixo latino Étimo de empréstimo: 50\% alemão ou inglês, 50\% holandês

Local: https://www.nrk.no/viten/doden-pa-utstilling-1.1850595

\section{Origem do significante:}

Ele foi inventado pelo criador da palavra, como explicado acima. 


\section{Considerações finais}

O objetivo dessa dissertação, como mostrado no subcapítulo 1.1., foi realizar a etimologia de elementos lexicais internacionais (internacionalismos), utilizando alguns exemplos de palavras sufixadas em -ção na língua portuguesa e que têm cognatas na língua norueguesa (-sjon). No mesmo subcapítulo indagamos sobre quais outros meios poderiam ser utilizados para definir o étimo de um internacionalismo quando a forma das cognatas nada indica e, então, definimos 5 procedimentos:

(1) atribuição da palavra a uma determinada especializada (tema)

(2) a representação escrita em correspondência com a pronúncia;

(3) a consideração do radical (sua forma e significado);

(4) cruzamentos panromânicos, como apresentado por Freitas (2013);

(5) a semântica da palavra

Após a análise dos elementos lexicais sufixados em -ção, concluímos que o procedimento (1) não é muito decisivo para fortalecer a determinação do étimo porque estes elementos geralmente fazem parte de temas que envolvem a ciência e a filosofia, que não são exclusivos de nenhuma língua; no entanto, pode nos dar alguma dica, como ocorre com o elemento lexical aberração, tanto na acepção óptica quanto na astronômica, que possivelmente seria um elemento lexical alemão, inglês, francês, italiano ou latino. Por meio do terminus a quo, contudo, definimos que o elemento com acepção astronômica é latino e, com acepção óptica, italiano. A respeito do elemento lexical argumentação, que tem a acepção de "condução de provas", percebemos que tenderia a ir na direção dos temas Direito e Retórica, dos quais se escreveu muito na língua latina. $O$ elemento lexical infecção, com a acepção de tema da medicina, poderia ter principalmente ocorrido em línguas de regiões com grande influência na medicina como, por exemplo, a França e a Itália. Em vista disso, o procedimento (1) pode ajudar a nos dar uma pista para a determinação do étimo.

De toda a amostragem utilizada, o procedimento (2) foi aplicado apenas parcialmente e hipoteticamente ao elemento lexical navegação. Em 
algumas das línguas ibéricas pode ter ocorrido o empréstimo do elemento lexical navegação, que sofreu o metamorfismo - $i->-e-e$, em seguida, emprestou para as outras línguas. Este procedimento está interligado com o (3), que se encontra abaixo.

O procedimento (3) foi aplicado apenas ao elemento lexical navegação. Demonstramos que a variação de radical navig- e naveg- pode apresentar dois caminhos diferentes que o elemento lexical percorreu. $O$ radical navig- remete ao latim e, em vista disso, não seria um radical exclusivo de nenhuma língua descendente; o radical naveg-, por outro lado, remete apenas a línguas da Península Ibérica.

A respeito do procedimento (4) de Freitas (2013), em que se postula que não há "em duas ou mais línguas românicas o mesmo empréstimo latino, uma vez que tende a ocorrer primeiro em uma das línguas, e desta, passar para as outras" (p. 443), verificamos que ele não se aplica ao elemento lexical infecção, pois não foi apenas uma língua que espalhou o elemento lexical latino infectio para as outras, mas sim que houve no mínimo duas frentes principais (i.e. francês, que traduziu Mondeville; inglês, que traduziu Lanfranc, sem contar as traduções diretas do latim para espanhol, holandês e italiano que não tivemos acesso). Em vista disso, um elemento lexical latino científico de grande relevância foi traduzido para outras línguas vernáculas em épocas diferentes, mas isso não significa que tenha ocorrido empréstimos dentre as vernáculas. Este procedimento também não se aplica ao elemento lexical adoção, uma vez que, por ter uso jurídico e de grande uso social, ele poderia ter sido emprestado do latim para cada língua românica separadamente. O mesmo ocorre com o elemento lexical argumentação, pois vimos que não foi apenas uma língua que espalhou para todas as outras, mas sim que pode ter havido duas frentes principais (francês e italiano). A respeito do elemento lexical libração, a hipótese também não se confirma porque seria extremamente possível que tanto o francês quanto o italiano emprestassem esse elemento lexical da obra latina de Hevelius, já que ela era muito conhecida. A hipótese possivelmente se confirma com gravitação, uma vez que foi o inglês que emprestou do latim científico e o divulgou para as outras línguas e, também, aberração, tanto com a acepção astronômica, 
que foi divulgada pelo francês, quanto com a acepção de "desvio" (e seus desdobramentos), que foi divulgada pelo inglês.

O procedimento (5) também tem sua importância porque, por meio do estudo das acepções da palavra, conseguimos definir o caminho que um elemento percorreu pelas línguas até chegar naquela estudada. Ele nos ajudou no elemento lexical aberração, deflação, navegação.

No caso do elemento adoção (e apenas com a acepção de "tomar como filho"), gravitação, libração e plastinação, apenas o terminus a quo foi relevante para a determinação do étimo.

Recapitulando nossa pergunta no subcapítulo 1.1. sobre quais outros meios poderiam ser utilizados para definir o étimo de um internacionalismo quando a forma das cognatas nada indica, concluímos que há uma grande complexidade, de fato, na análise de palavras com grande divulgação (como é o caso dos internacionalismos), uma vez que têm formas e até mesmo pronúncias parecidas. Estes meios citados acima, que chamamos de procedimentos em nossa dissertação, ajudam na pesquisa etimológica, pois nos dão pistas; no entanto, o principal elemento é a busca dos termini a quo de cada uma das línguas envolvidas no estudo.

Registramos o étimo e datação de cada uma das palavras da amostragem e cada um deles diverge do que registram os dicionários utilizados (Houaiss para o português e os cinco utilizados para o norueguês):

Aberração: o dicionário Houaiss afirma que tem étimo latino e que é uma derivação do verbo aberrare. Em nossa pesquisa determinamos que, com a acepção de "desvio", há $25 \%$ de chances de o étimo provir do latim medieval, $25 \%$ francês, $25 \%$ inglês e $25 \%$ italiano; com a acepção da "astronomia", $20 \%$ latino científico, $20 \%$ espanhol, $20 \%$ inglês, $20 \%$ italiano, $20 \%$ francês e, com acepção "óptica", 25\% italiano, 25\% espanhol, 25\% inglês e 25\% italiano. O dicionário Houaiss, portanto, afirma que a palavra veio diretamente do latim; afirma ainda que a primeira abonação é de 1813, mas pela pesquisa descobrimos que a primeira abonação óptica é de 1797, de desvio é de 1812 e, por fim, a acepção astronômica é de 1813. 
Aberrasjon: os dicionários noruegueses afirmam que o elemento lexical também vem do latim tanto para o bokmål quanto para o nynorsk. Em nossa pesquisa determinamos que, no bokmål, todas as acepções do elemento lexical têm étimo dinamarquês, sendo a primeira abonação no ano de 1910 para as acepções "desvio" e "óptica" e 1915, para a acepção "astronômica". A respeito do nynorsk, não encontramos um elemento lexical com a acepção de "desvio". O elemento lexical com acepção "astronomica" tem étimo dinamarquês e primeira abonação em 1911 e com acepção "óptica" tem étimo norueguês bokmål e primeira abonação em 1918.

Adoção: o dicionário Houaiss afirma apenas que a primeira datação está registrada no Vocabulário do Português Medieval de Cunha, quer dizer, não houve a preocupação em demonstrar no próprio dicionário a primeira abonação. No Vocabulário de Cunha há três abonações: duas no Vita Christi em lingoagem português e uma na Regra de nosso padre o muy bem aventurado sam Beẽto Abade, ambas datadas como do séc. XV. Em nossa pesquisa, no entanto, propomos uma data exata (i.e. 1488). A respeito do étimo, o dicionário apenas remete, igual aos dicionários do norueguês, à origem do item lexical, registrando que adoptio vem de adoptatio "adoção, perfilhamento", o que é errôneo pois cada um desses elementos lexicais vem de desenvolvimentos diferentes, como apresentado por Ernout \& Meillet (1932 [20016]) na parte latina da análise desse elemento lexical. Determinamos que o étimo pode ser $25 \%$ italiano, $25 \%$ espanhol, $25 \%$ francês e $25 \%$ latino.

Adopsion: com relação ao bokmål, os dicionários NbUiB, NTG e ROB afirmam na parte da etimologia que esse elemento lexical vem do latim, mas na verdade eles querem dizer que o latim é a origem. O NbUiB registra que ele vem do lat. ad "para, até" e optare "escolher", o NTG, que é um substantivo verbal do latim adoptere e o ROB, que vem do latim adoptare. Nenhum dos três dicionários apresentam o terminus a quo. Definimos o étimo como dinamarquês e que o terminus a quo se encontra no jornal Trondhjems Adresseavis em 1912. A respeito do nynorsk, determinamos que o étimo é norueguês bokmål com primeira abonação em 1916. O dicionário NyUiB também confunde a origem do elemento 
lexical com o étimo, pois afirma que o étimo seria "do latim, formada a partir de adoptere".

Argumentação: o dicionário Houaiss afirma que tem étimo latino. Em nossa pesquisa determinamos que há $100 \%$ de chances étimo ser latino medieval, pois a primeira abonação aparece na obra de Pedro Nunes, que é uma tradução da obra latina Sphaera mundi (1230) de Giovanni Sacrobosco. Portanto, neste caso o Houaiss está correto. Assim como o Houaiss afirma, a primeira abonação é de 1537.

Argumentasjon: apenas o NTG fala algo sobre a etimologia, que é um substantivo verbal latino de argumentere e nenhum deles coloca a datação. Em nossa pesquisa determinamos que, nos dialetos noruegueses, o primeiro registro é de 1893 e têm étimo norueguês nynorsk. O bokmål tem étimo no dinamarquês e primeira abonação em 1907 e o nynorsk, por fim, também tem étimo no dinamarquês e primeira abonação em 1869.

Deflação: o dicionário Houaiss apenas insere um terminus a quo (1926) e não indica a qual acepção está se referindo. Em nossa pesquisa definimos que a primeira abonação para a acepção "geológica" é 1954 e para a acepção "financeira", 1920. No campo etimologia ele insere informações já contidas em outros dicionários a respeito do inglês, que a primeira abonação da acepção geológica é 1892 e que a primeira abonação da acepção econômica é 1920. Já que ele inseriu para o inglês o terminus a quo de cada acepção, não entendemos o motivo de não ter feito o mesmo para o português. $O$ dicionário não define qual é, na verdade, o étimo desse elemento lexical português e apenas cita o significado dos componentes do item lexical latino deflate "soprar por cima", que é uma composição formada pelo prefixo de- e o verbo flo "soprar, bafejar". Determinamos que há $25 \%$ de chances do étimo do elemento lexical com acepção geológica ser: espanhol, francês, inglês ou alemão; e 50\% de chances do elemento lexical com acepção "financeira" ser: alemão ou inglês. A origem do significante da acepção "financeira" pode ser alemã ou inglesa porque pode ter ocorrido tanto um empréstimo do elemento lexical alemão com acepção geológica e a inserção do significado financeiro quanto a uma inserção desse novo 
significado financeiro inglês no significante que já havia nesse idioma com a acepção de "ação do ar sendo removido de alguma coisa".

Deflasjon: o dicionário de norueguês $\mathrm{NbUiB}$ afirma que a palavra veio do latim, por meio do inglês; o NTG, que vem do prefixo de- e de flatus, quer dizer, é como se a palavra tivesse sido criada no próprio norueguês por meio de elementos latinos; o ROB, por sua vez, afirma que vem do latim deflare e, nesse caso, também nos dá a impressão de que foi o norueguês que derivou esse verbo e formou o elemento lexical deflation. Nenhum dos dicionários nos fornece a data da primeira abonação. Em nossa pesquisa determinamos que, no bokmål, o elemento lexical com acepção da "geologia" tem étimo dinamarquês e primeira abonação em 1920; o elemento com acepção "financeira" tem 50\% de chances de ser alemão ou inglês e tem a primeira abonação em 1920. A primeira abonação no dinamarquês só surgiu em 1921. A respeito do nynorsk, a primeira abonação com acepção da "geologia" é de 1951 e tem étimo norueguês bokmål; já a primeira abonação com acepção "financeira" é de 1927 e também tem étimo no norueguês bokmål.

Gravitação: o dicionário Houaiss indica a obra e a data da primeira abonação (1726, Portugal médico ou Monarquia médico-lusitana) e afirma que o elemento lexical vem do inglês gravitation (cerca de 1645), que por sua vez vem do latim científico gravitatio. É um termo, segundo o dicionário, popularizado em francês pelas traduções das obras de Sir Isaac Newton. As considerações de Houaiss estão parcialmente corretas, mas a o elemento lexical, como vimos, não necessariamente vem do inglês. O termo pode sim ter sido popularizado por conta das traduções, mas não é algo que devemos tomar como único, pois há muitos artigos do final do séc. XVII na famosa revista científica Philosophical Transactions of the Royal Society of London em que aparece esse termo. Portanto, os principais divulgadores foram o inglês e o francês. Porém, a respeito do português, não temos nenhuma prova de que o termo veio diretamente dessas duas línguas, como também não temos nenhuma prova de que veio diretamente do italiano, latim científico ou alemão. Determinamos que há $25 \%$ de chances do étimo ser italiano, francês, inglês ou latino científico. A primeira abonação do Houaiss está correta. 
Gravitasjon: o dicionário NbUiB afirma que o elemento lexical é uma nova formação latina a partir de gravis "pesado". O NTG e o ROB afirmam que é uma nova formação latina a partir de gravitere. Os dois últimos estão corretos, pois ocorreu de fato uma derivação desse verbo latino, mas nenhum está de acordo com o que entendemos por etimologia. A afirmação dos dicionários faz parecer que foi o norueguês que formou esse elemento lexical com base no latim gravis ou de gravitere. Nenhum dos dicionários inseriram a primeira abonação. Determinamos que o étimo do bokmål é dinamarquês, com primeira abonação em 1908; o nynorsk também tem étimo dinamarquês, com primeira abonação em 1889.

Infecção: O dicionário Houaiss não deixa muito claro qual seria o étimo do elemento lexical, pois afirma que o latim tinha infectio na acepção de "ação de tingir, tintura" e, consequentemente, "mácula, desonra, estupro" e cita Joaquim Machado que supõe intermediação do fr. infection (sXIII) "mancha, mácula (de pecado)", (1314) "invasão (de uma parte do corpo) por germes infecciosos" e (1484) "moléstia infecciosa". Houaiss afirma que a primeira abonação é de 1566. Determinamos que há $25 \%$ de chances do étimo ser francês, espanhol, italiano ou latim científico e concordamos com a datação fornecida pelo Houaiss.

Infeksjon: Os dicionários NbUiB e NTG afirmam que o elemento lexical vem do latim infisere e apenas o ROB sugere uma intermediação com o francês ou alemão. Eles também não indicam sua datação. Por meio de nossa pesquisa, determinamos que o étimo do bokmål é dinamarquês e a primeira abonação é de 1892. A respeito do nynorsk, o dicionário NyUiB também afirma que o elemento lexical vem do latim infisere e não sugere nenhuma datação. Determinamos que o étimo é norueguês bokmål e a primeira abonação de 1918.

Libração: o dicionário Houaiss apenas afirma que o elemento lexical vem do latim libratio "ação de nivelar, nivelamento; movimento regular, oscilação" e determina a primeira abonação em 1716. Em nossa pesquisa, descobrimos que há $25 \%$ de chances do étimo ser francês, latim científico, alemão ou inglês. $A$ primeira abonação está de acordo com o Houaiss.

Librasjon: Apenas o ROB atesta esse elemento lexical, que teria vindo do latim. A respeito de sua origem ele está correto, mas não determina o étimo de 
acordo com nossos pressupostos. Determinamos que o étimo do bokmål é dinamarquês e a primeira abonação é de 1922. A respeito do nynorsk, o dicionário não registra esse elemento lexical. Determinamos que o étimo é norueguês bokmål, com a primeira abonação em 1976.

Navegação: o dicionário Houaiss afirma que a primeira abonação é de 1385 e que o étimo é latino. Nós determinamos que o elemento lexical com a acepção de "arte de navegar" é português. A primeira abonação com essa acepção é de 1499.

Navigasjon: o dicionário NTG de bokmål afirma que o elemento lexical vem do francês, que é uma derivação do latim; o ROB afirma que vem do latim e o NbUiB, por sua vez, nada afirma. Nenhum deles apresenta a data da primeira abonação do elemento. Determinamos que o étimo é dinamarquês e que a primeira abonação ocorreu em 1892. A respeito do nynorsk, o dicionário NyUiB afirma que vem do latim e não cita nenhuma datação. Em nossa pesquisa, por outro lado, determinamos que o étimo é norueguês bokmål e a primeira abonação é de 1916.

Plastinação: o dicionário Houaiss não tem essa palavra como entrada. Determinamos que ela tem $33,33 \%$ de chances de ser espanhol, italiana ou inglesa (ou alemã). Sua primeira abonação é no ano de 1991.

Plastinasjon: nenhum dicionário registra esse elemento lexical. Determinamos que há $50 \%$ de chances do étimo ser holandês ou inglês (ou alemão) no bokmål, com a primeira abonação em 2002. Não há esse elemento lexical no nynorsk.

Apresentamos acima apenas os resultados que obtivemos tanto na língua portuguesa quanto na norueguesa. Durante a análise também retrodatamos elementos lexicais de outras línguas.

Na subcapítulo sobre o étimo, também definimos que o étimo pode ser de dois tipos: de herança e de empréstimo (que também pode ter uma subdivisão em étimo de decalque). Também propusemos que as palavras tenham duas origens: a origem do significante e a origem do significado, uma 
vez que elas muitas vezes seguiram caminhos distintos até chega na palavra em questão.

Concluímos que, com base no que entendemos por étimo, muitas palavras importadas existentes no norueguês (bokmål, especialmente) só poderiam ter étimo dinamarquês, por conta do contato, pois o elemento lexical já estava sendo utilizado na Noruega muito antes do surgimento das duas normas norueguesas. A respeito do nynorsk, os étimos têm grande possibilidade de serem norueguês bokmål, pois esta é a norma mais utilizada em toda a Noruega e, em vista disso, justificamos novamente por meio do contato: muitos livros em nynorsk são traduções de livros em bokmål, principalmente quando se tratam de livros educacionais.

Também a respeito da análise de palavras com étimo de herança, realizamos um estudo sobre as sincronias pretéritas do norueguês no subcapítulo 2.3.2., se influenciando pela maneira com que Viaro (2015) realizou para as sincronias pretéritas do português, o que abre as portas para uma pesquisa mais aprofundada sobre os étimos de herança na língua norueguesa.

A respeito dos corpora, nunca poderemos tomá-los como finitos e, por conta disso, na maioria das vezes tampouco poderemos afirmar que o étimo de empréstimo é $100 \%$ verdadeiro, pois apenas utilizamos obras que se encontram online como, por exemplo, aquelas existentes no Google Books ou na Biblioteca Nacional Norueguesa (Nasjonalbibliothek); o número de obras não digitalizadas é muito maior. Portanto, quanto mais obras forem digitalizadas, mais dados teremos para a determinação do étimo. Um problema encontrado é a falha na digitalização, quer dizer, muitas vezes a palavra pode estar em uma determinada obra, mas por uma falha de digitalização não foi possível encontrá-la durante a pesquisa. Consideramos, portanto, como necessária a contínua digitalização de textos antigos, não apenas para conservá-los contra a idade e contra furtos, mas também em prol dos estudos etimológicos. O desenvolvimento de programas que digitalizem, 
por meio do OCR ou de novas tecnologias, com mais precisão também seria de extrema importância para os estudos etimológicos. 


\section{Referência Bibliográfica}

AASEN, I. Prøver af landsmaalet i Norge. Christiania: Carl Werner, 1853. . Norsk Grammatik. Christiania: Mallings Forlagsboghandel, 1864. . Norsk Ordbog: med dansk Forklaring. Christiania: Mallings Forlagsboghandel, 1873.

de AGUIAR, A. História da literatura portuguesa. Universidade da Califórnia: 1976 AMUNDSEN, L.; SEIP, D. A. Henrik Wergelands Skrifter. Bind 2. Oslo: J. W. Cappelens Forlag, 1959

ANTONSEN, E. H. A concise grammar of the older runic inscriptions. Tubingen: Max Niemeyer Verlag, 1975

- The Earliest Attested Germanic Languages, Revisited. NOWELE, Amsterdam \& Philadelphia, v. 23, n.1, p. 41-68, 1994.

. Runes and Germanic Linguistics (Trends in Linguistics).

Berlin/New York: Mouton de Gruyter, 2002

ANDREE, K. Verdenshandlens Geografi. B.2. Christiania [Oslo]: J. Rasch, 1873

ARNAULT, S. D. A batalha de Trancoso. Coimbra: Faculdade de Letras/Instituto de Estudos Históricos Dr. António de Vasconcelos, 1951

AUCHTER, D. Dictionary of Literary and Dramatic Censorship in Tudor and Stuart England. Conn: Greenwood Press, 2001.

AZEVEDO, V. Passando a limpo. Clube dos autores, 2009.

BARNES, M. P. The Transitional Inscriptions. In: DÜWEL, K. (Org.). Runeninshcriften als Quellen interdizplinärer Forschung. Berlin: Gruyter, 1998. P. 448461.

A New Introduction to Old Norse. Parte I: Grammar. Londres:

Viking Society for Northern Research, 2008.

BARNEY, S. et al. The Etymologies of Isidore of Seville. Cambridge: Cambridge University Press, 2006.

BASSETTO, B. F. Elementos de filologia românica. São Paulo: Edusp, 2005 
BEEKES, J. Comparative Indo-European Linguistics: An Introduction. Amsterdam: John Benjamins, 2011

BETZ, W. Deutsch und Lateinisch: Die Lehnbildungen der althochdeutschen Benediktinerregel. Bonn: Bouvier, 1949 . Lehnwörter und Lehnprägungen im Vor- und Frühdeutschen. Deutsche Wortgeschichte. Ed by. F. Maurer and F. Stroh, I.127-147. Berlin: de Gruyter, 1959

BIRKMANN, T. Von Ågedal bis Malt. Berlin: Gruyter, 1995.

BIZZOCCHI, A. Léxico e ideologia na Europa ocidental. São Paulo: Annablume/FAPESP/UNIP, 1998.

. A Ideologia das raízes. Língua Portuguesa, São Paulo, ano 3, n.

40, 2009.

BOER, C. de. Ovide Moralisé: poème du commencement du quatorzième siècle publié d'après tous les manuscrits connuns par C. De Boer. Tomo I (Livros I-III). Amsterdam: Johannes Müller, $1915 . \quad$ (Disponível em: https://archive.org/stream/DeBoerOvideMoralise1/De_Boer_Ovide_moralise_1\#pa ge/n0/mode/2up)

BRAMLEY, H. R. The Psalter, or Psalms of David and Certain Canticles with a Translation and Exposition in English by Richard Rolle of Hampole edited from manuscripts by the Rev. H. R. Bramley, M.A. Oxford: At the Clarendon Press, 1884. Disponível em: https://archive.org/stream/psalterorpsalms00bramgoog\#page/n12/mode/2up BREMMER, R. F. An Introduction to Old Frisian: History, Grammar, Reader, Glossary. Amsterdam/Philadelphia: John Benjamins Publishing Company, 2009.

BROWN, F. et al. A Hebrew and English lexicon of the Old Testament: with an appendix containing the Biblical Aramaic : based on the lexicon of William Gesenius as translated by Edward Robinson. Oxford: Clarendon Press, 1980. Disponível em: http://www.biblestudytools.com/lexicons/hebrew/ e http://www.greeklatin. narod.ru/bdb/0.htm 
BRØDUM-NIELSEN, J. Gammeldansk Grammatik, I-VIII. København: Schultz, 1950-1973

BURNS, W. E. The Scientific Revolution: an Encyclopedia. California, Denver, Oxford: ABC-CLIO, 2001.

BURSILL-HALL, S. Some notes on the Grammatical Theory of Boethius of Dacia. In: PARRET, H. History of Linguistic Thought and Contemporary Linguistics. Berlin: de Gruyter, 1975, p. 164-188

CAMPBELL, L.; POSER, W. Language Classification: History and Method. Cambridge: Cambridge University Press, 2008.

CHANTRAINE, P. Dictionnaire Étymologique de la Langue Greecque. Histoire de Mots. 2 tomos. Paris: Éditions Klincksieck, 1968.

CLARKE, C. C. Henri de Mondeville. Yale Journal of Biology and Medicine, vol. 3, n. 6, $1931 . \quad$ P. 459-478. (Disponível em: https://www.ncbi.nlm.nih.gov/pmc/articles/PMC2606324/?page=2)

do COUTO, H. H. Ecolingüística: estudo das relações entre língua e meio ambiente. Brasilia: Thesaurus, 2007

CUNNINGHAM, L.; EGAN, K. J. Christian spirituality: themes from the tradition. Paulist Press, 1996

CURCHIN, L. Celticization and Romanization of Toponymy in Central Spain. Emerita, 65, p. 257-279, 1997.

CURCHIN, L. Toponyms of Lusitania: a re-assessment of their origins. Conimbriga, 46, p. 129-160, 2007.

CURCHIN, L. Los topónimos de la Galicia Romana: nuevo estudio. Cuadernos de estudios gallegos. vol. 55, n.121, p. 109-136, 2008. Disponível em: http://estudiosgallegos.revistas.csic.es/index.php/estudiosgallegos/article/view/41/ 41

de MOULIN, D. A History of Surgery: with emphasis on the Netherlands. Dordrecht: Martinus Nijhoff, 1988

EGAN, H. D. An Anthology f Christian mysticism. Liturgical press, 1991 
ENDRESEN, R. T. Fremmedordenes byggeklosser. In: JOHNSEN, E.; BLOM, $\varnothing$. (Org.). Vårt eget språk: i går og i dag. Bind 1. Oslo: Aschehoug, 1987. p. 157-169.

FLO, R. Midlandsmaal: etter framelgge fraa rettskrivingsnemndi i 1899 ved Arne Garborg. Kristiania: Norli, 1906

FORTSON IV, B. W. Indo-European Language and Culture. Oxford: Blackwell, 2004.

FREITAS, É. O tempo e o mento. História do sufixo latino-mentum e de seu desenvolvimento na língua porttuguesa, em contratste com outras línguas românicas. Volume 1. Tese (doutorado) - Universidade de São Paulo, Faculdade de Filosofia, Letras e Ciências Humanas, São Paulo, 2013

HUIZENGA, E. Unintended Signatures: Middle Dutch Translator of Surgical Works. In: GOYENS, M.; de LEEMANS, P.; SMETS, A. Science Translated: Latin and Vernacular Translations of Scientific Treatises in Medieval Europe. Leuven: Leuven University Press, 2008.p. 415-448.

GRAUTOFF, F. Urkundenbuch der Stadt Lübeck. Vierter Theil. Lübeck.

GREEN, D. H. Language and history in the early Germanic world. Cambridge: Cambridge University Press, 1998

GRØNVIK, O. Fra Ågedal til Stre. Oslo: Universitetsforlaget, 1985 . Untersuchungen zur älteren nordischen und germanischen Sprachgeschichte. Frankfurt am Main: Lang, 1998.

HALL, J. R. C. A Concise Anglo-Saxon Dictionary for the use of students. New York: The Macmillan Company, 1916

HANSSEN, E. Dialekter i Norge. Bergen: Vigmostad \& Bjørke AS, 2010

HARRISON, H. Surnames of the United Kingdom: a concise etymological dictionary London: The Morland Press, LTD, 1918

HAUGEN, E. The analysis of linguistic borrowing. Language, v. 26, p. 210-231, 1950.

. The Norwegian language in America: the bilingual community. Philadelphia: University of Pennsylvania Press, 1953 
. The scandinavian languages: an introduction to their history. Cambridge, Massachusetts: Harvard university press, 1976. . Riksspråk og folkemål: norsk språkpolitikk i det 20. århundre. Oslo: Universitetsforlaget, 1968.

- Scandinavian Languages Structures: A Comparative Historical Survey. Minnesota: University of Minnesota Press, 1982

HAZENFRATZ, R. Andrene Wisse. Kalamzoo, Michigan: Medieval Institute Publications, 2000. Disponível em http://d.lib.rochester.edu/teams/publication/hasenfratz-ancrene-wisse

HELANDER, H. Language contact outside Scandinavia V: Loan from Latin and Greek. In: BANDLE, Oskar. (Org.). The Nordic Languages: An international Handbook of the History of the North Germanic Languages. Vol 2. Berlin/New York: Walter de Gruyter, 2002, p. 2086-2095.

HERCULANO, Alexandre (1810-1877). Refexões ethnographicas, philologicas e historicas a proposito de uma publicação recente sobre a origem celtica da lingua portugueza. In: O Panorama: Jornal litterario e instructivo da Sociedade propagadora dos conhecimentos uteis, Série 2, v. 3, p. 391-394. Lisboa, 1844

HOCK, H. H. Principles of Historical Linguistics. Berlin/New York: Mouton de Gruyter, 1991.

HOGNESTAD, K. R. Det trykte ord - bokens historie i Norge. Til Opplysning, Trondheim, Nummer 3, 2000.

HOEL, O. L. Nasjonalisme i norsk målstrid (1848-1865). KULTS skriftsserie nr. 51, Oslo: Norges Forkningsråd, 1996

HOVEDHAUgen, E. et al. The History of Linguistics in the Nordic Countries. Helsinki: 2000

HÆGSTAD, M. Norsk maallære Grammatik i Landsmaalet. Bergen: Nygaard, 1901. Innleiding til Gamalnorsk ordbok. Kristiania [Oslo]: Samlaget, 1909.

ILARI, R. Lingüística Românica. São Paulo: editora ática, 1999. 
INDREBØ, G. Norsk Målsoga. Bergen: John Grieg, 1951

ISAKSON, B. The Emergence of a Scandinavian Language: Development until around 900. NOWELE, Amsterdam \& Philadelphia, v. 36, n.1, p. 3-43, 2000.

JAHR, H. Dialekter og dialekt-bruk i Norge. In: JAHR, H (org.). Den store dialektboka. Oslo: Novus, 1990

JAKOBSEN, A. Norskhet i språket hos Petter Dass. 1. Svorkmo: Håløygminne, 1952

JESPERSEN, Otto. Language: its nature, developement and origin. London: George Allen \& Unwin, $1922\left(1954^{10}\right)$

JOHNSON, C. Globalization of Hesychasm and the Jesus Prayer: Contesting Contemplation. Bloomsbury Academic, 2010.

KELLY, L. G. Modus significandi: an interdisciplinary concept. Historiographia Linguistica, Amsterdam, vol. 6, n.2, p. 157-180, 1979.

KLEIN, E. A Compreensive Etymological Dictionary of the Hebrew Language. Jerusalem: Carta the Isreal Map \& Pub Co Ltd, 1987

KLIMOV, G. A. Einführung in die kaukasische Sprachwissenschaft. Hamburg: Buske, 1994.

KNUDSEN, K. Hvem skal vinne?: eller de historiske, dansknorske målstræveres stadpunkt. Kristiania: eget. forlag, 1886.

KOCH, J. Celtic culture: a historical encyclopedia. Santa Barbara: ABC-Clio, 2006

KOPAL, Z. The Moon. Dordrecht: D. Reidel Publishing Company, 1969

KRAHE, H. Germanische Sprachwissenschaft. Wortbildungslehre. Berlin: 1969

KOCSÁNY. P. Grundkurs Linguistik: ein Arbeitsbuch für Anfänger. Paderborn Fink, 2010.

KURATH, H; KUHN, S. M. Middle English Dictionary. Michigan: Ann Arbor, University of Michigan Press, 1952-2001)

LANE, G. Christian Spirituality: A Historical Sketch. Loyola Press, 2005.

LIE, B. Svend Bidevind: skolehistorier. Kristiania [Oslo]: Aschehoug, 1901. 
LIENHARD, J (ed.). The Fathers of the Church: Catecheses. St. Clement of Rome to St. Augustine of Hippo. Eerdmans, 2009

MAURER, T. H. A Unidade da România ocidental. São Paulo: Editora da USP, 1951

MCCALUM, J. E. Military Medicine: from ancient times to the 21th century. Oxford, Santa Barbara, Denver: ABC Clio.

METCALF, G. On Language diversity and relationship from Bibliander to Adelund. Amsterdam: John Benjamins Publishing, 2013.

de MOULIN, D. A history of surgery: with emphasis on the Netherlands. Dordrecht, Boston, Lancaster: Martinus Nijhoff Publishers, 1988

MUHLE, H. De origine linguarum variarum. Stirpeque ac Matre Græcæ. Latinæ \& Germanicæ. Hebræa dissertatio. Kiloni. Sumptibus Joh. Seb. Richelii, 1692

NESSE, A. Written and spoken languages in Bergen in the Hansa era. In: BRANMÜLLER, Kurt; FERRARESI, Gisella (Org.). Aspects of multilingualism in European language history. Amsterdam: Benjamins, 2003. p. 61-84.

NIELSEN, H. F. The Continental Backgrounds of English and its Insular Development until 1154. Odense: Odense University Press, 1998

NIELSEN, H. F. The early runic language of Scandinavia: studies in Germanic dialect geography. Heidelberg: C. Winter, 2000

NOREEN, A. Geschichte der nordischen Sprache: besonders in altnordischer Zeit. Strassburg: Trübner, 1913

PARASCHKEWOW, B. Wörter und Namen gleicher Herkunft und Struktur: Lexikon etymologischer Dubletten im Deutschen. Berlin/New York: Walter de Gruyter, 2004.

PIKE, M. Latin -tas and Related Forms. Tese (doutorado) - University of California, California, 2011. (Disponível em: https://www.academia.edu/2216769/Latin_t\%C4\%81s_and_Related_Forms) PILCHER, J. E. Guy de Chauliac and Henri de Mondeville - A Surgical Retrospect. Annals of Surgery. 21 (1). 84-102, 1895. 
PRÓSPER, B. M. Lenguas y religiones prerromanas del occidente de la península ibérica. Salamanca: Ediciones Universidad de Salamanca, 2002.

RANKE, F; HOFFMANN, D. Altnordisches Elementarbuch. Berlin/New York: de Gruyter, 1988

RASH, F. J. French and Italian lexical influences in German speaking Swizerland (1550-1650). Berlin/New York: de Gruyter, 1989.

RASK, R. Undersögelse om det gamle Nordiske eller Islandske Sprogs Oprindelse. Kjöbenhavn: Paa den Gydendalske Boghandlings Forlag, 1818.

REICHERT, H. Nordic language history and religion/ecclesiastical history I: The pre-Christian period. In: BANDLE, Oskar. (Org.). The Nordic Languages: An international Handbook of the History of the North Germanic Languages. Vol 1. Berlin/New York: Walter de Gruyter, 2002. p. 389-402.

RINGE, D. From Proto-Indo-European to Proto-Germanic. Oxford: Oxford University Press, 2006

RISCHEL, J. Nordic contributions to historical linguistics before 1800. In: BANDLE, Oskar. (Org.). The Nordic Languages: An international Handbook of the History of the North Germanic Languages. Vol 1. Berlin/New York: Walter de Gruyter, 2002a. p. 108-115.

. The contribution of the Nordic countries to historical-comparative linguistics: Rasmus Rask and his followers. In: BANDLE, Oskar. (Org.). The Nordic Languages: An international Handbook of the History of the North Germanic Languages. Vol 1. Berlin/New York: Walter de Gruyter, 2002b. p. 124132.

RIX. H (org.). Lexikon der Indogermanischen Verben: die Wurzeln und ihre Primärstammbildungen. Wiesbaden: Dr. Ludwig Reichert Verlag, 2001.

RUDBECK, O. J. Specimen usus linguæ Gothicæ. in Eruendis atque illustrandis obscurissimis quibusvis Sacræ Scripturæ locis: addita analogia linguæ Gothicæ Cum Sinica. Nec non Finnonicæ Cum Ungarica. Upsalis. Joh. Henr. Werner, 1717.

SALMONS, J. A History of German. Oxford: Oxford University Press, 2012 
SAMUELIAN: Classical Armenian culture: influences and creativity. Peeters Publishers, 1979.

SÃO LUIZ, D. F. de (Cardeal Saraiva). Memoria em que se pretende mostrar, que a lingua portugueza não he filha da latina, nem esta foi em tempo algum a lingua vulgar dos lusitanos. Memorias da Academia de Sciencias de Lisboa. Lisboa: Typ. da Academia, 1837. Ed. Facsimliar da Biblioteca Nacional de Lisboa.

SCARDIGLI, P. Contact with non-Germanic languages I: Relations to the West. In: BANDLE, O (org.). The Nordic Languages. Bd. 1. Berlin/New York: Walter de Gruyter, 2002, p. 572-582

SCHILLER, K; LÜBBEN, A. Mittelniederdeutsches Wörterbuch (6 Bände). Bremen: Verlag von J. Kühtmann's Buchhandlung, 1875

SCHLEICHER, A. Compendium der vergleichenden Grammatik der Indogermanischen Sprachen. Weimar: Hermann Böhlau, 1861

SCHMIDT, W. Geschichte der deutschen Sprache. Stuttgart: Hirzel Verlag, 2007.

SCHULTE, M. Grundfragen der Umlautphonemisierung. Berlin: Gruyter, 1998.

SCHUMANN, R. Germanische Sprachgeschichte. Ein Überblick, 2009. (Material de aula)

SCHWARZ, W. Geschichte der deutschen Sprache: ein Lehrbuch für das germanitische Studium. Stuttgart: Hirzel, 2007.

SEIP, D. A. Norsk språkhistorie til omkring 1370. Oslo: Aschehoug, 1931 . Studier i norsk språkhistorie. Oslo: Aschehoug, 1934 . Norsk språkhistorie til omkring 1370. Oslo: Aschehoug, 1955

SELLEY, R. C.; COCKS, L. R. M.; PLIMER, I. R. Encyclopedia of Geology. Oxford, UK: Elsevier Ltd., 2005.

SIHLER, A. New Comparative Grammar of Greek and Latin. New York/Oxford: Oxford University Press, 1995

SIMENSEN, E. The Old Nordic lexicon. In: BANDLE, O (org.). The Nordic Languages. Bd. 1. Berlin/New York: Walter de Gruyter, 2002, p. 951-962

SKARD, V. Norsk språkhistorie. Bd 1, til 1523. Oslo: Univeritetsforlag, 1973 
. Norsk språkhistorie. Bd. 2, 1523-1814. Oslo: Universitetsforlag, 1972

SKAUTRUP, P. Det danske sprogs historie. København: Gyldendal, 1994.

SPURKLAND, T. Norwegian Runes and Runic Inscriptions. Suffolk: The Boydell Press, 2005.

STAROSTIN, S.A. Gipoteza o genetičeskij svjazjax sinotibetskix jazykov s enisejskimi i severnokavkazskimi jazykami. Moscau, 1984.

STEELE, R. Medieval Lore: an epitome of the science, geography, animal and plant folk-lore and myth of the middle age. London: Elliot Stock 62, Paternoster Row, E. C., 1893

STUDZINSKI, R. Reading to live: the envolving practice of Lectio divina. Cistercian Publications Inc, 2010.

TELEMAN, U. The role of language cultivators and grammarians for the Nordic linguistic development in the 16th, 17th and 18th centuries. In: BANDLE, Oskar. (Org.). The Nordic Languages: An international Handbook of the History of the North Germanic Languages. Vol 1. Berlin/New York: Walter de Gruyter, 2002, p. 1379-1396.

TIEFENBACH, H. Altsächsisches Handwörterbuch. Berlin/New York: De Gruyter, 2010

TORP, A; VIKØR, L. S. Hovuddrag i norsk språkhistorie. Oslo: Gyldendal Norsk Forlag AS, 2000.

TORP, A. Sørlandet. In: JAHR, H. Den store dialektboka. Oslo: Novus, 1990

van COETSEM. The Vocalism $f$ the Germanic Parent Language. Systemic Evolution and Sociohistorical Context. Heidelberg: Universitätsverlag C. Winter, 1994.

VENNEMANN, T.; HAMEL, E. Vaskonisch war die Ursprache des Kontinents. In: Spektrum der Wissenschaft. Deutsche Ausgabe des Scientific American. Heidelberg: Spektrumverlag, 2002.

VENÅS, K. Den fyrste morgonblånen: tekster på norsk frå dansketida. Oslo: Novus, 1990 
VIARO, M. E. Etimologia. São Paulo: Contexto, 2011

. Reconstrução fonético-fonologica de seis sincronias do latim ao português. Estudos linguísticos e literários. Salvador, n. 52, ago-dez, p. 94-145, 2015.

VILLAR, F. Indoeuropeos y no indoeuropeos en la Hispania prerromana. Salamanca: Ediciones Universidad de Salamanca, 2000.

VOLMERT, J. Internationalismen und die Rolle des Lateins als „Muttersprache Europas“. In: BUCKHARDT, A.; LINKE, A. WICHTER, S. Internationalismen II: Studien zur interlingualen Lexikologie und Lexikographie. Tübingen: Max Niemeyer Verlag, 2003

WEINREICH, U. Der yivo un die problemen fur undzer tsayt. Yivo-bleter, New York, vol. 25, n.1, p. 3-18, 1945. . Languages in contact. New York: 1953 (tradução alemã com um prefácio de A. de Vincenz, München, 1977.

WESSÉN, E. Svensk språkhistoria, I. Ljudlära och ordböjningslära. 4. Upplagan. Stockholm: Filologiska föreningen vid Stockholms högskola, 1955.

. De nordiska språken. 10. Upplagan. Stockholm: AWE/Gebers, 1975.

WILLIAMS, E. B. Do Latim ao português. Rio de Janeiro: tempo brasileiro, 1973

ZILMER, K. "He drowned in Holmr's sea - his cargo-ship drifted to the sea-bottom, only three came out alive": records and representations of baltic traffic in the Viking Age and the Early Middle Ages in early nordic sources. 401 páginas. Dissertação - Universidade de Tartu. Estônia, 2005. (Disponível em: http://dspace.ut.ee/bitstream/handle/10062/741/zilmer.pdf?sequence=5\&isAllowed =y)

\section{Corpus:}

\section{Português:}

CORREIO BRAZILIENSE ou ARMAZEM LITERARIO (Vol. III). Londres: Impresso por W. Lewis, Paternoster.Row., 1809. 
GOIS, D. Chronica do Felicissimo Rei Dom Emanuel composta per Damiam de Goes, Diuidida em quatro partes.... Lisboa: em caso de Francisco Correa, 15661567.

GOULÃO, Dr. A. S. $2^{\circ}$ anno. - physica e metereologia. 205-207. O Instituto, Jornal Scientifico e Litterario. Segundo volume. Coimbra: Imprensa da Universidade, 1854. (Disponível

em: https://books.google.com.br/books?id=iR7mAAAAMAAJ\&pg=PA206\&dq=\%22aber ra\%C3\%A7\%C3\%A30\%22+\%C3\%B3ptico\&hl=pt-

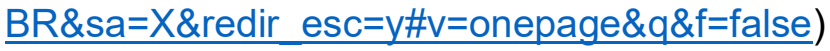

NUNES, P. Tratado de sphera com a Theorica do Sol e da Lua. E ho primeiro liuro da Geographia de Claudio Ptolomeu Alexa[n]drino ... Lixboa: per Germão Galharde empremidor, 1 Dezembro 1537.

STOCKLER, F. De B. G. Elogio Historico de João le Rond D’Alembert. Memorias da Academia Real das Sciencias de Lisboa. Tomo I (desde 1780 até 1788). Lisboa: $\mathrm{Na}$ Typografia da Aacademia, 1797. (Disponível em: https://babel.hathitrust.org/cgi/pt?id=nyp.33433004321901;view=1up;seq=9)

\section{Dinamarquês/Norueguês:}

AAHOLM, N.M. Norsk-fransk ordsamling og Parleur: Vocabulaire et dialogues: norvégiens-français. Christiania [Oslo]: Malling, 1861.

AF MORgenstieRne, B. H. V. Antikritik, eller et Ord til Publicum i Anledning af Hr. Procurator Debes's Kritiske Bemærninger o.s.v. Christiania [Oslo]: Paa Forfatterens, trykt hos N. J. Berg, 1808.

ARAGO, F. Aragos populære forelæsninger over Astronomien. Tradução de Chr. Langberg. Christiania [Oslo]: Johan Dahl, 1841

ARNDTSEN, A. Physik til Brug ved Borger- og Realskoler. Efter "Müllers Physik", "Naturens Bog”, etc. Christiania: Feilberg \& Landmarks Forlag, 1853.

ASTRAEA, ET TIDSSKRIVT. Første Bind. Kiøbenhavn, trykt hos Directeur Joh. Frederik Schulz, Kongelig og Universitetsbagtrykker,1797-1808

Billeder til Norgeshistorien for Skolen og Hjemmet efter nordiske Malere. Kristiania [Oslo]: Asbj. Knutsen, 1879. 
BRANDT, F. Forelæsninger over den norske retshistorie. 1. Kristiania [Oslo]: Damm, 1880.

BROCH, C. Udvalg af norske og danske læsestykker til middelskole-examen: samt prøver af svensk. Kristiania [Oslo]:Cappelen, 1888

BØVING-PETERSEN, J. O. Vor klodes saga: en skildring af jordens udvikling og fortidsliv. København, Gyldendal, 1912

CALLISEN, H. Physisk medizinske betragtninger over Kiöbenhavn (Vol. 2). København: Frederik Brummer, 1907.

CHRISTIE, H. H. Lærebog i Fysik for Middelskolen. Kristiania [Oslo]: Malling, 1871

COLLET, C. Mod Strømmen. Ny Række. Kjøbenhavn: Schous Forlag, 1885.

COLLETT, P. J. Den norske Familieret. Christiania [Oslo]:: Chr. Tønsberg Forlag, 1859.

DAA, L. K. Lærebog i Geografien. Kristiania [Oslo]: Abelsted, 1859

DUMAS, A. Josef Garibaldi. En Selvbiografi, udgivet af Alexander Dumas. Udgivet paa Norsk af Anthon Bang. Christiania: M. C. Fabritius's Forlag, 1861.

FÆRDEN, A. O. Om Forhandlingerne den 12te Febr. d. A. af Norges Forsvar i det skandinaviske Selskab, fra norsk Standpunkt. Christiania [Oslo]: Det Skandinaviske Selskab i Kristiania, 1867.

GEELMUYDEN, I. Lærebog i Geografien til Skolebrug. Christiania [Oslo]: Malling, 1851. . Lærebog i geografien. Kristiania [Oslo]: Malling, 1893.

GEELMUYDEN, C.T.H.; WILLE, C. Lærebog i Navigationen. Christiania [Oslo]: Jacob Dybwads Forlag, 1892.

GJESSING, A. Undersøgelse af Kongesagaens Fremvæxt. 1. Christiania: Christiania Videnskabs-Selskab, 1873. 
GUERIKE, H. E. F. Haandbog i Kirkehistorien. Deel 1. Christiania [Oslo]: Dahl, 1842

GUNNERUS, J. E. Hans opvækkelige Hyrdebrev til det velærværdige, høj- og vellærde Præsteskab i Tronhjems Stift. Tronhjem : Jens Christensen Winding, 1758

HANSTEEN, C. Lærebog i Mechaniken. D. 2: Faste legemers Bevægelseslære. Christiania: Johan Dahl, 1838.

HISTORISK PHILOSOPHYSKE SAMLINGER. Christiania : Det Kongelige Selskab for Norges Vel, 1813

HJELM-HANSEN, P. Den norske Søret: en Haandbog for Søfarende, Skibsredere og Handlende. Christiania [Oslo]: H.J. Jensen, 1862.

HJORT, H. Smith. Norsk læsebog. Anden Afdeling. Christiania [Oslo]: I Comission hos A Dzwonkowski, 1847

HOLBERG, L. Dannemarkes Riges Historie: deelt udi 3 Tomer. T. 2. Kjøbenhavn: trykt udi Hans Kongl. Majestæts og Universitets Bogtrykkerie af J. J. Høpffner, 1733.

- Dannemarkes Riges Historie ved Ludvig Holberg, Tomus III. Kjøbenhavn: trykt udi Hans kongl. Majests. og Universitets Bogtrykkerie, af Johan Jørgen Høpffuer, 1735.

HOLBERG. L. Adskillige Heltinders og navnkundige Damers sammenlignede Historier: efter Plutarchi Maade. Kjøbenhavn: Trykt paa Autors Bekostning udi $\mathrm{H}$. K. Majest. og Univ. Bogtrykkeri af Johan Jørgen Høpffner, 1745.

HOMPEL, C. Ugeskrift for Læger. Anden Række. Bind X. (no. 1-26). Kjöbenhavn: Forlagt af Universitetsboghandler C. A. Reitzel, 1849.

HORREBOW, P. Om Fixstiernernes Aberrationer som nu, efterat deres rigtige Theorie og Aarsage er funden, bør kaldes Refractioner eller Anaclases. Skrifter, som udi det Kiøbenhavnske Selskab af Lærdoms og Videnskabers Elskere ere Fremlagte og Oplæste i Aaret 1747. Tredie Deel, 107-121. Kjøbenhavn: Trykt af Gottmann Friderich Kifel, $1747 . \quad$ (Disponível em: 
https://books.google.com.br/books?id=U7FZAAAAcAAJ\&pg=PA109\&dq=aberratio $\mathrm{n} \& \mathrm{hl}=\mathrm{pt}-\mathrm{BR} \& \mathrm{sa}=\mathrm{X} \&$ redir_esc=y $\# \mathrm{v}=$ onepage $\& \mathrm{q}=$ aberration $\& \mathrm{f}=\mathrm{false}$ )

HUMBOLDT, A. Kosmos: Udkast til en physisk Verdenbeskrivelse, B.1. Kjøbenhavn: Eibe, 1847

JANZON, G. Mørke og Lys: Omvexlinger i Provsten Carlings Familie. Christiania [Oslo]: Grams Forl., 1858

JOHANSSEN, J. Latinsk Ordbog. Christiania [Oslo]: Cappelen, 1887

JOHANSSEN, O. Lærebog i mathematisk Geografi for Realgymnasiet. Kristiania [Oslo]: Cammermeyer, 1883

LANGLOIS, E. Le Couronnement de Louis, chanson de geste du XIle siècle. Paris: libraire honoré Champion, 1984.

LASSEN, A. Lærebog i den almindelige Historie. D. 1 : Lærebog i de gamle Staters Historie. Christiania [Oslo]: Hviid, 1830 . Lærebog i den almindelige Historie. D. 3-5 D. 4 : Lærebog i de nyere europæiske Staters Historie Indeholdende de europæiske Staters Historie fra den westphalsfe Fred indtil Frederich den andens Død. Christiania [Oslo]: Hviid, 1837 LASSEN, H. Henrik Wergelands Samlede Skrifter. Efter det norske Studentersamfunds Foranstaltning udgvine af Hartvig Lassen. Syvende Bind. Christiania [Oslo]: Chr. Tönsbergs Forlag, 1853.

LÜTKE, F. Ordforklaringer og Anmerkinger til H. H. Petersens franske Læsebog. T.hjem, 1875

LYNG, G. V. Hedenskabets Levnetsløb: Atten populære Foredrag. Christiania [Oslo]: Abelfeld, 1866

MAIR, J. Det methodiske Bogholderie, eller En ordentlig Indretning af Kiøbmænds Bøger efter den italienske Maade : hvorudi denne Videnskab bliver nøye forklaret, og bragt til Udøvelse ved forskjællige Exempler i alle Handelens Greene (trad. por $D E D E C H E N)$. Bergen: trykt hos ... H. Dedechen, 1775

MOD DET AF KAMMERADAVOCAT SCHØNHEIDER I OVENSTAAENDE INDLAEG ANBRAGTE, HAR JUSTITSRAAD ULDALL PAA OBERAUDITEUR ROSENSTANDS OG EGNE VEGNE OPPONERET FØLGENDE EXTRACTVIIS 
ANFØRTE GRUNDE. Astræa, et periodisk Skrivt. V. 1., n. 3., p. 284-303, 1797. (disponível em: https://books.google.com.br/books/reader?id=tYvAQAAMAAJ\&hl=pt-BR\&printsec=frontcover\&output=reader\&pg=GBS.PP1)

MORGENSTIERNE, B. Antikritik, eller et par ord til Publicum i Anledning af Hr. Procurator Debe's Kritiske Bemærkinger o.s.v. Christiania [Oslo]: Paa Forfatterens Forlag, trykt hos N. J. Berge, 1808

MUNCH, P. A. Verdenshistoriens vigtigste Begivenheder : fra de ældste Tider indtil den franske Revolution i kortfattet Fremstilling. Christiania [Oslo]: Cappelen, 1840

NISSEN, M. Extract og Register over Deres Kongelige Majestæters til Dannemark og Norge \&c. \&c. Forordninger, Forbude, Placater, Ordonancer, Fundatzer, Reglements, Laugs-Artikler, Privilegier, Rescripter og Placater som fra Aaret 1670 til 1768 ere udgangne. H. 3 : Extract og Register over Deres Kongelige Majestæters til Dannemark og Norge \&c. \&c. Forordninger, Forbude, Placater, Ordonancer, Fundatzer, Reglements, Privilegier, Rescripter, Canceliets, Generalitetets og Commissariatets, Cammer og General Kirke-Inspections Collegii samt General Postamtets Breve og Ordres, som fra Aaret 1670 til 1771 ere udgangne. Trinhiem: Trykt paa Autors Bekostning hos Jens C. Winding, 1771

NISSEN, R. T. Lærebog i Verdenshistorien for Middelskolen. Christiania [Oslo]: 1870

PETRI, L. A. Lærebog i den christelige Religion. Christiania [Oslo]: Johan Dahl, 1854

PFLUG. H. O. Den danske Pillegrim eller en almindelig geographisk og derhos kort historisk Beskrivelse over den heele bekiendte Verden. 1707

PLATOU, C. N. S.. Lærebog i Geographien. Christiania [Oslo]: Hviids Enke, 1840 SAGEN, Lyder. Bergens Beskrivelse. Bergen: Trykt paa Udgiv. Forlag hos Cht. Dahl. R.S., 1824

SCHIØTZ, O. E. Lærebog i Fysik. Kristiania: P. T. Malling, 1881 
SCHJØTT, H. Lærebog i verdenshistorien for middelskolen: en omarbeidelse af Nissen's og Daae's Verdenshistorie. 3 : Den nyere tid. Kristiania [Oslo]: Malling, 1889

SCHWACH, C.U. Mauritz Hansens Noveller og Fortællinger : efter Forfatterens Død samlede og ordnede. B. 2. Christiania: Chr. Tønsbergs Forlag, 1856.

SCHØNING, G. Heimskringla edr Noregs Konunga-sögor. Havniæ [København]: Augusti Friderici Steini, 1777

STEENBUCH, H. Bemærkninger over Norges Grundlov af 4de November 1814. Trondhjem [Trondheim]: trykt paa Forfatterens Forlag af. A. Steen, 1815.

STORM, G. P. A. Munch. Samlede Afhandlinger. I (1831-Marts 1849). Kristiania [Oslo]: Cammermeyer, 1873

STORTINGSFORHANDLINGER. 1874, Del 1. Stortingsforhandlinger. 23

STRØM, H. C. Politiske og økonomiske Betragtninger og Forslag. 1ste Række. Christiania [Oslo]: Trykt i det Wulfsbergske Bogtrykkerie, 1833

SWIFT, J. Gullivers Rejser: til Lilleput og Brobdingnag. Kristiania [Oslo]: Cammermeyer, 1878

VERNE, J. Jordens Opdagelseshistorie. [1] : De store Reisers og de store Reisendes Historie, eller Jordens Opdagelseshistorie fra de ældste Tider til Udgangen af det 17de Aarhundrede. Kristiania [Oslo]: P. T. Malling, 1879.

\section{Alemão:}

CASPAR, S. Christliche Leichpredigt/ Vom Absterben vnd Begräbnüß deß Ertzvaters Jacobs/ aus dem 49 vnd 50. Capitel des Buchs Moysis. Leipzig: Valentin Am $1612 . \quad$ (Disponível em: http://www.deutschestextarchiv.de/book/show/527026)

CONFESSIO ODDER BEKANTNUS DES GLAUBENS ETLICHER FÜRSTEN UND STEDTE; UBERANTWORT KEISERLICHER MAIESTAT AUFF DEM REICHSTAG GEHALTENN ZU AUGSPURG, ANNO. M. D. XXX. Ronneburg: 1557. 
https://books.google.com.br/books/reader?id=mBk sL sEKUC\&hl=ptBR\&printsec=frontcover\&output=reader\&pg=GBS.PT5)

DER NEÜ LAYENSPIEGEL VON RECHTSMÄSSIGEN ORDNUNGEN IN BURGERLICHEN UND PEINLICHN REGIMENTEN: MIT ADDITON: AUCH DER GULDIN BULLA; KÖNIGKLICH REFORMATON LANDFRIDEN AUCH BEWÄRUNG GEMAINER RECHT VN ANDERN ANTZAIGEN. 1512 (Disponível em:

https://play.google.com/books/reader?id=LHdmAAAAcAAJ\&printsec=frontcover\&o utput=reader\&hl=pt_BR\&pg=GBS.PP3)

ECKARD, M. Eine Christliche Leichpredigt/ Bey dem Begrebnis der Ehrntugendreichen frawen Justinae/ des Edlen/ Ehrnuhesten/ Wolbenambten Herrn Johann Lieben. Leipzig: Michael Lantzenberger, 1601. (Disponível em: http://www.deutschestextarchiv.de/book/show/510288)

FORTSETZUNG DES IM VORIGEN STÜCKE ABGEBROCHENEN AUSZUGES, AUS DEN SCHRIFTEN DER KAISERL. PETERSBURG AKADEMIE. Hamburgisches Magazin, oder gesammlete Schriften, zum Unterricht und Vergnügen aus der Naturforschung und den angenehmen Wissenschaften überhaupt. Bd. 7 ersters Stück. 339-356. Hamburg, bey Georg Christ. Grund, und in Leipzig bey Adam Heinr, 1751. (Disponivel em:https://books.google.com.br/books?id=QC1RAAAAcAAJ\&pg=PA354\&dq=aber ration+und\&hl=pt-

BR\&sa $=X \&$ redir_esc $=y \# v=$ onepage $\& q=a b e r r a t i o n \% 20$ und $\& f=$ false

GÖTTINGISCHE ANZEIGEN VON GELEHRTEN SACHEN: UNTER DER AUFSICHT DER KÖNIGL. GESELLSCHAFT DER WISSENSCHAFTEN. Der erste Band. Göttingen: gedruckt bey Pockwitz und Barmeier, 1763.

GUTAKER, P. E. Erklärung über das am 21. April 1734 in der Grafschaft Schackenburg gefundene güldene Horn. Altona, 1736. (Disponível em: https://books.google.com.br/books?id=wrZYAAAAcAAJ\&pg=PA17\&dq=aberration +und\&hl=pt-BR\&sa=X\&redir_esc=y\#v=onepage\&q=hernahmen\&f=false) 
HUNDT, M. Eyn kurtzes und sehr nutzbarlichs Regiment wider dye schwynde und erschreckliche kranckheit der pestilentz auß bewerten und geuebten ertzten tzu samen getragen, sampt einem kurtzen bericht der schweyßkranckheyt. Lepzig: Valentin Schumann, $1529 . \quad$ (Disponível em: https://books.google.com.br/books?id=3iJgAAAAcAAJ\&pg=PT7\&dq=infeccion+dur $\mathrm{ch}+$ das\&hl=pt-

BR\&sa $=X \&$ redir_esc $=y \# v=$ onepage $\& q=i n f e c c i o n \% 20$ durch $\% 20$ das $\& f=f a l s e)$

KANOLD, J. Von Witterungs-Krankheiten im Monatz Merz, Anno 1718. Sammlung von Natur- und Medicin- wie auch hierzu gehörigen Kunst- und LiteraturGeschichten so sich von 1717-26 in Schlesien und anderen Orten begeben ... und als Versuch ans Licht gestellet. 771-784, 1718. (Disponível em: https://books.google.com.br/books?id=tGBVAAAAcAAJ\&pg=PA773\&dq=aberratio $\mathrm{n}+\mathrm{und} \& \mathrm{hl}=\mathrm{pt}-\mathrm{BR} \& \mathrm{sa}=\mathrm{X} \&$ redir_esc $=\mathrm{y} \# \mathrm{v}=$ snippet $\& \mathrm{q}=$ aberration\&f=false $)$

MICRAELIUS, J. Drittes Buch Deß Alten Sächsischen Pommerlandes. Stettin: Rhete, 1639.

SCHUMANN, V. Eyne christiliche Meditation vnd Beschaulikeyt, darin vill nützlichs tzur Seligkeyt verfasset ist. Durch Valten Schumann, 1528.

STEINMANN, W. F. Makroskopische Präparationsmethoden in der Medizin. Stuttgart/New York: Thieme, 1982

WALTHER, J. Die Denudation in der Wüste und ihre geologische Bedeutung. Untersuchungen über die Bildung der Sedimente in den ägyptischen Wüsten. In: Abhandlungen der Mathematisch-Physischen Klasse der Königlich-Sächsischen Gesellschaft der Wissenschaften, 16, 3, Abhandlungen der Königlich-Sächsischen Gesellschaft der Wissenschaften 27, 345 - 570, VIII Taf.. Leipzig: S. Hirzel, 1891 (disponível em: http://digital.slubdresden.de/fileadmin/data/302335757/302335757_tif/jpegs/302335757.pdf)

WAGHNAER, L. J. Der erst Theil dess Spiegels der Seefart: von Navigation des Occidentischen Meers ... Amsterdam: Cornelius Claußsohn, 1589. (Disponível em: http://reader.digitale-sammlungen.de/resolve/display/bsb11302848.html) 
WELLICH, G. Christliche Leichpredigt. Vber den schönen Spruch des Geistreichen Hocherlauchten Apostels S. Pauli/ 2. timoth. 4. vers. 7. Ich habe einen gutten Kampff gekämpffet/ etc. Bey dem Begräbnüs Weylandt Des Ehrwürdigen/ Achtbaren vnd Wolgelarten [H]Ehrn Christoff Frümters. Oels: Johan Bössemesser, 1618

WIRTSCHAFTS- UND HANDELSLEBEN. Die Uhrmacher-Woche. 27. Jahrgang, Nr. 43. Leipzig, 23 de outubro de 1920. 506-507.

\section{Espanhol:}

BAILS, B. Elementos de Matemática. Tomo VI. Madrid: Por D. Joachin Ibarra, Impressor de Cámara de S. M. y de la Real Academia, 1781. (Disponível em: https://play.google.com/books/reader?id=xqxJAAAAMAAJ\&printsec=frontcover\&o utput=reader\&hl=pt_BR)

BARUEL, A. Memorias para servir á la História del Jacobinismo, escritas em francés por el abate Barruel. Tradução de F. R. S. V. Observante de la província de Mallorca. Tomo Primeiro. Palma: em la imprenta de Felipe Guasp., 1813

DE LOS REYES, C. G. J. El filosofo ocupacion de nobles y discretos contra la cortesana ociosidad: sobre los libros de cielo y mundo, meteoros, paruos naturales, ethica, economica, politica de Aristoteles y esfera de Sacro Bosco (...). Madrid, Por Domingo Garcia y Morràs, 1650

De HUERTA, G. Tradvcion de Los Libros de Caio Plinio Segundo de la Historia Navural de Los Animales. Hecha por El Licenciado Geronimo de Huerta, Medico, y Filosofo (...). Primera Parte. Madrid: Por Luis Sanchez, 1598. (Disponível em: https://books.google.com.br/books?id=PteaSerXIPkC\&printsec=frontcover\&hl=pt$B R \# v=$ onepage $\& q \& f=$ false $)$

LADVOCAT, J. B. Diccionario Historico Abreviado, que contiene La Historia de Los Patriarcas, Principes Hebreos, Emperadores, Reyes (...). Tomo III. Tradução de Don Agustin Ibarra. Madrid: em la imprensa de Joseph Rico, 1754 
ZUÑIGA, J. de. Observaciones astronomicas, y physicas hechas de orden de S. Mag. en los reynos del Perù. Por Jorge Juan, Comendados de Aliaga em el Orden de S. Juan, Socio Corres.pondiente de la R. Academia de las Ciencias de Parìs, y. D. Antonio de Ulloa, de la R. Sociedad de Londres, ambos Capitanes de Fragata de la R. Armada. De las Quales se Deduce La Figura, y Magnitud de la Tierra $y$ se aplica a la Navegacion. Madrid: 1748. (Disponível em: https://books.google.com.br/books?id=Uu8wIEQQ4tYC\&pg=PA16\&dq=aberraci\% C3\%B3n\&hl=pt-

$\mathrm{BR} \& \mathrm{sa}=X \&$ redir_esc $=\mathrm{y} \# \mathrm{v}=$ onepage $\& \mathrm{q}=$ aberraci\%C3\%B3n\&f=false)

\section{Francês:}

AUGE, C. Mensuel Illustré Revue Encyclopédique Universelle. 1907 à 1910. Paris: Librairie Larousse

BAPT. P. loanne. Astronomia Reformata. Le lovrnal des Scavans. Paris, 24 de Janeiro de 1667. Paris: chez lean Cvsson, ruë s. lacques, à l'Image de S. Iean Baptiste. (Disponível

em: https://books.google.com.br/books?id=fhbFqFzv 5oC\&pg=PA14\&dq=libration+\%2 2lune \%22\&hl=pt-BR\&sa=X\&redir esc=y\#v=onepage\&q=libration*\&f=false )

BOER, C. de. Ovide Moralisé: poème du commencement du quatorzième siècle publié d'après tous les manuscrits connuns par C. De Boer. Tomo IV (Livros XXIII). Amsterdam: N.V. Noord-Hollandsche Uitgevers-Maatschappij, 1936. (Disponível

em: https://archive.org/stream/DeBoerOvideMoralise4/De_Boer_Ovide_Moralise_4\#pa ge/n0/mode/2up)

BOS, A. La Chirurgie de Maitre Henri de Mondeville. Traduction contemporaine de L'auteur publiée d'après le Ms. Unique de la Bibliothèque Nationale par le Dr. A. Bos. Vol. II. Paris: Librairie de Firmin Didot Et Cie Rue Jacob, 56, 1898.

DUMAS, A. Mémoires de Garibaldi (traduits sur le manuscrit original par Alexandre Dumas). Paris: Michel LévyFréres, Libraires-Éditeurs, 1860 
ROBERT, U. L'art de chevalerie / trad. du "De Re militari" de Végèce, par Jean de Meun; publ. Avec une étude sur cette traduction et sur "Li Abrejance de l'ordre de chevalerie" de Jean Priorat, par Ulysse Robert. Paris: Librairie de Firmin Didot, 1897. (Disponível em: http://gallica.bnf.fr/ark:/12148/bpt6k548098/f233.image)

VERNE, J. Les grands voyages et les grands voyageurs. Découverte de la Terre, [1re-2e parties] par Jules Verne... Dessins par L. Benett et P. Philippoteaux... Facsimilé d'aprèslesdocumentsanciens et cartes par Dubail et Matthis. Paris: J. Hetzel , 1878

WEILL, R. La Presqu'ile du Sinai - Etude de Geographie et D'Histoire. Kesseinger Publishing, 1908.

YVES-GUYOT; RAFFALOVICH, A. Inflation et Déflation. Paris: Librairie Félix Alcan, 1921.

\section{Holandês:}

STRUYCK, N. Berigt om trent de Verschyning van Venus in de Zon, op den 6 Juny 1761. Uitgezogte Verhandelingen uit de Nieuwste Werken van de Societeiten der Wetenschappen in Europa en van andere Geleerde Mannen. Zesde Deel. 305-314. Amsterdam: F. Houttuyn, 1761. (Disponível em: https://books.google.com.br/books?id=antUAAAAcAAJ\&pg=PA305\&dq=\%22aberr atie $\% 22+\% 22$ van $\% 22 \&$ hl $=$ pt-

BR\&sa $=X \&$ redir esc $=y \# v=$ onepage \&q=\%22aberratie $\% 22 \% 20 \% 22 v a n \% 22 \& f=$ fals e)

WAGHENAER, L. J. Teerste deel vande Spieghel der Zeevaerdt ... Leiden: Christoffel Plantijn, $1584 . \quad$ (Disponível em: http://objects.library.uu.nl/reader/index.php?obj=1874210220\&lan=en\#page//85/89/77/85897763828196631021025139408982461487.j $\mathrm{pg} / \mathrm{mode} / 1 \mathrm{up})$ 


\section{Inglês:}

CELSIUS, A. [et al.]. The Figure of the Earth, determined from observations, made by order of the French King, at the polar circle. London: Printed for T. Cox [et al.], 1738. (Disponível em: http://www.nb.no/nbsok/nb/3011d718624f2c296b79658dacabcc77?index=13\#5)

CHAMBERS, E. A Supplement to Mr. Chambers's Cyclopaedia: or, universal Dictionary of Arts and Sciences in two Volumes. Vol. London, 1753. (Disponível em: https://archive.org/details/Cyclopaediachambers-SupplementVolume1)

KEMMERER, E. W. High Prices and Deflation. London, Oxford: Princenton University Press, 1920

SMITH, C. A New Method of Improving and Perfecting Catadioptrical Telescopes, by Forming the Speculums of Glass instead of Metal. Philosophical Transactions. Vol. 41. 326-340, 1739. (Disponível em:

http://rstl.royalsocietypublishing.org/content/41/452-461/326.full.pdf+html)

SWIFT, J. Into Several Remote nations of the World. In Four Parts. By Lemnuel Gulliver, first a Surgeon, and then a Captain of several SHIPS. London: Benj. Motte, 1776.

The Harleian Miscellany, or a Collection of scarce, curious, and entertaining Pamphlets and Tracts, as well in Manuscript as in Print, found in the late Earl of Oxford's Library, interspersed with Historical, Political, and Critical Notes. Vol. V. London: Printed for Robert Dutton, Gracechurch-Street, 1810. (Disponível em: https://play.google.com/books/reader?id=laQQAAAAYAAJ\&printsec=frontcover\&o utput=reader\&hl=pt BR)

WHISTON, W. A new theory of the earth, from its original, to the consummation of all things. Wherein the creation of the world in six days, the universal Deluge, and the general conflagration, as laid down in the Holy Scriptures are shewn to be perfectly agreeable to reason and philosophy. With a large introductory discouse concerning the genuine nature, stile, and extent of the Mosaick history of creation. Londres: Printed by R. Roberts, for Benj. Tooke at the Middle-Temple-Gate in 
Fleet-Street,

1696.

(Disponível

em:

http://lhldigital.lindahall.org/cdm/ref/collection/earththeory/id/1468)

\section{Italiano:}

Del FAGGIOL, R. P. Ragguaglio di una grotta, ove sono molte ossa di belve diluviane nei monti veronesi, e dei luoghi in quei contorni; e strati di pietra , tra i quali stanno i corni ammoni; e ove si ritrovano altre produzioni maritime impietrite, e come in dissegno si dimostra. Con rifflessioni sopra queste materie. Verona: Nella stamperia dei Fratelli Merlo, 1739

F. A. di C. Teatro Fisicosmografico: ovvero Trattato di Cosmografia, ove fisicamente si spiega il Sistema del Mondo, e come in esso si fomano i principali fenomeni. Londra: Per. J. Bettenham, 1724

GALILEI, G. Dialogo di Galileo Galilei Linceo Matematico Sopraordinario Dello Stvdio di Pisa. E Filosofo, e Matematico primario del Serenissimo Gr. Dvcadi Toscana. Doue ne i congressi di quattro giornate si discorre sopra i due Massimi Sistemi Del Mondo Tolemaico, e Copernicano (...). Fiorenza: Per Gio: Batista Landini, $\quad 1632 . \quad$ (Disponível em: http://lcweb2.loc.gov/cgibin/ampage?collld=rbc3\&fileName=rbc0001 2013rosen1350page.db\&recNum=8)

GUALANDI, A.; BÒNOLI, F. Eustachio Manfredi e la prima conferma ossevativa della teoria dell'aberrazione annua della luce. Atti del XXIl congresso nazionale di storia della fisica e dell'astronomia. 476-481. Genua, 2004.

L'ELVIENNESI O SAI LETTERE PROVINCIALI FILOSOFICHE. Tomo III. Napoli: Presso vincenzo Orsini, 1786. (Disponível em: https://books.google.com.br/books?id=esiKeltwqEC \&pg=PA267\&dq=\%22aberrazione $\% 22+$ filosofia\&hl=ptBR\&sa $=X \&$ redir_esc $=y \# v=$ onepage $\& q=\% 22$ aberrazione $\% 22 \& f=f$ alse $)$ LIONI, G. Supplementi al Giornale de' letterati d'Italia. Tomo I. Venezia: Apresso Gio. Gabbriello Hertz, $1722 . \quad$ (Disponível em: https://books.google.com.br/books?id=8gyTUSeRt0oC\&printsec=frontcover\&dq=\% 


\section{2aberrazione $\% 22 \& \mathrm{hl}=\mathrm{pt}-$}

BR\&sa $=X \&$ redir esc $=y \# v=$ onepage $\& q=\% 22$ aberrazione $\% 22 \& f=$ false $)$

METODO D' INVESTIGARE L'ORBITE DE' PIANETI, NELL'IPOTESI CHE LE FORZE CENTRALI O PURE LE GRAVITÀ [...]. Giornale de' Letterati D'Italia, $\begin{array}{lllll}\text { Venezia, } & \text { p. } & 447-467, & 1710 . & \text { (Disponível em: }\end{array}$ https://books.google.com.br/books/reader?id=anxcAAAAcAAJ\&hl=pt-

\section{BR\&printsec=frontcover\&output=reader\&pg=GBS.PP1)}

OPERE DI GALILEO GALILEI DIVISE IN QUATTRO TOMI. Tomo secondo. Padova: nella stamperia del Seminario: 1744

TASSI, F. Della misera dell'uomo, Giardino di consolazione, Introduzione alle virtù di Bono Giamboni aggiuntavi La scala dei claustrali. Testi inediti, tranne il terzo trattato, pubblicati ed illustrati com note dal dottor Francesco Tassi. Firenze: Preso Guglielmo Piatti, $1836 . \quad$ (Disponível em: https://archive.org/stream/bub_gb_G81CAAAAIAAJ\#page/n3/mode/2up)

\section{Latim:}

ANGLICUS, B. De proprietatibus rerum. Köln: Drucker der Flores Sancti Augustini (Jan Veldener). Vielmehr Johann Schilling (Solidi) auf Kosten von William Caxton, 1471. (Disponível em: http://digital.ub.uniduesseldorf.de/urn/urn:nbn:de:hbz:061:1-145937)

DEUSINGII, A. De Vero Systemate Mundi Dissertatio Mathematica qua Copernici Systema Mundi reformatur: sublatis interim infinitis penè orbibus, quibus in systemate Ptolemaico humana mens distrahitur. Amstelodami: Apud Ludovicum Elzevirium, $1643 . \quad$ (Disponível em: https://play.google.com/books/reader?id=52vooe9EqaQC\&printsec=frontcover\&ou tput=reader\&hl=pt_BR\&pg=GBS.PP1)

HEVELIUS, J. Johannis Hevelii Selenographia sive lunae descriptio : atque accurata, tam macularum ejus, ... delineatio, ...; addita est, lentes expoliendi nova ratio, ut et telescopia diversa construendi, et experiendi, ... explicatur. Hünefeld: Gedani, 1647 
HIRSCH, A.; GURLT, E. Die Chirurgie des Heinrich von Mondeville (Hermondaville) nach Berliner, Erfurter und Pariser Codices zum ersten Male nebst einer Abhandlung über Synonyma und einem Glossar von Moritz Steinschneider - hrsg. Von Julius Leopold Pagel. Berlin, 1892. (Disponível em: https://archive.org/details/diechirurgiedes00pagegoog)

SACROBOSCO, J. Sphaera Mundi: Textus de Sphera lohannis de Sacrobosco: cum additione quantum necessarium est adiecta, nouo co[m]mentario nuper edito ad vtilitatem studentiu[m] philosophice Parisien[sis] Accademie illustratus. Parisij: per Vvolffgangu[m] Hopyl, 1494 duodecima Februarij. (Disponível em: http://data.bnf.fr/13746667/johannes_de_sacro_bosco_de_sphaera/)

\section{Médio baixo-alemão:}

DEM VEREINE FÜR LÜBECKISCHE GESCHICHTE UND ALTERTHUMSKUNDE. Urkunden-Buch der Stadt Lübeck. Tomo IV. Lübeck: Ferdinand Grautoff, 1873 (Disponível em: https://play.google.com/books/reader?id=iAQPAAAAYAAJ\&printsec=frontcover\&o utput=reader\&hl=pt_BR\&pg=GBS.PA3)

\section{Sueco:}

KÄSTNER, A. G. Om Geometriska Aberrationer. Kong. Svenska Vetenskapsacademiens Handlingar. Vol. 14. 126-136, 1753 (disponível em: https://books.google.com.br/books?id=Lb44AAAAMAAJ\&pg=PA126\&dq=aberratio $\underline{\mathrm{n}+\text { svenska\&hl=pt- }}$

BR\&sa=X\&redir esc=y\#v=onepage\&q=aberration\%20svenska\&f=false)

RIKSKANSLEREN AXEL OXENSTIERNAS SKRIFTER OCH BREFVEXLING. Utgifna af Kongl. Vitterhets- Historie- och Antiqvitets-Akademien. 10 Bandet. Stockholm: P. A. Norstedt et Söners Förlag, 1900. (disponível em: https://archive.org/stream/rikskanslerenax01 palagoog\#page/n8/mode/2up)

\section{Dicionários, enciclopédias, etc:}


ALMENNYTTIGT DANSK KONVERSATOINS-LEXIKON. København: P. Larsen, 1849-1860. (Disponivel na Nasjonalbibliothek e em http://enzyklothek.de/allgemeinenzyklop\%C3\%A4dien/d\%C3\%A4nischeenzyklop\%C3\%A4dien/almennyttigt-dansk-konversations-lexikon-over-alt-1849)

BARBOSA, A. Dictionarium lusitanico latinum. Bracharae Bracharae: typis, \& expensis Fructuosi Laurentij de Basto, 1611

BASTOS, J. T. Diccionario Etymologico, Prosodico e Orthografico da Lingua Portugueza. Lisboa: Livrara Editora, 1912. (disponível na bibdig.biblioteca.unesp.br/)

BEEKES, R. Etymological Dictionary of Greek. Leiden: Brill, 2010

BJORVAND, B; LINDEMAN F. O. Våre arveord: etymologisk ordbok. Oslo: Institutet for sammenlignende kulturforskning, 2000

$\mathrm{BLOCH}, \mathrm{O}$. Dictionnaire étymologique de la langue française. Paris: Presses universitaires de France, 1964

BLUTEAU, R. Vocabulario portuguez \& latino: aulico, anatomico, architectonico ... Coimbra: Collegio das Artes da Companhia de Jesu, 1712 - 1728. 8 v.

- Vocabulario de synonimos, e phrases portuguezas. Lisboa: $\begin{array}{llll}\text { Patriarcal Officina } & \text { Musica, } & 1728\end{array}$ . Diccionario Castellano y Portuguez para facilitar a los castellanos el uso del Vocabulario Portuguez, y Latino. Lisboa: Occidental Officina de Pascoal da Silva, 1721

BONDESØN, A. Arithmetica Aurea Mercatoria eller den Gyldene Kiøbmands Reigning, hvilken efter den viit-berømte Italienske Practique med adskillige nyttige Exempler, alle Species Arithmeticae saaledes oplyset, at baade Ungdommen og andre, deraf kand bekomme grundig Information og Underviisning: Efter Danmarks Vægt og Maal indrettet. Kjøbenhavn: trykt hos Andreas Garvig Godiche, $1755 . \quad$ (Disponivel em: https://archive.org/stream/arithmeticaaure00bondgoog\#page/n2/mode/2up)

BRYNILDSEN, J. Norsk-engelsk. Kristiania [Oslo]: Mallings boghandels forlag, 1892 
. Norsk-engelsk. Kristiania [Oslo]: Aschehoug, 1917

de CAPRONA, Y. Norsk etymologisk ordbok: tematisk ordnet. Oslo: Kagge forlag, 2013

CARDOSO, J. Breve Dictionarium Vocum Ecclesiasticarum. In Dictionarium latinolusitanicum. Coimbra: João de Barreira, 1569-1570

CLAUSEN, P. A. Norsk-engelsk sø-ordbog. Kristiansand: Grøntoft, 1875

COLES, E. An English Dictionary explaining the difficult Terms that are used in Divinity, Husbandry, Physick, Philosophy, Law, Navigation, Mathematicks, and other Arts and Sciences. Containing many thousand of hard Words (and proper Names of Places) more than are in any other English Dictionary or Expositor. Together with the Etymological Derivation of them from their proper Fountains, whether, Hebrew, Greek, Latin, French, or any other Language. London: S. Collins, 1717

COROMINAS, J; PASCUAL, J..Diccionario Crítico Etimológico Castellano e Hispánico. Madrid: Editorial Gredos, 1984.

CORTELAZZO, M.; ZOLLI, P. II nuovo etimologico. Deli. Dizionario Etimologico della Lingua Italiana. Bolona: Zanichelli Editore SpA, 1999, CD-ROM

CUNHA, A. G. Dicionário Etimológico da Língua Portuguesa. $19823^{\mathrm{a}}$ ed. 2007 Rio de Janeiro: Lexikon Editora Digital, 1982 [2007³]

CUNHA, A. G. Vocabulário histórico-cronológico do português medieval. Rio de Janeiro: Fundação Casa de Rui Barbosa, 2007, CD-ROM.

DAUZAT, A. Dictionnaire étymologique et historique du français. Paris: Larousse, c1993.

DUDEN. Herkunftswörterbuch: Etymologie der deutschen Sprache. Berlin/Mannheim/Zürich: Dudenverlag, 2014

DUCANGE, D. Glossarium mediae et infimae latinitatis / conditum a Carolo Dufresne Domino Du Cange ; auctum a monachis Ordinis S. Benedicti ; cum supplementis integris D.P. carpenterii et additamentis Adelungii et aliorum ; digessit G.A.L. Henschel. Niort: L. Favre, Imprimeur-Éditeur, 1883. 
ENCYCLOPAEDIA BRITANNICA ULTIMATE REFERENCE SUITE. CD-rom. Chicago: Encyclopædia Britannica, 2015.

ERNOUT, A.; MEILLET, A. Dictionnaire étymologique de la langue latine. Histoire des mots. Paris: Klincksieck, 1932 [20016]

ESTIENNE, R. Dictionarium Latinogallicum. A Paris: De l'impremerie de Robert Estienne, 1539. (Disponível em: http://gallica.bnf.fr/ark:/12148/bpt6k505878/f1)

. Dictionarium Latinogallicum. Parisiis: Ex officina Roberti Stephani

typographi $\quad$ Regii, $1543 . \quad$ (Disponível

https://play.google.com/books/reader?id=GGwl2fnCqj0C\&printsec=frontcover\&out put $=$ reader\&hl=pt_BR\&pg $=$ GBS.PP7)

. Dictionarium Latinogallicum. A Paris: De l'impremerie de Robert

Estienne, $1549 . \quad$ (Disponível em: https://play.google.com/books/reader?id=hyJWAAAAYAAJ\&printsec=frontcover\&o utput=reader\&hl=pt_BR\&pg=GBS.PR4)

. Dictionarium Latinogallicum. Parisiis: Ex officina Roberti Stephani typographi Regii, $1552 . \quad$ (Disponível em: https://artflproject.uchicago.edu/content/dictionarium-latinogallicum)

FERREIRA, A. B. H. Novo dicionário Aurélio da língua portuguesa. Curitiba: Editora Positivo, 2009.

FICK, A.; FALK, H. Vergleichendes Wörterbuch der Indogermanischen Sprachen. Dritter Teil. Göttingen: Vandenboeck und Ruprecht, 1909.

FOLQMAN, C. Diccionario Portuguez, e Latino. Lisboa: Na officina de Miguel Manescal da Costa, (transcrição de Paula Cristina Araújo), 1755 da FONSECA, P. J. Parvum lexicum latinum lusitana interpretatione adjecta. Olisipone: Typographia Regia, 1798

FREIRE, L. Dicionário da Língua Portuguesa. Volume II. Rio de Janeiro: A Noite, S.A., 1954

GAFFIOT, F. Dictionnaire Latin-Français. Paris: Hachette, 1934

GAMILLSCHEG, E. Etymologisches Wörterbuch der französischen Sprache. Heidelberg: Universitätsverlag C. Winter, 1997. 
GEELMUYDEN, I.. Engelsk Ordbog : udarbejdet fornemmelig efter B.H. Smart's Pronouncing Dictionary of the English Language, London 1852 : med Angivelse af Ordenes Udtale efter Walter's Methode. Christiania [Oslo]: Malling, 1855.

. Engelsk Ordbog : med Angivelse af Ordenes Udtale efter Walker's Methode : fornemmelig til Skolebrug. Christiania [Oslo]: Malling, 1872

GLARE, P. G. W. Oxford Latin Dictionary. Oxford: Clarendon P, 1968.

GODEFROY, F. Dictionnaire de L'ancienne Langue Française et de tous ses dialectes Du IX au XV Siècle. Genève-Paris: Slatkine, 1891-1902 [1982]. Disponível em: http://gallica.bnf.fr/ark:/12148/bpt6k4191t/f3.image. Último acesso em: 1 de outubro de 2015

GRAND DICTIONNAIRE ROYAL DANOIS ET FRANÇOIS. Kiøbenhavn: trykt hos :M. Svare, 1759

GRÜNER, H. C. Norsk-engelsk handels-ordsamling med varianter og synonymer. Christiania [Oslo]: Cammermeyer, 1892

HANSEN, M. C. Fremmed-Ordbog, eller Forklaing over de i det norske Skrift- og Omgangs-Sprog almindeligst forekommende fremmede Ord og Talemaader. Christiania [Oslo]: Tønsbergs Forlag, 1851

HELLQUIST, E. Svensk etymologisk ordbok. Lund: C.W.K. Gleerups förlag, 1922.

HENNE, H. Grammatisch-kritisches Wörterbuch der Hochdeutschen Mundart, mit beständiger Vergleichung der übrigen Mundarten, besonders aber der Oberdeutschen. Bd. 1-4. Zweite vermehrte und verbesserte Ausgabe. Mit einer Einführung und Bibliographie von Helmut Henne. Neudruck der Ausgabe Leipzig, Breitkopf 1793-1801. Hildesheim, New York: Olms, 1970.

HULSIUS, L. DICTIONARIVM Teutsch und Frantzösisch, Deßgleichen Frantzösisch und Teutsch:Sampt einem nothwendigen unnd gründlichen Bericht, wie die Frantzosen Teutsch, und die Teutschen Frantzösisch recht außsprechen sollen. Framckfort am Mainn: L. Hulsii Wittiben, 1607.

JOHNSEN, J. C. Norsk Haandlexikon for almennyttige Kundskaber. Band II. Kristiania [Oslo]: Johnsens Forlag, 1884. 
KALKAR, O. Ordbog til det ældre danske sprog (1300-1700) (OADS). Bergen: Historisk institutt/Statsarkivet i Bergen, 2000 (Disponível em: http://www.hist.uib.no/kalkar/)

KAPER, J. Tysk-dansk-norsk Haand-Ordbog. Kjøbenhavn: Gyldendal, 1885 . Dänisch-Norwegisch-Deutsches Hand-Wörterbuch. Kopenhagen: Verlag der Gyldendalchen Buchhandlung, 1889 KATLEV, J. Politikens Etymologisk Ordbog. København: Politikens forlag, 2000 KLUGE, F. Etymologisches Wörterbuch der deutschen Sprache. Bearb. Von Elmar Seebold. 24. Berlin/New York: de Gruyter, 2002. CD-ROM

KOFOD, H.A. Conversations-Lexicon, eller Encyclopædisk Haandbog over de i selskabelig Underholdning og ved Læsning forekommende Gjenstande, Navne og Begreber. 1 : A og B. Kiøbenhavn: A. Coldin, 1816

- Conversations-Lexicon, eller Encyclopædisk Haandbog over de $i$ selskabelig Underholdning og ved Læsning forekommende Gjenstande, Navne og Begreber. 3 : D, E, F. Kiøbenhavn: A. Coldin, 1817

KROONEN, G. Etymological Dictionary of Proto-Germanic. Leiden/Boston: Brill, 2013

LAROUSSE. DICTIONNAIRE ÉTYMOLOGIQUE ET HISTORIQUE DU FRANÇAIS. Paris: Larousse.

LARSEN, A. Dansk-norsk-engelsk Ordbog = : A Dictionary of the Dano-Norwegian and English languages. Kjøbenhavn : Gyldendal, 1880

LARSEN, A. Dansk-norsk-engelsk ordbog. Kjøbenhavn: Gyldendalske Bokhandel, 1888

LAYCOCK, H. Engelsk-norsk Parleur. Christiania [Oslo]: Feilberg \& Landmark, 1847

LE PETIT ROBERT DE LA LANGUE FRANÇAISE. Paris: Dictionnaires Le Robert, 2014, CD-Rom 
LEHMANN, W. P. A Gothic Etymological Dictionary. Based on the third edition of Vergleichendes Wörterbuch der Gotischen Sprache by Sigmund Feist. Leiden: E. J. Brill, 1986

LEWIS, C. A Latin Dictionary founded on Andrew's Edition of Freund's Latin Dictionary. Revised, Enlarged, and in Great Part Rewritten by Charlton T. Lewis, Ph.D. Oxford: At the Clarendon Press, 2002.

LUND, J. Engelsk ordsamling til brug i Middel- og Borgerskoler. Kristiania [Oslo]: Cammermeyer, 1881

MACHADO, J. P. Dicionário etimológico da língua portuguesa : com a mais antiga documentação escrita e conhecida de muitos dos vocábulos estudados. Lisboa: Livros Horizonte, 1995.

MATASOVIĆ, R. Etymological Dictionary of Proto-Celtic. Leiden/Boston: Brill, 2009.

MEYER, L. Kortfattet Lexikon over fremmede, i det danske Skrift- og OmgangsSprog forekommende Ord, Konstudtrykt og Talemaader tilligemed de i danske Skrifter mest brugelige, fremmede Ordforkortelser. Kjøbenhavn, paa den Brummerske Boghandels Forlag, 1837. (Disponivel em: https://books.google.dk/books?id=EjZVAAAAcAAJ\&printsec=frontcover\&hl=da\&so urce=gbs_ge_summary_r\&cad $=0 \# v=$ onepage $\& q \& f=$ false $)$ . Kortfattet Lexikon over fremmede, i det danske Skrift- og OmgangsSprog forekommende Ord, Konstudtrykt og Talemaader tilligemed de i danske Skrifter mest brugelige, fremmede Ordforkortelser. Kjøbenhavn: Forlag af J. H. Schubothes Boghandling, 1844.

MEYERS KONVERSATIONS-LEXIKON. Vierter Band. Leipzig und Wien: Bibliographisches Institut, 1894.

MICHAELIS: MODERNO DICIONÁRIO DA LÍNGUA PORTUGUESA. São Paulo: Melhoramentos, 1998.

MURRAY, J. A.H.; BRADLEY, H. A New English Dictionary on Historical Principles. Oxford: At the Clarendon Press, 1888-1933. 
NASCENTES, A. Dicionário etimológico da língua portuguesa. Rio de Janeiro: F. Alves [etc.] 1952-1955

NEBRIJA, A. de. Dictionarium latino hispanicum. Impressum Salmantice [Juan de Porras], 1492

. Dictionarium hispano latinum. Salmantice [Juan de Porras], 1495

NYHUUS, H. Illustreret norsk konversations leksikon. Bind II. Kristiania [Oslo]: Forlagt af H. Aschehoug \& Co. W. Nygaard: 1908

ONIONS, C. T. The Oxford Dictionary of English Etymology. Oxford: Oxford University Press, 1966

OREL, V. A Handbook of Germanic Etymology. Leiden: Brill, 2003

OXFORD. Oxford Advanced Learner's Dictionary. Oxford: Oxford University Press, 2010, Cd-Rom

PALENCIA, A. Universal vocabulario en latin y em romance. 2 tomos. Sevilla, 1490. (Disponível em: http://www.cervantesvirtual.com/obra/universal-vocabularioen-latin-y-en-romance-tomo-i--0/)

POKORNY, J. Indogermanisches Etymologisches Wörterbuch. Band I, II, III. Bern: A. Francke AG, 1959

RAKNES, O. Fransk-norsk ordliste for gymnasi : til dei franske lære- og lesebøkene av Bødtker og Høst og Hermanstorff og Wallem. Oslo: Samlaget, 1914.

SEEBOLD, E. (org.). Chronologisches Wörterbuch des deutschen Wortschatzes. Berlin/New York: Walter de Gruyter, 2008

SILVA, A. de M. Diccionario da Lingua Portugueza composto pelo padre D. Rafael Bluteau, reformado e accrescentado por Antonio de Moraes Silva, natural do Rio de Janeiro. $1^{a}$ edição. Lisboa: na Of. De Simão Thaddeo Ferreira, 1789. (Disponível

em: https://archive.org/stream/diccionariodalin00mora\#page/n3/mode/2up) . Diccionario da lingua portugueza recomplicado dos vocabulários impressos até agora, e nesta segnda edição novamente emendado, e muito 
acrescentado. $2^{\mathrm{a}}$ edição. Lisboa: Typographia Lacerdina, 1813. (Disponível em: http://dicionarios.bbm.usp.br/pt-br/dicionario/2/aberra\%C3\%A7\%C3\%A3o)

- Diccionario da lingua portugueza recompilado de todos os impressos até o presente. $3^{\mathrm{a}}$ edição. Lisboa: Tip. M. P. de Lacerda, 1823. (Disponível em: https://babel.hathitrust.org/cgi/pt?id=uc1.\$b418683)

- Diccionario da lingua portugueza composto por Antonio de Moraes Silva natural do Rio de Janeiro. Quarta edição, reformada, emendada, e muito accrescentada pelo mesmo autor; posta em ordem, correcta, e enriquecida de grande numero de artigos novos e dos synonymos por Theotonio José de Oliveira Velho. Lisboa: $\mathrm{Na}$ impressão Regia, 1831. (Disponível em: https://babel. hathitrust. org/cgi/pt?id=nnc1.0035534206; view=1 up; seq=11; size=150 )

. Diccionario da Lingua Portugueza. $8^{a}$ edição. Lisboa: editora empreza litteraria Flminense de A.A. da Silva Lobo. Sede - Rio de Janeiro, Sucursal - Lisboa, 1890.

SKEAT, W. W. An Etymological dictionary of the English language. Oxford: Clarendon Press, 1956.

SUNDBY, T. Dansk-norsk-fransk Haand-Ordbog. B. 1 : A-L. Kjøbenhavn Gyldendal, 1883 . Dansk-norsk-fransk Haand-Ordbog. B. 2 : M-Ø. Kjøbenhavn : Gyldendal, 1884

de VAAN, M. Etymological Dictionary of Latin and the other Italic Languages. Leiden/Boston: Brill, 2008.

VELEZ, A. Index totius artis, 1599? in Emmanuelis Aluari e Societate lesu De institutione grammatica libri tres. Antonii Vellesii ex eadem Societate lesu in Eborensi Academia Praefecti studiorum opera aucti \& illustrati. Évora: Manuel de Lira, 1599

VIDSTEEN, C. Dansk-norsk ordbog. Lervik: Kommission hos det vestlandske Maalkontor, 1907 
de VRIES, J. Altnordisches Etymologisches Wörterbuch. Leiden: E. J. Brill, 1977 ZINGARELLI, N. Lo Zingarelli 2008: Vocabolario della lingua italiana di Nicola Zingarelli. Bolona: Zanichelli Editore SpA, 2008, CD-ROM

Dicionários ou enciclopédias online utilizados:

DAHLERUP, V. Ordbog over det Danske Sprog (ODS - 1700-1955). (Disponível em: http://ordnet.dk/ods)

DWDS (Das Wortauskunftssystem zur deutschen Sprache in Geschichte und Gegenwart). (Disponível em: http://www.dwds.de/)

GAMMELDANSK ORDBOG. (Disponível em: http://gammeldanskordbog.dk/) GRANDE DICIONÁRIO HOUAISS DA LÍNGUA PORTUGUESA. Versão ßeta. Rio de Janeiro: Objetivo, 2009. Disponível apenas para assinantes em: <http://houaiss.uol.com.br>. Último acesso em 1 de outubro de 2015.

HANSEN, A.; EEGHOLM-PEDERSEN, S. Holbergordbog. (Disponível em: http://holbergordbog.dk/)

LE ENCICLOPEDIE ONLINE TRECCANI. (Disponível em:

http://www.treccani.it/enciclopedia/)

LE TRÉSOR DE LA LANGUE FRANÇAISE INFORMATISÉ (TLFi). Analyse et traitement informatique de la langue française (Atilf), CNRS et l'université de Lorraine. (Disponivel em: http://atilf.atilf.fr/)

LEXER, M. Mittelhochdeutsches Handwörterbuch. Leipzig: Verlag von S. Hirzel, 1872. (Disponível em:

http://woerterbuchnetz.de/Lexer/?sigle=Lexer\&mode=Vernetzung\&lemid=LV02257 \#XLV02257)

MEYER, L. Meyers Fremmedordbog: Historisk fremmedordbog. Gyldendal, 1924. (Disponível em: http://meyersfremmedordbog.dk/)

MOTH, M. Moths Ordbog. (Disponível em: http://mothsordbog.dk/) 
PHILIPPA, M. Etymologisch Woordenboek van het Nederlands. (2003-2009). Disponível em: http://www.etymologiebank.nl/. Último acesso em: 1 de outubro de 2015

SVENSKA AKADEMIENS ORDBOK (1521-atual). Versão online. (Disponível em: http://g3.spraakdata.gu.se/saob/)

Von WARTBURG, W. Französisches Etymologisches Wörterbuch (FEW). (Disponível em: https://apps.atilf.fr/lecteurFEW/index.php/)

WOORDENBOEK DER NEDERLANDSCHE TAAL (1500-1921). s-Gravenhage: M. Nijhoff, 1882-1998. Disponível em: http://gtb.inl.nl/. Último acesso em: 1 de outubro de 2015

Corpus online utilizados:

Geral:

ARLIMA. Les Archives de littérature du Moyen Âge. (Disponível em: http://www.arlima.net/)

ECHO. Cultural Heritage Online. (Disponível em: http://echo.mpiwgberlin.mpg.de/home/search)

Hathitrust Digital Library. (Disponível em: https://babel.hathitrust.org/cgi/mb?colltype=updated)

MANDRAGORE. Base des manuscrits enluminés de la BnF. (Disponível em: http://mandragore.bnf.fr/jsp/rechercheExperte.jsp)

Alemão:

ANNO (Historische Zietungen und Zeitschriften). (Disponível em: http://anno.onb.ac.at/anno-suche\#searchMode=simple\&resultMode=list\&from=1)

DigiPress (Digitaliserte Zeitungen Bayerns). (Disponível em: http://digipress.digitale-sammlungen.de/)

DTA (Deutsches Textarchiv) (1600-1900). (Disponível em: http://www.deutschestextarchiv.de/) 
MDHBDB (Mittelhochdeutsche Begriffsdatenbank). (Disponível em: http://mhdbdb.sbg.ac.at/)

MDZ. Münchener DigitalisierungsZentrum (Digitale Bibliothek). (Disponível em: http://www.digitale-sammlungen.de/)

Obra de Johan Heinrich Zedlers: Grosses vollständiges Universal-Lexicon aller Wissenschafften und Künste. (Disponível em: http://www.zedlerlexikon.de/index.html?c=standardsuche\&l=de)

SLUB. Das Sächsische Landesbibliothek - Staats - und Universitätsbibliothek Dresden. (Disponível em: http://digital.slub-dresden.de/kollektionen/)

$\begin{array}{llll}\text { Süddeutsche } \quad \text { Zeitung } & \text { Archiv. } & \text { (Disponível }\end{array}$ https://archiv.szarchiv.de/Portal/restricted/Start.act)

Dinamarquês:

Diplomatarium Danicum. (Disponível em: http://diplomatarium.dk/)

Renæssancens Sprog i Danmark. A língua dinamarquesa na época da Renascença. (Disponível em: http://xn--renssancesprog-2ib.dk/)

Espanhol:

Corpus do espanhol (1200s-1900). (Disponível em:

http://www.corpusdelespanol.org/hist-gen/2008/x.asp)

DiCCA-XV (Diccionario del castellano del siglo XV em la Corona de Aragón). (Disponível em: http://ghcl.ub.edu/diccaxv/)

Francês:

The ARTFL Reference Collection. Corpus lexicográfico francês. (Disponível: https://artfl-project.uchicago.edu/content/artfl-reference-collection)

Galego:

Tesouro Medieval Informatizado da Lingua Galega (TMILG). (Disponível em: http://ilg.usc.es/tmilg/)

Holandês: 
Corpus de dicionários etimológicos: Etymologiebank. (Disponível em: http://www.etymologiebank.nl/)

Inglês:

Corpus of Middle English Prose and Verse. (Disponível em:

http://quod.lib.umich.edu/cgi/t/text/text-idx?page=simple $\& \mathrm{c}=\mathrm{cme}$ )

Early English Books Online. (Disponível em:

http://quod.lib.umich.edu/e/eebogroup/)

Newspapers. (disponível em https://www.newspapers.com/)

Italiano:

EDIZIONE DIGITALLE DELLE OPERE COMPLETE DI GALILEO GALILEI. (Disponível em: http://pinakes.imss.fi.it:8080/pinakestext/home.jsf)

LARSON, P.; ARTALE, E. Corpus OVI dell'taliano antico. (Disponível em: http://gattoweb.ovi.cnr.it/(S(pvyegvv3zyx414nyp1vwzsrh))/CatForm01.aspx)

Norueguês:

Diplomatarium Norvegicum. (Disponível em:

http://www.dokpro.uio.no/dipl_norv/diplom_field_eng.html)

Nasjonalnbiblioteket. Acervo da biblioteca nacional. (Disponível em: www.nb.no)

Português:

Acervo da Folha. Jornais da Folha de 1921. (Disponível em:

http://acervo.folha.uol.com.br/)

Acervo do Estadão. Jornais do Estadão. (Disponível em:

http://acervo.estadao.com.br/)

Acervo da Veja. Revistas da Veja (Disponível em:

http://veja.abril.com.br/complemento/acervodigital/index-novo-acervo.html)

Corpus lexicográfico do Português. (Disponível em:

http://clp.dlc.ua.pt/DIClweb/default.asp?url=Home)

Corpus do português (s.XIII-XX). (Disponível em:

http://www.corpusdoportugues.org/hist-gen/2008/) 
Hemeroteca Digital Brasileira. (Disponível em:

http://memoria.bn.br/hdb/periodo.aspx) 